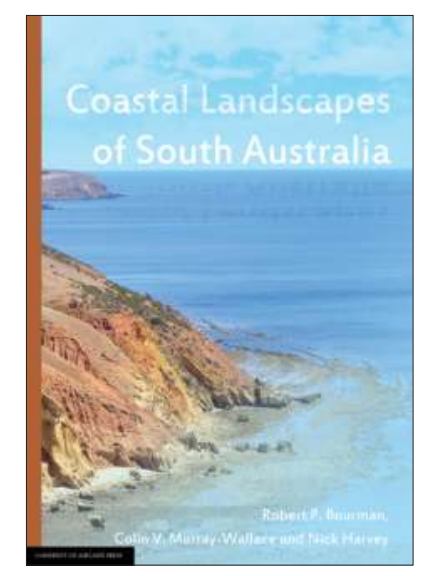

Welcome to the electronic edition of Coastal Landscapes of South Australia.

The book opens with the bookmark panel and you will see the contents page. Click on this anytime to return to the contents. You can also add your own bookmarks.

Each chapter heading in the contents table is clickable and will take you direct to the chapter. Return using the contents link in the bookmarks.

The whole document is fully searchable.

Enjoy.

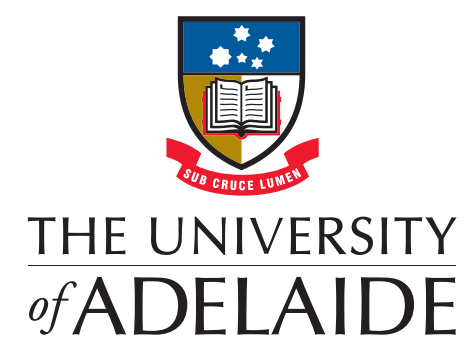




\section{Coastal Landscapes \\ of South Australia}

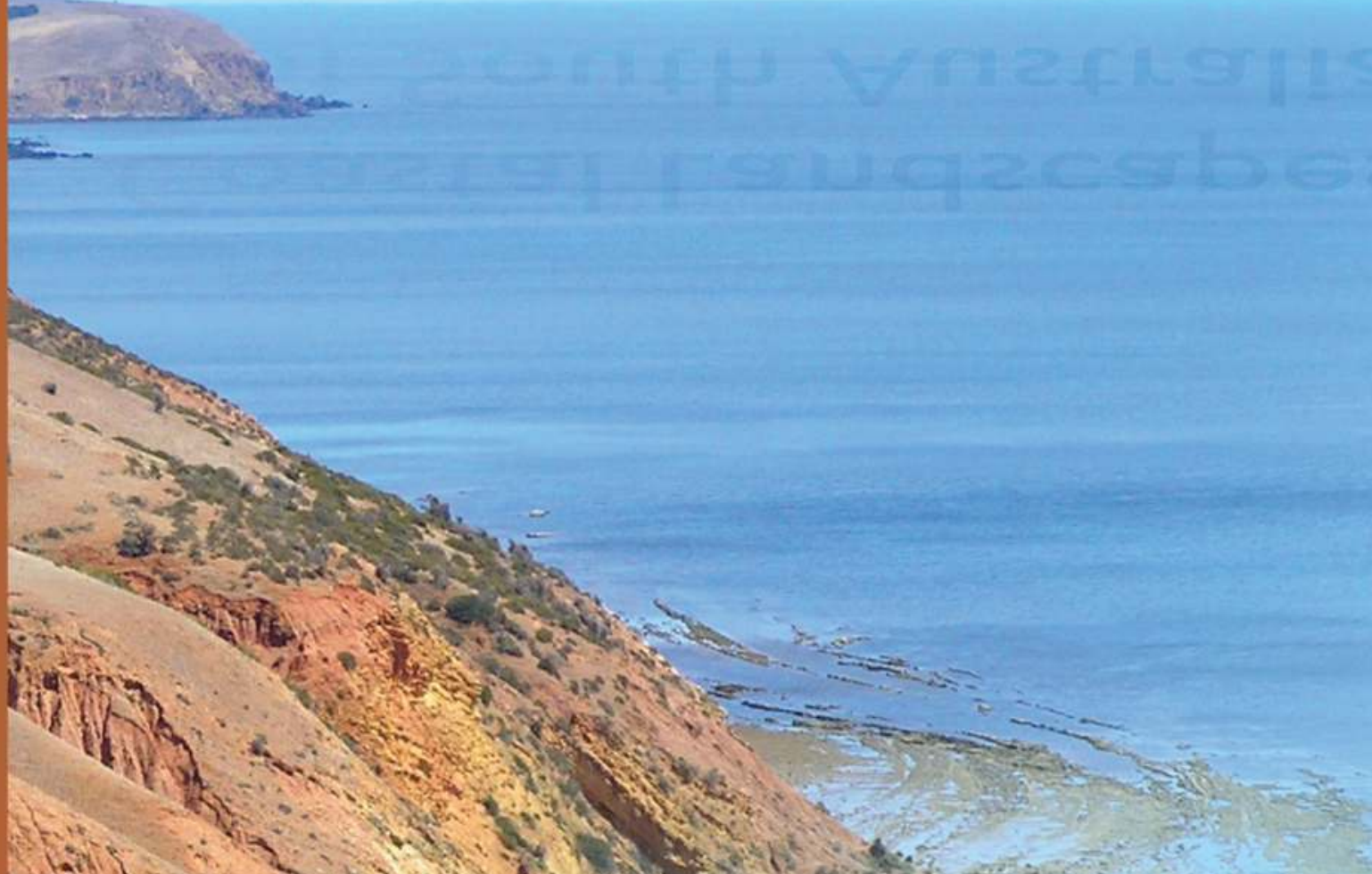

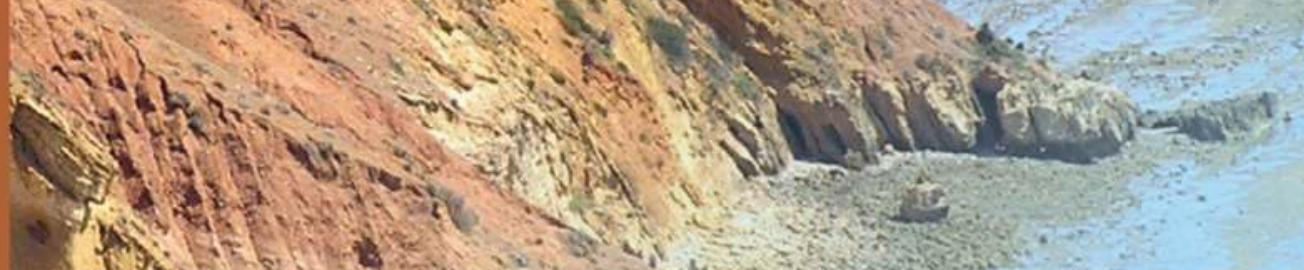

\&

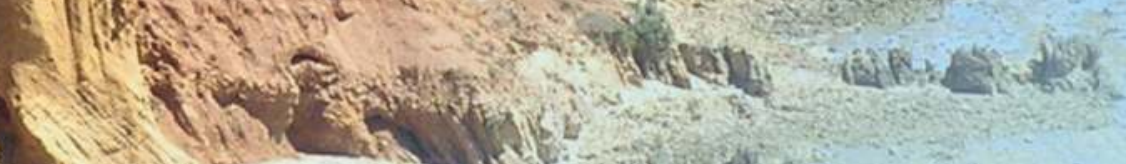

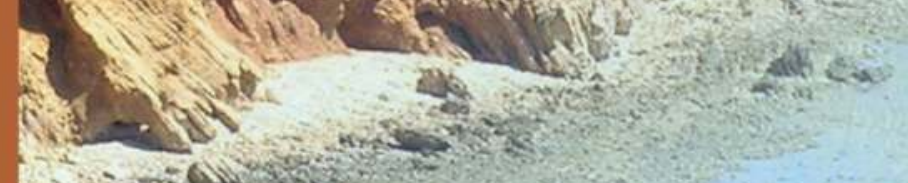

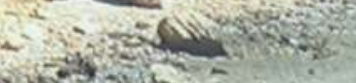
Siles. 


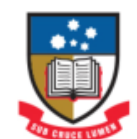

THE UNIVERSITY

of ADELAIDE

UNIVERSITY OF

ADELAIDE PRESS

\section{Coastal Landscapes of South Australia}

\section{Robert P. Bourman, Colin V. Murray-Wallace and Nick Harvey}

Geologically, the South Australian coast is very young, having evolved over only $1 \%$ of geological time, during the past 43 million years since the separation of Australia and Antarctica. It is also very dynamic, with the current shoreline position having been established from only 7000 years ago.

The South Australian mainland coast is $3816 \mathrm{~km}$ long, with islands providing an additional $1251 \mathrm{~km}$ of coast, giving a total coastline of just over $5000 \mathrm{~km}$. South Australian coastal landforms include cliffs, rocky outcrops and shore platforms, mangrove woodlands, mudflats, estuaries, extensive sandy beaches, coastal dunes and coastal barrier systems, as well as numerous near-shore reefs and islands.

This book is a landmark study into the variable character of the South Australian coast and its long-term evolution. 
Coastal Landscapes of South Australia 
This book is available as a free fully-searchable ebook from www.adelaide.edu.au/press

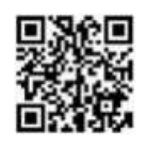




\section{Coastal Landscapes of South Australia}

by

Robert P. Bourman,

Colin V. Murray-Wallace

and Nick Harvey

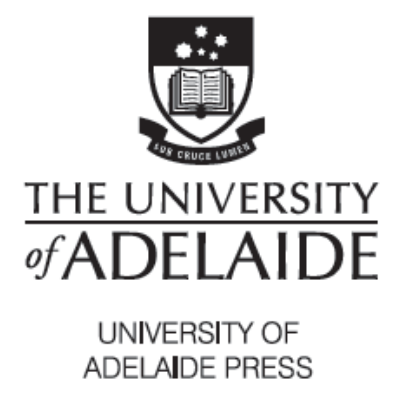


Published in Adelaide by

University of Adelaide Press

Barr Smith Library, Level 3.5

The University of Adelaide

South Australia 5005

press@adelaide.edu.au

www.adelaide.edu.au/press

The University of Adelaide Press publishes peer reviewed scholarly books. It aims to maximise access to the best research by publishing works through the internet as free downloads and for sale as high quality printed volumes.

(C) 2016 Robert P. Bourman, Colin V. Murray-Wallace and Nick Harvey

This work is licenced under the Creative Commons Attribution-NonCommercial-

NoDerivatives 4.0 International (CC BY-NC-ND 4.0) License. To view a copy of this licence, visit http://creativecommons.org/licenses/by-nc-nd/4.0 or send a letter to Creative Commons, 444 Castro Street, Suite 900, Mountain View, California, 94041, USA. This licence allows for the copying, distribution, display and performance of this work for non-commercial purposes providing the work is clearly attributed to the copyright holders. Address all inquiries to the Director at the above address.

For the full Cataloguing-in-Publication data please contact the National Library of Australia: cip@nla.gov.au

ISBN (paperback) 978-1-925261-20-2

ISBN (ebook: pdf) 978-1-925261-21-9

ISBN (ebook: epub) 978-1-925261-22-6

ISBN (ebook: kindle) 978-1-925261-23-3

DOI: http://dx.doi.org/10.20851/coast-sa

Editor: Rebecca Burton

Editorial support: Julia Keller

Book design: Zoë Stokes

Cover design: Emma Spoehr

Cover image: Robert P. Bourman — View of the cliffed coast from south of Sellicks Beach towards the southern headland of Myponga Beach, Gulf St Vincent. The shore platform cuts across Oligocene-Miocene limestone of the Port Willunga Formation about 30 to 16 million years old. The limestone has been folded in plan, as shown by the curved bedding planes on the platform, and tilted at angles of up to $45^{\circ}$ by earth movements (e.g. bottom left hand corner). Small sea stacks approximately $2 \mathrm{~m}$ above the shore platform have formed by erosion of an earlier, higher shore platform. A boulder beach up to $5 \mathrm{~m}$ high in the lower cliff zone contains marine shells of last interglacial age (125 000 years old), revealing the age of the former shore platform and providing evidence of $3 \mathrm{~m}$ of local tectonic uplift since the last interglacial shoreline. The modern platform is littered with boulders and pebbles derived by erosion of nearby Cambrian bedrock and Pleistocene alluvial and colluvial sediments in the cliff zone. Paperback printed by Griffin Press, South Australia 
This book is dedicated to Cliff Ollier for his exceptional contributions to the study of geomorphology and especially for his innovative and iconoclastic thinking. 



\section{Contents}

Preface $\quad$ ix

Biographies xi

Acknowledgements xiii

1 Coastal landscapes of South Australia 1

2 The coast of metropolitan Adelaide 45

3 The Fleurieu Peninsula coast 71

4 The River Murray Estuary 109

5 The Coorong Coastal Plain and the 145 Limestone Coast

6 The northern Gulf St Vincent tidal 177 coastline (the Samphire Coast)

7 The Yorke Peninsula coastline 197

8 The northern Spencer Gulf coast 243

9 The Gulf Coast of Eyre Peninsula 273

10 The Bight Coast - West coast of 309 Eyre Peninsula

11 Kangaroo Island 355

12 Explaining the coastal landscapes of 387 South Australia - A synthesis 



\section{Preface}

People have natural affinities with the sea and coastlines, using them for work, recreation and aesthetic enjoyment. Interest in coastal areas has increased with growing awareness of environmental sustainability, issues such as natural coastal vulnerability and potential climatic changes, as well as the development of a greater appreciation of impacts on coasts due to urban and industrial development.

In order to make a contribution towards an understanding of the evolution of the South Australian coast and its current changes, and thereby contribute towards its better management, the authors are sharing their coastal knowledge and research. Collectively the contributors, who have been friends and academic collaborators over several decades, have accumulated a vast amount of experience related to the evolution of coastal features of South Australia. From this unique position they have synthesised this information in a manner to make it accessible to students, planners and the general public.

Geologically, the South Australian coast is very young, having evolved only over $1 \%$ of geological time, during the past 43 million years since the separation of Australia and Antarctica. It is also very dynamic, with the current shoreline position having been established from only 7000 years ago. There is a remarkable diversity of coastal landscapes in South Australia, ranging through rocky cliffed coasts, submarine canyons, high wave energy sandy beaches and estuarine environments to tidally dominated coasts with sandflats and mangrove woodlands. This diversity of coastal landforms has resulted from the interaction of tides, winds and wave-generated processes operating on a range of rock types impacted by relative movements of the land and sea. Highlighting past changes at the coastline such as erosion, siltation, land movements and fluctuations in sea level provides a sound basis for understanding future changes and instigating appropriate planning strategies. Some features of the South Australian coast have national and global research significance for understanding sea level changes, coastal evolution and management by providing present analogues of past landforms.

The main aim of this book is educational. By explaining the variable character of the coast and its long-term evolution, it is hoped that this book will provide people 
with background information and awaken curiosity about the coast, enabling them to understand and interpret coastal landscapes, or 'to read the coastal landscape'. They may move from wondering about the way in which the coast developed to having their own ideas, thereby heightening an appreciation of, and sensitivity towards, the dynamic character of the coast and the potential impacts of people on the coast.

While much has been written about the South Australian coast, this book is unique in providing the only systematic synthesis of the long-term evolution of the South Australian coast, thereby explaining its diverse scenery. The idea for the book was spawned at an informal dinner party when the intricacies of the South Australian coast were discussed. As a result of this, Professor Cliff Ollier, to whom the book is dedicated, urged the authors to write a book summarising the geomorphic evolution of the South Australian coast. 


\section{Biographies}

Professor Robert P. Bourman - BA (Hons, $1^{\text {st }}$ Class), MA, Dip Ed, Dip T, PhD

Bob Bourman, formerly Professor of Geomorphology at the University of South Australia, is currently a Visiting Professorial Fellow at the University of Wollongong and a Visiting Research Fellow at The University of Adelaide. His early training in geomorphology was at The University of Adelaide with Dr C.R. Twidale, with whom he completed an Honours Degree and an MA investigating the geomorphology of Fleurieu Peninsula, awakening nascent curiosities and precipitating a lifelong interest in geomorphology. His $\mathrm{PhD}$ examined the origins of ferricrete and weathered zones in southern and southeastern Australia. Professor Bourman has researched a diverse range of topics (Permian glaciation, ferricretes, inselbergs, neotectonics, river terraces and alluvial sequences, paleofloods and human impacts on the landscape), publishing some 170 peer-reviewed geomorphic papers, half of which have been related to the South Australian coast. Professor Bourman is also an educator, and he has taught in Secondary Schools and Tertiary Institutions for over 40 years.

Professor Colin V. Murray-Wallace - BA (Hons), PhD, DSc, GCHEd, FGS, FRGS

Colin Murray-Wallace is a Quaternary geologist and currently a Professor in the School of Earth \& Environmental Sciences in the University of Wollongong. His $\mathrm{PhD}$ and DSc degrees are from The University of Adelaide. He has been undertaking research on aspects of the long-term geomorphological evolution of the coastline of South Australia since 1983. Colin has been particularly interested in the origin of sedimentary carbonates and the development of the vast accumulations of coastal carbonate dune deposits (aeolianite of the Bridgewater Formation) that have formed during the past 2 million years in response to repeated cycles of sea level change. His first book, Quaternary sea-level changes: A global perspective, was published by Cambridge University Press in 2014. 


\section{Emeritus Professor Nick Harvey - BA Hons ( $1^{\text {st }}$ Class), B Ed, M Plan, PhD}

Nick Harvey is an Emeritus Professor at the University of Adelaide and an adjunct Professor in the College of Marine and Environmental Sciences at James Cook University. He is currently the Director of the Centre for Coastal Research at The University of Adelaide and Vice-President and Life Member of the Australian Coastal Society. He was formerly Vice-Chair of the international scientific steering committee for 'Land-Ocean Interactions in the Coastal Zone' and a member of the South Australian Government's Coast Protection Board. Nick was also one of the Lead Authors for the $4^{\text {th }}$ Assessment Report of the Intergovernmental Panel on Climate Change (IPCC), which in 2007 was jointly awarded the Nobel Peace prize. Nick has 40 years of experience in coastal research, has over 200 publications including scientific papers and has written books such as Coastal Management in Australia published by Oxford University Press (2003) and republished by the University of Adelaide Press (2010) and Global Change and Integrated Coastal Management: The AsiaPacific Region published by Springer (2006). 


\section{Acknowledgements}

Our understanding of the nature of South Australian coastal landscapes has been influenced by many people with contrasting research interests, but having in common a general interest in the long-term coastal evolution of the region. They include Neville Alley, Tony Belperio, Amy Blakemore, Greg Bowman, Brendan Brooke, Solomon Buckman, John Cann, John Chappell, Francis Gorostiaga, Vic Gostin, John Hails, Patrick Hesp, Kris James, Noel James, the late John Hutton, Terry Lachlan, Kurt Lambeck, Annie Lucas, the late Nell Ludbrook, Tony Milnes, Tony Nicholas, Brad Pillans, the late John Prescott, Deirdre Ryan, Andy Short, the late George Trevorrow, Rowl Twidale, Chris Von der Borch, Martin Williams and Colin Woodroffe. Members of the Field Geology Club of South Australia and questioning students have also contributed to our thoughts and interpretations. We acknowledge past funding from the Australian Research Council, The University of Adelaide, the University of Wollongong and the University of South Australia. We would particularly like to thank Peter Johnson, cartographer par excellence, for preparing all the line drawings. $\mathrm{NH}$ would like to thank Romana Dew for her help as a research assistant. RPB is forever indebted to his partner and soul mate, Samantha Rowe, for her support, encouragement, active and enthusiastic participation in field activities as well as for sharing her insights and ideas. 



\section{Coastal landscapes of South Australia}

\subsection{Introduction}

People commonly have close affinities with coastlines, whether for recreation (swimming, fishing, boating, surfing, sunbathing), enjoying their generally milder climates, investigating their historical and cultural connections, admiring their inherent beauty or questioning the nature and formation of coastal landscapes. This book aims to assist people in interpreting coastal landforms, revealing how the coast has evolved and is continuing to do so under the influences of a range of processes acting upon a variety of geological settings. Developing an understanding of the ways in which coastlines have changed through time, by interpreting rock strata, landforms and coastal and marine processes, can add much to the enjoyment of coastal experiences. Study of coastal environments also offers opportunities to reconstruct past environments and to monitor ongoing changes that may relate to climatic changes. An understanding of coastal processes and development can also provide critical information relevant to the vulnerability of predicted rises in sea level and coastal flooding. ${ }^{1}$

Coasts are very complex environments, representing the interaction of physical, chemical and biological processes. Located at the boundary between land and sea, coasts are among the most dynamic environments on Earth as tides, winds, waves, weathering processes and currents modify landscapes and produce a range of erosional and depositional landforms, the stability and fragility of which may also be influenced by flora and fauna. Repeated sea level changes over the past 2.6 million years, coupled with crustal movements, add to the complexity of coastal development. Thus the coastline of South Australia must be considered as a dynamic system in a state of constant flux. In addition, some coastal features are inherited from coastlines that were formed during past ages. 
According to Geoscience Australia, the South Australian mainland coast is $3816 \mathrm{~km}$ long, with islands providing an additional $1251 \mathrm{~km}$ of coast, giving a total coastline of just over $5000 \mathrm{~km}$. South Australian coastal landforms include cliffs, rocky outcrops and shore platforms, mangrove woodlands, mudflats, estuaries, extensive sandy beaches, coastal dunes and coastal barrier systems, as well as numerous nearshore reefs and islands. These coastal landforms have developed under the influence of a range of tidal conditions and wave regimes, varying from high energy on exposed open ocean coasts (for example, the west coast of Eyre Peninsula) to low energy in protected shorelines with high tidal ranges (such as in the northern gulfs).

\subsubsection{How has the coastline of South Australia evolved over time?}

The general character of the South Australian coastline is the result of the interactions between the sea and the various terrestrial landscapes at the ocean/land interface. Much of the interesting coastal variability of South Australia can be explained in geological terms. Three major geological provinces influence the coastline: the Gawler Craton, the Mount Lofty/Flinders Ranges and younger sedimentary basins such as the Eucla, St Vincent and Murray Basins (Figure 1.1). ${ }^{2}$

The oldest known rocks in South Australia are those of the ancient and tectonically stable Gawler Craton, which extend back at least $3.15 \mathrm{Ga}$ (billion years). ${ }^{3}$ A major geological province, the Gawler Craton consists of crystalline basement rocks, which are exposed over most of Eyre Peninsula and parts of western Yorke Peninsula. ${ }^{4}$ They also underlie Neoproterozoic $(-1000 \mathrm{Ma}$, or million years) to Cambrian $(-500 \mathrm{Ma})$ rocks of the Mount Lofty/Flinders Ranges, and some younger Cenozoic sedimentary basins ( $<65 \mathrm{Ma}$ ) such as the Eucla, Murray, Otway and Duntroon basins (Figure 1.1). Inliers (outcrops of older rocks surrounded by younger strata) of the Gawler Craton occur within or on the margins of the Mount Lofty/Flinders Ranges, such as at Little Gorge on Fleurieu Peninsula.

These major geological provinces have experienced different tectonic histories, which, in turn, have influenced coastal evolution. The Gawler Craton consists of former sediments, which over billions of years were metamorphosed (changed by heat and pressure) into crystalline rocks such as schists and gneisses, and were subjected to multiple folding events accompanied by granite intrusions. The oldest rocks on the coast at $2.46 \mathrm{Ga}$ (billion years) occur at Cape Carnot near Port Lincoln, while the last major deformation occurred about $1.45 \mathrm{Ga}$ ago. In marked contrast, as well as providing ramparts against coastal erosion, this ancient crystalline complex today forms a highly stable datum ${ }^{5}$ from which sea level changes around the coast may be assessed.

The Mount Lofty/Flinders Ranges, including parts of Kangaroo Island, formerly occupied by the Adelaide Geosyncline, an actively subsiding sedimentary basin, 


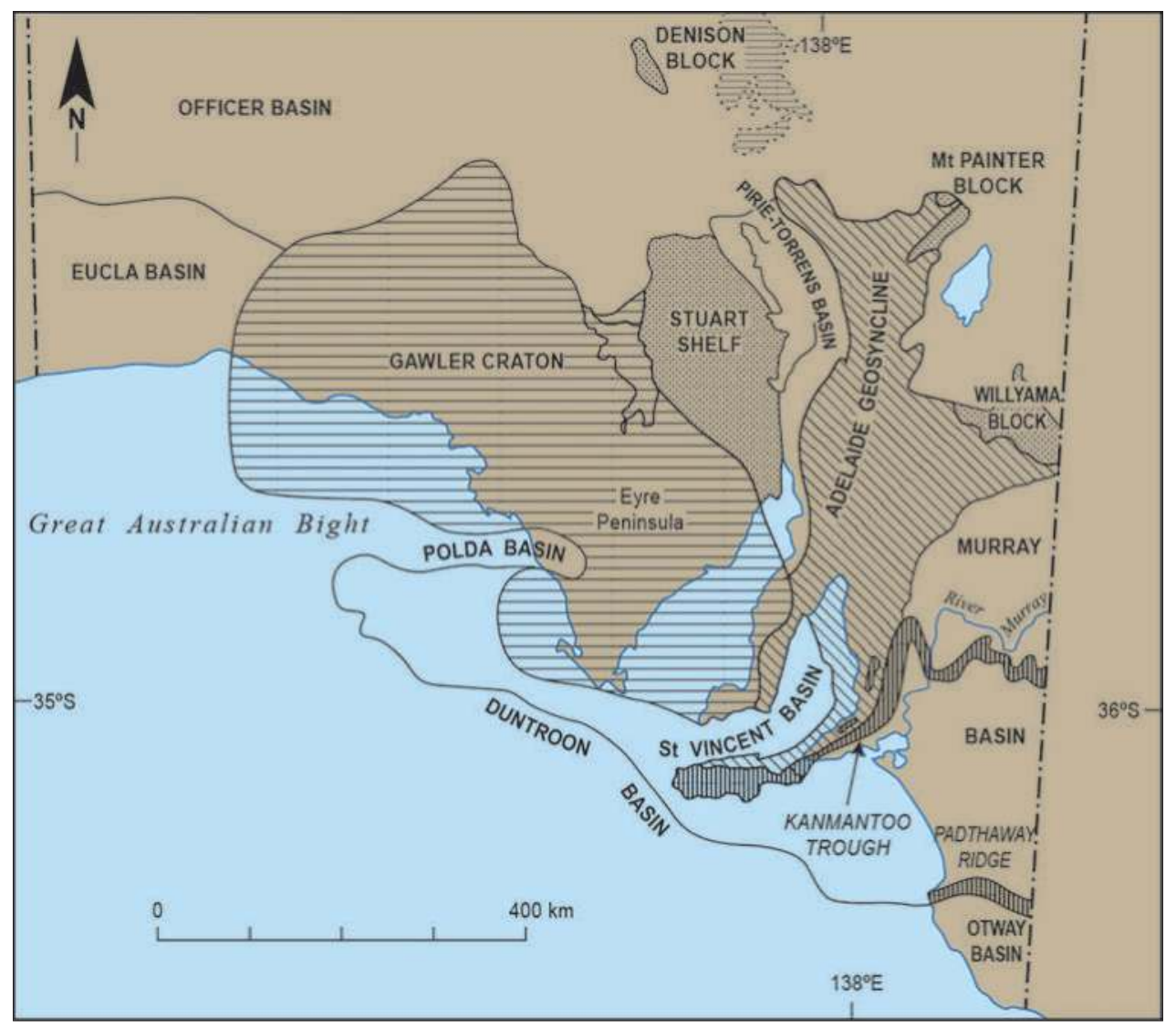

Figure 1.1 Major geological provinces of South Australia (after Ludbrook, 1980) showing the locations of the Gawler Craton, Adelaide Geosyncline (now partially occupied by the Mount Lofty/Flinders Ranges) and younger sedimentary basins.

Source: Modified and reproduced with permission of the Department of State Development's Resources and Energy Group.

experienced dramatic Earth movements during the past $500 \mathrm{Ma}$. A thickness of up to $24 \mathrm{~km}$ of marine and glacial sediments along with rare volcanic rocks accumulated in the waters of this vast subsiding basin during the Neoproterozoic (the Adelaidean Period from 1300 to $542 \mathrm{Ma})^{6}$ and the Cambrian (541 to $485 \mathrm{Ma}$ ), which included rocks of the Normanville and Kanmantoo Groups. An unconformable contact representing a large time break occurs between rocks of the Gawler Craton and the Adelaidean System and is marked by a basal conglomerate of rounded boulders, some of which have been exposed by coastal erosion and currently form coastal pebbles and boulders at Lady Bay on Fleurieu Peninsula. An unconformity also occurs at the base 
of the Cambrian sequences, some of which were deposited as deep sea fans. A thin sequence of undeformed Adelaide Geosyncline sediments occurs west of Lake Torrens and forms the Stuart Shelf, which intersects the western coast of northern Spencer Gulf, where it influences the morphology of the coastline and provides the source for beach pebbles and boulders.

During the Delamerian Orogeny, a mountain building event about $500 \mathrm{Ma}$ ago, the sediments of the Adelaide Geosyncline were variably metamorphosed, folded, faulted and intruded by granitic rocks such as the Encounter Bay Granites. ${ }^{7}$ Compressive movements of the Earth's crust formed a huge fold mountain range, the Delamerides ${ }^{8}$, perhaps of Himalayan proportions, during Cambrian to Early Ordovician times, over many millions of years.

Over a period of $200 \mathrm{Ma}$, following the Early Ordovician, the Delamerides were eroded, and by Early Permian times (299 to $290 \mathrm{Ma}$ ) the Encounter Bay Granites, which were originally emplaced at depths in the mountain chain of perhaps some $7 \mathrm{~km}$ below the landsurface, had been exposed by weathering and erosion. Exposure occurred either before or during the passage of a continental ice sheet during the Permian, which overrode the mountain range, approaching from the southeast. The granites were exposed at the time of the Permian glaciation because glacially scoured and polished surfaces occur on granite at Port Elliot. ${ }^{9}$ Furthermore, granite erratics are widespread over Fleurieu Peninsula, with some being carried as far as Yorke Peninsula, where they form boulders on beaches. Permian glacial imprints occur in various locations on the South Australian coast: Backstairs Passage is a modified glacial trough; the distribution of the granite islands of Encounter Bay was established by Permian glacial activity, which also influenced the coastlines at Christmas Cove, Smith Bay (Kangaroo Island) and parts of the sea cliffs at Hallett Cove. ${ }^{10}$ Sediments deposited by the melting ice sheet have also contributed significantly to beach sediments at many locations on the coast.

Since the Permian glaciation, the landscape of the State has been affected by ongoing weathering and erosion processes, reducing the former fold mountain range to a region of relatively low relief and preparing resistant rock types for coastal erosion where contacts between weathered and unweathered rocks intersect the sea. Basaltic extrusions of Middle Jurassic age occur on Kangaroo Island ${ }^{11}$ and in the Polda Trough of Eyre Peninsula. ${ }^{12}$ These possibly formed about $165 \mathrm{Ma}$ ago due to pre-rifting stresses between Australia and Antarctica, which culminated in separation of the two continents and the birth of the South Australian coastline approximately $43 \mathrm{Ma}$ ago. ${ }^{13}$ Thus, in geological terms, the coast is young, having been in existence for only approximately $1 \%$ of the 4.5 billion years of Earth history.

Throughout the Cenozoic, ongoing faulting uplifted the denuded Delamerides to form the Mount Lofty-Flinders Ranges, which are flanked by range-bounding reverse 
faults giving rise to an 'open-3' or 'lazy $S$ ' shape in plan view. Compensating subsidence produced the adjacent Murray, St Vincent, Pirie-Torrens and Uley-Wanilla-Cummins basins and accentuated the Eucla Basin (Figure 1.1). These basins provided avenues for incursions of the sea and deposition of Cenozoic limestones.

\subsubsection{What is the Geological Timescale and how was it developed?}

Throughout this book there are various references to the Eras, Periods and Epochs of geological time, warranting an early introduction to the Geological Timescale (Figure 1.2). ${ }^{14}$ However, ages in years will also often be given so that constant reference to the timescale will not be essential. Abbreviations for ages will be used, such as ka (kilo-anna or 1000 years), Ma (Mega-anna or 1 million years) or Ga (Giga-anna), which equals 1 billion years (1000 million years using American terminology).

The timescale was established by recognising some of the key events in Earth history such as ice ages, the development of mountain ranges and episodic marine flooding of continents, which have left distinctive and easily recognisable sedimentary deposits of different ages. It was assumed that sediments were originally deposited horizontally (Law of Horizontality) and that beds at the bottom of a sequence were older than those at the top (Law of Superposition). Igneous rocks such as granite and dolerite were considered to be younger than the rocks they intruded, and extrusive basalts younger than the rocks they overlie. Thus, based on the relative age of rock successions, geologists in the nineteenth century began to identify relatively older and younger rocks in vertical stratigraphical profiles or layers. Geological mapping revealed the wide geographical extent of different assemblages of strata as noted by the engineering geologist William Smith (1769-1839) in his surveys for the construction of canals in Britain. There is no one place on Earth where there is a continuous stratigraphical sequence of all rocks and sediments. Usually, there are only isolated partial sequences. It may be possible to trace physically a distinctive marker bed from one locality to another, but this opportunity is also relatively rare. However, the recognition that different stratigraphical sequences contained particular assemblages of plant and animal fossils allowed correlation over widespread areas, especially where fossils are very distinctive, had evolved rapidly and had died out suddenly (Index Fossils). Thus the Law of Superposition, along with correlation using fossils, allowed the development of a relative timescale. Later, the development of geochronological methods of numerical dating allowed ages in years to be assigned to the timescale.

Geological time is divided into Eras, Periods and Epochs. Eras refer to the longest intervals of time and may include several Periods such as the Paleozoic Era, which comprises in ascending order the Cambrian, Ordovician, Silurian, Devonian, Carboniferous and Permian (Figure 1.2). Periods represent major intervals of geological time with durations mostly of several tens of millions of years $(\mathrm{Ma})$, and their names 
are derived from places where the strata of particular ages were first identified, or were based on particular properties of strata. For example, Roderick Impy Murchison (1787-1871) named the Permian (299 to $252 \mathrm{Ma}$ ) in 1841 based on mapping of limestones in the Perm province of Russia ${ }^{15}$, while William Conybeare (1787-1857) and William Phillips (1800-1874) named the Carboniferous in 1822 following the identification of coal-bearing sedimentary successions in the Midlands of England. The Quaternary, the youngest period of Earth history, was based on mapping of recently deposited strata in the Paris Basin. During the Quaternary, anatomically modern humans emerged, and this Period has also been characterised by multiple episodes of long-term climate change with the waxing and waning of continental ice sheets. Epochs refer to divisions of time within Periods.

Subdivision of the geological timescale preceded the discovery of radioactivity and the development of geochronological methods such as uranium/lead or rubidium/ strontium dating. As a result, the numerical ages of the geological Periods were not resolved until the twentieth century. The ages of geological boundaries to the Periods are constantly being revised as new geological information becomes available which more accurately defines the onset and completion of a Period. The most recent revisions of the geological timescale were published in 2012, when the Quaternary boundary was backdated from 1.86 to $2.59 \mathrm{Ma}^{16}$

The rocks on which the coastline of South Australia has developed span a great range of ages, but there are also several Periods of the rock record, which are either poorly or not represented. These include the Silurian, Devonian, Carboniferous, Triassic, Jurassic and Cretaceous, representing $378 \mathrm{Ma}$ of time. The oldest rocks, granites and gneisses occur on western Eyre Peninsula. Proterozoic strata crop out along much of the Fleurieu Peninsula coastline and give rise to rocky shorelines. Permian glacigene strata occur at Hallett Cove south of Adelaide, on Yorke Peninsula and Kangaroo Island. The youngest strata, in the form of coastal dune and beach deposits, were deposited during the Holocene, an Epoch, which commenced 11.7 ka ago.

Compressing the history of the Earth into one year and resolving the timing of key events on that basis can help us to appreciate the magnitude of geological time. The granites and gneisses of Eyre Peninsula would have been last deformed on 7 September, and the Permian glacigene sediments at Hallett Cove deposited on 14 October. The Late Pleistocene shelly limestones of the Glanville Formation, fringing large sectors of the coastline and deposited at a time of higher sea level some 125000 years ago,

Figure 1.2 (right) The Geological Timescale, illustrating some of the principal geological events that have ultimately shaped the coast of South Australia.

Source: Modified from Gradstein, Ogg, Schmitz \& Ogg (2012). 
ERA PERIOD EPOCH Age

GEOLOGICAL EVENTS

(at boundary in

millions of years)

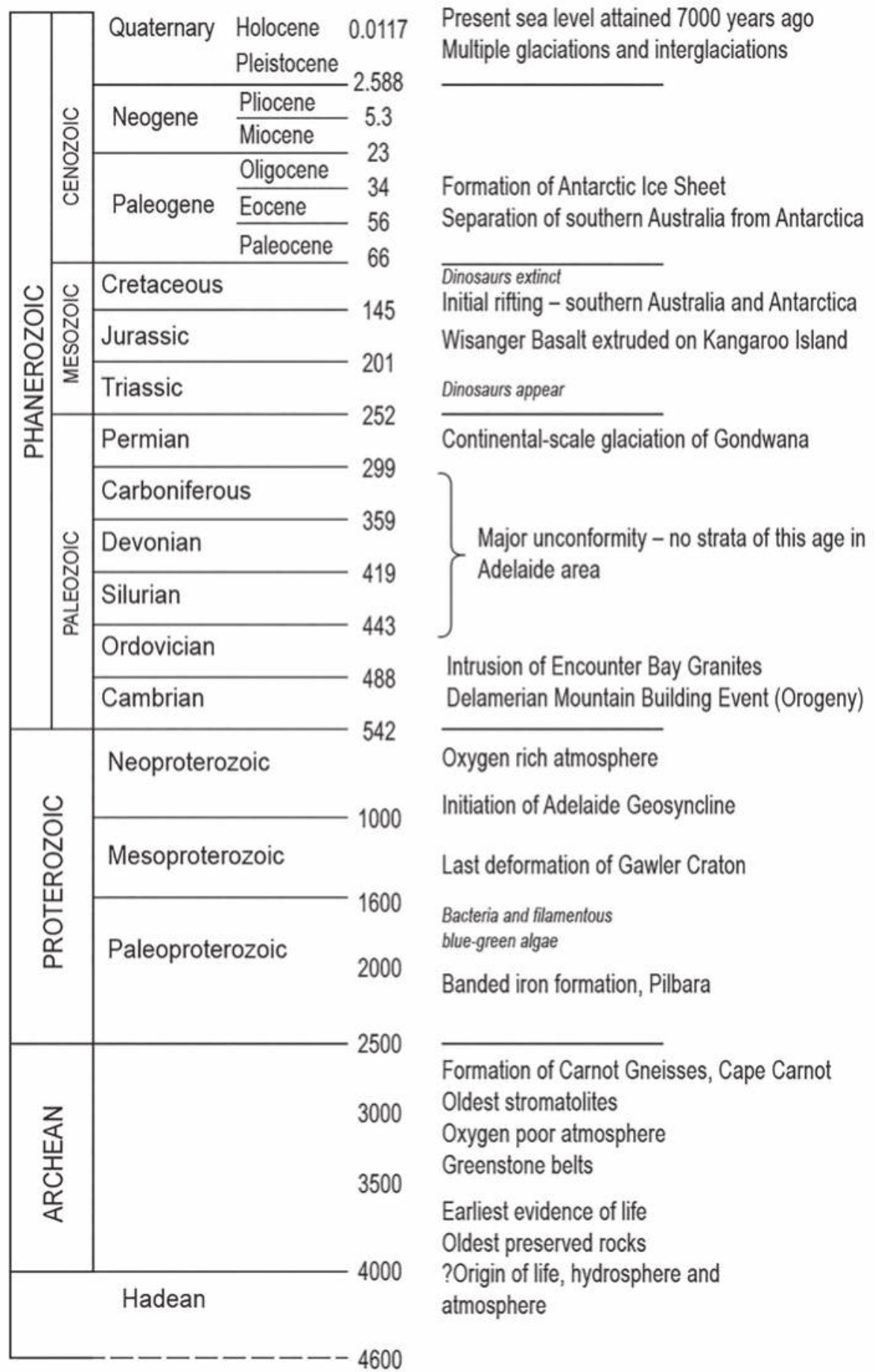


would have formed at approximately 14 minutes before midnight on the last day of the year. The dune sands of Younghusband Peninsula would have been deposited approximately 48 seconds before midnight on 31 December, and the founding of the City of Adelaide 1.2 seconds before midnight.

\subsubsection{How old is the South Australian coast?}

In geological terms the South Australian coastline is young; it was initiated only when Australia and Antarctica were slowly separating about the time of dinosaur extinction some 65 million years ago in the Paleogene ${ }^{17}$, after which an intercontinental seaway was produced, forming the broad outline of the present coast. The South Australian coast is developed on a trailing edge passive continental margin in an intra-plate position $^{18}$ and thus is free from young fold mountains and active volcanoes. However, episodic volcanism in the Late Pleistocene and Holocene resulted in the formation of 'hot spot' volcanic cones and ash deposits near Mount Gambier in the southeast of the State $^{19}$, influencing coastal development there.

Precursors of rifting occurred in the Permian (290 to $252 \mathrm{Ma})^{20}$; associated basalt extrusion occurred in the Jurassic at $170 \mathrm{Ma}^{21}$; and early rift separation took place about $100 \mathrm{Ma}$ ago, with more rapid divergence at $43 \mathrm{Ma} \mathrm{ago}^{22}$, forming a well-defined offshore continental shelf. Since then, the Australian continent has drifted $3000 \mathrm{~km}$ to the northeast.

Following continental separation, marine sediments were deposited along the fractured continental border, which approximated the position of the present coastline. During sea level rises, or marine transgressions, in the Middle to Late Eocene (48 Ma) and in the Late Oligocene (23 Ma) to Early Miocene (23 to $16 \mathrm{Ma}$ ), thick sequences of fossiliferous limestones were deposited. Marginal marine sedimentation in the Early Pliocene (5 Ma) was followed by a widespread Late Pliocene (3.6 to 2.6 Ma) transgression of the sea. Throughout much of the Cenozoic the position of the South Australian coastline fluctuated. Repeated marine incursions penetrated into major tectonic basins such as the Eucla and Murray Basins, withdrawing in association with gentle uplift of the land. Ancient shorelines, such as the Ooldea Range, a former coastal barrier over $650 \mathrm{~km}$ long, are now stranded more than $150 \mathrm{~km}$ inland from the Great Australian Bight. During the Pleistocene (2.6 Ma to $11.7 \mathrm{ka}$ ), evidence for repeated fluctuations in global sea level has been variably preserved around the South Australian coast, reflecting varying tectonic and isostatic influences. Although sited on a relatively stable continental intra-plate position, parts of the South Australian coast have undergone deformation that is easily recognised by the varying elevations of fossiliferous marine limestones of known ages.

In addition to tectonically driven changes in land level, the Earth's crust can be depressed by loading and can also rebound following unloading. The continental crust 
is predominantly of granitic composition and floats like a raft on denser basaltic mantle rocks, a concept known as isostasy. As a raft on water will float lower in the water when heavily loaded, so will the continental crust. In areas affected by continental Pleistocene glaciations, such as North America, northern Europe and Great Britain, the huge weight of the ice masses depressed the crust, which rebounded after the ice retreated. For example, during glacial times, the ice-covered area of Scotland was depressed while, in a compensating movement, the ice-free areas of southeastern England rose. In reverse, after ice melt-out and a lag time, Scotland slowly rebounded, while southern England sank. These glacio-isostatic movements continue today even though the ice has been gone for thousands of years. Pleistocene glaciations did not directly have an impact on South Australia, but they indirectly affected its coastal margins. For example, as sea level rose during interglacial times, the weight of sea water depressed the continental shelf, while in a compensating seesaw fashion the land area rose. The reverse occurred during glacial times when sea level retreated. These land movements resulting from loading and unloading of the continental shelves by fluctuating water volumes is termed 'hydro-isostasy'. ${ }^{23}$

Thus the land has been variably deformed, while superimposed on this were climatically driven global fluctuations in sea level; glacial episodes produced low sea levels, and warmer interglacial periods were associated with high sea levels. Over the past $1.2 \mathrm{Ma}$, sea level has repeatedly oscillated on a regular cycle of approximately 100000 years, falling to depths of up to $125 \mathrm{~m}$ during glacial episodes and rising to approximately the same level as now during interglacials. ${ }^{24}$ Before $1.2 \mathrm{Ma}$ ago, the Middle Pleistocene transition, there were $41 \mathrm{ka}$ cycles of sea level fluctuations. Changing astronomical relationships between the Sun and the Earth drove these climatic cycles as the distance between the two changed, the tilt of the Earth's axis varied and the axis wobbled like a spinning top. The resulting fluctuating sea levels left a sporadic sedimentary record along the coast. Much of the record lies below present sea level, but in the Southeast Coastal Plain former high-energy coastal barriers have been progressively uplifted to produce an excellent on-land record of the major glacialinterglacial cycles of the Quaternary. At least 18 major glacial-interglacial Quaternary cycles are clearly preserved and separated ${ }^{25}$ as beach/dune coastal barriers similar to the modern Younghusband Peninsula. However, these stranded barrier complexes are also strongly cemented by calcium carbonate and mantled with resistant calcareous soils (or calcrete layers), which preserve their shapes. Such lithified coastal dunes are referred to as the Bridgewater Formation ${ }^{26}$ and have been named 'aeolianite', a term coined by Sayles $^{27}$, who reported on the carbonate dune successions of Bermuda.

In contrast to the sequences of the uplifted Southeast Coastal Plain, the relatively stable Eyre and Yorke Peninsulas display a complex mix of stacked consolidated dune complexes of superimposed interglacial successions, separated by calcretes and paleosols (relict soil profiles), which represent subaerial conditions during drier glacial and 
interstadial times. Coastal erosion of these aeolianite sequences has formed spectacular cliffed shorelines.

The last interglacial shoreline (132 to $118 \mathrm{ka})^{28}$, which along the South Australian coastline stood about $2 \mathrm{~m}$ higher than present sea level ${ }^{29}$, is particularly useful to demonstrate neotectonic deformation, as it is well preserved over widely separated localities. Its elevation reveals stability of the Gawler Craton, subsidence of the gulfs, uplift of the Mount Lofty Ranges, subsidence of the Murray Estuary and uplift of the Coorong Coastal Plain. ${ }^{30}$

The culmination of this long history of geological processes has produced the modern coastline of South Australia, which has only existed in its present general form since the sea surface attained its current level about 7000 years ( $7 \mathrm{ka}$ ) ago, after the most recent melting of the continental ice sheets. In marked contrast, some 22 ka ago, at the height of the Last Glacial Maximum, most of the continental shelf was exposed as dry land. At this time mainland South Australia and its near-shore islands, including Kangaroo Island, were joined as one landmass. Consequently, the present coastal zone has only existed for a few thousand years, and except where active tectonic uplift of the land has occurred it reflects conditions operating during a rising sea level, which submerged former exposed land areas.

\subsubsection{What is happening to sea level around the South Australian coastline?}

The present level of the sea surface around the South Australian coastline was broadly established about 7000 years ago, but since then it has experienced minor fluctuations, which continue to the present. It is generally accepted that global sea levels are rising. Tide data derived from reliably sited gauges in Australia suggest an average rate of sea level rise of $+0.3 \mathrm{~mm} /$ year. ${ }^{31}$ Tide gauges record the regular cycles of high and low tides, which are caused by the gravitational attractions of the Sun and Moon on the oceans as the Earth rotates, as well as by the impacts of storms and changes in atmospheric pressure. These records can be analysed to provide information on long-term trends in the level of the sea surface.

Historical tidal records may establish recent changes in sea level, but they only record the local relative relationships between the sea and the land. Global changes in sea level occur as glaciers melt and as the oceanic waters expand when warmed, but there are other factors that can affect changes at specific locations. Human influences may impact on the reliability of tidal records. For example, harbour construction and constrictions may result in higher water levels than those previously recorded on open shorelines. In addition, loading of the substrate with breakwaters can cause subsidence of tide gauges. Subsidence and sediment compaction have also resulted from withdrawal of groundwater and dewatering associated with coastal reclamation. ${ }^{32}$ 
Tectonic deformation of the coast also impacts on the relative level of the land and sea over a range of timescales. South Australia has a very reliable datum from which to measure tectonic movements of the coast over the past 125000 years, the Glanville Formation, which refers to all coastal sediments deposited along the coast of South Australia at a time of higher sea level during the Last Interglacial (130 to $118 \mathrm{ka}$ ago). ${ }^{33}$ Fringing the coast of Eyre Peninsula on the stable Gawler Craton, the Glanville Formation lies consistently at $2 \mathrm{~m}$ above present sea level (APSL), whereas in the gulfs' region it has been tectonically depressed ( $-7 \mathrm{~m}$ at Port Adelaide), uplifted on Fleurieu Peninsula $(+10 \mathrm{~m}$ at Normanville; $+6 \mathrm{~m}$ at Victor Harbor), depressed at Goolwa $(-0.8 \mathrm{~m})$ in the Murray Estuary, and progressively uplifted on the Coorong Coastal Plain to a maximum of $+18 \mathrm{~m}$ south of Mount Gambier. ${ }^{34}$ The Glanville Formation contains intertidal, warm-water, but now locally extinct fauna such as the mollusc Anadara trapezia, which equates this higher than present shoreline with elevated temperatures.

Another factor influencing relative sea level is the loading of the continental shelf during major rises in sea level (hydro-isostasy). As the rising waters weigh down the continental shelf, there is a compensating seesaw rise of the land, providing evidence of a consistent postglacial warping of the continental margins over the last 6500 years. This is demonstrated by sea level curves from different stations supported by study of marine and intertidal sediments of the South Australian gulfs. ${ }^{35}$

South Australia has five long-term tide gauge stations at Thevenard (since 1985), Port Lincoln, Port Pirie, Port Adelaide (Outer Harbor) and Victor Harbor. Two other stations have been decommissioned: the gauge at Port MacDonnell was silted up following breakwater construction in 1990, while the station at Inner Harbor was abandoned for financial reasons in 1997. The tide gauges, sited in different geological

\begin{tabular}{|l|l|l|l|l|l|l|}
\hline Tide gauge & Years of record & Sea level trend & $\begin{array}{l}\text { Geologic } \\
\text { adjustment }\end{array}$ & $\begin{array}{l}\text { Isostatic } \\
\text { adjustment }\end{array}$ & $\begin{array}{l}\text { Anthropogenic } \\
\text { effects }\end{array}$ & $\begin{array}{l}\text { Adjusted sea } \\
\text { level trend }\end{array}$ \\
\hline & & $(\mathrm{mm} /$ year $)$ & $\begin{array}{l}\text { (mm/year) high- } \\
\text { (mm/ands (Holocene) }\end{array}$ & (mm/year) \\
\hline Thevenard & 30.8 & $+0.02( \pm 0.08)$ & assumed 0 & $0.06(0.4 \mathrm{~m})$ & assumed 0 & 0.08 \\
\hline Port Pirie & 63.2 & $-0.19( \pm 0.03)$ & assumed 0 & $0.33(2.2 \mathrm{~m})$ & assumed 0 & 0.14 \\
\hline Outer Harbor & 55.1 & $+2.08( \pm 0.04)$ & -0.016 & $0.35(2.1 \mathrm{~m})$ & -2.2 subsidence & 0.21 \\
\hline Inner Harbor & 41.1 & $+2.06( \pm 0.04)$ & -0.016 & $0.35(2.1 \mathrm{~m})$ & -1.8 subsidence & 0.59 \\
\hline Port Lincoln & 32.3 & $+0.63( \pm 0.06)$ & -0.008 & $0.13(0.8 \mathrm{~m})$ & assumed 0 & 0.75 \\
\hline Victor Harbor & 30.8 & $+0.47( \pm 0.07)$ & 0.032 & $0.17(1.0 \mathrm{~m})$ & assumed 0 & 0.67 \\
\hline Pt MacDonnell & 21.7 & $+0.49( \pm 0.09)$ & 0.128 & $0.14(0.84 \mathrm{~m})$ & Silting of gauge & $<0.76$ \\
\hline
\end{tabular}

Table 1.1 Sea level trends calculated from South Australian tide gauge data.

Source: Harvey, N., Belperio, A.P., Bourman, R.P. \& Mitchell, W. (2002). Geologic, isostatic and anthropogenic signals affecting sea level records at tide-gauge sites in southern Australia. Global and Planetary Change, 32, 1-11. 
settings, are affected by varying geologic, isostatic and anthropogenic inputs, which can be corrected to produce more reliable global sea level indicators. If mean sea level trends are established purely on tide-gauge data for the seven stations, there are large differences. For example, at Port Pirie the data show a fall in sea level of $0.19 \mathrm{~mm} / \mathrm{yr}$, whereas Outer Harbor reveals a rise in sea level of $2.27 \mathrm{~mm} / \mathrm{yr} .{ }^{36}$ Table 1.1 shows sea level trends for seven tidal stations adjusted for geologic, isostatic and anthropogenic impacts. Rising sea levels increase the threat of coastal flooding and the dangers of increased erosion, particularly during storms.

\subsubsection{How do Quaternary molluscs (seashells) help to explain coastal evolution?}

We have all noticed various shells on beaches, but probably have not realised how valuable they are in providing insights into coastal development. Molluscs are extremely important for understanding and explaining coastal environments: not only do they provide materials for coastal sediments, but, by analogy with living species, they also allow the reconstruction of past coastal environments, ages and former sea levels. The phylum Mollusca is one of the most successful groups of invertebrates in the geological record, flourishing since the Cambrian (541 Ma). Up to 50000 species currently live in marine, coastal and terrestrial realms, while 60000 species have been described from the fossil record. ${ }^{37}$ Molluscs comprise a shell generally made of the mineral aragonite, the unstable polymorph of calcite. However, some species such as oysters produce calcite shells. The shell protects the soft tissue of the organism, particularly from predation.

Many species of molluscs frequent specific habitats (environments) such as protected estuaries, as well as open ocean beaches and rocky shorelines, such as shore platforms. Accordingly, they are useful indicators of former environments. Gastropods (single valves such as snails) and bivalves (two valves joined along a hinge line) are the most conspicuous faunal elements in coastal environments.

Although many species of molluscs tolerate a range of water depths, some provide useful information about former water depths at the time they were living, partly because their mode of life was in a specific subenvironment. The Goolwa cockle Donax deltoides, for example, is commonly found shallowly buried in sand within the foreshore setting of high-energy dissipative beaches. The cockle (bivalve mollusc) Katelysia sp. frequents shallow water, protected estuarine environments, and, in particular, $K$. scalarina occurs in intertidal to shallow subtidal settings, while K. rhytiphora tends to favour shallow subtidal environments immediately below the lower limit of the intertidal zone ${ }^{38}$ (Figure 1.3). On a broader scale, some species of molluscs frequent specific faunal provinces and provide information on past temperatures; for example, the South Australian coastline occurs in the Southern Australian Temperate Region. ${ }^{39}$

Fossil molluscs record environmental changes based on extinction events in the geological record. For example, the estuarine bivalve Anadara trapezia, which can 


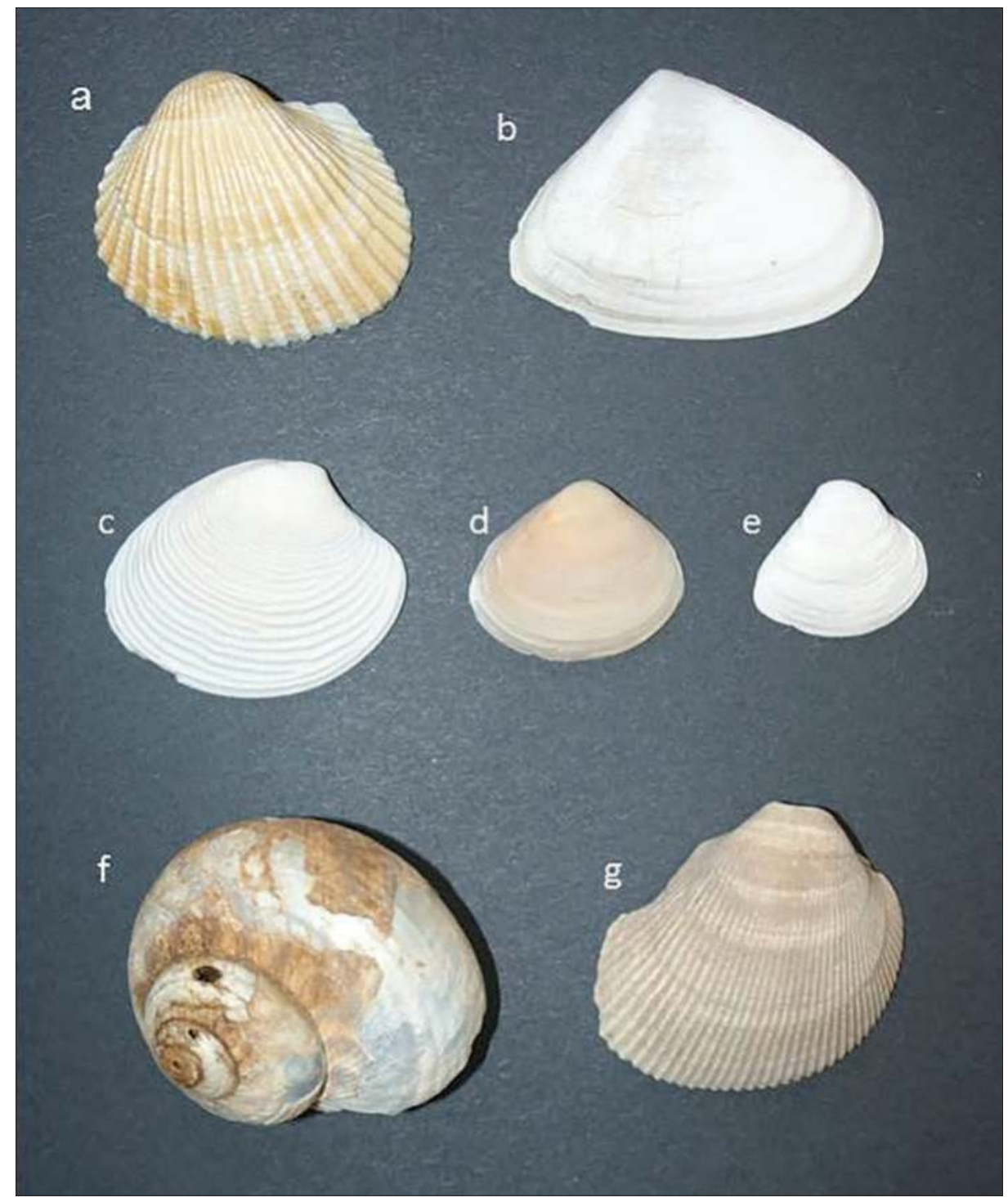

Figure 1.3 Some examples of marine molluscs commonly found in Quaternary coastal sedimentary environments in South Australia.

a. Anadara trapezia (on mudflats within estuaries, and reworked in other coastal sediments - now extinct in South Australia)

b. Donax deltoides (within sandy sediment in the foreshore zone)

c. Katelysia rhytiphora (occurs in shallow subtidal waters immediately below the low water limit of the intertidal zone)

d. Mactra australis (on sandy shoals in the intertidal zone)

e. Notospisula trigonella (within mud or sandy mud in estuaries)

f. Turbo undulatus (on rocky coastlines in the intertidal to subtidal transition)

g. Fulvia tenuicostata (in sand and mud up to a water depth of $30 \mathrm{~m}$ ). 
tolerate a wide range of temperatures, was widespread along the South Australian coast during the Last Interglacial, 125000 years ago, but no longer lives here. ${ }^{40}$ Fossils of $A$. trapezia are commonly associated with other subtropical molluscs such as the Shark Bay pearl oyster Pinctada albina, the conical gastropod Pyrene bidentata, and the foraminifers Marginopora vertebralis, Pseudomassilina australis and Quinqueloculina polygona. ${ }^{41}$ The former more extensive distribution of Anadara trapezia in southern Australia relates to an enhanced Leeuwin Current, which brought warmer water across from the Western Australian coast. This event also coincided with higher, less seasonally concentrated levels of rainfall and river discharge. ${ }^{42}$

\subsection{Subdivisions of the South Australian coastline}

Investigation of the geological evolution of the South Australian coast reveals the presence of discrete sections of the coast with distinctive characteristics that contrast with adjoining sectors and provide a convenient framework for discussion (Figure 1.4). The chapters in this book are broadly arranged in order of proximity to areas of greatest population and ease of access, so that readers may have some awareness of what is being discussed before deliberately travelling the coast. This arrangement also recognises links between adjoining coastal sectors.

After the introductory chapter, the coast of South Australia is discussed in the following order: the coast of metropolitan Adelaide (Chapter Two), Fleurieu Peninsula (Chapter Three), River Murray Estuary (Chapter Four), Coorong Coastal Plain and Limestone Coast (Chapter Five), northern Gulf St Vincent (Chapter Six), Yorke Peninsula (Chapter Seven), northern Spencer Gulf (Chapter Eight), the Gulf Coast of Eyre Peninsula (Chapter Nine), west coast of Eyre Peninsula (The Bight Coast) (Chapter Ten) and Kangaroo Island (Chapter Eleven). A final synthesis chapter (Chapter Twelve) highlights the distinctive characteristics of the South Australian coast.

\subsubsection{Chapter Two: The coast of metropolitan Adelaide}

This section of coast, which occurs in the most populated part of South Australia, provides an excellent example of intense human use of coastal resources and also illustrates problems arising from urban development without due care for coastal processes. Arcuate northeast-southwest trending fault lines, which separate the Mount Lofty Ranges from the coastal plains and produce a series of fault angle depressions filled with Cenozoic limestone and sands, provide the fundamental setting for this section of coast. The faults trend seaward and, where they intersect the coast, uplift has produced resistant bedrock cliffs and headlands. In contrast, in the intervening areas sandy beach compartments occupy the fault angle depressions. The variable nature of the bedrock has produced spectacular cliffs and headlands both on Precambrian 


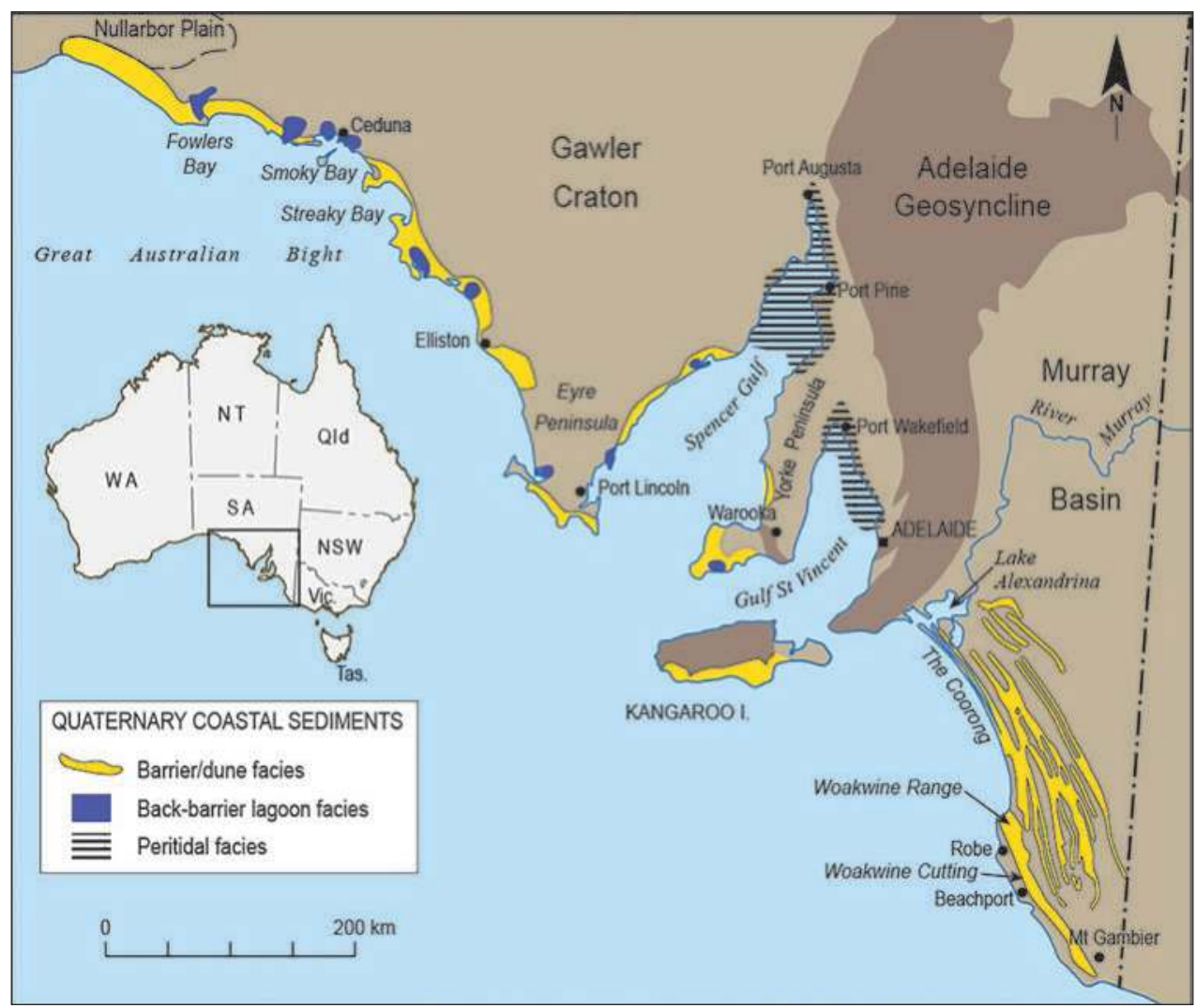

Figure 1.4 Major coastal provinces of South Australia, showing the Quaternary coastal sediments of the South Australian coastline with respect to the major structural settings of the Gawler Craton, gulfs area, Mount Lofty Ranges and the Murray Basin.

Source: Modified from Bourman, R.P., Murray-Wallace, C.V., Belperio, A.P. \& Harvey, N. (2000). Rapid coastal geomorphic change in the River Murray Estuary of Australia. Marine Geology, 170 (1\&2), 141-168.

rocks and on more easily eroded Cenozoic sediments, exposing scientifically important geological sections. Cliff erosion is evident at Blanche Point south of Maslin Beach, where erosion has formed a cliffed coast with a sea stack, Gull Rock. A similar sea stack offshore from Witton Bluff, Table Rock, was completely eroded in 1911.

A series of beach compartments occurs along the coast north from Sellicks Beach to Outer Harbor with sand derived mainly from erosion of pre-existing fluvial, marine and glacial sediments as well as from the continental shelf during the last major rise in sea level. The dominant direction of longshore sediment transport is from the south to the north, but there is little sand bypassing the headlands that separate the bays. 


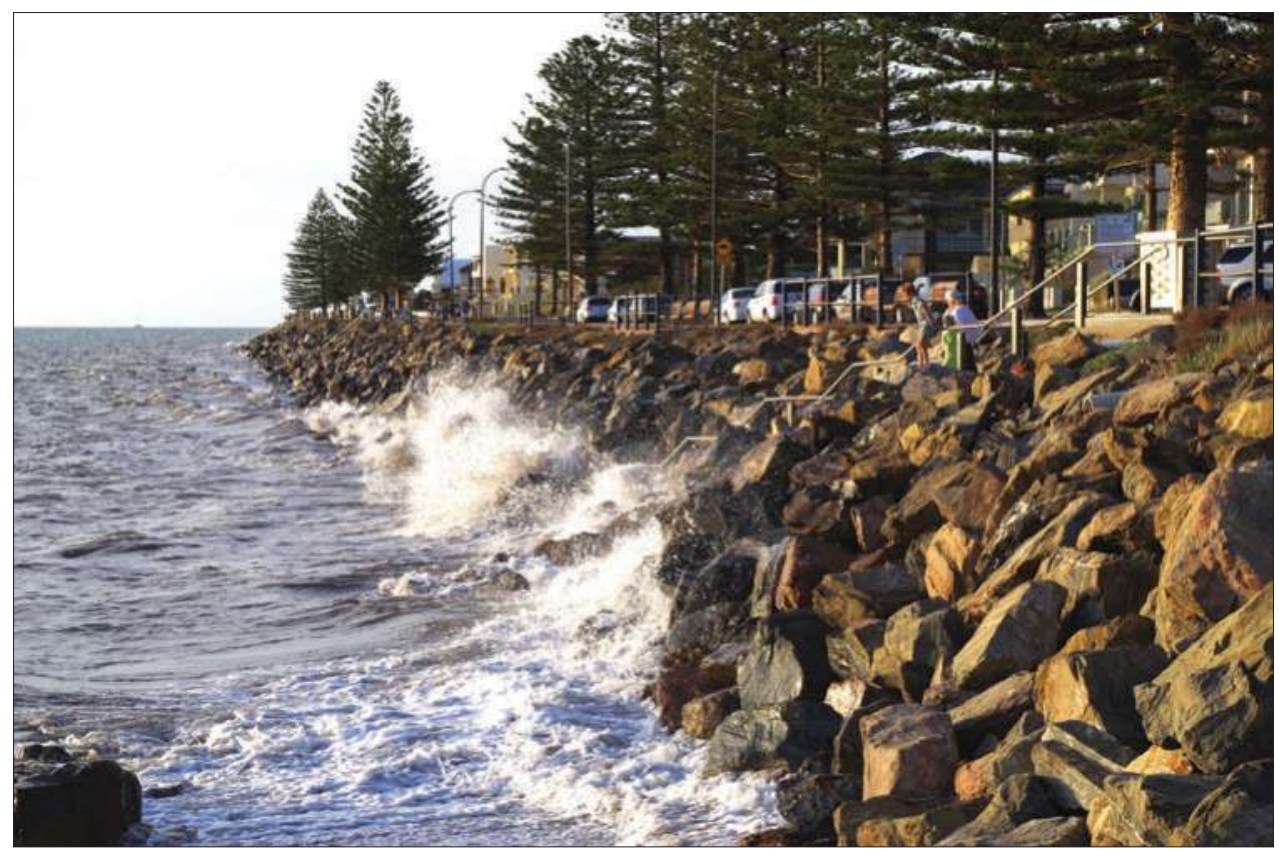

Figure 1.5 View north along the metropolitan coast during high-tide conditions at Brighton in 2014, showing rip-rap boulder protection of the coast. The rock wall is designed to absorb wave energy and allow water to percolate slowly back seawards without scouring the beach. The large facing boulders are progressively underlain by layers of smaller rocks, allowing penetration by water but not of the rocks themselves. Many sections of the metropolitan coast are protected in this way.

Source: Authors' own work, NH.

The largest stretch of sandy beach is from near Marino to Outer Harbor: this stretch of coast, which is $29 \mathrm{~km}$ long, forms the main recreational beaches for metropolitan Adelaide. Constructed by northward drift of sand over the past 7000 years, Le Fevre Peninsula formed as a series of recurved sand spits, sand shoals that protruded into the water. A line of dunes up to $15 \mathrm{~m}$ high and $400 \mathrm{~m}$ wide originally backed the well-nourished beaches. However, as settlement proceeded these dunes were removed, levelled and covered by roads, housing and protective walls (Figure 1.5) until they were isolated from the beach system. They were no longer able to provide a natural source of sand nourishment for the beaches. In addition, there have been many artificial interruptions to the natural northward movement of sand through the construction of breakwaters, groynes and diversions of natural river outlets. An active sand management program has been implemented to nourish the beaches and bypass some of the artificial interruptions to sand movement. Further problems have been caused by runoff from 
the land causing seagrass destruction. Studies show that the supply of sand to Adelaide beaches was naturally running out before the arrival of Europeans, but that human intervention has greatly hastened this trend.

\subsubsection{Chapter Three: The Fleurieu Peninsula coast}

Fleurieu Peninsula is part of the Mount Lofty Ranges and has been uplifted essentially as a single tectonic block. The combination of ongoing uplift and resistant crystalline and metamorphic rocks has led to the development of a rugged, cliffed coastline with isolated pocket beaches, beach compartments and former stranded embayments. The area was glaciated about 300 million years ago during Permian times. Backstairs Passage was carved out by the ice mass and the broad distribution of the granite islands and headlands of Encounter Bay was established at this time. Sandy sediments deposited by the ice have subsequently been transported to the coast by numerous streams, providing

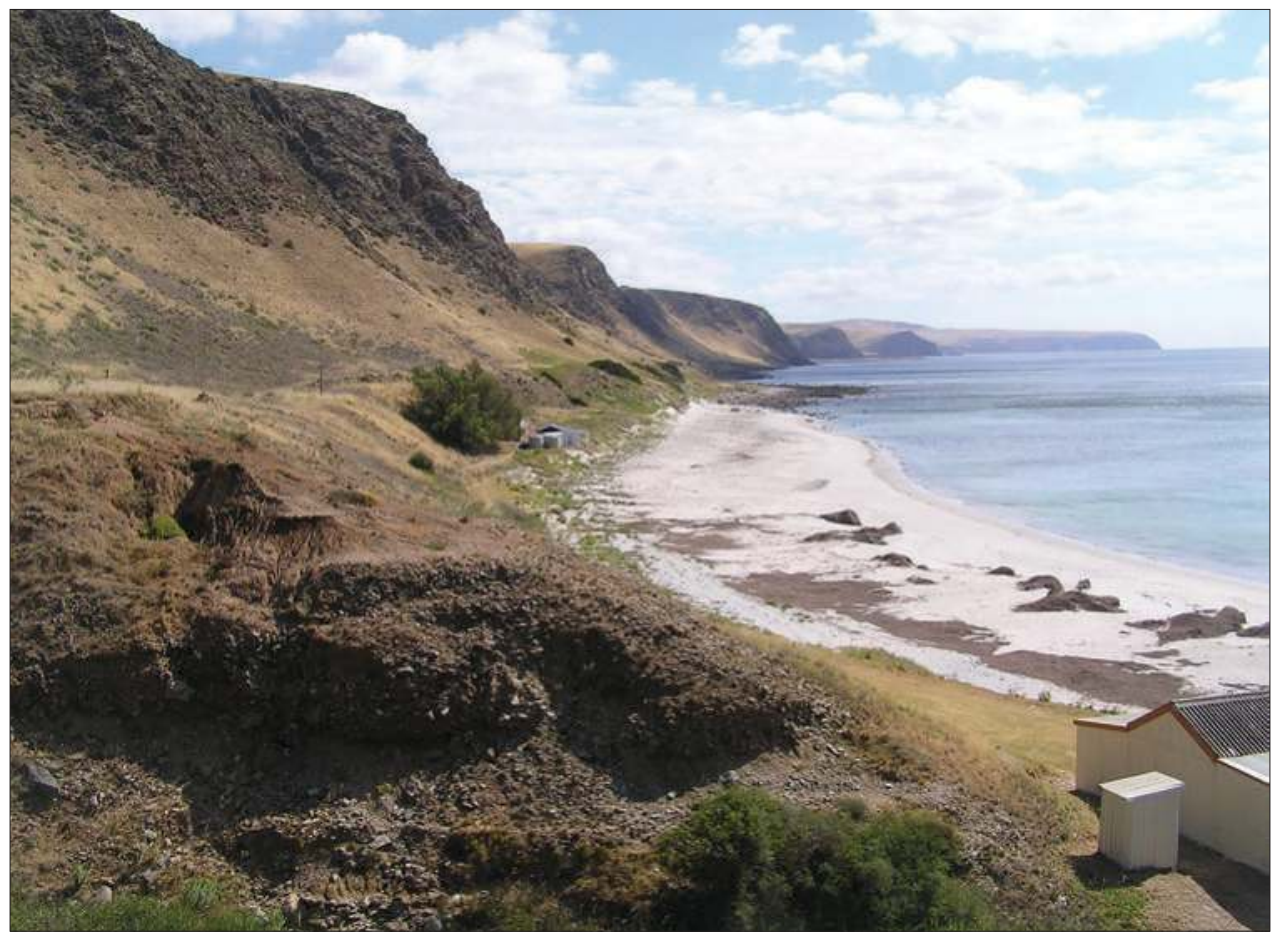

Figure 1.6 View south of Little Gorge to Rapid Head, illustrating a portion of the bedrockdominated western coast of Fleurieu Peninsula. A stranded last interglacial terrace of river gravels is evident in the foreground. The steep cliffs were formed during the high sea level of the Last Interglacial and have subsequently been tectonically uplifted beyond the level of the modern coast, leading to the formation of gentler scree slopes at the foot of the cliff line.

Source: Author's own work, RPB. 
sand for many of the beaches of Fleurieu Peninsula. Abandoned sea cliffs (partly covered with scree deposits), marine benches and river terraces characterise the tectonically uplifted last interglacial (125 ka) embayments at Normanville, Tunkalilla and Victor Harbor (Figure 1.6). Dramatic recent changes to the Fleurieu coastline include natural erosion of the Middleton coastline and the artificial infilling of Rapid Bay.

\subsubsection{Chapter Four: The River Murray Estuary}

The River Murray Estuary includes Lakes Alexandrina and Albert, and the Coorong Lagoon, which have formed by a combination of tectonic subsidence of former coastal barrier systems and interdune corridors, the outfall of Australia's largest river system which flows to the sea, and of the ingress of the ocean. Sea level attained near to its present level some 7000 years ago, when the modern coastal barriers of Sir Richard Peninsula and Younghusband Peninsula began to form. These barriers continue to migrate landwards. The River Murray Mouth area has subsided by more than $2 \mathrm{~m}$ over the past 125000 years. The southern half of Hindmarsh Island formed as an extensive sandflat from about 5000 years ago. Many generations of sand dunes occur in the Murray Estuary area, including distinctive desert sand dunes of red-yellow colouring, which formed about 21000 years ago when sea level was some $125 \mathrm{~m}$ lower than at present. The mouth of the River Murray is in a condition of constant flux; it has migrated through a range approaching $2 \mathrm{~km}$ since the mouth was first surveyed in 1839, but migrations of up to $6 \mathrm{~km}$ have been identified over the past 3000 years.

Construction of barrages has reduced the tidal flow through the mouth by $90 \%$, and extraction of fresh water from the system has reduced river discharge by up to $80 \%$. Associated with these changes has been the progressive growth and consolidation of a flood tidal delta (Bird Island), which is about $1 \mathrm{~km}$ in diameter (Figure 1.7). Additional siltation by sediments pushed into the mouth by flood tides has required major dredging operations to maintain the channel through the mouth to the Coorong to try to maintain its delicate ecosystem.

\subsubsection{Chapter Five: The Coorong Coastal Plain and the Limestone Coast}

The Coorong Coastal Plain and the Limestone Coast of the southeast of South Australia is a classic coastal region of global significance because the interplay between regional neotectonic uplift and regular glacio-eustatic sea level changes has produced an uplifted record of sea level fluctuations over the past 1 million years. There have been more than 45 major episodes of glacier expansion and retreat in the past 3.2 Ma, astronomically driven by regular changes in the configuration of the Earth's orbit around the Sun. For approximately the past 1.2 Ma, these glacial cycles have occurred over intervals of 100000 years involving 90000 years of ice accumulation and sea level fall, followed by 10000 years of warm interglacial conditions with high sea levels. Before 


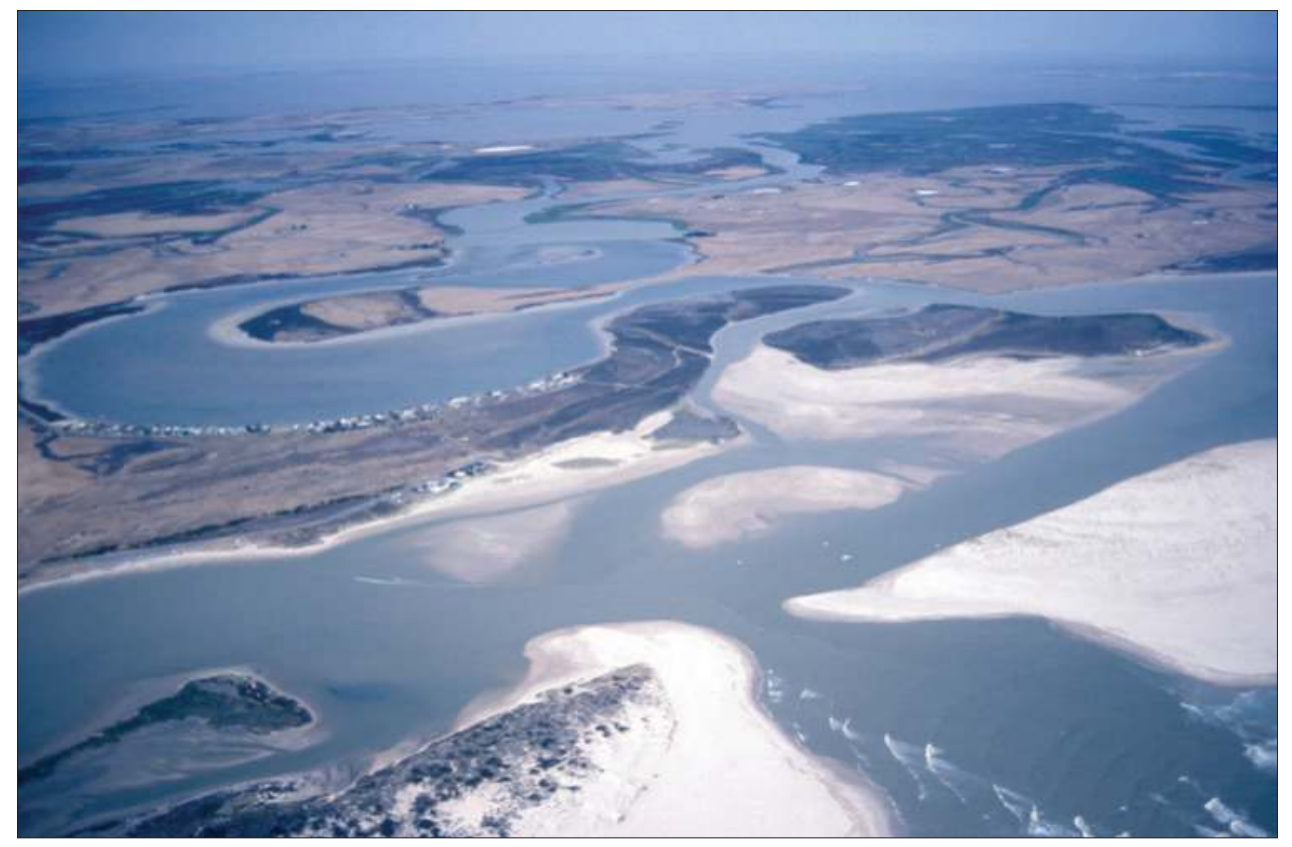

Figure 1.7 Oblique aerial view of the Murray Mouth, the recently formed Bird Island (centre right) and the Mundoo Channel, which is lined with shacks and houses on Hindmarsh Island. The Mundoo barrage separates the salt water of Mundoo Channel from the fresh water of Holmes Creek, to the right of which is Mundoo Island. Note the sand shoals and sandflats in the Goolwa Channel, which are the result of sand delivered through the mouth from the coast by tides and waves.

Source: Authors' own work, RPB.

about 1.2 Ma ago, these changes occurred more frequently, occurring every $41 \mathrm{ka}$, but with lower amplitudes. ${ }^{43}$ Although the rate of tectonic uplift $(0.7 \mathrm{~mm} / \mathrm{yr})$ is slow, it has been sufficient to elevate and preserve many of the relict coastal barriers formed during each high sea level maximum, which approximately reached up to the current level of the sea.

The Coorong Lagoon and Younghusband Peninsula (a coastal barrier) formed over the past $7 \mathrm{ka}$; they are analogues of the preserved, uplifted coastal barriers and interdunal flats between the coast and Naracoorte. These coastal barriers consist of aeolianite, a consolidated carbonate dune sand, preserved and protected by calcrete on their upper surfaces (Figure 1.8). The tectonic uplift and tilting of the coastal barriers downwards towards the Murray Mouth and upwards in the Mount Gambier region is also associated with Quaternary volcanism, which was witnessed by Aboriginal people, the shell middens of whom provide evidence of past activities and coastal change. 


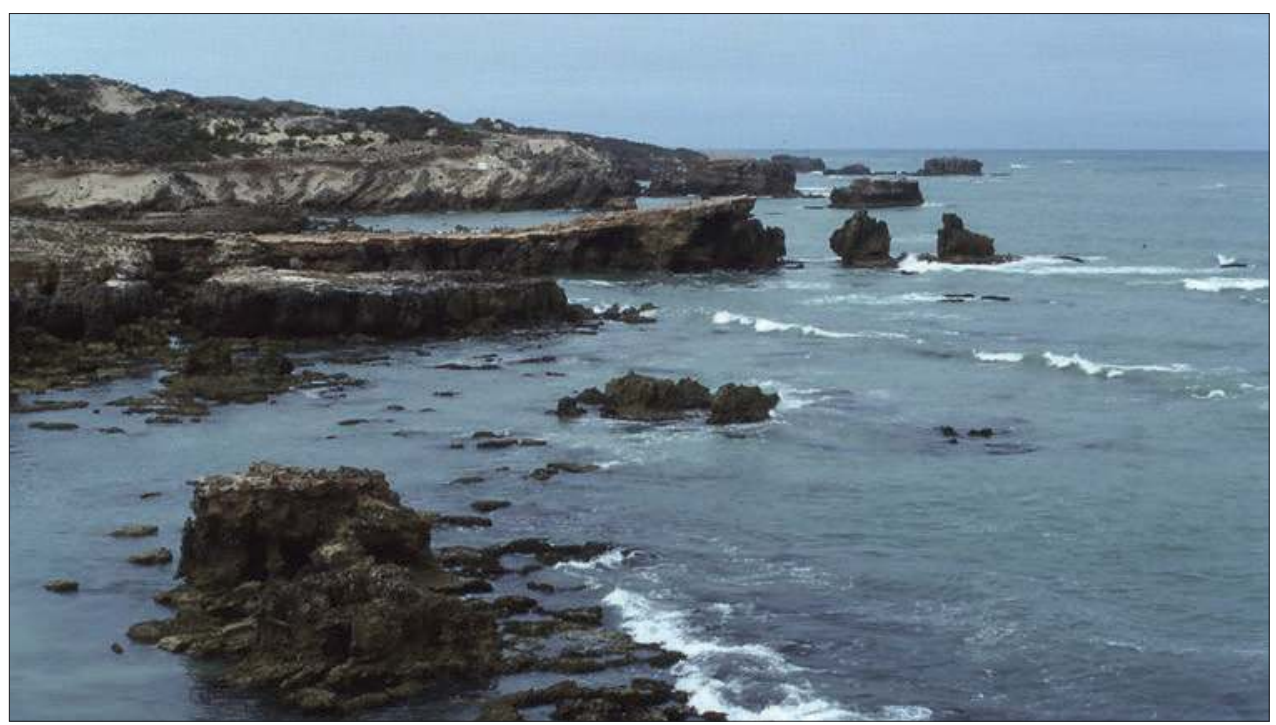

Figure 1.8 Coastal cliffs at Robe developed on consolidated carbonate dune sand (aeolianite) of the Late Pleistocene Bridgewater Formation.

Source: Author's own work, CMW.

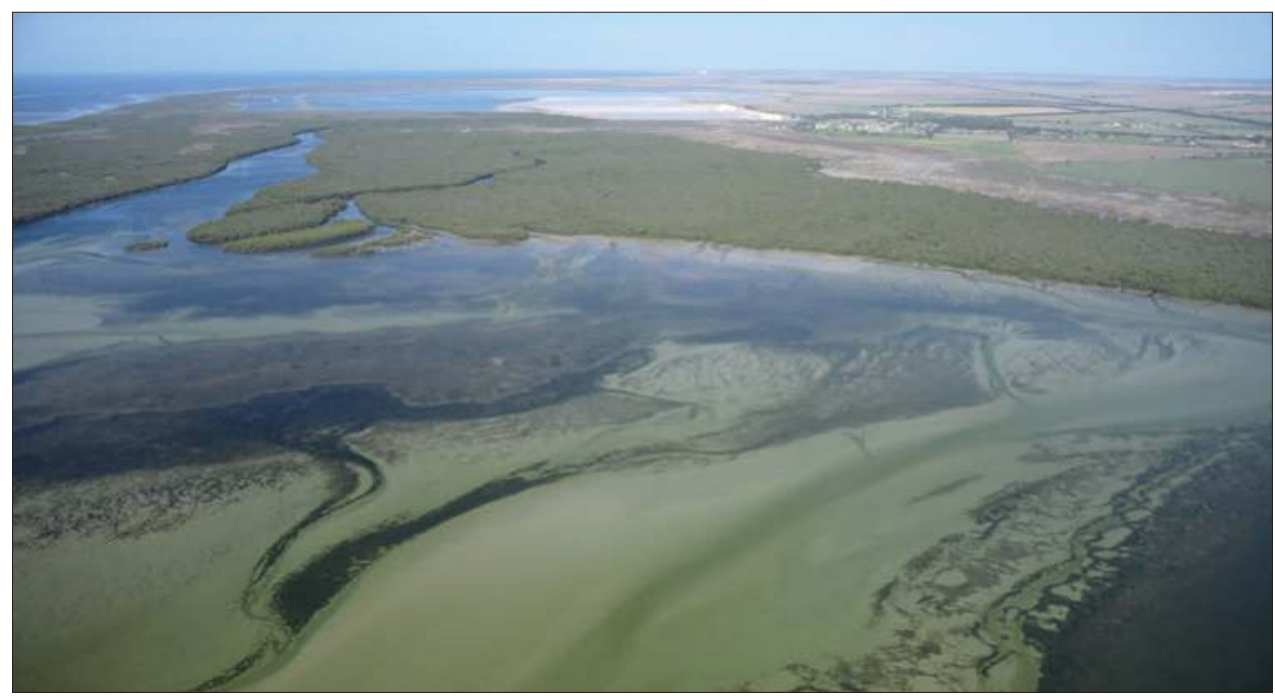

Figure 1.9 View over Wills Creek Conservation Park, northwestern Gulf St Vincent. Note the tidal channels, intertidal sandflat, mangrove woodland, samphire marsh, Price saltpans and silos at Ardrossan.

Source: Reproduced with permission of the Coast Protection Board, 2014. 


\subsubsection{Chapter Six: The northern Gulf St Vincent tidal coastline (the Samphire Coast)}

North of Outer Harbor, the coast changes from sandy beaches to peritidal sequences of seagrass meadows, sandflats, mangrove woodlands, samphire flats and saline marshland, reaching from subtidal zones to supratidal zones, which extend beyond all but the highest tides (Figure 1.9). This change in the character of the coastline reflects the dominance of tidal processes and their interrelationships with peritidal fauna and flora. Seagrasses thrive in the shallow warm waters, while the high productivity of calcareous algae, foraminifers and molluscs results in a vast production of calcareous sediment. Thus biologically driven sedimentation and coastal progradation are effective, generating the resultant wide intertidal and supratidal sand- and mudflats visible today. The basic shape of the coast has resulted from faulting and the spread of alluvial deposits from the Mount Lofty Ranges and Yorke Peninsula. Much of the shoreline is underlain by the calcreted Glanville Formation, which marks the location of the coast 125000 years ago.

\subsubsection{Chapter Seven: The Yorke Peninsula coastline}

Tectonic faulting during the Cenozoic is responsible for the basic shape of the Yorke Peninsula coastline: the peninsula is flanked by the subsiding Gulf St Vincent and Spencer Gulf. Yorke Peninsula has been differentially uplifted, with greatest uplift in the north and along the east coast, which is marked by both abandoned and active cliffs, initiated during the last interglacial sea level, which was $+2 \mathrm{~m}$ high. There is pronounced coastal erosion at Ardrossan in cliffs cut into Hindmarsh Clay of Pleistocene age (Figure 1.10). Rocks of the Gawler Craton underlie much of the peninsula, and these are well exposed on the foot of the peninsula. Swell and waves travel up the gulf and have formed a series of cuspate forelands at Sultana Point, Stansbury, Port Vincent, Black Point, Salt Creek and Coobowie. Swell and waves have also influenced the formation and migration of Troubridge Island, a sand island, which rests on a reef and shares some of the characteristics of the sandy cays on the Great Barrier Reef. At Port Vincent, Port Victoria and Waterloo Bay, Early Permian (299 to 290 Ma old) glacial deposits form sections of the coast, where they provide sandy beach sediments, while the formation of Wardang Island and Point Pearce Peninsula may be partly attributed to erosion by Permian ice. There are extensive Permian deposits across the ankle of the peninsula, which was also a seaway at various times in the past.

The coast from Troubridge Point to Corny Point is exposed to high-energy southwesterly winds and waves, and hence is rugged and varied, particularly between Stenhouse Bay and Corny Point. This section of coast contains steep cliffs cut in aeolianite, with long surf beaches separated by rocky headlands. The beaches are generally coarse-grained, steeply sloping and often have backing active dunes derived from aeolianite. 


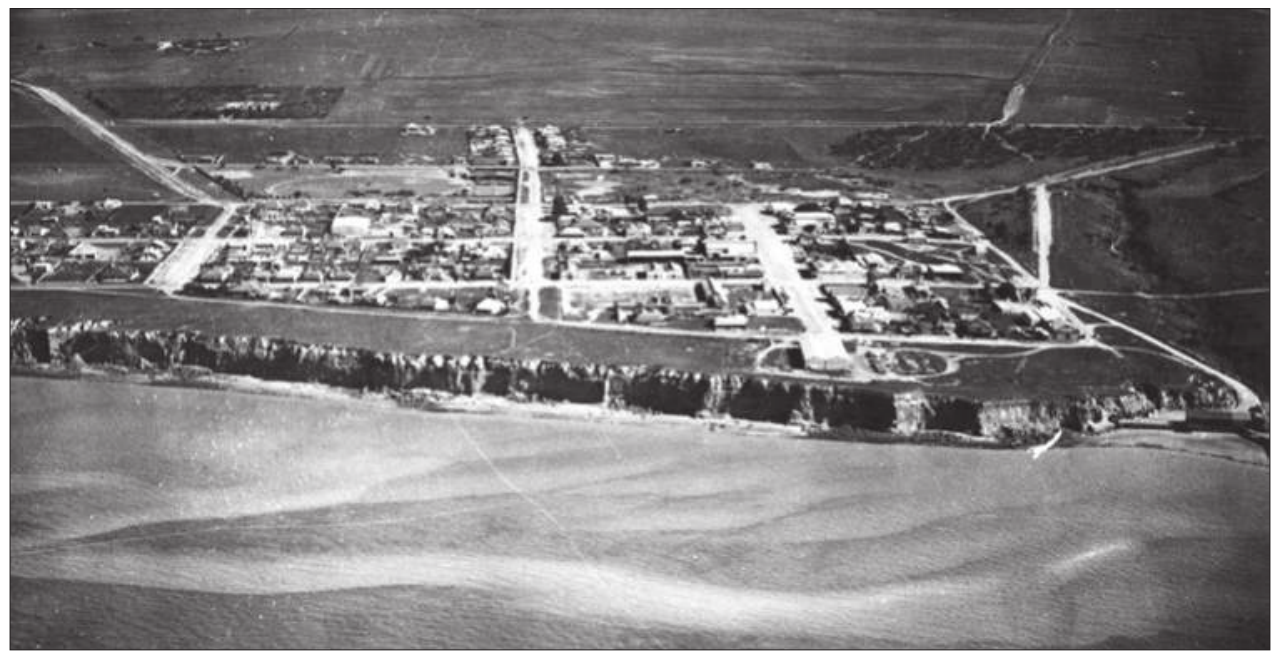

Figure 1.10 Oblique aerial photograph of the eroding sand and clay cliffs at Ardrossan, taken in the 1930s. There is a long history of coastal erosion at this location.

Source: Courtesy of the State Library of South Australia. <www.slsa.sa.gov.au>.

Although the west coast of the peninsula is more exposed than the east coast, very broad intertidal sandflats and rock flats inhibit wave attack. Soft Permian sediments underlie the coast between Point Souter and Port Victoria; much of this coast is backed by low-lying last interglacial embayments, now filled with Holocene dunes and shell ridges. Low cliffs and headlands developed on the last interglacial Glanville Formation separate broad bays. Much of the coast here comprises long sandy beaches and shore platforms with a single dune or a narrow belt of landward dunes. Extensive sandflats are exposed at low tide, but at high tide there is usually only a narrow beach backed by dunes. Exceptions are the limestone cliffs at Point Turton, the rocky coast at Port Victoria, Point Pearce and north of Point Riley, and the clay cliffs at Balgowan and Moonta Bay. Extensive areas of unstable and drifting dunes occur at Hardwicke Bay, south of Port Victoria and at Cape Elizabeth. At Wallaroo and Moonta Bay cliff erosion is presenting hazards to housing. Coastal erosion is also occuring on Wardang Island.

Parts of the Yorke Peninsula coast, such as Innes National Park at the foot of the peninsula, are of great conservation significance. As a holiday playground for many, Yorke Peninsula is experiencing development pressures for marinas, housing and shacks. Some shack sites, in particular, are vulnerable to coastal erosion.

\subsubsection{Chapter Eight: The northern Spencer Gulf coast}

In the sheltered northern Spencer Gulf (Figure 1.11), north of Whyalla-Port Broughton, wave action is restricted, tidal processes dominate and the coastline is characterised 
by thick offshore seagrass meadows, wide intertidal sandflats, mangrove woodlands and supratidal saline marshland. Headlands of bedrock separate open bays on the eastern side of the gulf, where there are large shingle ridges, which are anomalous in that setting given the very limited wave fetch. They have possibly been hydro-isostatically uplifted to their positions above high-tide level during the past 7000 years. Northern Spencer Gulf experiences the highest tides along the South Australian coast due to amplification in the $\mathrm{V}$-shaped and constricted portion of this gulf setting.

\subsubsection{Chapter Nine: The Gulf Coast of Eyre Peninsula}

The east coast of Eyre Peninsula is subdued in character in comparison with the rugged west coast, mainly because of the absence of the large masses of aeolianite (former sand dunes turned into rock), which have been eroded into spectacular high cliffs on the west coast, and the much quieter wave climate in the sheltered Spencer Gulf. Highly stable crystalline rocks of the Gawler Craton underlie most of the coastal zone of the east coast. The southwest to northeast trend of the coast from Port Lincoln to Whyalla

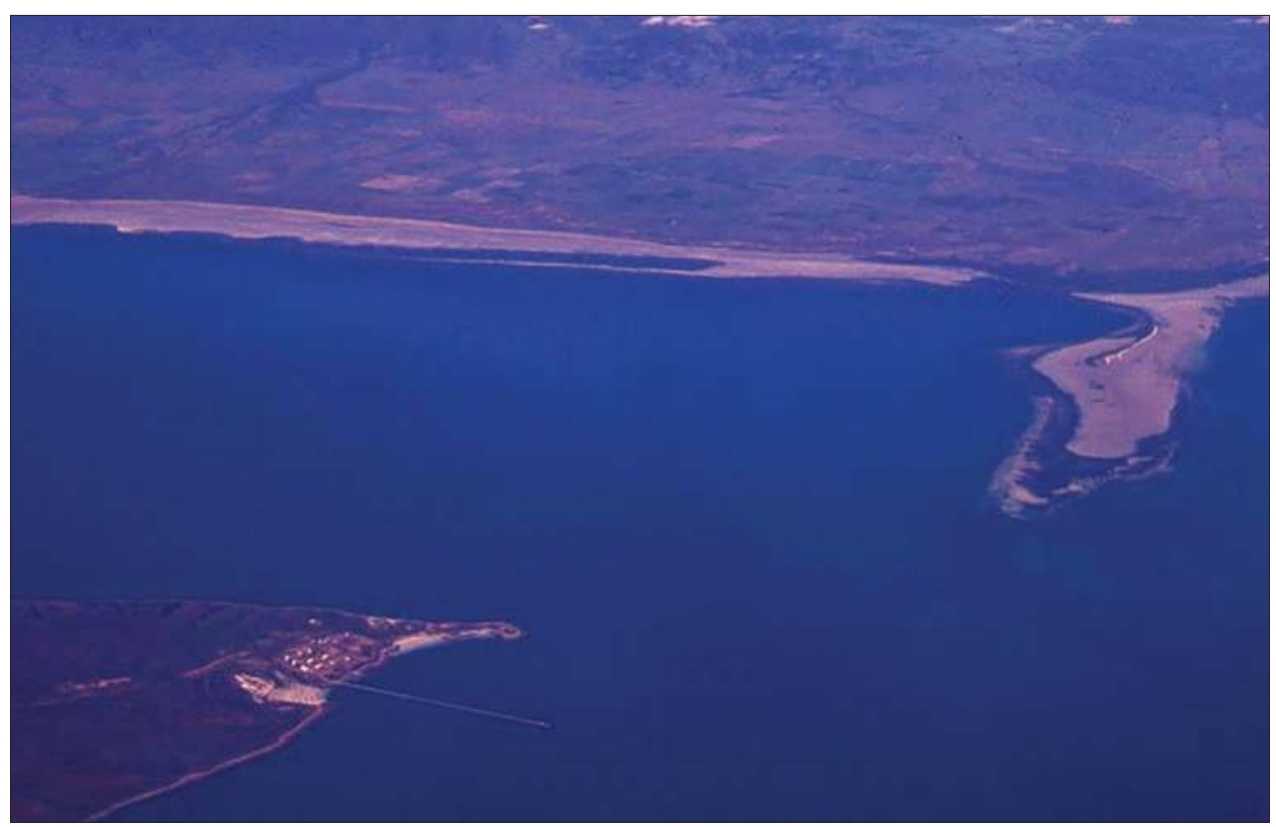

Figure 1.11 View of the northern Spencer Gulf, showing Point Lowly and Port Bonython on the left, Ward Spit on the right, and extensive sandflats and alluvial fans of the Flinders Ranges in the background.

Source: Author's own work, RPB. 


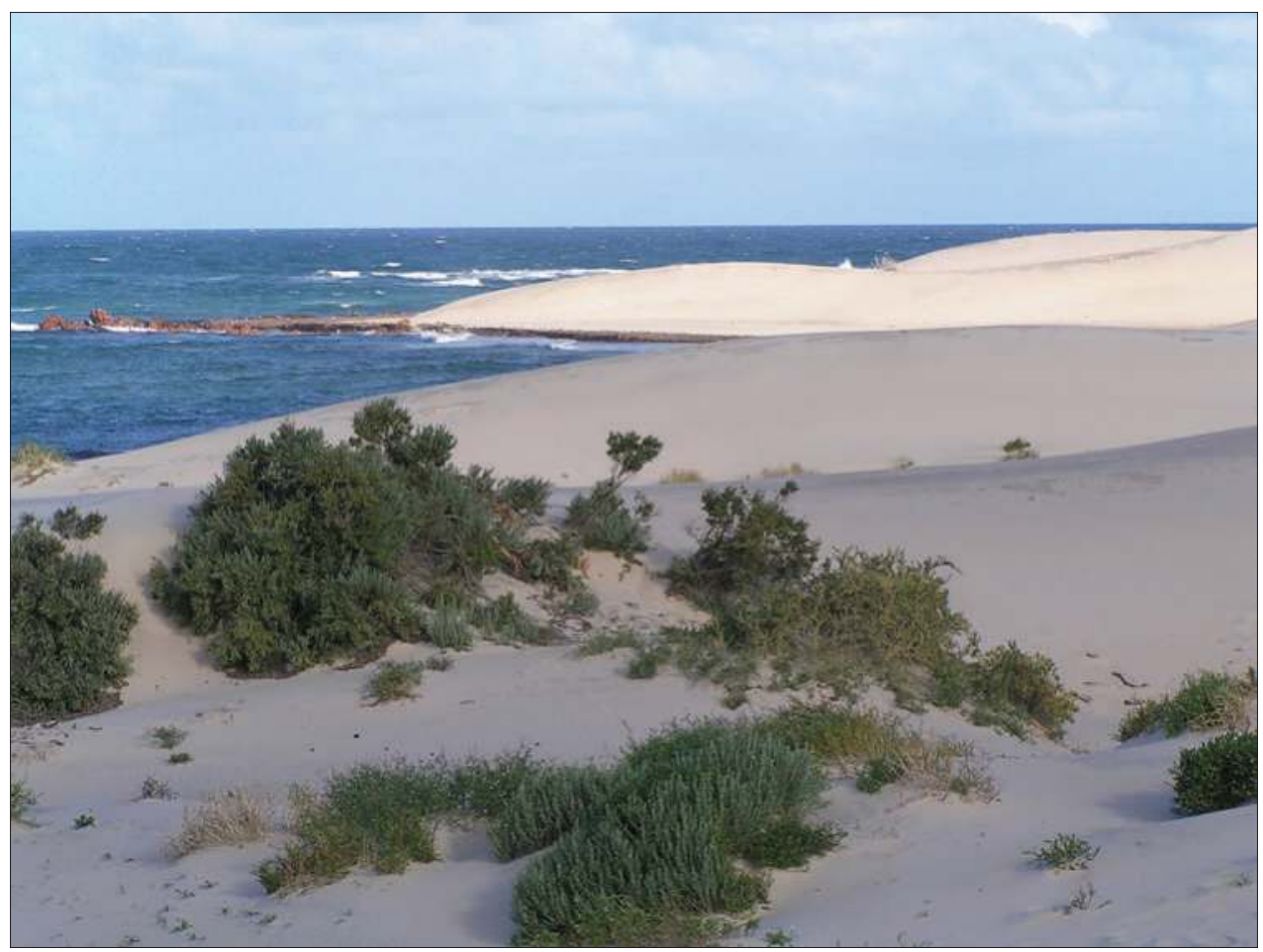

Figure 1.12 Point Gibbon, protected by resistant rocks of the Blue Range Beds and overlain by sand derived from Mills Beach.

Source: Author's own work, RPB.

is broadly associated with observed and inferred faults and associated escarpments that separate uplands from coastal plains. Faulting on the margin of the Gawler Craton has uplifted parts of the peninsula, such as the Lincoln and Cleve Uplands and the Blue Range, which give way to the eastern Coastal Plain that provides the backdrop to the coastline. In some locations, such as the shores of Boston Bay and Port Lincoln proper, the shoreline closely follows the Lincoln Fault. Coastal samphire marshes in places fronted by mangroves occur, such as those on the shores of Franklin Harbor. Elsewhere, disconnected saline lagoons and samphire swamps are isolated from the sea by dune barriers. Active sand dunes occur on Jussieu Peninsula but are rare in the north, apart from those at Mills Beach (Figure 1.12).

\subsubsection{Chapter Ten: The Bight Coast - West coast of Eyre Peninsula}

This rugged section of coast is dominated by ancient, resistant crystalline rocks of the stable Gawler Craton, and aeolianite, the coastal erosion of which has formed 
a cape and bay coastline with imposing cliffs cut into the aeolianite. Large modern dune fields, principally derived from the erosion of aeolianite, commonly back the bay areas. Many islands occur along this section of coastline. The tectonic stability of this coastline makes it a reliable datum from which to measure sea level movements. Large waves, especially from the west and southwest, have contributed to the general rugged character of this section of coastline, but there are some protected embayments such as Baird Bay. The basic arcuate shape of the coast was established about $43 \mathrm{Ma}$ after the Australian and Antarctic continents had separated. Spectacular eroding cliffs form the coast of the Nullarbor Plain (Figure 1.13).

\subsubsection{Chapter Eleven: Kangaroo Island}

Kangaroo Island, a southern extension of the Mount Lofty Ranges of Fleurieu Peninsula, is separated from the mainland by Backstairs Passage, an exhumed glacial valley, carved out by westerly moving Permian ice about 300 million years ago. Relicts of this glaciation occur along the north coast of the island at Christmas Cove, Smith Bay and Boxing Bay. Only 21000 years ago, during a time of low sea level, Kangaroo Island was joined to the mainland. It became an island about 10000 years ago. Several

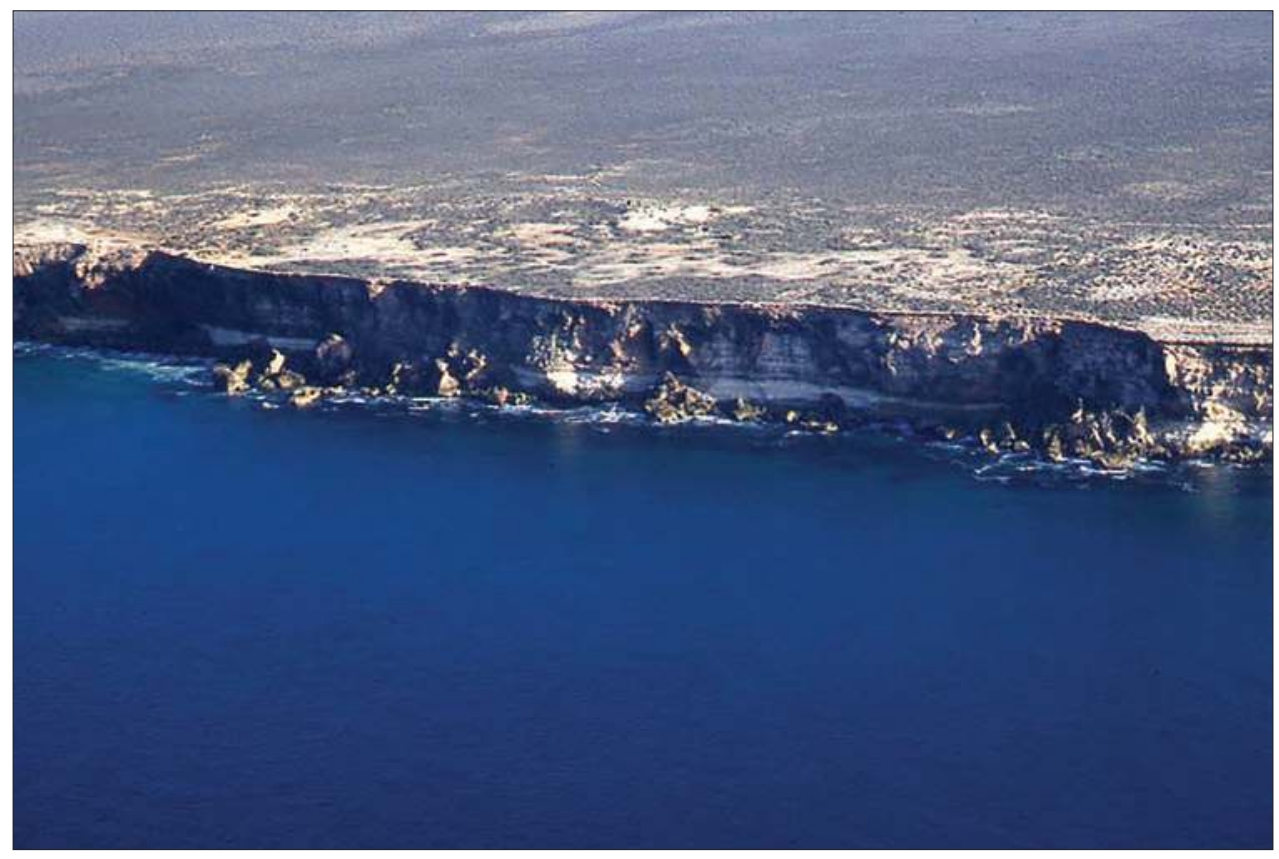

Figure 1.13 Active erosion of the Bunda Cliffs at the edge of the Nullarbor Plain; these cliffs are $100 \mathrm{~m}$ high. Note the irregular cliff top and the rock falls at the base of the cliffs. Source: Author's own work, RPB. 


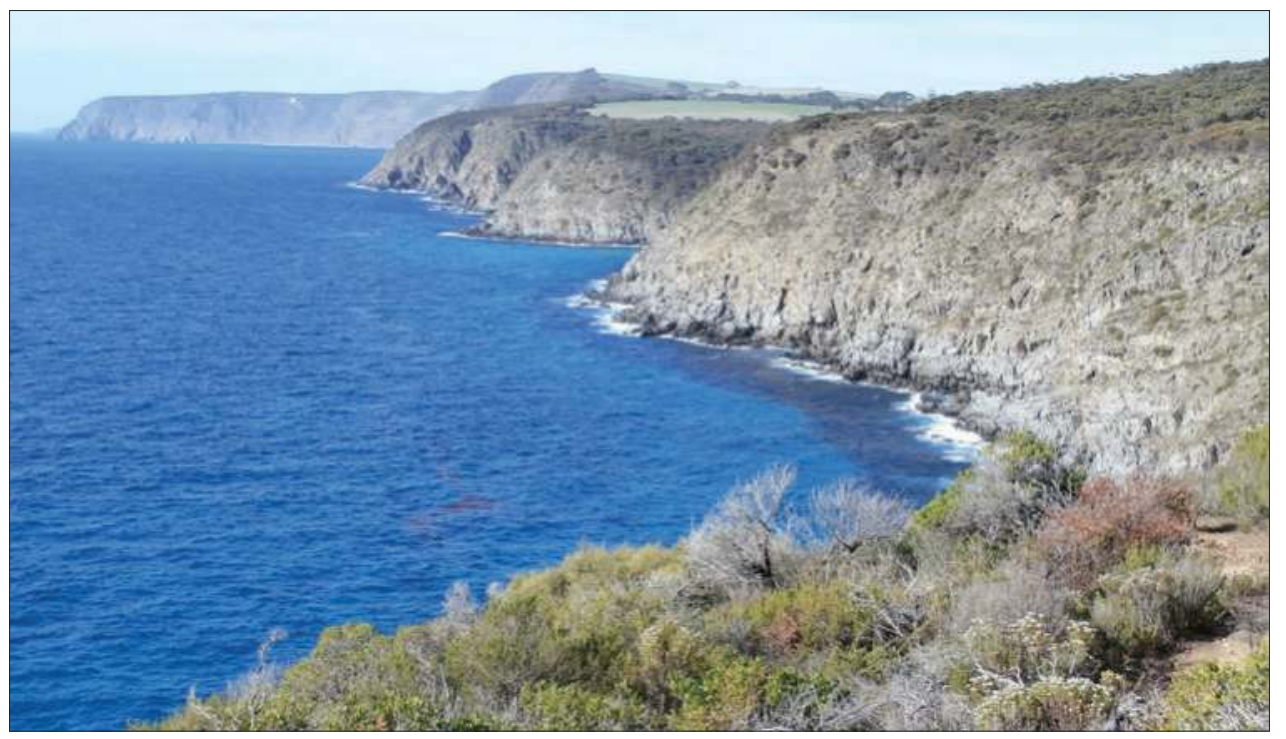

Figure 1.14 View from Scott Cove towards Cape Torrens and Cape Forbin on the northwest coast of Kangaroo Island. The cliffs, cut into Kanmantoo Group metasediments of Cambrian age (500 Ma), exceed $200 \mathrm{~m}$ in height.

Source: Author's own work, RPB.

times in the past, Kangaroo Island has been divided into two islands, the Dudley Peninsula and a larger western island, when there were seaways through the Pelican Lagoon area. ${ }^{44}$

Kangaroo Island preserves a remarkable diversity of coastal features. The island has been tectonically uplifted in the northwest and tilted down towards the southeast, leading to the formation of high rugged cliffs on parts of the north and west coasts, where Cambrian and Precambrian rocks are exposed (Figure 1.14). Granitic headlands such as Cape Willoughby and Remarkable Rocks, which punctuate the east and south coasts, are coeval with the Encounter Bay Granites on the mainland. Extensive coastal carbonate dune deposits (aeolianites) blanket large sectors of the southern coast of the island, and occur sporadically on the north coast (for example, Emu Bay). The aeolianites preserve a rich and lengthy record of environmental change spanning the past 1 million years, with near-shore marine shell beds and paleosols interbedded within the thick dune limestones. The ancient soils formed at times of lower sea level than present or in interdune swales. Broad open pocket beaches and bedrock-dominated coastlines with shore platforms and gravel beaches are also common features of the island's coastline. Spectacular coastal features include Admirals Arch at Cape du Couedic, the Remarkable Rocks and Cape Willoughby, various elevated beach deposits, 
Prospect Hill, Mt Thisby (a large Holocene sand dune), and unconsolidated coastal dune sands at Little Sahara and Vivonne Bay. Nearby, offshore, are giant submarine canyons, which are amongst the largest in the world.

\subsection{What kinds of landforms occur along the South Australian coast?}

Coastal landforms can be broadly subdivided into erosional and depositional landforms.

\subsubsection{Landforms and processes of eroding coasts}

Landforms characteristic of retreating or eroding coastlines include cliffs, commonly with undercut notches at their bases, arches, blowholes, stacks, shore platforms and headlands. The processes of erosion are sometimes so active that direct observation of erosion is possible. For example, in 1911 a small sea stack on the Adelaide coast, Table Rock, was swept away, exposing Witton Bluff to additional wave attack. ${ }^{45}$ The coastlines at Ardrossan on Yorke Peninsula and at Middleton on the south coast between Port Elliot and Goolwa have also suffered considerable erosion since European settlement ${ }^{46}$ and regular, almost weekly, collapse occurs along the cliffs of the Nullarbor (Figure 1.13) according to local tourist operators. Cliff lines with crenulated shapes when viewed from above indicate that rapid active erosion is occurring, and such sites should be avoided for permanent development. There are great variations in rates of coastal erosion. On some very resistant rocks, virtually no coastal recession may have occurred in the past 7000 years, while up to $1 \mathrm{~km}$ of coastal recession has occurred in aeolianite near Robe during this time, and cliffs developed in alluvium have retreated at rates of up to $4 \mathrm{~m}$ per year. ${ }^{47}$

The detailed features of these erosional landforms depend not only on the severity of the coastal processes but also on the nature of the rock forming the coastline. For example, the spectacular, cliffed coasts such as those of the Great Australian Bight have developed on flat-lying calcareous bedrock and differ considerably from the granite-cliffed coast of Cape Willoughby (Kangaroo Island). This, in turn, differs from the rugged coast of southern Fleurieu Peninsula, where steeply dipping resistant metasedimentary rocks crop out, and from the low-cliffed coast of southeastern South Australia cut into consolidated aeolianite.

The essential character of coastal landscapes is a reflection of major geological structures such as folds, faults, and the dips and strikes of rocks, which commonly control the broad orientation of rocky shorelines. The detailed character of the coast is commonly reflected in the relative resistance of the rocks to erosion as influenced by their mineralogical compositions and susceptibilities to weathering. Different coastal features will develop depending on whether the rocks are uniformly soft or hard, or alternating soft and hard; whether they are horizontal, dipping or contorted; and whether they possess joints and other lines of weakness. Erosional processes readily exploit any pre-existing weathered zones that come into contact with the present 
coastline. The effectiveness of these processes of erosion is related to the degree of exposure of the coast to wind, current and wave attack, especially during storms, which can be exacerbated by tidal influences. Changes in relative sea level due to tectonic movements of the land or to global (eustatic) changes in ocean volume also leave their imprint on the coast.

\subsubsection{Wave action}

Wave action, a dominant coastal process, is generated by the frictional drag between wind and water. Elliptical movements within the uppermost water column cause a waveform to move shorewards with minimal lateral movement of water until the wave starts to break. Where strong winds are blowing onshore, driving waves to the coast, the waves are steep, having a relatively short wavelength but a large height. Wavelength is the horizontal distance between successive waves; wave height is the vertical distance between the crest of the wave and its lowest point or trough; and wave period is the time taken in seconds for successive wave crests to pass a fixed point. Wave amplitude may be confused with wave height, but it is only half the value of height as it is the distance from a centre line, or still position, to the top of a crest or to the bottom of a trough. On breaking, steep waves tend to scour the beach, moving sand from the beach face to form an offshore bar; these waves are called forced or destructional waves. Fetch, or the distance of open water over which waves can build up, can influence wave size. For example, open ocean waves have a large fetch (a large body of open water over which the waves can develop), whereas those in sheltered coasts such as gulfs have a limited fetch, resulting in smaller waves.

Waves often break at the shoreline even when there is no wind, or they may even approach the coast into an offshore wind. This type of wave may have been initiated considerable distances out to sea by storms, and the wave disturbance from the storm has persisted well beyond the storm's influence. Such swell waves, sometimes referred to as free or constructional waves, have longer wavelengths and smaller wave heights than forced waves. The swash of swell waves moves beach sediment from offshore bars onto the beach face building up a beach ridge or berm.

It has been observed that waves tend to break due to frictional drag of the wave base on the sea floor, when the water depth is approximately half of the wavelength. Because of this, water depths at the break initiation can be estimated. The following formula ${ }^{48}$ can be used to estimate the wavelength of waves by noting the time taken for the passage of successive open water crests past a fixed point, taking the average of multiple readings.

Wavelength (in metres) $=1.56 \mathrm{~T}^{2}$

( $\mathrm{T}$ is the wave period, the time in seconds for the average passage of successive crests.)

For example, if the wave period were 10 seconds, the wavelength would be $1.56 \times 10 \times 10=156 \mathrm{~m}$. 
Waves have been noted to effectively erode to a depth of at least $10 \mathrm{~m}$ due to the elliptical movement of particles involved in the wave motion. Sediment may be moved at depths greater than $10 \mathrm{~m}$ for fine-grained sediment, but the erosional capacity of this movement is minimal. Because wave energy is rapidly dissipated by frictional retardation, there is a severe limit to the lateral extent of wave erosion. Wave erosion of platforms is probably limited to less than $500 \mathrm{~m}$ unless erosion is accompanied by a slowly rising sea level or slow depression of the land. Rock resistance is another important factor in explaining the lateral extent of shore platforms.

Waves may also result from earthquakes, volcanic eruptions or large-scale slope failures. Waves resulting from these processes are often incorrectly called tidal waves when, in fact, they are completely independent of tides. Triggered by the above processes, these waves, known as tsunamis or seismic sea waves, have extremely long wavelengths of hundreds of kilometres, a very limited height that is virtually unnoticeable on the open ocean, and a speed of several hundred kilometres per hour. On reaching a coastline, tsunamis can build up to great heights, causing great damage and loss of life.

\subsubsection{Currents}

Thermally driven ocean currents are probably of little significance from a point of view of erosion or transport of coastal sediments. However, they can be very important in providing an environment suitable for appropriate organisms. For example, the Leeuwin Current, an ocean surface current that moves southwards along the Western Australian coastline, extends along the south coast of Australia, thereby transferring warmer water onto the continental shelves of South Australia and providing a habitat for organisms with warmer-water affinities. ${ }^{49}$

Rip, tidal and wave-generated currents have the potential to erode and transport sediment. Rip currents result from the hydraulic build-up of water at the shoreline, due to lateral translation of water by breaking waves. In order to relieve the hydrostatic head, water returns seawards at depth along pre-existing depressions, deepening them as it does so. The deeper water of rips results in a gap in the breaking waves, the rips commonly meeting the beach in megacusps, offshore from which are plumes of sediment. Permanent rips are common on some headlands and may assist sediment transfer between adjoining beach compartments.

The effectiveness of tidal currents depends on the tidal range and the dimensions of the straits or channels through which the tide passes. Long, narrow inlets with high tidal ranges erode or keep tidal channels clear. The flood and ebb tides can redistribute shells and other sediments across intertidal sandflats and contribute to the aggradation (vertical accretion of sediment) and progradation (seaward advance of the coastline) of tidally dominated environments. Wind-induced currents commonly 
follow the direction of longshore drift, and the two processes are sometimes difficult to distinguish.

\subsubsection{Weathering processes}

Weathering processes are particularly active in the coastal zone. Wind-driven waves are the most obvious processes impacting on coasts. Considerable hydraulic power is exerted by waves, particularly storm waves. The weight of water alone can be a very effective process of erosion; there are numerous examples of boulders ranging from $25 \mathrm{~kg}$ to 25 tonnes, which have been lifted by the sea. In addition, air trapped in crevices by waves is compressed only to expand on the retreat of the wave, causing flaking of rock fragments. Cavitation may also result from this process, when, due to high velocity flows, bubbles formed in the water suddenly collapse or implode, causing erosion from shock waves. The contribution of this process to coastal erosion is probably not great, and waves are much more effective erosional agents when armed with sand, pebbles and boulders, which undergo attrition and cause abrasion of the rocky shore. Abrasion by waves carrying sand, pebbles and boulders is often thought of as the dominant process of coastal erosion, undercutting cliffs and forming so-called wave-cut platforms. However, less dramatic but important weathering processes such as solution, alternate wetting and drying, and salt crystallisation weaken the shoreline rocks, while wave action may merely evacuate the weathered debris.

Limestones are very susceptible to solution weathering, even though sea water is heavily enriched in calcium carbonate. Solution may occur at night when $\mathrm{CO}_{2}$ is more soluble due to lower temperatures, causing increased acidity. During the day, dissolved calcium carbonate can be precipitated, dispersed by waves and currents, and deposited on the sea floor. Because there are two tides a day, the processes associated with wetting, drying and salt action on coasts are frequently repeated and so are probably of greater significance than generally thought. Alternate wetting and drying in the splash and tidal zones may be responsible for the breakdown of rocks alone, without involving solutional processes. Enlargement and coalescence of pools on rocks through this process of water-layer weathering assist both the formation and destruction of rock platforms. Various marine plants assist this process by retaining water. Additional biological weathering can occur by marine organisms boring into the rock surfaces, ultimately lowering them. Salt crystallisation is an important weathering process at the coastline as the growth of salt crystals enlarges and weakens crevices in rocks. Because processes other than wave action are involved in coastal erosion it is more appropriate to describe the rock benches at the shoreline as 'shore platforms' rather than 'wave-cut platforms'.

The relative significance of individual coastal processes may vary from place to place. Waves are likely to be most effective as agents of erosion during high-tide and storm conditions, when they approach the shoreline little impeded by friction. 
They are also very effective in reworking unconsolidated beach sediments. Subaerial (surface) processes such as rainwash, gullying, slumping and weathering attack the coastline as well, and in some cases waves only act as a transporting medium, removing the weathered debris from or along the shoreline. Especially where cliff recession is related to mass movements, shoreline retreat can be very rapid. Rapidly eroding cliffed coastlines typically have an irregular, scalloped appearance in plan view and indicate potential danger.

\subsubsection{Landforms and processes of depositional coasts}

The accumulation of unconsolidated sediments of clay, silt, sand, pebbles, cobbles and boulders forms distinctive depositional coastal landforms. The most important processes affecting depositional landforms are those related to wind and waves. When waves approach the coast at an angle and break, the swash also moves up the beach at an angle to the trend of the shoreline. Some of the swash will percolate into the beach, but the remainder runs back down the beach as backwash, roughly perpendicular to the shore. Consequently, a series of successive waves will transport beach sediment (for example, sand and pebbles) in a zigzag path along the beach face. Sediment in the surf zone between the outer line of breakers and the beach face is moved along the shore in a similar fashion; in fact, more sediment is transported beneath the water in the surf zone than on the beach. Movement of sediment along the shore by these processes is called longshore drift. Some experimental work has suggested that longshore drift is at a maximum when the wave front approaches the shoreline at an angle of $30^{\circ} .50$

Longshore transport of beach sediment commonly leads to the deflection of river mouths, the accumulation of sediment in front of both natural and artificial obstacles, and to the growth of sand spits and bars into bays and harbours. These features provide morphological and sedimentary evidence of the dominant direction of longshore sediment transport, but some experimental investigations can throw further light on this process. Sometimes nature can provide distinctive rock types of limited distribution which can be dispersed along a beach over thousands of years and may diminish in size away from the source area. Flints associated with the Gambier Limestone of the southeast area of the State provide an example on the Limestone Coast. It is very useful in understanding and managing coastlines to establish the direction of longshore drift, the source of the sediments, the ultimate sediment 'sink' or depositional site and the volumes of sediment involved.

Currents are of limited significance in transporting sediment along beaches, possessing insufficient energy to move significant amounts of sand-sized material. Moreover, spits and bars have been observed to form in lakes and wave tanks where there are no currents. Consequently, longshore transport of material along beaches by wave action is most important in forming depositional coastal landforms. 
Sandy shorelines typically exhibit beaches with offshore bars and backing sand dunes. These are commonly flanked by headlands, which constrain beaches within distinct beach compartments. Sand spits may grow out from sandy beaches into bays to produce recurved spits or hooks; triangular spits (cuspate forelands) often form in the lee of near-shore islets (for example Granite Island) and may form links to the mainland as tombolos. Sand bars are often formed in bays as bay-mouth, mid-bay and bay-head bars. In estuaries, sand can be delivered from the coast into tidal inlets forming flood tidal deltas, sandflats and coastal wetlands, which can include mudflats, salt marshes and salt flats. The permanence of these features can be affected by river runoff from the land, but generally in South Australia, apart from the River Murray estuary, coastal processes dominate over flows from the land due to the generally low discharge from rivers and due to the semi-arid climatic conditions. Even in the case of the River Murray there is no classic river delta where it enters the sea. ${ }^{51}$

\subsubsection{Beaches}

Many beaches display a seasonal rhythm. During calmer summer months, constructive waves with a frequency of about 13 to 16 waves per minute carry sand shorewards to build up the beach. Dry sand is subsequently blown landwards to form a foredune immediately at the back of the beach. Destructive waves with a greater frequency of 6 to 8 per minute, especially during winter storms when high tide levels are accentuated, tend to scour the beach and dune, carrying sand seawards, where it is deposited in offshore bars only to be moved landward once more during quieter wave conditions. Wave energy, which is expressed in wave steepness (that is, the ratio of wave height to wavelength), determines whether waves will erode or build up a beach. Some wave tank experiments suggest that summer-type beach profiles build up when wave steepness in deep water is $<0.03 .^{52}$ Beaches are accordingly dynamic features representing sediment masses in motion onshore, offshore, alongshore, or all three of these with time.

Beach sediment may be derived from offshore sources, particularly from the inner continental shelf above the wave base of storm waves, delivered to the coast by rivers or streams, sourced from coastal erosion, or conveyed to the beach by longshore transport. Much of the sediment on the South Australian coast is of biogenic origin derived from the physical breakdown of molluscs, bryozoans, foraminifers and coralline algae from the continental shelves. ${ }^{53}$ In tidally dominated environments, vast amounts of biogenically produced sediments have caused the build-up and seaward growth of the shorelines in sheltered settings (for example, northern Spencer Gulf). On wave-dominated open ocean coasts, comminuted calcareous marine organisms along with quartz and other minerals were swept landwards during rising sea levels of the Pleistocene to form beaches and dunes that were later lithified into aeolianite. Much of this material has been recycled during subsequent fluctuations in global sea level, when 
the high sea levels repeatedly reached similar elevations. Coastal erosion, particularly of susceptible materials such as aeolianites, Cenozoic sands and limestones, Permian glacigene sediments and Quaternary alluvial and colluvial sediments provide much sediment to the beaches. Erosion of the older and harder rocks makes only a small contribution. Beach sand delivered by streams is very limited in South Australia. The River Murray has made some alluvial contributions to the Encounter Bay shoreline ${ }^{54}$, while considerable volumes of Permian glacigene sediments have been delivered to the beaches of Fleurieu Peninsula by streams such as the Inman, Hindmarsh and Bungala rivers. Erosion of alluvial fan and/or glacial sediments can provide vast amounts of coarse clasts, sand and clay for beaches. Fine clays are usually dispersed into the sea, where they settle out but may be reactivated from time to time by storm waves; sand forms a beach in the intertidal zone, while coarse sediment forms boulder and shingle ridges at the back of the beach. If there is little sand in the sediment, the beach may consist entirely of shingle. Generally, the coarser the beach sediment the steeper the beach face. Sand beaches can carry slopes of only a few degrees, whereas cobble and pebble beaches may slope seawards at angles of up to $17^{\circ}$.

The vast majority of the world's sandy coastlines are undergoing erosion. This is especially noticeable where structures have been built near the shoreline, providing a datum from which erosion can be measured. There are many potential explanations for this phenomenon including both natural and human-induced causes. ${ }^{55}$ Mining, deforestation and agriculture, including overgrazing, all of which lay areas of land bare, may increase sediment supply to streams, and this, when delivered to the coast, may result in coastal progradation and well-nourished beaches. Serious erosion in unconsolidated Permian glacial sediments in the Inman Valley resulted in the coastline at Victor Harbor near the mouth of the Inman River prograding up to $15 \mathrm{~m}$ between 1920 and 1970. ${ }^{56}$ However, subsequently improved agricultural practices greatly reduced the amount of sediment reaching the coast and the shoreline is currently being actively eroded. In some cases, excessive erosion from the land can have deleterious impacts on marine life. For example, smothering with sediment derived from erosion of alluvial fan deposits by Sellicks Creek has impacted on the Aldinga Reef.

Dam construction will reduce the delivery of sediment to beaches. Beach erosion can also be related to reduction in sand supply due to breakwater, groyne and seawall construction, deliberate sand removal from beaches and backing dunes, and landward drift of sand resulting from destruction of dune vegetation by the intensive passage of people and vehicles. Artificial breakwaters can alter the angle of wave approach and focus erosion on a stretch of beach formerly in equilibrium with the natural conditions, such as near the causeway at Victor Harbor. ${ }^{57}$ At Rapid Bay, the coastline prograded seawards 230 m when quarried waste material was dumped between 1940 and 1970 . The coast remained relatively stable until 1982 when dumping ceased, after which the coastline retreated rapidly. ${ }^{58}$ 
Natural causes of erosion include glacio-eustatic rises in sea level, tectonic subsidence of the land, increased storminess, reduction of sediment supply to coasts due to reduced rainfall, decreased supplies of sediment from eroding cliffs, and losses of sand by landward migration of dunes. Under natural conditions, the coastline of the River Murray Estuary was undergoing erosion due to two main causes: during its evolution the coastal dune/barrier system has migrated landward, exposing back-barrier sediments on the modern beach, and the region has experienced tectonic subsidence. Following earthquake activity in about 1900, the coast at Middleton retreated about $400 \mathrm{~m}$ over a period of 20 years, and there is ample evidence of the long-term tectonic subsidence of this section of coastline. ${ }^{59}$

A universal factor influencing coastal erosion is the cessation of sea level rise, which in southern Australia occurred about 7 ka ago. During sea level rise, sediment was constantly being delivered to beaches, but when sea level stabilised, the supply of beach sediments from the inner continental shelf was significantly reduced. ${ }^{60}$ Bowman and Harvey demonstrated that the Adelaide coast has a finite sand source and that pulses of sediment deposition on the coast decreased in magnitude during the Holocene from a maximum of 64000 to $81000 \mathrm{~m}^{3}$ per year between 7000 and 5000 years ago, to 27000 to $44000 \mathrm{~m}^{3}$ per year (4000 to 3000 years ago), and to 10000 to $17000 \mathrm{~m}^{3}$ per year between 2000 and 1000 years ago. ${ }^{61}$

The shape of beaches in plan view commonly has resulted from the refraction of waves, except where there are strong structural influences. Especially where the coast is composed of a series of headlands and bays, the plan view of the beach is often remarkably coincident with the wave refraction pattern, which is clearly evident on aerial photographs. Originally linear wave crests approaching shallow water at headlands and islands bend or refract as the wave passage is delayed at headlands but continue unimpeded in the deeper water of the bays.

The orientation of some South Australian beaches has been determined by the refraction of open ocean swell waves from the Southern Ocean. Davies demonstrated that swell waves approaching the coast with a 14-second period between successive wave crests bottom on the shallowing sea floor and mould the sandy beaches into their present configuration, explaining the sweeping arcuate coastline of Encounter Bay from Middleton to Cape Jaffa. ${ }^{62}$

\subsubsection{Coastal dunes}

Systems of coastal dune ridges, parallel to the coast, commonly back the shores of sandy beaches and at times even occur atop steep cliffs. Dunes derive sand from beaches, which in turn are supplied with sand from alongshore or offshore sources. The dunes may also provide a source of nourishment for eroded beaches. Coastal vegetation is of prime importance in stabilising sandy coastlines and in explaining 
coastal evolution and modification. ${ }^{63}$ Plants trap drift sand and encourage the growth of sandflats, beach ridges and dunes. Most of the South Australian shoreline presents a hostile environment for plants due to high summer temperatures, exposure to strong winds, saline conditions, porous sandy soils, sand blast and burial by drifting sand. Some of the coastal plants have affinities with hardy desert vegetation.

Foredunes at the backs of beaches are colonised by plants such as Spinifex, whereas the older secondary dunes have greater diversity of plant cover. The typical sequence from the beach landwards includes a foredune at the back of the beach colonised by dune grasses, which aid the growth of the dune by trapping sand. Inland from the foredune, successive hind dunes separated by swales display a plant succession to scrub and woodland.

In South Australia, common primary colonisers of beach ridges and foredunes include the native plants of Spinifex (Spinifex sericeus) and Coast fescue (Austrofestuca littoralis), and introduced sand stabilisers such as Coastal rocket (Cakile maritima), Marram grass (Ammophila arenaria), Sea spurge (Euphorbia paralias) and Sea wheatgrass (Thinopyrum junceiforme). The introduced plants have impacted on the ecology and geomorphology of the coastline, as they are more effective trappers of sand than the native species, which are displaced, leading to the formation of new dunes, the enhancement of foredunes and ridges and the formation of sand hummocks, thereby leading to the narrowing of beaches ${ }^{64}$ as well as restricting the development of blowouts and landward sand movement essential for regeneration of dune ecosystems. Pyp grass (Ehrharta villosa) in the dune areas is particularly effective in preventing drift but can smother the native grasses and shrubs, transforming the natural character of dune areas. The plants have been introduced, deliberately or accidentally, and dispersed by wind or water.

The older hind dunes carry a greater diversity of plants that include groundcovers, creepers, shrubs, bushes and small trees. Common plants include Coastal wattle (Acacia longifolia), Pigface (Carpobrotus rossii), Coast cherry (Exocarpus syrticola), Sea-heath (Frankena cupularis), Coast daisy-bush (Olearia axillaris), Thyme riceflower (Pimelea serpyllifolia), Common boobialla (Myoporum insulare), Knobby club rush (Isolepis nodosa), Variable groundsel (Senecio lautus), Muntries (Kunzea pomifera), Dune fanflower (Scaevola calendulacea), Bower spinach (Tetragonia implexicoma), Cushion bush (Calacephalus brownii), Native correa (Correa reflexa), Seaberry saltbush (Rhagodia candolleana) and the introduced African boxthorn (Lycium ferocissimum).

The main dune systems are aligned parallel with the coast as transverse dunes, and are commonly stabilised by dune vegetation. However, once vegetation is disturbed, blowout dunes, normal to the coast, can evolve into larger transgressive dune sheets with associated migrating parabolic dunes, and these may smother the vegetated secondary transverse dunes. Where large areas are devoid of sand and where the coast is 


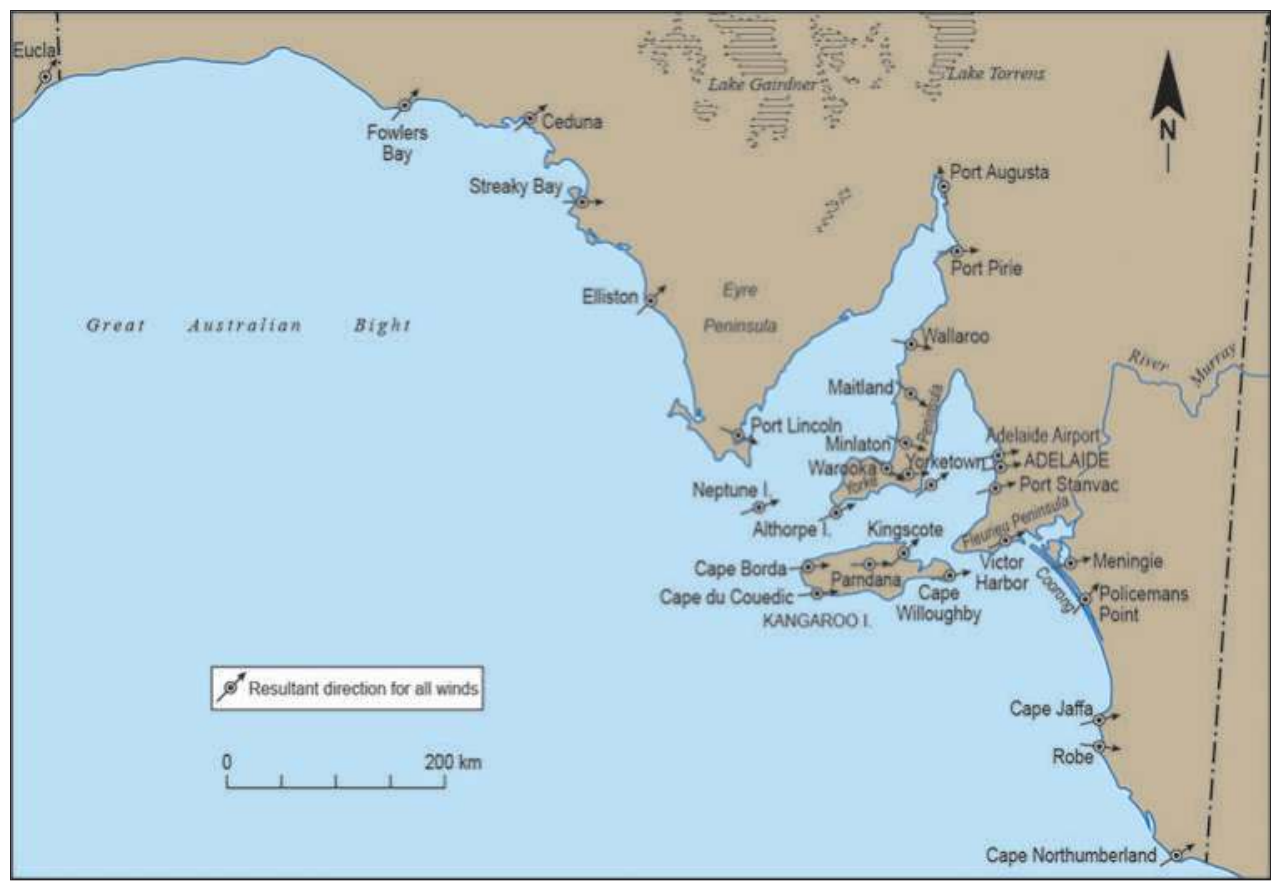

Figure 1.15 Resultants of sand-shifting winds along the South Australian coast, calculated using the Landsberg (1956) formula, which demonstrates the dominance of onshore southwesterly winds. ${ }^{72}$

Source: Modified from Bourman, R.P. (1979). Geomorphological contributions to Coastal Management. In: Corbett, D. \& Sibly, J. (Eds), Southern heritage: Proceedings of the Conference Focus on our southern heritage. Conservation Council of South Australia and the Department of Continuing Education, The University of Adelaide, pp. 80-88.

exposed to strong winds, transgressive dune sheets may migrate landward quite rapidly. The horns or wings of the parabolic dune (also known as hairpin or U-dunes) point upwind and are usually fixed by vegetation, whereas the central unvegetated part of the dune migrates downwind. The axial orientation of the parabolic dune coincides with the resultant forces of winds that are capable of moving sand.

Sand drifts may be initiated by human impacts such as grazing and vehicular access in dune areas, and deliberate removal of dune vegetation. There are many examples of human-induced sand drifts that have migrated over roads along the Coorong ${ }^{65}$ and the telegraph station at Eucla. However, pre-European drifts have occurred. For example, Matthew Flinders noted large areas of sand drift on the Younghusband Peninsula on his maps in $1802 .{ }^{66}$ Some drifts also occurred earlier during colder, drier and windier climatic conditions, when there was reduced vegetation cover. Sand drifts may be 
initiated by storm waves breaching foredunes, thereby providing strong onshore winds with ample sand supplies for landward dune migration. Sand drifts are important in disturbing older senescent vegetation on dunes and providing opportunities for vegetation regeneration. ${ }^{67}$

Landsberg developed a formula demonstrating a close relationship between the orientation of the axis of parabolic, hairpin or U-shaped dunes and local wind regimes. ${ }^{68}$ Later, Jennings established that it is the onshore winds which source sand from beaches that play the dominant role in U-shaped dune formation. ${ }^{69}$ As wind speeds increase, they are exponentially more effective in moving sand. Figure 1.15 only shows the resultant direction for all winds and not the actual length of the resultant, which would indicate the erosional potential at given sites. ${ }^{70}$ The localities in South Australia with the greatest erosion potentials include Fowlers Bay, Neptune Islands and the Althorpe Islands, with the nearby Daly Head dunes exhibiting massive drift. ${ }^{71}$

\subsubsection{Aeolianite or dune limestone}

Former coastal dunes cemented by calcium carbonate, known as aeolianite (dune limestone) have an extensive distribution along the South Australian coastline and are mapped as the Bridgewater Formation. ${ }^{73}$ Sedimentary successions of aeolianite occur on western Eyre Peninsula, southwestern Yorke Peninsula, Kangaroo Island (especially the south coast), and along and inland of the Coorong and Limestone Coasts in the southeast of South Australia.

These now consolidated dunes were deposited along former sandy shorelines during relatively high interglacial or interstadial stands of the sea during the Pleistocene $e^{74}$, especially during the past 1 million years. Although partially lithified (turned into rock), original bedding structures formed during dune development are still discernible, revealing sedimentary layers dipping at various angles. The sand was deposited at different angles depending on whether the sand was being blown up to the dune crest or tumbling down the advancing dune face. Known as cross-bedding, these internal dune structures can be used to reveal the wind direction during the formation of the dune. Resistant layers of calcrete, lithified parts of fossil soils, commonly preserve the original dune topography. Waves, shallow water currents and aeolian processes were responsible for the landward entrainment of the bioclastic sediments that were later incorporated into the dunes.

Aeolianite typically comprises sand-sized $(0.063$ to $2 \mathrm{~mm})$ fragments of skeletal carbonate derived from the physical breakdown of marine invertebrates such as molluscs, echinoids, bryozoans, corals and coralline algae. Foraminifers, sponge spicules and non-carbonate minerals such as quartz and heavy minerals are also commonly present. The vast aeolianite deposits on the South Australian coast illustrate the high bio-productivity of the surrounding shelf environments and are part of the 
world's largest aeolianite province, which extends from western Victoria to north of Shark Bay, Western Australia. ${ }^{75}$ Aeolianites have sometimes been described by the nongenetic term 'calcarenite', as subaqueous processes deposited some facies within these successions. Although by definition calcarenites contain $>50 \%$ calcium carbonate as framework grains and cement, some aeolianites have been noted to have as little as $10 \%$ by mass of calcium carbonate. ${ }^{76}$

\subsubsection{Tidally dominated shorelines}

In shallowing, sheltered, tidally dominated gulfs, embayments, estuaries and inlets, enhanced biogenic carbonate production and the accumulation of the resulting marine organisms cause the build-up (aggradation) and seaward growth (progradation) of the coastline. There are marked zones in these peritidal environments, which are dependent upon marine animals and vegetation for their formation and preservation. In subtidal zones, seagrasses dominate, and in intertidal areas mangroves thrive, while samphires occupy areas occasionally inundated. Areas above high tides are marked by salt-resistant vegetation species.

Tidally dominated shorelines occur within regions characterised by low wave energy so that tidal forces influence coastal landscape development. The small fetch over which winds may generate waves ensures that the northern portions of Spencer Gulf and Gulf St Vincent are tidally dominated landscapes. In these shallow water settings, the amplitude of tides is also accentuated due to the large volume of water channelling into the shallow, funnel-shaped portions of these northern gulfs.

Coasts influenced by tidal processes are characterised by extensive mud- or sandflats. The advancing flood tides add fine sediment particles to the surfaces of mud- and sandflats. The cohesive nature of the sediment renders it difficult to be remobilised by the receding, ebb tides. As a result, the flats build up slowly and uniformly in a vertical direction (accrete).

Commonly there is a systematic zonation in marine aquatic plants which relates to the frequency and magnitude of inundation by sea water, which in turn influences the types of sediments deposited in these environments. Seagrasses such as the longbladed seagrass Posidonia australis grow prolifically in subtidal environments, and play an important role in promoting sedimentation by baffling currents and depositing sedimentary particles. They are succeeded landwards by low intertidal sandflats with Zostera and Heterozostera seagrasses. Mangroves such as Avecinnia marina (the grey mangrove), for example, grow within the intertidal zone (specifically from mean sea level up to near spring high-tide level) and form laterally persistent woodland fringes along the margin of the intertidal to supratidal transition. They give rise to distinctive, highly organic and strongly reduced muds where there is no oxygen. Samphire marsh associations occur landward of the mangrove fringe, dominated by Halosarcia- 
Sarcocorina and Sclerostegia-Halosarcia respectively and by saltbush (Atriplex spp.) in the more landward situations.

Distinctive suites of marine animals colonise each vegetation zone. For example, the bare sandflats of the intertidal zone host numerous intertidal molluscs (such as Katelysia scalarina and Anapella cycladae) and tiny foraminifera. These live on and beneath the surface of the sandflat ${ }^{77}$ and assist the build-up of the shoreline and its seaward growth. Mangrove areas are hosts to a range of gastropods, bivalves, foraminifera and diatoms.

In the supratidal environment, bare sandflats with carbonate sediment dominate the landscape. Marine waters, apart from during occasional high-energy storm events, seldom inundate this region. Beach ridges representing the general former position of shorelines or the result of episodic storms occur in this setting. Commonly the ridges are composed of large accumulations of reworked marine shells derived from subtidal environments. In these settings in the northern gulfs, characterised by a semi-arid climate where evaporation far exceeds rainfall, evaporative minerals such as salts and gypseous clays are formed.

\subsection{A final comment}

Achieving a basic understanding of the discussion in this chapter should provide the reader with sufficient information to raise levels of curiosity, to be able to ask fundamental questions about the South Australian coast and to begin to understand the way in which this coast has evolved. This general information will be used in explaining the evolution of various sections of the South Australian coast in succeeding chapters.

\section{Notes}

1 Harvey, N., Belperio, A.P., Bourman, R.P. \& Bryan, B. (2000). Regional coastal vulnerability assessment using Holocene geological mapping of the northern Spencer Gulf, South Australia. Asia Pacific Journal on Environment and Development, 6 (2), 1-25.

2 Ludbrook, N.H. (1980). A guide to the geology and mineral resources of South Australia. Handbook 4, Department of Mines and Energy, South Australia, 230 pp.

3 Preiss, W. (1987). The Adelaide Geosyncline: Late Proterozoic stratigraphy, sedimentation, palaeontology and tectonics. Geological Survey of South Australia, Bulletin 53, D.J. Woolman, Government Printer, South Australia, Adelaide, 438 pp.

4 Ludbrook (1980).

5 Preiss (1987).

6 Preiss (1987). 
7 Thomson, B.P. (1969). The Kanmantoo Group and Early Palaeozoic tectonics. In: Parkin, L.W. (Ed.), Handbook of South Australian Geology. Geological Survey of South Australia, pp. 97-108; Preiss, W. (1990). A stratigraphic and tectonic overview of the Adelaide Geosyncline, South Australia. In: Jago, J.B. \& Moore, P.S. (Eds), The evolution of a late Precambrian-early Palaeozoic rift complex: The Adelaide Geosyncline. Geological Society of Australia, Special Publication, 16, pp. 1-33.

8 Daily, B., Firman, J.B., Forbes, B.G. \& Lindsay, J.M. (1976). Geology. In: Twidale, C.R., Tyler, M.J. \& Webb, B.P. (Eds), Natural history of the Adelaide Region. Royal Society of South Australia, Adelaide, pp. 5-42.

$9 \quad$ Milnes, A.R. \& Bourman, R.P. (1972). A Late Palaeozoic glaciated granite surface at Port Elliot, South Australia. Transactions of the Royal Society of South Australia, 95, 149-155.

10 Bourman, R.P. \& Alley, N.F. (1990). Stratigraphy and environments of deposition at Hallett Cove during the Late Palaeozoic. Mines and Energy Review, South Australia South Australian Department of Mines and Energy, 157, 68-82.

11 Daily, B., Milnes, A.R., Twidale, C.R. \& Bourne, J.A. (1979). Geology and geomorphology. In: Tyler, M.J., Twidale, C.R. \& Ling, D. (Eds), Natural history of Kangaroo Island. Royal Society of South Australia, Adelaide, pp. 1-38; Milnes, A.R., Cooper, B.J. \& Cooper J.A. (1982). The Jurassic Wisanger basalt of Kangaroo Island South Australia. Transactions of the Royal Society of South Australia, 106 (1), 1-13; Alley, N.F., Bourman R.P. \& Milnes, A.R. (2013). Late Paleozoic Troubridge Basin sediments on Kangaroo Island, South Australia. MESA Journal, 70 (3), 18-37.

12 Milnes, Cooper \& Cooper (1982).

13 Veevers, J.J. (Ed.) (2000). Billion-year Earth history of Australia and neighbours in Gondwanaland. Gemoc Press, Sydney.

14 Gradstein, F.M., Ogg, J.G., Schmitz, M. \& Ogg, G. (2012). The Geologic Time Scale 2012. Elsevier, Boston.

15 Rudwick, M.J.S. (2014). Earth's deep history: How was it discovered and why it matters. The University of Chicago Press, Chicago, 360 pp.

16 Gradstein, Ogg, Schmitz \& Ogg (2012).

17 Ludbrook (1980).

18 Inman, D.L. \& Nordstrom, C.E. (1971). On the tectonic and morphologic classification of coasts. Journal of Geology, 79, 1-21.

19 Sheard, M.J. (1995). Quaternary volcanic activity and volcanic hazards. In: Drexel, J.F. \& Preiss, W.V. (Eds), The geology of South Australia, Vol. 2, The Phanerozoic. South Australian Department of Mines and Energy Bulletin, 54, pp. 264-268.

20 Wopfner, H. (1970). Permian palaeogeography and depositional environment of the Arckaringa Basin, South Australia. In: Haughton, S.H. (Ed.), Second Gondwana Symposium, Pretoria, South Africa, Proceedings and Papers. Council for Scientific and Industrial Research, Pretoria, pp. 273-291.

21 Milnes, Cooper \& Cooper (1982).

22 Veevers (2000).

23 Nakada, M. \& Lambeck, K. (1989). Late Pleistocene and Holocene sea-level change in the Australian region and mantle rheology. Geophysical Journal, 96, 497-517. 
24 Murray-Wallace, C.V. \& Woodroffe, C.D. (2014). Quaternary sea-level changes: A global perspective. Cambridge University Press, Cambridge, 484 pp.

25 Murray-Wallace \& Woodroffe (2014); Harvey, N., Belperio, A.P. \& Bourman R.P. (2001). Late Quaternary sea levels, climate change and South Australian coastal geology, Chapter 17. In: V. Gostin (Ed.), Gondwana to greenhouse: Environmental geoscience - an Australian perspective. Australian Geological Society of Australia Special Publication, 21, 201-213.

26 Boutakoff, N. (1963). The geology and geomorphology of the Portland Area. Geological Survey of Victoria, Memoirs, 22, p. 172.

27 Sayles, R.W. (1931). Bermuda during the ice age. Proceedings of the American Academy of Arts and Sciences, 66, 381-467.

28 Eisenhauer, A., Zhiu, Z.R., Collin, L.B., Wyrwoll, K-H. \& Eichstatter, R. (1996). The last interglacial sea level change: New evidence from the Abrolhos islands, West Australia. Geologische Rundschau, 85, 606-614.

29 Murray-Wallace, C.V. \& Belperio, A.P. (1991). The last interglacial shoreline in Australia - A review. Quaternary Science Reviews, 10, 441-461.

30 Murray-Wallace, C.V., Bourman, R.P., Prescott, J.R., Williams, F., Price, D.M. \& Belperio, A.P. (2010). Aminostratigraphy and thermoluminescence dating of coastal aeolianites and the later Quaternary history of a failed delta: The River Murray Mouth region, South Australia. Quaternary Geochronology, 5, 28-49.

31 Mitchell, W. (1999, May). Australian mean sea level survey. Permanent Committee on tides and mean sea level Circular 43.

32 Belperio, A.P. (1993). Land subsidence and sea level rise in the Port Adelaide estuary: Implications for monitoring the greenhouse effect. Australian Journal of Earth Sciences, 40, 359-368; Harvey, N., Belperio, A.P., Bourman, R.P. \& Mitchell, W. (2002). Geologic, isostatic and anthropogenic signals affecting sea-level records at tide-gauge sites in southern Australia. Global and Planetary Change, 32, 1-11.

33 Ludbrook, N.H. (1976). The Glanville Formation at Port Adelaide. Quarterly Geological Notes, Geological Survey of South Australia, 57, 4-7; Ludbrook, N.H. (1984). Quaternary molluscs of South Australia. Handbook, 9. Department of Mines and Energy, South Australia, $327 \mathrm{pp}$.

34 Murray-Wallace \& Belperio (1991); Murray-Wallace, C.V., Belperio, A.P. Cann, J.H., Huntley, D.J. \& Prescott, J.R. (1996). Late Quaternary uplift history, Mount Gambier region South Australia. Zeitschrift für Geomorphologie. N.F., Supp. Bd 106, 41-56.

35 Barnett, E.J., Harvey, N., Belperio, A.P. \& Bourman, R.P. (1997). Sea-level indicators from a Holocene, tide-dominated coastal succession, Port Pirie, South Australia. Transactions Royal Society of South Australia, 121 (4), 125-135.

36 Harvey, Belperio, Bourman \& Mitchell (2002).

37 Beesley, P.L., Ross, G.J.B. \& Wells, A. (Eds) (1998). Mollusca: The southern synthesis, fauna of Australia, Vol. 5. CSIRO Publishing, Melbourne, Part A \& Part B, 1234 pp.; Taylor, P.D. \& Lewis, D.N. (2005). Fossil invertebrates. Natural History Museum, London, 208 pp.

38 Roberts, D. (1984). The genus Katelysia (Bivalvia: Veneridae) in southern Australia. Journal of the Malacological Society of Australia, 6, 191-204.

39 Wilson, B.R. \& Gillett, K. (1971). Australian shells: Illustrating and describing 600 species of 
marine gastropods found in Australian waters. Reed Books, Sydney, 168 pp.

40 Murray-Wallace, C.V., Beu, A.G., Kendrick, G.W., Brown, L.J., Belperio, A.P. \& Sherwood, J.E. (2000). Palaeoclimatic implications of the occurrence of the arcoid bivalve Anadara trapezia (Deshayes) in the Quaternary of Australasia. Quaternary Science Reviews, 19, 559-590.

41 Cann, J.H. \& Clarke, J.D.A. (1993). The significance of Marginopora vertebralis (Foraminifera) in surficial sediments at Esperance, Western Australia, and in last interglacial sediments in northern Spencer Gulf, South Australia. Marine Geology, 111, 171-187.

42 Murray-Wallace, Beu, Kendrick, Brown, Belperio \& Sherwood (2000).

43 Lisiecki, L.E. \& Raymo, M.E. (2005). A Pliocene-Pleistocene stack of 57 globally distributed benthic d18O records. Paleoceanography, 20, PA1003, 1-17.

44 Milnes, Lindsay, Ludbrook \& Cooper (1983).

45 Bourman, R.P. (1976). Environmental geomorphology: Examples from the area south of Adelaide. Proceedings of the Royal Geographical Society of Australia, South Australian Branch, 76, 1-23.

46 Bourman, R.P. (1979). Geomorphological contributions to Coastal Management. In: Corbett, D. \& Sibly, J. (Eds), Southern heritage: Proceedings of the Conference Focus on our southern heritage. Conservation Council of South Australia and the Department of Continuing Education, The University of Adelaide, pp. 80-88.

47 Bourman, R.P., Murray-Wallace, C.V., Belperio, A.P. \& Harvey, N. (2000). Rapid coastal geomorphic change in the River Murray Estuary of Australia. Marine Geology, 170 (1\&2), 141-168.

48 Bird, E.C.F. (1985). The study of coastline changes. Zeitschrift für Geomorpholgie, 57, 1-9.

49 Cann \& Clarke (1993).

50 King, C.A.M. (1967). Techniques in geomorphology. Edward Arnold, London. 342 pp.

51 Murray-Wallace, Bourman, Prescott, Williams, Price \& Belperio (2010).

52 King (1967).

53 James, N.P. \& Bone, Y. (2011). Neritic carbonate sediments in a temperate realm. Springer, Dordrecht, $254 \mathrm{pp}$.

54 Sprigg, R.C. (1952). The geology of the South-East Province South Australia, with special reference to Quaternary coast-line migrations and modern beach developments. Geological Survey of South Australia Bulletin, 29, 120 pp.

55 Bird (1985).

56 Bourman, R.P. (1974). Historical geomorphic change, Fleurieu Peninsula, South Australia. Proceedings International Geographic Union. New Zealand Geographical Society, 8, 289-297.

57 Bourman, R.P., Scobie, D. \& Tscharke, M.T. (1989). Origin and development of Police Point Spit, Victor Harbor, South Australia. South Australian Geographical Journal, 89, $25-45$.

58 Bourman, R.P. (1990). Artificial beach progradation by quarry waste disposal at Rapid Bay, South Australia. Journal of Coastal Research, Special Issue 6, 69-76.

59 Bourman, Murray-Wallace, Belperio \& Harvey (2000).

60 Thom, B.G. (1974). Coastal erosion in Eastern Australia. Search, 5, 198-204. 
61 Bowman, G. \& Harvey, N. (1986). Geomorphic evolution of a Holocene beach-ridge complex, Le Fevre Peninsula, South Australia. Journal of Coastal Research, 2 (3), 345-362.

62 Davies, J.L. (1960). Beach alignment in southern Australia. Australian Geographer, 8, 42-44; Davies, J.L. (1972). Geographical variation in coastal development. Oliver and Boyd, Edinburgh, 204 pp.

63 Carolin, R.C. \& Clarke, P.J. (1991). Beach plants of South Eastern Australia. Sainty and Associates, Potts Point, NSW, 119 pp.

${ }^{64}$ Heyligers, P.C. (1985). The impact of introduced plants on foredune formation in south eastern Australia. Proceedings of the Ecological Society of Australia, 14, 23-41; Hilton, M. \& Harvey, N. (2002). Management implications of exotic dune grasses on the Sir Richard Peninsula, South Australia. Proceedings of Coast to Coast 2002, Australia's National Coastal Conference on dune development in Australia and New Zealand: A case study of Ammophila arenaria and Thinopyrum junceiforme. Australian Geographer, 37 (3), 313-334; Harvey, N., Bourman, R., Hilton, M. \& James, K. (2003). Impact of exotic dune grasses on the foredune habitat of Younghusband Peninsula. Native Vegetation Research Grants Program 2002/2003, Final Report; James, K.J. (2012). Gaining new ground: Thinopyrum junceiforme, a model of success along the South Eastern Australian coastline. Unpublished PhD Thesis, The University of Adelaide, 221 pp.

65 Gilbertson, D.D. (1978). The off-road use of vehicles and aspects of the bio-physical systems of the Lower Coorong region, In: Gilbertson, D.D. \& Foale, M.R. (Eds), The southern Coorong and lower Younghusband Peninsula of South Australia. Nature Conservation Society of South Australia (Inc.), Adelaide, pp. 1-18.

66 Flinders, M. (1814). A voyage to Terra Australis: Undertaken for the purpose of completing the discovery of that vast country and, prosecuted in the years 1801, 1802 and 1803, in His Majesty's Ship, the Investigator, 2 Volumes and Atlas. G. \& W. Nicol, London; Cumpston, J.S. (1986). Kangaroo Island 1800-1836. Roebuck Society Publication No. 1, Roebuck Book, Canberra, 218 pp.

67 Hilton, M., Harvey, N. \& James, K. (2007). The impact and management of exotic dune grasses near the mouth of the Murray River, South Australia. Australasian Journal of Environmental Management, 14 (4), 220-228.

68 Landsberg, S.Y. (1956). The orientation of dunes in Britain and Denmark in relation to wind. Geographical Journal, 122, 176-189.

69 Jennings, J.N. (1967). On the orientation of parabolic or U-dunes. Geographical Journal, $123,474-480$.

70 E.g. Harris, C. (1974). Wind speed and sand movement in a coastal dune environment. Area, 6, 243-249.

71 Bourman (1976); Bourman (1979).

72 Bourman (1979).

73 Boutakoff (1963).

74 Lachlan, T.J. (2011). Aminostratigraphy and luminescence dating of the Pleistocene Bridgewater Formation, Kangaroo Island, South Australia: An archive of long term climate and sea-level change. $\mathrm{PhD}$ thesis, University of Wollongong; Blakemore, A.G., MurrayWallace, C.V., Westaway, K.E. \& Lachlan, T.J. (2015). Aminostratigraphy and sea-level 
history of the Pleistocene Bridgewater Formation, Mount Gambier region, southern Australia. Australian Journal of Earth Sciences, 62, 151-169.

75 James \& Bone (2011); Murray-Wallace, C.V. (2002). Pleistocene coastal stratigraphy, sealevel highstands and neotectonism of the southern Australian passive continental margin - A review. Journal of Quaternary Science, 17, 469-489; Playford, P.E., Cockbain, A.E., Berry, P.F., Roberts, A.P., Haines, P.W. \& Brooke, B.P. (2013). The geology of Shark Bay, Geological Survey of Western Australia, Bulletin 146, 281 pp.

76 Murray-Wallace, C.V., Brooke, B.P., Cann, J.H., Belperio, A.P. \& Bourman, R.P. (2001). Whole-rock aminostratigraphy of the Coorong Coastal Plain, South Australia: Towards a 1 million year record of sea-level highstands. Journal of the Geological Society, London, 158, 111-124.

77 Barnett, Harvey, Belperio \& Bourman (1997). 


\section{The coast of metropolitan Adelaide}

\subsection{Introduction}

The coast of metropolitan Adelaide extends from Sellicks Beach in the south to Le Fevre Peninsula in the north (Figure 2.1). Situated in the most populated part of South Australia, the coast provides an excellent example of intense human use of coastal resources, illustrating the impact of urban development and artificial modification of the coast. A lack of understanding about coastal processes during European development has resulted in coastal degradation.

The dominant geological influence on this section of coast is a series of arcuate northeasterly trending faults (Figure 2.2), which extend from the hills and define the landward limit of the coastal plains. Differential faulting of Neoproterozoic to Cambrian strata and Paleogene and Neogene sedimentary rocks has formed the template for the metropolitan coastline. The uplifted zones are associated with prominent cliffs and headlands, while between these uplifted sections of coast, embayments occupy fault angle depressions producing sandy bays. Although important rivers such as the Onkaparinga and the Torrens have their outlets on this section of coast, they deliver minimal sediment to Gulf St Vincent. The exposure of differentially faulted rocks and sediments has provided a north-south sequence of beach compartments.

\subsection{Geological setting}

The geological influences on the coast of metropolitan Adelaide date back to the folded, metamorphosed and uplifted Neoproterozoic and Cambrian strata of the Adelaide Geosyncline, which broadly coincides with the modern Mount Lofty and Flinders Ranges. Through major crustal deformation events of the Delamerian 


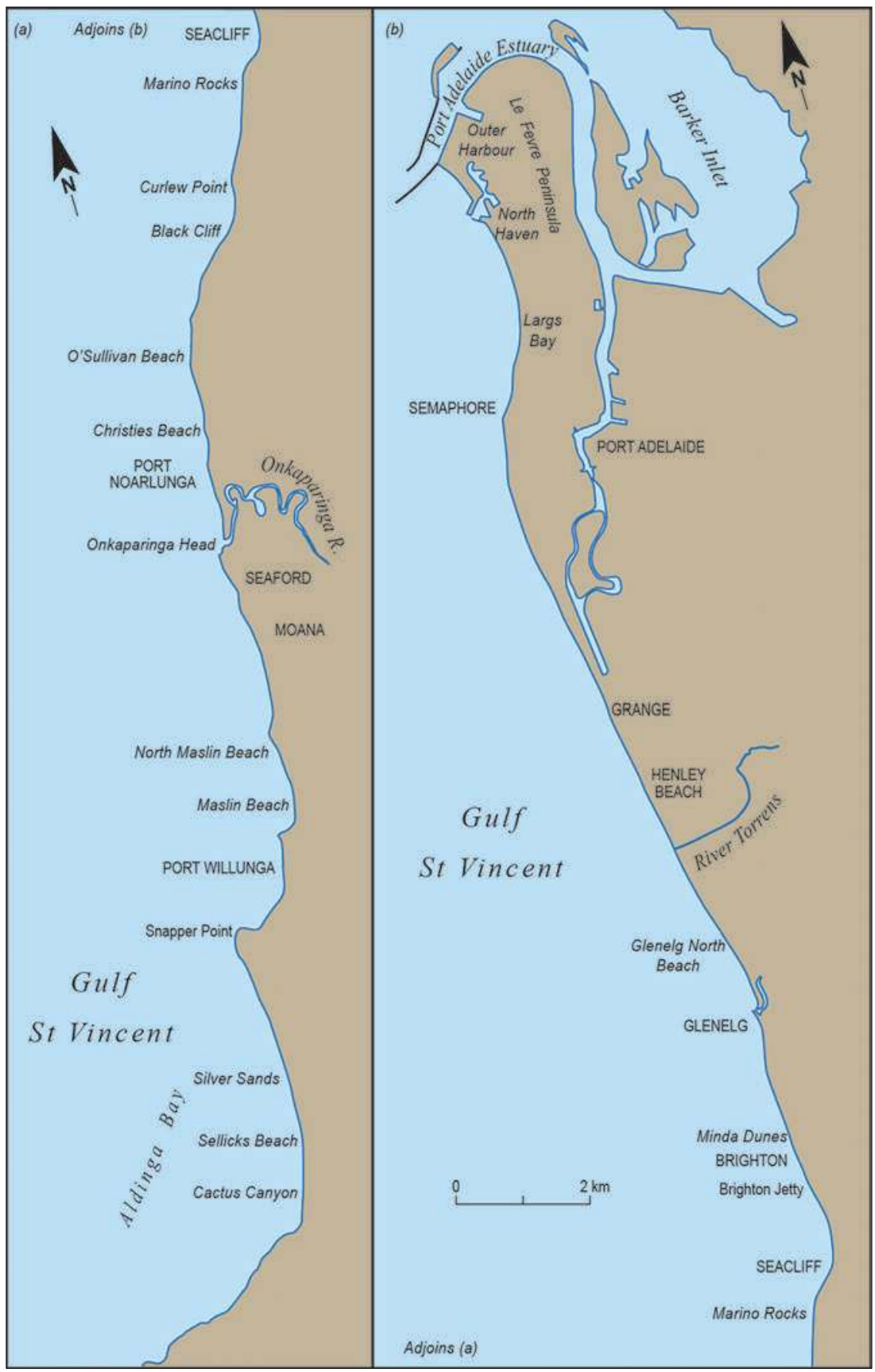

Figure 2.1 Location of the metropolitan coast of Adelaide showing key locations referred to in the text.

Source: Author's own work, NH. 


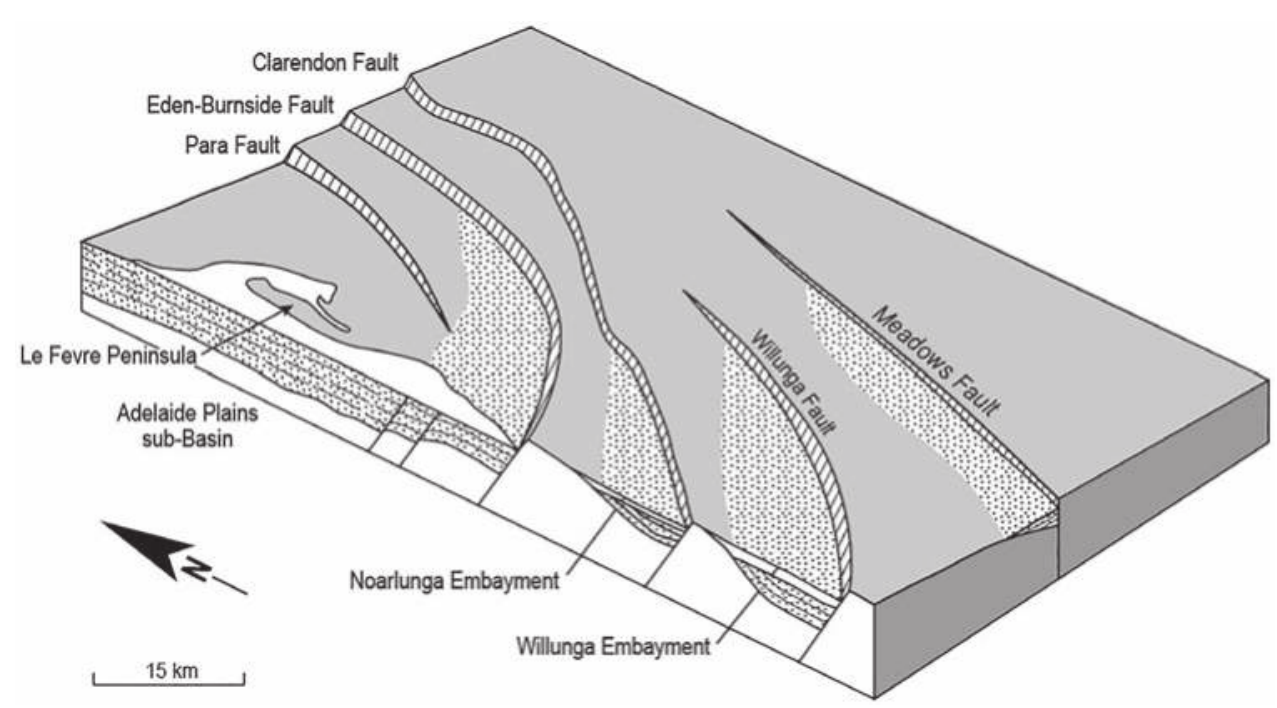

Figure 2.2 Major arcuate range-bounding faults of the Mount Lofty Ranges. Uplifted Neoproterozoic to Cambrian age rocks are exposed as coastal cliffs on the metropolitan coast. The arcuate-shaped fault scarps trend broadly in a northeasterly direction and lowlands between the uplifted fault blocks have formed, such as the Willunga, Noarlunga and Adelaide-Golden Grove Embayments and the Adelaide Plains Sub-basin. Fault activity has determined the general distribution of bedrock cliffs, sandy bays and beaches.

Source: Talbot, J.L. \& Nesbitt, R.W. (1968). Geological excursions in the Mount Lofty Ranges and the Fleurieu Peninsula. Angus and Robertson, Adelaide. Modified and reproduced with permission.

Orogeny from $514 \pm 3$ to $490 \pm 3 \mathrm{Ma}^{1}$, the region was transformed to an extensive fold mountain range of Himalayan proportions, named the Delamerides. ${ }^{2}$ From the Middle Ordovician (c. $470 \mathrm{Ma}$ ) through to earliest Permian time (299 Ma), the Delamerides were deeply eroded. The remnants of this major mountain chain influence the overall shape and character of the modern coast. Mainly during Early Permian times (299 to $290 \mathrm{Ma}$ ), the region experienced extensive glaciation. ${ }^{3}$ Evidence of this glaciation is spectacularly preserved at Hallett Cove, where the ice flow was from the south to the north with bedrock structures diverting the overall southeast-northwest movement ${ }^{4}$ (see Chapter Three — The Fleurieu Peninsula coast).

Erosion of the Delamerides continued for millions of years, exposing the core of the mountain range and reducing it to a planation surface of relatively low relief. ${ }^{5}$ Following the break-up of the ancient supercontinent of Gondwana and the final separation of Australia and Antarctica some $43 \mathrm{Ma}$ ago, faulting of the area was reinitiated, which ultimately formed the Mount Lofty Ranges and Gulf St Vincent ${ }^{6}$, producing the broad template for the modern coastline. The separation of southern 
Australia from Antarctica was a decisive event heralding the early development of the South Australian coastline.

Sedimentation in the St Vincent Basin was marked by the deposition of terrestrial freshwater sediments (North Maslin Sand) in the Middle Eocene. ${ }^{7}$ This was followed by deposition of the marginal marine South Maslin Sand and later marine sediments, including the Blanche Point Formation and the Port Willunga Formation, during Eocene through to Miocene time. ${ }^{8}$ A marine transgression during the Pliocene deposited the Hallett Cove Sandstone, which currently varies in elevation from $30 \mathrm{~m}$ above present sea level (APSL) at Hallett Cove to well below modern sea level in the St Vincent Basin, beneath the Adelaide Plains, illustrating the effects of tectonic movements of the land in the Neogene. ${ }^{9}$ The aforementioned successions crop out in cliff sections along the southern metropolitan coast, indicating differential faulting.

During the Pleistocene (2.59 Ma to $11.7 \mathrm{ka}$ ago), coastal regions were impacted by the effects of global (glacio-eustatic) sea level fluctuations. The earliest Pleistocene shallow marine succession in the Adelaide area is the Burnham Limestone ${ }^{10}$, which crops out on the metropolitan coast at Marino, Port Willunga and Sellicks Beach, but extends well below sea level at Port Adelaide. This again illustrates the long-term influence of tectonic processes on coastal development, and, in particular, uplift of the fault blocks of the Mount Lofty Ranges and subsidence of the St Vincent Basin. Although there were more than 30 major migrations of the shoreline during the Pleistocene, known from independent evidence (for example, oxygen isotope records from deep sea and ice cores), past sea levels extended from some $2 \mathrm{~m}$ APSL during the Last Interglacial Maximum (132 to $118 \mathrm{ka}$ ) to $125 \mathrm{~m}$ below present sea level (BPSL) during the Last Glacial Maximum (21 ka). As each interglacial sea level highstand attained a similar elevation, there is little record in the Adelaide area of Pleistocene shoreline successions older than the Last Interglacial Maximum (132 to $118 \mathrm{ka}$ ). ${ }^{11}$ These major cyclic fluctuations in sea level meant that the present area of Gulf St Vincent was periodically exposed as dry land, and some higher sea level events such as the Last Interglacial experienced even larger areas of sea coverage. There is widespread preservation of the last interglacial marine Glanville Formation, which indicates that the level of the sea some $125 \mathrm{ka}$ ago was approximately $2 \mathrm{~m}$ higher than today, as noted from shelly limestones on Eyre Peninsula (see Chapter Ten), and has also been offset by faulting in the Adelaide Plains Sub-Basin. ${ }^{12}$ Furthermore, the climate at that time was warmer and wetter than today, with the Leeuwin Current bringing warmer ocean surface waters from Indonesia and the northeastern Indian Ocean.

During the Last Glacial Maximum, about $21 \mathrm{ka}$ ago, sea level stood as much as $125 \mathrm{~m}$ below the present shoreline. At that time, the current Gulf St Vincent was a wide and shallow valley with drainage extending from the Adelaide Plains across the continental shelf. ${ }^{13}$ 
The modern metropolitan coast and the lowland embayments between the major fault scarps were shaped during the Holocene (the past $11.7 \mathrm{ka}$ ), with pronounced development of the sandy metropolitan coast north of Kingston Park. The St Kilda Formation, which includes both the white sand dunes that back the coastline and the estuarine and lagoonal mud facies landward of the dunes, was deposited during this time. ${ }^{14}$ The original dunes formed over the past 7000 years, after sea level had stabilised to near its present level following a period of sea level rise from 17000 years ago at the end of the Last Glacial Maximum. ${ }^{15}$ The formation of the sand dunes and the northward drift of sand along the coast formed Le Fevre Peninsula and the estuaries of the Port River and the Patawalonga. ${ }^{16}$ Inland of the estuarine zone lies an older line of distinctive red- to yellow-coloured sand dunes, the Fulham Sand on which many of the city's golf courses are built. ${ }^{17}$ These older dunes do not display the same linearity of the modern coastal dunes. They broadly parallel the coastline but also seem to have migrated inland from the coast, possibly during a phase of dune reactivation under conditions of enhanced aridity in the Last Glacial Maximum. The age of the Fulham Sand is around 75000 years $^{18}$, at which time sea level was possibly $80 \mathrm{~m}$ lower than today. Thus the Fulham Sand was probably blown from the exposed sea floor of the gulf, while parts of it would have been incorporated into the coastal dunes as sea level rose to near its present position. ${ }^{19}$

\subsection{Sellicks Beach to Ochre Point}

The Sellicks Beach township sits landward of coastal cliffs eroded into Pleistocene alluvial fan sediments comprising conglomerates, sands and clays. The alluvial fan sediments represent weathered rock and sediment shed from the Mount Lofty Ranges during uplift and denudation. These cliffs are at an elevation of around $70 \mathrm{~m}$ near Cactus Canyon, where the Willunga Fault intersects the coast, resulting in an uplifted Willunga block to the south and a dramatic cliffed coastline in older resistant Neoproterozoic strata. ${ }^{20}$ The Pleistocene sediments near Cactus Canyon overlie the Oligocene-Miocene Port Willunga Formation, which is exposed as a low-lying cliff, an intertidal shore platform and a subtidal reef with a low backing notch and low cliff $(<3 \mathrm{~m})$. The shore platform extends seawards to form a subtidal reef at the mouth of the Canyon. At extremely low tides, the shore platform is exposed up to $500 \mathrm{~m}$ offshore, and parts of it are domed upwards, probably by tectonic activity.

The cliffs at Sellicks Beach are developed on unconsolidated alluvial fan sediments and consequently are susceptible to erosion, deep gullying and slumping. A good example of such slumping can be seen in the cliffs, where a section $200 \mathrm{~m}$ by $50 \mathrm{~m}$ slumped rotationally and pushed sediment into the beach zone (Figure 2.3). ${ }^{21}$ The slump of Late Holocene age was possibly related to saturation of sedimentary beds from draining of the nearby slopes, coupled with earthquake activity. At this location, 
a cobble storm ridge at the back of the beach protects the cliffs, and the elevation of the cliffs gradually drops northward toward Sellicks Creek. ${ }^{22}$ Dramatic post-European erosion has occurred along Sellicks Creek, in part related to land clearing and creek diversion along a roadway. Human-induced erosion led to excessive delivery of sediment to the coast, impacting on reef ecology north of the outlet.

Along the Sellicks Beach coast, a sand and gravel beach is backed by a distinctive shingle ridge that is $2 \mathrm{~m}$ high and extends from the outlet of Cactus Canyon in the south, gradually diminishing in size to the north of Aldinga Scrub. The shingle has been sourced from the erosion of soft Pleistocene alluvial fan sediments containing older Cambrian resistant rocks ${ }^{23}$, which have subsequently been transported in a northerly direction along the coast. North of Sellicks Creek is one of the last remaining coastal wetlands at the intermittently flooded Washpool Lagoon, which creates an open channel through to the beach at times of high flow. The low-lying section of the coast continues to Silver Sands, where there is a low-angle beach with medium to coarse sands. The sand fines to the north near Aldinga Scrub, where there is a small low-lying dune field extending about $2 \mathrm{~km}$ inland.

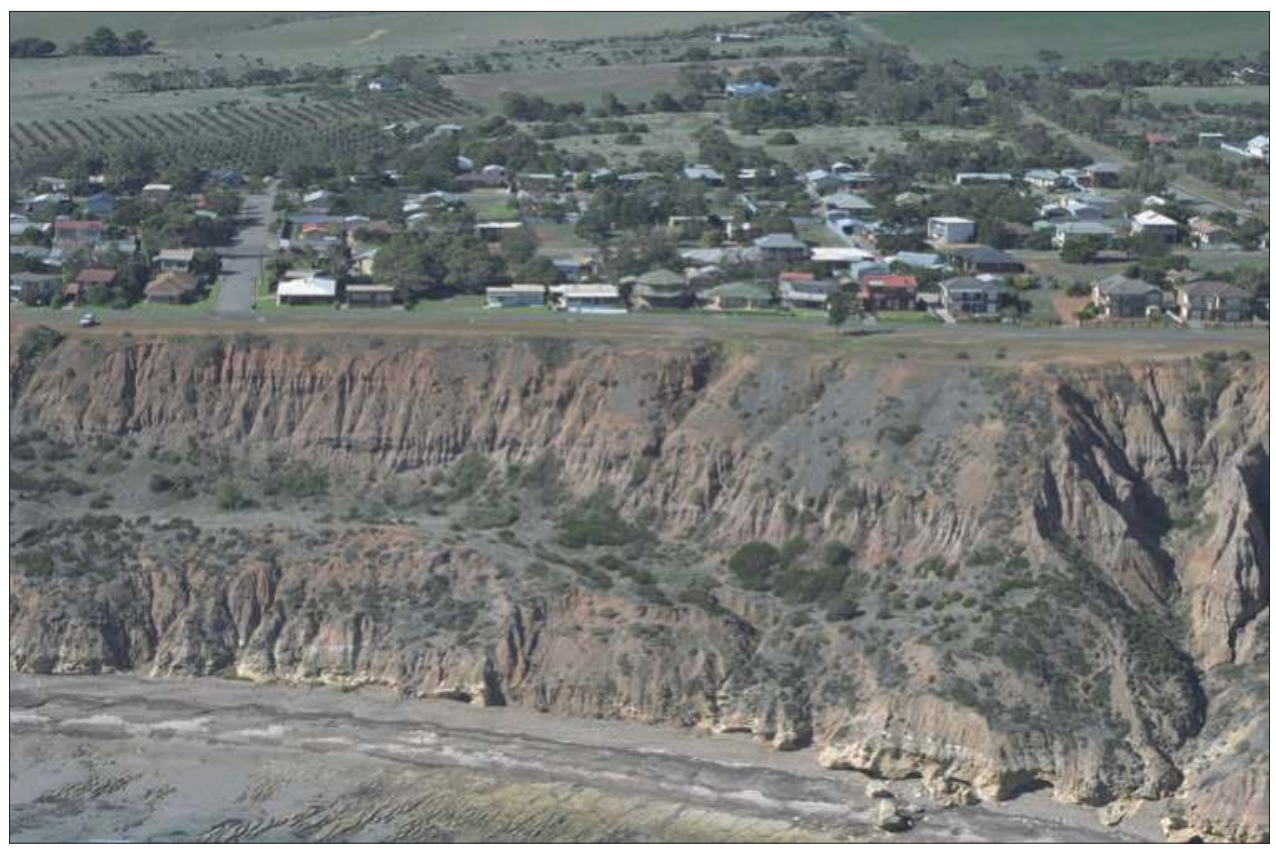

Figure 2.3 Sellicks Cliffs. This picture illustrates a shore platform, beach and backing cobble ridge, outcrop of the Port Willunga Formation, Pleistocene cliffs with a slump feature and deep gullying.

Source: Reproduced with permission of the Coast Protection Board, 2003. 


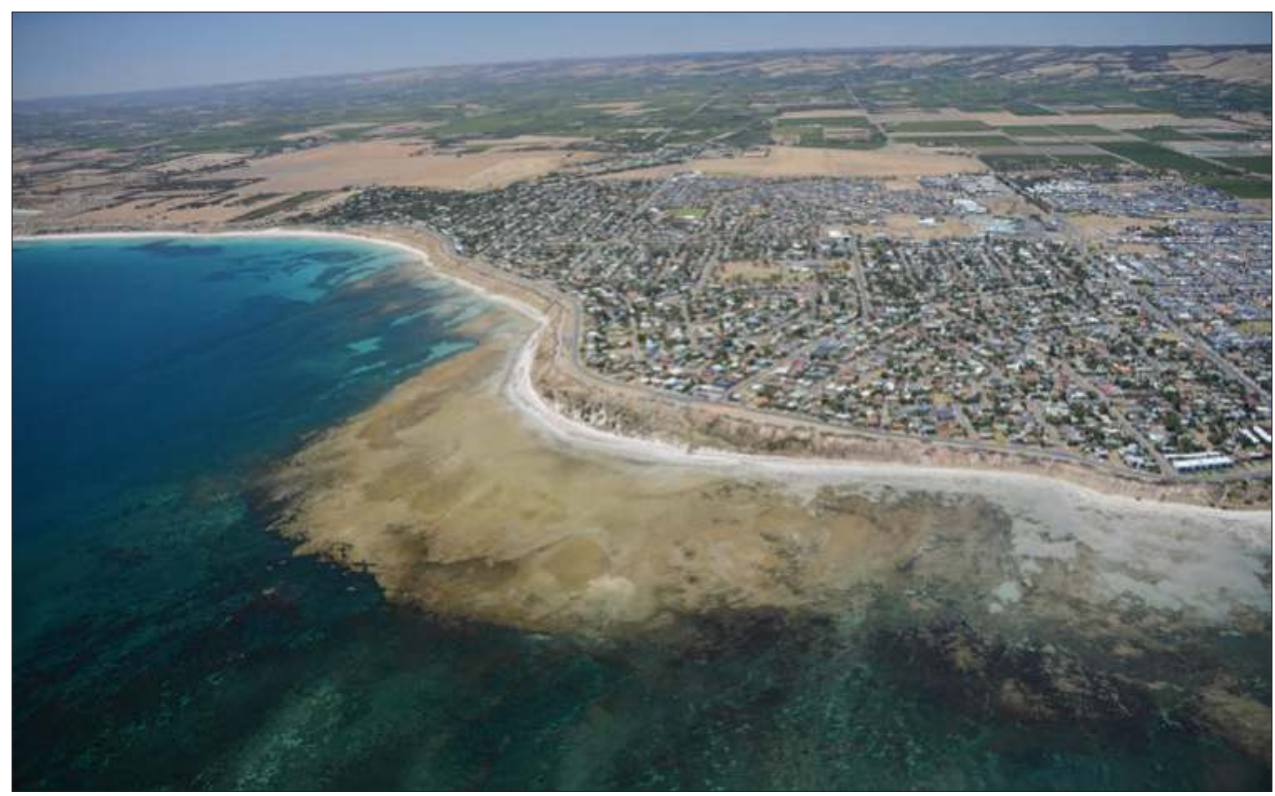

Figure 2.4 Snapper Point and reef formed from underlying hard Hallett Cove Sandstone exposed as a wide low-tide reef stretching over a kilometre into the Gulf. A sloping beach at the point is backed by a small dune field about $0.2 \mathrm{~km}$ in length.

Source: Reproduced with permission of the Coast Protection Board, 1995.

Further north, between Aldinga Scrub and Snapper Point, the height of the coastal cliffs of Pleistocene limestones, marls and alluvium gradually increases behind a narrow beach. At Snapper Point, where there is significant wave protection, a sloping beach is backed by a small dune field about $0.2 \mathrm{~km}$ in length. Offshore, the underlying hard Hallett Cove Sandstone is exposed as a wide low-tide reef stretching over a kilometre into the Gulf.

On the northern side of Snapper Point, terrestrial alluvial deposits of Pleistocene age are revealed in the cliffs as red and mottled clays, continuing to the south of Port Willunga, where the beach forms a narrow strip of sand and rubble alongside low steep cliffs cut into the Pleistocene sediments (Figure 2.4). Near Port Willunga, the cliffs cut into Cenozoic limestone reveal minor faulting.

Between Willunga Creek, a small (30 km² catchment) ephemeral creek, and Blanche Point to the north, the cliffs are oriented south-north, and gradually increase in elevation. They reveal progressively younger sediments on top of the Late Eocene Blanche Point Limestone, from the clays, silts and sands of the Late Eocene Chinaman Gully Formation, followed by the Oligocene-Miocene Port Willunga Formation of 


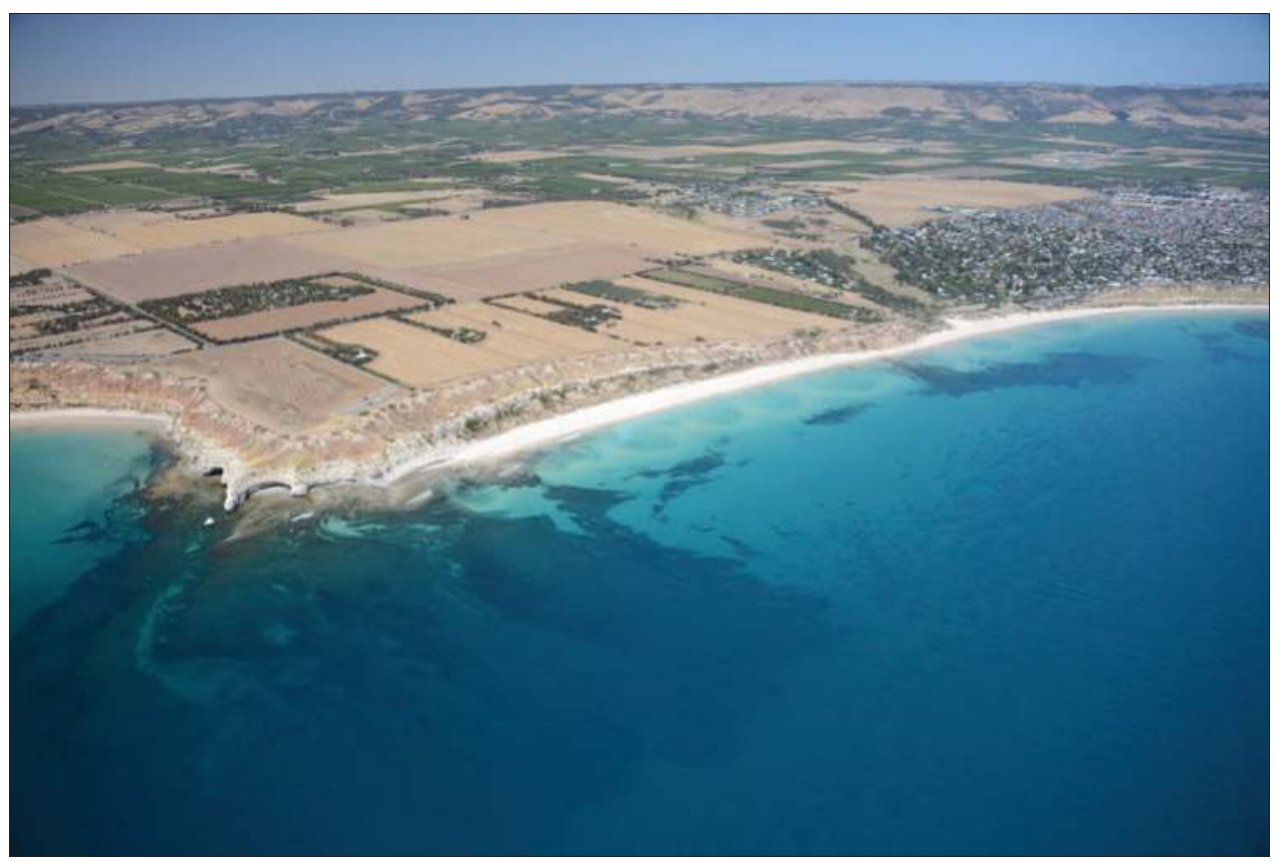

Figure 2.5a Aerial view of the eroding headland of Blanche Point and Gull Rock with Maslin Beach to the left. To the south (right), the cliffs decrease in elevation towards Port Willunga. Source: Reproduced with permission of the Coast Protection Board, 2003.

limestone, sands and clays. ${ }^{24}$ Cliff erosion at Blanche Point has produced an embayed shoreline and an isolated sea stack, Gull Rock (Figure 2.5a).

The lower part of the cliffs (in the top left section of Figure 2.5b) comprises the Paleogene-Eocene South Maslin Sand, which is overlain by a thin layer of Tortachilla Limestone (38.5 to $40 \mathrm{Ma}$ ) followed by the pale-coloured Late Eocene Blanche Point Formation. ${ }^{25}$ This is overlain by a relatively thin layer of Pliocene Hallett Cove Sandstone (best seen in Figure 2.5b as the rock capping in the cliff exposures below the Pleistocene clays at Blanche Point). The Paleogene-Neogene sequences are overlain by Pleistocene sediments, which include the earliest Pleistocene marine unit, the Burnham Limestone. The cliff foot zone has relatively steep slopes with undercutting at the base, but these slopes are less steep towards the mid-section of the cliffs, reflecting the concentration of marine weathering processes on the lower slope and subaerial processes on the upper slopes. The upper gentler slopes are formed on soft Pleistocene sands and clays of the Pleistocene Seaford and Ochre Cove Formations and the calcareous Quaternary Ngaltinga Clay. ${ }^{26}$ 
Between the two headlands of Blanche Point and Ochre Point to the north, a west-facing sandy beach, Maslin Beach, narrows towards both ends of the open embayment. The beach contains medium-grade mineral sands and is backed by cliffs up to $40 \mathrm{~m}$ high, revealing some spectacular geological sequences of PaleogeneNeogene sedimentary rocks, which dip toward Blanche Point. At North Maslin Beach, Eocene sand deposits have been heavily mined, creating a large quarry with an artificial sediment mound forming a coastal barrier. Under natural conditions these sands were providing sediments for the North Maslin Beach. This gives way to a cliffed coast containing exposures of Permian clay immediately south of Ochre Point.

The section of coast around Ochre Point is intersected by a major arcuate, rangebounding fault, the Clarendon-Ochre Cove Fault, where Neoproterozoic quartzites form the shore platform. Here, the Clarendon Block has been uplifted and tilted down towards the southeast so that the older rocks gradually pass beneath younger sedimentary sequences to the south. ${ }^{27}$

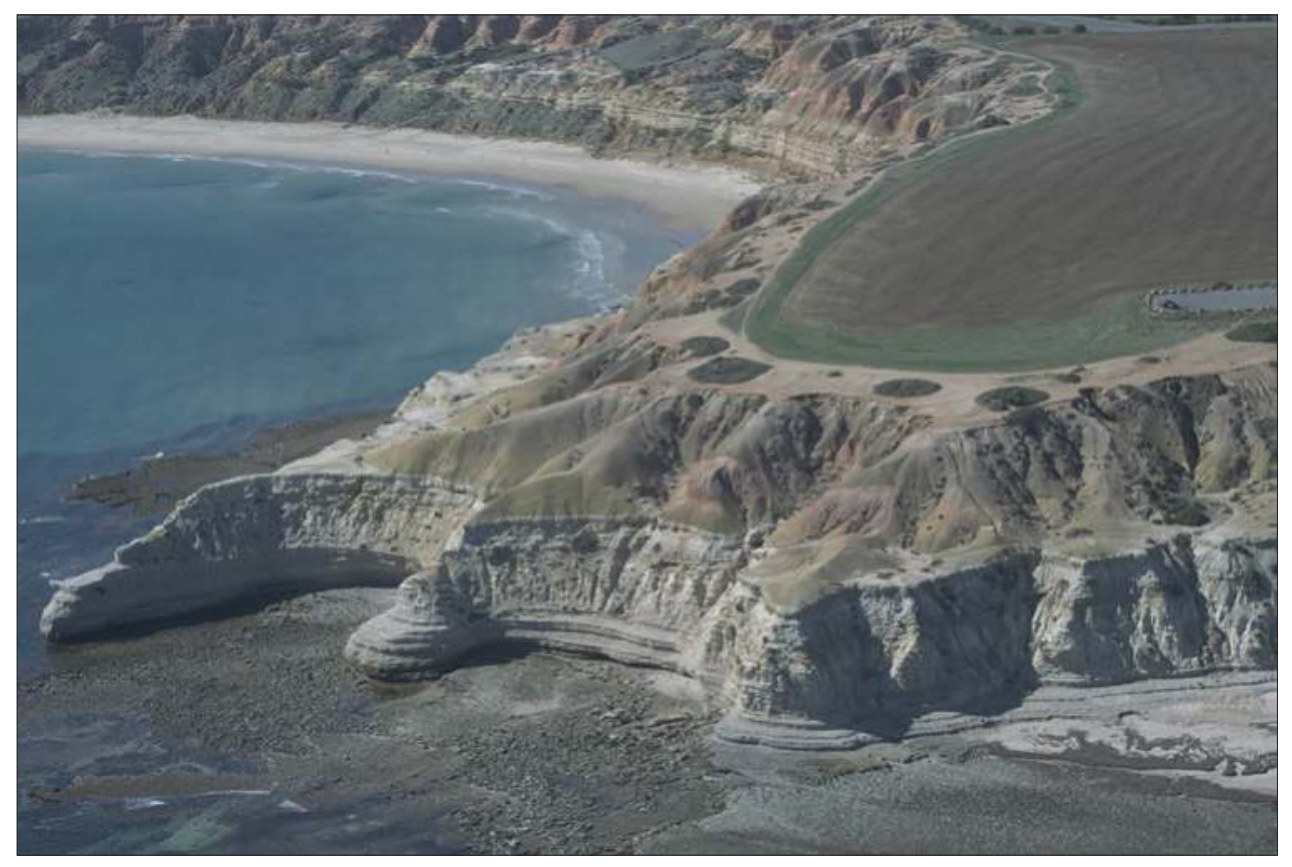

Figure 2.5b Detailed view of stratigraphy in the cliffs at Blanche Point, illustrating Paleogene-Neogene marine and terrestrial sediments. Tortachilla Limestone forms the shore platform; the Blanche Point Formation is the lighter-coloured sediment in the lower half of the cliff, above which is a thin white layer of Hallett Cove Sandstone. This is overlain by more easily eroded Pleistocene terrestrial sediments.

Source: Reproduced with permission of the Coast Protection Board, 2003. 


\subsection{Moana to Marino Rocks}

Ochre Point is the northern end of the Willunga Embayment, which lies between the Clarendon and Willunga Fault blocks (Figure 2.2). A section of cliffed coast about $50 \mathrm{~m}$ high stretches from Ochre Point to Moana, where a stretch of low gradient beach $2 \mathrm{~km}$ long is backed by a low-lying sand dune plain with a modern foredune that is 2 to $5 \mathrm{~m}$ high. A heavily disturbed sequence of Holocene and Pleistocene dunes occurs landward of the modern foredune. Pedler Creek forms the northern boundary of the Moana Sands Conservation Park, which has a small catchment and an ephemeral estuary with a low-lying flood plain.

A wide sandy beach at Moana grades northward into sand and pebble beaches, which back shore platforms formed in Paleogene-Neogene limestones. Just north of Moana, low cliffs appear and gradually increase in height to approximately $40 \mathrm{~m}$ at Onkaparinga Head. Near Moana the cliffs comprise marls, sands and clays, but toward the Onkaparinga River the higher-elevation cliffs reveal underlying PaleogeneNeogene limestones. These form the lower part of the sequence and are exposed in the cliffs at the mouth of the Onkaparinga estuary along with soft Late Eocene sediments.

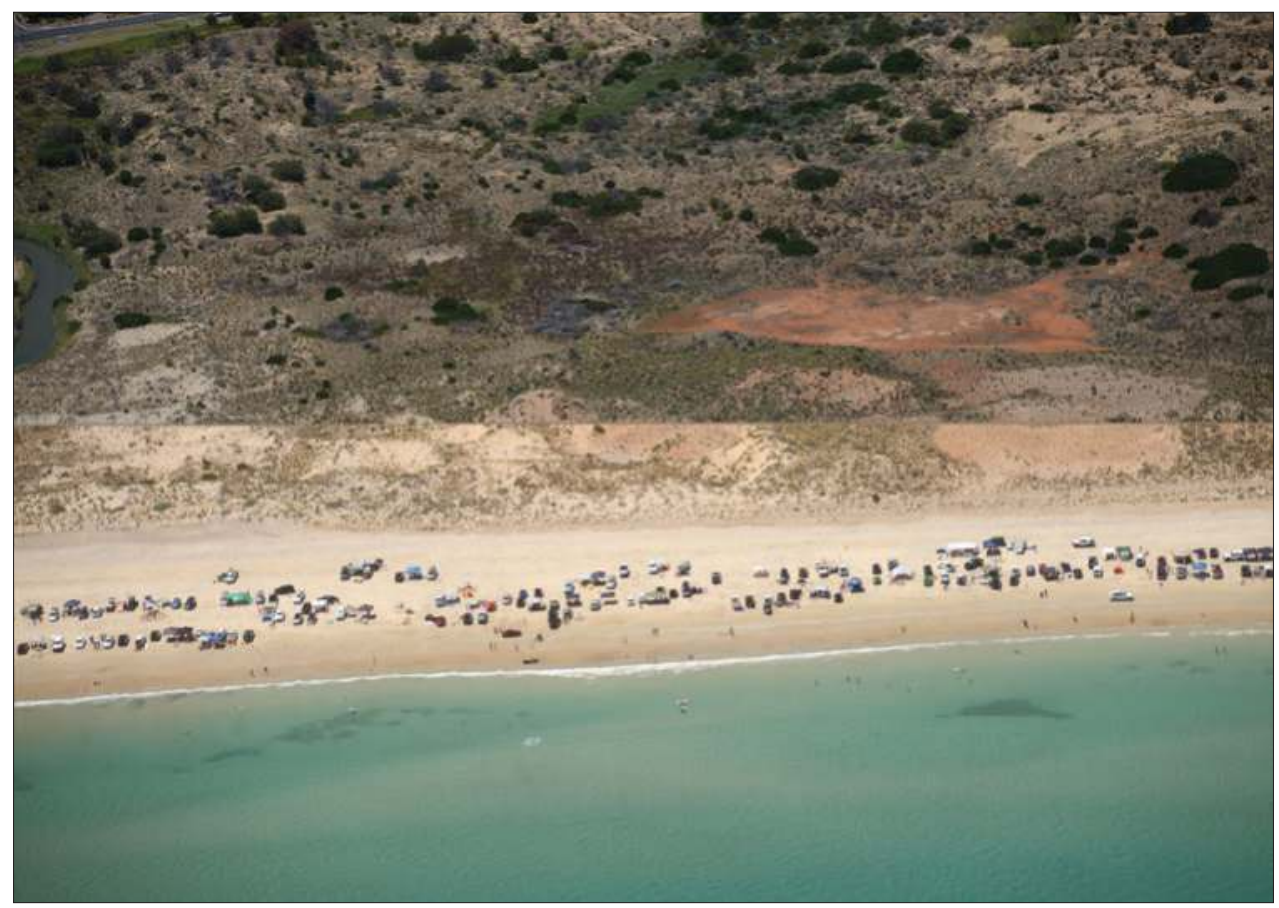

Figure 2.6 Moana Beach, a flat west-facing beach $2 \mathrm{~km}$ long backed by foredunes 2-5 m high, in the Moana Sands Conservation Park.

Source: Reproduced with permission of the Coast Protection Board, 2003. 


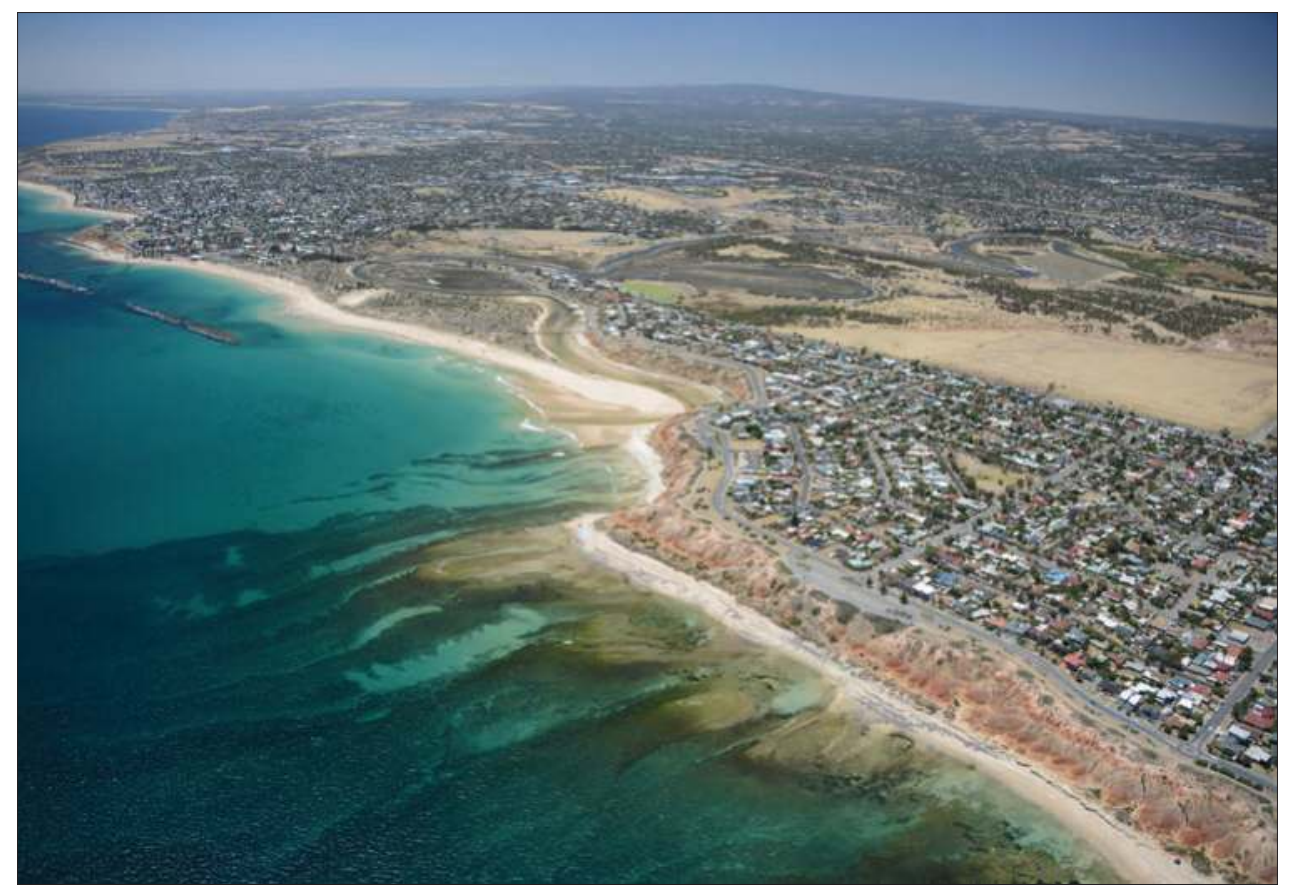

Figure 2.7 Onkaparinga Estuary and the spit, which is $2 \mathrm{~km}$ long and has diverted the river to the south against the cliffs. On the left of the photograph, the shore-parallel Noarlunga Reef protects the beach.

Source: Reproduced with permission of the Coast Protection Board, 1995.

The Onkaparinga is a river-dominated estuary with a catchment area of $554 \mathrm{~km}^{2}$. It is flanked by an extensive river flood plain with river terraces and areas of samphire. However, the river has been so highly modified that on average only a quarter of its natural flow now reaches the estuary, resulting in the lower reaches becoming more tidally dominated. ${ }^{28}$

A sand spit extending south across the Onkaparinga estuary indicates a local southerly littoral drift on this section of coast, due to waves being refracted by the Noarlunga Reef. ${ }^{29}$ The dune on the spit is almost $2 \mathrm{~km}$ in length, $250 \mathrm{~m}$ wide, and up to $20 \mathrm{~m}$ high. To the north of the spit is an extensive sandy beach protected by an offshore calcarenite reef near the Port Noarlunga jetty. North of the jetty is a section of cliffs with a distinctive platform shelf formed by a more resistant siliceous sedimentary rock. The cliffs at Witton Bluff, however, unlike the resistant cliffs on Neoproterozoic strata, are made up of soft clay and sandstone of Pleistocene age overlying Cenozoic limestone. Erosion of these cliffs removed a former sea stack, Table Rock, in 1911. 
Concern over continuing erosion at the Bluff has necessitated installation of extensive rock protection. ${ }^{30}$

Sandy beaches occur from Christies Beach to O'Sullivan Beach, where there is a low-gradient, fine-grained, mineral sand beach and a sloping coastal plain, contrasting with the cliffed coast to the north. Christies Beach has two embayments that are separated by a protruding section of coast protected by an offshore reef. Well-defined sandy beaches also occur around O'Sullivan Beach and Port Stanvac, where artificial structures have blocked the natural littoral drift and caused sand accumulation.

From Port Stanvac to Hallett Cove, resistant folded Neoproterozoic strata form cliffs up to $20 \mathrm{~m}$ high, with the adjacent serrated shore platforms revealing complex folds of the Delamerian Orogeny. The only river in this section of coast is the Field River at the southern end of Hallett Cove. With a catchment area of $55 \mathrm{~km}^{2}$, it is much modified by urban development and is not important in terms of sediment supply to the coast. In the southern portion of Hallett Cove, numerous large boulders (glacial erratics) occur on the beach. The host sediments to the boulders, deposited during the Permian glaciation, have been more recently exposed by coastal erosion. Small pocket embayments with sand and shingle beaches occur near Curlew Point to the south of Hallett Cove, but are not receiving any natural sediment supply.

The coastal features in the area result from four distinct periods of sedimentation with major gaps between them. There is a gap of around $320 \mathrm{Ma}$ between the exposed dark Precambrian folded rocks and the overlying pale-coloured Permian glacial deposits of sand, clay and boulders. In some places, including on the shore platform, exotic boulders or erratics derived from further south were dumped from melting ice. ${ }^{31} \mathrm{~A}$ spectacular exposure of soft glacial meltwater sediments occurs at the Sugarloaf, which is highly eroded but protected on its upper surface by a younger Pleistocene clay band. There is a break in sedimentation of about $290 \mathrm{Ma}$ from the Permian glacial sediments to the marine fossiliferous Pliocene Hallett Cove Sandstone. ${ }^{32}$ The Permian sediments were once eroding and supplying considerable sediment to the beach, but this process is now much reduced. The former well-nourished Hallett Cove sandy beach has been replaced by sporadic patches of sand on the higher parts of the shore platform. The fourth and uppermost band of sediments comprises Pleistocene (2.59 Ma) alluvial clays clearly seen in cliff exposures.

Hallett Cove is an internationally important site geologically because features of the Permian glaciation are so well preserved here. The Permian ice moved across the area in a northerly direction when Australia was still connected to Antarctica. The resistant Precambrian rocks at Black Cliff display clear striations (Figure 2.8) where ice scoured the now exposed surface. ${ }^{33}$ On the shore platform below the cliff, Precambrian sedimentary rocks are distinctly banded and were folded before they were truncated by coastal erosion. The cliffs and shore platforms on Precambrian strata continue north, 


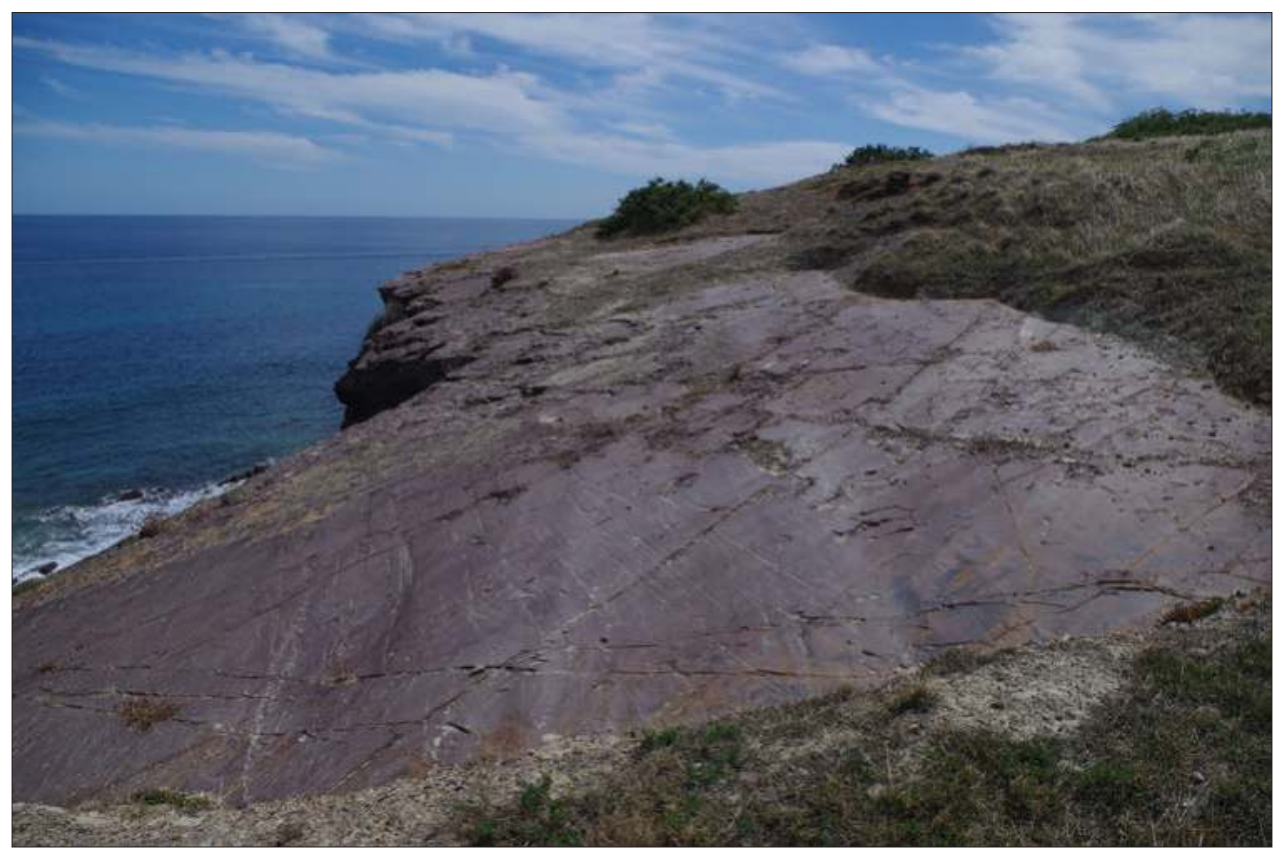

Figure 2.8 Glacially smoothed, grooved, polished and striated bedrock surface exposed at Hallett Cove, relating to a Permian-age glaciation at a time when Australia was joined to Antarctica. The relatively fresh appearance led early geologists to mistakenly attribute these rocks to the last major Pleistocene glaciation.

Source: Author's own work, NH.

past Black Cliff. Coastal erosion has cut off part of the folded beds, giving a distinct sawtooth and jagged appearance to the serrated shore platform (Figure 2.9).

At Marino Rocks, cliffs and shore platforms dominate the coast. There is very little sand and any beaches comprise coarse shingle derived from erosion of the alluvial Pleistocene Ochre Cove Formation. This locality contains the type section for another ancient ice age, the Neoproterozoic Marinoan glaciation (approximately 650 to $635 \mathrm{Ma}$ ), and has been designated as a geological monument. Resistant Neoproterozoic rocks extend from the Hallett Cove Conservation Park in the south to the Marino Rocks boat ramp in the north. Excellent cliff exposures of siltstone, shales and sandstones from this period get progressively older from the south to the north, beginning with the Seacliff Sandstone, followed by the Reynella Siltstone member of the Elatina Formation and the Marino Arkose of the Wilmington Formation, which is exposed in the core of an anticline. ${ }^{34}$ Despite being metamorphosed, sedimentary layers are still distinguishable and form distinct shore platforms revealing steep inland dips, the result of folding during the Delamerian Orogeny $(514 \pm 3$ to $490 \pm 3 \mathrm{Ma}) .^{35}$ 


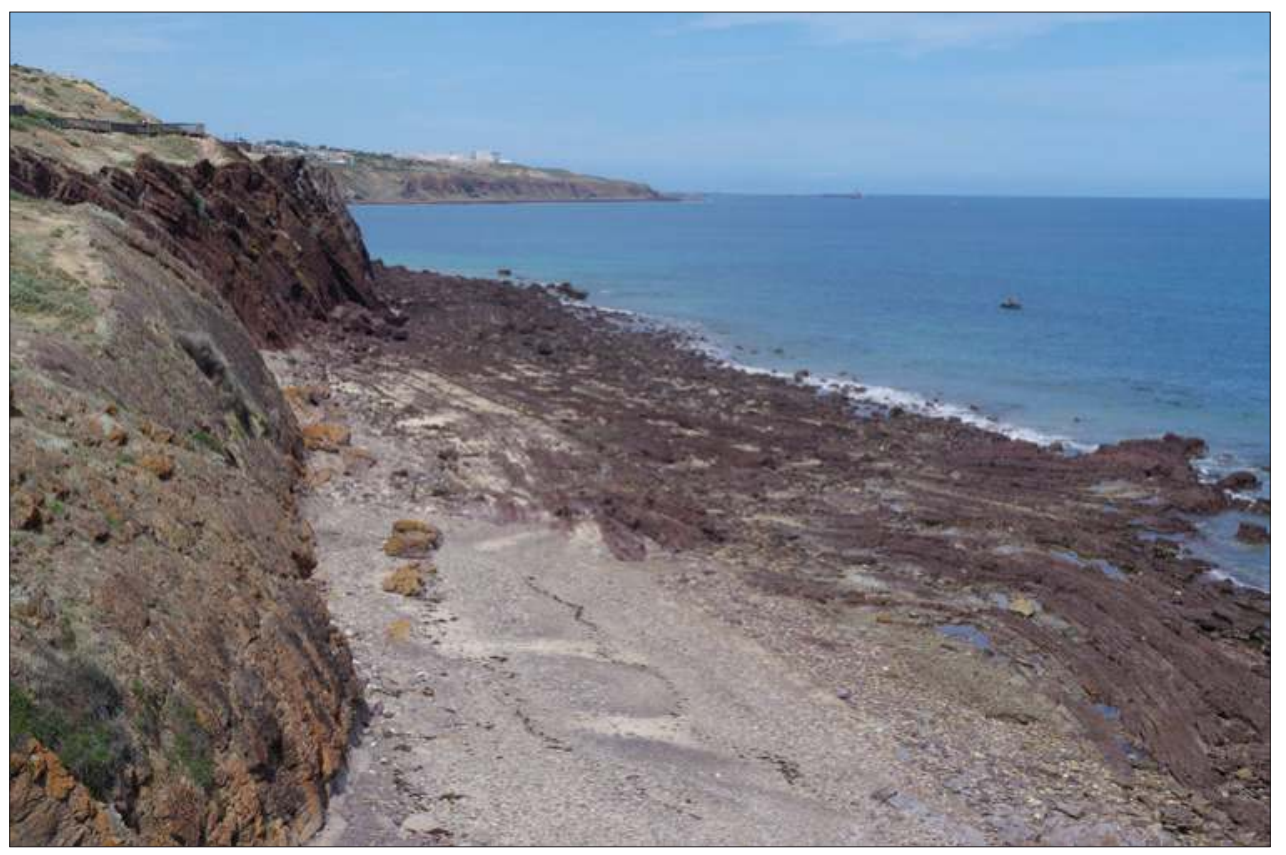

Figure 2.9 Neoproterozoic strata at Black Cliff, Hallett Cove showing distinctly banded sedimentary rocks on the shore platform below. These rocks were folded before they were truncated by coastal erosion.

Source: Author's own work, NH.

Between O'Sullivans Beach and Marino Rocks, these resistant Neoproterozoic strata lie below younger Paleogene-Neogene and Quaternary sediments, which form the Noarlunga Basin. The relatively younger sediments are exposed along the coast from the Onkaparinga Estuary to Christies Beach. Near Kingston Park, where the Eden-Burnside Fault intersects the coast, uplifted resistant bedrock has produced steep cliffs, while to the north there is a dramatic change to a low-lying sandy coast. At Kingston Park, the Eden Block has its maximum uplift on the coast, tilting down to the south (Figure 2.2). The fault influences the development of different coastal landforms, and their erosion exposes ancient uplifted sediments, revealing the geological evolution of the area.

\subsection{Seacliff to Outer Harbor}

At the southernmost part of this coastal section, the foot of the Eden-Burnside fault scarp is buried by alluvial fans of the subdued Adelaide Plains, defining the next section of coast. ${ }^{36}$ This sandy coast, which is $29 \mathrm{~km}$ long, is often referred to as the 
metropolitan beach proper: a line of dunes up to $400 \mathrm{~m}$ wide and $15 \mathrm{~m}$ high originally backed the coast, providing an abundant reservoir of sand for the healthy beaches. However, the entire metropolitan coast has been so highly modified that very little of the natural coastline exists. In addition, there have been many artificial interruptions to the natural northward movement of sand by the construction of breakwaters and groynes, causing accretion updrift of the structures and accelerated erosion downdrift of them. Artificial coastal accretion has occurred on the south sides of breakwaters at Glenelg, North Haven and Outer Harbor. Construction of the breakwater at Glenelg in 1964 (extended in 1997) created significant coastal accretion, which, together with the construction of an offshore protective breakwater, allowed permanent coastal development well seaward of the original shoreline. ${ }^{37}$ An offshore breakwater constructed at Semaphore has also modified the coast with sand accreting in its lee.

The trapping of sand on the south sides of artificial structures deprives northern beaches of sand supplies, resulting in serious erosion such as at Glenelg North, which required artificial protection. The majority of this coast now has hard rock protection (rip-rap), as well as an artificial sand management program to maintain its beaches. Some rock protection occurred in the 1800s but became more important in the 1900s, at first to provide protection at the landward ends of six recreational jetties. ${ }^{38}$ These works were expanded following major storm damage events, particularly in the 1950s and 1960s. ${ }^{39}$ Some of the seawalls were ineffective, especially those made of cement with a concave slope facing the sea. Such walls increased damage by forcefully reflecting the waves, which undercut the seawalls and accelerated longshore transport. Since the 1960s, rock revetments or rip-rap have been constructed along most of the coast, first from Kingston Park to Grange, and followed by sites further north at Semaphore and Largs Bay. ${ }^{40}$

The sector between Seacliff and Outer Harbor is the most modified coast in South Australia. The original coastal landscape of large sand dunes in the south, grading to a series of low-lying, recurved beach ridges in the north, has been obscured by urban development. ${ }^{41}$ Even where the southernmost sand dunes pass into clay-rich sediments at Kingston Park, severe erosion has necessitated rock wall protection and the removal of several houses. The coastal dunes, part of the Holocene St Kilda Formation, accreted during and after the postglacial sea level rise, which stabilised near its present level some 7000 years ago. The advancing sea pushed unconsolidated sand landwards from the shallow gulf floor. Predominant southwesterly onshore winds subsequently moved the sand inland, gradually building up the coastal dunes. In addition, wave action driven by the prevailing onshore southwesterly winds transported sand dominantly northward along the coast at relatively rapid rates of 30000 to $60000 \mathrm{~m}^{3}$ per annum. However, south of Kingston Park, longshore drift is only $10000 \mathrm{~m}^{3}$ per annum or less, resulting in a significant sediment supply deficit and a natural tendency for the northward movement of beach sand to create natural erosion of the coastal dunes in order to 
replenish the beaches. ${ }^{42}$ Less frequent northwesterly winds have also been associated with some severe erosion events. The predominant northward movement of sand is not replenished from further south because of the lack of sediment-bearing rivers. In addition, the trapping effect of hard bedrock cliffs that form beach compartments further reduces the supply of beach sediment from the south.

The coast from Seacliff to the Patawalonga estuary is a low-lying coastal landscape of Holocene sand overlying Paleogene-Neogene sediments. The Holocene dunes become more defined here, but as settlement expanded the coastal dunes were partly removed and covered by housing and roadways (Figures 2.10a and 2.10b) until they were isolated from the beach system and were no longer able to provide a natural source of sand nourishment for the beaches.

This gradually resulted in coastal erosion, exacerbated at times by storm surge events, which elevate water levels up to $1.5 \mathrm{~m}$ above high-tide level, allowing larger waves to reach the coast and create damage above normal levels. The coastal erosion and lack of natural sand replenishment necessitated hard rock protection. In addition, polluted stormwater and sewage outfalls in nearshore waters created raised nutrient

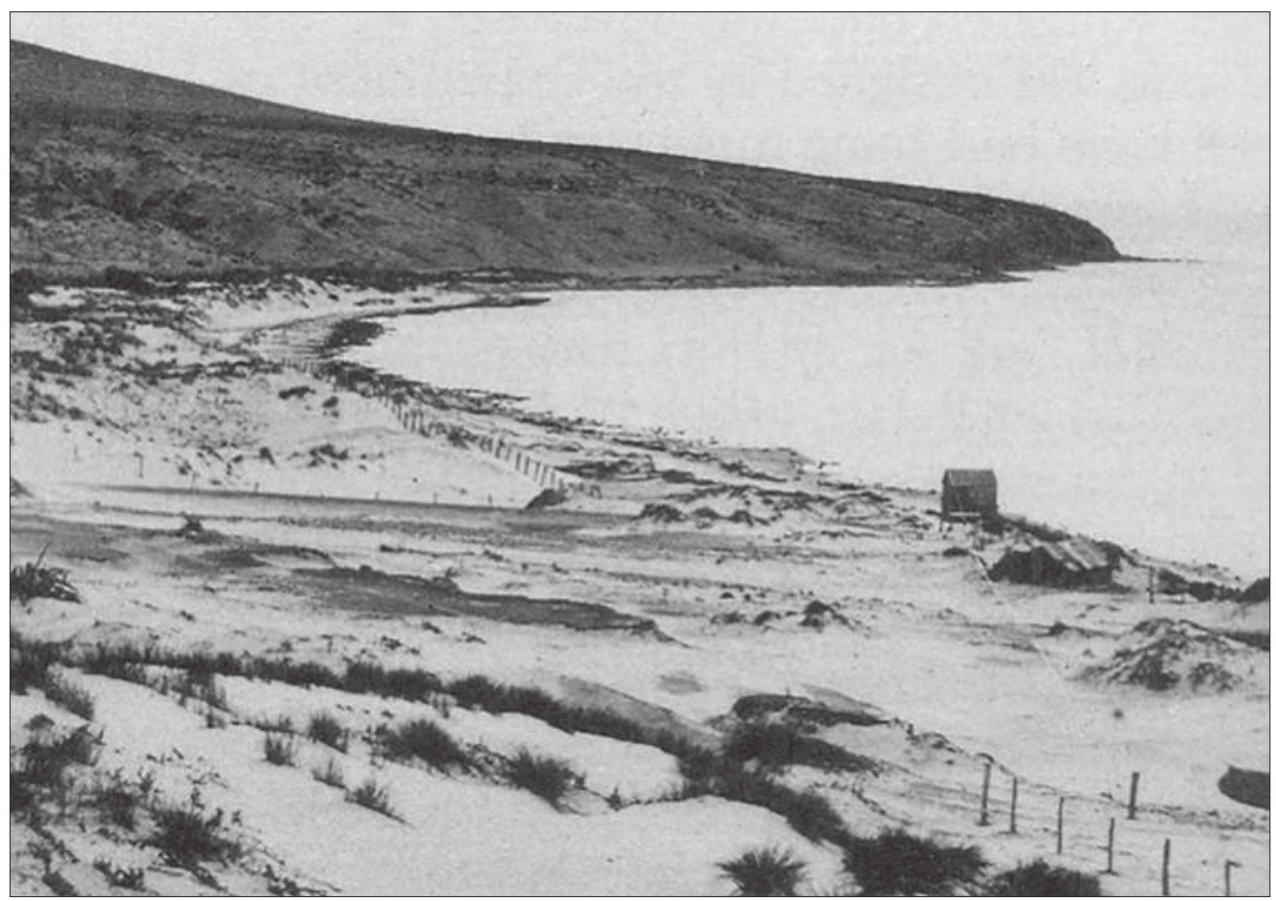

Figure 2.10a The coast at Brighton in the mid-1800s, showing the condition of coastal dunes and vegetation at that time.

Source: Reproduced with permission of the Coast Protection Board. 


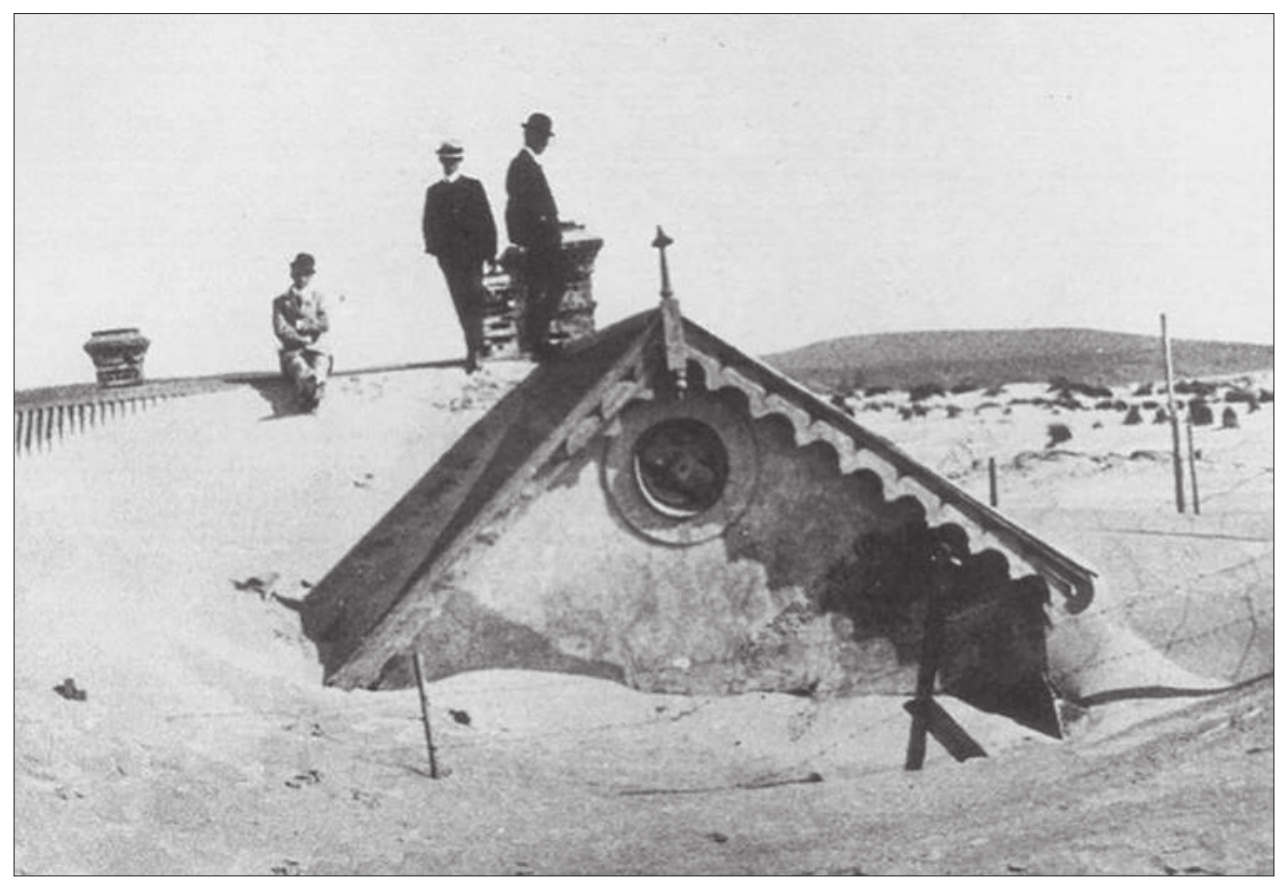

Figure 2.10b Early settler's house engulfed by sand drift, Brighton Beach, South Australia. Source: Reproduced with permission of the Coast Protection Board.

levels, causing dieback and destabilisation of seagrass beds, which resulted in further erosion. ${ }^{43}$ The Minda Dunes (Figure 2.11), between Brighton and Somerton Park, are a remnant of the original coastal landscape at a point where there is a relatively wide beach with some protection from a nearshore reef. ${ }^{44}$ The beach on this section of coast is largely artificially maintained through sand replenishment, which has resulted in the development of new dunes between Seacliff and the Brighton jetty. Sand replenishment in this area now relies on an automated pumping system. The artificial sand build-up at times interferes with local drainage catchments, with concrete stormwater outlets at times becoming blocked by sand.

Apart from the Port River estuary, the only other natural estuary on this section of coast was at Glenelg; both of these estuaries have now been highly modified. At Glenelg, the Patawalonga estuary is the coastal outlet for the Sturt River catchment, an area of just over $200 \mathrm{~km}^{2}$. Originally, there were mangrove woodlands and mudflats around the Patawalonga estuary, which had a Melaleuca-lined inlet. A mangrove mudflat was exposed by coastal erosion in 1948 near the Broadway, south of the jetty. ${ }^{45}$ The Patawalonga estuary is now highly modified, with a system of gates at its outlet, 


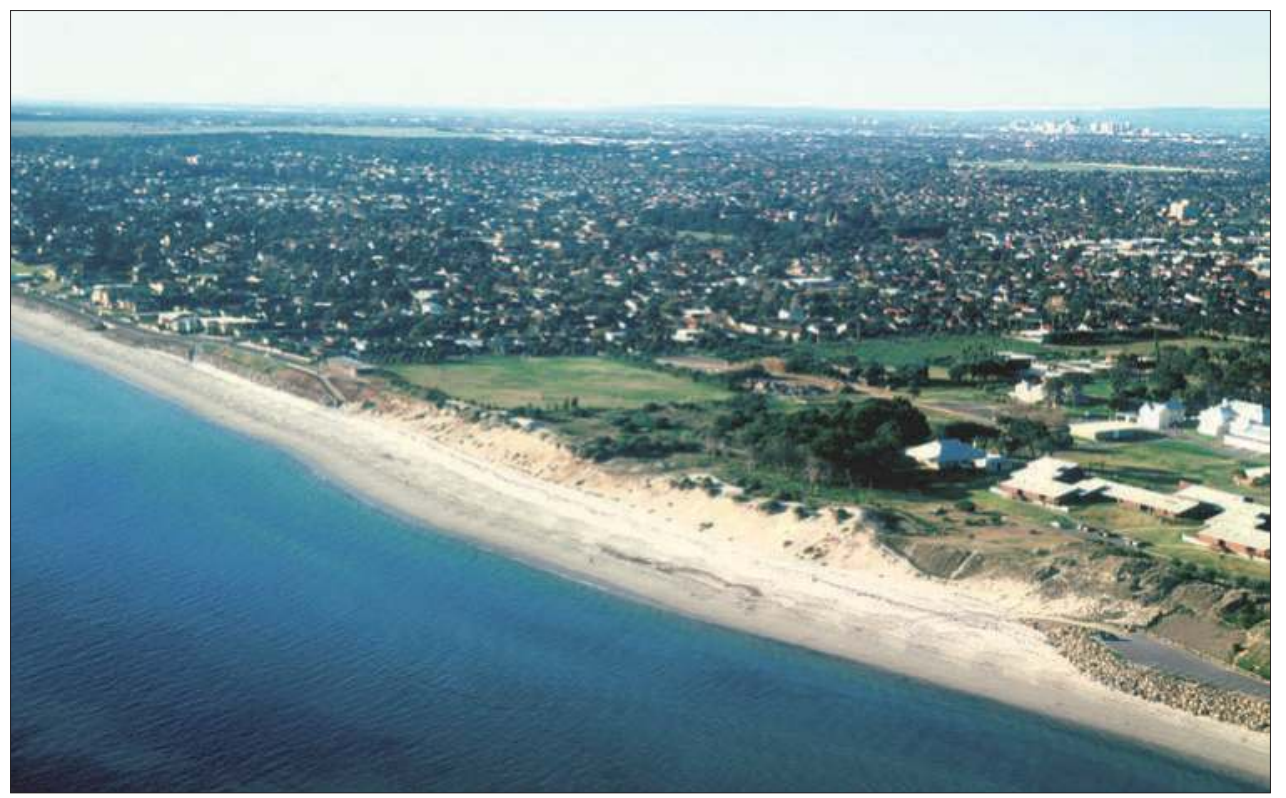

Figure 2.11 Minda Dunes, showing artificial hard rock protection to the north and south with a wider beach in front of the remnant coastal dunes.

Source: Author's own work, NH, 1982.

which have sometimes resulted in flooding upstream of the gates by floodwaters. A rock groyne south of the estuary, which was constructed in 1964 and extended in 1967, created an artificial interruption to the northerly littoral drift. The groyne filled with sand a few years after construction, starving the Glenelg North Beach of its natural sediment supply. ${ }^{46}$ The lock gates at the mouth of the estuary prevent natural tidal exchange, create a build-up of silt and heavy metals, and at times cause flooding problems.

Another interruption to northward littoral drift is caused at West Beach, where a rock-protected boat ramp (built in 1998) acts as an offshore breakwater. Connected by a road bridge, the breakwater has caused deposition of sand and seagrass in its lee and erosion of the West Beach dunes to the north. South of the boat ramp, an artificial stormwater outlet, Barcoo Outlet, has been constructed for the 1:100-year flood event to avoid flooding in the Patawalonga Estuary. Concrete outlet culverts are submerged beneath the beach. Polluted sediments, carried to the Patawalonga and Barcoo outlets by large flood events from the Sturt River, reach the shore and travel northward along the coast with deleterious impacts on seagrasses. This pollution sometimes results in beach closures. 
The coast between West Beach and Point Malcolm comprises a Holocene veneer of sediment over Paleogene-Neogene clays, sands and limestones, together with riverine sediments and coastal dunes. It is a moderate-energy, dissipative beach comprising mostly siliceous sands. Originally, some $10 \%$ of the beach sand was calcareous, but this has diminished as pollution is reducing mollusc production and more quartz sand has been introduced by artificial sand replenishment. An artificial break in the coastal dunes was created in the 1930s at West Beach by cutting an outlet to the sea for the River Torrens to prevent flooding in the back-dune area of the 'Reed Beds', where the river is now constrained by levee banks (Figure 2.13). ${ }^{47}$

The outlet acts as a hydraulic groyne, interrupting the dominant northerly longshore drift so that sand builds up on the beaches south of the Torrens outlet. The River Torrens, which has a catchment of over $500 \mathrm{~km}^{2}$, evacuates a significant component of urban stormwater. Originally the river drained into the 'Reed Beds' at Henley, as shown on maps from the 1880s, and at times of higher flow water would drain both to the north into the Port River Estuary and to the south into

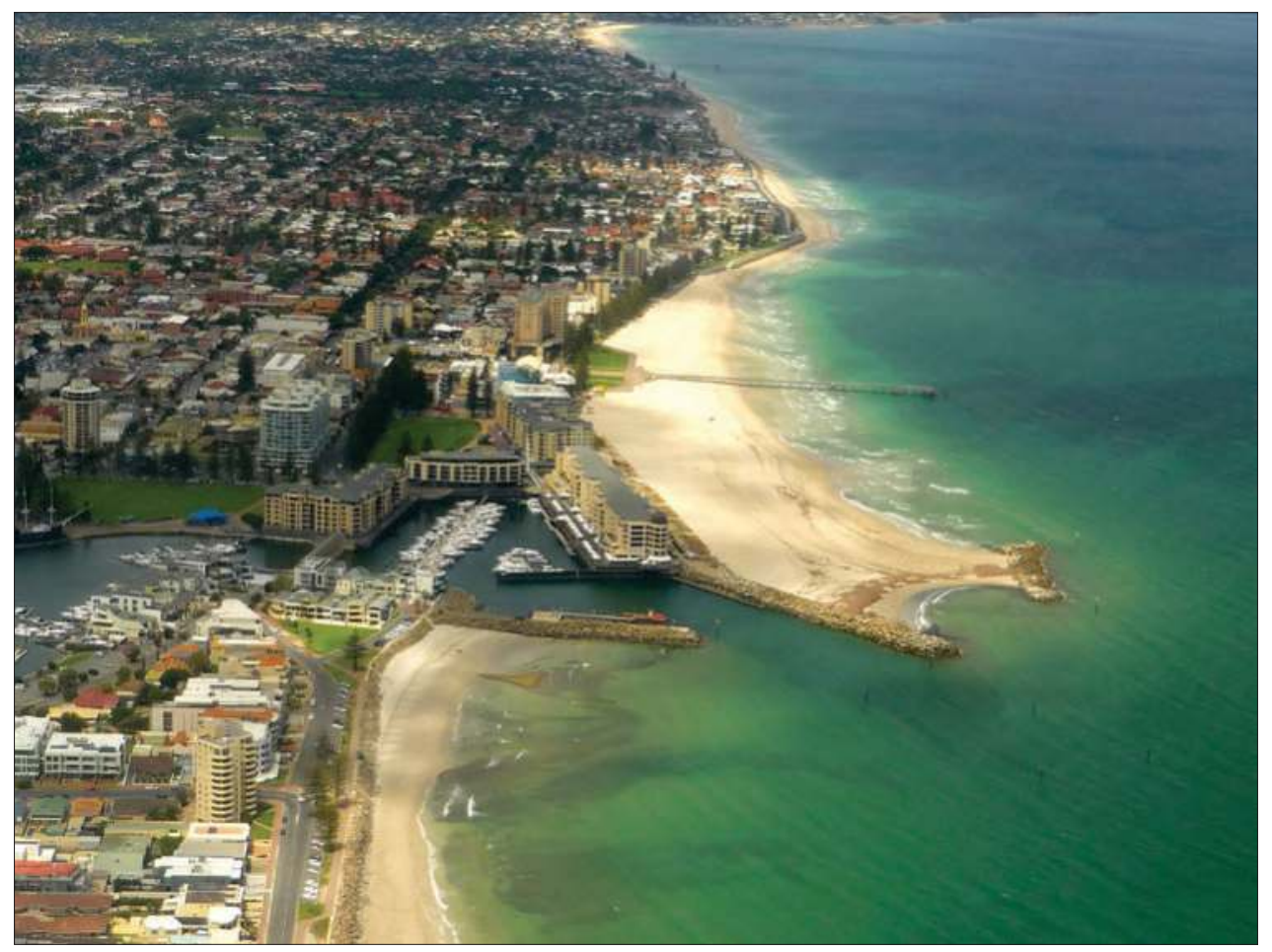

Figure 2.12 The Patawalonga Estuary, marina and breakwaters, showing residential development on reclaimed land and sand build on the south (upper) side with downdrift narrow beach on the north (lower) side.

Source: Author's own work, NH, 2015. 


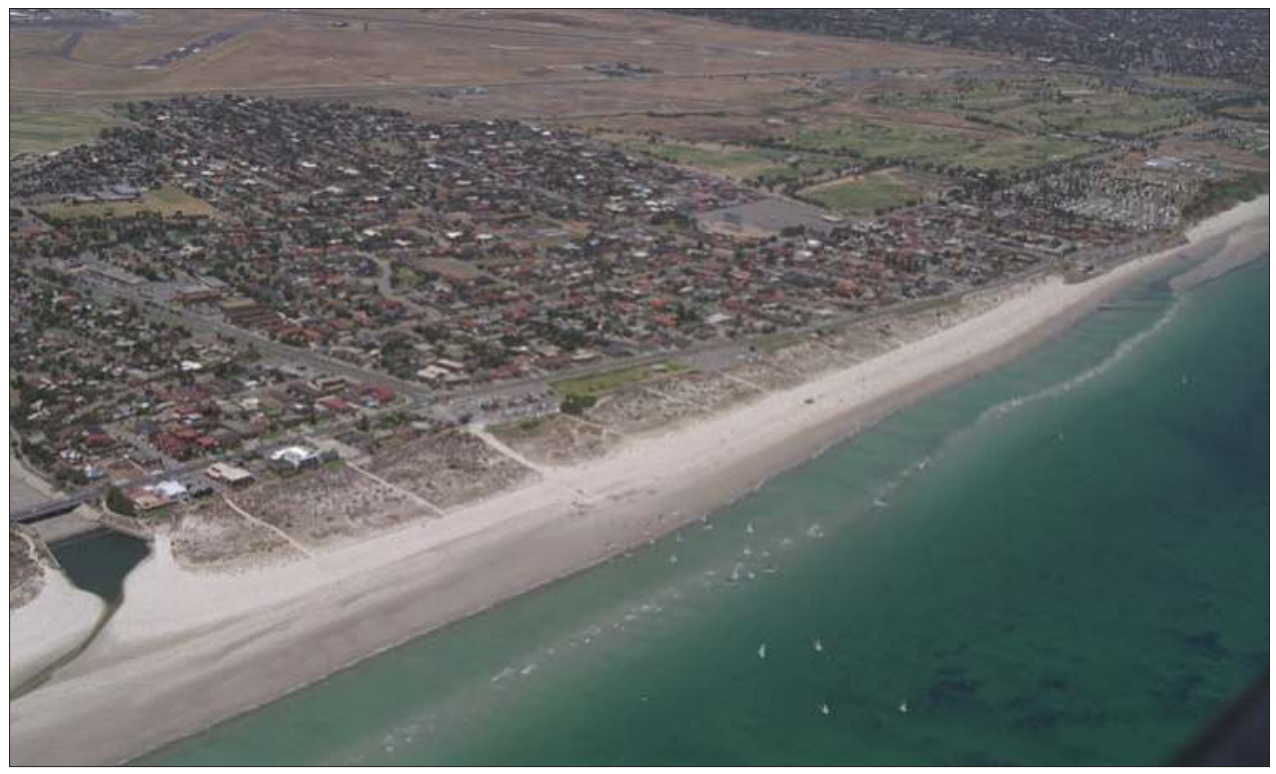

Figure 2.13 Torrens Outlet to West Beach, illustrating the extensive build-up of sand south (to the right of the photograph). The sand has been trapped partly because the outlet acts as a hydraulic groyne but also because of an extensive dune revegetation programme of native species.

Source: Reproduced with permission of the Coast Protection Board, 1995.

the Patawalonga Estuary. As most sediment was deposited in the 'Reed Beds', little sediment was delivered to the coasts.

From Point Malcolm north to Largs Bay, accumulated sand has formed dunes a few hundred metres wide. This sediment accumulation has recently increased due to the construction of an artificial offshore breakwater at Point Malcolm. Rapid beach aggradation has also occurred at Semaphore and Largs Bay, resulting from northerly longshore drift of sand from the southern metropolitan beaches along with movement of sediment from degraded seagrass meadows. The low-wave energy beach in this area comprises fine to medium sand with 'ridge and runnel' features; it is a reflective beach at high tide.

There is evidence of northward movement of sand over the past 7000 years, as shown by the progressive northward growth of Le Fevre Peninsula. ${ }^{48}$ Aerial photography from the 1940s reveals a wide series of low beach ridges on the western side of Le Fevre Peninsula, indicating rapid sediment accretion from just north of Port Adelaide to the current Outer Harbor. ${ }^{49}$ The growth of Le Fevre Peninsula was accompanied by the development of a beach ridge system (Figure 2.14), which is widest in the north 

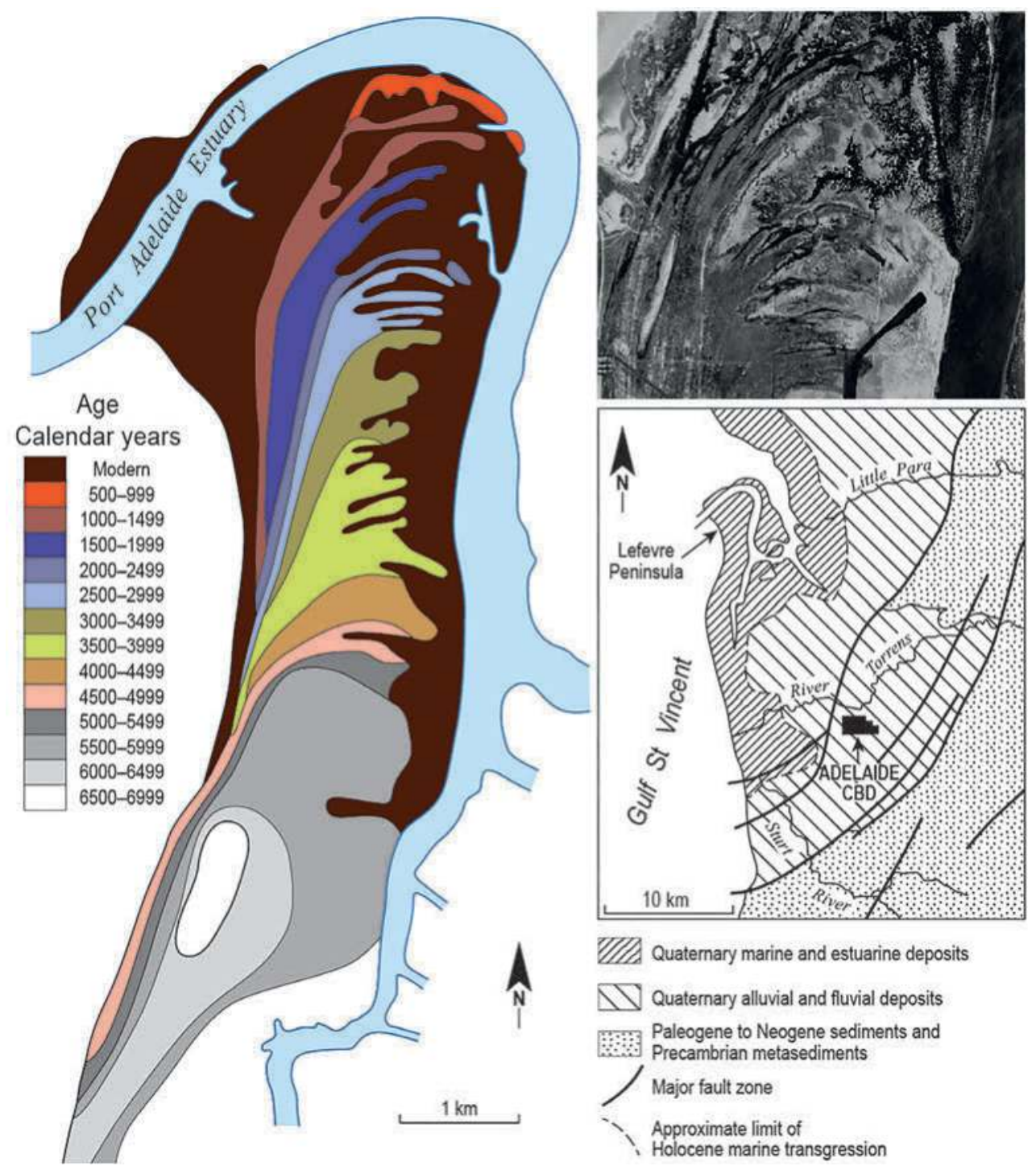

UIIA Quaternary marine and estuarine deposits

Duaternary alluvial and fluvial deposits

F.: Paleogene to Neogene sediments and

i.... Precambrian metasediments

Major fault zone

Approximate limit of

Holocene marine transgression

Figure 2.14 Beach ridge sequence, Le Fevre Peninsula, illustrating the location of transect lines used by Bowman and Harvey (see Note 16) to map the evolution of the peninsula, and a 1949 aerial photograph of the northern part of the peninsula.

Source: Bowman, G. \& Harvey, N. (1986). Geomorphic evolution of a Holocene beach ridge complex, Le Fevre Peninsula, South Australia. Journal of Coastal Research, 2, 345-362 The aerial photograph is reproduced with the permission of the Resource Information Division, Department of Environment and Heritage. 
where the ridges recurve inland and interfinger with estuarine and mangrove muddy sediments. ${ }^{50}$ The work of Bowman and Harvey showed that over the past 7000 years, since present sea level stabilised, the metropolitan coast has been naturally running out of sand, making the metropolitan coast very vulnerable to the subsequent detrimental impacts of European settlement. ${ }^{51}$

The northward growth of Le Fevre Peninsula forced the Port River estuary north to its current position, where it has since been constrained by breakwaters and dredging to maintain a navigable channel. Between 1903 and 1905, the Outer Harbor breakwater was built and land reclaimed, creating a barrier to northerly littoral drift. ${ }^{52}$ This resulted in $250 \mathrm{~m}$ of coastal accretion south of the breakwater, where there is now extensive residential and marina development at North Haven. ${ }^{53}$ The southern breakwater of the marina itself, constructed in 1974, subsequently created further coastal accretion of $200 \mathrm{~m} .^{54}$

The section of coast from Seacliff, in the south, to Outer Harbor and the Port River, to the north, marks the end of the wave-dominated sandy metropolitan coast and the start of the more tidally dominated mangrove woodland coast. However, mangroves from the southern parts of the Port River Estuary have been cleared, and there are only small areas of mangrove and samphire remaining at Mutton Cove and Mangrove Cove. Geological studies by Belperio (discussed in Chapter Six) indicate significant subsidence around the Port River Estuary, in part related to groundwater withdrawal since European settlement. ${ }^{55}$ Moreover, the Port Adelaide area has subsided tectonically some $10 \mathrm{~m}$ during the past 125000 years, based on the dislocation of the last interglacial shoreline ${ }^{56}$, exacerbating the erosion problems of the Adelaide coast.

\subsection{Summary and conclusions}

The metropolitan Adelaide coast extends from Sellicks Beach in the south to Le Fevre Peninsula in the north. In the south, prominent coastal cliffs formed on Neoproterozoic to Cambrian bedrock, Paleogene-Neogene marine limestones and Pleistocene alluvial fan successions separate open sandy bays. North of Seacliff, the coast, which demarks the western margin of the gently sloping Adelaide Plains, in its natural state formed a continuous sandy shoreline affected by northward longshore drift. The sandy beaches and dunes of this coastal sector were delicately balanced in a vulnerable condition before European settlement, and extensive coastal erosion followed urbanisation.

During the past 7000 years, sand accumulated in the northern sector of the coast to form the coastal barrier sand spit, Le Fevre Peninsula, resulting from a prolonged period of northward longshore sediment transport. Extensive mangrove woodlands and tide-dominated mudflat complexes developed in the more protected sections of coast to the east of the peninsula. The limited supply of beach sediment from the shallow gulf floor and the river catchments of the Adelaide region accentuated humaninduced coastal erosion. 
The overall development of the metropolitan coastline can be viewed at a range of temporal scales. The earliest geological events that ultimately affected coastal development relate to the formation of the Mount Lofty Ranges, in which a series of well-defined fault blocks and associated fault angle depressions led to the alternating cliffed headlands and bays between Sellicks Beach and Seacliff. Repeated sea level changes during the Quaternary have enhanced coastal cliff recession and have locally concentrated the accumulation of sand in beaches and coastal dunes. During falling sea levels, sediment was eroded and transported seawards, while sediments were entrained landwards as sea level rose.

Geologically, the most recent phase of coastal development occurred following the culmination of sea level rise that accompanied the demise of the continental-scale ice sheets. From about 17000 years ago sea level began to rise, and by 10000 years ago it began to flood the shallow depression of what is now Gulf St Vincent. By 7000 years ago, the sea surface had reached its present level and the outline of the coastline was broadly established as a delicately balanced coast, very vulnerable to human impacts.

\section{Notes}

1 Foden, J., Elburg, M., Dougherty-Page, J. \& Burtt, A. (2006). The timing and duration of the Delamerian Orogeny: Correlation with the Ross Orogen and implications for Gondwana assembly. Journal of Geology, 114, 189-210.

2 Hasenohr, P. \& Corbett, D. (Eds) (1986). A field guide to the coastal geology of Fleurieu Peninsula: Port Gawler to Victor Harbor. Field Geology Club of South Australia, Marden, SA; Preiss, W.V. (1987). The Adelaide Geosyncline: Late Proterozoic stratigraphy, sedimentation, palaeontology and tectonics. Geological Survey of South Australia, Bulletin 53, D.J. Woolman, Government Printer, South Australia, Adelaide, 438 pp.

3 Hasenohr \& Corbett (1986); Bourman, R.P. \& Alley, N.F. (1990). Stratigraphy and environments of deposition at Hallett Cove during the Late Palaeozoic. Mines and Energy Review, South Australian Department of Mines and Energy, 157, 68-82.

4 Daily, B., Firman, J.B., Forbes, B.G. \& Lindsay, J.M. (1976). Geology. In: Twidale, C.R., Tyler, M.J. \& Webb, B.P. (Eds), Natural history of the Adelaide region. Royal Society of South Australia, Occasional Publications No. 1, pp. 5-42; Giesecke, R. (Ed.) (1999). A field guide to the geology of Hallett Cove and other locations with glacial geology on Fleurieu Peninsula. $1^{\text {st }}$ ed. Field Geology Club of South Australia, Adelaide.

5 Twidale, C.R. (1976). Geomorphological evolution. In: Twidale, C.R., Tyler, M.J. \& Webb, B.P. (Eds), Natural history of the Adelaide region. Royal Society of South Australia. Occasional Publications No. 1, pp. 43-59.

6 Hasenohr \& Corbett (1986).

7 Hasenohr \& Corbett (1986).

8 Hasenohr \& Corbett (1986); McGowran, B. \& Alley, N.F. (2008). History of the 
Cenozoic St Vincent Basin in South Australia. In: Shepherd, S.A., Bryars, S., Kirkegaard, I., Harbison, P. \& Jennings, J.T. (Eds), Natural history of Gulf St Vincent. Royal Society of South Australia, Occasional Publications No. 8, pp. 13-28; Bourman, B., Harvey, N. \& Bryars, S. (2010). Catchments and Waterways, Chapter 3. In: Daniels, C.B. (Ed.), Adelaide: Water of a city. Wakefield Press, Kent Town, SA, pp. 69-89.

9 Lindsay, J.M. (1969). Cainozoic foraminifera and stratigraphy of the Adelaide Plains SubBasin, South Australia. Geological Survey of South Australia, Bulletin 42, Department of Mines, South Australia, Adelaide, 60 pp.

10 Ludbrook, N.H. (1983). Molluscan faunas of the Early Pleistocene Point Ellen Formation and Burnham Limestone, South Australia. Transactions of the Royal Society of South Australia, 107, 37-49.

11 Murray-Wallace, C.V. \& Woodroffe, C.D. (2014). Quaternary sea-level changes: A global perspective, Cambridge University Press, Cambridge, 484 pp.

12 Murray-Wallace, C.V. \& Belperio, A.P. (1991). The last interglacial shoreline in Australia - A review. Quaternary Science Reviews, 10, 441-461.

13 Hasenohr \& Corbett (1986); Bourman, Harvey \& Bryars (2010).

14 Hasenohr \& Corbett (1986); Cann, J.H. \& Gostin, V.A. (1985). Coastal sedimentary facies and foraminiferal biofacies of the St Kilda Formation at Port Gawler, South Australia. Transactions of the Royal Society of South Australia, 109, 121-142.

15 Cann, J.H., Murray-Wallace, C.V., Riggs, N.J. \& Belperio, A.P. (2006). Successive foraminiferal faunas and inferred palaeoenvironments associated with the postglacial (Holocene) marine transgression, Gulf St. Vincent, South Australia. The Holocene, 16, 224-234.

16 Bowman, G. \& Harvey, N. (1986). Geomorphic evolution of a Holocene beach-ridge complex, Le Fevre Peninsula, South Australia. Journal of Coastal Research, 2, 345-362.

17 Bourman, Harvey \& Bryars (2010).

18 Bourman, R.P., Belperio, A.P., Murray-Wallace, C.V. \& Cann, J.H. (1999). A last interglacial embayment fill at Normanville, South Australia and its neotectonic implications. Transactions of the Royal Society of South Australia, 123, 1-15.

19 Bourman, Harvey \& Bryars (2010).

20 Hasenohr \& Corbett (1986).

21 Bourman, R.P. \& May, R.I. (1984). Coastal Rotational Landslump. Australian Geographer, $16,144-146$.

22 Cann, J.H., Lower, C.S. \& Jago, J.B. (2014). Provenance and sediment characteristics of contemporary gravel deposits at Sellicks Beach, eastern shore of Gulf St Vincent, South Australia. Australian Journal of Earth Sciences, 61, 819-836.

23 Crichton, R. (1984). Pebble sorting at Sellicks Beach, Taminga, 21 (4), 24-30; Cann, J.H., Lower, C.S. \& Jago, J.B. (2014). Provenance and sediment characteristics of contemporary gravel deposits at Sellicks Beach, eastern shore of Gulf St Vincent, South Australia. Australian Journal of Earth Sciences, 61, 819-836.

24 Hasenohr \& Corbett (1986).

25 Hasenohr \& Corbett (1986).

26 Ward, W.T. (1966). Geology, geomorphology and soils of the southwestern part of County 
Adelaide, South Australia. CSIRO Soil Publication, 23. Commonwealth Scientific and Industrial Research Organization, Australia, Melbourne, 115 pp.

\section{Proceedings of the International Geographic Union Regional Conference and Eighth New} Zealand Geographic Conference, 8, 289-297.

31 Giesecke (1999).

32 Giesecke (1999).

33 Giesecke (1999).

34 Hasenohr \& Corbett (1986); Murray-Wallace \& Woodroffe (2014).

35 Foden, Elburg, Dougherty-Page \& Burtt (2006); Murray-Wallace \& Woodroffe (2014).

36 Selby, J. (1984). Geology and the Adelaide environment. Handbook No. 8. Department of Mines and Energy, South Australia, Adelaide, 168 pp.

37 Selby, Geology and the Adelaide environment; Department for Environment and Heritage (2005). Adelaide's living beaches: A strategy for 2005-2025. Technical Report. Department for Environment and Heritage, South Australia, Adelaide.

38 Coastal Management Branch (1984). Adelaide coast protection strategy review. Prepared for the Coast Protection Board, South Australia by the Coastal Management Branch, Conservation Programmes Division, Department of Environment and Planning, South Australian Department of Environment and Planning, Adelaide.

39 Coastal Management Branch (1984); Harvey, N. \& Caton, B. (2010). Coastal management in Australia. University of Adelaide Press, Adelaide, $342 \mathrm{pp}$.

40 Selby (2005); Department for Environment and Heritage (2005).

41 Crichton, R. (1984). Pebble sorting at Sellicks Beach, Taminga, 21 (4), 24-30.

42 Harvey \& Caton (2010).

43 Bourman, Harvey \& Bryars (2010).

44 Hasenohr \& Corbett (1986); Department for Environment and Heritage (2005).

45 Cotton, B.C. (1949). An old mangrove mud-flat exposed by wave scouring at Glenelg, South Australia. Transactions of the Royal Society of South Australia, 73 (1), 59-61.

46 Coastal Management Branch (1984).

47 Coastal Management Branch (1984).

48 Hasenohr \& Corbett (1986); Bowman \& Harvey (1986).

49 Bowman \& Harvey (1986).

50 Bowman \& Harvey (1986); Harvey, N. (2006). Holocene coastal evolution: Barriers, Beach Ridges, and Tidal Flats of South Australia. Journal of Coastal Research, 22, 90-99; Harvey, N. \& Bowman, G.M. (1987). Coastal management implications of a Holocene sediment budget: Le Fevre Peninsula, South Australia. Journal of Shoreline Management, 3, 77-93.

51 Bowman \& Harvey (1986). 
52 Coastal Management Branch (1984).

53 Short, A.D. (2012). Adelaide Beach Management 1836-2025, Chapter 2. In: Cooper, J.A.G. \& Pilkey, O.H. (Eds), Pitfalls of shoreline stabilization: Selected case studies. Coastal Research Library 3. Springer, Dordrecht, pp. 15-36.

54 Short (2012).

55 Belperio, A.P. (1993). Land subsidence and sea level rise in the Port Adelaide estuary: Implications for monitoring the greenhouse effect. Australian Journal of Earth Sciences, 40, 359-368.

56 Bourman, Belperio, Murray-Wallace \& Cann (1999). 


\section{The Fleurieu Peninsula coast}

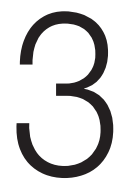

\subsection{Introduction}

Fleurieu Peninsula, the smallest of South Australia's three main peninsulas, was named by Nicolas Baudin in 1802 after Captain Charles Pierre Claret de Fleurieu, a Member of the Institute of France, which promoted Baudin's expedition. The Fleurieu coast, which extends about $140 \mathrm{~km}$ from Sellicks Beach in the north to Middleton in the southeast (Figure 3.1), is bedrock-dominated and exhibits cliffs, bluffs, rocky islands, shore platforms and reefs; sandy pocket beaches occupy small bays where valleys intersect the coast. More extensive beaches at Normanville, Tunkalilla and Victor Harbor front last interglacial embayments, formed when sea level was about $2 \mathrm{~m}$ higher than present. Vast arrays of geological features, past ice ages, climatic changes, prior shoreline positions and erosional and depositional stream activities have impacted on the coast.

\subsection{Geological evolution}

Part of the South Mount Lofty Ranges, Fleurieu Peninsula is underlain by resistant, folded rocks and granite intrusions, now exposed at the coast due to progressive tectonic uplift and erosion (Figure 3.2). During the Early Permian (299 to $290 \mathrm{Ma}$ ), an ice sheet some 1000 to $2000 \mathrm{~m}$ thick covered Fleurieu Peninsula, travelling towards the northwest. The ice sheet aided exposure of the Encounter Bay Granites ${ }^{1}$, produced the present distribution of granite headland and islands of Encounter Bay, eroded deep valleys such as Backstairs Passage and deposited great thicknesses of glacial sediments, which today provide sand sources for many beaches. ${ }^{2}$

Throughout the Mesozoic (253 to $66 \mathrm{Ma}$ ), Fleurieu Peninsula was exposed to continual weathering and erosion. After the separation of Australia and Antarctica, 


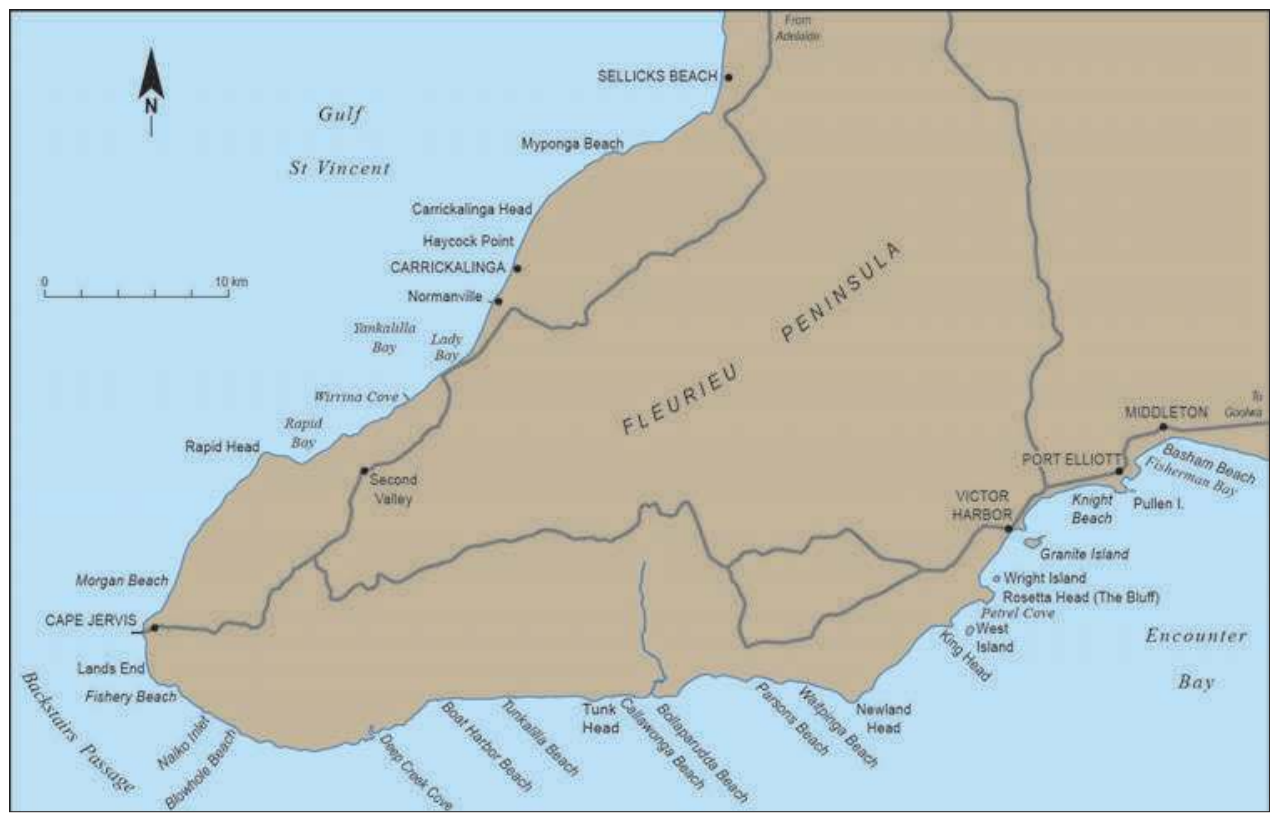

Figure 3.1 Map of Fleurieu Peninsula, showing principal localities referred to in the text. Source: Author's own work, RPB.

various marine incursions invaded the Paleogene and Neogene (65 to 2.6 Ma) basins fringing Fleurieu Peninsula and partially re-excavated Permian valleys within the ranges. Progressive tectonic uplift of Fleurieu Peninsula is revealed by the offset of these Cenozoic marine sediments. In the Myponga Basin, limestone 20 Ma old occurs at up to $240 \mathrm{~m}$ APSL, while at Sellicks Beach, only $12 \mathrm{~km}$ away, it extends below sea level. Active tectonism has uplifted the peninsula largely as a single tectonic block, tilted slightly to the south and exposing resistant bedrock at the coast to initiate and maintain the rugged, cliffed Fleurieu coast.

The worldwide climatic changes and sea level fluctuations of the Pleistocene (2.6 Ma to $11.7 \mathrm{ka}$ ) have influenced the Fleurieu coastline, including the presence of aeolianite deposits, although they are not as widespread as on the Eyre and Yorke Peninsulas, the Coorong Coast and Kangaroo Island, probably because of the protection offered by Kangaroo Island. Some of the fluctuations in sea level are recorded in river valleys by the formation of terraces. Only $21 \mathrm{ka}$ ago, sea level stood $125 \mathrm{~m}$ below present, when there were land links with Kangaroo Island, but by 7 ka, rapid glacier melting raised sea level to near its present position. 
There is a threefold division of the Fleurieu coast, based on variations in geological structures and exposure of bedrock of contrasting characteristics. The Delamerian Orogeny (see Chapter One) produced an overfold on the west coast (Figure 3.3), so that the rocks on both sides of the peninsula dip in the same direction; beds on the west coast dip landward, while those on the east dip seawards, giving rise to different cliff

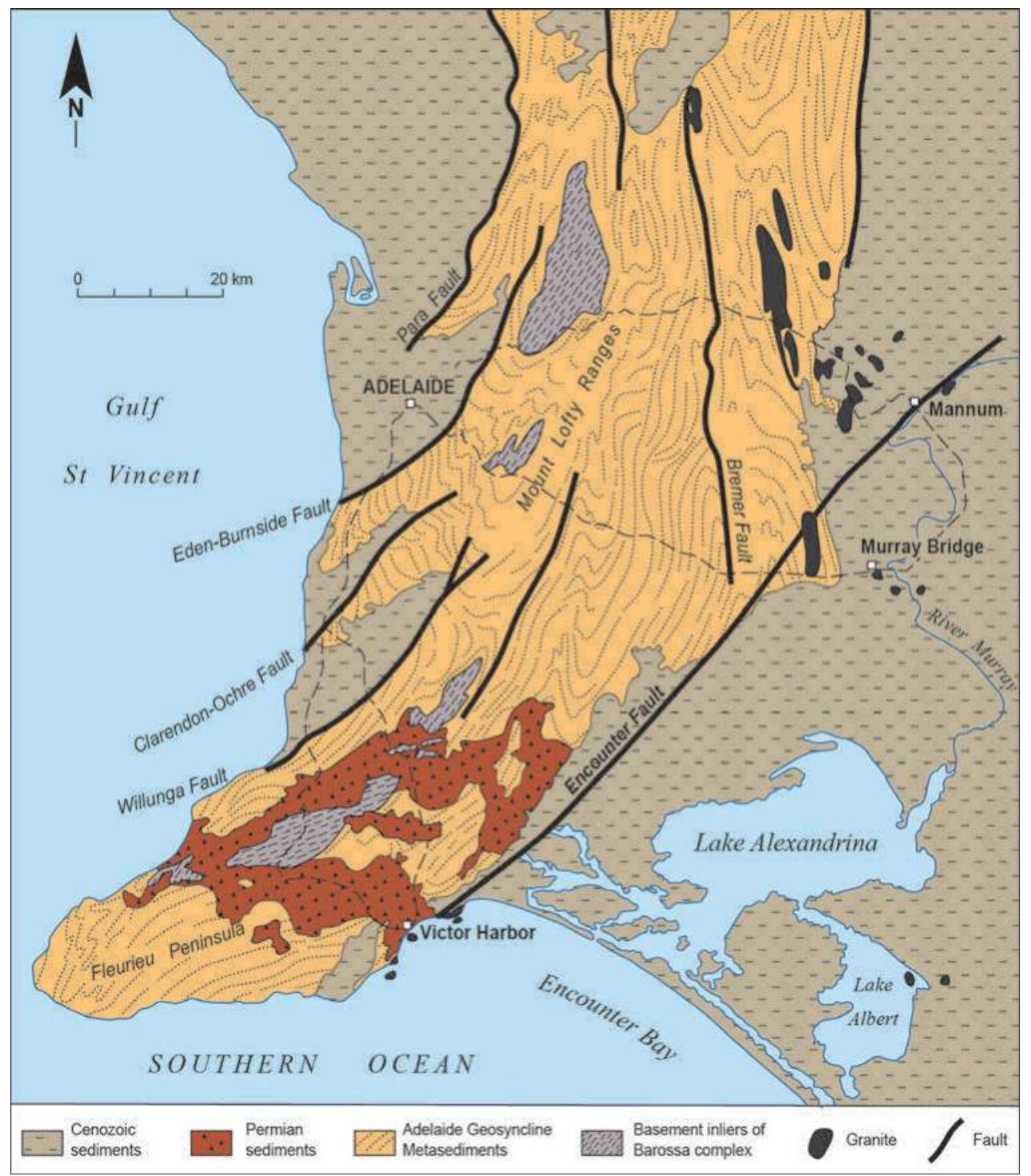

Figure 3.2 Geology map of Fleurieu Peninsula, showing major faults and rock units.

Source: Talbot, J.L. \& Nesbitt, R.W. (1968). Geological excursions in the Mount Lofty Ranges and the Fleurieu Peninsula. Angus and Robertson, Adelaide. Reproduced with permission. 


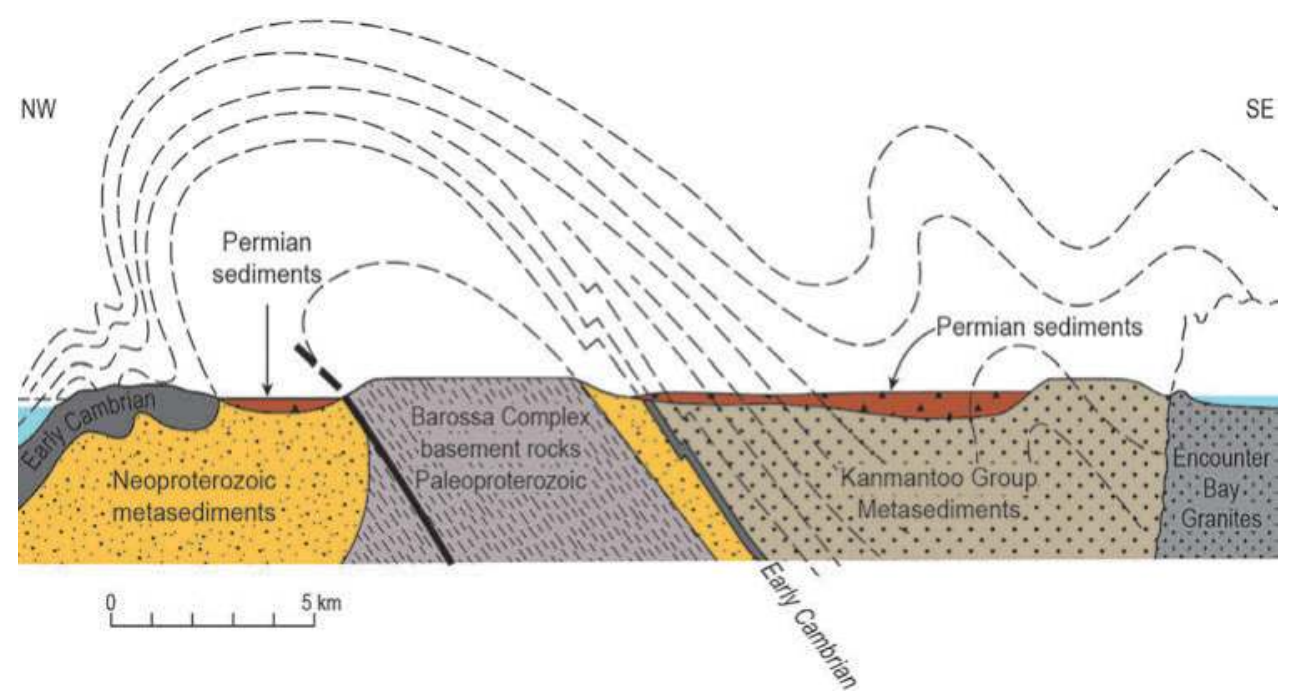

Figure 3.3 Reconstructed fold mountain range produced by the Delamerian Orogeny of about $500 \mathrm{Ma}$ ago, shown as dashed lines, and the underlying eroded remnant rocks that form the foundation of Fleurieu Peninsula.

Source: Talbot, J.L. \& Nesbitt, R.W. (1968). Geological excursions in the Mount Lofty Ranges and the Fleurieu Peninsula. Angus and Robertson, Adelaide. Reproduced with permission.

morphologies. Along the south coast, the edges of the bedding planes point seawards, a structural variation that produces a ragged and irregular edge to the coastline.

\subsection{Northwestern Fleurieu coast}

The northwest-facing Fleurieu coastline, from Sellicks Beach to Cape Jervis, lies in the semi-protected and relatively shallow waters of Gulf St Vincent. Cenozoic tectonic uplift has produced cliffs up to $80 \mathrm{~m}$ high, topped by gently seaward-sloping surfaces, possibly degraded remnants of uplifted marine platforms, which are reminiscent of the even more tectonically active southern Californian coast. Both active and abandoned cliffs dominate the coastline, with occasional sandy pocket beaches such as Myponga Beach, Second Valley Beach, Wirrina Cove and Rapid Bay. These sandy beaches are essentially trapped within the rocky bays, with minimal sand bypassing headlands into adjoining coastal compartments. Near Little Gorge, the abandoned cliffed coast is characterised by intertidal shore platforms, up to $50 \mathrm{~m}$ wide, and shingle beaches, which abut the steep debris slopes, alluvial fans and terraces. Storm waves are actively eroding some of the debris slopes, liberating clasts for the boulder beaches. 


\subsubsection{Southern Aldinga Bay}

This rocky cliffed coastline consists of Cambrian (500 Ma) limestones, sandstones and shales, with the shape of the coastline reflecting the structural influences of the Willunga Fault Zone. There is a general coincidence of the shoreline with curved bedrock structures and with the steep reverse thrust fault that parallels the coastline. Where the coast intersects the Willunga Fault Zone, the shoreline changes its orientation from a northerly to a west-southwesterly trend, weathered and brecciated Cambrian rocks of the Heatherdale Shale replace Pleistocene fanglomerates, and the sandy beach becomes boulder-strewn. Knickpoints, abrupt changes in the long profiles of stream valleys, generated by the tectonic uplift of the peninsula, have produced intermittent coastal cliff waterfalls.

Earth movements have uplifted a last interglacial cobble beach that rests on a former shore platform $5 \mathrm{~m}$ APSL (Figure 3.4) cut across the tilted limestone of the Port Willunga Formation, indicating a local uplift of Fleurieu Peninsula of $3 \mathrm{~m}$ in the past $125 \mathrm{ka}^{3}$ Dune sand approximately $35 \mathrm{ka}$ old overlies the cobble beach, while several small isolated sea stacks rise abruptly from the modern shore platform as remnants of

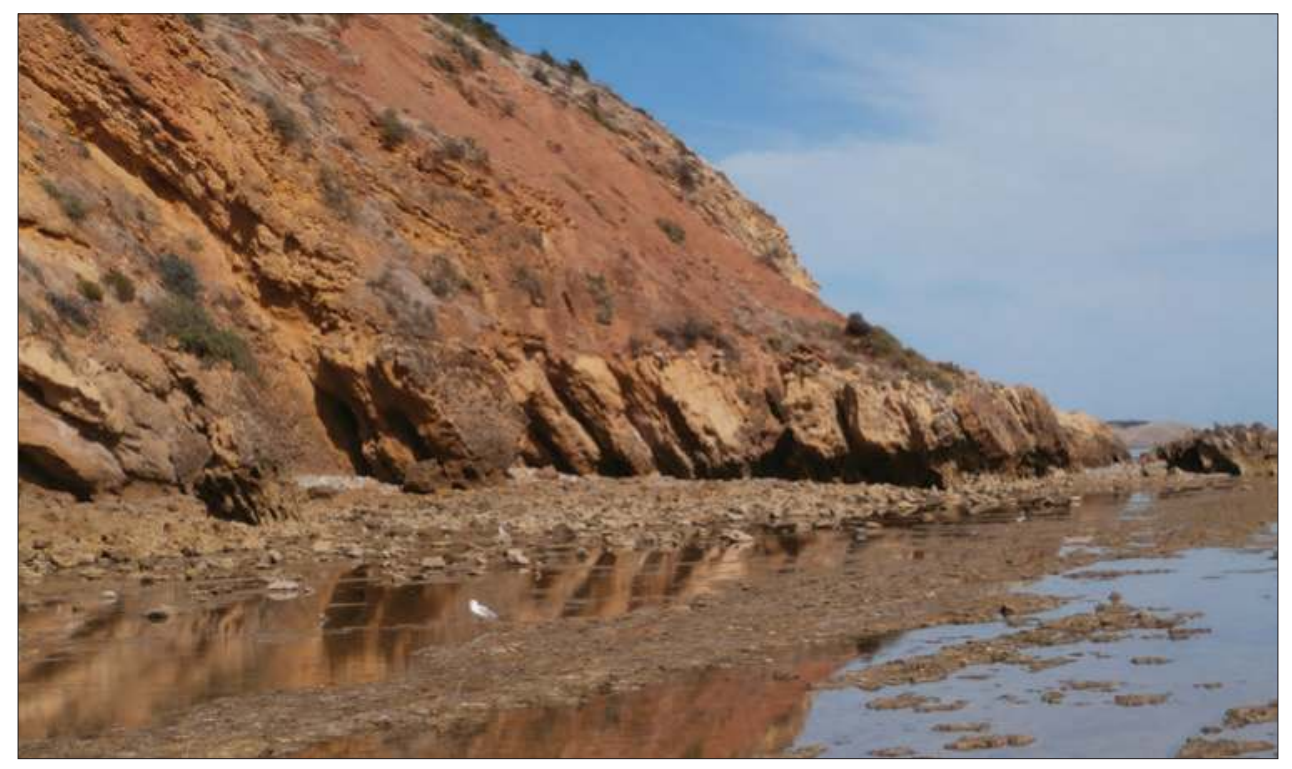

Figure 3.4 Uplifted last interglacial bench on a relict intertidal shore platform cut across tectonically tilted limestone of the Port Willunga Formation. The uplifted cobble beach lies $5 \mathrm{~m}$ above the modern intertidal shore platform and is overlain by dune sand and terrestrial sediments. Small sea stacks, erosional remnants of the formerly more extensive last interglacial shore platform, stand above the current shore platform, and are illustrated on the front cover of the book.

Source: Author's own work, RPB. 
a formerly more extensive high-level platform. A headland cut in Heatherdale Shale occurs just south of the last outcrop of Neogene limestone; beyond this, the coastline to Myponga Beach consists dominantly of Cambrian limestone of the Sellick Hill Formation and the Fork Tree Limestone.

\subsubsection{Myponga Beach}

Myponga Beach is a small bedrock-constrained pocket beach that is $0.5 \mathrm{~km}$ wide and faces north-northwest. It is flanked by limestone headlands of the Sellick Hill Formation that are $50 \mathrm{~m}$ high (Figure 3.5). The beach is located at the outflow of the Myponga River, which has cut a deep V-shaped valley up to $200 \mathrm{~m}$ deep through resistant Cambrian rocks down to sea level, attesting to the ongoing tectonic uplift of Fleurieu Peninsula. On the southwestern side of the bay, marine erosion has produced a serrated shore platform, variably mantled by boulders and pebbles. The beach is isolated with minimal sand transport towards Sellicks Beach, even though the wave approach suggests longshore drift to the northwest, as does the greater accumulation

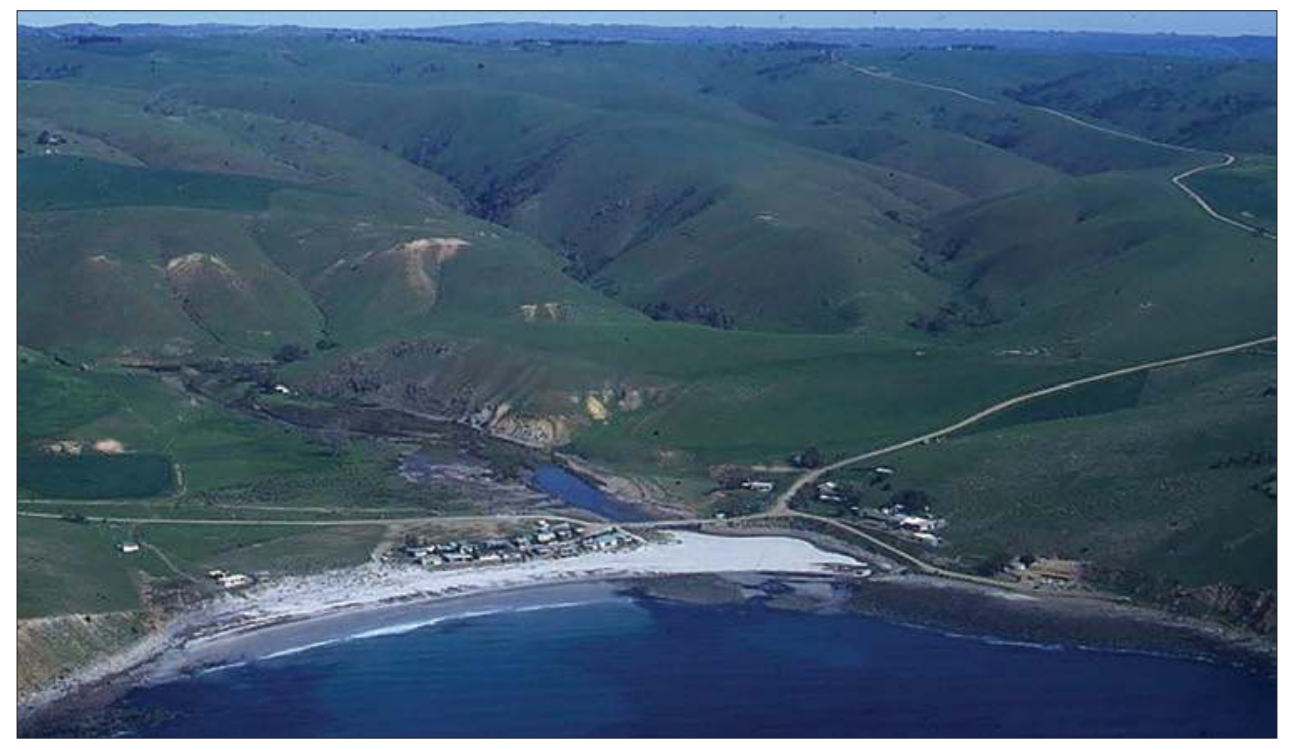

Figure 3.5 Oblique aerial view of Myponga Beach, a small pocket beach at the mouth of the Myponga River, the main source of the beach sediments derived from Permian glacial deposits. The flanking headlands are formed of Cambrian limestone of the Sellick Hill Formation, as is the shore platform on the right-hand side. Note the deep V-shaped valleys, suggesting active uplift of the peninsula.

Source: Author's own work, RPB. 
of beach sediment in this sector of the bay. In contrast to the expected direction of longshore sediment transport, the river mouth hugs the southern side of the bay. This suggests either the influence of river meander development and/or strong wave refraction around the southern headland, causing waves to approach from the northwesterly quarter, thereby effectively trapping the sand in the beach compartment.

Fine-grained quartzose sand, scatterings of boulders and pebbles, and occasional shells make up the beach sediment, the majority of which has been delivered by the Myponga River and sourced from Permian glacial sediments, as revealed by the presence of Permian erratics on the beach. Alluvial (red-coloured) and estuarine sediments occupy parts of the valley upstream of the coast, but no major river terraces, such as those found at Normanville, survive, probably due to the narrowness of the valley and erosion by the Myponga River. No major sand dunes occur behind the beach, and boulders have been placed here to protect some dwellings close to high tide from coastal erosion.

Beyond Myponga Beach to Carrickalinga Head, some $7 \mathrm{~km}$ of rocky cliffs up to $60 \mathrm{~m}$ high form the coast, with inland slopes rising to $200 \mathrm{~m}$. Ten streams dissect the cliffed shoreline cut into Cambrian limestone, shales and sandstones. Spurs between the V-shaped valleys have been truncated by coastal erosion, forming steep cliffs and headlands, between which there are rocky reefs, shore platforms, bedrock-constrained coves and boulder beaches.

\subsubsection{Yankalilla Bay}

Yankalilla Bay, which is dominated by cliffs up to $120 \mathrm{~m}$ high cut into Cambrian and Neoproterozoic bedrock, extends for $25 \mathrm{~km}$ from Carrickalinga Head to Rapid Head. Some of the cliffs are still active, but others have been abandoned through tectonic uplift and sedimentation in the cliff foot zone. The cliffs formed predominantly during the Last Interglacial (125 ka), when sea level was $2 \mathrm{~m}$ higher than present. Subsequently, following a fall in sea level and tectonic uplift of the peninsula, the cliffs were elevated beyond the influence of the sea, following which fan-shaped deposits of colluvium (talus or scree) accumulated at the base of the cliffs. The cliff line is broken and the coastal topography lowered where streams enter the coast or where valleys originally carved by Permian ice have been re-exposed.

During the high sea level of the Last Interglacial, inlets of various dimensions embayed the coast, including Carrickalinga Bay North and the Normanville Embayment, both of which are backed by relict sea cliffs and have been infilled with alluvium, colluvium, beach and dune sediments. Rocky shore platforms with small sea stacks and reefs up to $100 \mathrm{~m}$ wide occur at and near headlands, while boulder ridges commonly lie at the back of sandy pocket beaches. Occasionally sand blown from the beaches has migrated up the cliff faces. 


\subsubsection{Normanville Embayment}

A sandy beach $8 \mathrm{~km}$ long and backed by vegetated sand dunes up to $15 \mathrm{~m}$ high occupies a break in the rugged sea cliffs of Yankalilla Bay between Haycock Point and Lady Bay (Figure 3.6). A low-lying coastal plain, 2 to $15 \mathrm{~m}$ APSL, backs the dunes, while its landward margin is marked by a stranded, arcuate cliff line cut in Cambrian and Neoproterozoic rocks and Permian glacigene sediments. The abandoned cliffed coastline marks the landward edge of a last interglacial marine embayment formed 125 ka ago. ${ }^{4}$

The Bungala and Yankalilla Rivers and Carrickalinga Creek have helped to infill the former embayment with alluvial deposits on which river terraces have formed. The highest terraces are underlain by red/brown alluvium of the Pooraka Formation of last interglacial age, and the lower inset terraces and flood plains consist of grey/ black sediments of mid-Holocene age. ${ }^{5}$ The streams have also delivered sands to the shoreline, derived predominantly from extensive deposits of Permian glacial sediments inland. Marine shells do occur on Normanville Beach, but the beach sediments, and especially the fine dune sand, consist primarily of quartz, revealing its terrestrial origin.

Sand is essentially held between the rocky headlands of the embayment. Longshore sediment transport is predominantly to the north: greater sand accumulations and larger coastal dunes occur in the north compared with the south, where there is a small shelly sandy beach and low dunes. At Little Gorge and Lady Bay, shore platforms formed on Proterozoic gneiss and Pleistocene beach rock predominate. At the latter site, coarse boulders cover the platform, some of which were derived from the basal conglomerate of the Adelaidean rocks of the former Adelaide Geosyncline. At extreme low tides, the shore platform extends up to $500 \mathrm{~m}$ offshore.

The area occupied by the Lady Bay Golf Course is underlain by last interglacial marine sand with warm-water shells, mainly Mactra australis. ${ }^{6}$ These shells occur up to $12 \mathrm{~m}$ APSL, suggesting $10 \mathrm{~m}$ of local uplift and coastal emergence in the past 125000 years. Following uplift and a fall in sea level, the gently seaward-sloping plain of marine aggradation became irregular, as streams dissected the abandoned cliff and formed alluvial fans at the scarp/plain junction. To the south, between Lady Bay and Little Gorge, impressive debris slopes formed of coarse, angular locally derived clasts developed at the foot of the abandoned sea cliff. A distinctive high-level alluvial surface with perched river gravels at the outlet of Little Gorge is another indicator of ongoing uplift of the peninsula (see Figure 1.6).

Wind action has reworked parts of the former marine surface, with sand dunes landward of the modern coastal dunes, giving a hummocky topography to the abandoned embayment. Originally white, these sands have been weathered to a red/ brown colour where they are exposed in the bunkers of the golf course. These dunes 


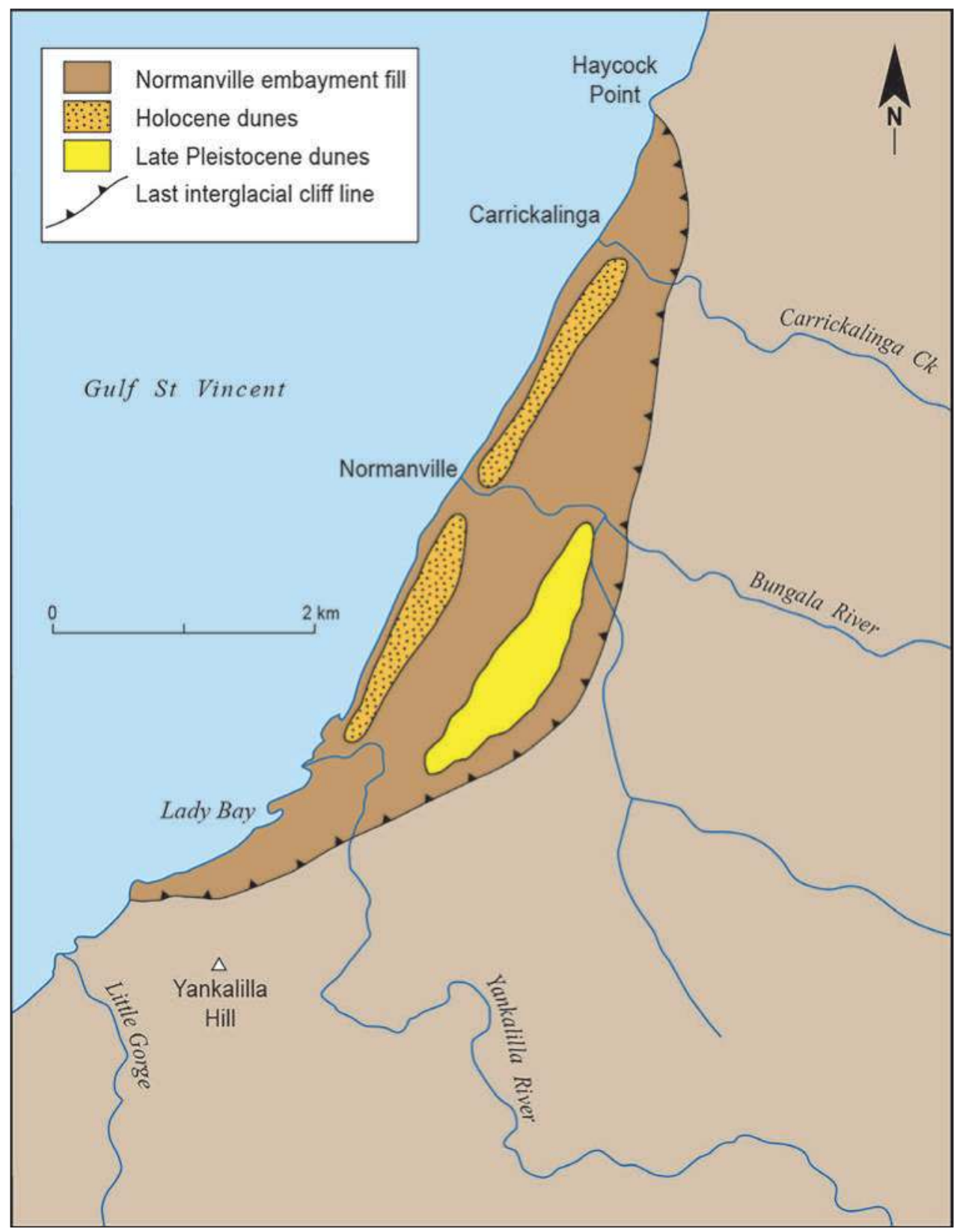

Figure 3.6 Map of Normanville Embayment.

Source: Bourman, R.P., Belperio, A.P., Murray-Wallace, C.V. \& Cann, J.H. (1999). A last interglacial embayment fill at Normanville, South Australia, and its neotectonic implications. Transactions of the Royal Society of South Australia, 123 (1), 1-15. 
are at least $52 \mathrm{ka}$ old, and their character, ages and settings have affinities with the Fulham Sand, a common substrate for many of the golf courses built on the Adelaide Plains. ${ }^{7}$ The modern sandy shoreline and its associated dune system developed over the past 7000 years, when sea level stabilised to near its present level. The dunes are generally well fixed with vegetation, but the quartzose sands were partially mined for the production of glass by ICI during the 1970s, until objections by conservationists were heeded.

\subsubsection{Little Gorge to Rapid Bay}

Between Little Gorge and Rapid Bay, precipitous rocky cliffs exceeding $100 \mathrm{~m}$ in places (Figure 3.7) back a relatively straight section of coast $7 \mathrm{~km}$ long. Streams dissect the cliff line, producing inlets at Wirrina and Second Valley. At Wirrina Cove, where the Anacotilla River enters the sea, a marina, Marina St Vincent, has been constructed. Second Valley is drained by Parananacooka Creek through a narrow gap to the rocky coast, where two sandy beaches are backed by cobbles. Second Valley is quite broad,

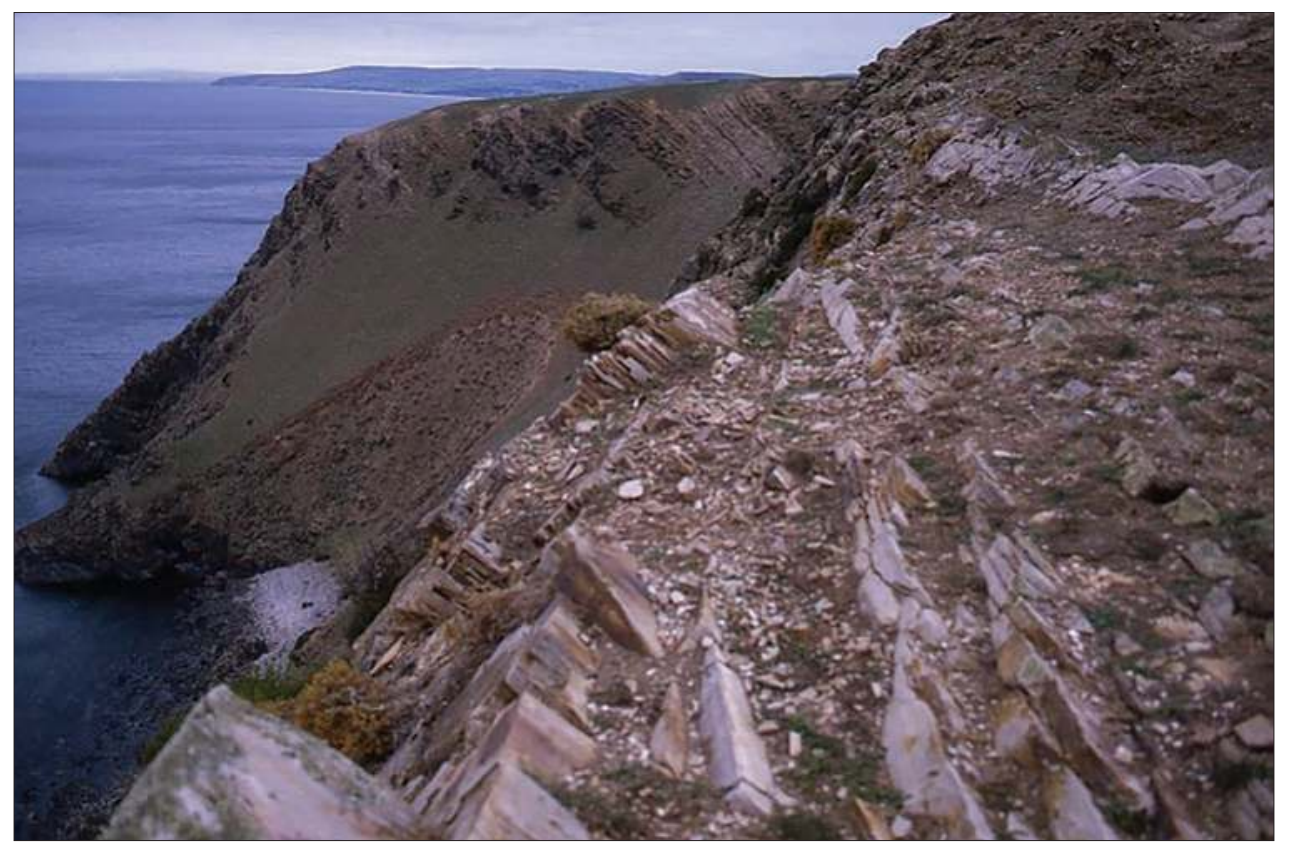

Figure 3.7 Northward view of the rugged cliffed coastline near Second Valley. Note the landward-dipping rock strata, part of the large overfold produced during the Delamerian mountain building episode about 500 million years ago. Also note the eroded scree or talus slope, which is providing sediment for the cobble beach at its base. A high-level bench on the distant headland may represent a Cenozoic marine bench.

Source: Author's own work, RPB. 
and the Parananacooka Creek is a misfit stream occupying a bedrock valley carved by Permian ice some $300 \mathrm{Ma}$ ago.

\subsubsection{Rapid Bay}

Named in 1836 by Colonel William Light after his vessel, Rapid Bay is an embayment at the outlet of the Yattagolinga River, which has eroded a steep, deep valley. Permian glacial ice initially excavated the Yattagolinga valley and established the location of Rapid Bay itself. Alluvial last interglacial sediments, which flank the Yattagolinga River, have been eroded to form a stranded coastal cliff $6 \mathrm{~m}$ APSL at the back of the bay; these provide further evidence for uplift of Fleurieu Peninsula.

Rapid Bay is a classic example of excessive artificial nourishment of a beach. Rapid Bay was filled with fine waste from a limestone quarry on the western headland, where coarse debris was also dumped over the cliffs. ${ }^{8}$ The line of trees at the back of the beach marks the approximate position of the original shoreline. Before dumping, Rapid Bay had a rocky shore with a sandy beach and low dunes in the eastern half of the bay. Steep Late Pleistocene scree slopes backed by high cliffs also occur on the far eastern side of the bay. Limestone was first quarried in 1938 for use as a flux in the smelting of iron ore at Newcastle and Port Kembla (New South Wales) and Whyalla (South Australia). Between 1942 and 1982, some 15 million tonnes of limestone were quarried, of which 1.8 million tonnes were used to infill the bay to an elevation of $3 \mathrm{~m}$ above high tide.

Changes in the coastline are illustrated in Figure 3.8; in 1975 it reached its maximum extent, some $250 \mathrm{~m}$ seaward of its original position. A large, formerly active sea cave on the far eastern side of the bay has now been stranded due to the artificial infilling of the bay. After 1975, less waste was placed on the shore; and in 1982, systematic dumping of waste ceased, following which the coastline retreated rapidly. Gradually, erosion slowed as the shoreline was achieving new quasi-equilibrium conditions, but large protective boulders were placed on the southern shoreline to prevent erosion of stockpiles of gravel.

Waves dominantly approach the bay from the west and southwest, causing longshore transport towards the east-northeast. Between 1975 and 1984, approximately 30000 to 45000 tonnes of sediment were lost from the shoreline every year, largely moving along the coastline towards Second Valley rather than offshore, where the rocky substrate indicates that sedimentation here was not significant. Sediment has drifted beyond the eastern side of the bay, infilling several small swimming and diving coves and pools, and is reaching towards Second Valley. ${ }^{9}$ Here a natural rocky groyne will inhibit movement along the coast, but the possibility remains of the general northeasterly drift transporting sediment as far as the Marina St Vincent at Wirrina. 


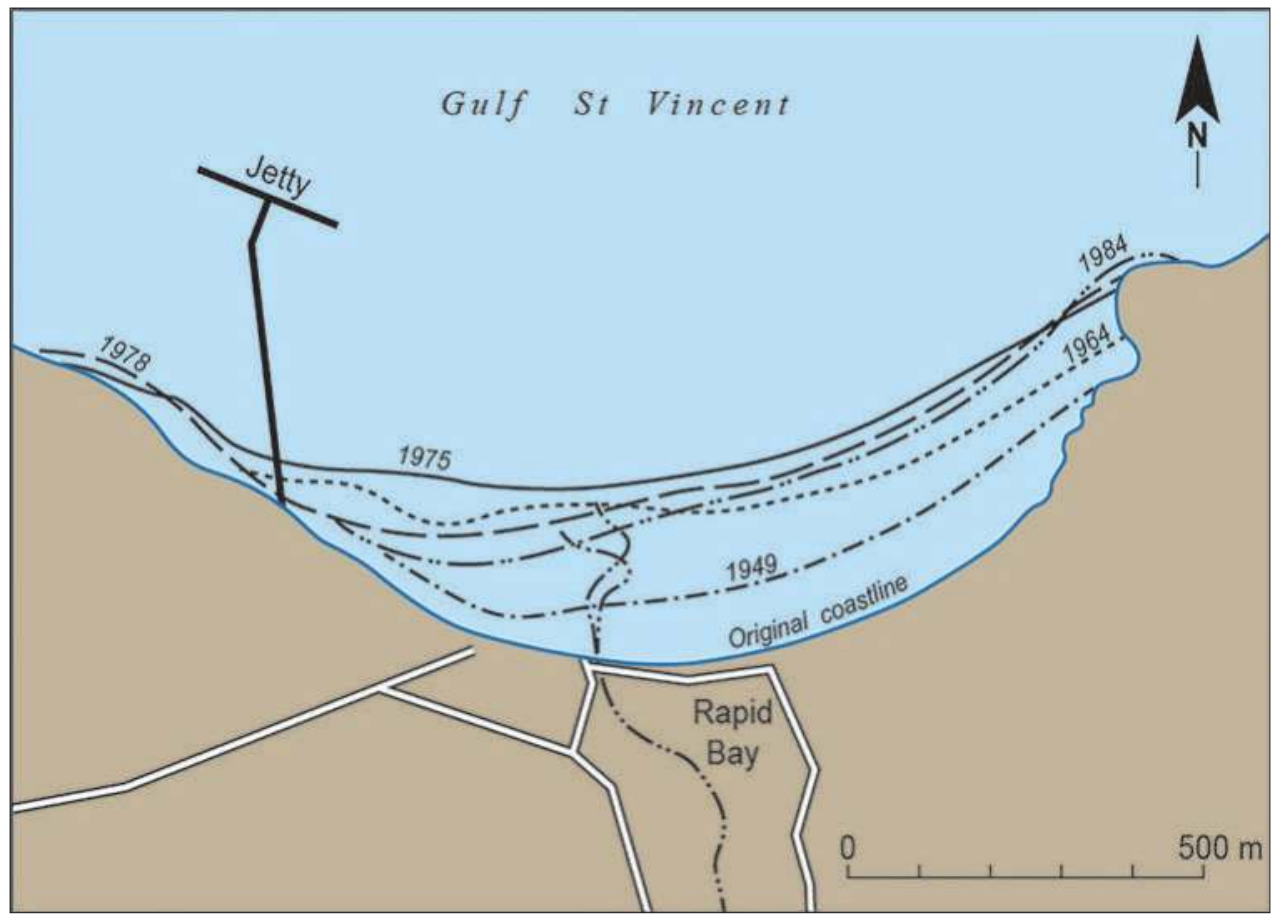

Figure 3.8 Changes in the shoreline position at Rapid Bay due to dumping of quarry waste. Source: Bourman, R.P. (1990). Artificial beach progradation by quarry waste disposal at Rapid Bay, South Australia. Journal of Coastal Research, Special Issue 6, 69-76.

\subsubsection{Rapid Head to Cape Jervis}

A linear section of coastline $12 \mathrm{~km}$ long extends from Rapid Head to Cape Jervis; it consists of steep cliffs and bluffs 100 to $150 \mathrm{~m}$ high cut into folded metasedimentary rocks of the Cambrian Kanmantoo Group. An inland plateau extends up to $300 \mathrm{~m}$ APSL, from which some 20 streams debouch, dissecting the cliff line. Numerous common features characterise this rocky coast: they include small rocky coves, shore platforms up to $50 \mathrm{~m}$ wide, rocky reefs, projecting headlands, extensive cobble and boulder beaches, colluvial debris slopes at the bases of cliffs (some of which are currently suffering erosion), alluvial fans, small protruding boulder deltas (for example, Stockyards Creek) and alluvial terraces (for example, Salt Creek).

\subsubsection{Cape Jervis}

Backstairs Passage separates Cape Jervis, at the western extremity of Fleurieu Peninsula, from Kangaroo Island. A rocky intertidal shore platform 100 m wide, underlain by 
metasandstone of the Cambrian Carrickalinga Head Formation, forms the coast between the jetty and Morgan Beach. The type section of the Permian Cape Jervis Formation (glacial deposits 299 to $290 \mathrm{Ma}$ old) is situated north of the lighthouse, where a sedimentary succession $60 \mathrm{~m}$ thick records the advance of a wet-based ice mass 1 to $2 \mathrm{~km}$ thick and its progressive decay and stagnation in Backstairs Passage. Here, sediments were dropped from the melting ice, first into lakes and finally into the sea as sea level rose. ${ }^{10}$ Exotic boulders, cobbles and pebbles litter the shore platform and include large erratics of Encounter Bay Granites. Steep slopes up to $50 \mathrm{~m}$ high have been cut into the easily eroded Permian glacigene sediments, which nourish Morgan Beach (Figure 3.9), where sand is trapped between rocky reefs and headlands before being blown towards the top of the backing cliff, which is $50 \mathrm{~m}$ high.

Former shorelines have been identified at Cape Jervis near the site of the Permian type section: the fossiliferous Early Pleistocene Point Ellen Formation shoreline deposit, 2.6 Ma old at $60 \mathrm{~m}$ APSL; a Late Pleistocene shoreline $(125 \mathrm{ka})$ at $6 \mathrm{~m} \mathrm{APSL}$; and a cobble beach of probable Holocene age (6 to $4 \mathrm{ka}$ ), which occurs at about $1 \mathrm{~m}$ APSL.

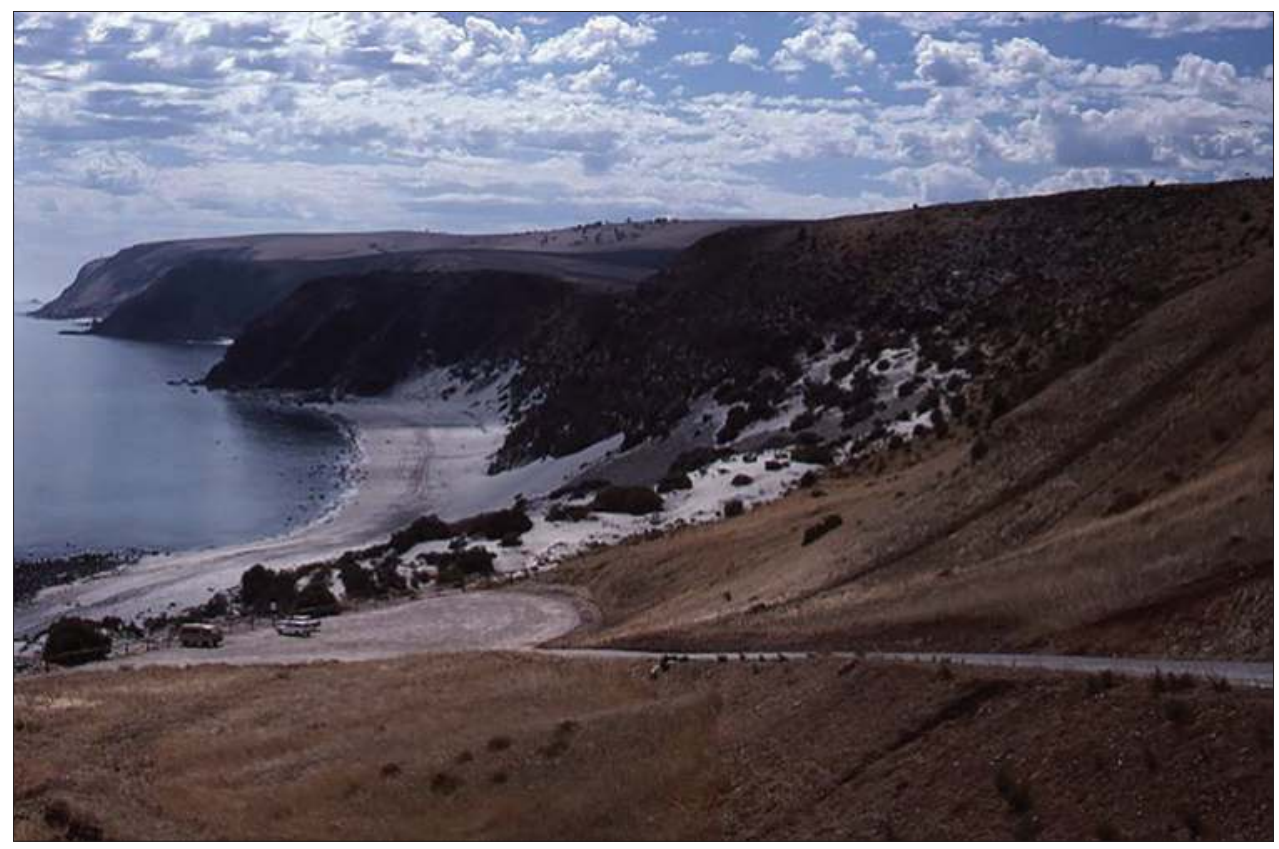

Figure 3.9 View to the north from Cape Jervis across Morgan Beach and beyond. Note the steep rugged cliffs cut into Cambrian bedrock, which separate small bays, and the sand dunes climbing the cliff faces. Beach sand has been derived mainly by erosion of abundant Permian glacial sediments in the area. Glacial erratics are common on the beaches in this area.

Source: Author's own work, RPB. 
The equivalent Early Pleistocene limestone (Burnham Limestone) at Sellicks Beach occurs at only $8 \mathrm{~m}$ APSL, indicating a tectonic offset of some $50 \mathrm{~m}$ between the two localities over 2.6 Ma. ${ }^{11}$ Most of the Cape Jervis Lowland, which slopes gently seawards over a distance of about $3 \mathrm{~km}$, grades to the $60 \mathrm{~m}$ level: it has been impacted on by earlier stands of the sea and later uplifted by tectonic processes.

Inland from the coast, three dominant topographic features are evident: a Backwall Scarp, Spurlands at the scarpfoot and a Lowland, which slopes gently seaward (Figure 3.10). ${ }^{12}$ The backwall escarpment occurs at 180 to $240 \mathrm{~m}$ APSL, separating high plateau country from the gently sloping Cape Jervis Lowland. On its southern and northern flanks, the escarpment merges with precipitous sea cliffs. The origin of the prominent backwall escarpment is not resolved; faulting, structural influences, erosion by Permian ice and marine abrasion could have played roles in its formation. Evidence of stranded marine sediments, such as cobble beaches between 36 and $120 \mathrm{~m}$ APSL and Neogene marine limestones at high levels on Fleurieu Peninsula, support the notion of the scarp being a relict sea cliff.

A calcreted, aeolianite dune-like structure up to $40 \mathrm{~m}$ APSL occupies the area between Lands End and Fishery Beach, the only known outcrop of aeolianite on the gulf shores of Fleurieu Peninsula. A persistent coastal platform at 6 to $8 \mathrm{~m}$ APSL extends south for $2 \mathrm{~km}$ from the outlet of Central Creek. A bedrock bench progressively decreases in height, but the elevation of the bench is maintained at $8 \mathrm{~m}$ by increasingly thicker deposits of aeolianite until it makes up some $6 \mathrm{~m}$ of the bench height. Rounded marine cobbles occurring on this bench are most likely uplifted sediments of last interglacial age $(125 \mathrm{ka})$, common on the peninsula.

Quaternary alluvium forms river terraces in stream valleys of the Cape Jervis Lowland and provides further evidence of tectonic uplift. A high red/brown river terrace at $8 \mathrm{~m}$ APSL, near the mouth of Fishery Creek, correlates with the nearby marine bench. The highest stream terraces are underlain by red/brown alluvium, the Pooraka Formation, which originally graded to the last interglacial shoreline. A lower set of terraces formed of grey/black alluvium occupies valleys cut into the red alluvium.

\subsection{Southern Fleurieu Peninsula}

The east-west-oriented southern coast of Fleurieu Peninsula extends for some $50 \mathrm{~km}$ from Cape Jervis to Newland Head (Figure 3.1). It is bedrock-dominated, with rugged cliffs up to $100 \mathrm{~m}$ high, cut into resistant metasedimentary rocks of Cambrian age. Three major sandy beaches, Tunkalilla, Parsons and Waitpinga, occupy compartments between rocky headlands, while some smaller pocket beaches occur at the outlets of streams that drain the backing high country. The linear character of this section of coast suggests that faulting may have influenced its plan morphology. There 


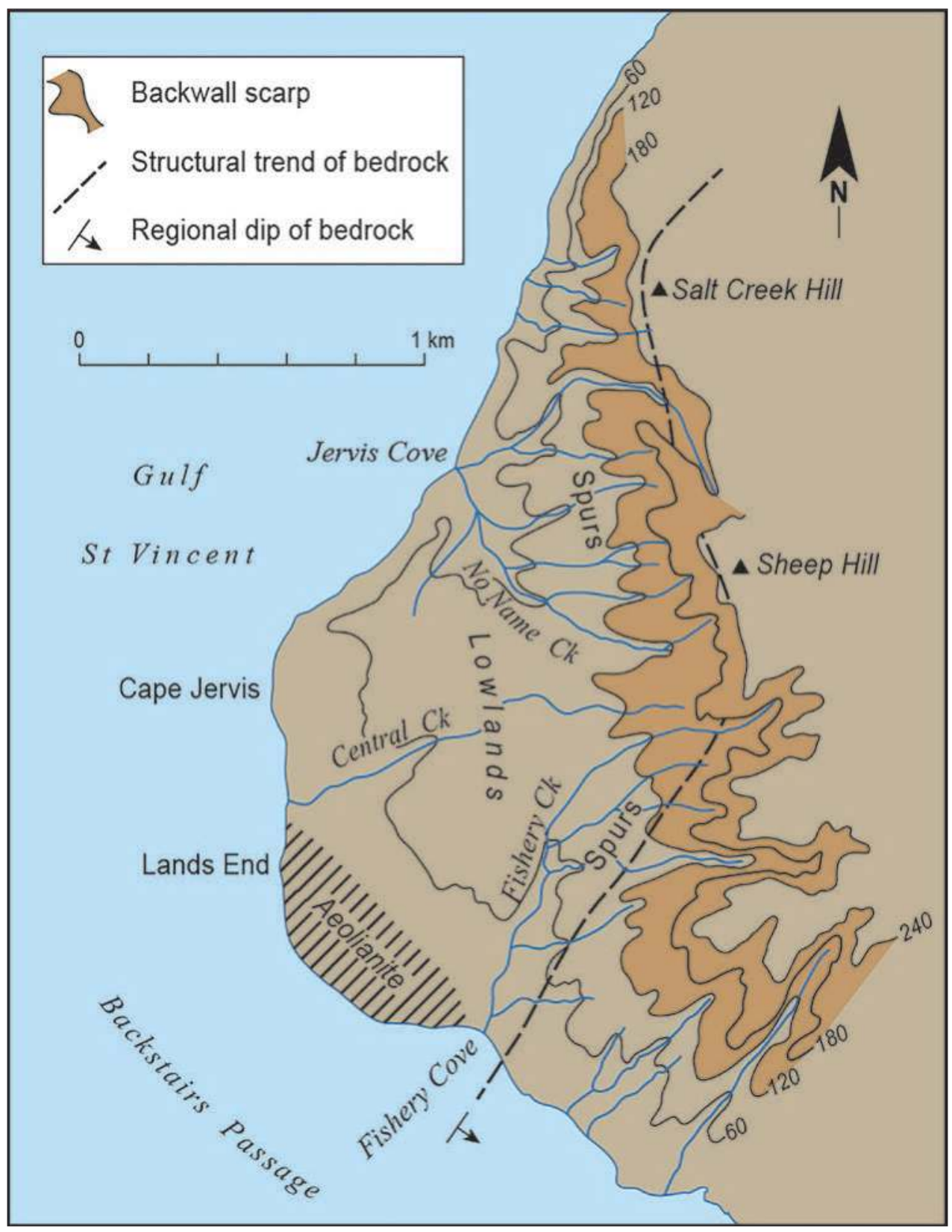

Figure 3.10 Map showing the Backwall Scarp, Spurlands and Lowland at Cape Jervis. Source: Modified from Brock, E.J. (1964). The denudation chronology of Fleurieu Peninsula, South Australia. Unpublished MA Thesis, The University of Adelaide. Reproduced with permission. 
is a steep drop of at least $10 \mathrm{~m}$ below sea level along parts of this coast, where there are few shore platforms. The orientation of this coastline cuts across the bedding in the basement rocks, producing a ragged and irregular shoreline in detail. This section of coast receives some protection from Kangaroo Island but heavy seas are still experienced, with waves 2 to $3 \mathrm{~m}$ high being common. Rips, some of which are permanent, are common on these south coast beaches. Much of this spectacular coastline is not easily accessible, but walking trails facilitate hiking access.

\subsubsection{Backstairs Passage}

From high points above Cape Jervis, outstanding views are available of Backstairs Passage and Kangaroo Island. The shortest distance across the passage is only about $14 \mathrm{~km}$, and as the Mount Lofty Ranges continue onto Kangaroo Island in an arcuate curve, the passage cuts transversely across the ranges. The passage is deepest near Cape St Albans (78 $\mathrm{m}$ ) on Kangaroo Island and Cape Jervis $(69 \mathrm{~m})$ on the mainland. ${ }^{13}$ The passage was carved by wet-based Permian ice, broadly moving from the southeast to the northwest, funnelled through a pre-existing lowland. Permian glacial sediments occur either side of the passage at Christmas Cove and Cape Jervis, and have been intersected in bores under the passage, to depths exceeding $330 \mathrm{~m} .{ }^{14}$ The Pages, small islands in the passage, are possibly relicts of exhumed rochés moutonneés (asymmetrical glaciated rock knobs) formed on Middleton Sandstone of the Kanmantoo Group during the Permian ice age. Despite Backstairs Passage originating as a glacial landform, substantial erosional modification of the original glacial trough has occurred over the past $300 \mathrm{Ma} .{ }^{15}$

\subsubsection{Coalinga Creek Beach and Naiko Inlet}

Coalinga Creek Beach, a short sandy cobble ridge beach, occupies a small cove at the outlet of Coalinga Creek (also known as Campbell Creek), where the stream has cut a deep steep-sided valley into resistant rocks of the Cambrian Talisker Formation. River terraces similar to those at Fishery Creek extend inland for about $1 \mathrm{~km}$. Naiko Inlet, or Madigan Inlet, about $600 \mathrm{~m}$ east of Coalinga Creek, contains two sandy pocket beaches backed with cobbles and boulders, and flanked by headland cliffs up to $50 \mathrm{~m}$ high. Small outcrops of the Early Cambrian Heatherdale Shale and the Fork Tree Limestone form the headland between the two beaches.

\subsubsection{Blowhole Beach}

On the western border of Deep Creek Conservation Park, Blowhole Beach (Figure 3.11), along with a small adjoining bay, occupies an inlet almost $1 \mathrm{~km}$ wide eroded into relatively soft metasiltstone rocks with minor sandstone beds. Blowhole Creek, which 


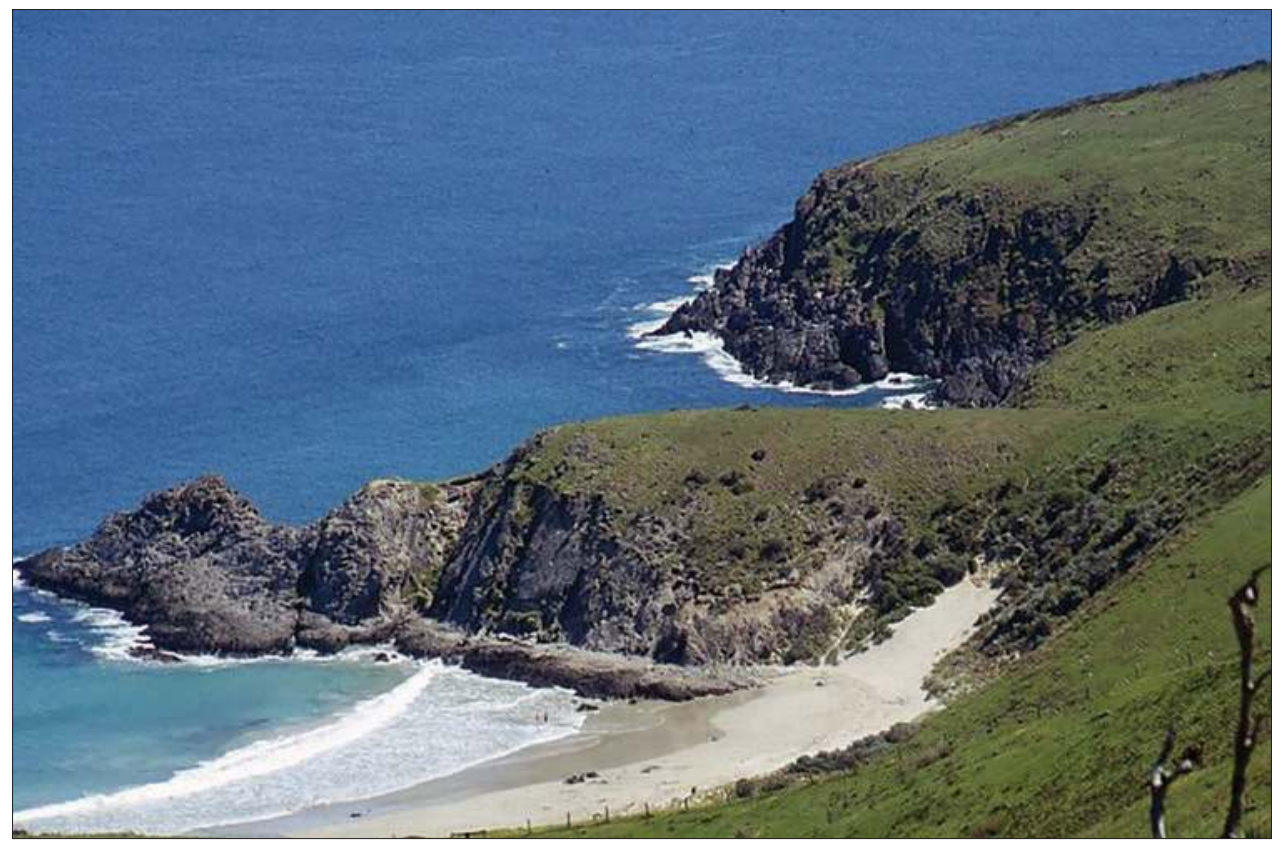

Figure 3.11 View of Blowhole Beach, a pocket beach in a bedrock bay eroded into Cambrian bedrock at the outlet of Blowhole Creek, which has delivered sediments to the beach. Note the prominent rock shore platform about $2 \mathrm{~m}$ above sea level at the foot of the steep cliff and the climbing dune at the far end of the beach.

Source: Author's own work, RPB.

is remarkably straight, follows a shear zone of weakness to the coast at Blowhole Beach, where marine processes have exploited this weakness.

A sandy pocket beach about $130 \mathrm{~m}$ wide has been nourished with sediments from inland via Blowhole Creek. A climbing dune extends up the cliff on the northwestern side of the bay, while a large vegetated boulder ridge up to $2 \mathrm{~m}$ APSL occurs at the back of the bay. A large boulder sits precariously on the rocky eastern shore of the bay, but it is not directly due to marine processes: it is a result of a rockslide. The slope of the western cliffs follows the inclination of the bedrock, which dips steeply to the east, and large slabs of bedrock have slid down the cliff face onto the prominent shore platform. A dark-coloured basic dyke about $0.5 \mathrm{~m}$ thick intrudes the lighter-coloured bedrock, extending through the rocky headland to the adjoining western bay. The dyke is less resistant than the surrounding bedrock, as it is being more rapidly eroded.

Honeycomb weathering, probably related to salt crystallisation, has produced interesting features on both the cliff and shore platform. Although current processes 
are modifying the shore platform, producing numerous small weathering pans, it probably developed during a higher sea level as equivalent platforms occur nearby, while an inactive boulder ridge at the back of the bay suggests that sea level has fallen relative to the land since the main period of platform development. The majority of the boulders and cobbles are of Kanmantoo Group metasedimentary rocks and the seaward toe of the ridge is occasionally eroded during storms.

The Cambrian Tapanappa Formation, a very thick sequence of dark-coloured metasandstones with grey phyllite interbeds ${ }^{16}$, dominates the coast between Blowhole Creek and Tunkalilla Beach $(16 \mathrm{~km})$. The beds dip eastward between $25^{\circ}$ and $55^{\circ}$ and strike in a northeasterly direction; erosion of the weaker beds has produced small structurally controlled bays cut into steep cliffs.

\subsubsection{Blowhole Beach to Deep Creek}

Continuous precipitous cliffs between $50 \mathrm{~m}$ and $100 \mathrm{~m}$ high occupy $10 \mathrm{~km}$ of the south coast between Blowhole Beach and Deep Creek Cove, making the coastline inaccessible to all but the most adventurous. Streams such as Marrano Creek, Aaron Creek, Tent Rock Creek and numerous unnamed creeks drain to the rocky coastline. Some of the short streams plunge over the cliffs to sea level, as for example at Porpoise Head. The steep cliffs also continue well below sea level, with the submarine contour of $10 \mathrm{~m}$ being closest to the shoreline along this section of the southern Fleurieu coast.

Perched valleys with intermittent waterfalls hang above the cliff line, and the steep submarine slopes may reflect rapid coastal erosion, including when sea level was lower than at present. It is unlikely that the current waves would produce steep submarine slopes $10 \mathrm{~m}$ below sea level. This cliffed coastline has developed in resistant Cambrian metasedimentary rocks of the Backstairs Passage and Tapanappa Formations. A major fault, now submerged, may have provided the geological setting for the formation of this rugged cliffed coast and guided the erosive Permian glacial ice, which moved in an east-west direction through Backstairs Passage.

\subsubsection{Deep Creek Cove Beach}

The Deep Creek Cove Beach is a small cobble and sand beach at the mouth of Deep Creek; it extends $100 \mathrm{~m}$ up-valley as washover flats of sand and cobbles, beyond which are some small dunes. Headlands protruding a couple of hundred metres seawards of the beach provide a degree of shelter for the cove and its beach. Valley fill sediments in the lower reaches of Deep Creek are restricted to Holocene grey/black alluvium. A currently active, narrow marine abrasion platform related to present sea level occurs at the cliff foot from east of Deep Creek to Coolawang Creek. 


\subsubsection{Boat Harbor Beach}

Some nine streams, including Tapanappa Creek, at the mouth of which lies Boat Harbor Beach, dissect the final $4 \mathrm{~km}$ of the rugged cliffed coastline of the Deep Creek Conservation Park. The beach lies at the terminus of a deep V-shaped valley, where a high-tide/storm cobble ridge, built up well above normal high-tide level, backs the sandy beach. The cobble ridge, which is derived from local rock types, curves upvalley on its western extremity. Cobble beach ridges also back two small rocky coves immediately east of Boat Harbor Beach. About $2 \mathrm{~km}$ of rocky cliffed coastline with minor headlands separate Boat Harbor Beach from the eastern end of Tunkalilla Beach, and sporadically carry a cut rock bench at $200 \mathrm{~m}$ APSL on the coastal slopes between Boat Harbor Creek and Tunkalilla Creek. ${ }^{17}$

\subsubsection{Tunkalilla Beach Embayment}

Tunkalilla Beach fronts an alluvial lowland backed by an arcuate stranded cliff line cut into Cambrian metasedimentary rocks. The now stranded cliff line formed during last interglacial times when sea level was at least $2 \mathrm{~m}$ higher than at present: it has also been uplifted tectonically. Some spectacular earth flows stand out prominently on the abandoned sea cliffs (Figure 3.12), and alluvial/colluvial fans have formed towards the base of the cliffs. Low-level calcreted coastal deposits occur behind the eastern end of the beach, as do stranded cobble deposits. Three streams with prominent river terraces flow across the lowland; the terraces record fluctuations in relative sea level over the past $125 \mathrm{ka}^{18}$

None of the streams transports a sandy bedload, suggesting derivation of beach sand by coastal erosion or from offshore sources. During the rise in sea level from $-125 \mathrm{~m}$ to the present from 17 to $7 \mathrm{ka}$, sediments on the continental shelf were swept shorewards to nourish the beach. Erosion of aeolianite in the surf zone has produced small shore platforms and stacks, suggesting that pre-existing coastal deposits have also contributed to the Tunkalilla Beach sediments. There is a net eastward transport of sediment on Tunkalilla Beach with erosion in the west and accumulation in the east. Aerial photographs reveal spectacular beach cusp development along Tunkalilla Beach. Coastal erosion of alluvial

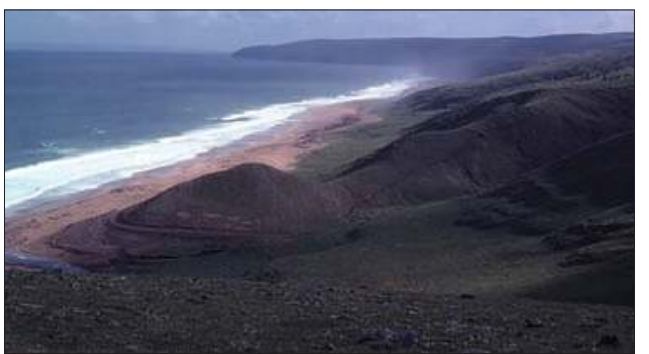

Figure 3.12 View to the west across the Tunkalilla Beach Embayment from the outlet of Tunkalilla Creek. Note the abandoned sea cliffs, which are of last interglacial age, and the earthflows on the steep valley sides.

Source: Author's own work, RPB. 
sediments is also contributing to the beach sediments. Cliffs have been eroded into Late Pleistocene river alluvium of the creek near Tunkalilla, as indicated by truncated fence lines; early survey data suggest that the alluvial coastline has been eroded back some $30 \mathrm{~m}^{19}$ since first surveyed.

\subsubsection{Tunk Head to Parsons Beach}

Between Tunk Head and Parsons Beach, a distance of $10 \mathrm{~km}$, the rocky cliffed coastline with headlands exceeding $100 \mathrm{~m}$ in height is not readily accessible. Medium- to coarse-grained metasandstones interbedded with metasiltstones and some small-scale conglomerates crop out along this coast. There is a strong influence of rock structure on cliff morphology, with cliffs commonly following the strike or cleavage of the bedrock. Streams draining the inland plateau, which extends up to $400 \mathrm{~m}$ APSL, have cut deep valleys on the plateau margin, producing small bays where they meet the sea. Sandy pocket beaches, up to $250 \mathrm{~m}$ wide and commonly with coarse boulders in their upper reaches, occupy the lower valleys of the Callawonga, Bollaparudda and Coolawang Creeks, all of which display abandoned coastal cliffs of probable last interglacial age.

\subsubsection{Coolawang Beach}

The upper part of the small beach at the mouth of the Coolawang Creek is covered with cobbles up to $20 \mathrm{~cm}$ in diameter and slopes at $15^{\circ}$, contrasting markedly with the low angle slopes on the sandy part of the beach. Paired river terraces underlain by the mid-Holocene grey/black alluvium extend to the coast at Coolawang Beach. Their formation is probably related to relative changes in sea level, as they are associated with an elevated marine cobble beach, similar to the modern one. Permian glacial deposits occur in headwaters of Coolawang Creek and have contributed to the beach sediments.

\subsubsection{Parsons Beach and Waitpinga Beach}

The locations of Parsons Beach $(1.6 \mathrm{~km})$ and Waitpinga Beach $(3.5 \mathrm{~km})$ are related to fold structures in the underlying rocks of the Cambrian Balquhidder Formation. Although the bedrock dips at high angles to the southeast, folding has caused a repetition in the beds so that Parsons Beach occurs within a broad-scale syncline and Waitpinga Beach within an anticline, with the axes of the structures plunging to the southwest. ${ }^{20}$ Calcreted marine sediments and/or aeolianite occur on Waitpinga Head at elevations of up to $30 \mathrm{~m}$ APSL, and back Parsons Beach, where a well-preserved calcrete-capped platform is at a uniform elevation of $6 \mathrm{~m}$ APSL over a distance of $100 \mathrm{~m} .^{21}$ These benches may relate to former shoreline positions, now uplifted. Inland from Parsons Beach, a reddish alluvial fill terrace grades to the same elevation as the calcrete-capped bench. 
Calcrete also backs Waitpinga Beach, extending inland for almost $2 \mathrm{~km}$ and up to elevations of $60 \mathrm{~m} \mathrm{APSL}{ }^{22}$ Along the coast, modern sand dunes and older unconsolidated Holocene dunes are present. Small patches of aeolianite have been eroded to form shore platforms and reefs along both Parsons and Waitpinga Beaches. The modern beach sediment contains large amounts of comminuted shell debris, largely sourced by recycling of the calcareous aeolianite dunes. Additional beach sediment may have been delivered by Waitpinga Creek, which drains large areas of Cenozoic sands. Most beach sediment, however, is probably from offshore sources derived from the continental shelf during the postglacial rise in sea level from 17 to $7 \mathrm{ka}$ ago. The majority of beach sediment is held within the two beach compartments, with little bypassing of the enclosing headlands. A sand bar commonly blocks the outlet of Waitpinga Creek, leading to occasional inundation of alluvial flats. The location of the Waitpinga Creek mouth has changed in historical time, with a former breakthrough point, prior to 1940 , occurring on the far western side of the valley, as indicated by fluvial sediments extending beneath the sand bar.

Two large erratics of coarsely crystalline Encounter Bay Granites, several metres in diameter, typical of those currently exposed at the Bluff (Rosetta Head), occur on the beach towards the eastern end of Waitpinga Beach, having been derived from preexisting Permian glacial deposits. These boulders are occasionally buried by beach sand, which tends to migrate towards the east.

Both Parsons (Figure 3.13a) and Waitpinga (Figure 3.13b) Beaches are popular with surfers and surf-fishers. There are persistent moderate to high swell waves from the Southern Ocean and permanent rips at the headlands. Waves typically break more than $100 \mathrm{~m}$ offshore on a nearshore bar and the beach is crenulated with megacusps marking the locations of prominent rip zones, which are also indicated by smooth gaps in the approaching breaking waves.

\subsubsection{Newland Head}

Newland Head is a headland $60 \mathrm{~m}$ high, and it marks a change in the orientation of the coastline from east-west to southwest-northeast. The lower half of the headland consists of steeply dipping resistant metasedimentary rocks of the Kanmantoo Group. The upper half of the headland comprises a complex sequence of red- and yellowcoloured cross-bedded sands, interbedded with three calcrete horizons, with a final massive calcrete at the top, some 3.6 m thick. ${ }^{23}$

A Holocene vegetated parabolic dune field occurs on the calcreted surface north of Newland Head. ${ }^{24}$ The trend of the parabolic dunes is at $281^{\circ}$ (almost eastwest), which is at variance with the current wind regime, which has an orientation of $233^{\circ}$ (southwest), suggesting a change in the wind regime since the parabolic dunes were formed. The Newland Head parabolic dunes are also cliff-top dunes, which were 


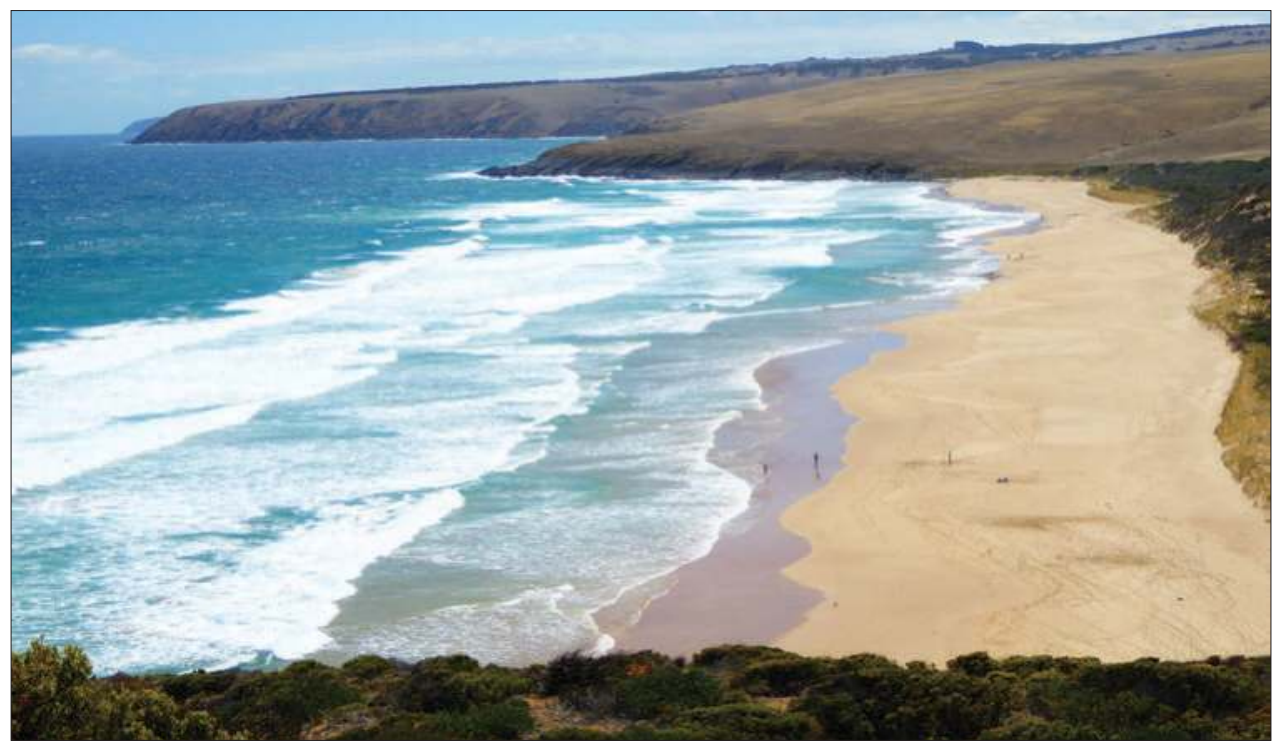

Figure 3.13a View to the west along Parsons Beach, a beach compartment between rocky headlands, with Tunk Head in the distance. Note the rip current offshore from the large cusp towards the far end of the beach.

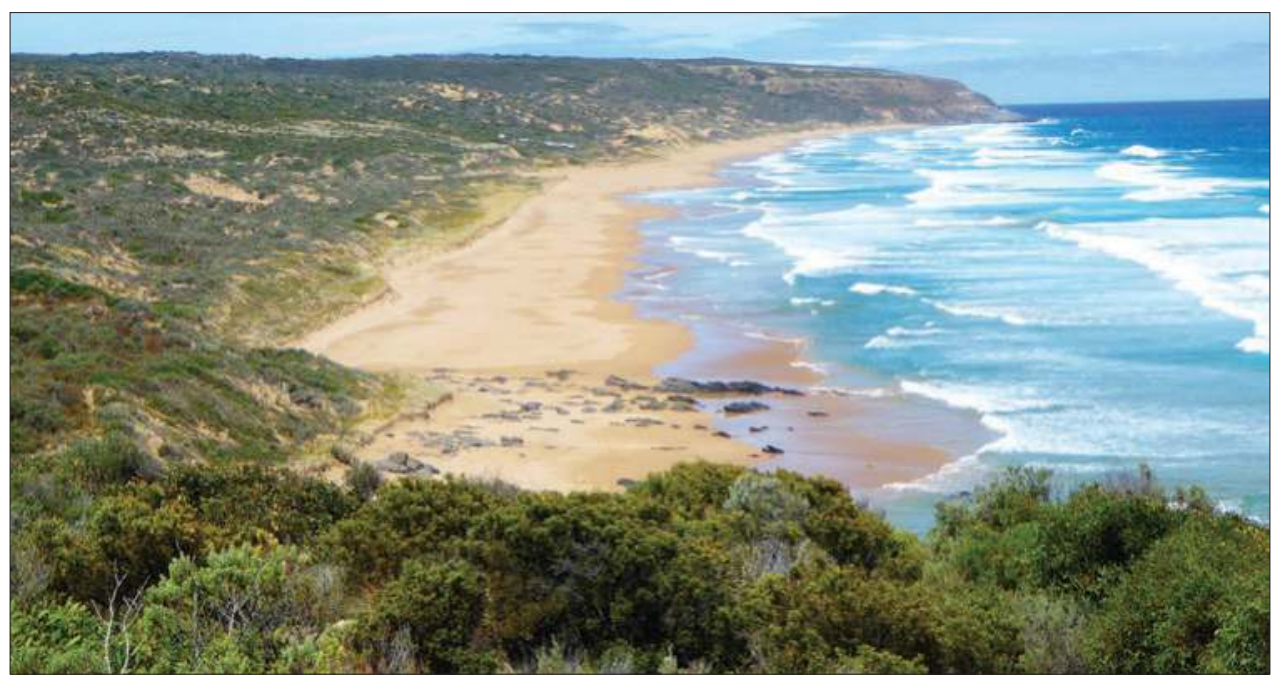

Figure 3.13b View of Waitpinga Beach from the west. The headland in the distance, Newland Head, is underlain by resistant Cambrian rocks of the Balquhidder Formation and overlain by Quaternary aeolianite and Holocene sand dunes. Most of the beach sand has been derived from the reworking of aeolianite. Note the beach cusps along the shoreline and the seaward-flowing rip currents.

Source for both figures: Author's own work, RPB. 
sourced from Waitpinga Beach and then blown up a sand ramp to the summit of Newland Head.

\subsection{The Encounter Coast: Newland Head to Middleton Beach}

The southeastern Fleurieu Peninsula coast (Figure 3.14) covers only $30 \mathrm{~km}$ but displays great variability. Steep rugged cliffs, granite bluffs and islands, shore platforms and reefs, sand spits, fossil sand dunes, river terraces, stranded marine benches and evidence of changes in relative sea level, plus the outlets of two major rivers, illustrate the variety of landforms along this coast. The coastline trends southwest-northeast, following the orientation of hard basement rocks and the granites, which intruded them. Cliffs up to $120 \mathrm{~m}$ high, supported by steeply dipping Cambrian metasedimentary rocks and aligned with the Encounter Fault, occur northeast of Newland Head, diminishing in height towards King Point and the Bluff (Rosetta Head). Small pocket beaches, largely derived from erosion of Permian glacial deposits, occupy bays eroded into less resistant Cambrian rocks. An ancient glacial depression, the Inman Trough, cut through resistant Cambrian and Neoproterozoic rocks, now largely filled with Permian glacial deposits and more recent alluvial sediments, extends east-west across Fleurieu Peninsula, parallel to the similarly glaciated Backstairs Passage. The coast sits astride this ancient, buried and partly exhumed depression. Thus the geological setting for much of the modern coastline was initiated some $300 \mathrm{Ma}$ ago.

Differential erosion explains the character of much of this coastline. Bays have developed in less resistant rocks and sediments, while headlands are composed of, or are protected by, resistant outcrops. For example, the large bay, which extends from Rosetta Head to the granite outcrops of Port Elliot, has developed in relatively easily eroded glacigene, marine and alluvial deposits. Between Watson Gap and Boomer Beach, sporadic outcrops of indurated fossil sand dunes (aeolianite) occur in the shore zone, forming shore platforms and cliffs at Knight Beach, where their erosion is contributing to beach sediments. Along this section of the shore, beach cusps are also prominent. Two other significant bays reflecting differential erosion include Horseshoe Bay and the bay that extends from Frenchman Rock to the basement rock outcrops at Middleton Point.

Beach sediment within the Encounter Coast has been derived from weathering and erosion of metamorphic rocks and granites of Encounter Bay ${ }^{25}$, from Permian glacial sediments, from modern and relict marine sediments, and from sands delivered to the shore by streams. Longshore drift in Encounter Bay is generally from the Bluff towards Port Elliot, driven by dominant southwesterly winds. The eastward deflections of the mouths of the Hindmarsh and Inman Rivers (before entrainment by engineering works) and a general increase in sand on beaches to the east reflect the dominant 


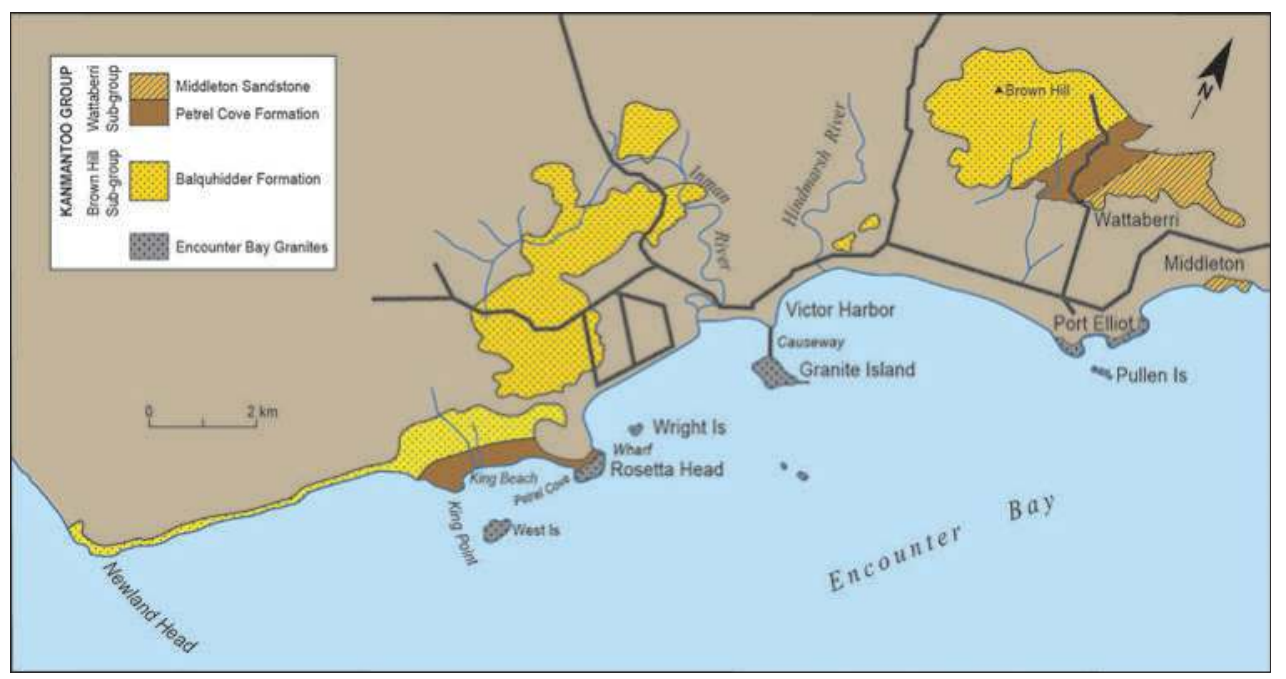

Figure 3.14 Southeastern Fleurieu coast, showing a strong geological influence on the shape and orientation of the coastline.

Source: Modified from Daily, B. \& Milnes A.R. (1973). Stratigraphy, structure and metamorphism of the Kanmantoo Group (Cambrian) in its type section east of Tunkalilla Beach, South Australia. Transactions of the Royal Society of South Australia, 97 (3), 213-251.

direction of longshore sediment transport. However, complex wave refraction patterns result from wave interaction with resistant granite outcrops such as West Island, Rosetta Head, Wright Island, Granite Island, Pullen Island, Commodore Point and Frenchman Rock. Waves also interact with small outcrops of basement rocks, lithified Permian glacigene rocks, and with reefs, shoals and shore platforms eroded across coastal, calcareous sandstones. These resulting complex wave refraction and diffraction patterns locally affect the direction of longshore transport and mould the shape of the coastline. The wave patterns have formed many sand spits, such as the Inman Spit (also known as Taylor Point) near the mouth of the Inman River, small spits near Yilki, Police Point Spit leeward of Granite Island, Hayborough Spit and Chiton Spit.

\subsubsection{Newland Head to King Beach}

Steeply dipping resistant metamorphic rocks of the Balquhidder Formation (500 Ma) crop out along the linear coast from Newland Head towards King Beach, supporting precipitous coastal cliffs up to $120 \mathrm{~m}$ high, broadly following the strike of the bedrock. The trend of the coastline may have originally followed a fault zone (the Encounter 


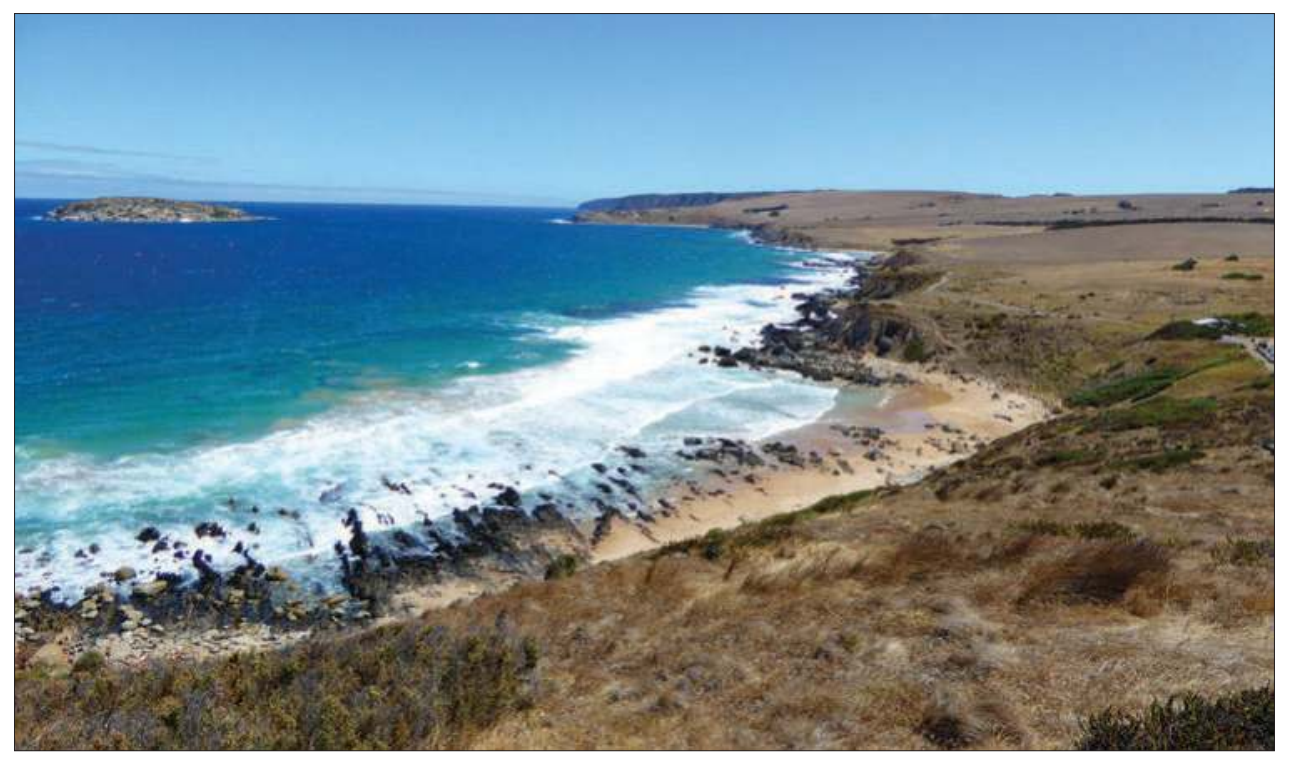

Figure 3.15 View along the coast from the granite headland of Rosetta Head (The Bluff) towards Newland Head. The high cliffs in the distance are formed on resistant seaward dipping rocks of the Cambrian Balquhidder Formation, while the lower cliffs are formed on less resistant rocks of the Petrel Cove Formation. The promontory between the two, King Head, is underlain largely by easily eroded Permian glacial sediments, but is protected by hard rock outcrops on its extremity. The beach sediments here are derived mainly from the glacial sediments. Note the rugged serrated shore platform and the smooth but asymmetrical form of West Island.

Source: Author's own work, RPB.

Fault), but the present shape of the cliffs can be explained in terms of the dip of the rocks, their resistance to erosion and strong wave attack. The rocks dip at $70^{\circ}$ to the southeast (Figure 3.15), forming part of a great anticlinorium (an anticline comprising numerous smaller folds) or up-fold, which extended across Fleurieu Peninsula (Figure 3.3), and which may have been up to $10 \mathrm{~km}$ high, implying substantial erosion of the former fold mountain chain, the Delamerides. A very rocky foreshore occurs at the cliff base, and narrow benches 0.5 to $1 \mathrm{~m}$ wide sporadically occur about a third of the way up the cliff face. Small fossil molluscs plastered onto these precipitous cliffs up to $10 \mathrm{~m}$ APSL may be remnants of a former aeolianite cover that has subsequently been all but removed. Thus the cliffs may be partly resurrected features. Approximately $1 \mathrm{~km}$ south of King Beach, the cliffs decrease markedly in elevation, reaching only 9 to $18 \mathrm{~m}$ APSL; this topographic variation corresponds with a change to less resistant phyllites and schists of the Petrel Cove Formation (500 Ma). 


\subsubsection{King Beach to Rosetta Head (The Bluff)}

At King Point, the coastline protrudes seawards. Much of King Point is composed of Permian glacial sediments that include large granite boulders ${ }^{26}$, but these readily erodible sediments are protected by a headland of resistant rock, which is also sheltered from the full force of wave attack by West Island. A serrated shore platform extends from King Point to the sandy pocket beach, with granite boulders at Petrel Cove. Small coves either side of granitic Rosetta Head have been eroded into less resistant metamorphic rocks of the Petrel Cove Formation, while sand for these pocket beaches was derived from Permian glacial sediments.

\subsubsection{Rosetta Head (The Bluff)}

From the summit of Rosetta Head, a prominent granite headland $101 \mathrm{~m}$ high, spectacular views are available along the coastline. The summit was used as a lookout for whales during early European settlement. Part of a granite intrusion, Rosetta Head was covered by 1 to $2 \mathrm{~km}$ of ice during the Permian glaciation ${ }^{27}$, suggesting that it could be a glacial landform, either a roche moutonnée (an asymmetrical rock knob with the gentler side facing the direction of ice approach), or a rock knob with a deposit of glacial sediments in its lee (a crag-and-tail feature). There is no direct evidence of ice action on the Bluff, but glacial sediments do occur in a bedrock basin on its landward side, suggesting that it may once have been a glacial landform, subsequently modified by weathering and erosion, especially by the sea. ${ }^{28}$

\subsubsection{The Victor Harbor Embayment}

A last interglacial (125 ka) embayment extends from Rosetta Head to Watson Gap (Figure 3.16). Abandoned and degraded sea cliffs up to $1.6 \mathrm{~km}$ inland back the Newland Lowland, the Victor Harbor Lowland and a marine bench with fossil shell beds along the train line from the Hindmarsh River to Watson Gap. The stranded shell beds contain the mollusc Anadara trapezia, a subfossil shell with warm water affinities. Pooraka Formation alluvium deposited by the Inman and Hindmarsh Rivers filled parts of the Victor Harbor Embayment during this high sea level of some 125000 years ago, and was later stranded as river terraces when sea level fell and the land rose. ${ }^{29}$

\subsubsection{The Yilki Terrace}

Now occupied by housing, the Yilki Terrace (Figure 3.16) consists of red/brown alluvial deposits of the last interglacial Pooraka Formation, sediments that were originally deposited in relation to a $2 \mathrm{~m}$ higher stand of the sea and later uplifted tectonically. The cliff fronting the Yilki Terrace was subsequently trimmed by the sea, forming a 


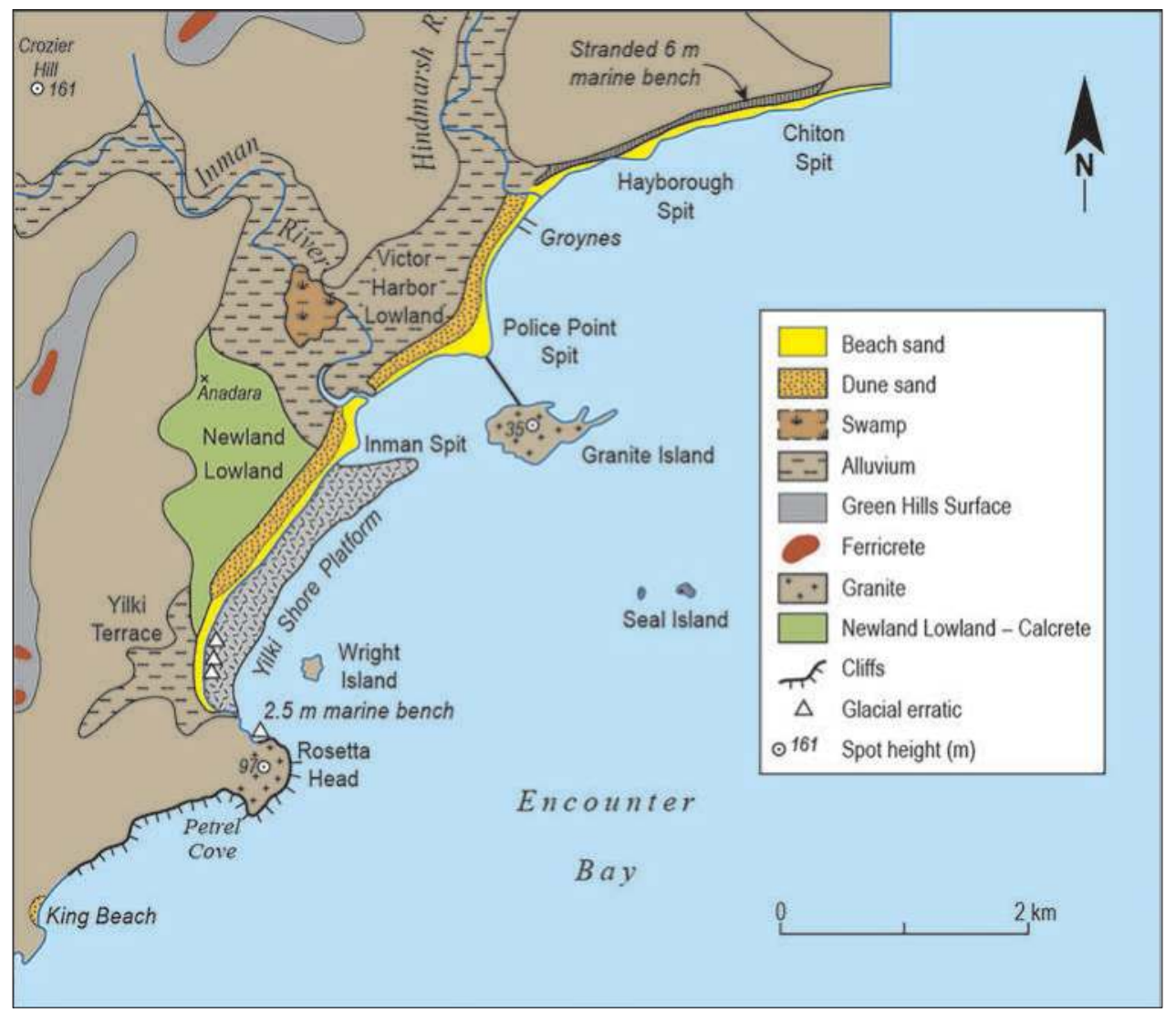

Figure 3.16 Map of the Victor Harbor Embayment, showing its major geomorphic features. Source: Modified from Bourman, R.P., Scobie, D. and Tscharke M.T. (1989). Origin and development of Police Point Spit, Victor Harbor, South Australia. South Australian Geographical Journal, 89, 25-45.

pronounced bench and backing cliff during a slightly higher stand of the sea in the mid-Holocene about 5000 years ago. ${ }^{30}$

\subsubsection{Newland Lowland and Yilki Shore Platform}

The Newland Lowland, which is underlain by last interglacial coastal deposits containing shell fragments, is capped by calcrete mantled by grey/black soil. It reaches up to $6 \mathrm{~m}$ APSL and occupies the coast from the Yilki Terrace to the Inman River. A shore platform formed on the same sediments extends up to $800 \mathrm{~m}$ offshore from the Newland Lowland. In places, granite boulders, some of which are glacial erratics, have been incorporated into the Yilki shore platform sediments. Other shallow reefs in the bay at various localities have a similar character and origin. 


\subsubsection{Terraces of the Inman and Hindmarsh Rivers}

Three major river terraces, former flood plains now stranded above the influence of 'normal' flood levels, extend upstream from the coast in the Inman and Hindmarsh river valleys, recording former sea levels. ${ }^{31}$ The two highest terraces have formed on red/brown alluvial deposits of the last interglacial (125 ka) Pooraka Formation and grade to the last interglacial shoreline, which at this location is $6 \mathrm{~m}$ APSL. Adare Park, the Encounter Bay Oval and parts of Victor Harbor Golf Course are built on this terrace. As sea level fell and the land uplifted, the meandering rivers carved erosional terraces into the alluvial sediment of the Pooraka Formation ${ }^{32}$; remnants of this terrace occur at Adare Park and the Victor Harbor High School.

Further uplift of the land and a large fall in sea level, perhaps to $125 \mathrm{~m}$ below present sea level some 21000 years ago, allowed the rivers to cut deep valleys into the Pooraka Formation sediments. When sea level rose to near its present level about 7000 years ago, sediment washed down the river systems filled these estuarine valleys to form flood plains comprising grey/black sands. Further uplift of the land and a slight fall in sea level stranded some of these flood plains as the Breckan Filltop terrace, as, for example, at the Victor Harbor Oval and the Victor Harbor Primary School.

\subsubsection{Victor Harbor Lowland}

The lower Hindmarsh and Inman Rivers flank the Victor Harbor Lowland; its landward margin is the $10 \mathrm{~m}$ contour at the base of a pronounced escarpment, a last interglacial cliff line marked by marine shells $125 \mathrm{ka}$ old. A detailed topographic map (1926) of the Victor Harbor Lowland ${ }^{33}$ reveals complex sand dune topography on the cuspate foreland of Police Point Spit. These dunes, which extended along the coast to both the Inman and Hindmarsh Rivers have now largely been flattened and destroyed by urban development.

\subsubsection{Police Point Spit}

Police Point Spit, the site of the first police station in the area, is a triangular sand spit or cuspate foreland protruding towards Granite Island. From its apex, a causeway, completed in 1875, links the mainland to Granite Island. Police Point Spit has been moulded by wave refraction around Granite Island, which bends waves so that they approach the apex of the spit from opposite directions, accumulating sand in the lee of the island and extending the spit towards the island. However, there is no evidence of present active growth of Police Point Spit towards Granite Island. ${ }^{34}$ The formation of a tombolo, a sand spit linking the island to the mainland, could occur with a fall in sea level, tectonic uplift of the land or an increase in sediment delivery to the coast, but these options are not likely at present. The spit may have actually retreated since European settlement, as early surveys suggest that the spit has been eroded. Bullock wagons transported cargo across to Granite Island before causeway construction, 
although there is no direct evidence that a permanent sand spit formerly linked mainland and island. Construction of the Granite Island breakwater, which extends some $300 \mathrm{~m}$ into the sea, caused a steeper angle of wave approach on the eastern side of the spit, focusing erosion near the boat ramp on its eastern extremity.

In contrast, until very recently, the western side of the spit has been stable and was reported to have prograded seawards about $15 \mathrm{~m}$ between 1920 and 1970, when large volumes of soft Permian glacial and Quaternary alluvial sediments were delivered to the coast by the Inman River. ${ }^{35}$ Through improved farming practices upstream, sediment delivery has been reduced and the western side of the spit is now being eroded. Entrainment of the Inman River mouth by rock walls may have also had an impact: originally able to migrate freely at the coast and liberate sand stored there, sand has now accumulated permanently east of the training walls.

\subsubsection{River mouth changes}

The outlets of rivers debouching to the sea at sandy shorelines typically change depending on the balance between river flows, wind, tide and wave conditions: such is the case with the mouths of the Inman and Hindmarsh Rivers, both of which naturally migrated and were commonly deflected towards the northeast under the influence of persistent southwesterly winds and waves. Rivers entering the sea at sandy shorelines are notorious for continually changing locations at their points of entry. Generally, the best approach to managing such areas is to identify the range of migration of the mouth and keep built structures out of that range, allowing nature to establish its own changing, dynamic equilibrium.

There was a major change in the position of the Hindmarsh River mouth in 1946, when, following $200 \mathrm{~mm}$ of rainfall at Victor Harbor on 17 and 18 January, river floods short-circuited the eastward loop of the river, shortening its length by $400 \mathrm{~m}$ and abandoning its former channel as a lagoon, which persists today. ${ }^{36}$ This two-day summer rainfall exceeded the total monthly rainfall for any month of records. When river flow is the dominant influence, the outlet tends to move towards the southwest, with the river often cutting through the sand bar built up previously by longshore drift towards the northeast. Two wooden groynes built on the southwestern side of the Hindmarsh River mouth may have helped to protect the immediate coastline, although the best approach is to keep permanent structures well away from migrating river mouths.

\subsubsection{Chiton Rocks}

Chiton Rocks are enigmatic. They do not comprise the underlying Kanmantoo Group metasedimentary rocks. Furthermore, they have pronounced circular structures, which do not occur in nearby shore zone Quaternary aeolianite as at Knight Beach, 
Port Elliot. Faint bedding structures in the Chiton Rocks suggest that they could be aeolianite, but mineralogically they are quite different. Aeolianite typically contains calcium carbonate, whereas the rocks at Chiton Beach consist of dolomite. The most likely explanation for the character of Chiton Rocks is that they are Permian glacial sediments, for sand rock and sandstone sediments containing erratics have been described in former erosion gullies from the Chiton Beach area ${ }^{37}$, as have large spherical concretions, which, colloquially, were referred to as 'giant's kettles'.

\subsubsection{Watson Gap-Boomer Beach to Knight Beach}

The bench and cliff line of the last interglacial shoreline $(125 \mathrm{ka})$ is followed by the railway line from near the mouth of the Hindmarsh River to Watson Gap, where stranded shell beds, including the subfossil Anadara trapezia, occur at about $10 \mathrm{~m}$ APSL in the railway cutting, indicating tectonic uplift of at least $6 \mathrm{~m}$.

Between Watson Gap and the granite headlands of Port Elliot, the beach is backed by a coastal aeolianite dune of the Bridgewater Formation, erosion of which contributes an ongoing supply of beach sediment. Beach cusps are prominent intertidal features of this coastal section; they are destroyed by storms but quickly re-form with abating wave conditions. No evidence of the elevated last interglacial shoreline shell beds that occur at Watson Gap has been reported from this section of coast, but casehardened remnants of an aeolianite dune occur within the surf zone (Figure 3.17). These remnants suggest that either sea level was lower than at present when the dune formed, or the land has sunk tectonically since its formation.

Internal structures of the lithified fossil coastal dune are visible in the cliffs backing Knight Beach; it is capped by a thick calcrete. Isolated pods of calcrete/ aeolianite cling to the granite headland on the eastern side of Knight Beach, suggesting that the majority of the headland was once completely covered. The sandy calcareous sediment with small shell fragments beneath the calcrete is much softer. Pronounced layering occurs in the aeolianite dune: these layers are not horizontal and parallel but are disposed at various angles to each other, a feature called 'cross-bedding', which illustrates changes in wind direction as sand grains were blown from the beach up a slope and tumbled over the top of the dune at different angles. Sand dune growth and migration under the influence of dominant onshore, but variable, winds explain the somewhat chaotic disposition of the bedding.

The last interglacial shoreline, an excellent indicator of tectonic dislocation, can be consistently traced around Encounter Bay from near the Bluff to Watson Gap, where it is close to $10 \mathrm{~m}$ APSL. Beyond Watson Gap, evidence of it is not known for a farther $8 \mathrm{~km}$ along the coast, where it reappears at an elevation of less than $1 \mathrm{~m}$ APSL. A major fault zone (the Encounter Fault) lies on the eastern margin of the Mount Lofty Ranges and extends out to sea just east of Watson Gap, so that the Port Elliot area has probably undergone subsidence over the past $125 \mathrm{ka}$. 


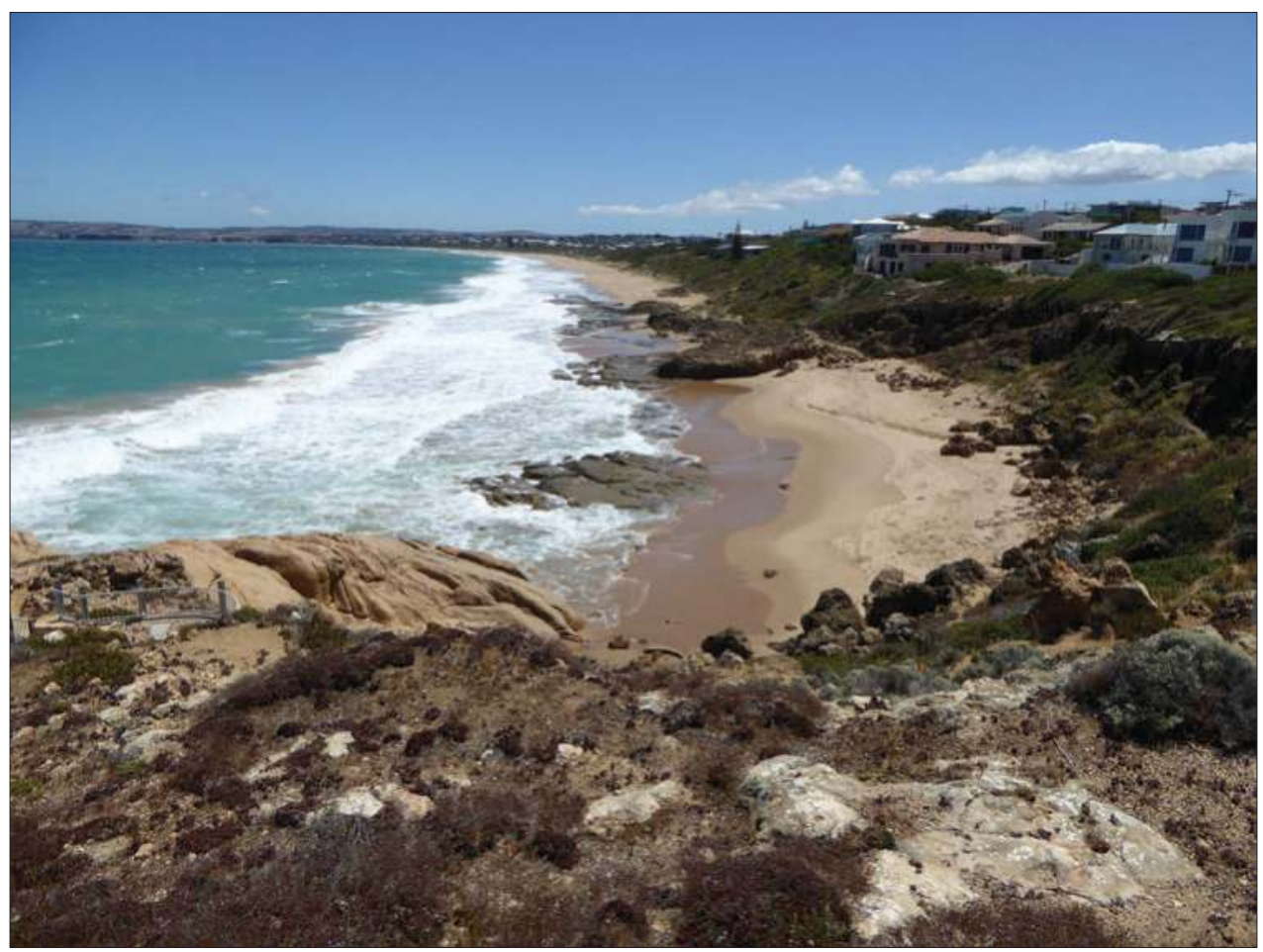

Figure 3.17 View along the Encounter Bay coastline from Knight Beach towards Victor Harbor. A former coastal dune, now turned into rock (lithified), has been eroded to form shore platforms. Coastal erosion of the aeolianite dune of the Bridgewater Formation indicates that sea level was lower when the dune formed. The granite headland carries small remnants of aeolianite, suggesting that the dune once covered it.

Source: Author's own work, RPB.

\subsubsection{The Granite Islands}

The Encounter Bay Granites form headlands and islands from West Island to Port Elliot. These include West Island, Rosetta Head, Wright Island, Granite Island, Seal Island, Freeman Knob, Pullen or Seagull Island, the Sisters, Commodore Point and Frenchman Rock. Approximately concordant with the strike of the Kanmantoo Group country rock, the granite intrusion or pluton extends southwest to Cape Willoughby on Kangaroo Island, a distance of more than $50 \mathrm{~km}$. The intrusion occurred at a depth of about $7 \mathrm{~km}$ about $500 \mathrm{Ma}$ ago through remelting of crustal rock; it was coincident with the Delamerian Orogeny, which culminated in the formation of a large fold mountain range. Occasional xenoliths, blocks of Kanmantoo Group rocks into which 
the granite was intruded, occur as roof pendants, revealing that the top of the pluton was close to the present land surface. ${ }^{38}$ The granites were exposed at the surface either before or during the Early Permian glaciation, about 300 Ma ago.

The islands of Encounter Bay have occasionally been described as abraded and smoothed by ice ${ }^{39}$, although no direct evidence of glacial activity on them has been reported. Moreover, recent coastal weathering and erosion processes have considerably modified them. The islands exhibit a suite of forms typically developed on granite, which reflect the characteristics of granite as a rock, particularly joints and sheeting structures. Joints or fractures, which divide the granite mass into cubic blocks and guide weathering processes, transform cubes into rounded boulders. Massive sheeting structures, resulting from pressure release as the overlying rocks are eroded, peel off from the main granite mass as curvilinear sheets up to $1 \mathrm{~m}$ thick and more. These sheets of rock are commonly subparallel to the ground surface and strongly influence the rounded character of major granite landforms such as the Encounter Bay islands.

The largest of the islands, Granite Island, is linked to the mainland by a causeway. It carries no direct evidence of glacial activity, but other landform features demonstrate ongoing changes since the Permian glaciation. Quarrying reveals tightly closed and widely spaced joints in fresh granite, but the summit is covered with calcrete and soil, while subsurface weathering has produced rounded isolated corestones, which could not have survived the passage of a thick ice sheet. Other minor, postglacial weathering features include tafoni (tortoise-shell rocks), shield and boss forms, and weathering pans or gnammas. These features are best developed on the open ocean side of the island, suggesting that their distribution may be related to sea spray and rain driven by south and southwesterly winds. Weathering features on Granite Island include Umbrella Rock, Nature's Eye and Rocking Stone.

West Island, which displays a very smooth, whale-back appearance, has been most frequently cited as an ice-smoothed island, even though no glaciated bedrock has been found on it. West Island is markedly asymmetrical, but has the opposite orientation for it to be a roche moutonnée, with the steeper ocean-facing side of West Island resulting from marine erosion. A massive sheeting plane extends through the island and may have played an important role in the development of its smoothed morphology.

Wright Island has a pronounced asymmetrical profile, too, which is also oriented the wrong way for it to be a classic roche moutonnée (Figure 3.18). Huge joint blocks support steep coastal cliffs on the ocean side, while the gentler landward slopes are underlain by smaller joint blocks and less resistant, Kanmantoo Group metasedimentary basement rocks. Refracted waves, which sweep around the island, meet on the eastern extremity, constructing a small sandy beach.

The plan form of Pullen (Seagull) Island is strongly influenced by jointing. Huge sheeting planes dip landward, while to seaward they have been truncated, suggesting 


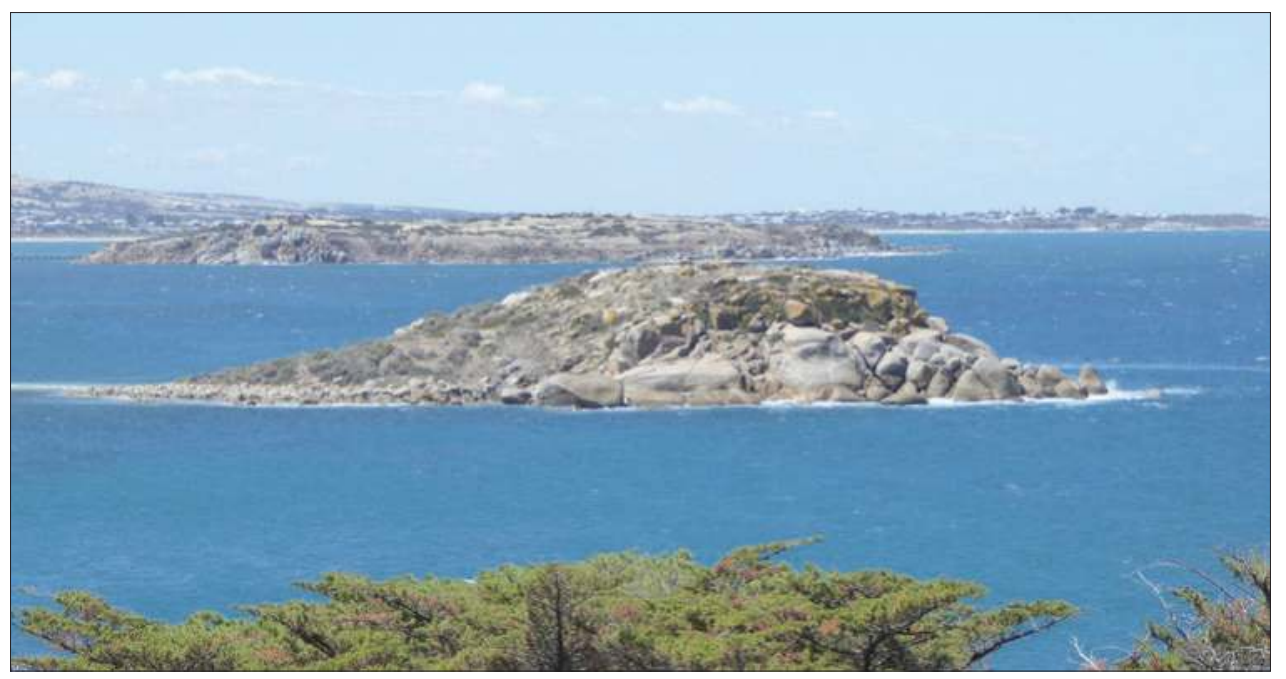

Figure 3.18 View of Wright Island from Rosetta Head, showing its markedly asymmetrical form, with Granite Island in the background.

Source: Author's own work, RPB.

the former presence of a huge dome structure extending far to the south. On Pullen Island spectacular examples of onion weathering, scattered isolated boulders and welldeveloped weathering pits represent non-glacial processes. Seal Island, meanwhile, possesses a large number of apparently loose, rounded boulders, which could not have survived the passage of the huge Permian ice sheet.

\subsubsection{The granite coast of Port Elliot}

From Knight Beach to Fisherman Bay, also called Sandy Bay, the coastline is dominated by granite outcrops forming headlands, islands and rocky reefs, the shapes of which are strongly influenced by jointing in the rock. Resistant granite impacts strongly on the approaching waves, which have moulded sandy bays such as Horseshoe Bay and Crockery Bay between the headlands. A walking path from Knight Beach to Fisherman Bay provides access to many of the geological features of the area as well as to excellent viewing points of the coastal geomorphology and scenery. The headland at Knight Beach is the only known locality where there is evidence of glacial action on the granite. ${ }^{40}$ Along the pathway between Knight Beach and Green Bay, over a distance of $30 \mathrm{~m}$, there is an undulating, glacially smoothed and polished granite surface. The best exposure, which is only $1 \mathrm{~m}^{2}$, is strongly polished, striated and grooved, indicating a local east-west ice movement. The glaciated surface demonstrates that the granite 
mass, which formed deep in the Earth's crust during the Delamerian Orogeny, was exposed at the surface in Early Permian times (299 to $290 \mathrm{Ma}$ ).

\subsubsection{Green Bay}

Green Bay, a rock-walled bay, has been carved into the granite mass along major joints and rock fractures, exposing the dome-like form of the underlying granite. The headlands trap sand in separate beach compartments, but strong wave action stirs up much sand, so that some of it bypasses the headlands. Calcrete-capped aeolianite forms a steep cliff at the back of the bay, and patches of aeolianite, with bedding dipping seawards, occur in the intertidal zone. Aeolianite probably infilled much of the bay during a time when sea level was relatively lower than it is now, with erosion reexposing the bay. East of Green Bay, the backshore of Rocky Cove, a small indentation in the granite coastline, is strewn with large granite boulders, revealing the power of storm waves on this exposed coast. Evidence for the power of storm waves is also provided by destruction of the Port Elliot breakwater, which was originally $110 \mathrm{~m}$ long and $8.5 \mathrm{~m}$ high, with $2.5 \mathrm{~m}$ of the structure standing above sea level. It was constructed of rock masses weighing between 8 and 10 tonnes. ${ }^{41}$

\subsubsection{Horseshoe Bay}

Overviews of Horseshoe Bay from its headlands (Freeman Nob and Commodore Point) reveal its essential character (Figure 3.19). Freeman Nob carries a capping of Permian and Pleistocene sediments as well as a weathered regolith unit with small dark red mottles, which has developed on the granite surface. It is visible in small patches on the walking paths on the western side of Horseshoe Bay.

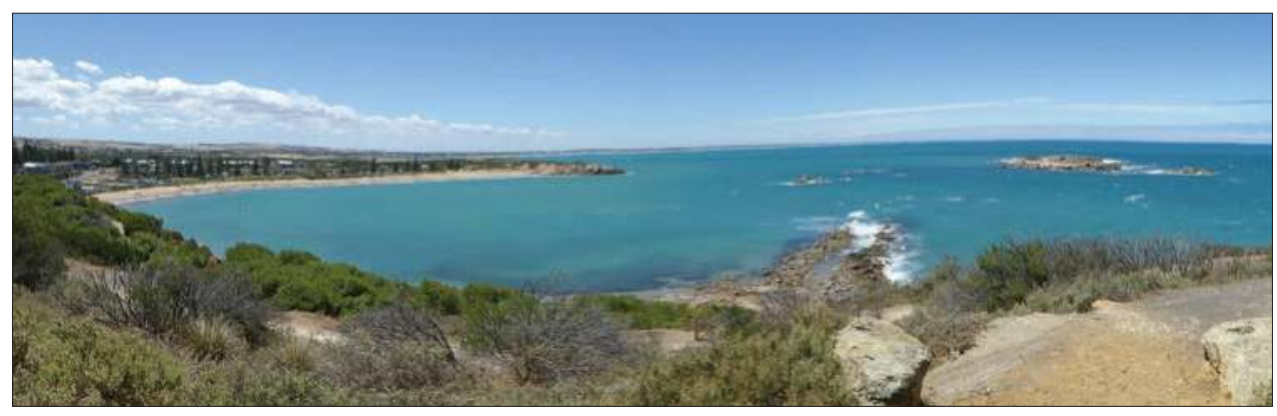

Figure 3.19 View of Horseshoe Bay, showing granite outcrops forming the headland of Commodore Point, Pullen Island (also known as Seagull Island), the Sisters, Plum Pudding Rock and Frenchman Rock. Remnants of an artificial breakwater occur in the foreground. The beach, which dips steeply into the water, is commonly characterised by prominent beach cusps along its length.

Source: Author's own work, RPB. 


\subsubsection{Crockery Bay}

Between Commodore Point and Frenchman Rock, there is a small indentation in the rocky granite shoreline, Crockery Bay, which is a well-protected, sandy pocket beach flanked by granite headlands with bright orange lichen along the granite shoreline above the level of wave action. Occasional large boulder beaches are clearly active, as they carry no cover of orange lichen. However, some higher, lichen-covered boulder beaches indicate inactivity for some time and may reflect a relatively higher sea level or more severe wave attack in the past.

\subsubsection{Fisherman Bay (Sandy Bay) and Basham Beach}

The final sandy beach compartment of the southeastern Fleurieu coast extends from the granite headland near Frenchman Rock to the sandstone outcrops at Middleton. At Frenchman Rock, the coastline trends due east-west for $200 \mathrm{~m}$ or so, following the edge of an even-grained granite outcrop. Fisherman Bay is protected by the granite outcrops, which strongly refract waves approaching from the south and southwest. The waves separate into an intensely refracted, nearshore section into Fisherman Bay and an offshore section that continues in a northwesterly direction towards the northern segment of the bay.

Purple-coloured beach sands occur along this section of coast. They contain the heavy mineral rutile, which has a source in both the granitic and metasedimentary rocks of the area. A line of recent, vegetated transverse dunes backs the bay from Fisherman Bay to Basham Beach, generally increasing in size in this direction. Gaps in the dunes occur where drainage lines from the hinterland break through the dunes. From time to time the dunes are severely cliffed, causing shrubs and bushes to tumble on to the beach. A coastal reserve backs the dunes and occupies what was probably a minor embayment during a relatively higher stand of the sea.

At Basham Beach, hard rocks of the Middleton Sandstone of Cambrian (500 Ma) age crop out on the eastern end of the beach. These rocks comprise the youngest known part of the Kanmantoo Group of metasedimentary rocks that are exposed along the southern shore of Fleurieu Peninsula from Cape Jervis to Middleton. Muds, silts, sands and pebbles deposited in the Adelaide Geosyncline were subjected to heat $\left(<540^{\circ} \mathrm{C}\right)$ and pressure $(<3 \mathrm{~kb})$ during the granitic intrusion and folding of the Delamerian Orogeny. ${ }^{42}$ Original sedimentary structures in the Middleton Sandstone have survived metamorphism, revealing cross-bedding that indicates sediment derivation from the west. Occasional large isolated boulders of Middleton Sandstone suggest displacement by storm waves. 


\subsection{Summary and conclusions}

The Fleurieu Peninsula coast displays remarkable diversity over relatively short distances. Much of the coast is bedrock-dominated, forming cliffs and headlands, with numerous individual beach compartments often associated with stream valleys intersecting the coast. Larger embayments such as those at Normanville and Victor Harbor correspond with ancient glacial valleys filled with easily eroded Permian glacial deposits that provide beach sediments. Other coastal features inherited from the Permian glaciation include the present distribution of granite islands and headlands in Encounter Bay as well as the basic form of Backstairs Passage between Fleurieu Peninsula and Kangaroo Island. Stranded marine cliffs, fossil beaches and river terraces record both fluctuations in eustatic sea level caused by the waxing and waning of massive ice sheets over the past million years, as well as ongoing tectonic uplift of the peninsula. Human impacts on the coast are most marked at Rapid Bay, where quarry waste was dumped in the bay; at Normanville, where sand dunes were mined; and at Victor Harbor, where foredunes have been levelled and built over, beach sediment supply impacted by inland farming practices, river mouths entrained by engineering works and wave approaches influenced by breakwater construction.

\section{Notes}

1 Milnes, A.R. \& Bourman, R.P. (1972). A Late Palaeozoic glaciated granite surface at Port Elliot, South Australia. Transactions of the Royal Society of South Australia, 96, 149-155.

2 Bourman, R.P. (1987). A review of controversial issues related to the Late Palaeozoic glaciation of southern South Australia. In: Gardiner, V. (Ed.), International geomorphology, Part 2. John Wiley \& Sons, Chichester, pp. 725-742.

3 Murray-Wallace, C.V. \& Bourman, R.P. (2002). Amino acid racemisation dating of a raised gravel beach deposit, Sellicks Beach, South Australia. Transactions of the Royal Society of South Australia, 126 (1), 21-28.

4 Bourman, R.P., Belperio, A.P., Murray-Wallace, C.V. \& Cann, J.H. (1999). A last interglacial embayment fill at Normanville, South Australia, and its neotectonic implications. Transactions of the Royal Society of South Australia, 123 (1), 1-15.

5 Bourman, R.P. (2006). River terraces of the Fleurieu Peninsula. South Australian Geographical Journal, 105, 1-24.

6 Bourman, Belperio, Murray-Wallace \& Cann (1999).

7 Bourman, Belperio, Murray-Wallace \& Cann (1999).

8 Bourman, R.P. (1990). Artificial beach progradation by quarry waste disposal at Rapid Bay, South Australia. Journal of Coastal Research, Special Issue 6, 69-76.

9 Bourman (1990).

10 Alley, N.F. \& Bourman, R.P. (1984). Sedimentology and origin of Late Palaeozoic glacigene 
deposits at Cape Jervis, South Australia. Transactions of the Royal Society of South Australia, 108, 63-75.

11 Bourman, Belperio, Murray-Wallace \& Cann (1999).

12 Brock, E.J. (1964). The denudation chronology of Fleurieu Peninsula, South Australia. Unpublished MA Thesis, The University of Adelaide.

13 Bauer, F.H. (1959). The regional geography of Kangaroo Island. Unpublished PhD Thesis, Australian National University, Canberra.

14 Alley, N.F., Bourman, R.P. \& Milnes, A.R. (2013). Late Paleozoic Troubridge Basin sediments on Kangaroo Island, South Australia. South Australia MESA (Mines and Energy, SA) Journal, 70 (3), 24-43.

15 Bourman, R.P. (1973). Geomorphic Evolution of Southeastern Fleurieu Peninsula. Unpublished MA Thesis, The University of Adelaide.

16 Daily, B. \& Milnes A.R. (1971). Stratigraphic notes on Lower Cambrian fossiliferous metasediments between Campbell Creek and Tunkalilla Beach in the type section of the Kanmantoo Group, Fleurieu Peninsula, South Australia. Transactions of the Royal Society of South Australia, 95, 199-214.

17 Brock (1964).

18 Bourman, R.P. (2006). River terraces of the Fleurieu Peninsula. South Australian Geographical Journal, 105, 1-24.

19 Bourman, R.P. (1979). Geomorphological contributions to Coastal Management. In: Corbett, D. \& Sibly, J. (Eds), Southern heritage: Proceedings of the Conference Focus on our southern heritage. Conservation Council of South Australia and the Department of Continuing Education, The University of Adelaide, pp. 80-88.

20 Daily, B. \& Milnes A.R. (1973). Stratigraphy, structure and metamorphism of the Kanmantoo Group (Cambrian) in its type section east of Tunkalilla Beach, South Australia. Transactions of the Royal Society of South Australia, 97 (3), 213-251.

21 Bourman (1973).

22 Murray-Wallace, C.V., Bourman, R.P., Prescott, J.R., Williams, F., Price, D.M. \& Belperio, A.P. (2010). Aminostratigraphy and thermoluminescence dating of coastal aeolianites and the later Quaternary history of a failed delta: The River Murray Mouth region, South Australia. Quaternary Geochronology, 5, 28-49.

23 Bourman (1973).

24 Cleland, J.B. \& Howchin, W. (1931). Geological and botantical notes on the Victor Harbour district. Field Naturalists Section of the Royal Society of South Australia, Publication No. 2, 37 pp.

25 Farrell, B. (1968). A beach sand study of the Fleurieu Peninsula. Unpublished BSc Hons Thesis, The University of Adelaide.

26 Bourman, R.P. \& Alley, N.F. (1995). Late Palaeozoic glacigene sediments at King Point, southwestern Troubridge Basin, South Australia. Quarterly Geological Notes, Geological Survey of South Australia, 128, 1-7.

27 Alley \& Bourman (1984).

28 Bourman (1973). 

Formation and its implications: Some preliminary results from
Transactions of the Royal Society of South Australia, 121 (3), 83-94. $25-45$.

35 Bourman, R.P. (1974). Historical geomorphic change, Fleurieu Peninsula, South Australia. Proceedings International Geographic Union New Zealand Geographical Society, 8, 289-297; Bourman, R.P. (1976). Environmental geomorphology: Examples from the area south of Adelaide. Proceedings Royal Geographical Society of Australia (SA Branch), 76, 1-23.

36 Bourman (1969).

37 Guppy, D.J. (1943). A geological reconnaissance of part of the Hundreds of Encounter Bay and Goolwa. BSc Hons Thesis, The University of Adelaide.

38 Milnes, A.R. (1973). The Encounter Bay Granites and their environment. Unpublished PhD Thesis, The University of Adelaide; Milnes, A.R. (1990). The Encounter Bay Granites, Fleurieu Peninsula and Kangaroo Island. Geological Society of Australia. Special Publication No. 16, pp. 421-449.

39 Howchin, W. (1926). Geology of the Victor Harbour, Inman Valley and Yankalilla districts, with reference to the great Inman Valley glacier of Permo-Carboniferous age. Transactions of the Royal Society of South Australia, 50, 89-116; Crawford, A.R. (1959). Unpublished preliminary notes for Encounter Geology Sheet explanatory notes. South Australian Geological Survey.

40 Hodge, C.R. (1932). Encounter Bay: The miniature Naples of Australia - A short history of the romantic South Coast of South Australia. The Advertiser, Adelaide, 173 pp.

41 Hodge (1932).

42 Daily \& Milnes (1973). 


\section{The River Murray Estuary}

\subsection{Introduction}

The River Murray Estuary is a complex series of waterways comprising Lake Alexandrina, Lake Albert, the Murray Mouth, Coorong Lagoon and the coastal barrier systems of Younghusband and Sir Richard Peninsulas. The region has long been a source of fascination because of its inherent natural beauty, its social and cultural history, and because of the records of explorations by Matthew Flinders, Nicholas Baudin, Charles Sturt, Collet Barker and others. The Coorong became immortalised as the setting for Colin Thiele's novel and film, Storm Boy. Aboriginal people had a finely developed understanding of their environment and occupied the area sustainably for many thousands of years before the arrival of Europeans.

In 1802, Matthew Flinders and Nicholas Baudin, during their charting of the southern Australian coastline, met offshore from the Murray Mouth in Encounter Bay, the outfall of Australia's largest exoreic river system, although neither navigator recognised it. This is not remarkable; they were many kilometres offshore, the coast is low-lying and there were no large freshwater flows containing sediment. ${ }^{1}$ Captain Charles Sturt reached the Murray Estuary in 1830 after an intrepid boat trip down the River Murray and was forced to return the same way after his efforts at accessing the sea were thwarted by sand bars in the Goolwa Channel. Hopes were high that the Lower Murray area would support a thriving port and that Goolwa would become the 'New Orleans of Australia'. ${ }^{2}$ However, the mouth could not always be reliably navigated, there was no natural site for a deep-sea port, and the romance of the paddle steamers was finally quashed by the construction of more reliable railways. Today the area has become a focus for conservation, tourism, recreation and retirement. 


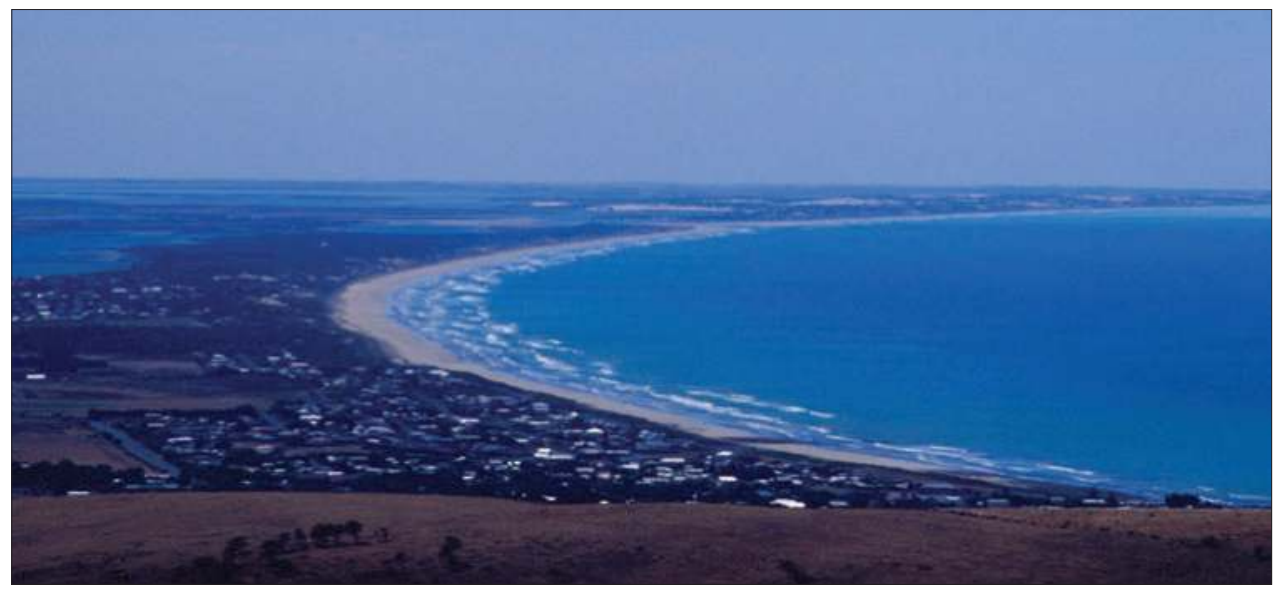

Figure 4.1 View across the Murray Estuary from the Mount Lofty Ranges at Crows Nest Lookout. Note the inland waters of the estuary and the arcuate sweeping shoreline of Encounter Bay, which fringes the seaward margin of the estuary. The lines of breakers are typical of dissipative beaches.

Source: Author's own work, RPB.

\subsection{Physical setting}

The arcuate sweeping shoreline of Encounter Bay fringes the seaward margin of the Murray Estuary, stretching from the uplands of the Mount Lofty Ranges towards the southeast (Figure 4.1). It includes part of the longest beach $(194 \mathrm{~km}$ ) in Australia. Unconsolidated sand forms most of the shoreline as long, narrow coastal barriers (Sir Richard and Younghusband Peninsulas) separate the open ocean from the elongate back-barrier lagoons of the Goolwa Channel and Coorong Lagoon. The name 'Coorong' has been anglicised from the Ngarrindjerii word 'Kurangh', which means a long neck of water.

Lakes Alexandrina and Albert and the Coorong Lagoon (Figures 4.2 and 4.3), covering some $750 \mathrm{~km}^{2}$, comprise the original estuary of the River Murray, the largest drainage system in Australia that reaches the sea, with an area exceeding 1 million $\mathrm{km}^{2}$ or one-seventh of Australia's land area. The Murray Estuary is regarded as a part of the coast because of its intimate association with the sea. Although aided by wind-assisted ebb tides, river flows are essential for the long-term maintenance of the Murray Mouth ${ }^{3}$, through which estuarine-dependent fish migrate and sediments are transported. The coastline is thus closely connected with the estuary and with the greater hinterland from which freshwater runoff is produced.

The intermixing of freshwater river flows with tidal oceanic waters originally formed a vibrant, dynamic and highly productive estuarine ecosystem, now much 

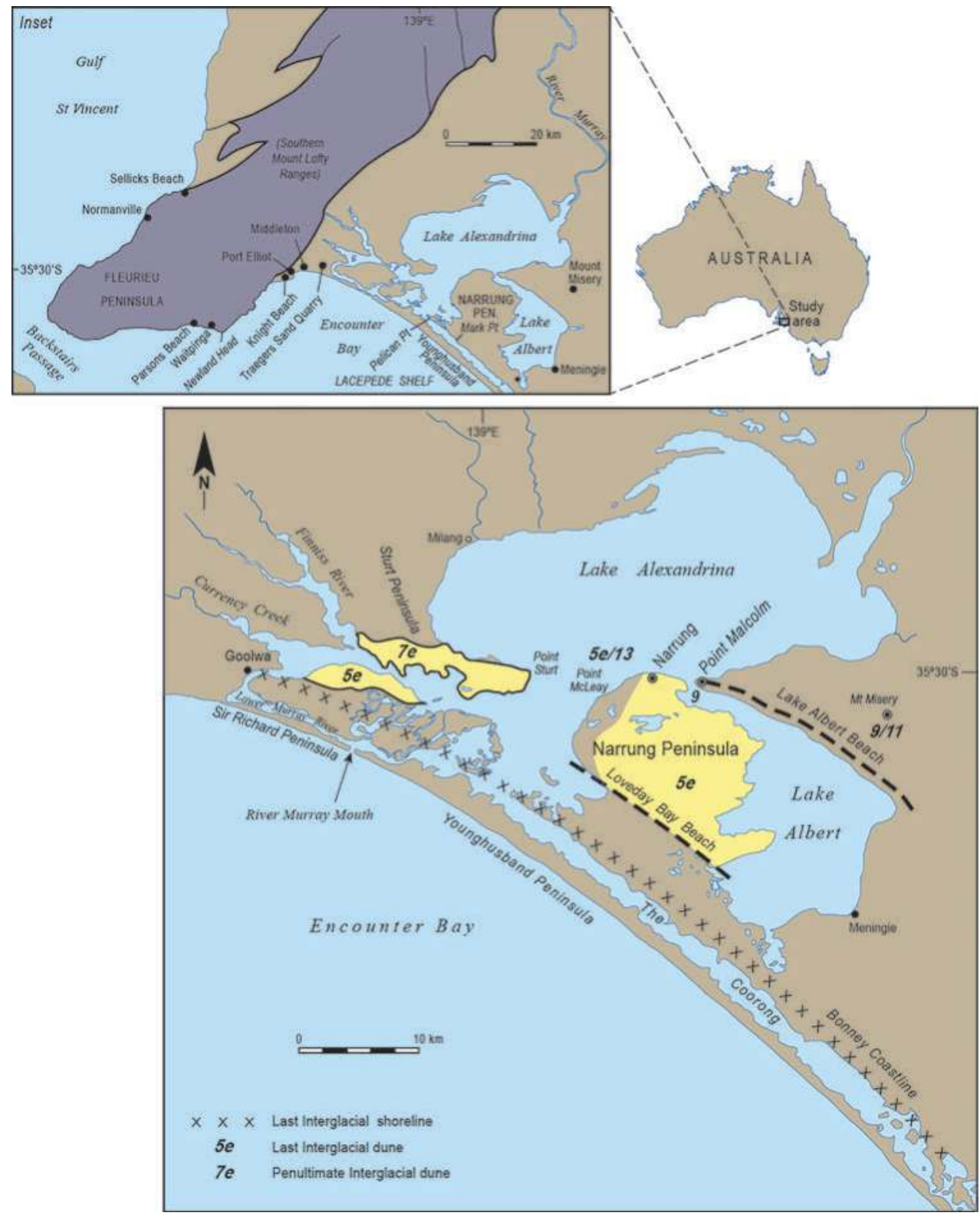

Figure 4.2 Maps of the Murray Estuary, showing its location and the positions of the last interglacial (125 ka) shoreline, last interglacial coastal dunes $(5 \mathrm{e})$ and the next oldest, penultimate interglacial dune (7e). Remnants of even older dunes occur at Narrung, Point Malcolm and Mount Misery. The last interglacial shoreline passes along the landward side of the Coorong and through the centre of Hindmarsh Island, towards Goolwa.

Source: Murray-Wallace, C.V., Bourman, R.P., Prescott, J.R., Williams, F., Price, D.M. \& Belperio, A.P. (2010). Aminostratigraphy and thermoluminescence dating of coastal aeolianites and the later Quaternary history of a failed delta: The River Murray mouth region, South Australia. Quaternary Geochronology, 5, 28-49. 


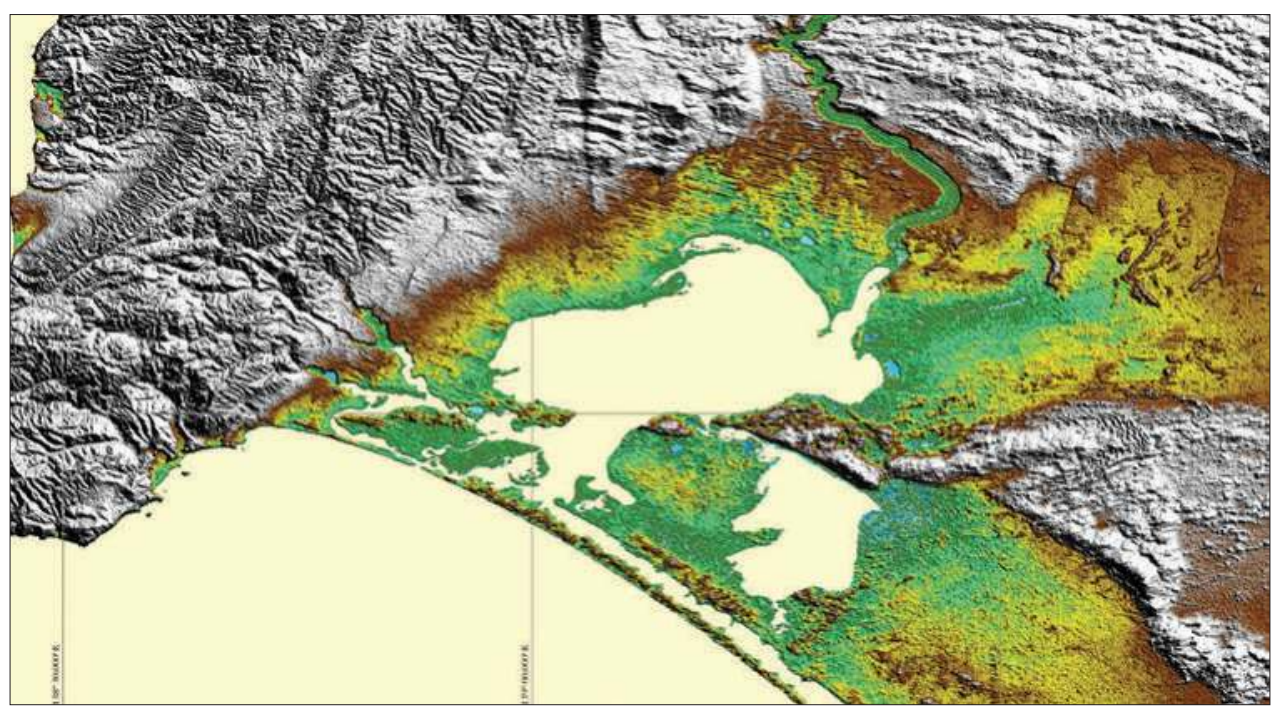

Figure 4.3 Digital elevation model of the Murray Estuary, showing Lakes Alexandrina and Albert and part of the Coorong Lagoon.

Source: Jarvis, A., Reuter, H.I., Nelson, A., Guevara, E. (2008). Hole-filled SRTM for the globe Version 4, available from the CGIAR-CSI SRTM 9Om Database. <http://srtm.csi.cgiar.org>.

depleted by freshwater extraction and river regulation. The wetland habitats of the Murray Estuary are regarded as a protected site under the international Ramsar Agreement (wetlands of international significance). In their pre-European condition, Lakes Alexandrina and Albert were dominated by freshwater flows from the River Murray ${ }^{4}$, with pulses of salt water entering the lakes only during times of protracted drought. However, after large volumes of fresh water were extracted for irrigation upstream, marine tidal waters with stingrays and sharks penetrated the lakes upriver to Murray Bridge and Mannum, prompting construction of barrages across the lower reaches of the estuary, completed in 1940.

Long-term freshwater conditions are indicated by the presence of modern and fossil freshwater shells beneath and around the lake margins, freshwater diatoms ${ }^{5}$ together with extensive beach ridges and sand spits composed of quartz fragments derived from the land. In contrast, the Coorong Lagoon is regarded as an inverse estuary, increasing in salinity away from the Murray Mouth, despite occasional inputs of fresh water into the southern Coorong Lagoon from Salt Creek and groundwater flows. Salinity in the Southern Lagoon far exceeds that of sea water, and it becomes hypersaline following reduced river flows. Average salinities for the South Lagoon are 140 ppt (parts per 
thousand), for the North Lagoon 80 ppt and for sea water 35 ppt. During droughts, salinities can increase up to five to seven times that of sea water.

This chapter examines the geological background and long-term evolution of the Murray Estuary, including the formation of major landforms of the estuary such as Lakes Alexandrina and Albert, the coastal barriers of Sir Richard and Younghusband Peninsulas, which separate the Coorong from the sea, and Hindmarsh Island. Continuing changes such as coastal erosion, landward barrier movement, mouth migration and closure are also discussed. Some of the changes, especially blockage of the river mouth, the growth of Bird Island ${ }^{6}$ and increased lakeshore erosion and sedimentation are closely related to reduced freshwater flows and regulation of the river and its estuary by weirs and barrages. ${ }^{7}$

\subsection{Geological background}

Located in the southwestern portion of the Murray Basin, the Murray Estuary abuts the ancient, folded and uplifted rocks of the Mount Lofty Ranges. Younger rocks and sediments of Permian and Cenozoic ages in the Murray Basin are relatively undeformed and rest at depth on downfaulted, older metamorphosed and granitic rocks. Near the Murray Mouth, at least $230 \mathrm{~m}$ of Permian $(-300 \mathrm{Ma})$ and younger sediments underlie the estuary, but sporadic outcrops of ancient granite occur within and on the margin of Lake Albert, illustrating considerable variability in topographic relief of the ancient underlying rocks.

At Morgan, the River Murray takes a sharp right-angle bend to the south, flowing subparallel with the Mount Lofty Ranges. Some have suggested that the river once flowed westward to Spencer Gulf near Port Pirie ${ }^{8}$ before uplift of the Mount Lofty Ranges, while others believe that the Mount Lofty Ranges existed before the lower course of the river was established. ${ }^{9}$ Whatever the situation, the Mount Lofty Ranges are responsible for the final southerly course of the river to the sea. The river in South Australia cuts through limestone deposits $20 \mathrm{Ma}, 16 \mathrm{Ma}$ and $4 \mathrm{Ma}$ old, as well as through lake sediments $2.4 \mathrm{Ma}$ old of the former Lake Bungunnia. ${ }^{10}$ Some workers consider that the ancestral River Murray was located in western Victoria during the Early Pliocene and that the modern River Murray in South Australia has only been in existence for the past $700 \mathrm{ka}$, following earth movements and the draining of Lake Bungunnia. ${ }^{11}$

Relatively low-lying land surrounds the Murray Estuary; it consists of former coastal sand barriers or dune ranges of aeolianite 15 to $50 \mathrm{~m}$ high, up to several kilometres across at their widest points and extending laterally for more than $200 \mathrm{~km} .{ }^{12}$ They are similar to the present-day Younghusband Peninsula, but have been preserved and hardened (lithified) by weathering processes forming very resistant surface 
cappings of calcrete (a soil feature formed on calcareous sediments). ${ }^{13}$ Back-barrier lagoonal corridors separate successive dune ranges. The dune ranges represent former high sea levels during interglacial times, when water held in glaciers and polar ice sheets melted and warmer global temperatures caused thermal expansion of the oceans and sea level rise. Successive high sea level events, separated by intervals of roughly 100000 years, reached elevations close to modern sea level. Near Robe and Naracoorte in the southeast, the dune ranges trending northwest-southeast have been separated by ongoing uplift of the coastal plain (see Chapter Five). ${ }^{14}$ However, the coastal plain also tilts down towards the Murray Estuary, as indicated by a reduction in elevation of the former shorelines in that direction, and the northwesterly flow of both surface and subsurface drainage. ${ }^{15}$ When traced to the northwest, the dunes converge and overlap, blurring correlations with the well-established chronologies of the southeast. ${ }^{16}$ This demonstrated subsidence, combined with the global postglacial rise in sea level between 17 and $7 \mathrm{ka}$ ago, drowned the interdunal corridors and formed the Murray Estuary through which the River Murray reaches the coast. Lake Alexandrina was possibly as much as one-third larger 7000 years ago, extending well into low-lying lake margins. ${ }^{17}$ During earlier sea level lowstands, erosional scouring by the river had helped to create the broad depression occupied by Lakes Alexandrina and Albert.

The ages of some of the dune ranges of the estuary area have now been established. ${ }^{18}$ For example, one of the youngest, the last interglacial shoreline of 125000 years ago (the Woakwine Range of the southeast or the Bonney coastline) can be traced on the landward shore of the Coorong Lagoon as former shelly beach deposits from near the southern tip of Lake Albert to Goolwa (Figure 4.2). When these shells were deposited, sea level was about $2 \mathrm{~m}$ APSL, so that the current elevation of these shells indicates the amount of movement of the land in the past 125000 years. At Goolwa, the last interglacial beach, formerly $2 \mathrm{~m}$ APSL, lies $0.8 \mathrm{~m}$ BPSL, and on Hindmarsh Island the shells occur at $0.9 \mathrm{~m}$ APSL. These sites indicate ongoing subsidence of 1.1 to $2.8 \mathrm{~m}$ in the last 125000 years, a rate between 0.02 to $0.022 \mathrm{~mm} /$ year. In contrast, uplift has occurred further west at Victor Harbor (shells at $6 \mathrm{~m}$ ) and at Salt Creek to the southeast $(4 \mathrm{~m})$. The long history of tectonic subsidence of the Murray Estuary continues today.

Last interglacial dunes associated with the shelly shoreline deposits occur farther inland. South of Meningie, dunes of the last interglacial shoreline form a recurved spit on the southeastern side of Lake Albert, and much of the Narrung Peninsula is covered with aeolian calcareous sand dunes of last interglacial age, which at Point McLeay (Raukkan) and Narrung overlie older, downtilted calcreted dune ranges. The high dune range and beach ridges on the northern half of Hindmarsh Island (Figure 4.2) are also equivalent to the Woakwine Range (125 ka years old). In places on Hindmarsh Island, these last interglacial calcreted sands overlie remnants of a dune range older than $329 \mathrm{ka}^{19}$ 


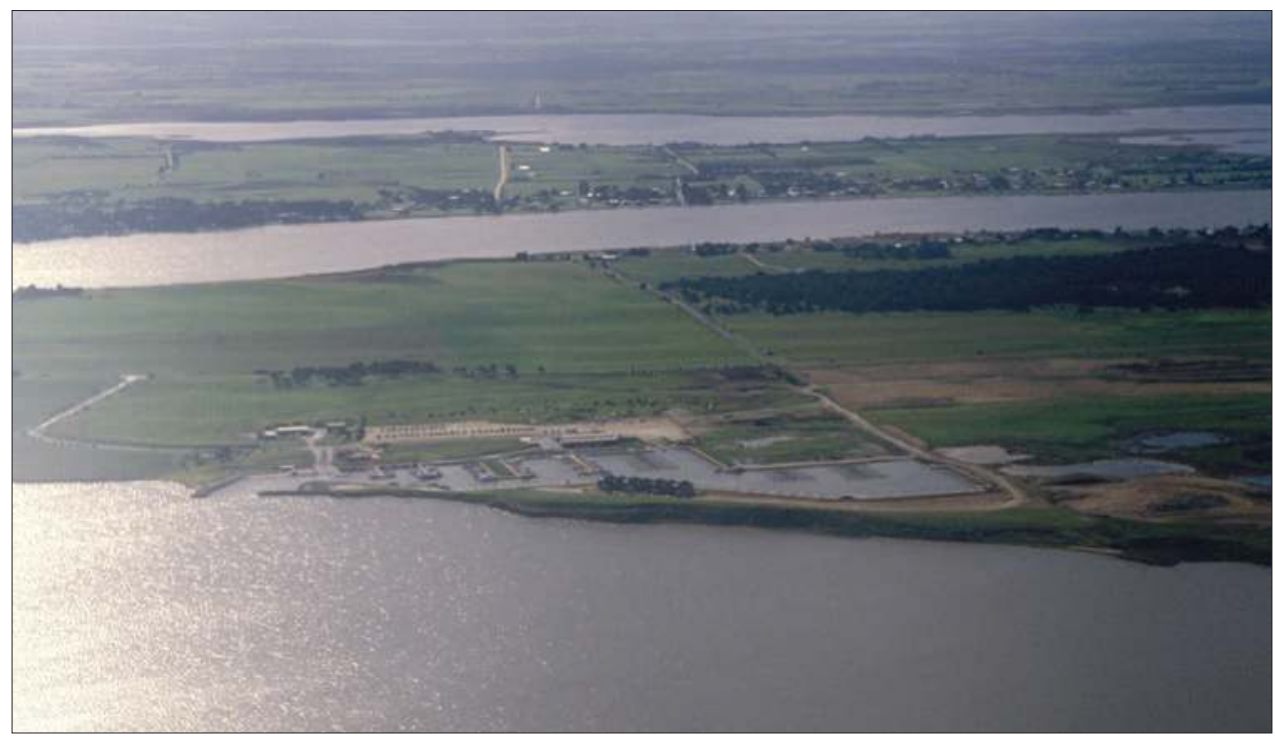

Figure 4.4 View across the Goolwa Channel, Hindmarsh Island, the Lower Murray Channel, the Clayton Bay-Point Sturt Peninsula and the estuary of the Finniss River. Note the former beach ridges on Hindmarsh Island, which are of last interglacial age (125 ka). The Clayton Bay-Point Sturt Peninsula represents an older interglacial coastal barrier some 250 ka old.

Source: Author's own work, RPB.

The main, deepest river channel (Lower Murray or Goolwa Channel) flows around the northern and western sides of Hindmarsh Island and forms part of the elbow after which Goolwa is named. Why does the river take this circuitous course when it could have taken a more direct one on the eastern side of the island? The channels (Mundoo, Boundary Creek, Ewe Island, Tauwitchere), which cut into lithified last interglacial deposits east of Hindmarsh Island, are generally broad and shallow, whereas the Goolwa Channel is relatively narrow and deep. It has been the main channel at least since the Last Interglacial, during which time large volumes of sand were transported along the coast towards the northwest by wave action, forming recurved beach ridges where they abutted the river. As this sand progressively piled up, it pushed the river mouth towards the west, giving rise to the deflection of the river around Hindmarsh Island.

The next-oldest dune range inland of the Woakwine equivalent forms Point Sturt Peninsula, on which the township of Clayton Bay is sited (Figure 4.4). It has been dated at approximately $250 \mathrm{ka}$ and forms the northern bank of the Lower Murray Channel. This feature may be the equivalent of the Loveday Bay shoreline on the eastern side of Lake Alexandrina (Figure 4.2). An older dune remnant occurs at Milang, but its age is unknown. 
The northeastern shore of Lake Albert follows a former marine coastline, Lake Albert Beach (Figure 4.2), which is backed by a calcreted dune range up to $50 \mathrm{~m}$ high and is highlighted by the arcuate shape of this former open ocean shoreline feature. A minimum age of $250 \mathrm{ka}$ on this feature has been obtained from near the Point Malcolm Lighthouse. Ages have also been obtained at Pt McLeay (Raukkan) (488+ $72 \mathrm{ka})$, and at Mount Misery $(348+66 \mathrm{ka})$, the most inland of the dune ranges near the estuary. ${ }^{20}$

\subsection{What determines the shape of the Encounter Bay coast?}

Apart from restricted outcrops of aeolianite, no hard rocks front the Murray Estuary on Encounter Bay. Unconsolidated sand dominates the shoreline, so that it is the processes of waves, winds and tides which dictate the morphology or shape of the coastline in plan view and determine the character of the beaches. Two main types of waves influence the shape of the coastline: swell waves and storm waves.

Constructive, open ocean swell waves, approaching the curved coast from the southwest, have moulded the regular, curved shape of the Encounter Bay coastline (Figures 4.1 and 4.2). They impinge on the southern part of the Encounter Bay at an angle that causes longshore drift to the northwest, but causes drift to the east on

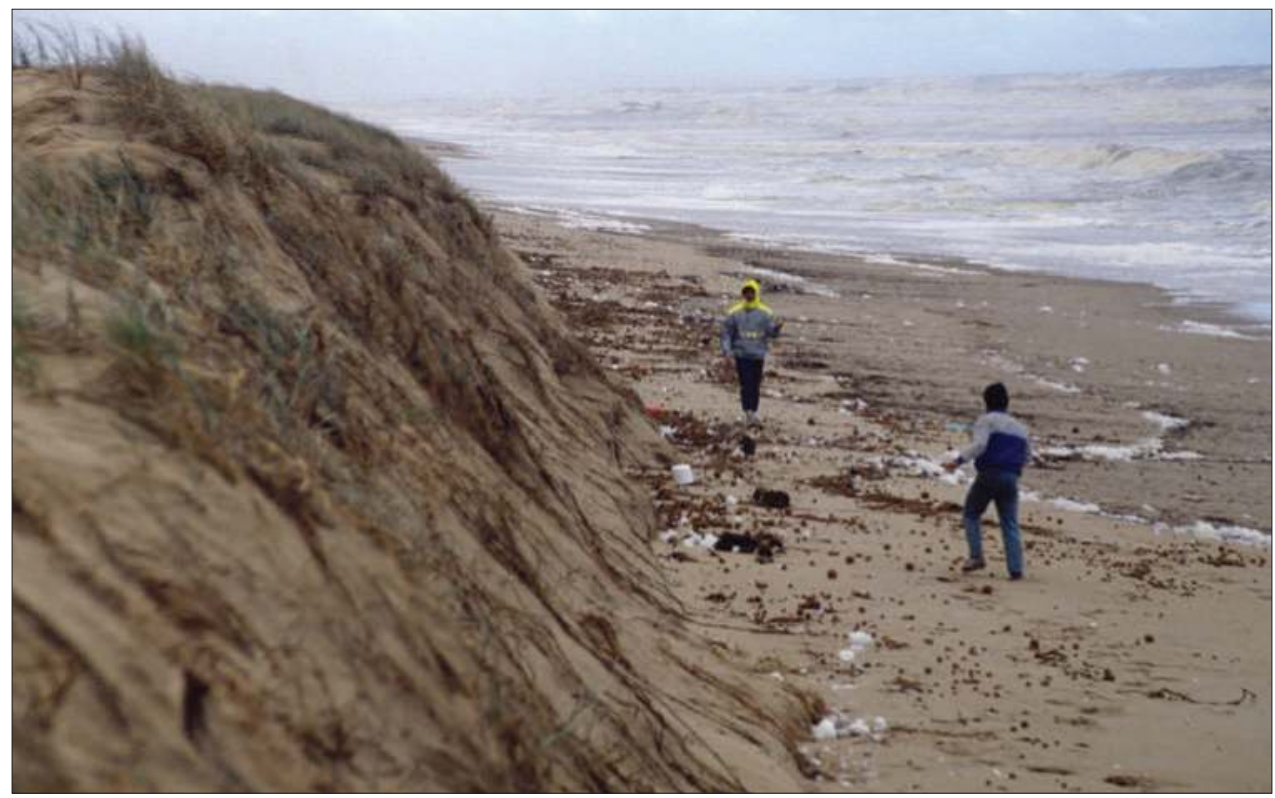

Figure 4.5 A section of Sir Richard Peninsula $100 \mathrm{~m}$ long near the Murray Mouth was eroded back some $14 \mathrm{~m}$ in 24 hours during a storm in March 1984, redistributing many thousands of tonnes of sand.

Source: Author's own work, RPB. 


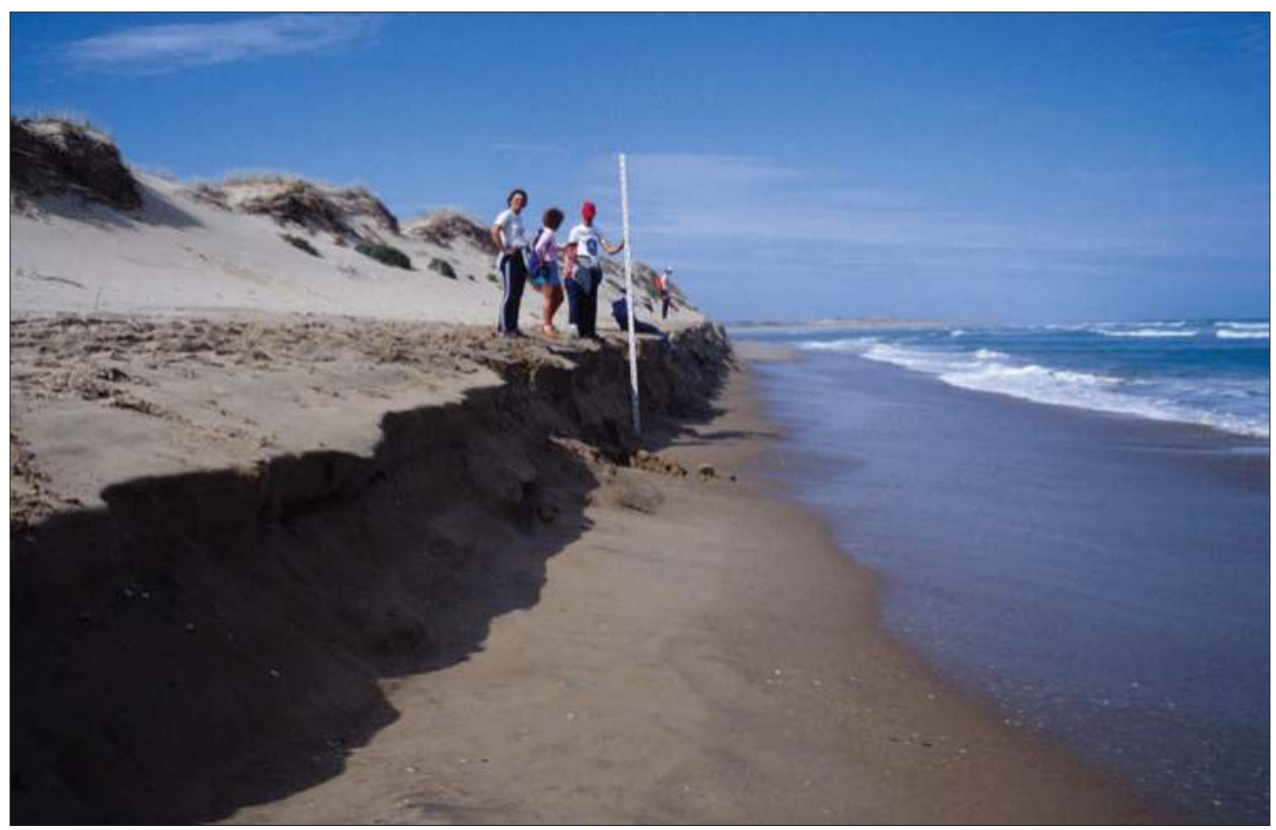

Figure 4.6 The same section of beach as in Figure 4.5 several years later, illustrating the build-up of a high-level beach by constructive waves and subsequent storm wave lowering of the beach profile by about $1 \mathrm{~m}$.

Source: Author's own work, RPB.

the northern part of the coast. These opposed sand drift directions help to explain the general position of the Murray Mouth as well as the huge accumulation of sand towards the northern extremity of Younghusband Peninsula. The average movement of sand along the Encounter Bay coast has been calculated at $260000 \mathrm{~m}^{3}$ per year for the period 1940-1990, but with a maximum potential westerly movement that exceeds 1 million $\mathrm{m}^{3} .^{21}$

Storm waves, usually driven by local westerly storm events, have a short wavelength with a wave period of 6 to 8 seconds; they can effect considerable erosion of the shoreline (Figures 4.5 and 4.6). For example, an overnight storm in March 1984 eroded a $100 \mathrm{~m}$ section of Sir Richard Peninsula back by some $14 \mathrm{~m}$, redistributing many thousands of tonnes of sand. Local storm-generated waves tend to move sediment towards the east on Sir Richard Peninsula. Sand-shifting winds also tend to move sand from the beaches into dunes from a southwesterly direction, a direction also indicated by migrating dunes. The Encounter Bay coastline is influenced by a microtidal regime of only $0.8 \mathrm{~m}$, although storm surges can increase the range up to more than $2 \mathrm{~m}$. 


\subsection{The modern coastal barriers of Sir Richard and Younghusband Peninsulas}

Sir Richard and Younghusband Peninsulas are sandy coastal barrier systems formed over the past 7000 years. During the Last Glacial Maximum some 21000 years ago, when sea level stood at least $125 \mathrm{~m}$ lower than today, desert-type red/yellow sand dunes trending east-west developed around and across the site of the present-day lakes and Hindmarsh Island, and on the exposed continental shelf. ${ }^{22}$ As sea level rose, unconsolidated sediments, including the desert dunes of the Last Glacial Maximum, were swept landwards across the exposed continental shelf. When sea level stabilised about 7000 years ago, the barriers, which evolved as aeolian dunes were deposited on shelly beach ridges and washover fans. In places, sand and shells are still being blown from the fronting beaches onto and across the landward-migrating dune systems. As the sandy barriers migrate landward they override former interdunal areas and backbarrier lagoonal sediments, which are sporadically exposed on the modern beach.

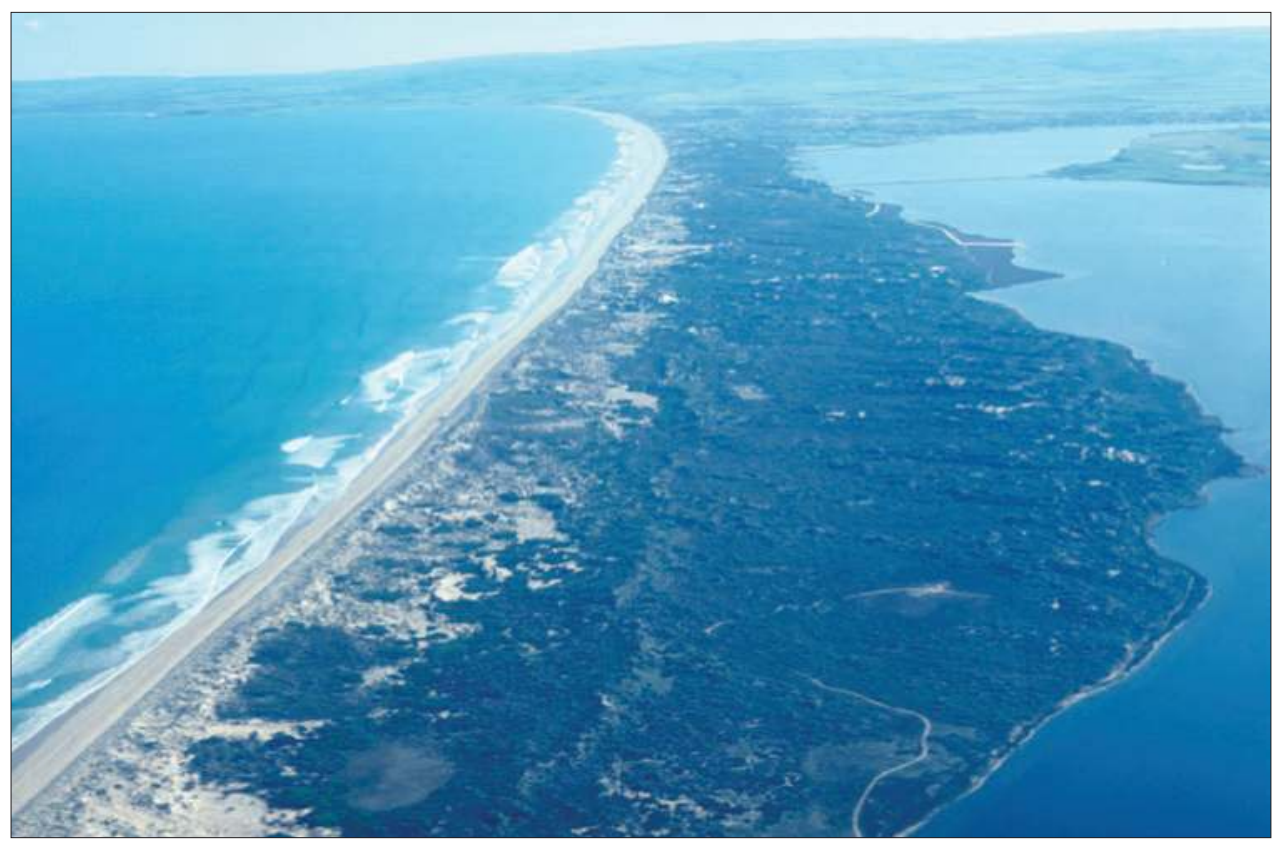

Figure 4.7 Oblique view of Sir Richard Peninsula from near the Murray Mouth towards Goolwa and the Goolwa barrage. Bare sand derived from the beach and foredune is migrating landward. An earlier frontal dune, now vegetated, is clearly visible in the lower central part of the peninsula, with fingers of dunes extending to the right of this dune.

Source: Author's own work, RPB. 


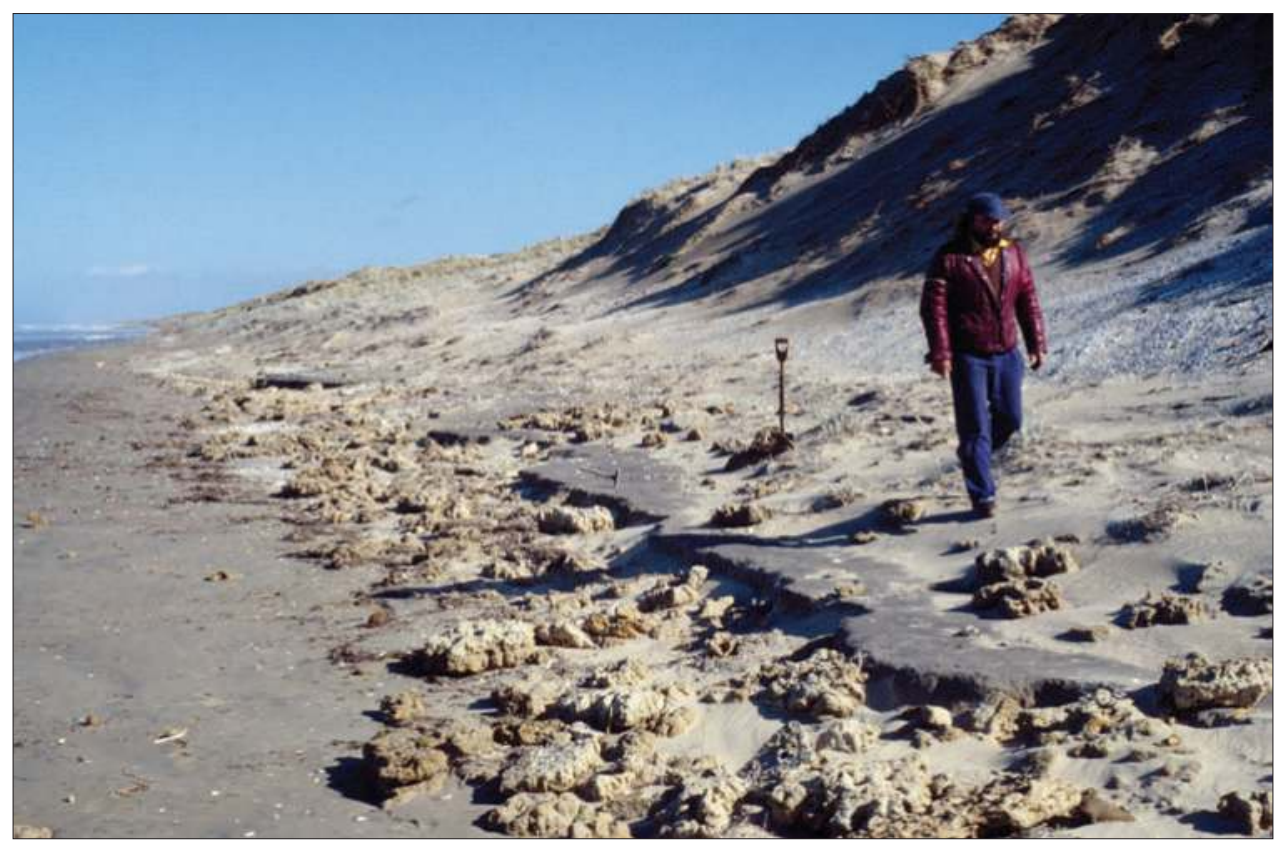

Figure 4.8 Interdune corridor sediments, now lithified and capped by a soil, originally formed well inland of the beach, but were exposed by wave erosion during shoreline transgression. Erosion of the shoreline is also indicated by the white-coloured midden shells (to the right of the figure), which were originally located on dunes well inland of the shoreline.

Source: Author's own work, NH.

Sir Richard Peninsula (Figure 4.7) is a coastal sand barrier $10 \mathrm{~km}$ long attached to the mainland at Goolwa, where it overlies calcreted aeolianite. Nearly all of the barrier consists of unconsolidated sand dunes that vary in elevation between 25 m near Goolwa and $10 \mathrm{~m}$ towards the Murray Mouth. The spit is widest in its central section $(1 \mathrm{~km})$, narrowing to $0.5 \mathrm{~km}$ at its extremities. The substrate on which the dunes of the barrier sit consists of former beaches marked by thin shell layers deposited by waves washing over the initial barrier into the backing lagoon. The ongoing landward migration of the barrier system and its erosion at the shoreline reveal occasional exposures of dark, organic-rich back-barrier lagoonal sediments and soils developed on former interdunal corridor sediments (Figure 4.8). These also form a foundation for parts of the barrier system. The age of the spit is variable, due to migration of the Murray Mouth and reworking of the coastal side of the barrier by storm waves. Several generations of dune activity are evident on the spit. Modern foredunes with occasional blowouts occur at the back of the beach. An older transverse dune with fingers of sand blowing out from the dune lies immediately inland of the frontal dune, while a second vegetated transverse dune, from which parabolic dunes extend, occurs farther inland. 


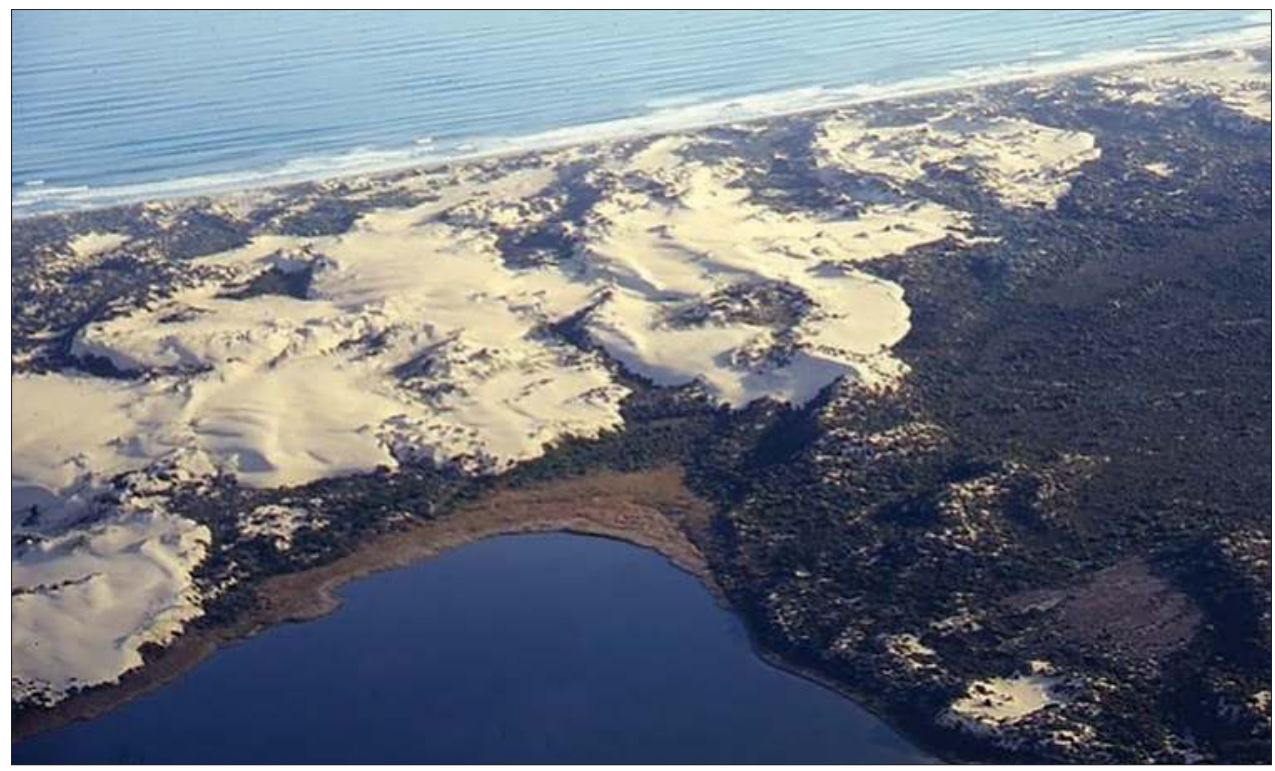

Figure 4.9 Transgressive sand dunes migrating over Younghusband Peninsula, burying dune and marsh vegetation, and clearly demonstrating the landward migration of this coastal barrier system. The weight of the sand causes the underlying muds to be depressed in some places and squeezed up in others.

Source: Author's own work, RPB.

Younghusband Peninsula differs from Sir Richard Peninsula in several respects. It is much larger than Sir Richard Peninsula, extending some $100 \mathrm{~km}$ to the southeast and containing much larger dunes. Far more of the sandy barrier rests on remnants of a consolidated aeolianite barrier about 80000 years old, which initially formed separate islands in its early history of formation. Fossil oyster shells on the landward side of the Coorong Lagoon indicate that some 6000 years ago Younghusband Peninsula was not a single landform feature, and that gaps to the open ocean existed. ${ }^{23}$ By 2000 to 3000 years ago, the separate islands were linked and overridden by more recent sand to develop the continuous barrier of the present day.

During his epic voyage around Australia in 1802, Matthew Flinders noted large areas of drifting sand on Younghusband Peninsula, revealing that some sand drift is a part of the natural system. A moderate degree of disturbance, which engenders renewal, is an essential part of a healthy and vibrant dune ecosystem. These active, semi-vegetated coastal barriers contain unique coastal flora, including specialised Spinifex (Spinifex sericeus) and Sand tussock species, adapted to episodic and ongoing sand mobilisation 
and deposition (Figure 4.9). Trapping sand and temporarily stabilising dunes, these plants produce environments to support other plants and nurture animals.

Following European occupation of the land, the grazing of cattle and sheep and the introduction of the rabbit on the coastal barriers accelerated sand drift across the barriers and into the back-barrier lagoons (Figure 4.10). More recent control of the exotic herbivores and the introduction of foreign plants have greatly inhibited sand drift. Today some introduced species, especially Marram grass (Ammophila arenaria), Pyp grass (Ehrharta villosa var. maxima) and Sea wheat-grass (Thinopyrum junceiforme), have been highly successful in restraining sand drift. Pyp grass, in particular, has been too effective as a drift inhibitor, reducing bare sand on Sir Richard Peninsula to $10 \%$ of its 1945 extent and effectively eradicating the sporadic sand drift, which is an important process in revitalising dune vegetation and producing a robust ecosystem. ${ }^{24}$ Pyp Grass out-competes native grasses as well as smothering larger shrubs and bushes, illustrating some of the detrimental impacts of alien species. As well as moving sand inland, wind occasionally moves considerable volumes of sand along the beaches parallel to the shoreline $^{25}$ (Figure 4.11).

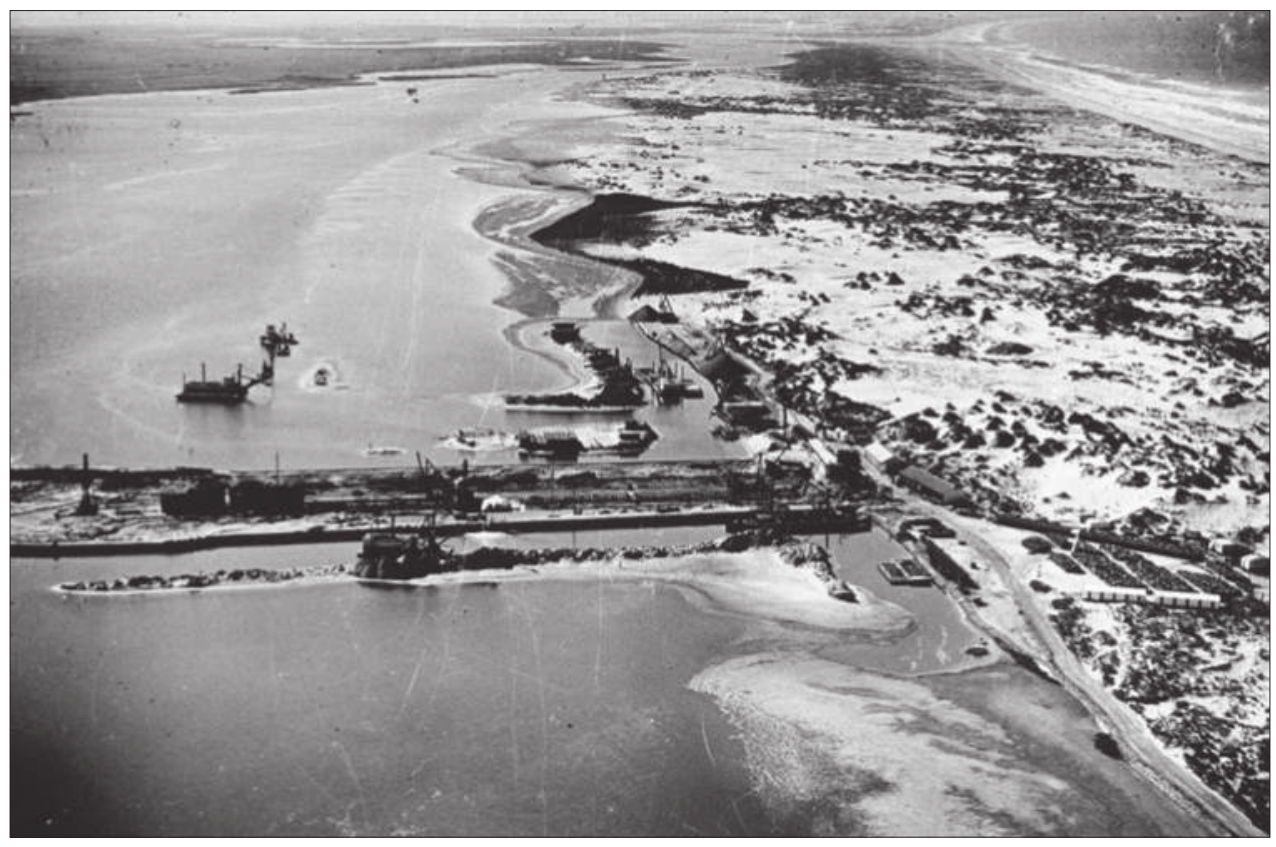

Figure 4.10 Sir Richard Peninsula during construction of the Goolwa Barrage in the 1930s. Large areas of drifting sand related to the effects of sheep, cattle and rabbits were infilling the Goolwa Channel. Compare with Figure 4.7.

Source: Courtesy of the State Library of South Australia. <www.s/sa.sa.gov.au>. 


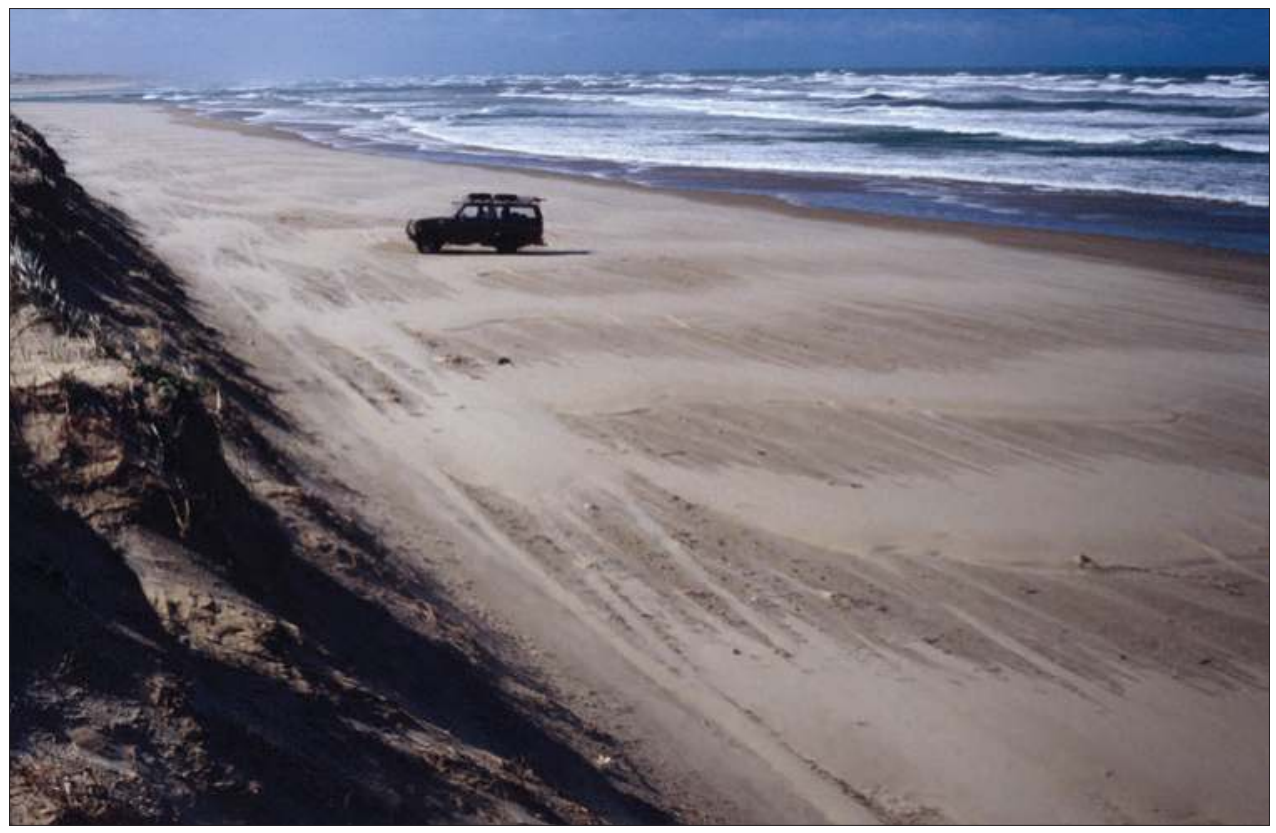

Figure 4.11 Ephemeral sand ridges on the ocean beach fronting Sir Richard Peninsula. These ridges were formed on 25 March 1984, when westerly winds up to $60 \mathrm{~km}$ per hour transported approximately 5000 tonnes of sand along the beach towards the Murray Mouth. Source: Author's own work, RPB.

\subsection{Hindmarsh Island sandflat}

Much of the southern half of Hindmarsh Island consists of an extensive sandflat ranging up to $2 \mathrm{~m}$ APSL (Figure 4.12). Marine shells within the sandflat sediments have a radiocarbon age of approximately 5000 years BP (Before Present), some 2000 years younger than the onset of barrier formation. How did marine-derived sediments form an extensive plain landward of the coastal barrier system, Sir Richard Peninsula? First, when the sandflat formed, relative sea level may have been up to $1 \mathrm{~m}$ higher than at present. ${ }^{26}$ Under these conditions, the Murray Mouth would have been much wider than today, even perhaps 1 to $2 \mathrm{~km}$ wide, so that active flood tides and wave action could transport large volumes of sand through it to construct the sandflat. The quiet water conditions landward of the developing barrier system would have favoured deposition of the sandflat. A network of natural spillways (Figure 4.12) criss-crosses the Hindmarsh Island mid-Holocene sandflat as distributary channels, effectively dispersing flood waters, as was clearly demonstrated during the 1956 flood. 


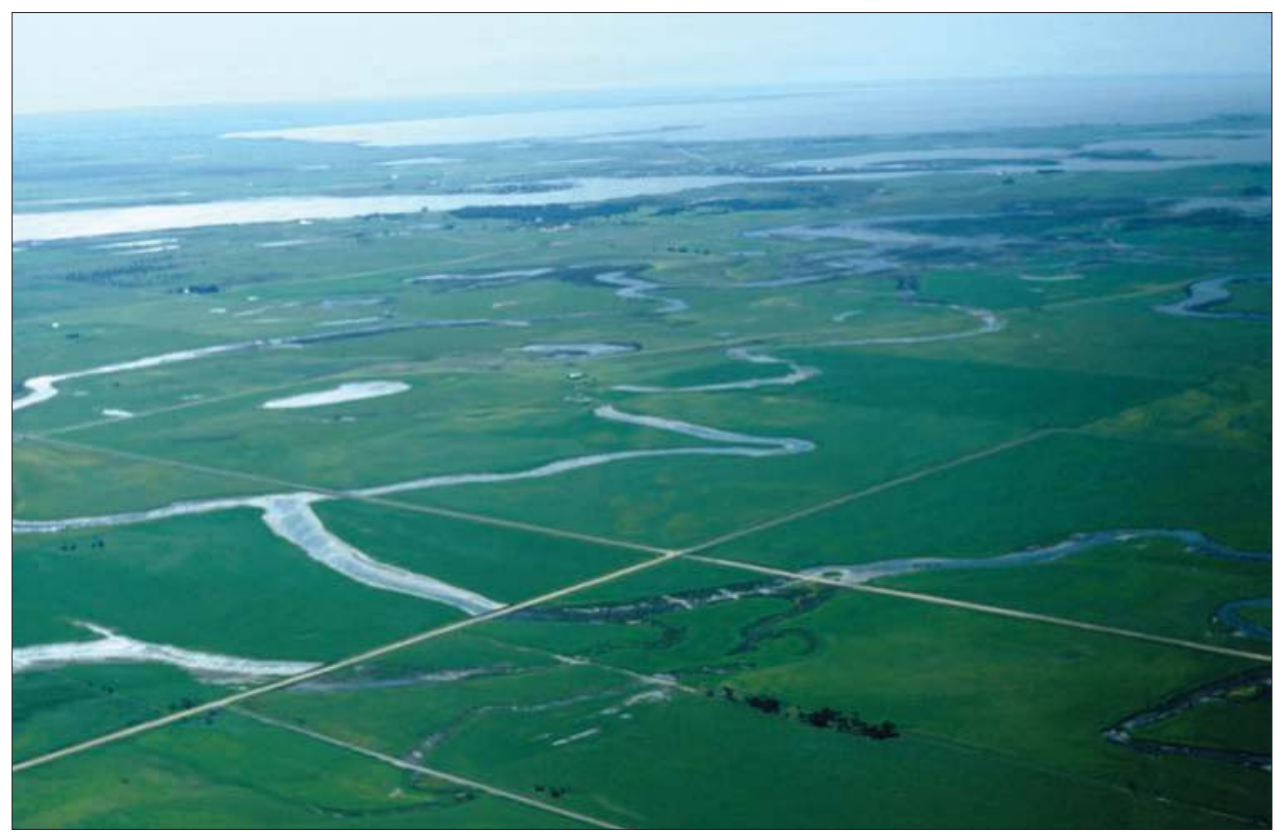

Figure 4.12 Part of the mid-Holocene sandflat, which is about $2 \mathrm{~m}$ high and forms the southern half of Hindmarsh Island. A network of distributary channels across the sandflat disperses floodwaters. Some of the channels are disrupted by roadworks.

Source: Author's own work, RPB.

\subsection{The Murray Estuary - present and future coastal changes}

A distinctive characteristic of the Murray Estuary coast is that it is an extremely dynamic environment: the coastline is eroding, the coastal sand barriers are migrating landward, new sand islands are forming and the shorelines of the former estuarine lakes are eroding.

\subsubsection{Coastal erosion}

The entire length of the Murray Estuary coast is eroding and migrating landward. Middleton Beach provides evidence of dramatic coastal changes over the past century, when the coastline eroded at least $200 \mathrm{~m}$ to form alluvial cliffs that back the present beach (Figures 4.13a and 4.13b). Early descriptions and photographs indicate that the Middleton coast was a broad sandy beach, up to $400 \mathrm{~m}$ wide, and backed by extensive sand dunes. ${ }^{27}$ Before 1900 , the beach was used extensively for gymkhanas and other events. The height of the cliff line decreases towards the east, indicating that 
the alluvium (Pooraka Formation) was derived from the Mount Lofty Ranges and deposited as an alluvial fan sloping away from the ranges. These alluvial sediments were deposited during the Last Interglacial (132 to $118 \mathrm{ka}$ ) under warmer, wetter conditions, when sea level was $2 \mathrm{~m}$ higher than at present.

What was the cause of this rapid coastal erosion? The vast majority of the world's sandy beaches are undergoing erosion, and this has been variably attributed to human interference, global (glacio-eustatic) rises in sea level, increased frequency and severity of storms, volumetric changes in the oceans due to temperature and salinity variations, and diminished sand supplies from either alongshore or offshore sources. ${ }^{28}$ Direct human interference at the Middleton coast can be discounted. Only minor removal of beach sediment by local residents has occurred, and no major engineering works have been undertaken. Furthermore, the weir and barrage system in the River Murray was completed after the onset of rapid erosion. The other factors mentioned would have impacted on coastal erosion along the whole coastline, but nowhere else is it as pronounced as at Middleton. At Tunkalilla Beach, about $40 \mathrm{~km}$ to the west, similar

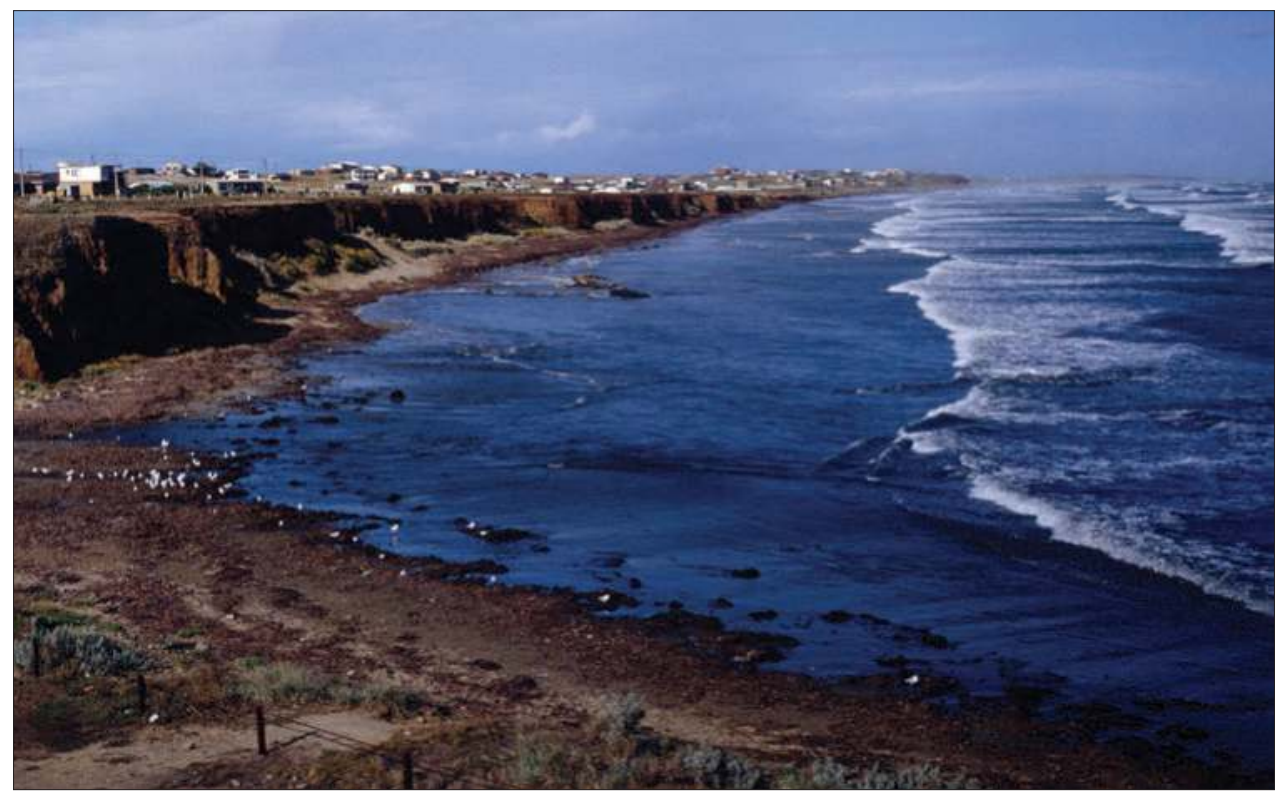

Figure 4.13a View in the 1970s of cliffs cut into Late Pleistocene alluvium at Middleton Beach on the western extremity of the Murray Basin. The shoreline has been eroded at least $200 \mathrm{~m}$ since 1900. The presence of shallowly buried resistant rocks of Middleton Sandstone in the swash zone helps to resist erosion.

Source: Author's own work, RPB. 


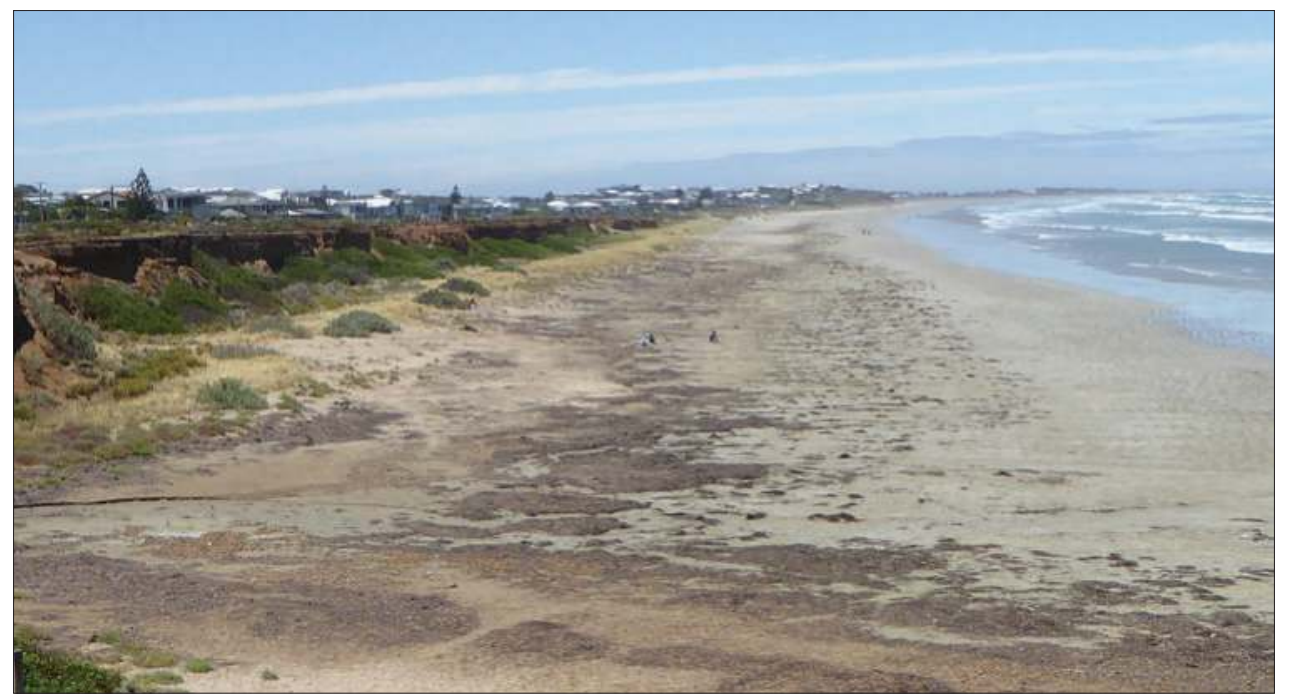

Figure 4.13b Middleton cliffs in 2016. Note that the cliffs are no longer actively eroding. Sand has accumulated at the base of the cliffs and has been vegetated, while a foredune has developed in front of the cliffs. The Middleton cliffs provide an excellent example of the initial rapid changes that follow a disturbance and the gradual reduction in the rate of change followed by the establishment of new equilibrium conditions. However, future tectonic subsidence, a rise in sea level or increased storminess could initiate renewed erosion of the vulnerable clay cliffs.

Source: Author's own work, RPB.

alluvial sediments form cliffs, but erosion is 10 times less than at Middleton. ${ }^{29} \mathrm{~A}$ local cause of the rapid erosion could be related to tectonic subsidence of the land. Several earthquakes occurred near the end of the nineteenth century, coincident with the onset of rapid erosion, and this may have upset the pre-existing equilibrium of the sandy shoreline. An historical seismic event, centred on Beachport and related to deep basement faulting, occurred on 10 May 1897, with a 'Felt Intensity' between 8 and 9 at the Murray Estuary. ${ }^{30}$ During this event, a large mass of aeolianite split and fell into the sea near Cape Jaffa, while calcreted aeolianite was deeply fractured near Mount Benson. ${ }^{31}$ Aftershocks continued for some months. Another earthquake (19 September 1902), with an epicentre at Warooka, Yorke Peninsula, affected the Murray Lakes region with a 'Felt Intensity' of 5. Goolwa residents reported a severe tremor at this time, and some of the buildings were badly cracked. ${ }^{32}$

Initially coastal erosion was very rapid, but the rate of erosion gradually slowed, and a new quasi-equilibrium has been reached, as indicated by the build-up and vegetation of sand dunes at the base of the cliffs. A housing development landward of the cliff line is protected by a buffer zone of about $45 \mathrm{~m}$, which seems reasonable in light of the present reduced erosion of the cliff line. However, future earthquakes, 
subsidence and sea level rise ${ }^{33}$ could activate a new phase of erosion. There is a longterm history of tectonic subsidence of this area, as indicated by shoreline deposits of the Last Interglacial (125 ka). Originally deposited when sea level was $2 \mathrm{~m} \mathrm{APSL}{ }^{34}$, these deposits are now $0.8 \mathrm{~m}$ BPSL at Goolwa, whereas at Victor Harbor they stand $6 \mathrm{~m} \mathrm{APSL}^{35}$, having been offset by faulting. Thus the western margin of the Murray Basin is subsiding relative to the uplifting Mount Lofty Ranges.

At Surfers Beach immediately east of Middleton, the cliffed coastline consists of aeolianite, a consolidated former coastal dune 100000 years old that formed when sea level was possibly as much as $12 \mathrm{~m}$ BPSL. Erosion of this former dune is providing sandy sediment for the modern beach. Further along the coast at Goolwa Beach, coastal erosion can be demonstrated by the erosion of European-built structures such as beach shelters and roads, originally surveyed to within $30 \mathrm{~m}$ of high water, but now occupying the subtidal zone. ${ }^{36}$ At Goolwa Beach, dark organic-rich sands are sporadically exposed. Microfossils in these sediments reveal that they were originally deposited in a lagoon landward of the coastal dune but were gradually exposed on the modern beach by coastal erosion and shoreline retreat. ${ }^{37}$

\subsubsection{Migration of the Murray Mouth}

Since its position was first surveyed in 1839, the Murray Mouth (Figure 4.16) has migrated over a range of at least $1.6 \mathrm{~km}$ (Figures $4.15 \mathrm{a}$ and $4.15 \mathrm{~b})^{38}$, reflecting the impacts of river flows, tidal fluxes, wave action and storms on the unconsolidated sandy coastal sediments. ${ }^{39}$ In pre-historic times, mouth migration has been even more extreme, perhaps as much as $7 \mathrm{~km}$ in 3000 years. Aboriginal middens only occur on the western half of Sir Richard Peninsula (Figure 4.16), suggesting that mouth migration towards the west partly destroyed the barrier, which later reformed as the mouth migrated back to the east. ${ }^{40}$ End points of migration are marked by abandoned flood tidal deltas at Mulloway Point on Mundoo Island and Swan Point on Hindmarsh Island (Figures 4.16 and 4.17). $A$ jumbled mass of sand dunes up to 4000 years old fringes much of the south coast of Hindmarsh Island. The dunes formed from coastal sands delivered through the river mouth during mouth migrations.

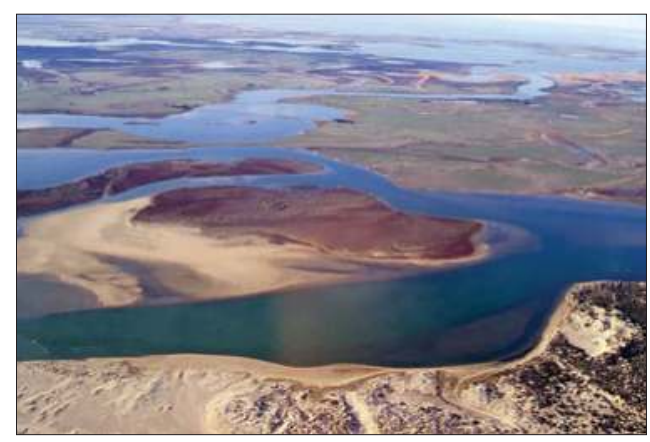

Figure 4.14 Oblique aerial view, showing washover channels on the northern tip of Younghusband Peninsula. Other features include Bird island, the Mundoo Channel, Hindmarsh Island, Mundoo Island and Lake Alexandrina in the far distance.

Source: Author's own work, RPB. 

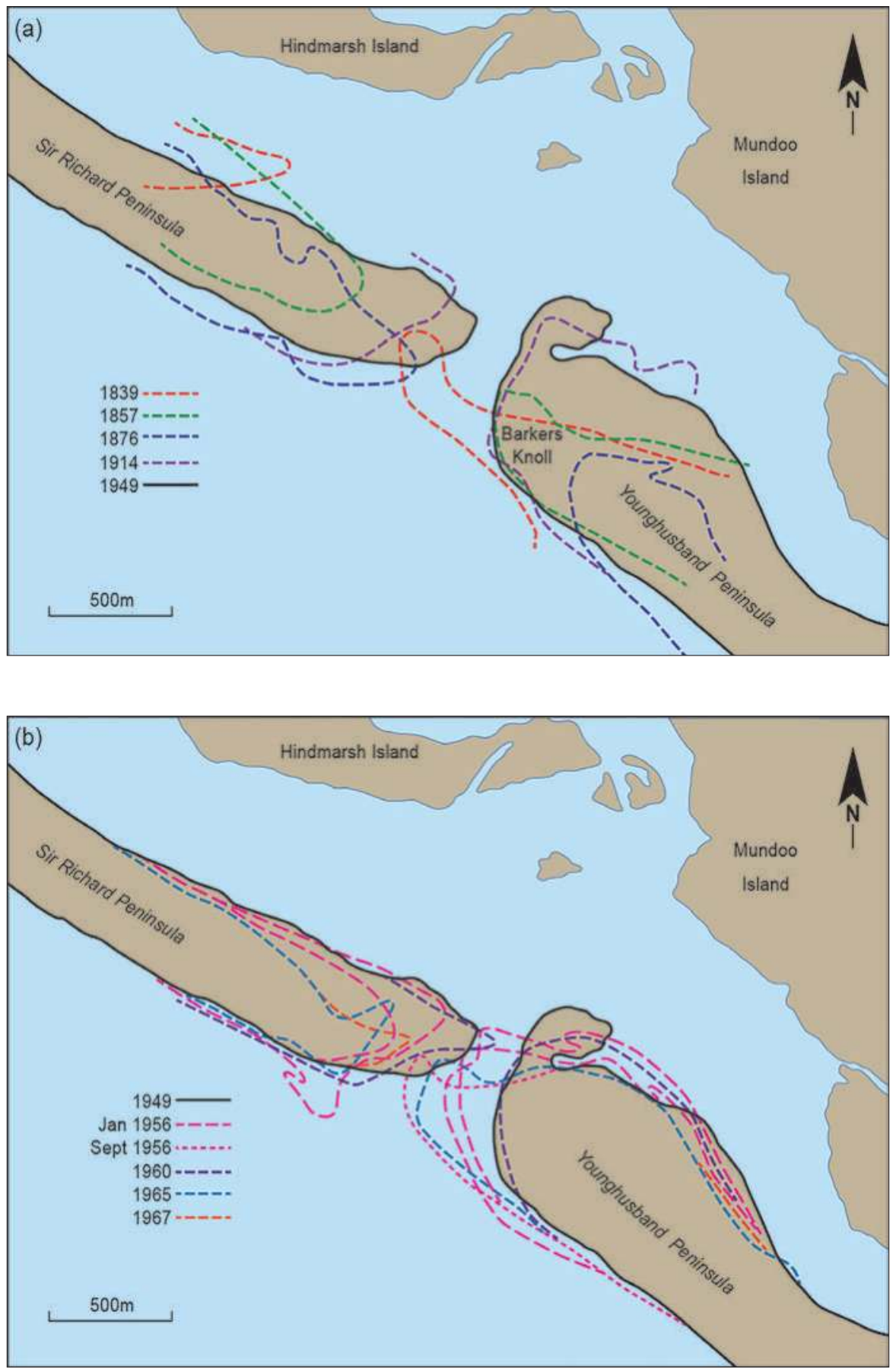

Figures 4.15a and 4.15b The migration of the Murray Mouth between 1839 and 1967. Source: Thomson, R.M. (1973). The geomorphology of the Murray Valley in South Australia. MA Thesis, The University of Adelaide. Reproduced with permission of the author. 


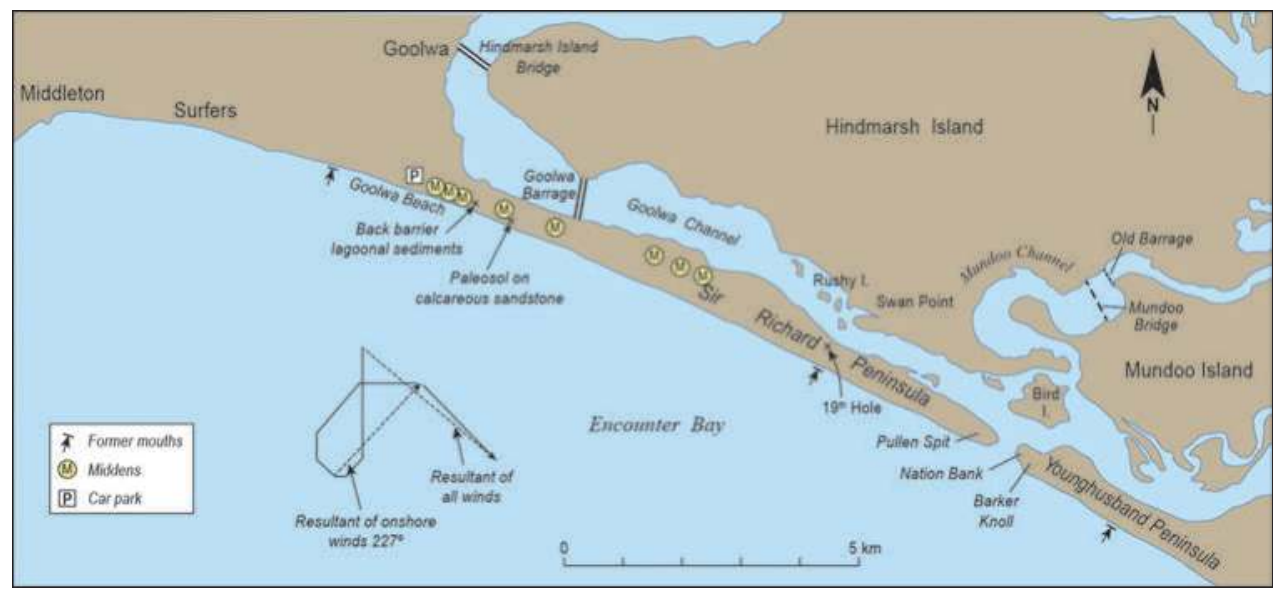

Figure 4.16 Extreme points of migration of the Murray Mouth are marked by abandoned flood tidal deltas at Mulloway Point on Mundoo Island and Swan Point on Hindmarsh Island. Aboriginal middens (M) only occur on the western half of Sir Richard Peninsula, supporting the view that the eastern end of the peninsula has been more recently reformed after initial mouth migration to the west. The resultant of all sand-shifting onshore winds indicates the dominant direction of sand drift across the peninsula.

Source: Bourman, R.P. \& Murray-Wallace, C.V. (1991). Holocene evolution of a sand spit at the mouth of a large river system: Sir Richard Peninsula and its significance for management of the Murray Mouth, South Australia. Zeitschrift für Geomorphologie, 81, 63-83.

After artificial opening of the mouth in 1981, major mouth migration was towards the west, but this trend was reversed following clearance by dredging when the mouth began migrating back towards the east in about 2005. This trend continues.

\subsubsection{Impacts of river and estuary regulation}

The River Murray and its major tributaries, the Murrumbidgee and Darling Rivers, form the world's fourth-longest river system at $5300 \mathrm{~km}$. This drainage basin has been transformed into a highly regulated river system by construction of dams, weirs and barrages (Figures 4.18 and 4.19). A low-gradient stream system with variable flows has been replaced by a

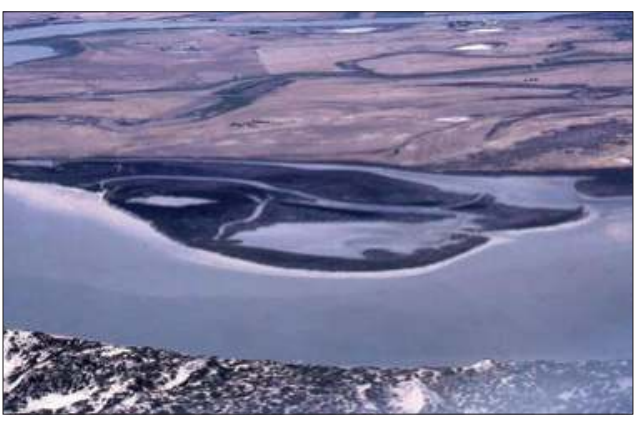

Figure 4.17 Abandoned flood tidal delta sediments at the southern extremity of Mundoo Island (Mulloway Point), marking a former position of the Murray Mouth through Younghusband Peninsula.

Source: Author's own work, RPB. 
series of long, narrow lakes with near-constant elevated water levels. ${ }^{41}$ While Lakes Alexandrina and Albert have been dominantly fresh for thousands of years ${ }^{42}$, the lower parts of the Murray Estuary, originally characterised by mixing of fresh and salt water, have now also been turned into permanent freshwater lakes.

Completed by 1940 , the locks upstream and the barrages near the coast were constructed to improve conditions for navigation, assure water supplies for irrigation and reduce salinity levels in the terminal lakes ${ }^{43}$ after large volumes of fresh water had been extracted from the system. These aims were initially achieved, and the current freshwater lakes of the estuary most closely represent the original dominantly freshwater pre-European environment. ${ }^{44}$ However, there have been detrimental impacts related to the regulatory structures and their management. ${ }^{45}$ Past management has been largely directed towards maintaining water levels for irrigation and navigation. However, in the future it is hoped that more sensitive operation of an automated barrage system will more closely simulate the natural environment, improve the ecology of the estuary and facilitate migration of estuarine-dependent fish through the barrage system. Fishways have now been constructed at many of the weirs and barrages.

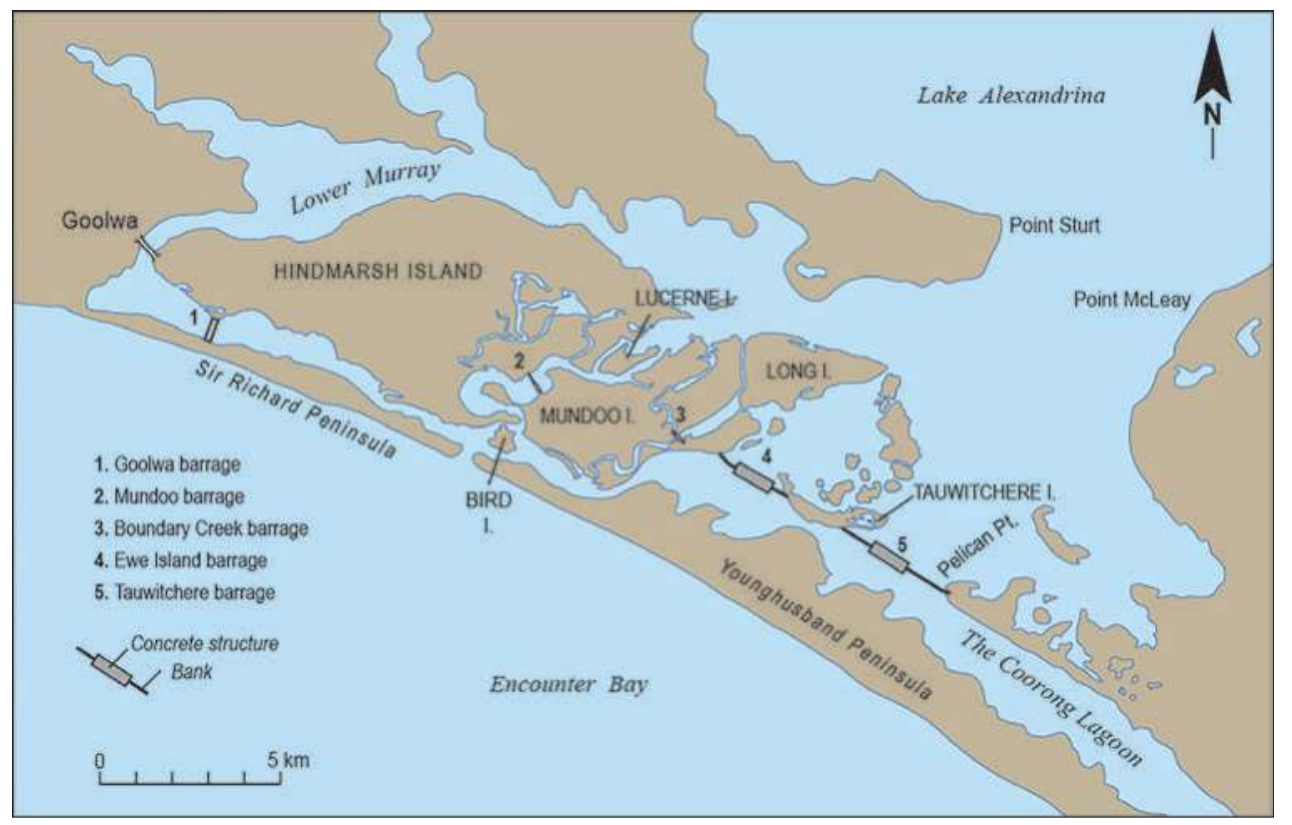

Figure 4.18 Map of barrages across the Lower Murray lake system.

Source: Bourman \& Murray-Wallace (1991). 


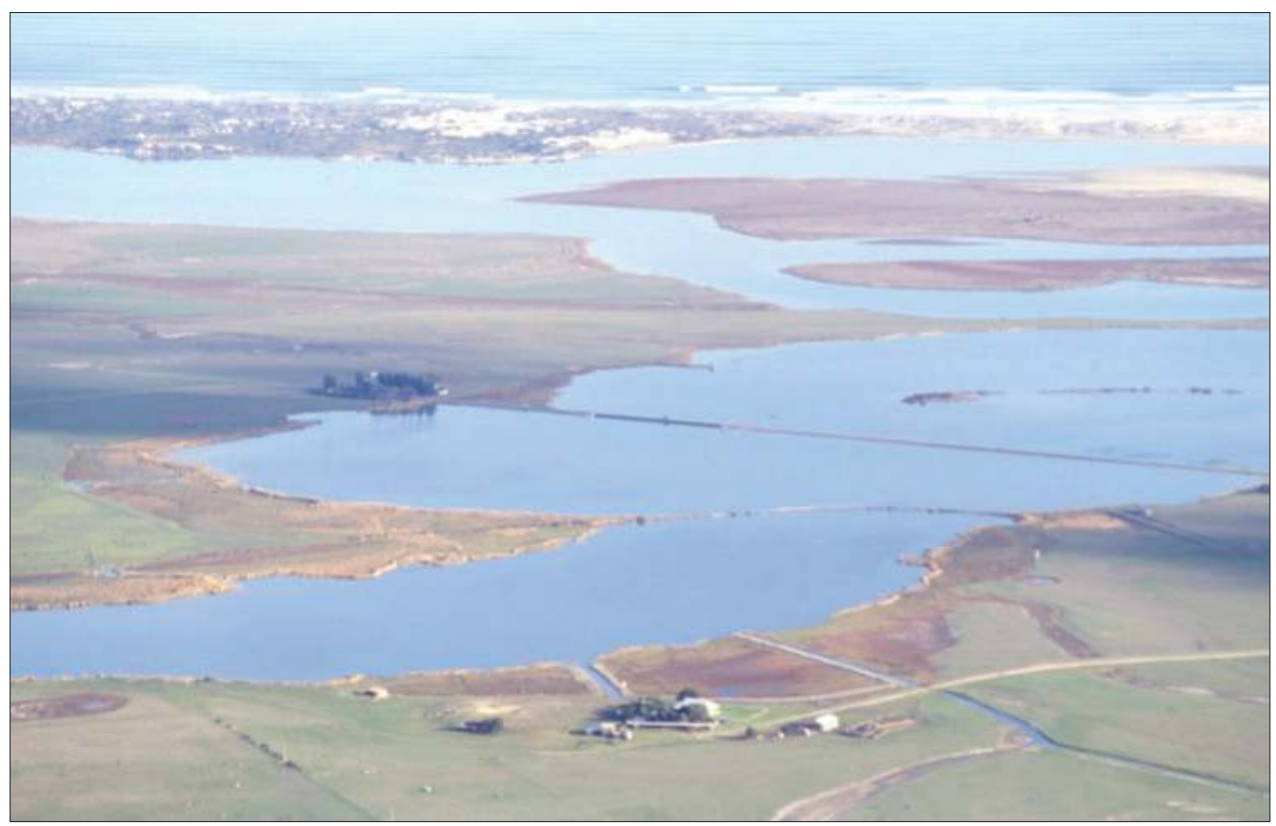

Figure 4.19 View across the Mundoo Channel, Mundoo Barrage and Bird Island to Younghusband Peninsula and the ocean. Only a small portion of Mundoo Barrage has operable gates to allow flows through, the remainder being a causeway. An early wooden curved barrage structure, built in 1915, is also visible.

Source: Author's own work, RPB.

\subsubsection{Barrages}

Five barrages and intervening causeways more than $10 \mathrm{~km}$ in length were built across the Lower Murray Lakes (Figures 4.16, 4.18 and 4.19) from Goolwa in the north to Pelican Point in the south. The causeways were originally designed to act as spillways during flood events. All barrages, except the Goolwa Barrage, were constructed across shallow channels cut into 'limestone reefs'. These reefs are now known to be the hardened beach sediments of the last interglacial shoreline, which trends parallel with the present-day shoreline but 2 to $3 \mathrm{~km}$ inland. The main channel of the Lower Murray is the giant elbow of the Goolwa Channel, which during maximum flows discharges up to $70 \%$ of the flow. This was also the case for many thousands of years, even when sea level was $125 \mathrm{~m}$ BPSL, $21 \mathrm{ka}$ ago, at which time the channel was at least $20 \mathrm{~m}$ deep. Now largely filled with fine sand and silt, the Goolwa Barrage required timber piles $19 \mathrm{~m}$ long to be driven into the unconsolidated sediments in order to provide its footings.

Two major impacts accompanied building of the regulatory structures. First, water abstraction for agriculture, industry and town use reduced the outflow of water to the sea 
by about $75 \%$. Second, the flow of tidal water through the mouth diminished by about $90 \%$. Both of these factors led to dramatic changes at the coast. Management of the artificial system exacerbated these changes. Even though the Mundoo Channel carried only $10 \%$ of the river's maximum flow, it provided the shortest and steepest channel to the sea, with considerable potential to clear sand shoals at the Murray Mouth. However, because the Mundoo Barrage is used as a bridge and was extremely cumbersome to operate, it was rarely opened over a 70-year period. This favoured the build-up of sediments upstream of the barrage and flood tidal deltaic sediments immediately inland of the mouth, where a large sand island, Bird Island, has formed (Figure 4.14). Mundoo Barrage now has some automated gate openings, but they are unlikely to correct decades of shoaling.

\subsubsection{Bird Island}

Bird Island is a sand island $1 \mathrm{~km}$ in diameter, situated in the back-barrier lagoon immediately inland from the Murray Mouth (Figure 4.20). Sand dunes on the island

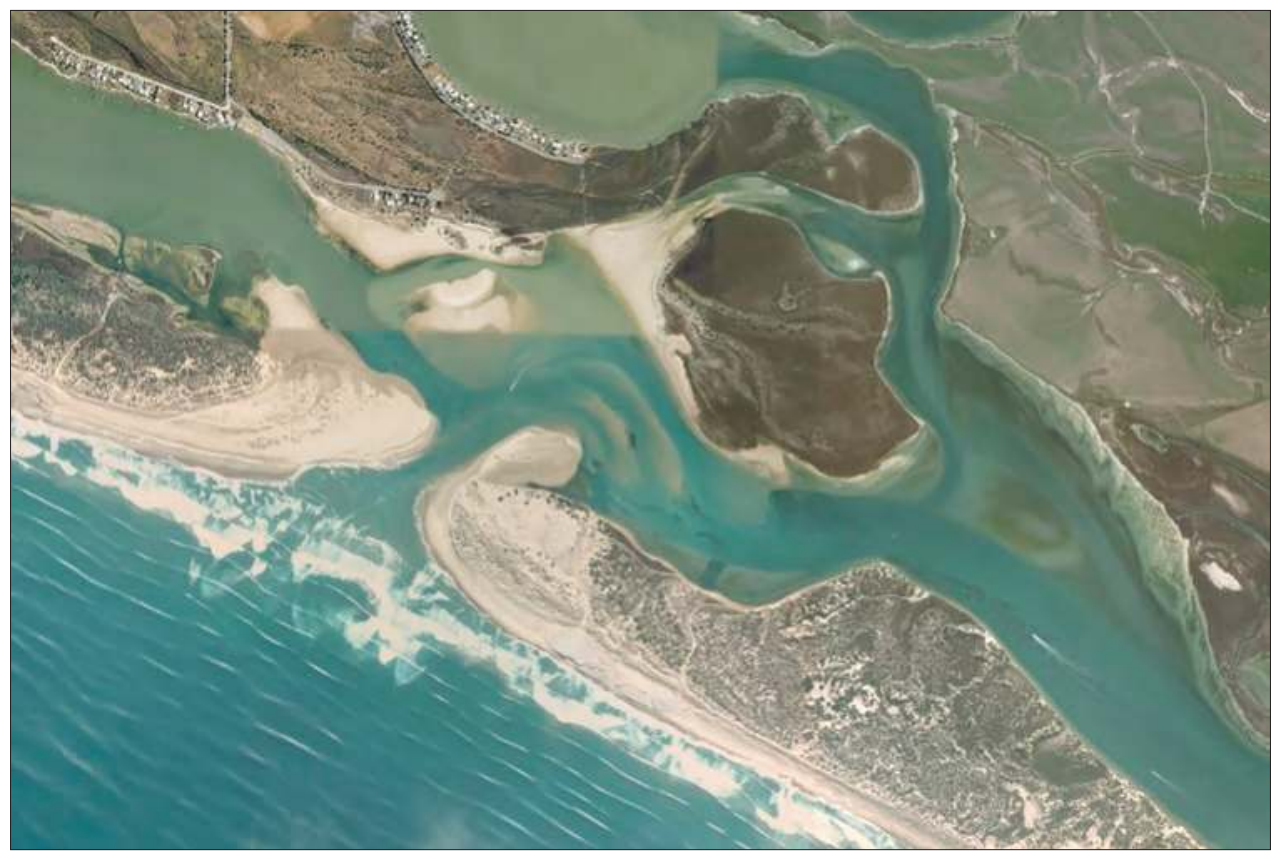

Figure 4.20 Aerial view of the Murray Mouth in 2014, showing the major features of Bird Island and plumes of flood tidal sediments. Dredging was undertaken to prevent closure of the mouth. Spoil heaps from the dredging occur on the beach either side of the mouth and show as slightly darker patches.

Source: Google Earth image @ 2014 Google. 


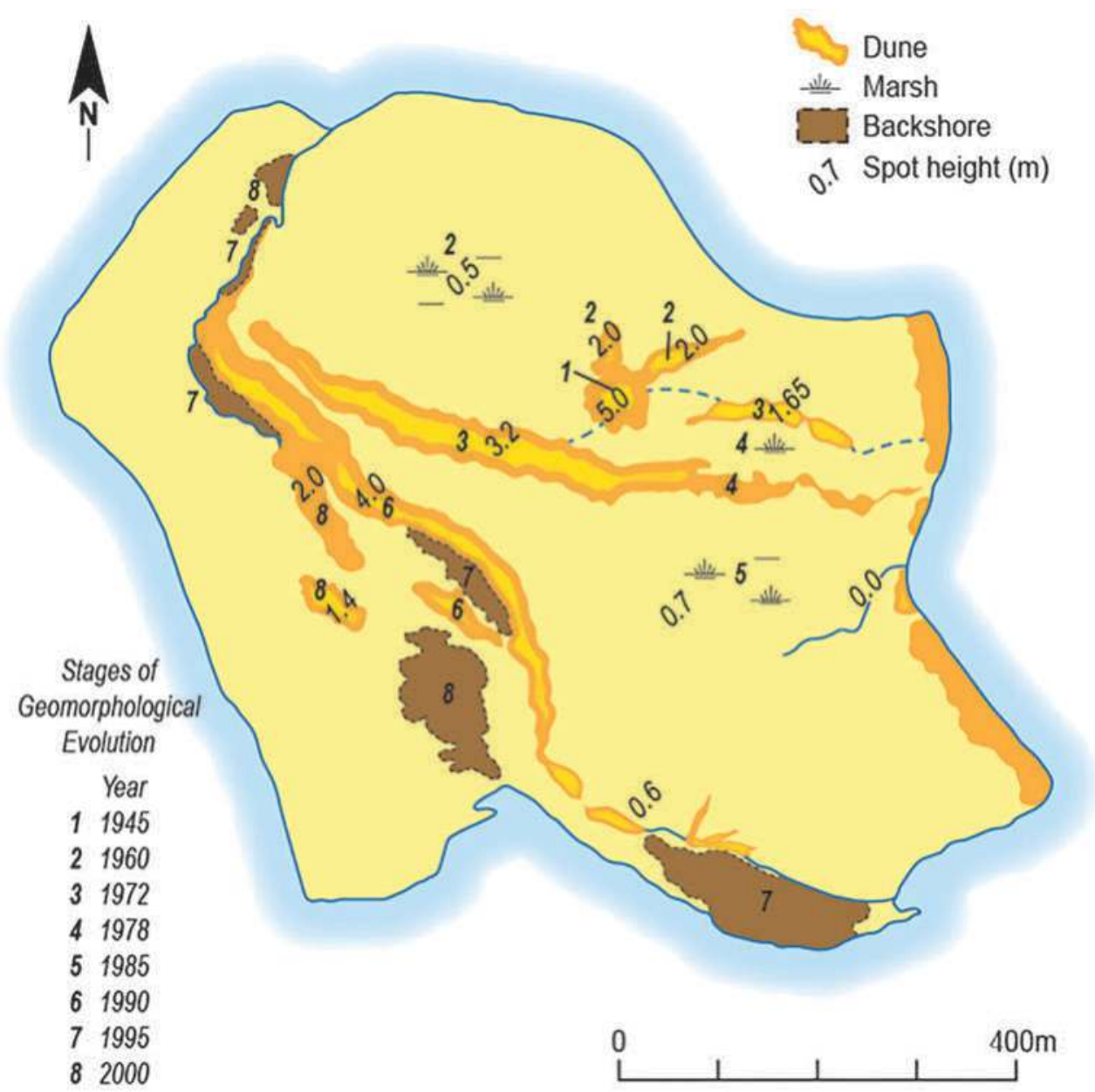

Figure 4.21 Evolution of Bird Island from 1940 (1) to the present (8), sourced from aerial photographs.

Source: James, K.F., Bourman, R.P. \& Harvey, N. (2015). Rapid evolution of a flood tidal deltaic island in the River Murray Estuary, South Australia: A canary in the cage of river management. Journal of Coastal Research, 31, 1103-1119.

vary in elevation between 1 and $5 \mathrm{~m}$ APSL and, for all but a bare frontal sandflat, the island is covered with some 80 species of salt marsh and dune vegetation. ${ }^{46}$ The growth of the island is further restricting tidal movements and enhancing sediment accumulation that, without dredging, would lead to permanent blockage of the mouth and attachment to Hindmarsh Island. Over recent years, dredging has maintained the ocean-lagoon channel-ways, thereby limiting sediment availability for further island growth. 
Before river regulation, Bird Island did not exist, but shoals of a flood tidal delta formed inside the migrating Murray Mouth as coastal sand was carried through the mouth by waves and flood tides. These shoals were perpetually reworked by ebb tides and river flows, which returned sediment to the sea and inhibited stabilisation with vegetation. High-energy wave action at the coast prevented the formation of an ebb tidal delta; sandy sediments were rapidly incorporated into offshore bars. Tidal flows could maintain the mouth, especially when ebb tides were accompanied by strong northerly winds that pushed lake water through the mouth ${ }^{47}$, while substantial freshwater flows were essential to prevent the mouth from permanently closing.

This dynamic system was transformed by barrage construction of the 1930s, which reduced the tidal flow through the mouth by up to $90 \%$. Increasing amounts of fresh water $(75 \%)$ were diverted from the river, further aggravating the situation, so that by the mid-1950s lobes of the flood tidal delta were becoming more permanent, allowing colonisation by vegetation. Surrounded by bare sand, a circular dune initially formed around a small patch of vegetation, which became the core of Bird Island. Wing-like dunes attached to the central dune developed, and their migration was blocked by samphire (salt marsh) vegetation, which colonised the northern half of the island. A combination of salt marsh expansion and sand supply sourced from bare flood tidal shoals, delivered through the mouth, led to the progressive growth of sand dunes at the salt marsh margins. Since the early 1970s, the mouth has migrated towards the northwest, changing the position of the bare, tidally derived sandflats, the source of dune sand. Consequently, successive dunes, now fixed in place by vegetation, display a varying clockwise orientation, coincident with the migration of the mouth and the growth of salt marsh (Figure 4.21). ${ }^{48}$ The evolution of Bird Island reveals a close association between geological processes and vegetation colonisation. Vegetation influenced the locations of landforms on the island and later preserved them.

\subsubsection{Mouth closure}

If it were not for the River Murray, Sir Richard and Younghusband Peninsulas would form a continuous sand barrier separating the back-barrier lagoons from the ocean. The mouth has formed by fluvial breaching of the barrier, although it may be maintained for some periods of no flow by tidal flushing, given appropriate weather conditions.

In pre-regulation times, mouth closures may have occurred during prolonged droughts. However, in the century following the first survey of the mouth in 1839 , there is no evidence of closure. ${ }^{49}$ Between 1940 and 1980, there were some anecdotal accounts of possible closure or near-closure, and in 1973 vehicles could be driven onto Bird Island from the tip of Sir Richard Peninsula, although the channel through the mouth to the Coorong remained open. ${ }^{50}$ In 1981, a complete blockage of the mouth occurred as a large flood tidal delta formed in response to low river flows, reduced 


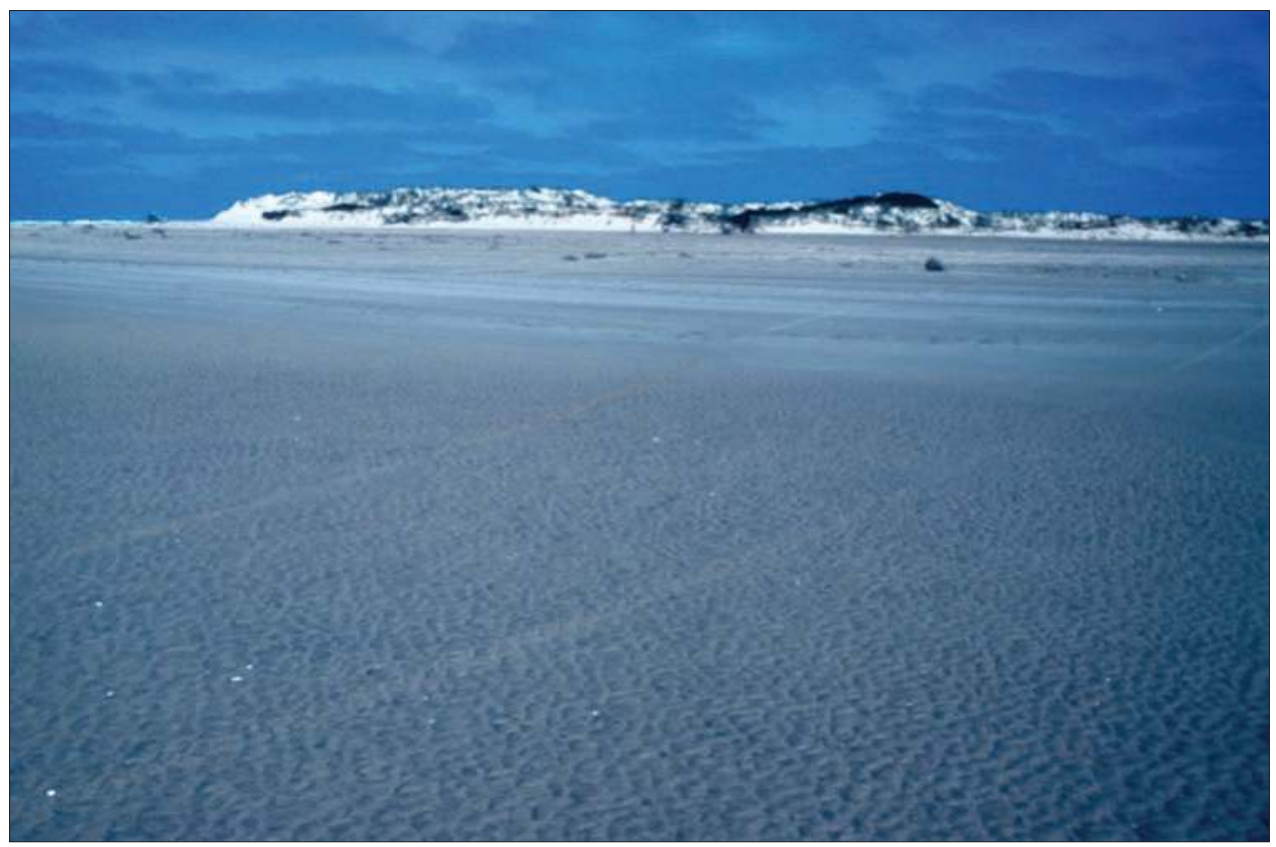

Figure 4.22 Site of the Murray Mouth in 1981 when it was completely blocked. View from inland towards Sir Richard Peninsula.

Source: Author's own work, RPB.

high tides and calm weather conditions (Figure 4.22). Diminishing tidal exchanges commonly precede mouth closure. Eventually the sand bar across the former mouth position grew to $1.72 \mathrm{~m}$ APSL, as sand was pushed landward by wave overwash and sand drift. ${ }^{51}$ Up to 1 million tonnes of sand a year were transported along the shore by persistent moderate- to high-energy wave action, contributing to the closure. A shallow but temporary channel was cut through from the ocean to the back-barrier lagoon during a storm surge event, but the channel was short-lived. By the time that large river flows were approaching the mouth, the danger was that the sand bar would raise water levels higher than the greatest known flood of 1956, thereby providing a stimulus to cut an artificial channel to the sea. Channels were excavated through the sand bar, successfully reopening the mouth on 15 July 1981, with strong flows severely eroding the landward side of Sir Richard Peninsula.

A further and potentially more severe closure of the Murray Mouth was thwarted in 2001 by the use of two dredges clearing the areas from the mouth to the Coorong Lagoon and Goolwa Channel. Sediment dredged from the flood tidal delta was discharged at the coast either side of the Murray Mouth. Eventually these dumped 
sediments will be reincorporated into the coastal system by longshore drift and mouth migration. Discharging the dredged material on the spits landward of the shore may have been a better option, by lengthening the storage time of the sediments before they are reincorporated into the flood tidal deposits. Throughout the 2002-2010 drought, the mouth was artificially cleared by dredging, improving water quality in the backbarrier lagoons; later, the mouth was flushed by strong river flows, which are essential for mouth maintenance as well as for evacuation of accumulated salt.

Since it was first surveyed in $1839^{52}$, there is no account of mouth closure until $1981^{53}$, and there is minimal evidence of protracted mouth restrictions in the past 3000 years. ${ }^{54}$ The 1956 flood, the largest in European times, produced a flow of 341000 megalitres/day (giving a return interval of about 170 years). ${ }^{55}$ Although it substantially cleared the mouth, the central dune of the embryonic Bird Island survived. There is evidence of flooding greater than the 1956 flood: a flood 3000 years ago was slightly higher than the 1956 event, and there were several similar floods over the past 2500 years. However, the largest flood known is that of about 1760, which had a discharge of 664000 megalitres/day, almost twice the volume of the 1956 flood, with a return interval of about 1000 years. ${ }^{56}$ Such floods would have had large impacts on the mouth area.

Today, because of upstream water extractions, the Murray Mouth, once a riverdominated feature, has become a site of accumulation of coastal sediments where a migrating flood tidal delta has been transformed into a permanent and vegetated Bird Island. The situation was exacerbated by low flows due to drought. Of the flows recorded since 1879, the lowest 25 flows were almost all in the first decade of the twenty-first century, coinciding with the dredging period (2002-2010). From June 2000 to May 2003, it was estimated that sand movement into the Murray Mouth was approximately $100000 \mathrm{~m}^{3}$ per year, an amount compatible with the known rates of littoral drift. ${ }^{57}$ Dredging of the mouth occurred from October 2002 until December 2010, with more than 6 million $\mathrm{m}^{3}$ of sediment removed from the mouth area at a cost of almost $\$ 40$ million by July $2010 .{ }^{58}$ After substantial freshwater flows, dredging stopped for a few years but it was reinstated and was still operating in 2016.

\subsubsection{Lakes Alexandrina and Albert}

The River Murray does not form a classic river delta at the coastline; the terminus of the river has, in fact, been described as a failed delta. ${ }^{59}$ Entering the settling basins of Lakes Alexandrina and Albert some $40 \mathrm{~km}$ from the coast, the river has deposited silt jetties parallel to the main channel to form a digitate delta. Similar deltas occur in the lower reaches of Currency Creek and the Finniss River (Figure 4.23).

Lake Alexandrina has a greatest length of $35 \mathrm{~km}$ and width of $24 \mathrm{~km}$, with a maximum water depth of $4.5 \mathrm{~m}$, while Lake Albert is $16 \mathrm{~km}$ long and 8 to $13 \mathrm{~km}$ wide, 
with a maximum water depth of only $2.5 \mathrm{~m}$ (mainly less than $1.8 \mathrm{~m}$ deep). Evaporation losses from these broad and shallow lakes are pronounced, accounting for half of South Australia's annual water allocation of 1850 gigalitres (1 gigalitre equals one billion litres). Lake Albert has no direct outflow to the sea, but is linked to Lake Alexandrina by a channel, 'The Narrows', near Narrung. This causes an ongoing build-up of salinity in Lake Albert. Occasionally, water levels in Lake Alexandrina are lowered sufficiently to drain water from Lake Albert, but this allows saline groundwater to enter the lake. Land clearance in the Murray Basin has caused groundwaters to rise, bringing towards the surface salts that had formerly been stored well below the subsoil. In the past, Lake Albert may have had a southern outlet into the Coorong Lagoon ${ }^{60}$, and at various times plans have been proposed to dig a channel to drain accumulated lake salts into the Coorong. However, the flow gradients may not be sufficient to ensure that the procedure would be successful.

Drought conditions and overallocation of water upstream have had some dramatic impacts on the lower lakes in the first decade of the twenty-first century. Dominantly held at $0.75 \mathrm{~m}$ AHD (Australian Height Datum, an approximation of mean sea level), the lakes dropped almost $1 \mathrm{~m}$ below sea level, exposing acid sulphate soils. Through evaporation and seepage, the waters became increasingly saline, impacting on freshwater flora and fauna. Temporary flow regulators were constructed across major channels and water was pumped into these holding basins to help protect threatened areas. Fortunately, heavy rains in the catchment produced strong and persistent flows, which have rectified the situation to some extent, leading to the removal of the socalled regulators.

\subsubsection{Lake shoreline erosion}

Accelerated lake shoreline erosion has been a consequence of barrage construction and artificial elevation of lake water levels. Lake levels were artificially increased to $0.75 \mathrm{~m}$ AHD and maintained for as long as possible, thereby reducing the natural variability of lake shoreline levels and juxtaposing lake levels with easily eroded sandy deposits. Shoreline erosion on Lakes Alexandrina and Albert averaged $1 \mathrm{~m}$ per year, up to 1992 , with a maximum rate of 10 m per year, costing millions of dollars in land and production losses, as well as destroying wildlife habitats and increasing salinity, turbidity and nutrient levels. ${ }^{61}$

Erosion varies with the nature of the sediments at the shoreline and the prevailing waves and winds. ${ }^{62}$ Four major geological/soil settings occur around the lake margins: soils associated with calcrete-capped aeolianite undergo little erosion; Black Swamp and Border Association Soils have only a moderate erosion potential; but thin clay soils overlying sandy subsoils are readily eroded. Prolonged winds with squalls up 


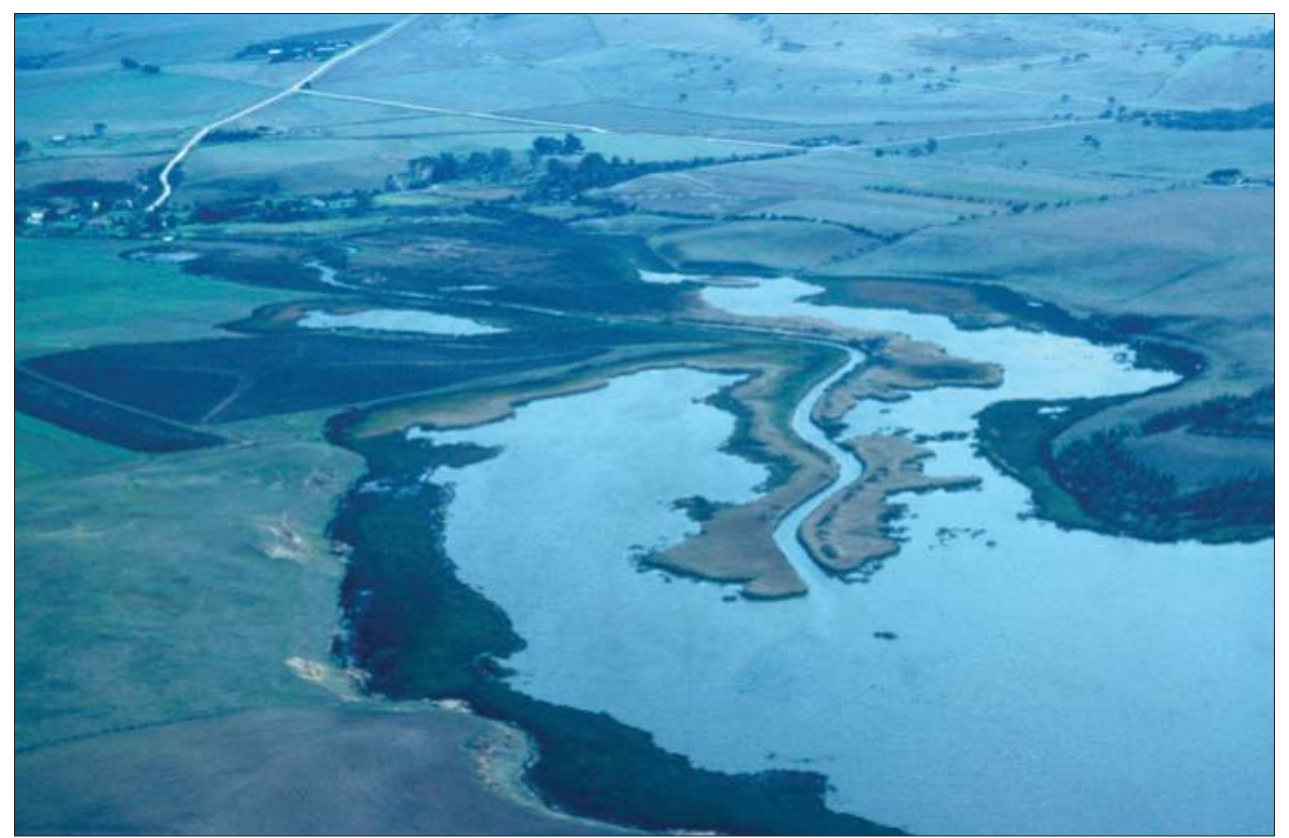

Figure 4.23 Digitate delta of Currency Creek, where it enters the waters of the Lower Murray Lakes.

Source: Author's own work, RPB.

to $50 \mathrm{~km}$ per hour approaching dominantly from the south to the west maximise erosion damage on the northern and eastern shores. A strong, prolonged wind blowing over a large expanse of water can cause a lake set-up effect, increasing water levels on one side of the lake by up to $1.1 \mathrm{~m} .{ }^{63}$ Although the maximum wave height is only $1 \mathrm{~m}$, these waves can cause considerable damage to the shoreline: single extreme weather events have caused shoreline retreat of up to $2 \mathrm{~m}$.

Land management practices have also impacted on shoreline stability. Pasture grasses have replaced shoreline-stabilising native plants such as salt marsh vegetation, lignum and paperbarks, while uncontrolled grazing of the foreshore by livestock has sometimes destabilised the shoreline. Stock exclusion to foster colonisation by rushes and reeds has proved effective in sheltered areas, whereas engineering works are required to stabilise exposed, rapidly eroding shorelines. Mantling the shores with tyre walls (Figure 4.24), rock walls, breakwaters and groynes has had various degrees of success in restricting shoreline retreat. Overall, the rates of shoreline retreat appear to be decreasing. 


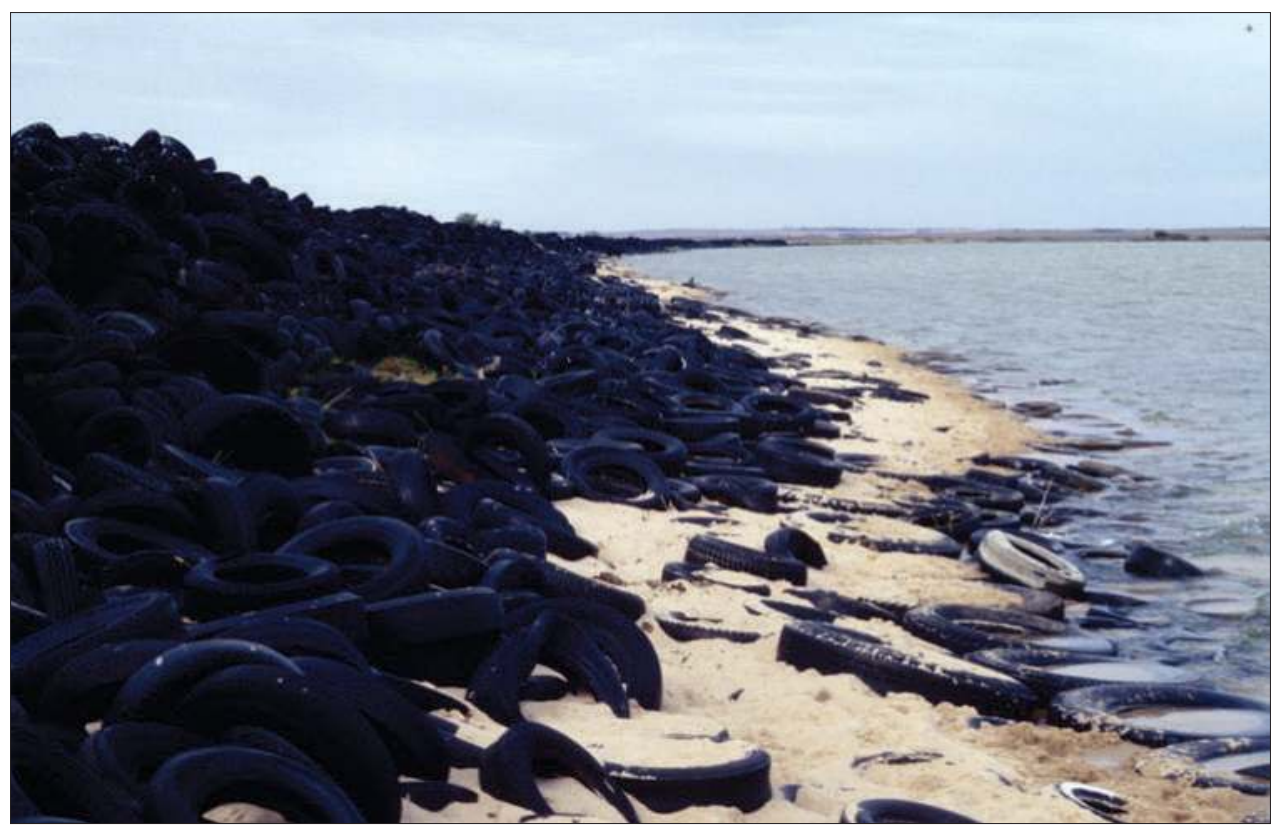

Figure 4.24 A tyre wall on part of the northwestern shoreline of Lake Alexandrina installed to inhibit shoreline erosion.

Source: Author's own work, RPB.

\subsubsection{Increased sedimentation in the lakes}

Sediments transported by the River Murray into the estuary today are largely finegrained muds. Weirs upstream have effectively trapped coarser sediments, although in pre-regulation times substantial amounts of quartzose, sandy sediments were delivered to the coast through the Murray Mouth. Despite the reduction in coarse sediment supply, the rate of sedimentation in the estuary has increased over the last century, probably related to land clearance and lakeshore erosion. Long-term sedimentation in the central channel region of Lake Alexandrina was previously $0.5 \mathrm{~mm} /$ year, whereas since European settlement it has been measured at $1.7 \mathrm{~mm}$ per year. ${ }^{64}$ Upstream of the Goolwa Barrage, rapid deposition of mud over coarser sand has occurred at the rate of $4.5 \mathrm{~mm}$ /year during the past 50 years. Increases in organic carbon, phosphorous and copper concentration accompanied accelerated sedimentation. The lakes are naturally eutrophic, and blue-green algal blooms occasionally occur. One of the earliest reports of the effects of algal blooms in the scientific literature was from the Lower Murray Lakes in the 1880 s. ${ }^{65}$ 


\subsection{Summary and conclusions}

The Murray Estuary has evolved through long-term and continuing tectonic subsidence allied with repeated rises and falls in global sea level, which laid the foundation for the final drowning of the network of abandoned coastal barrier systems, culminating about 7000 years ago. The Murray Estuary occurs at the interplay of Australia's largest exoreic river system with the ocean, and it forms a dynamic and delicate environment, dramatically impacted by human interference since European settlement.

The aesthetics of the Murray Estuary and its shoreline masks an ecosystem suffering from overregulation and exploitation of its resources, particularly those related to freshwater diversions and restrictions of tidal flows. As in the past, the land slowly subsides, the coastline erodes, and the coastal barriers continue to move inland. The Murray Mouth perpetually migrates and sediments accumulate in the lakes and backshore lagoons. The system is deteriorating, and without the permanent reinstatement of substantial freshwater flows allied with more sensitive management of the barrage system, it will continue to decline.

\section{Notes}

1 James, K.F., Bourman, R.P. \& Harvey, N. (2015). Rapid evolution of a flood tidal deltaic island in the River Murray Estuary, South Australia: A canary in the cage of river management. Journal of Coastal Research, 31, 1103-1119.

2 Hodge, C.R. (1932). Encounter Bay: The miniature Naples of Australia - A short history of the romantic South Coast of South Australia. The Advertiser, Adelaide, 173 pp.

3 Walker, D.J. (1990). The role of river flows in the behaviour of the Murray Mouth. South Australian Geographical Journal, 90, 50-65; Frick, R.A., Bourman, R.P. \& Lucic, D. (1996). Towards a control model for the Murray Mouth. Modelling changes at the Murray Mouth. Environmental Modeling and Assessment, 1, 37-44; James, Bourman \& Harvey (2015).

4 Goode, J.R. \& Harvey, P.D. (2009). Water resources. In: Jennings, J. (Ed.), Natural history of the Riverland and Murraylands. Royal Society of South Australia, Adelaide, pp. 162-177; James, Bourman \& Harvey (2015).

5 Barnett, E.J. (1994). A Holocene paleoenvironmental history of Lake Alexandrina. Journal of Paleolimnology, 12, 259-268; Barnett, E.J. (1995). Distinguishing natural and anthropogenic influences: A case study of Lake Alexandrina. South Australian Geographical Journal, 94, 36-49.

6 James, Bourman \& Harvey (2015).

7 Bourman, R.P., Murray-Wallace, C.V., Belperio, A.P. \& Harvey, N. (2000). Rapid coastal geomorphic change in the River Murray Estuary of Australia. Marine Geology, 170, 141-168.

8 Williams, G.E. \& Goode, A.D.T. (1978). Possible western outlet for an ancient Murray 
River in South Australia. Search, 9 (12), 443-447.

9 Gostin, V.A. \& Jenkins, R.J.F. (1980). Possible western outlet for an ancient Murray River in South Australia - An alternative viewpoint. Search, 11 (7-8), 225-226; Harris, W.K., Lindsay, J.M. \& Twidale, C.R. (1980). Gostin, V.A. \& Jenkins, R.J.F. (1980). Possible western outlet for an ancient Murray River in South Australia - A discussion. Search, 11 (7-8), 226-227.

10 McLaren, S., Wallace, M.W., Gallagher, S.J., Miranda, J.A., Holdgate, G.R., Gow, L.J., Snowball, I. \& Sandgren, P. (2011). Palaeogeographic, climatic and tectonic change in southeastern Australia: The late Neogene evolution of the Murray Basin. Quaternary Science Reviews, 30, 1086-1111.

11 McLaren, Wallace, Gallagher, Miranda, Holdgate, Gow, Snowball \& Sandgren (2011).

12 Murray-Wallace, C.V., Bourman, R.P., Prescott, J.R., Williams, F., Price, D.M. \& Belperio, A.P. (2010). Aminostratigraphy and thermoluminescence dating of coastal aeolianites and the later Quaternary history of a failed delta: The River Murray mouth region, South Australia. Quaternary Geochronology, 5, 28-49.

13 Blackburn, G., Bond, R.D. \& Clarke, A.R.P. (1965). Soil development associated with stranded beach ridges in South-east South Australia. CSIRO Soil Publications, 22. Commonwealth Scientific and Industrial Research Organization, Australia, Melbourne, 66 pp.

14 Hossfeld, P.S. (1950). The Late Cainozoic history of the south-east of South Australia. Transactions of the Royal Society of South Australia, 73, 232-279; Tindale, N.B. (1959). Pleistocene strandlines of the Upper South-East of South Australia. Transactions of the Royal Society of South Australia, 82, 119-120; Cook, P.J., Colwell, J.B., Firman, J.B., Lindsay, J.M., Schwebel, D.A. \& von der Borch, C.C. (1977). The late Cainozoic sequence of southeast South Australia and Pleistocene sea-level changes. Bureau MR Journal of Australian Geology and Geophysics, 2, 81-88; Schwebel, D.A. (1983). Quaternary dune systems. In: Tyler, M.J., Twidale, C.R., Ling, J.K. \& Holmes, J.W. (Eds), Natural history of the south east. Royal Society of South Australia Inc., Adelaide, pp. 15-24; Huntley, D.J., Hutton, J.T. \& Prescott, J.R. (1993). The stranded beach-dune sequence of south-east South Australia: A test of thermoluminescence dating, 0-800 ka. Quaternary Science Reviews, 121, 1-20; Belperio, A.P. (1995). The Quaternary, In: Drexel, J.F. \& Preiss, W.V. (Eds), The geology of South Australia. Vol. 2, The Phanerozoic. Geological Survey of South Australia, Bulletin 54, pp. 218-281.

15 Sprigg, R.C. (1952). The geology of the South-East Province South Australia, with special reference to Quaternary coast-line migrations and modern beach developments. Geological Survey of South Australia, Bulletin 29, 120 pp.; Sprigg, R.C. (1959). Stranded sea beaches and associated sand accumulations of the Upper South-East. Transactions of the Royal Society of South Australia, 82, 183-193.

16 Murray-Wallace, Bourman, Prescott, Williams, Price \& Belperio (2010).

17 de Mooy, C.J. (1959a). Notes on the geomorphological history of the area surrounding Lake Alexandrina and Albert, South Australia. Transactions of the Royal Society of South Australia, 82, 99-118; de Mooy, C.J. (1959b). Soils and potential landuse of the area around Lake Alexandrina and Albert, South Australia. CSIRO Soils and Landuse Series No. 29; von der Borch, C.C. \& Altmann, M. (1979). Holocene stratigraphy and evolution of the Cooke Plains embayment, a former extension of Lake Alexandrina, South Australia. Transactions of the Royal Society of South Australia, 103, 69-78. 

in South Australia, Unpublished PhD thesis, Australian National University. Luebbers, R. (1982). The Coorong report: An archaeological survey of the northern Coorong Lagoon, South Australian Department of Environment and Planning; Harvey, N. (1981). Coastal geomorphology of South East South Australia. Taminga, 18, 1-15; Harvey, N., Bourman, R.P \& James, K.F. (2006). Evolution of the Younghusband Peninsula, South Australia: New evidence from the Northern Tip. South Australian Geographical Journal, 105, 37-50.

24 Hilton, M., Harvey, N. \& James, K. (2007). The impact and management of exotic dune grasses near the mouth of the Murray River, South Australia. Australasian Journal of Environmental Management, 14 (4), 220-228.

25 Bourman, R.P. (1986). Aeolian sand transport along beaches. Australian Geographer, 17, 30-34.

26 Lewis, S.E., Sloss, C.R., Murray-Wallace, C.V., Woodroffe, C.D. \& Smithers, S.G. (2013). Post glacial sea-level changes around the Australian margin: A review. Quaternary Science Reviews, 74, 115-138.

27 Bourman, R.P. (1974). Historical geomorphic change, Fleurieu Peninsula, South Australia. Proceedings of the International Geographic Union, New Zealand Geographical Society, 8, 289-297; Bourman, R.P. (1976). Environmental geomorphology: Examples from the area south of Adelaide. Proceedings of the Royal Geographical Society of Australia (SA Branch), 76, 1-23; Bourman, R.P. (1979). Geomorphological contributions to Coastal Management. In: Corbett, D. \& Sibly, J. (Eds), Southern heritage: Proceedings of the Conference Focus on our southern heritage. Conservation Council of South Australia and the Department of Continuing Education, The University of Adelaide, pp. 80-88.

28 Bird, E.C.F. (1985). The study of coastline changes. Zeitschrift für Geomorphologie. 57, 1-9; Thom, B.G. (1974). Coastal erosion in Eastern Australia. Search, 5, 198-209.

29 Bourman (1979).

30 Sprigg (1952). 
31 Sprigg (1952).

32 Bourman, Murray-Wallace, Belperio \& Harvey (2000).

33 Mitchell, B. (1991). Sea level and climate change. Proceedings of the Second Australasian Hydrographic Symposium, Special Publication 27, Australian Hydrographic Society, Sydney, pp. 327-342.

34 Murray-Wallace, C.V. \& Belperio, A.P. (1991). The last interglacial shoreline in Australia - A review. Quaternary Science Reviews, 10, 441-461.

35 Bourman, R.P., Belperio, A.P., Murray-Wallace, C.V. \& Cann, J.H. (1999). A last interglacial embayment fill at Normanville, South Australia, and its neotectonic implications. Transactions of the Royal Society of South Australia, 123, 1-15.

36 Bourman (1979).

37 Bourman, R.P. \& Murray-Wallace, C.V. (1991). Holocene evolution of a sand spit at the mouth of a large river system: Sir Richard Peninsula and its significance for management of the Murray Mouth, South Australia. Zeitschrift für Geomorphologie, 81, 63-83.

38 Thomson, R.M. (1973). The geomorphology of the Murray Valley in South Australia. MA Thesis, The University of Adelaide.

39 Bourman, R.P. (1997). A moving experience: The Murray Estuary. In: Carey, C. (Ed.), Our hidden state: South Australia through the eyes of scientists. ANZAAS (SA Division), The University of Adelaide, pp. 73-76; James, K. (2004b). Shifting sands at the Murray Mouth: Evidence from historic surveys 1839-1938. South Australian Geographical Journal, 103, 25-42.

40 Bourman \& Murray-Wallace (1991).

41 Thoms, M.C. \& Walker, K.F. (1992). Channel changes related to low-level weirs on the River Murray, South Australia. In: Carling, P.A. \& Petts, G.E. (Eds), Lowland floodplain rivers: Geomorphological perspectives. John Wiley \& Sons, Chichester, pp. 237-249.

42 Goode \& Harvey (2009).

43 Lawrie, E.R. (1939). Barrages near the mouth of the River Murray. Unpublished Manuscript, October 1939. Environment and Natural Resources Library; McIntosh, M. (1949). The River Murray Barrages. Journal of Agriculture, 425-429; Oliver, H.G. \& Anderson, W.M. (1940). The River Murray barrages at Mundoo, Boundary Creek, Ewe Island and Tauwitchere Channels. Engineering and Water Supply Document, Adelaide, 23 pp.; Radock, R. \& Stefanson, R.C. (1975). Seawater exclusion from Australia's River Murray. Journal de l'Association Internationale des Sciences Hydrologiques, 117, 817-829.

44 James, Bourman \& Harvey (2015).

45 Bourman, R.P. \& Barnett, E.J. (1995). Impacts of river regulation on the terminal lakes and mouth of the River Murray, South Australia. Australian Geographical Studies, 33 (1), 101-115.

46 James, Bourman \& Harvey (2015).

47 Johnston, E.N. (1917). Report on the harbour for the River Murray Valley. Parliamentary Papers, Adelaide No. 38, 304-312.

48 James, K.F. (2004a). The bio-geomorphological evolution of a former Flood Tidal Delta (Bird Island) in the Murray Mouth Estuary of South Australia. Unpublished MAppSc Thesis. University of South Australia, 248 pp.; James, Bourman \& Harvey (2015). 
49 James (2004b).

50 Bourman (1976).

51 Bourman, R.P. \& Harvey, N. (1983). The Murray Mouth Flood Tidal Delta. Australian Geographer, 15, 403-406.

52 James (2004a; 2004b).

53 Bourman \& Harvey (1983).

54 Cann, J.H., Bourman, R.P. \& Barnett, E.J. (2000). Holocene foraminifera as indicators of relative estuarine-lagoonal and oceanic influences in estuarine sediments of the River Murray, South Australia and their palaeoclimatic implications. Quaternary Research, 53, 378-391.

55 Snowball, D., Gibbs, J., Bourman, R.P. and Alley, N.F. (2006). Prehistoric flooding in the River Murray, South Australia. In: McCarthy, D., Rogers, T. \& Casperson, K. (Eds), Floods in South Australia 1836-2005. Australian Government, Bureau of Meteorology, pp. 189-210.

56 Snowball, Gibbs, Bourman \& Alley (2006).

57 Shuttleworth, B., Woidt, A., Paparella, T., Herbig, S. \& Walker, D. (2005). The dynamic behaviour of a river-dominated tidal inlet, River Murray, Australia. Estuarine, Coastal and Shelf Science, 64, 645-657.

58 James, Bourman \& Harvey (2015).

59 Murray-Wallace, C.V., Bourman, R.P., Prescott, J.R., Williams, F., Price, D.M. \& Belperio, A.P. (2010). Aminostratigraphy and thermoluminescence dating of coastal aeolianites and the later Quaternary history of a failed delta: The River Murray mouth region, South Australia. Quaternary Geochronology, 5, 28-49.

60 Taylor, J.K. \& Poole, H.G. (1931). Report on the soils and the bed of Lake Albert, South Australia. Journal of Commonwealth Scientific and Industrial Research, 4, 83-95; Gloster, A. (1998). The Late Pleistocene and Holocene sedimentary history of Lake Albert, South Australia. Unpublished MSc Thesis, Flinders University of South Australia. 177 pp.

61 McCord, A.K. (1979). Shoreline erosion on Lakes Alexandrina and Albert in South Australia. Soil Conservation Branch Report S7/79. South Australian Department of Agriculture; Coulter, C. (1992). Investigating options for improving the management of Lakes Alexandrina and Albert. Murray Darling Association Inc., Canberra, 66 pp.

62 McCord (1979); Coulter (1992).

63 Noye, B.J. \& Walsh, P.J., (1976). Wind induced water level oscillations in shallow lagoons. Australian Journal of Marine and Freshwater Research, 27, 417-430.

64 Barnett (1994).

65 Barnett (1995). 



\section{The Coorong Coastal Plain and the Limestone Coast}

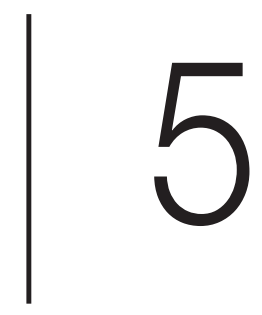

\subsection{Introduction}

The $400 \mathrm{~km}$ coastal sector from the mouth of the River Murray to the border of South Australia and Victoria is primarily a depositional coastline of low topographical relief ( $<50 \mathrm{~m})$, dominated by coastal dunes of Late Quaternary age ( $<125 \mathrm{ka})$.

From the River Murray mouth area south to Cape Jaffa, the coastline is formed by the coastal barrier landform Younghusband Peninsula and the associated Coorong Lagoon. The sector from Cape Jaffa to the border is dominated by rocky coastal cliffs, developed on Pleistocene dune limestone (aeolianite) with sandy pocket beaches and shingle beaches, comprising flint cobbles to the east of Port MacDonnell. Extensive sand sheets with migrating dunes occur at many locations along this coast. In only a few localities does bedrock older than Paleogene age (>66 Ma) crop out along the coastline, such as 'The Granites' north of Kingston SE. No rivers reach the sea along this coastline. Relative sea level changes associated with glacial cycles of the Quaternary have accordingly promoted sediment exchange from the continental shelf to the adjacent coastline and given rise to the region's principal coastal landforms, coastal barrier systems, uplifted over tens of thousands of years. From Cape Jaffa, south to Discovery Bay in western Victoria, the coastline displays slightly higher topographical relief in places, due to uplifted outcrops of aeolianite of Late Pleistocene age. These sediments are more strongly cemented, and give rise to vertical coastal cliffs.

The sediments and landforms of the modern coastline form the latest stage of the geological development of a succession of similar but older coastal barrier landforms. The Younghusband Peninsula and the Coorong Lagoon thus provide a modern analogue of the older shoreline features, which extend $500 \mathrm{~km}$ inland from 


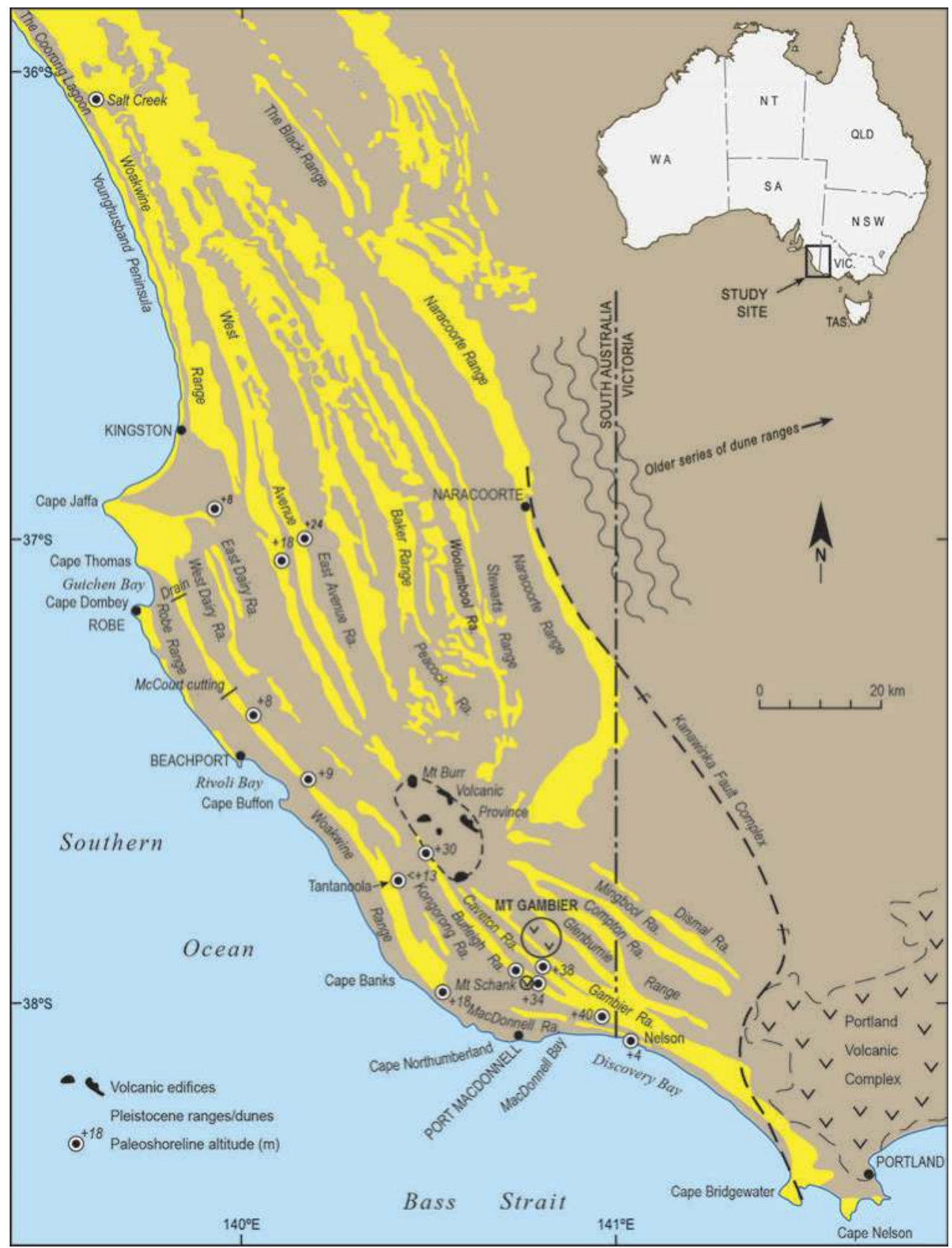

Figure 5.1 Map of the Coorong Coastal Plain and Limestone Coast, South Australia. Progressively older, relict shoreline features (coastal barriers) occur inland from the modern coastline and are indicated by yellow shading.

Source: Author's own work, CMW. 
the modern coastline, and back in time to approximately $6 \mathrm{Ma}$ as a later phase in the early sedimentary infill of the Murray and Gambier Basins (Murravian Gulf). ${ }^{1}$ These stranded coastal dune barriers developed at times of high sea levels during Pleistocene interglacials.

The generalised distinction between unconsolidated Holocene sediments dominating the modern coastline to the north of Cape Jaffa and consolidated Pleistocene aeolianite being more prevalent to the south reflects variable vertical crustal movements. The region between Benson Hook in South Australia, and Nelson in western Victoria underwent uplift in the Middle and Late Pleistocene, whereas the coastal sector from Kingston SE heading north to the River Murray mouth either remained stable (for example, the Salt Creek area) or subsided during the same interval of time (for example, the northern Coorong and River Murray lakes region.) ${ }^{2}$ These subtle differences in crustal behaviour have influenced the development of coastal landforms within the region. Unconsolidated dune sands rest on a foundation of Pleistocene aeolianite along the northern portion of Younghusband Peninsula, whereas in the south, outcrops of aeolianite are increasingly more common, reflecting the faster rate of uplift within the region. The landforms and coastal evolution of Younghusband Peninsula, the southern Coorong Lagoon and the Limestone Coast are reviewed in this chapter, a sector of coast extending from Parnka Point and Hells Gate in the southern Coorong Lagoon to Discovery Bay in western Victoria (Figure 5.1).

\subsection{Regional geological setting}

The Coorong and Limestone Coasts occur within the Murray and Gambier Basin provinces (the latter also termed the Gambier Embayment of the Otway Basin), two sedimentary basins of Paleogene-Neogene age in southern South Australia. ${ }^{3}$ The basins developed following the rifting and early phase of separation of Australia and Antarctica; they preserve sediments that range in age from Late Paleocene (c. $60 \mathrm{Ma}$ ) to Middle Miocene (c. $16 \mathrm{Ma}$ ). Basement rocks underlying these basins are Cambrian metasediments (Kanmantoo Group), which are not exposed within this region, but crop out in the eastern Mount Lofty Ranges. Volcanic and intrusive granitic rocks associated with the Cambro-Ordovician Delamerian Orogeny (a mountain-building event, c. 510 to $490 \mathrm{Ma}$ ) crop out sporadically as isolated residual hills and whalebacks across the coastal plain, as part of a basement structure termed the Padthaway Ridge. ${ }^{4}$ These features were islands, archipelagos and headlands during Quaternary high sea levels. Along the modern coastline, the northern limit of the Gambier Basin is approximately $40 \mathrm{~km}$ to the north of Kingston SE. The Padthaway Ridge, comprising a variety of granitic rock types, delineates the northern landward extent of the Gambier Basin and separates the basin from the adjoining Murray Basin to the north. Several welldefined faults occur within the region and have influenced the longer-term evolution of these sedimentary basins and the overlying Quaternary sedimentary successions. In 
particular, the Kanawinka Fault has influenced the Pleistocene evolution of the region and the position of the Naracoorte Range, a relict shoreline feature (Figure 5.1).

A karstified upper surface on the Late Eocene (c. $37 \mathrm{Ma}$ ) to Middle Miocene (c. $16 \mathrm{Ma}$ ) Gambier Limestone is exposed in the Mount Gambier area due to regional uplift. ${ }^{5}$ Sediments of Quaternary age rest unconformably on this marine abrasion surface, which was formed throughout multiple cycles of sea level change eroding the upper surface of the formation. The regional warping of the Gambier Limestone is associated with the emplacement of igneous intrusions expressed in the Pleistocene and Holocene volcanoes of the region. Midway between the volcanic centres of Mount Gambier and Mount Burr, the eroded upper surface of the Gambier Limestone is $80 \mathrm{~m}$ above present sea level (APSL), but approximately $40 \mathrm{~km}$ to the southwest and $5 \mathrm{~km}$ offshore from Lake Bonney SE, the upper surface lies $75 \mathrm{~m}$ below present sea level (BPSL), illustrating the magnitude of crustal doming. ${ }^{6}$

Igneous rocks of contrasting geological ages and rock types occur sporadically within the region. Rocks associated with moderately deeply emplaced igneous intrusions of Cambro-Ordovician age have been exposed at the Earth's surface by prolonged erosion, such as at 'The Granites' $20 \mathrm{~km}$ to the north of Kingston SE. To the southeast, the Mount Burr-Mount Gambier volcanic complex is marked by episodes of volcanic activity that extended from the Pleistocene, possibly $1 \mathrm{Ma}$ ago through to Middle Holocene time, as recently as 5000 years ago. ${ }^{7}$ The volcanic province is genetically related to the 'Newer Volcanics', an extensive volcanic region of western Victoria.

Along the Coorong and Limestone Coasts, the high-energy, swell and stormdominated Lacepede and Bonney shelves form the adjacent continental shelf. Modal deep-water wave heights are typically $>2.5 \mathrm{~m}$, and long-period swell waves $(>12 \mathrm{~s}$ ) with wavelengths of $200 \mathrm{~m}$ have been reported. ${ }^{8}$ The sediment surfaces of these shelves are constantly being reworked by wave action. ${ }^{9}$ For much of southern Australia, significant wave heights exceed $3.5 \mathrm{~m}$ for $30 \%$ to $50 \%$ of the year. ${ }^{10}$ On the innermost portion of the Lacepede Shelf, adjacent to the Younghusband Peninsula, water depths are $<20 \mathrm{~m}$ and the sea floor gradient is $1: 150$. More than $75 \%$ of the incident wave energy reaches the shore, giving rise to low-gradient inner shelf settings termed 'dissipative beaches', in which the waves break for up to $500 \mathrm{~m}$ offshore over well-defined offshore bars. ${ }^{11}$ The magnitude of incident wave energy decreases to the south along this coastline, particularly in Lacepede Bay, and further south, where the Bonney Shelf narrows and inner shelf gradients steepen. Along the coastal sector between Robe and Beachport, which is $45 \mathrm{~km}$ long, eroded remnants of the coastal dune range, Robe Range, occur between $500 \mathrm{~m}$ to $2 \mathrm{~km}$ offshore, and further reduce incident wave energy. Tides are microtidal $(<2 \mathrm{~m})$ along the entire coastline, with mean spring high tides of $1.1 \mathrm{~m}$ at Port MacDonnell and $1.2 \mathrm{~m}$ at Kingston SE. ${ }^{12}$ 


\subsection{Modern coastal landscapes from the southern Coorong Lagoon to Discovery Bay}

\subsubsection{Younghusband Peninsula}

As outlined in Chapter Four, the Younghusband Peninsula is a coastal barrier of Holocene age formed during the past 7000 years at sea levels close to present. The term 'barrier' refers to a coastal landform that separates the mainland from the open ocean. This wave-dominated coast comprises Australia's longest beach, yet paradoxically, it has no official name. ${ }^{13}$ It is also one of the world's highest-energy beaches. ${ }^{14}$ Its dune sediments remain unconsolidated and are locally stabilised by coastal vegetation. The sediments forming these coastal landforms comprise mixtures of sand-sized particles ( 0.063 to $2 \mathrm{~mm})$ of quartz and calcium carbonate, the latter derived from brokenup marine invertebrates such as molluscs, bryozoans, coralline algae, echinoids and foraminifers sourced from the continental shelf. The percentage of calcium carbonate within the sediment ranges between $10 \%$ and $90 \%$ of the total sediment and is commonly $50 \%$ of the sediment by volume.

On Younghusband Peninsula, the coastal dunes display a variety of forms relating to their contrasting origins. Many of the dunes are part of extensive aeolian sand sheets and include massive, transverse and landward-migrating parabolic dunes. The unconsolidated and unvegetated dunes are being actively reworked by strong onshore winds with the formation of dune blowouts and isolated knolls (coppice dunes or nebkhas) capped by vegetation. In restricted areas, the dunes are migrating landward, cascading into the Coorong Lagoon. Other dune forms relate to beach ridge formation (relict coastal foredunes) in the earlier Holocene development of the peninsula; these are confined to the seaward side of the barrier. Older cemented dunes of Late Pleistocene age comprise dune limestone (aeolianite), which forms coastal cliffs, subdued islands in the Coorong Lagoon and offshore, and the substrate to Younghusband Peninsula. Active dune fields occur south of the Murray Mouth, at Nine Mile Sandhills north of Euro Point and in the lee of Canunda and Admella Beaches.

Together, the Younghusband Peninsula and Lacepede Bay provide an example of an asymmetrically curved bay or zetaform beach. ${ }^{15}$ In plan view, this coastal sector has a well-developed 'half-heart' shape. The southern sector of Younghusband Peninsula at Lacepede Bay curves more sharply than the northern sector towards the Murray Mouth. The overall shape of the coastline is in part a function of swash alignment of the shoreline under high-energy wave conditions along the northern coastal sector with some northward longshore sediment transport. The contrasting shapes of the coastline reflect a higher incident wave energy towards the north and a more protected, lower-energy coastline near Cape Jaffa. Outcrops of aeolianite south of Cape Jaffa and immediately offshore, such as Margaret Brock Reef and North Reef, protect the southern Lacepede Bay coastline from the southwesterly swell. 
The Younghusband Peninsula began to form about 7000 years ago, after the culmination of the most recent postglacial marine transgression. From about 16000 years ago, with the shrinking of the continental ice sheets, sea level rose and flooded the Lacepede and Bonney Shelves. During this interval, the shoreline advanced from near the edge of the continental shelf to broadly its present position, involving a relative rise of sea level of about $125 \mathrm{~m}$. As sea level rose, shoreline-transported sands advanced across the continental shelf forming a proto-barrier. A series of barrier islands were progressively joined through longshore sediment transport. This interpretation is supported by radiocarbon dating of an oyster shell from a midden at Hack Point, which yielded an age of $5910 \pm 70$ years BP, indicating an open marine connection at this time. ${ }^{16}$

\subsubsection{The Coorong Lagoon and associated lakes}

The main Coorong Lagoon can be viewed from a number of localities en route from Adelaide to Kingston SE. The lagoon is a shallow body of marine water formed in the lee of the Holocene barrier of Younghusband Peninsula (Figure 5.2). The total length of the lagoon is approximately $150 \mathrm{~km}$. It is commonly 3 to $4 \mathrm{~km}$ wide in the north and tapers to approximately $1 \mathrm{~km}$ in the south. Water depth is mostly less than $2 \mathrm{~m}$, although it exceeds $4 \mathrm{~m}$ in the vicinity of Salt Creek. Water is introduced to the Coorong Lagoon through the combined effects of tidal exchange through the Murray Mouth, flows from the River Murray and rainfall and seepage from unconfined nearsurface aquifers. Before significant drainage works, water also entered the Coorong from Salt Creek. ${ }^{17}$ Some of the flow from Salt Creek into the Coorong Lagoon has been reinstated by artificial channel deepening. Historically, the regional pattern of surface water flow has been to the northwest, along the length of the back-barrier depressions. The construction of an artificial drainage network for agricultural purposes has significantly modified surface water flows and permanently drained many of the back-barrier depressions. ${ }^{18}$

The surface water level of the lagoon is influenced by up to $1 \mathrm{~m}$ of tidal oscillation and a further 1 to $1.5 \mathrm{~m}$ fluctuation from winter to summer, associated with seasonal fluctuations in mean sea level due to changes in prevailing wind directions. In winter, the surface water level of the Coorong Lagoon is approximately 1 to $1.5 \mathrm{~m}$ above that attained in summer, when the combined effects of high evaporation rates, reduced surface runoff and prevailing southeasterly winds push the lagoonal waters northward. ${ }^{19}$

Before barrage construction in the terminal lakes area of the River Murray (Lakes Alexandrina and Albert, further discussed in Chapter Four), the salinities varied widely in the Coorong Lagoon, depending on the flow of the River Murray, local rainfall and regional groundwater flow. Since the barrages were built and large drainage channels constructed, a much more stable salinity gradient has resulted, varying from normal 


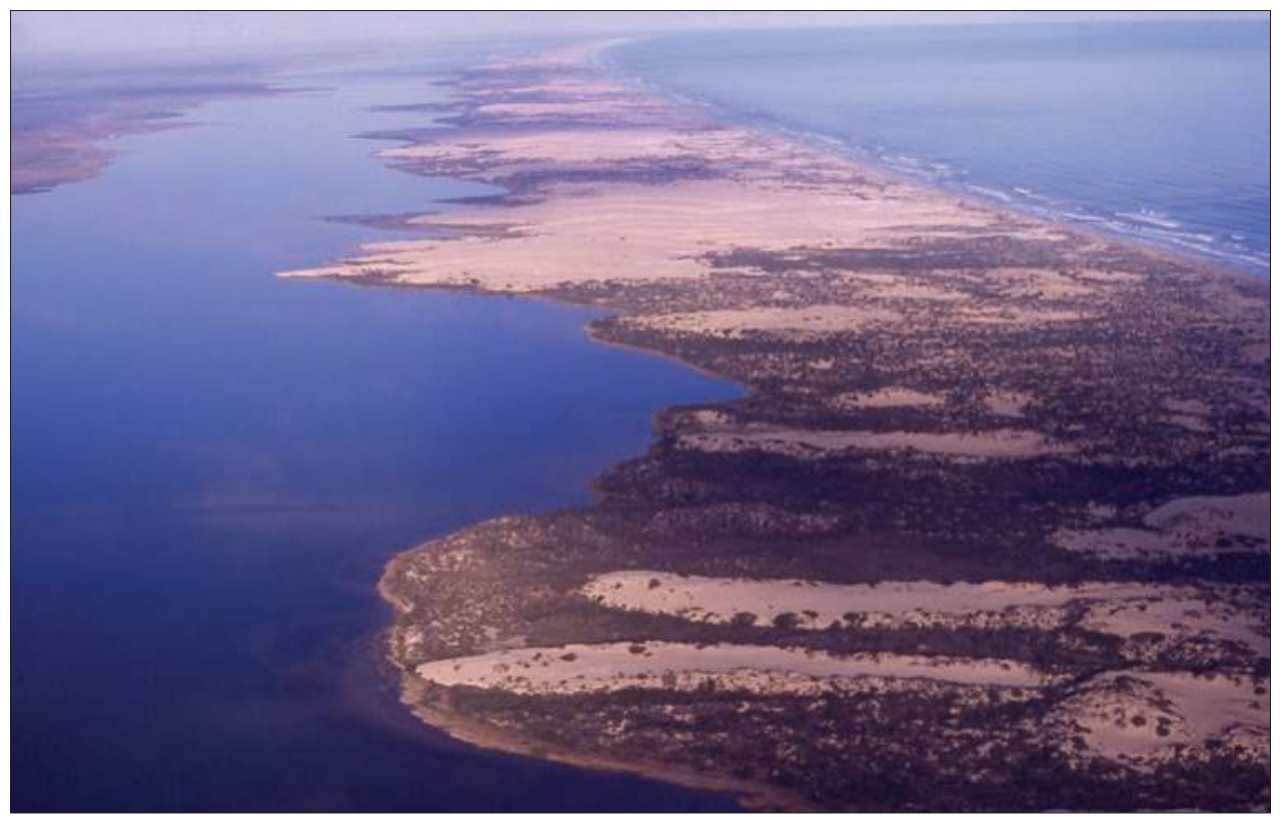

Figure 5.2 Oblique aerial view, looking southeast along the Coorong Lagoon and Younghusband Peninsula, a Holocene coastal barrier which formed in the past 7000 years during the high sea level of the present Holocene Interglacial.

Source: Author's own work, CMW.

marine salinity at the Murray Mouth to hypersaline conditions ( $>5 \%)$ in the southern ephemeral reaches of the Coorong.

Hells Gate at Parnka Point is a narrow constriction separating the northern from the southern Coorong Lagoon. A Late Pleistocene aeolianite peninsula, extending southwards from Magrath Flat, forms the constriction of 'The Narrows' (Figure 5.1). South of Hells Gate, several islands occur along the axis of the lagoon; these are erosional remnants of aeolianite (for example, Cow, Long, Round and Swan Islands). ${ }^{20}$ Policeman Point is a small peninsula extending into the Coorong Lagoon, and numerous islands also occur in this region including North Pelican, Seagull and Wild Dog Islands.

Bioclastic sand and laminated aragonitic and calcitic pelletal mud are the main sedimentary products of the lagoon floor. ${ }^{21}$ Ostracods and foraminifers are common constituents, and a molluscan fauna (Notospisula trigonella, Anapella cycladea, Tellina (Macoma) deltoidalis, Katelysia sp.), serpulids and bryozoans are present in less restricted parts of the lagoon. The gastropod Coxiella confusa and the foraminifer Ammonia 
beccarii are extremely common. ${ }^{22}$ Around the lagoon margins, a winter storm beach of comminuted shell debris and a summer strandline of Coxiella remains are prominent. The tar-like remains of Coorongite can sometimes be observed. These are the weathered remains of cyanobacterial and botryococus algal blooms that occur sporadically. The Coorong Lagoon water is similar to normal sea water, although with elevated salinity and $\mathrm{pH}$. Aragonitic sediment is precipitating under these conditions at the southern ephemeral end of the lagoon, where it is rapidly pelletised by biota. ${ }^{23}$

The Holocene sediments of the Coorong Lagoon rest on a calcrete surface (relict, hardened calcareous soil profile), developed on an earlier body of aeolianite of Late Pleistocene age. ${ }^{24}$ The calcrete surface is commonly exposed around the Coorong margins, and the internal structure of the sediments is visible in eroding embankments. Representative profiles are exposed in road cuttings on Loop Road south of Halite Lake, where solution pipes, rhizomorphs (tree root replacement features) and a soft calcareous earthy profile associated with the carbonate paleosols extend down several metres below the surficial carbonate hardpan. At the same site, encrusting bryozoans occur on loose boulders on the shore platform on the landward side of the Coorong Lagoon.

A series of ephemeral, alkaline, saline lakes extends southwards from the main Coorong Lagoon towards Kingston SE. These reflect the progressive infilling and shoaling of a formerly more extensive lagoon during the past 6000 years, with associated changes to groundwater-dominated lake environments. These lakes are actively precipitating a variety of carbonate muds including dolomite, magnesite, aragonite and magnesian calcite. Modern dolomite precipitation has been reported in Kingston and Hawdon Lakes. ${ }^{25}$ Modern dolomite formation on the coastal plain occurs only where shallow groundwater lakes pass through an annual desiccation phase (that is, north of $37.5^{\circ}$ latitude, where annual rainfall is $<700 \mathrm{~mm}$ ). ${ }^{26}$ Five mineralogically unique lakes are located in close proximity within the Coorong National Park immediately to the south of Salt Creek. These display the range of mineralogical and sedimentary processes that occur in these carbonate-dominated lakes, reflecting subtle differences in the degree of continental groundwater influences, in part related to the height of the different lakes above present sea level. The lakes annually fill with groundwater in winter and spring to depths up to $2 \mathrm{~m}$. Carbonate sediments precipitate in spring and summer, aided by $\mathrm{pH}$ increase due to aquatic plant growth and evaporitic concentration. Four of the lakes (North Stromatolite Lake, Pellet Lake, Dolomite Lake and Halite Lake) were once connected to the Coorong Lagoon through a marine corridor ${ }^{27}$, now filled with sediments. Milne Lake had no former marine connection and its sedimentary history is related purely to groundwater processes.

A low-lying corridor of Holocene shell beds termed a 'coquina' marks the former marine connection between North Stromatolite Lake and the Coorong Lagoon. Cemented and unconsolidated shell beds are exposed in bulldozer scrapes. 


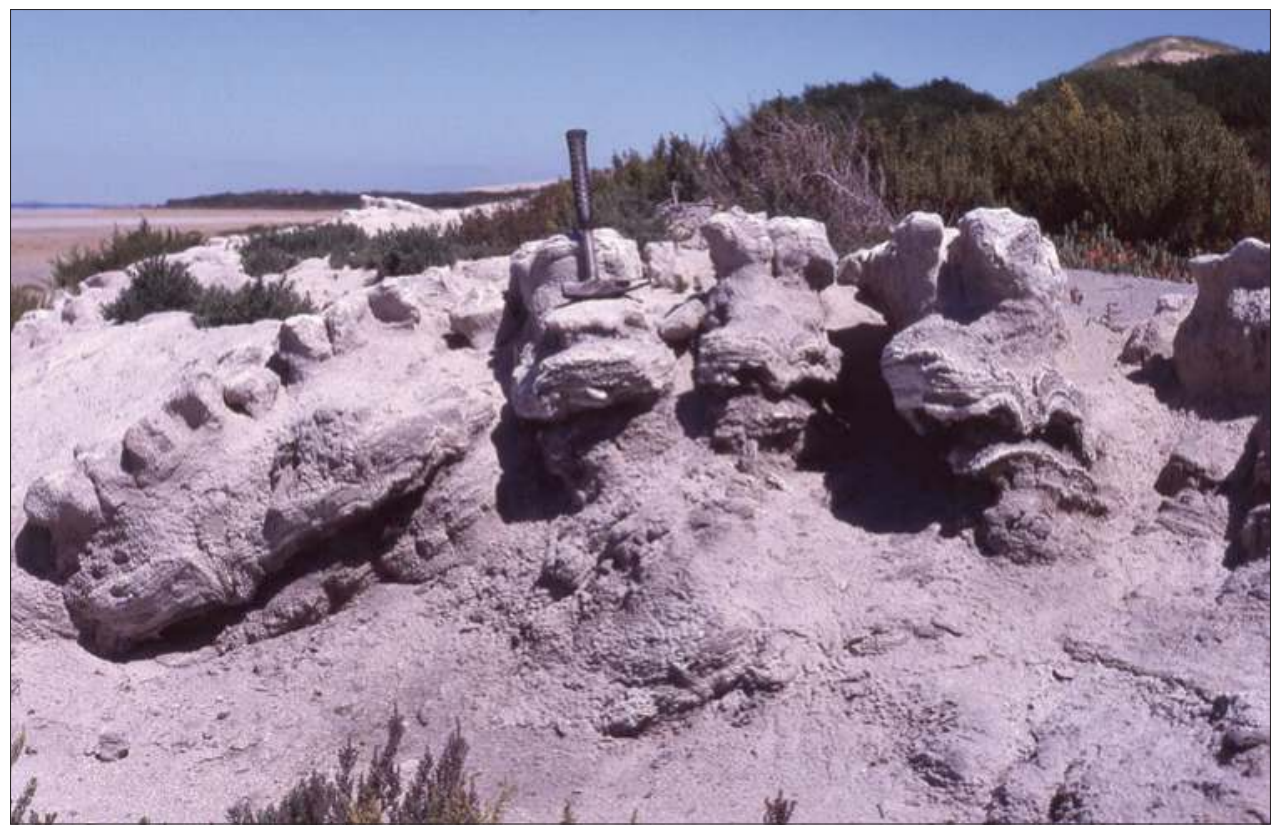

Figure 5.3 Deformed Holocene lagoonal muds at the southern Coorong Lagoon near Forty-Two-Mile Crossing. The deformation of the muds has resulted from the load imposed by landward-migrating coastal parabolic dunes.

Source: Author's own work, CMW.

The cemented shell beds pass down into finer-grained and better-sorted shelly quartz sands. Fossil shell remains are dominated by the bivalve mollusc Notospisula sp. with minor Tellina sp. and Katelysia sp. indicating a similar sedimentary environment to the modern Coorong Lagoon. Along the margins of the corridor, a gradation up into a gastropod coquina (Hydrococcus brazieri and Coxiella confusa) reflects increasing restriction and hypersalinity.

At Forty-Two-Mile Crossing towards the southern limit of the Coorong lagoon, back-barrier lagoonal sediments have been deformed on the seaward side of the lagoon, resulting from the load imposed by landward-migrating Holocene coastal dunes (Figure 5.3). ${ }^{28}$ The dunes are part of southernmost Younghusband Peninsula and include transverse dunes and migrating coastal parabolic dunes. In this area, the peninsula is approximately $2 \mathrm{~km}$ in cross-section and the dunes attain heights of up to $20 \mathrm{~m}$ APSL. The dunes are migrating landward in response to erosion of the barrier shoreline and foredunes immediately backing the beach, in part related to ongoing sea level rise. Dune reactivation has formed deflation hollows where large dunes were once situated, due to the entrainment of sand in a landward direction under the influence 
of strong onshore winds. The landward advance of coastal dunes is also revealed by the burial of vegetation and, in one location, the diversion of the Old Melbourne Road. ${ }^{29}$ The periodic exposure of back-barrier lagoonal sediments, swamp vegetation and peats on the ocean beach indicate landward retreat of Younghusband Peninsula. ${ }^{30}$ Similar evidence for coastal erosion has been identified on the main beach of Sir Richard Peninsula. ${ }^{31}$ Large-scale coastal erosion and barrier migration have resulted from the combined effects of recent sea level rise, and, more locally, human impacts on the landscape, such as grazing and the active removal of vegetation that formerly stabilised dunes. In places, recreational vehicles have also initiated dune erosion. ${ }^{32}$

\subsubsection{Woakwine Range at Salt Creek}

The last interglacial (125 ka) Woakwine Range is a prominent coastal barrier shoreline structure that can be traced southeasterly from northern Hindmarsh Island near the mouth of the River Murray to south of Mount Gambier, where the equivalent landform feature is termed the MacDonnell Range. ${ }^{33}$ The Woakwine Range is a coastal landform of similar origin to Younghusband Peninsula and includes relict beach, beach ridge, transgressive and parabolic dunes, and back-barrier lagoon sediments. When it formed during the high sea level stand ( $-2 \mathrm{~m}$ APSL) of the Last Interglacial (125 ka) the open ocean lapped against its western side, while a large coastal lagoon existed on its eastern side. Its core is formed of older aeolianite associated with an earlier interglacial. ${ }^{34}$ The majority of the dune range consists of aeolian-derived, mixed quartz-skeletal carbonate sand also termed 'calcarenite'. The aeolianite has been mapped as the Bridgewater Formation, the type section of which is in Bridgewater Bay in western Victoria. ${ }^{35}$

At Salt Creek, consolidated planar cross-bedded, calcarenite beach sediments are exposed within a drainage cutting on the seaward side of Woakwine Range near the Coorong National Park office (Figure 5.4). The molluscan faunal assemblage is dominated by disarticulated, convex-up, transported valves of Anapella sp. of last interglacial age $(125 \mathrm{ka})$. The relict foreshore sediments occur up to $3 \mathrm{~m}$ APSL, indicating a higher sea level during the Last Interglacial.

\subsection{4 'The Granites' at Ocean Beach}

An overview of the changing scale and morphology of the Holocene barrier lagoon complex of the southernmost Younghusband Peninsula can be discerned along the road from Salt Creek to 'The Granites'. The Coorong Lagoon becomes increasingly restricted in this region and breaks into a number of isolated depocentres, which dry out by the end of summer. The multiple dune blowouts, with landward-migrating sand sheets that characterise northern Younghusband Peninsula, gradually diminish southward, changing to a lower, more stable coastal barrier. At 'The Granites' (Figure 5.5), Younghusband Peninsula comprises four discrete beach ridges (relict foredunes) 


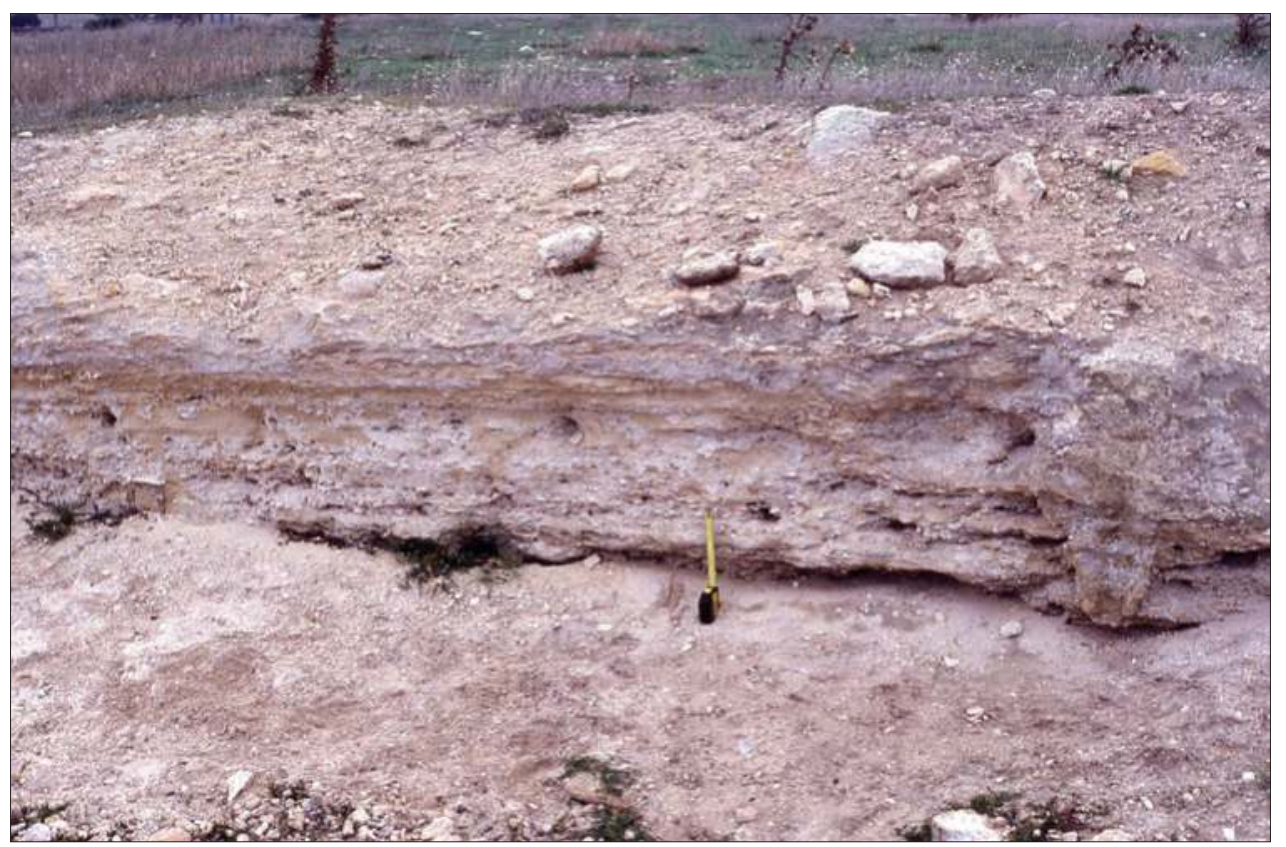

Figure 5.4 Planar cross-bedded shelly sands on the seaward side of Woakwine Range at Salt Creek. The shelly sands represent a former beach deposit of last interglacial age (125 ka) and formed at a sea level approximately $2 \mathrm{~m}$ APSL.

Source: Author's own work, CMW.

with a relatively stable and well-vegetated modern foredune. The extreme, highenergy dissipative surf zone of the northern Younghusband Peninsula systematically diminishes southward towards the protective lee of Cape Jaffa. Several domes of granite (whaleback features) crop out on Ocean Beach and are developed on the CambroOrdovician ( $475 \pm 65 \mathrm{Ma}$ ) Taratap Granite, a biotite granodiorite with mica foliation and large phenocrysts of orthoclase felspar. ${ }^{36}$ The whalebacks possibly represent the roof of an igneous intrusion that was originally emplaced several kilometres below the Earth's surface and now crops out at the surface due to a prolonged period of erosion and regional landscape lowering.

\subsubsection{Kingston SE to Cape Thomas}

From Kingston SE to Cape Jaffa, the coastline trends broadly northeast-southwest defining Lacepede Bay. A beach ridge plain landward of Long Beach occurring to the north of Kingston SE is backed by three large coastal lagoons trending north-south (Paranki: $5.5 \mathrm{~km}$ long; Partiari: $0.5 \mathrm{~km}$ long; and Teilaka: $2.7 \mathrm{~km}$ long); these occupy 


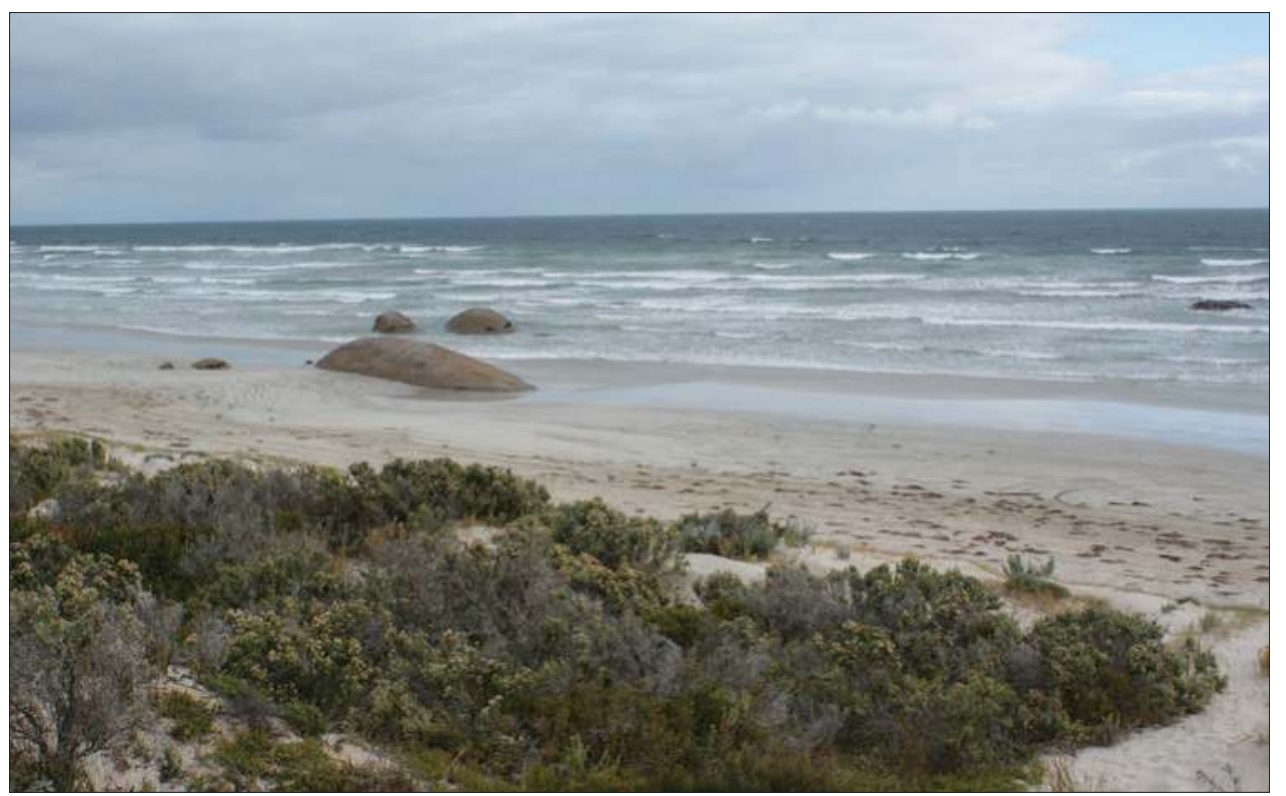

Figure 5.5 Whaleback features developed on the Cambro-Ordovician Taratap Granite, north of Kingston SE.

Source: Author's own work, CMW.

the site of a single back-barrier lagoon dating from the Middle to Late Holocene. The modern coastline southeast of Cape Jaffa is structurally controlled and trends parallel with the Late Pleistocene ( $-125 \mathrm{ka})$ Woakwine Range for $8 \mathrm{~km}$; from Wright Bay, it trends north-south for $5 \mathrm{~km}$ to the northern seaward limit of Guichen Bay at Cape Thomas.

\subsubsection{Guichen Bay, Rivoli Bay and the Robe-Woakwine Seaway}

Guichen and Rivoli Bays are erosional re-entrants cut through the Pleistocene aeolianite of Robe Range, infilled with beach ridges (relict foredunes). The embayment fill within Guichen Bay is $10 \mathrm{~km}$ long (north-south) and up to $4 \mathrm{~km}$ across. Sequences of up to 80 beach ridges (relict foredunes) progressively infilled the embayment during the past 6000 years. The relict foredune ridges of both Guichen and Rivoli bays display a remarkable periodicity dating back to between $8 \mathrm{ka}$ and $5 \mathrm{ka} .{ }^{37}$ The individual ridges are subdued features, but are laterally persistent, largely uninterrupted and run parallel to the modern Long Beach. The ridges are typically up to $2 \mathrm{~m}$ above the intervening interdune depressions with ridge crests on average up to $50 \mathrm{~m}$ apart (Figure 5.6). The beach ridges have been dated using luminescence methods, which measure the last 
time that grains of quartz sand were exposed to sunlight. The dating reveals that the embayment infilled rapidly after sea level inundated the area in the Middle Holocene. Between 7000 and 5000 years ago, the beach advanced in a seaward direction by up to $1.6 \mathrm{~km}$. This was followed by an average rate of beach ridge formation of one dune every 80 years from 3900 years ago to the present. ${ }^{38}$

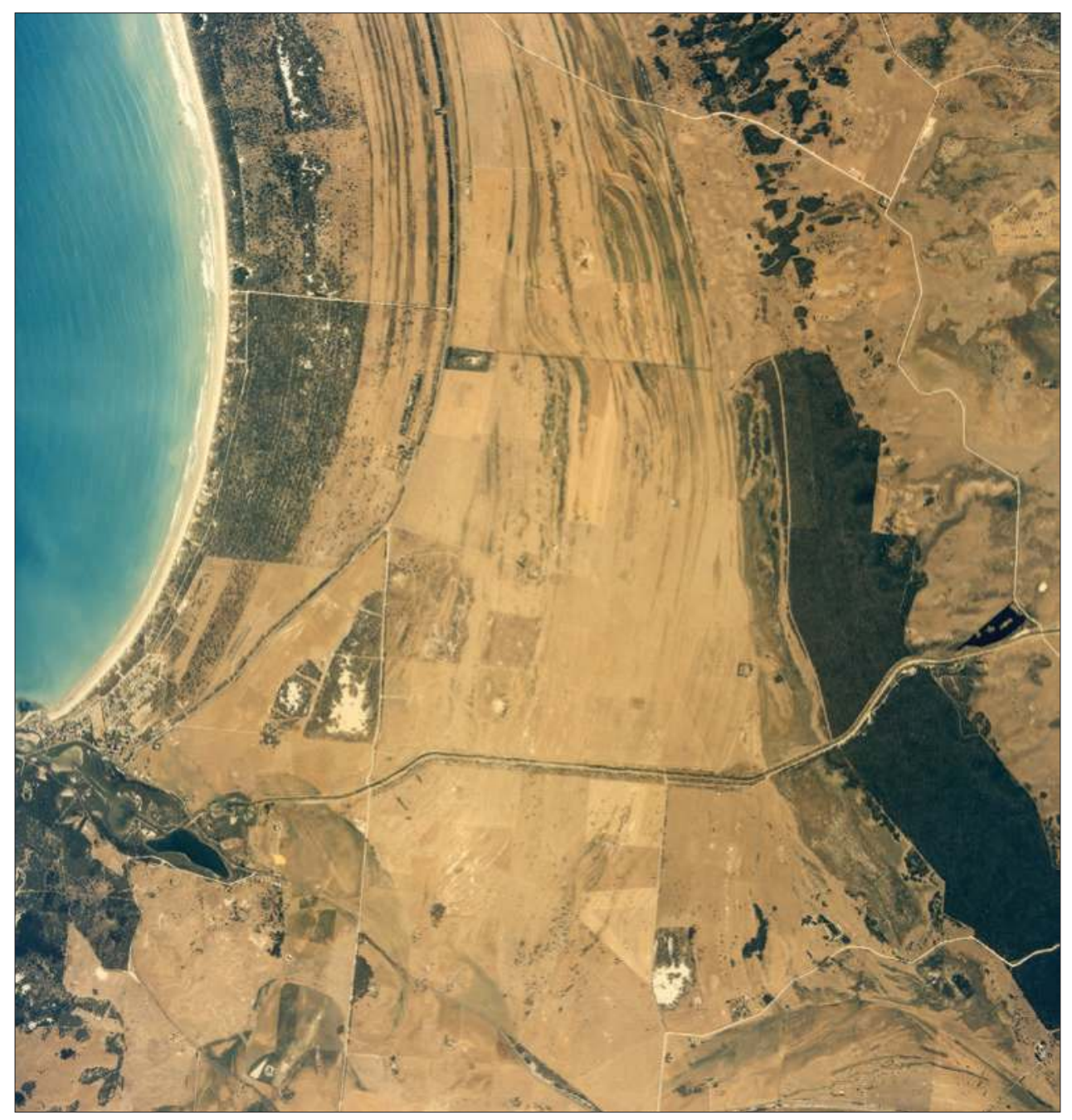

Figure 5.6 Aerial view of beach ridges (relict foredunes) at Guichen Bay. Each ridge represents the former position of the shoreline. The bay has progressively infilled and advanced in a westerly direction with sand derived from the inner continental shelf beginning about 6000 years ago. The most recent beach ridge (foredune) has been dated to $51 \pm 5$ years (see Note 37 ).

Source: The aerial photograph is reproduced with the permission of the Resource Information Division, Department of Environment and Heritage. <www.environment.sa.gov.au>. 
At Rivoli Bay near the town of Beachport, an extensive beach ridge plain (14 km long and $2 \mathrm{~km}$ across) has developed immediately to the southeast of Lake George. The combined effects of beach ridge formation and longshore sediment transport have created a sand barrier approximately $500 \mathrm{~m}$ wide, isolating Lake George from the open ocean. ${ }^{39}$

The low-lying land between the rocky coastline of Robe Range and the more inland Woakwine Range was a fully marine seaway in Early Holocene times when the postglacial rise in sea level flooded the region. Progressively, the region infilled with shelly sands and was transformed to a series of isolated lakes which characterise the area today. Marine shell beds that record the progressive infilling of the seaway from 7 to $2 \mathrm{ka}$ ago are exposed in small roadside borrow pits and cuttings around the modern Lakes Robe, Eliza and George (Figure 5.7). ${ }^{40}$ These lakes now have no direct connection to the sea, and water quality varies from fresh to hypersaline depending on the balance between marine and continental groundwater infiltration, evaporation, rainfall and artificial drainage measures.

\subsubsection{Robe Range}

Robe Range is the most seaward and youngest of the emergent Pleistocene coastal barriers of the Coorong Coastal Plain and Limestone Coast. Excellent exposures of the dune range occur between Cape Dombey at Robe and Glen Point at Beachport. The limestones of this dune range, mapped as Bridgewater Formation, are well exposed in subdued coastal cliffs and are commonly capped by unconsolidated and partially vegetated Holocene and modern coastal dunes.

Two constructional stages in the development of Robe Range have been equated with separate high sea

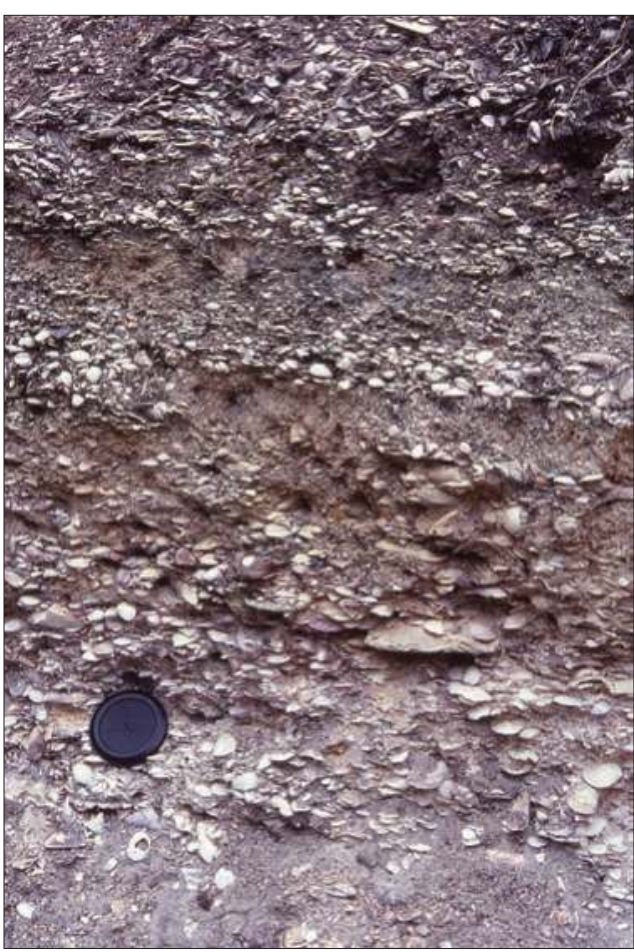

Figure 5.7 Holocene shell beds (coquina) near Lake Eliza in the Robe-Woakwine Corridor, the lower relief between the Robe and Woakwine Dune Ranges. The accumulation of shells, which has been radiocarbon dated at 3700 years (see Note 22), illustrates the high carbonate bioproductivity within the region. The lens cap, for scale, is $52 \mathrm{~mm}$ in diameter.

Source: Author's own work, CMW. 


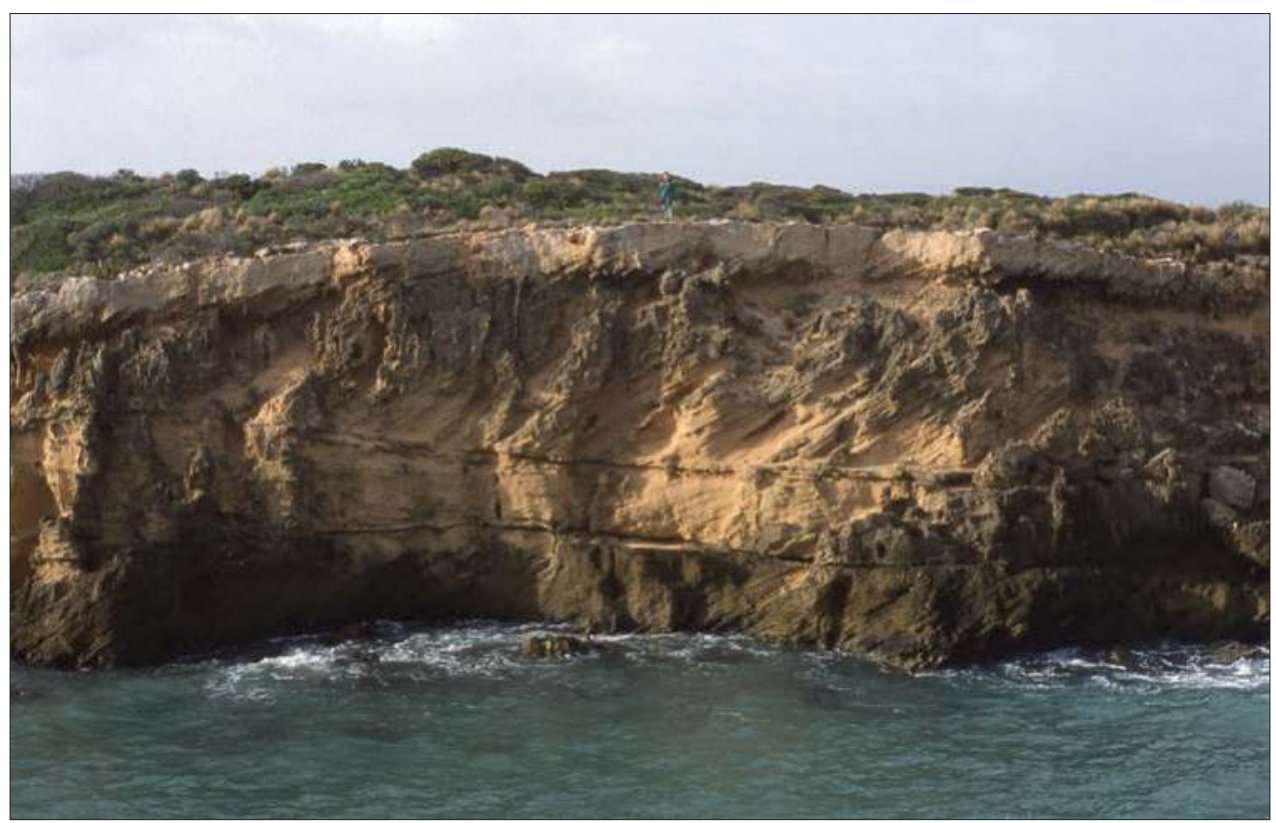

Figure 5.8 Dune limestones (aeolianite) of Robe Range at Cape Dombey. Three sets of planar cross-beds (slip faces of former coastal dunes, as the dunes migrated in a landward direction at the time of their formation), separated by two broadly horizontal paleosols (fossil soil horizons), are evident. The arched shape of the dune structure represents its original surface relief. The succession is capped by a thick calcrete. The cliff is $20 \mathrm{~m}$ high.

Source: Author's own work, CMW.

level stands in the Late Pleistocene, one at approximately $100 \mathrm{ka}$ ago and a subsequent phase at about $82 \mathrm{ka}$ ago, during which times global sea levels peaked at approximately $8 \mathrm{~m}$ and $14 \mathrm{~m}$ below present sea level (BPSL) respectively. ${ }^{41}$ The basal Pleistocene sediments of Robe Range rest unconformably on the Gambier Limestone some 10 to $15 \mathrm{~m}$ BPSL. Robe Range aeolianite is exposed in a number of road cuttings, pits and eroding headlands within Robe Township (Figure 5.8). The older of the two Late Pleistocene dune units of Robe Range exposed on the western headland, termed Robe III, has been dated by luminescence methods as $116 \pm 6 \mathrm{ka} .{ }^{42} \mathrm{Near}$ the obelisk at Cape Dombey, coastal cliff exposures of Robe Range aeolianite reveal large-scale planar cross-bedding representing the leeward slip faces of coastal dunes as they advanced landward during the Late Pleistocene (Figure 5.8). A calcrete paleosol is developed on the crest of the structure. A former shoreline elevation of $9 \mathrm{~m} \mathrm{BPSL}$ relative to present sea level is inferred for this region when corrected for tectonic uplift. ${ }^{43}$ 
Between Robe and Beachport, the coastline has a crenulated form in plan view, represented by headlands of aeolianite and small, open pocket beaches (Figure 5.1). Numerous nearshore islands, which developed on erosional remnants of Robe Range, illustrate the relatively rapid rates of coastal erosion in this region. North of Nora Creina Bay, the islands are commonly up to $0.5 \mathrm{~km}$ offshore; and near Lake St Claire, they extend up to $2 \mathrm{~km}$ offshore, having formed during the past 7000 years by coastal erosion under present sea level conditions. It appears that the alignment of the modern coastline is subparallel with the trend of the nearshore islands, which are erosional remnants of Robe Range. The contrasting orientations may relate to differential uplift in this region during the past $100 \mathrm{ka}$ since the formation of Robe Range.

\subsubsection{Woakwine Range at McCourt Cutting}

McCourt Cutting, a drainage channel $1 \mathrm{~km}$ long near Lake George, provides a spectacular view of the internal sedimentary structures through the Woakwine Range (Figures 5.9 and 5.10). ${ }^{44}$ In summer it is possible to completely traverse the length of the cutting. The Woakwine Range is mostly a single rectilinear feature from about $30 \mathrm{~m}$ high, rising to some $60 \mathrm{~m}$ near Cape Jaffa, where it bifurcates to form an easterlytrending bar or 'hook'. At McCourt Cutting the Woakwine Range is $7 \mathrm{~km}$ inland from the modern coastline and illustrates the former position of the shoreline during the Last Interglacial some 125000 years ago. The floor of the drain rises gently from west to east, from approximately 6 to $8 \mathrm{~m}$ APSL. On entering the cutting from the west (seaward side), one encounters four distinctive groups of sedimentary packages (facies). These are:

1. shallow subtidal facies

2. littoral (beach) facies

3. dune facies.

They make up the coastal sand barrier together with a back-barrier lagoonal facies on the landward side.

Shallow subtidal facies are visible in the lowermost metre of the drain walls. These strata comprise seaward-dipping, parallel-laminated, medium- to coarsegrained, moderately well-sorted bioclastic sand. Slightly pebbly and shelly layers are also present. The consistent seaward-dipping laminae indicate a dominance of return

Figure 5.9 (right) View looking west from the observation platform at McCourt Cutting of the last interglacial (125 ka) Woakwine Range. Lake George, a back-barrier coastal lagoon, and Younghusband Peninsula are visible in the middle distance and horizon respectively.

Source: Author's own work, CMW. 


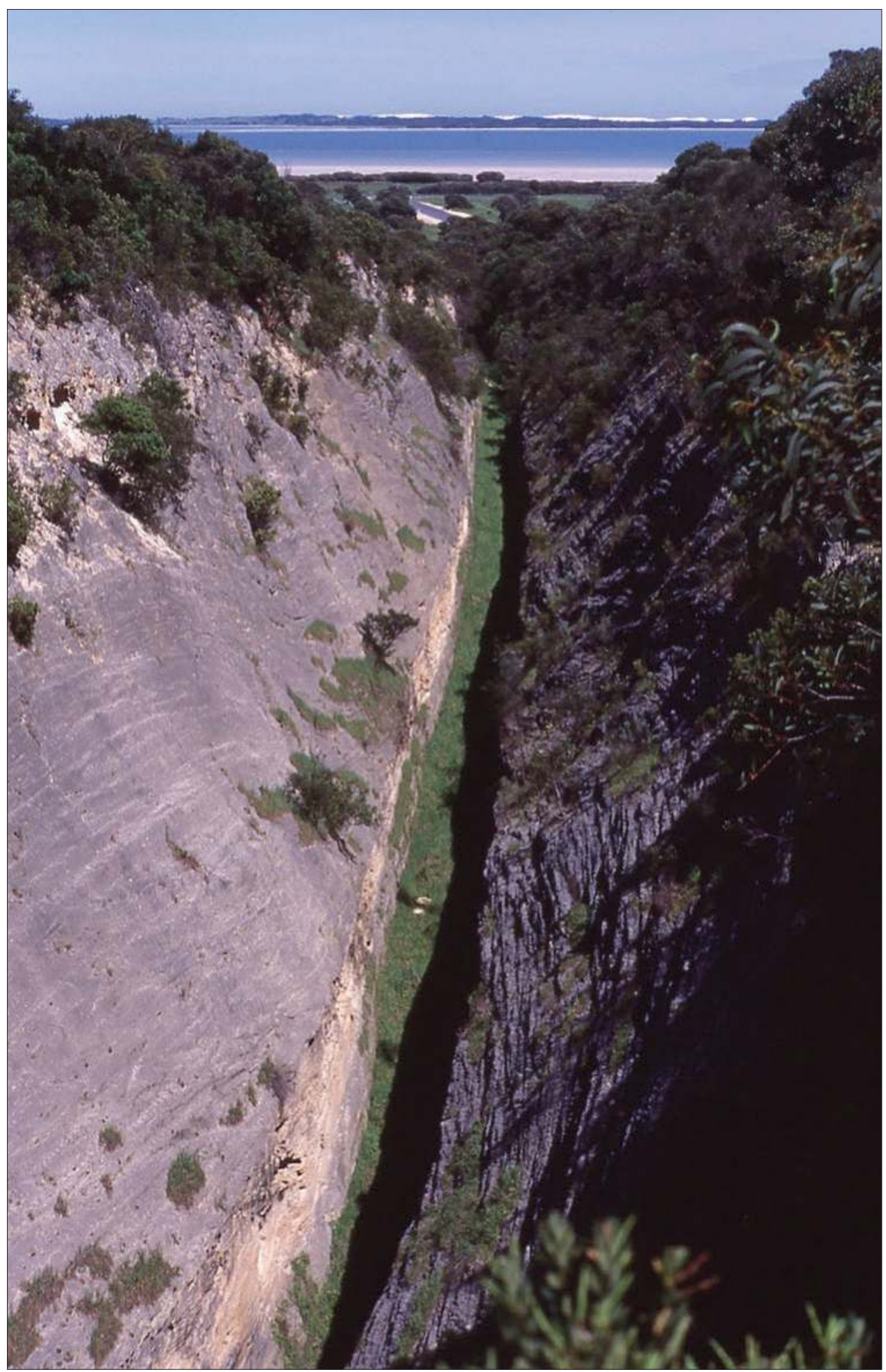



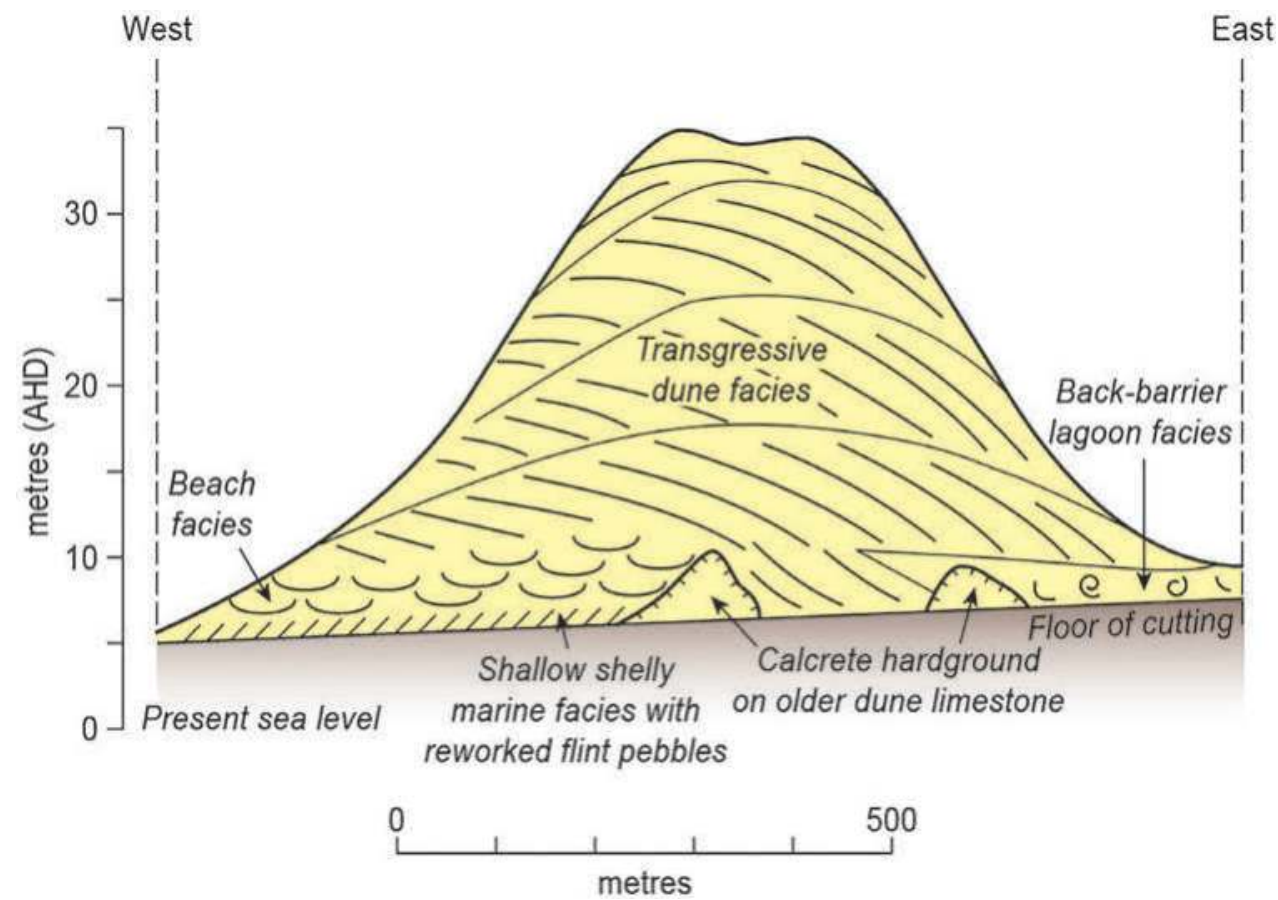

Figure 5.10 Schematic representation of the internal sedimentary structures (facies architecture) of the last interglacial (125 ka) Woakwine Range, as seen in McCourt Cutting near Robe (see Notes 33 and 45).

Source: Modified and reproduced with the permission of the Department of State Development's Resources and Energy Group.

water flow in the lowermost littoral to shallow subtidal zone. Littoral (beach) facies occupy an interval from 1 to $3 \mathrm{~m}$ above the drain floor, rising eastwards to $6 \mathrm{~m}$. They comprise bi-directional trough cross-bedded and tabular cross-bedded, medium- to coarse-grained, well-sorted bioclastic sand. Bedform wavelengths of about $2 \mathrm{~m}$ are indicated. Pebbly and shelly lag horizons with calcrete clasts and reworked flint pebbles derived from the Gambier Limestone are common, particularly towards the centre of the barrier, where this facies merges with parallel-laminated washover fan deposits. The littoral facies indicate that the paleoshoreline elevation decreased from about 10 to $7 \mathrm{~m}$ (uncorrected for tectonic uplift) during construction of this barrier.

The foredune and dune facies overlie the lower two facies and rise up to $30 \mathrm{~m}$ above the former shoreface. They comprise slightly finer bioclastic sands in large sets, up to $10 \mathrm{~m}$ thick, of landward-dipping cross-beds. Reactivation surfaces between sets are weakly cemented and may host paleosols and rhizolith concentrations. The back- 
barrier lagoon facies is visible towards the eastern end of the cutting (Figure 5.10). Flat-lying shelly mud containing the fossil molluscs Katelysia and Ostrea and small gastropods is common and exposed for up to $1.5 \mathrm{~m}$ above the drain floor, lapping on to calcreted hardground. Transgressive dunes subsequently buried the former lagoonal sediments, asphyxiating the cockle population. Similar processes occur today on the landward side of Younghusband Peninsula, where transgressive dunes are migrating into the Coorong Lagoon. Specimens of the fossil bivalve mollusc Katelysia, from a similar setting at Drain L and at the McCourt Cutting, have been correlated with the Last Interglacial Maximum. ${ }^{45}$ The lagoon facies indicates a paleosea level of about $10 \mathrm{~m}$ APSL, uncorrected for tectonic uplift of about $7 \mathrm{~m}$ since its formation 125000 years ago.

\subsubsection{Nora Creina Bay}

Nora Creina Bay is a protected pocket beach formed in an erosional re-entrant within the Late Pleistocene aeolianite of Robe Range. The beach, which is protected from the open ocean, comprises mixed quartz-skeletal carbonate sand and is backed by partially vegetated dunes. The open ocean coastline here is predominantly a rocky coastline with small cliffs formed by the erosion of Robe Range. Sea stacks formed on the dune limestone of Robe Range extend up to $1 \mathrm{~km}$ offshore and indicate, in geological terms, the high rate of coastal erosion. The accordant surfaces of small shore platforms rimming the sea stacks and islands attest to the impacts of coastal erosion during the present high sea level stand of the past 7000 years.

Aboriginal middens marked by food remains such as shells and bones, as well as by flint tools and charcoal, occur extensively on the surfaces of Holocene dunes within the region, and record the progressive evolutionary changes of these coastal landscapes together with associated changes in marine fauna. ${ }^{46}$ On the southern headland of Nora Creina Bay, a midden on a Holocene dune that overlies the Pleistocene dune limestone comprises numerous whole shells of the gastropod Turbo undulatus. The largest shells are up to $10 \mathrm{~cm}$ in diameter. Radiocarbon dating of an operculum (trap door) of the gastropod Turbo shell from the midden yielded an age of $740 \pm 160 \mathrm{yr} \mathrm{cal} \mathrm{BP} .^{47}$

\subsubsection{Cape Buffon to Carpenter Rocks}

From Cape Buffon, which defines the southern extent of Rivoli Bay, southeastwards to Carpenter Rocks, the coastline is structurally controlled trending parallel with the Robe Range. Unconsolidated Holocene coastal dunes occur extensively along this sector of coast and drape the Late Pleistocene aeolianites of Robe Range. For the first $6 \mathrm{~km}$ southeast of Cape Buffon, the coastline is moderately embayed, a function of the high wave energy actively eroding the aeolianite. Further south along Geltwood and Canunda Beaches, the aeolianites are covered by modern beach sand 
and transverse coastal dunes up to $20 \mathrm{~m}$ high. Longshore sediment transport is most likely responsible for this contrasting coastal morphology having locally concentrated sources of sediment for dune formation. From Canunda Beach south to Pelican Point, numerous nearshore islands have developed on eroded remnants of Robe Range.

Lake Bonney SE occurs landward of Canunda Beach, and along this sector of coast the modern coastal dunes that drape Robe Range extend 1 to $2 \mathrm{~km}$ inland from the beach. Lake Bonney SE is a large Holocene coastal lagoon situated between the Robe and Woakwine Ranges. The lake is a long, narrow, shallow coastal lagoon (23 km x $4 \mathrm{~km}$, with an average central depth of $3 \mathrm{~m}$ ) on the Limestone Coast, varying between fresh and brackish. It may have been permanently fresh in immediate preEuropean times, but over longer time periods the lake may have been alternately saline and fresh..$^{48}$ Lake Bonney has had a chequered history of human interference. Water levels in the lake were probably quite variable; Woods $(1862)^{49}$ noted that much of the lake was dry in 1850 , but it was quite full in the $1860 s^{50}$

Drainage schemes and pollution from wood pulp factory wastewater have impacted on the lake, although the quality of wastewater discharged has improved since 1975, when the lake was badly polluted. ${ }^{51}$ Natural overflow from Lake Bonney appears to have been through Bucks Crossing and Bucks Lake to the coast near Carpenters Rocks. Two artificial outlets have been created to reduce the impacts of flooding, with the first built in 1915 and another in 1958. Since then, there have been many managed discharges to the sea to prevent flooding of pastures fringing the lake. Since 1972, water depths in the lake have varied between $0.4 \mathrm{~m}$ and $2.1 \mathrm{~m} .{ }^{52}$ Pine logs were stored in the lake following the fires of February 1983, and some remained as boating hazards, causing the lake to be closed to boating. However, it was reopened for kayaks and canoes by the Department of Planning, Transport and Infrastructure in October 2013.

\subsubsection{Carpenter Rocks to Port MacDonnell}

This coastal sector is a highly embayed coastline with several pocket embayments; the larger features include Lighthouse, Bucks and Bungaloo Bays. From Pelican Point at the southernmost portion of Bungaloo Bay to Cape Douglas, Robe Range has undergone substantial erosion: there are fewer islands, and the more 'embayed' coast is backed by lower topography situated closer to the coastline. At several locations between Pelican Point and Port MacDonnell, the Gambier Limestone crops out in the modern shore platforms, also indicating a higher rate of crustal uplift within this region and exposing part of the former continental shelf of Late Eocene to Middle Miocene age ( 37 to $16 \mathrm{Ma}$ ). The more highly eroded Robe Range in this region reflects the faster rate of crustal uplift, and, accordingly, a greater proportion of Robe Range, which formed when sea level was lower than present, has been brought closer to modern sea level with increased susceptibility to erosion. 


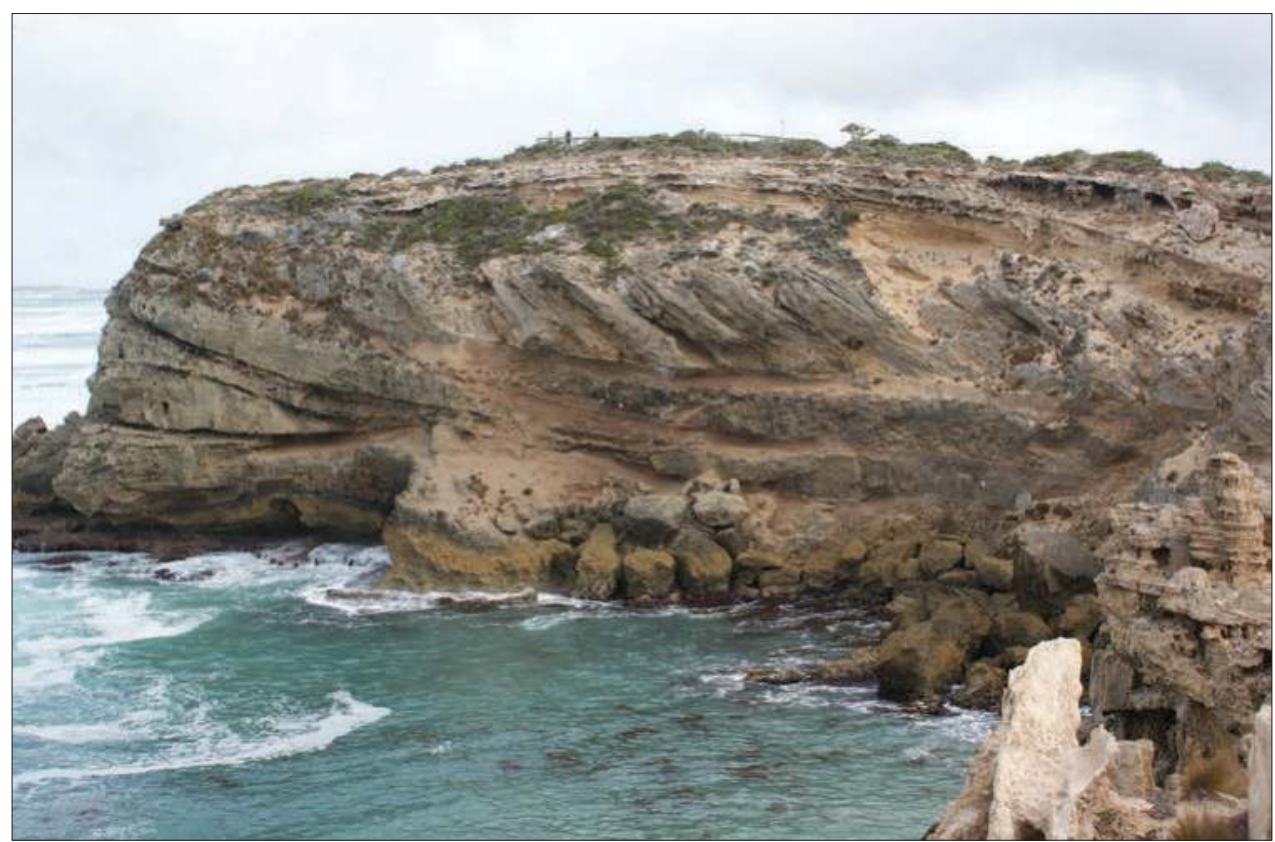

Figure 5.11 Coastal cliff exposures of aeolianite (dune limestone) up to $30 \mathrm{~m}$ high in the Cape Northumberland area. The high angle cross-beds represent the slip faces of coastal dunes as they advanced in a landward direction. Relict soil profiles (paleosols) are represented by subhorizonatal, arcuate-shaped truncation surfaces within the dune limestone, commonly occurring beneath small overhangs of cross-bedded strata, as seen in the centre of the photograph.

Source: Author's own work, CMW.

The Cape Northumberland headland is the southernmost point of the South Australian coastline. Spectacularly cross-bedded aeolianites with interbedded calcrete paleosols and rhizoliths are exposed in the cliff faces and as sea stacks. The paleosols, or more weakly developed pedogenic features termed 'protosols', represent breaks in dune deposition and phases of landscape stability, probably associated with the establishment of vegetation. The paleosols can be traced within the coastal cliffs as laterally persistent, undulating surfaces exposed beneath overlying cross-bedded strata. The cliff exposures in aeolianite, up to $30 \mathrm{~m}$ APSL (Figure 5.11), are a continuation of Robe Range. Along the rocky shoreface towards Port MacDonnell, the disconformable contact between these sediments and the underlying Gambier Limestone can be observed. The surface has a wider regional expression in the area between Mount Gambier and Port MacDonnell; it represents a marine abrasion surface, the result of multiple phases of coastal erosion during successive sea level cycles. ${ }^{53}$ It is characterised by an eroded surface on the Gambier Limestone typified by bare, karstified limestone. 


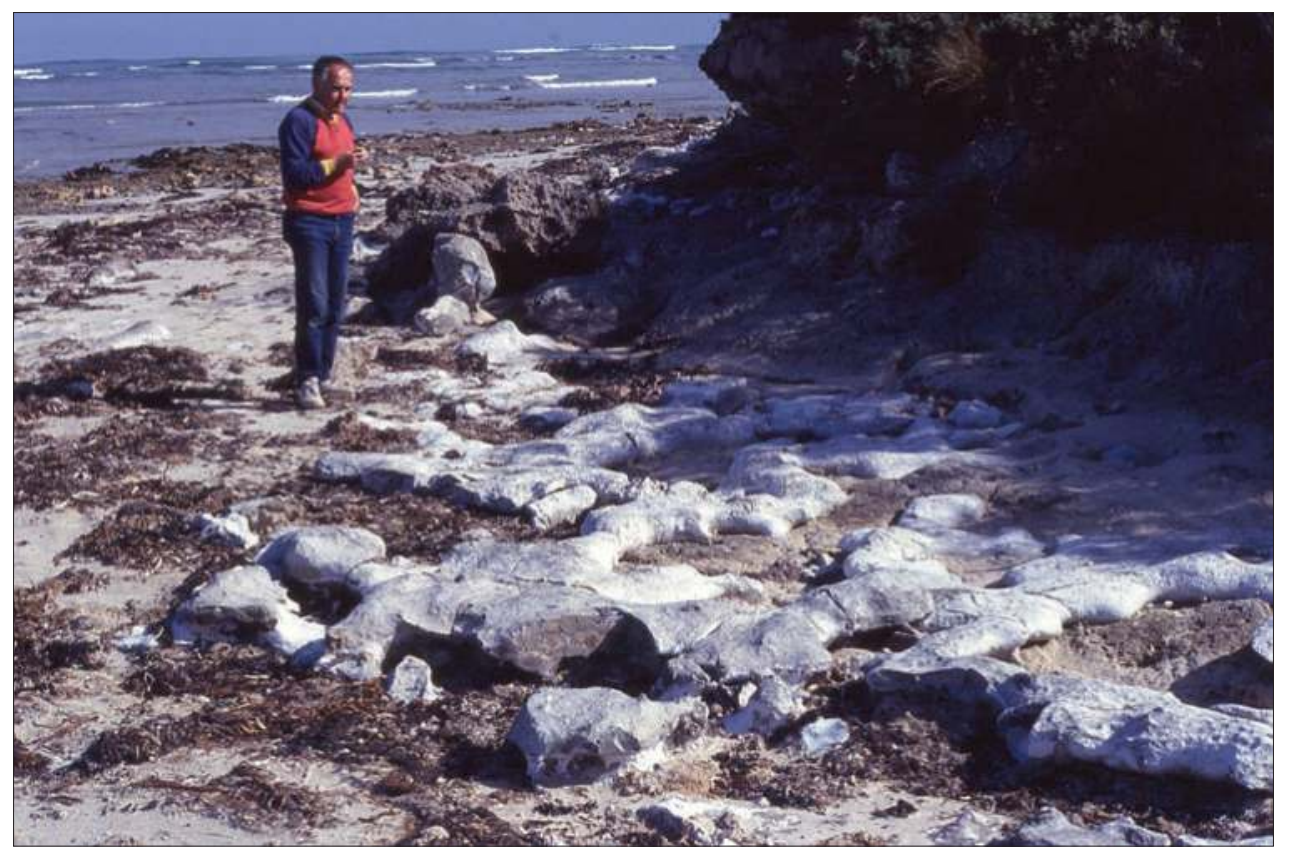

Figure 5.12 An in situ branching network of flint of diagenetic origin formed in the OligoMiocene Gambier Limestone and exposed on the landward limit of a modern shore platform to the west of Port MacDonnell. The flint has been exposed by differential weathering, which has removed the less resistant bryozoan matrix of the Gambier Limestone. Outcrops such as this represent the source of the flint for the beaches to the east of Port MacDonnell. Source: Author's own work, CMW.

\subsubsection{Flint cobble beaches at Port MacDonnell}

Thick anastomosing layers of nodular flint occurring within horizons of the Gambier Limestone are exposed near present sea level to the west of the township of Port MacDonnell (Figure 5.12). ${ }^{54}$ The in situ flint concretions are of diagenetic origin, having formed from the re-precipitation of silica in solution derived from needle-like sponge spicules, during the long burial history of the Gambier Limestone. On the main shore platform immediately to the west of the township of Port MacDonnell, small pedestals ( $<1 \mathrm{~m}$ high) of flint also occur sporadically across the platform surface and have erroneously been termed a 'petrified forest' on local signage. These 'pipes' give an indication of shore platform development, in places showing reduction of the platform surface by up to $1 \mathrm{~m}$. Elsewhere on the main shore platform, large solution depressions up to $1 \mathrm{~m}$ in diameter are rimmed within in situ flint of diagenetic origin. As the fragile fabric of the bryozoal limestone is destroyed by coastal erosion, cobble- 
sized fragments of resistant flint (64 to $256 \mathrm{~mm}$ in diameter) have been released and redistributed by waves, indicating an easterly direction of longshore transport.

East of Port MacDonnell, cobbles of flint form modern storm shingle beaches with classic high angle beach faces at Racecourse, Riddoch, and Brown Bays (Figure 5.13). A well-defined shore platform developed on Gambier Limestone occurs seaward of the shingle beach deposits and is commonly exposed at low tide. The main road (Eight Mile Creek Road) is constructed along a ridge of these flint cobblestone gravels. The crests of the shingle beach ridges are higher than the hinterland, which they protect. As a result, a network of drains was constructed for agricultural purposes to avoid flooding of the low-lying hinterland. Flap gates have also been used to prevent the sea from flooding back at high tide.

The cobble beaches have been 'hand mined' intermittently since 1909 as a source of flint for ball mills and high-grade silica for cements. ${ }^{55}$ In much earlier times, Aboriginal people produced cutting and piercing tools from the flint, and there is evidence that the flint was traded considerable distances inland. The Piccaninnie Ponds Conservation Park occupies the easternmost sector of the coastline, which is $5 \mathrm{~km}$ long, to the border of South Australia and Victoria; it contains karst features including caves and sinkholes developed in the Gambier Limestone.

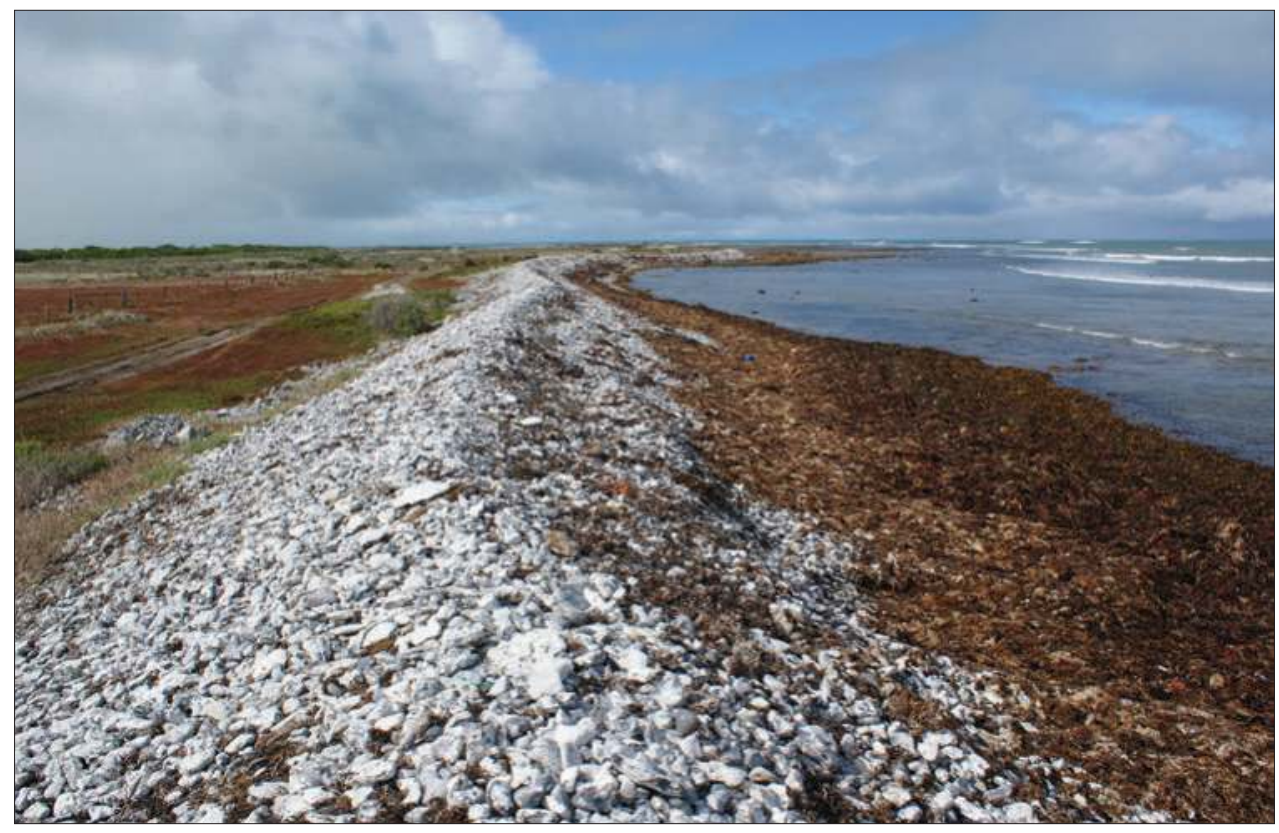

Figure 5.13 A modern storm beach with a classic high angle beach face comprising cobbles of flint, east of Port MacDonnell.

Source: Author's own work, CMW. 


\subsection{Quaternary volcanism}

Although the volcanic landscapes of southern South Australia do not occur at the modern coastline, deeply emplaced intrusions of magmas have driven coastal uplift, partly accounting for the formation of coastal cliffs developed on the aeolianites of Robe Range. Situated $22 \mathrm{~km}$ north of the modern coastline, Mount Gambier is a site of significant Holocene volcanism in Australia. ${ }^{56}$ Mount Gambier and Mount Schank (12 km inland from the modern coastline) are Holocene volcanoes that resulted from basaltic phreatomagmatic explosions, which involve both magma and water. These two eruptive complexes are among the youngest in a province of several hundred centres distributed over a very wide area of southeastern Australia and extending across much of western Victoria. ${ }^{57}$ Magmas were derived by partial melting of basanite parent materials in either deep crustal or upper mantle environments. An older group of eruptive centres with lava flows, composite domes, cones and maars occur northwest of Mount Gambier (the Mount Burr group). These exhibit erosional modifications by Pleistocene high sea levels ${ }^{58}$, and are locally covered in places by shoreline sands, which are estimated to be older than $400 \mathrm{ka}$, although they have not yet been reliably dated.

Radiocarbon dating of charcoal associated with volcanic ash, along with luminescence dating of quartz sand and baked tuffs buried beneath lava flows, indicate that the Mount Gambier and Mount Schank eruptions occurred between 5 to $4.2 \mathrm{ka}$ ago. ${ }^{59}$ Low maars, lava flows and scoria cones developed before a series of dramatic phreatomagmatic explosions. Ash, lapilli and volcanic bombs formed layered deposits up to $8 \mathrm{~km}$ from the source vents, with an estimated tephra volume of $\sim 1.3 \mathrm{~km}^{3}$ ejected. No modern eruptions have been observed, although Aboriginal legends indicate human witness to such events within the province. ${ }^{60}$ It has been suggested that geologically recent submarine lava flows on the Bonney shelf are broadly coincident with the location of epicentres of the 1897 and 1948 earthquakes. ${ }^{61}$

\subsection{Soils, paleosols, calcrete and karst}

Soils have progressively developed over the calcareous dune ranges and interdune flats throughout the Quaternary. The exact distinction between modern and ongoing soil development and paleosols is not always easy to establish. Paleosols are soils of the geological past and are indicative of periods of landscape stability or cessation of dune deposition. Calcrete paleosols are particularly well developed along the Limestone Coast, preserving fragile dunes.

Calcrete formation involves leaching and re-precipitation of calcium carbonate within sediments above the water table. Carbonate soil profiles formed on and within the Bridgewater Formation vary greatly in nature, thickness and induration. They include chalky, peloidal, nodular and laminar calcrete forms that reflect variable degrees 


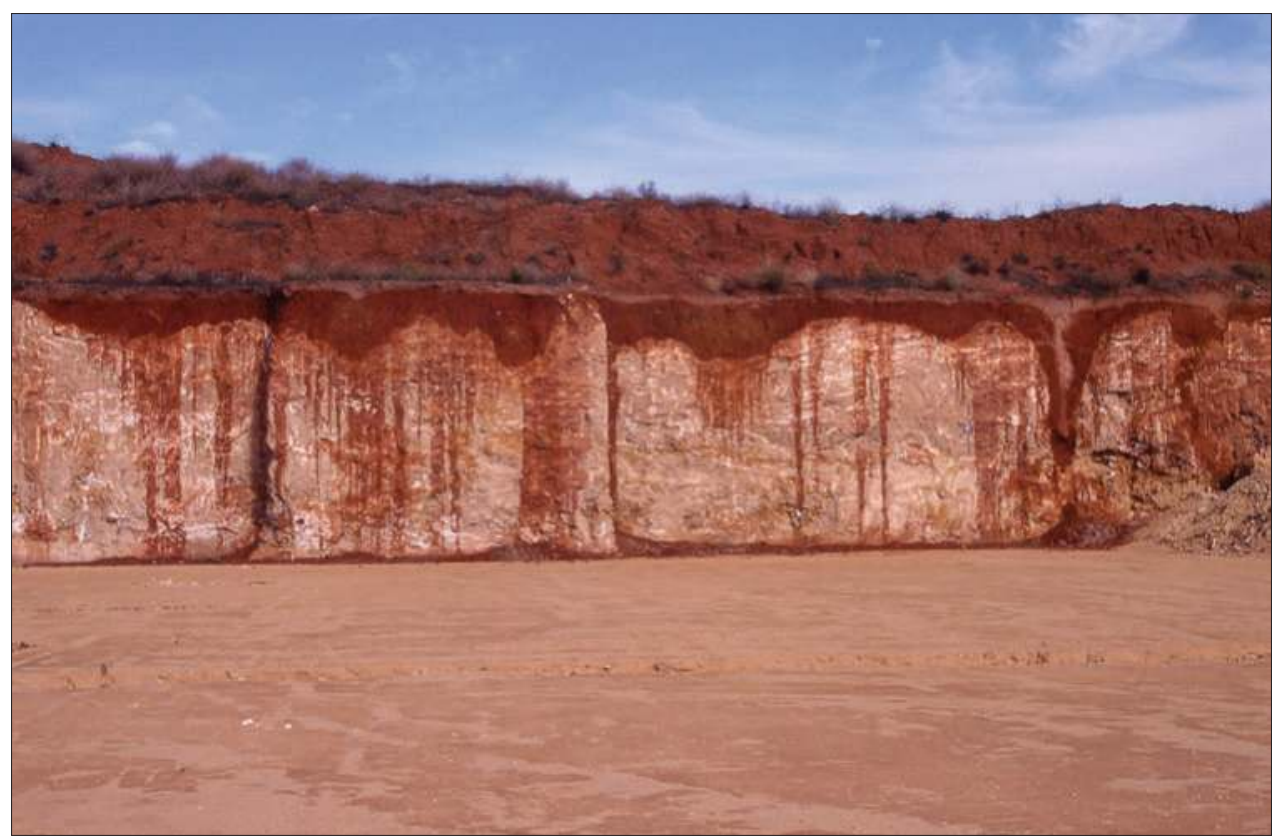

Figure 5.14 A terra rossa soil developed on dune limestone of the Bridgewater Formation at Wrattonbully Quarry near Naracoorte. The soil has an irregular base and the profile varies considerably in its thickness laterally. Reworked soil as a result of excavation work has been placed on the in situ terra rossa soil.

Source: Author's own work, CMW.

of soil development, truncation and alteration. Lithification of the differentiated horizons to form carbonate hard pans with a high preservation potential is common.

Calcretes of the Limestone Coast are associated with two Great Soil Groups: podzols with well-developed siliceous sand profiles, and terra rossas with distinctive uniform red earth profiles (Figure 5.14). ${ }^{62}$ In both groups, there are sharp transitions to underlying, case-hardened limestone (calcrete) and a more diffuse transition to the parent material of weakly consolidated calcarenite. Terra rossa soil is essentially residual, derived from the acid-insoluble residue of the underlying parent calcarenite, with probable contributions of aeolian-derived silt from adjacent lagoonal plains. Small-scale terra rossa soil development associated with internally draining topographic depressions can be seen in a number of drain cuttings east of Robe. Terra rossa soil occurs extensively between Coonawarra and Penola, where it is a critical component of Australia's premier red wine district. Terra rossa appears to be best developed on the seaward toes of the calcarenite dune ranges close to, or associated with, lagoonal 
facies. With increasing age of barriers, the terra rossa soils show progressively deeper soil profile development, thicker calcareous subsoil horizons, incipient ferruginous and manganiferous pisoliths and deeper solution pipes. ${ }^{63}$

The Limestone Coast experiences a seasonally wet, humid to subhumid climate and hosts a variety of temperate climate karst features. Karst refers to weathering forms developed on limestone as a result of its dissolution by weak acids such as carbonic acid. Characteristic features of karst landscapes include the general absence of welldefined river channels and surface drainage, the presence of enclosed depressions in the land surface, sinkholes, subterranean drainage and caves. Karst features that developed in calcareous dunes of the Bridgewater Formation include clay-pots, karst pavements, horizontal solution features and some cave development along the coast. ${ }^{64}$ Karstrelated landforms in the Gambier Limestone are more spectacular and extensive than in the younger dune limestones of the Pleistocene Bridgewater Formation, and include karren (small grooves on limestone), large cenotes (collapse sinkholes partly filled with water), dolines (large enclosed circular depressions) and joint-controlled cave systems.

Accessible caves in the Mount Gambier area include Tantanoola Cave, with welldeveloped speleothems, Umpherston Cave, Engelbrecht Cave and Mitchell Cave (Cave Gardens, Mount Gambier). Collapses intersecting the present-day water table (cenotes) include Little Blue Lake and Hells Hole, while The Shaft forms a spectacular waterfilled collapse chamber with a narrow entrance. The depth to which karst features have developed increases towards the coast due to an increasing thickness of the Gambier Limestone and lower sea levels and water tables during Pleistocene glacial periods.

\subsection{Evolution of the Coorong and Limestone Coasts during the} past 2 million years

The modern coastal landscapes of the Coorong Coastal Plain and Limestone Coast are part of an older sequence of coastal landforms that extend up to $500 \mathrm{~km}$ inland from the present coastline towards the margin of the Murray Basin. Coastal barrier and shallow marine sedimentation began some time before $6 \mathrm{Ma}$ ago in the Late Miocene; progressively, through time, a succession of several hundred coastal barriers developed. Through the combined effects of regional uplift and repeated cycles of global sea level change, associated with the waxing and waning of continental ice sheets, a succession of shoreline deposits has been preserved across the basin.

The relict shoreline successions are coastal barrier complexes formed during interglacial high sea level stands similar to the present Holocene interglacial. The relict shoreline features have formed in a similar manner to the modern Younghusband Peninsula, which was initiated with the most recent attainment of high sea level some 7000 years ago. Between Robe and Naracoorte, up to 18 coastal barriers have been identified, although they are not all present in a single line of cross-section. ${ }^{65}$ They 
are locally termed 'dune ranges' and have been assigned names. The individual relict shoreline features in their lees preserve estuarine-lagoonal deposits commonly with fossil marine shells, as seen in the Woakwine Range in the McCourt Cutting, Drain L, and other exposures through the dune range. The relict shoreline complexes attain heights of up to $30 \mathrm{~m}$ above the general level of the coastal plain and in cross-section are between 1 to $3 \mathrm{~km}$ wide. They have been preserved as a result of long-term uplift and pervasive, protective calcrete development.

Each dune range is progressively younger in age in a seaward direction by about 100000 years. In a transect from Robe to Naracoorte, the uplift rate of the coastal plain is $70 \mathrm{~mm} / \mathrm{ka}$ and increases to $130 \mathrm{~mm} / \mathrm{ka}$ in the Mount Gambier region. ${ }^{66}$ The rate of uplift progressively declines in a northwesterly direction towards the Murray River mouth region, where a history of subsidence is evident. ${ }^{67}$ Collectively, the relict coastal landforms indicate that interglacial sea levels returned to a broadly similar level and did not differ by more than $6 \mathrm{~m}$ for each interglacial over the past $1 \mathrm{Ma}^{68}$ The low gradient $(0.5 \%)$ of the coastal plain, however, has ensured that the individual barriers are physically separated and up to $10 \mathrm{~km}$ apart. ${ }^{69}$

The sources of the sediment for these coastal successions were the Lacepede and Bonney Shelves, which represent a subtidal carbonate factory with the profilic growth of calcareous marine invertebrates such as molluscs, bryozoans, coralline algae, echinoids, and foraminifers. ${ }^{70}$ The post mortem attrition of these organisms leads to the formation of sand-sized sedimentary particles of calcium carbonate, which are entrained landward across the inner continental shelf by high-energy swell and stormgenerated waves. Once the sediment is brought to the beach, upon drying, onshore winds transport the sediment landward. There, it accumulates in the form of coastal dunes, where it may with the passage of time become partially cemented to form aeolianite (dune limestone). Cementation involves the dissolution and re-precipitation of calcium carbonate grains. The River Murray delivers the non-carbonate mineral components (for example, quartz and heavy minerals) to the Lacepede Shelf. Along the Coorong and Limestone Coasts, these processes have dominantly occurred during periods of sea level rise (transgression) and during sea level highstands. As sea level rises, the coastline is forced landwards and sediments formerly on the inner shelf are concentrated and accumulate to form barrier shoreline structures. Once a sea level highstand is attained, sediment remaining on the inner shelf will continue to be supplied to the coast, provided that it is above storm wave base. Reworking of sedimentary carbonates and formation of localised dune deposits may also occur at times of lower sea level when the continental shelves are subaerially exposed.

Geologically, the most recent phase of landscape development of the Coorong and Limestone Coasts has occurred during the past 7000 years, accompanying the attainment of the current sea level highstand. This led to the formation of Younghusband Peninsula, the Coorong Lagoon and other coastal lagoons to the south of the Coorong. 
During this time the dune limestone of Robe Range was covered by modern dunes. In the early phase of the development of Younghusband Peninsula, large back-barrier coastal lagoons would have marked the lee of the feature. The lagoons have subsequently contracted in size through the combined effects of sediment infilling (aggradation) and gradual uplift of the regional landscape.

\subsection{Summary and conclusions}

The Coorong and Limestone Coasts are highly dynamic landscapes. The sediments of these coastal landforms have been derived principally from the adjacent continental shelf and have been entrained landwards by a complex set of wave-related and aeolian processes. The absence of rivers within the region has greatly curtailed the supply of terrestrial sediment to these coastal landforms. The River Murray at the northern extremity of this coastal sector is the main source of terrestrial sediment deposited on the Lacepede Shelf. Sea level changes associated with the waxing and waning of the continental ice sheets have repeatedly exposed the Lacepede and Bonney Shelves. Successive rises in sea level following glaciations have led to a concentration of shelfderived sediment to produce barrier shorelines such as Younghusband Peninsula. The geological record tends to preserve evidence for barrier features associated with interglacials, formed at times of highest sea levels and lowest continental ice volumes. Coastal barriers associated with warm interstadials such as Robe Range are less likely to be preserved, explaining the significant erosion experienced by this shoreline complex. A series of volcanoes erupted in the Mount Burr-Mount Gambier region during the Quaternary, and crustal uplift along the southern Limestone Coast, important in preserving the paleoshorelines, appears to relate to the emplacement of igneous intrusions within the lower crust.

\section{Notes}

1 Sprigg, R.C. (1952). The geology of the South-East Province, South Australia, with special reference to Quaternary coast-line migrations and modern beach developments. Geological Survey of South Australia, Bulletin 29, 120 pp.

2 Murray-Wallace, C.V., Bourman, R.P., Prescott, J.R., Williams, F., Price, D.M. \& Belperio, A.P. (2010). Aminostratigraphy and thermoluminescence dating of coastal aeolianites and the later Quaternary history of a failed delta: The River Murray mouth region, South Australia. Quaternary Geochronology, 5, 28-49.

3 Alley, N.F. \& Lindsay, J.M. (1995). Tertiary. In: Drexel, J.F. \& Preiss, W.V. (Eds), The geology of South Australia. Vol. 2, The Phanerozoic. Geological Survey of South Australia, Bulletin 54, pp. 150-217.

4 Twidale, C.R., Campbell, E.M. \& Bourne, J.A. (1983). Granite forms, karst and lunettes. 
In: M.J. Tyler, C.R. Twidale, Ling, J.K. \& Holmes, J.W. (Eds), Natural history of the south east. Royal Society of South Australia, pp. 25-37.

5 Sprigg (1952); Blakemore, A.G., Murray-Wallace, C.V., Westaway, K.E. \& Lachlan, T.J. (2015). Aminostratigraphy and sea-level history of the Pleistocene Bridgewater Formation, Mount Gambier region, southern Australia. Australian Journal of Earth Sciences, 62, 151-169.

6 Cook, P.J., Colwell, J.B., Firman, J.B., Lindsay, J.M., Schwebel, D.A. \& von der Borch, C.C. (1977). The late Cainozoic sequence of southeast South Australia and Pleistocene sea level changes. BMR Journal of Australian Geology and Geophysics, 2, 81-88; MurrayWallace, C.V., Belperio, A.P. \& Cann, J.H. (1998). Quaternary neotectonism and intraplate volcanism: The Coorong to Mount Gambier Coastal Plain, southeastern Australia: A review. In: Stewart, I. \& Vita-Finzi, C. (Eds), Coastal tectonics, Geological Society, London, Special Publications, 146, 255-267.

7 Blackburn, G., Allison, G.B. \& Leaney, F.W.J. (1982). Further evidence of the age of tuff at Mt. Gambier, South Australia. Transactions of the Royal Society of South Australia, 106, 163-167; Smith, B.W. \& Prescott, J.R. (1987). Thermoluminescence dating of the eruption of Mt. Schank, South Australia. Australian Journal of Earth Sciences, 34, 335-342; Sheard, M.J. (1995). Quaternary volcanic activity and volcanic hazards. In: Drexel, J.F. \& Preiss, W.V. (Eds), The Geology of South Australia. Vol. 2, The Phanerozoic. Geological Survey of South Australia, Bulletin 54, pp. 264-268; Robertson, G.B., Prescott, J.R. \& Hutton, J.T. (1996). Thermoluminescence dating of volcanic activity at Mount Gambier, South Australia. Transactions of the Royal Society of South Australia. 120, 7-12.

8 Short, A.D. \& Hesp, P.A. (1982). Wave, beach and dune interactions in southeastern South Australia. Marine Geology, 48, 259-284.

9 James, N.P. \& Bone, Y. (2011). Neritic Carbonate Sediments in a Temperate Realm. Springer, Dordrecht, $254 \mathrm{pp}$.

10 Short \& Hesp (1982); Short, A.D. (2006). Beaches of the South Australian coast and Kangaroo Island: A guide to their nature, characteristics, surf and safety. Sydney University Press, Sydney, 346 pp.

11 Short \& Hesp (1982); Short (2006).

12 Short \& Hesp (1982).

13 Short \& Hesp (1982).

14 Short, A.D. \& Woodroffe, C.D. (2009). The coast of Australia. Cambridge University Press, Cambridge, 288 pp.

15 Halligan, G.H. (1906). Sand movement on the New South Wales Coast. Proceedings of the Linnean Society of New South Wales, 31, 619-640; and Chapman, D.M. (1978). Zetaform or Logarithmic Spiral Beach. Australian Geographer, 14, 44-45.

16 Harvey, N., Bourman, R.P. \& James, K. (2006). Evolution of the Younghusband Peninsula, South Australia: New evidence from the Northern Tip. South Australian Geographical Journal, 105, 37-50.

17 England, R. (1993). The cry of the Coorong. S.E. Kingston, Leader, 48 pp.

18 Williams, M. (1964). The historical geography of an artificial drainage system: The lower south-east of South Australia. Australian Geographical Studies, 2, 87-102. 
19 Noye, B.J. (1973). The Coorong - Past, present, future. The University of Adelaide, Department of Adult Education, Publication No. 38, 47 pp.

20 Cann, J.H. \& Murray-Wallace, C.V. (2012). Interstadial age (MIS 5c) beach-dune barrier deposits in the Coorong Lagoon, South Australia. Australian Journal of Earth Sciences, 59, 1127-1134.

21 Brown, R.G. (1965). Sedimentation in the Coorong lagoon, South Australia. Unpublished $\mathrm{PhD}$ thesis, The University of Adelaide.

22 Cann, J.H., Murray-Wallace, C.V., Belperio, A.P. \& Brenchley, A.J. (1999). Evolution of Holocene coastal environments near Robe, southeastern South Australia. Quaternary International, 56, 81-97.

23 von der Borch, C.C. (1965). The distribution and preliminary geochemistry of modern carbonate sediments of the Coorong area, South Australia. Geochimica et Cosmochimica Acta, 29, 781-799.

24 Cann \& Murray-Wallace (2012); Huntley, D.J. \& Prescott, J.R. (2001). Improved methodology and new thermoluminescence ages for the dune sequence in south-east South Australia. Quaternary Science Reviews, 20, 687-699.

25 von der Borch, C.C. (1976). Stratigraphy and formation of Holocene dolomitic carbonate deposits of the Coorong area, South Australia. Journal of Sedimentary Petrology, 46, 952-966.

26 von der Borch, C.C. \& Lock, D. (1979). Geological significance of Coorong dolomites. Sedimentology, 26, 813-824.

27 Rosen, M.R., Miser, D.E. \& Warren, J.K. (1989). Sedimentology, mineralogy and isotopic analysis of Pellet Lake, Coorong region, South Australia. Sedimentology, 35, 105-122.

28 Brown (1965).

29 Bourman, R.P. \& Harvey, N. (1986). Landforms. In: Nance, C. \& Speight, D.L. (Eds), A land transformed: Environmental change in South Australia. Longman Cheshire, Sydney, pp. 78-125.

30 Harvey, Bourman \& James (2006); Bourman, R.P., Murray-Wallace, C.V., Belperio, A.P. \& Harvey, N. (2000). Rapid coastal geomorphic change in the River Murray Estuary of Australia. Marine Geology, 170, 141-168.

31 Bourman, R.P. \& Murray-Wallace, C.V. (1991). Holocene evolution of a sand spit at the mouth of a large river system: Sir Richard Peninsula and the Murray Mouth, South Australia. Zeitschrift für Geomorphologie, Suppl.-Bd. 81, 63-83.

32 Gilbertson, D.D. (1978). The Off-road use of vehicles and aspects of the bio-physical systems of the Lower Coorong region, In: Gilbertson, D.D. \& Foale, M.R. (Eds), The Southern Coorong and Lower Younghusband Peninsula of South Australia. Nature Conservation Society of South Australia Inc., Adelaide.

33 Sprigg (1952); Murray-Wallace, Bourman, Prescott, Williams, Price \& Belperio (2010); Blakemore, Murray-Wallace, Westaway \& Lachlan (2015); Huntley, D.J., Hutton, J.T. \& Prescott, J.R. (1993). The stranded beach-dune sequence of south-east South Australia: A test of thermoluminescence dating, 0-800 ka. Quaternary Science Reviews, 12, 1-20; Huntley, D.J., Hutton, J.T. \& Prescott, J.R. (1994). Further thermoluminescence dates from the dune sequence in southeast of South Australia. Quaternary Science Reviews, 13, 201-207; Murray-Wallace, C.V., Belperio, A.P., Bourman, R.P., Cann, J.H. \& Price, D.M. 
(1999). Facies architecture of a last interglacial barrier: A model for Quaternary barrier development from the Coorong to Mount Gambier Coastal Plain, southeastern Australia. Marine Geology, 158, 177-195; Blakemore, A., Murray-Wallace, C.V. \& Lachlan, T.J. (2014). First recorded evidence of subaqueously-deposited late Pleistocene interstadial (MIS 5c) coastal strata above present sea level in Australia. Marine Geology, 355, 377-383. South Australia, Bulletin 54, pp. 54-57.

37 Sprigg (1952); Thom, B.G., Bowman, G.M., Gillespie, R., Temple, R. \& Barbetti, M. (1981). Radiocarbon dating of Holocene beach-ridge sequences in southeast Australia. Monograph 11, University of New South Wales, Department of Geography; MurrayWallace, C.V., Banerjee, D., Bourman, R.P., Olley, J.M. \& Brooke, B.P. (2002). Optically stimulated luminescence dating of Holocene relict foredunes, Guichen Bay, South Australia. Quaternary Science Reviews, 21, 1077-1086.

Subcommittee, 10 pp. <www.sa.gsa.org.au>.

41 Schwebel, D.A. (1984). Quaternary stratigraphy and sea-level variation in the southeast of South Australia. In: Thom, B.G. (Ed.), Coastal geomorphology in Australia. Academic Press, Sydney, pp. 291-311; Murray-Wallace, C.V. \& Woodroffe, C.D. (2014). Quaternary sealevel changes: A global perspective. Cambridge University Press, Cambridge, 484 pp.

42 Huntley, Hutton \& Prescott (1994); Banerjee, D., Hildebrand, A. N., Murray-Wallace, C.V., Bourman, R.P., Brooke, B.P. \& Blair, M. (2003). New quartz SAR-OSL ages from the stranded beach dune sequence in south-east South Australia. Quaternary Science Reviews, 22, 1019-1025.

43 Belperio, A.P. (1995). The Quaternary. In: Drexel, J.F. \& Preiss, W.V. (Eds), The geology of South Australia. Vol. 2, The Phanerozoic. Geological Survey of South Australia, Bulletin 54, pp. 218-281.

44 Murray-Wallace, Belperio, Bourman, Cann \& Price (1999).

45 Murray-Wallace, Belperio, Bourman, Cann \& Price (1999).

46 Cann, Murray-Wallace, Belperio \& Brenchley (1999).

47 Cann, J.H. \& Murray-Wallace, C.V. (1999). Source of food items in an Aboriginal midden at Little Dip, near Robe, southeastern South Australia: Implications for coastal geomorphic change. Transactions of the Royal Society of South Australia, 123, 43-51.

48 Environment Protection Authority (2004). Lake Bonney South East, South Australia: Past, present and possible future. Environment Protection Authority, South Australia. 16 pp.

49 Woods, J.E.T. (1862). Geological observations in South Australia. Green, Longman, Roberts \& Green, London. 
$$
\text { Publication 23, pp. 361-375. }
$$

58 Sprigg (1952); Blackburn, G., Bond, R.D. \& Clarke, A.R.P. (1965). Soil development associated with stranded beach ridges in southeast South Australia. CSIRO Soil Publication, 22. Commonwealth Scientific and Industrial Research Organization, Australia, Melbourne, $66 \mathrm{pp}$.

59 Blackburn, Allison \& Leaney (1982); Smith \& Prescott (1987); Sheard (1995); Robertson, Prescott \& Hutton (1996); Blackburn, Bond \& Clarke (1965).

60 Smith, C. (1880). Booandik tribe of South Australian aborigines: A sketch of their habits, customs, legends and language. Government Printer, Adelaide, $150 \mathrm{pp}$.

${ }_{61}$ Sprigg, R.C. (1959). Presumed submarine volcanic activity near Beachport, South-East South Australia. Transactions of the Royal Society of South Australia, 82, 195-203.

62 Blackburn, Bond \& Clarke (1965).

63 Blackburn, Bond \& Clarke (1965).

64 Twidale, Campbell \& Bourne (1983).

65 Sprigg (1952); Hossfeld, P.A. (1950). The Late Cainozoic history of the south-east of South Australia. Transactions of the Royal Society of South Australia, 73, 232-279.

${ }^{66}$ Murray-Wallace, C.V., Belperio, A.P., Bourman, R.P., Cann, J.H., Huntley, D.J. \& Prescott, J.R. (1996). Late Quaternary uplift history, Mount Gambier region, South Australia. Zeitschrift für Geomorphologie, Suppl.-Bd. 106, 41-56.

${ }_{67}$ Murray-Wallace, Bourman, Prescott, Williams, Price \& Belperio (2010); Bourman, Murray-Wallace, Belperio \& Harvey (2000); Bourman \& Murray-Wallace (1991).

68 Belperio (1995).

69 Murray-Wallace, Belperio \& Cann (1998).

70 James \& Bone (2011); Murray-Wallace, C.V. (2014). The continental shelves of SE Australia. In: Chiocci, F.L. \& Chivas, A.R. (Eds), Continental shelves of the world: Their evolution during the last glacio-eustatic cycle. Memoirs 41, Geological Society, London, 273-291. 


\section{The northern Gulf St Vincent tidal coastline (the Samphire Coast)}

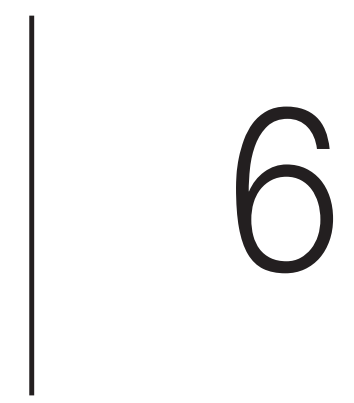

\subsection{Introduction}

The northern coastline of Gulf St Vincent (GSV) is a low-energy environment dominated by wide tidal flats with a peritidal sequence of subtidal seagrass meadows, intertidal sandflats and mangroves, and supratidal saline marshland. ${ }^{1}$ The broad form of the coast reflects the dominance of intertidal processes and their interrelationships with peritidal fauna and flora. Seagrasses thrive in the subtidal and intertidal shallow warm waters, with extremely productive calcareous algae, foraminifers and molluscan organisms manufacturing vast amounts of calcareous sediment. The accumulation of these biogenically derived sediments has generated the resultant wide intertidal and supratidal flats visible today by causing the shoreline to aggrade (build up) and prograde (build seawards). ${ }^{2}$

Most of the northern GSV coast is bordered by mangroves (Figure 6.1), which occur from the Port River Estuary on the eastern side of the gulf around to Price on the northwestern side of the gulf. ${ }^{3}$ The mangrove woodlands are quite extensive around Barker Inlet, Middle Beach and the Light River delta on the eastern side of the gulf $f^{4}$, at the northernmost part of GSV north of Sandy Point, Port Wakefield and continuing through the head of GSV to its western side around Port Clinton, Mangrove Point and Price. ${ }^{5}$ In the Barker Inlet, Caton et al. estimated that over 900 hectares (ha) is remnant vegetation, most of which is mangrove. ${ }^{6}$

An extensive area of the northern GSV mangroves occurs within the Clinton and Wills Creek Conservation Parks. The Clinton Conservation Park (1923 ha) is a boomerang-shaped reserve extending from Sandy Point through Port Wakefield and 
around the western side and head of the gulf, to just north of the township of Port Clinton. ${ }^{7}$ The Wills Creek Conservation Park (2130 ha) is situated at Mangrove Point on the northwestern shores of GSV and extends from Port Clinton south to the town of Price. ${ }^{8}$

An equally dominant feature of the northern GSV coastline is the extensive salt marsh environment occupying the intertidal to supratidal areas ${ }^{9}$ resulting in the GSV coast being referred to locally as 'the Samphire Coast'. This type of coast is particularly important for its conservation significance, given the loss of large areas of similar salt marsh environment on the metropolitan coast. ${ }^{10}$ Within the Gulf, it is estimated that there are 6000 ha of salt marsh on the eastern side, 2000 ha at the head of the gulf and around 4700 ha on the western GSV coast. ${ }^{11}$ The majority of salt marsh occurs in the northern GSV, although there are pockets further south.

\subsection{Geological setting}

The broad framework of the Gulf of St Vincent is due to Cenozoic faulting, resulting in subsidence of the gulf and uplift of Yorke Peninsula and, especially, of the Mount Lofty Ranges. The northwestern part of the gulf is closely constrained by the Ardrossan Fault, which broadly defines the eastern coast of Yorke Peninsula. However, the more detailed location of the coast relates to Quaternary alluvial and colluvial sediments, derived from the uplifted Yorke Peninsula, which have pushed the shoreline to the east. The roadway follows a low but persistent abandoned cliff line, which fringes the northwestern coast of GSV, cut into Quaternary alluvium. ${ }^{12}$ This stranded cliff was eroded during a relatively higher stand of the sea, probably during the Last Interglacial (125 ka). A series of faults trending north-south (the Templeton, Whitwarta and Redbanks faults) cuts across the northeastern coastline of the gulf and has formed the gulf lowland. ${ }^{13}$

However, it has been the deposition of the alluvial sediments of the Early Pleistocene Hindmarsh Clay, derived from the uplifted Mount Lofty Ranges and deepening westward, that influenced the more detailed position of the coastline, and provides the substrate for the modern coast. ${ }^{14}$ The Late Pleistocene Glanville Formation onlaps the thick alluvial plain sequence, demarking the position of the last interglacial shoreline $125 \mathrm{ka}$ ago. This corresponds closely with the modern shoreline deposits of the Holocene St Kilda Formation, which is $<6600$ years old. ${ }^{15}$ Subaerial exposure and pedogenesis separated the long time interval $(\sim 120 \mathrm{ka})$ between these two marine transgressions, cementing and calcreting the last interglacial deposits, and forming the foundation for the modern shoreline. Thus the present-day coastal morphology is largely inherited from last interglacial times. ${ }^{16}$ The Glanville Formation also provides a valuable datum from which to demonstrate dislocation of the last interglacial shoreline; in the Port Adelaide area, the Glanville Formation is 3 to $4 \mathrm{~m}$ lower than at Sandy Point and Port Wakefield, demonstrating subsidence of the Port Adelaide region relative to the head of the gulf due to compaction ${ }^{17}$ and tectonic activity. 


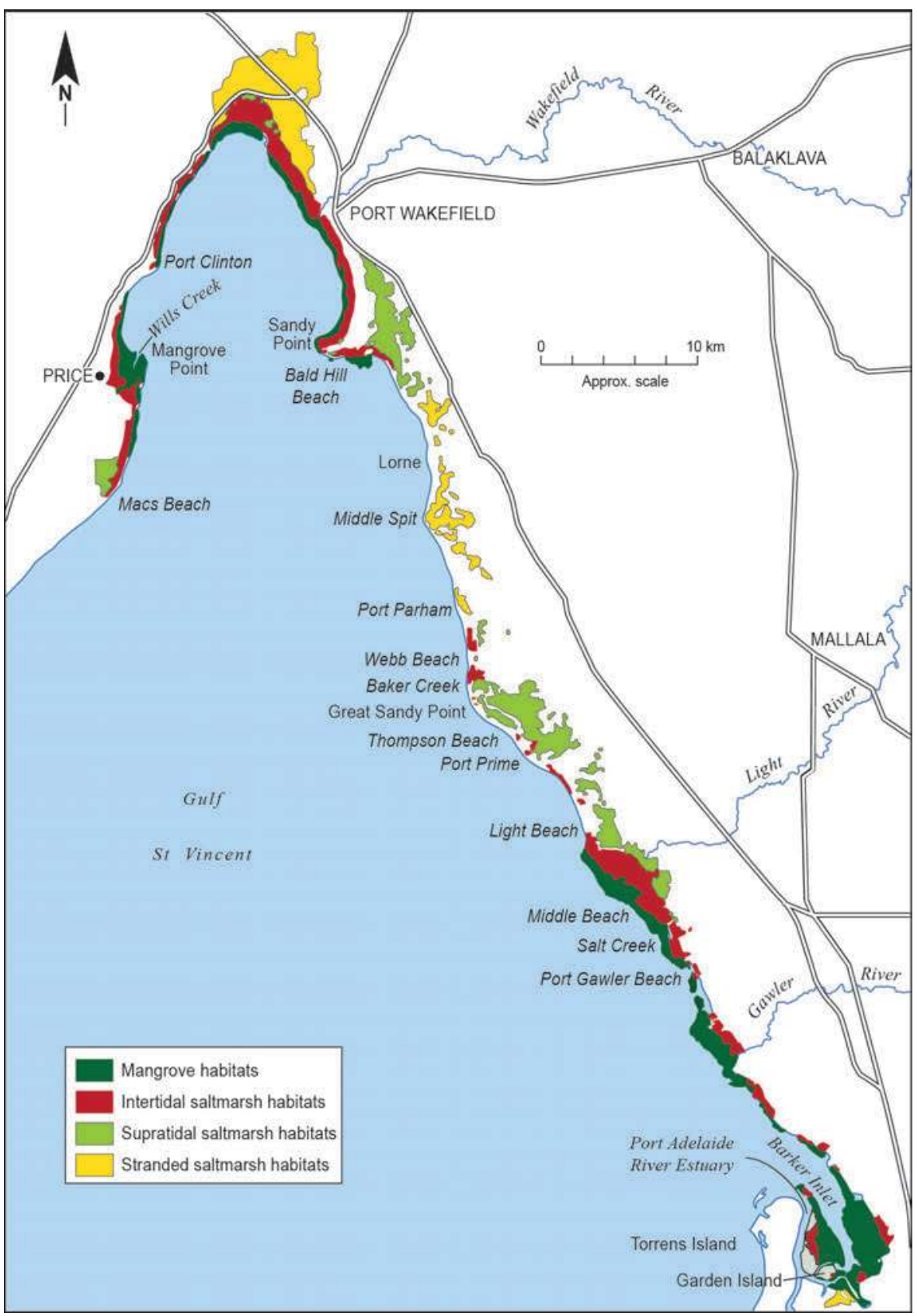

Figure 6.1 Map of northern Gulf St Vincent, indicating distribution of mangroves, samphires and salt marshes along with key locations referred to in the text.

Source: Modified from Fotheringham, D. \& Coleman, P. (2008). Salt marshes. In: Shepherd, S.A., Bryars, S., Kirkegaard, I., Harbison, P. \& Jennings, J.T. (Eds), Natural history of Gulf St Vincent. Royal Society of South Australia, Inc., Adelaide, pp. 81-94. Modified and reproduced with the permission of the Royal Society of South Australia. 
Sedimentation began in the St Vincent Basin during the Paleogene and Neogene Periods (66.0 to $2.6 \mathrm{Ma}$ ago) with the deposition of terrestrial freshwater sediments followed by marginal marine and later marine sediments, many of which outcrop on the coast from the middle to the lower parts of Gulf St Vincent. Paleogene-Neogene lignite deposits occur close to the coast in the northern part of the Gulf, particularly near Clinton, and are overlain by Paleogene-Neogene clay, silt and sand. However, it is the overlying Pleistocene and Holocene successions which have had most influence on the shoreline of the Upper Gulf St Vincent.

During the Pleistocene Epoch (2.59 Ma to $11.7 \mathrm{ka}$ ago), coastal sediments were dominated by the effects of multiple global glacio-eustatic sea level fluctuations, but there is only evidence for the last two of the high sea levels on the gulf margin. There is sedimentary evidence for a high sea level during the Last Interglacial some $125 \mathrm{ka}$ ago, when sea level was at least $2 \mathrm{~m}$ higher than present, and the climate was warmer and wetter than today. Peritidal and shallow marine sediments of the Glanville Formation, which crops out in the current supratidal zone, provide evidence of this event in the northern Gulf St Vincent. The Glanville Formation occurs as gravel beach ridge deposits from Port Wakefield to the southeast, decreasing in elevation from Port Wakefield to Port Gawler because of differential subsidence. ${ }^{18}$ During the Last Glacial Maximum some 20000 years ago, when sea level stood as much as $125 \mathrm{~m}$ BPSL, the current Gulf St Vincent was dry and streams from the Adelaide area continued across the exposed sea bed. ${ }^{19}$

Although the position of much of the northern Gulf St Vincent coast has been inherited from the Last Interglacial $(125 \mathrm{ka})^{20}$, during the most recent Holocene epoch (the past $11.7 \mathrm{ka}$ ), layers of sediment of the St Kilda Formation, which includes various deposits of marine origin, have been plastered onto the underlying Pleistocene sediments. ${ }^{21}$ The Holocene sedimentary successions in this area include coastal seagrass banks, mangrove deposits, coastal aeolian dunes, coastal gypsum and sandy beach and shell deposits. These Holocene sediments increase in thickness to the south as the elevation of the Glanville Formation progressively decreases due to subsidence. In the south, where greatest subsidence has occurred, Holocene sediments are $>10 \mathrm{~m}$ thick at Port Adelaide, 5 to $8 \mathrm{~m}$ at Torrens Island, and 2 to $5 \mathrm{~m}$ at St Kilda. In contrast, at Sandy Point and Port Wakefield in the north, the higher elevation of the Glanville Formation has inhibited significant intertidal accumulation, beach ridge construction and coastal progradation ${ }^{22}$ so that only thin layers of Holocene sediments have accumulated.

There is a paucity of terrestrial sediment input to the gulf coast due to its semiarid climate and an annual evaporation rate that exceeds precipitation from the predominantly winter rainfall. The lack of freshwater input and the high evaporation rates mean that more moisture leaves the northern parts of the gulf than enters it, making it an inverse estuary in which salinity increases towards the head of the estuary. ${ }^{23} \mathrm{~A}$ low-energy environment prevails in the upper parts of the gulf where the 
coastal processes are dominated by tides (tidal range $-3 \mathrm{~m}$ ) and local wind waves. ${ }^{24}$ This shallow, low-energy environment provides a suitable environment for carbonatesecreting biota such as molluscs, formanifers, bryozoans and coralline algae.

\subsection{Torrens Island and the Port River to Port Gawler}

A low-gradient coastal plain fringed by mangrove woodlands, mudflats and supratidal flats covered by samphire vegetation dominates the coast on the sheltered eastern side of Le Fevre Peninsula. These coastal environments are fronted by the low-energy estuarine environment of Barker Inlet and the Port Adelaide River. On the eastern side of the estuary, Torrens Island and Garden Island protect the mudflats and mangroves of the Angus and Barker Inlets, also creating a low-energy environment (Figure 6.2). Stands of mangroves occur on the eastern and southern sides of both islands, and their central areas contain samphires and cyanobacterial muds, artificially modified on Garden Island. On the northern side of the river, large sand deposits of the Section Banks (expanded by channel dredging and dumping) add further protection to this section of coast.

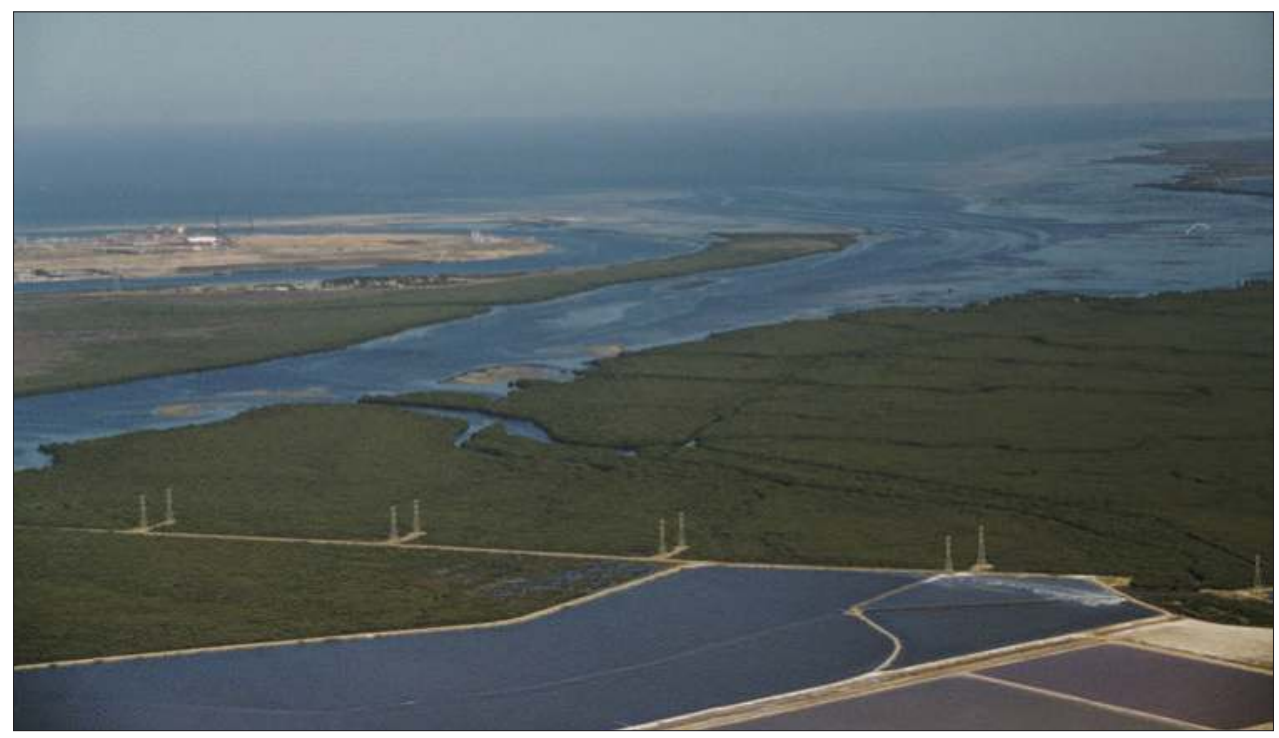

Figure 6.2 Mangroves of Barker Inlet constrained by levees for salt harvesting in the foreground, with the mangroves of the northern part of Torrens Island in the middle distance, and the Port River estuary and the northern tip of Le Fevre Peninsula and Section Banks in the distance.

Source: Reproduced with permission of the Coast Protection Board, 2005. 
Barker Inlet and the Port Adelaide River form a tidally dominated estuary with a catchment of $346 \mathrm{~km}^{2}$. In the southern part of the system, tidal water enters through the artificial West Lakes residential development, which has a marine intake at its southern end. This development cleared the original mangroves and salt marsh swamps when it was created in the mid-1970s. Similarly, there has been extensive modification of the original Port Adelaide River estuary. The low-lying coast around Port Adelaide, which is naturally subsiding, is subject to flooding, particularly during high tides and storm surges. The natural subsidence of the area has been been exacerbated by groundwater withdrawal. ${ }^{25}$

The dominant influences shaping the modern coastline are tidal flows associated with a strong zonation of subtidal through to supratidal vegetation, each producing a distinctive coastal sedimentary facies. ${ }^{26}$ Backing these environments, at slightly higher elevations, are beach ridges, low sand/shell grit dunes and occasional chenier ridges (storm-driven shelly deposits overlying muddy sediment).

The coast is made up of geologically very recent $(<7 \mathrm{ka})$ marginal marine sediments that form a flat topography. The shallow subtidal and intertidal vegetation is important both in hosting organisms that produce calcium carbonate and in promoting deposition of sediment, which leads to coastal aggradation and the progradation of the shoreline and its associated facies zones. ${ }^{27}$ The Posidonia australis seagrass in the subtidal zone grows predominantly on carbonate shelly sands, which form the seaward margins of the sandflat, and which can be observed at low tide. A Zostera seagrass facies occurs at a slightly higher elevation in the mid-tidal area associated with muddy carbonate/ quartz sand deposits. ${ }^{28}$ Here, the shallower water with subdued wave and tidal action encourages the deposition of fine organic rich sediment.

Landward of the two seagrass sedimentary facies is an intertidal zone of mangroves dominated by one species, Avicennia marina (the 'grey mangrove'). This sedimentary facies comprises carbonate quartz silts, muds and sands interspersed with organic material and cyanobacterial mats. ${ }^{29}$ The mangrove trees have a distinctive radial lateral root system with vertical pneumatophores of 20 to $30 \mathrm{~cm}$ protruding from the ground. The mangrove woodlands extend south around Torrens Island and the Barker Inlet, where they form an important part of an aquatic reserve. Since European settlement the mangroves in this area have advanced inland in response to relative sea level rise and have encroached into the supratidal lagoonal and samphire zone. ${ }^{30}$ This supratidal zone is less frequently inundated by the tides and is populated with carbonate-producing organisms, cyanobacterial mats and samphire vegetation, which traps sediment. Fine windblown carbonate sand, precipitation of calcium carbonate and high evaporation can produce gypsum. The samphire zone under normal conditions would migrate inland as its seaward margin is encroached by mangroves, but migration of both has been constrained in some places by artificial levees associated with industrial salt evaporation ponds. This constrained coastal migration of species has been referred to as 'coastal squeeze'. 
Within this flat coastal landscape, the only elevated coastal forms are the storm ridges/cheniers and sand dunes. The storm ridges are made up of storm-driven sand and shell detritus such as a large ridge $(1.5 \mathrm{~km}$ long and $2 \mathrm{~m}$ high) in the mangrove woodland south of the Gawler River. Inland, windblown sand has created some low sand dunes.

The Gawler River forms the northern boundary of this section of coast. It is an intermittent stream with seasonal winter flows, and it experiences flooding every 10 years or so. While historic flows have created localised coastal deltaic deposits, the river has very little influence on the present tidally dominated coast; it is only during heavy rainfall events that fine-grained deposits are transported and redistributed into the marine environment.

\subsection{Middle Beach to Light River Delta}

This section of coast is dominated by extensive mangrove woodland up to $1 \mathrm{~km}$ wide, backed by a low-gradient coastal plain. The mangroves in this area appear to be actively colonising the prograding intertidal flat. ${ }^{31}$ Middle Beach itself is just over $1 \mathrm{~km}$ in length and is mostly surrounded by mangroves (Figure 6.3). The exception is near the mouth of nearby Salt Creek, where an ebb tidal delta of silt and sandy sediment has

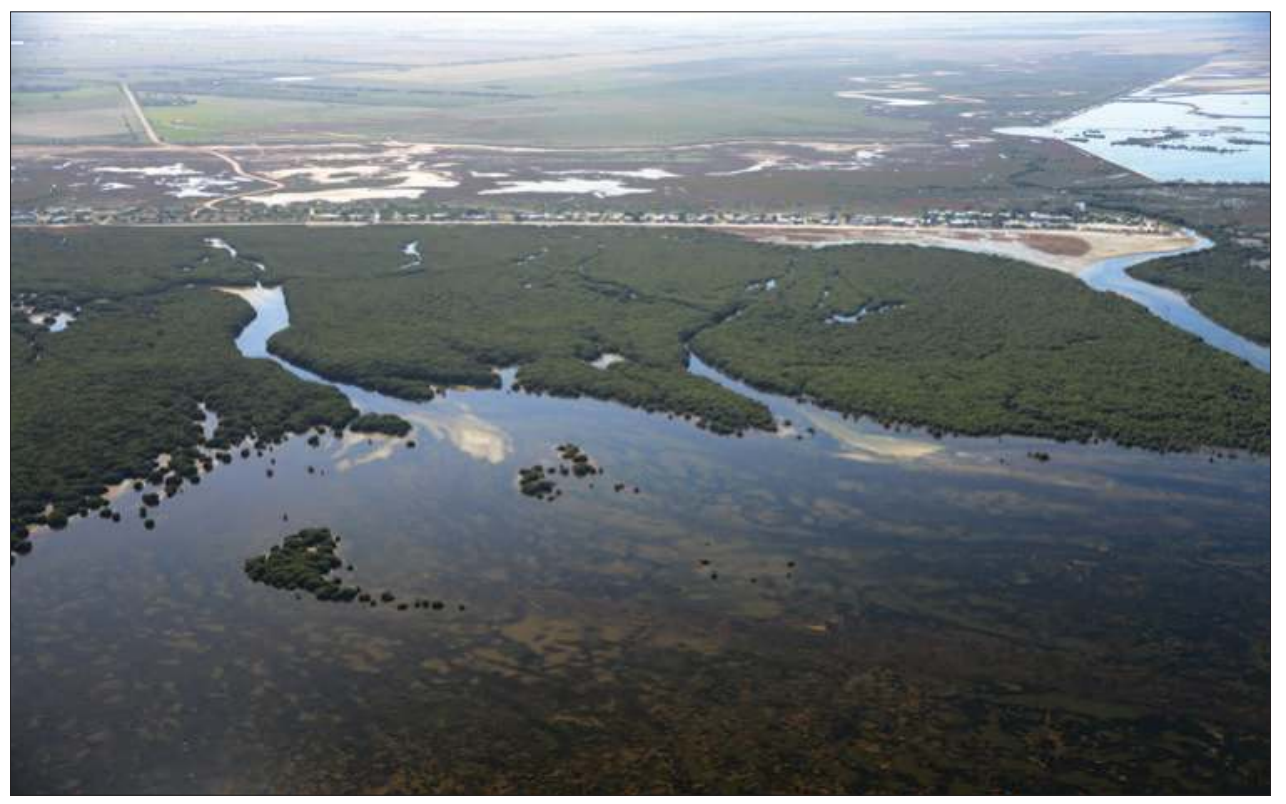

Figure 6.3 Middle Beach mangroves and seagrass beds in the foreground. Holiday homes have been constructed on the shell grit ridge behind the mangroves, and the Salt Creek outlet can be seen in the middle distance. In the far distance are salt evaporation pans.

Source: Reproduced with permission the of the Coast Protection Board, 2003. 


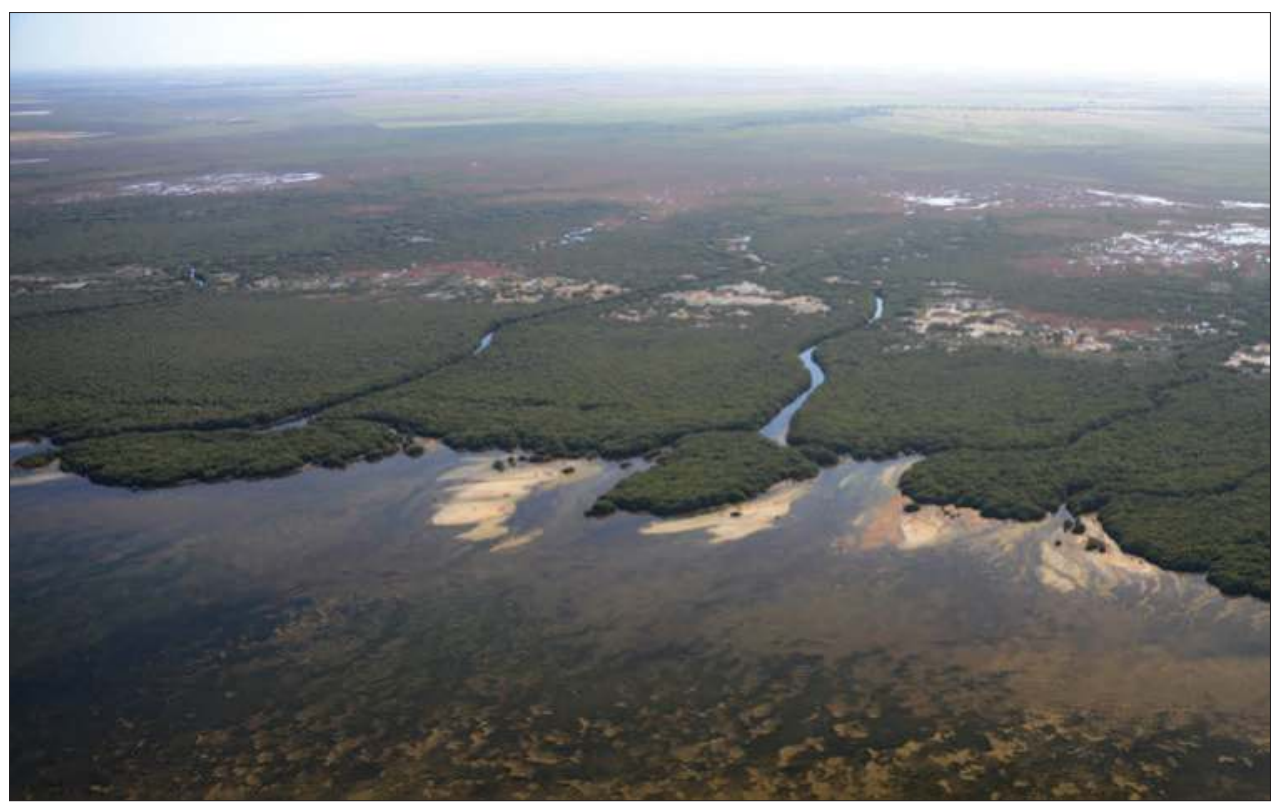

Figure 6.4 Light River Delta mangroves and seagrass beds in the foreground with ebb tide deltaic deposits of sand at the mouths of most mangrove creeks. A shore-parallel chenier/ sand ridge can be seen in the middle distance.

Source: Reproduced with permission of the Coast Protection Board, 2003.

formed across the mudflat. Similarly, a number of sandy ebb tide deltas occur further north at the mouths of various channels across the Light River Delta (Figure 6.4). The Light River catchment of just over $1000 \mathrm{~km}^{2}$ in area has limited freshwater flow. The delta has created a wide plain with distinct vegetation $z^{2} e^{32}$, associated with a succession of coastal forms. There are subtidal dense seagrass beds seaward of the mangroves, intertidal mangrove sediments about $1.5 \mathrm{~km}$ wide, intertidal samphire flats some $1.2 \mathrm{~km}$ wide, with supratidal samphire flats just under $1 \mathrm{~km}$ wide. There are also saline mudflats (sabkhas), which occur at higher elevations and are only inundated at spring high tides. The mangrove-dominated coastline continues from the delta north to Light Beach.

Other features of this coast are Holocene low sand and shell grit dunes, chenier ridges and beach ridges. The chenier ridges are storm-deposited sand and shell sediments that often appear as isolated and stranded ridges on mudflats within the mangroves. ${ }^{33}$ These are different in origin to beach ridges, which are formed at the back of the beach from wave- and wind-driven sediments, although in places the beach ridge and storm deposits are intermixed. At the southern part of this coastal section, 
there is a wide chenier/beach ridge plain, which has been heavily impacted by offroad recreational vehicles. ${ }^{34}$ On the Light River Delta plain, a number of chenier/ sand ridges extend inland to within $3 \mathrm{~km}$ of the seaward edge of the mangroves. It is uncertain what component of these are storm-driven chenier deposits or fossil beach ridges on an accreting coastal plain.

\subsection{Light Beach to Sandy Point}

The majority of this coastal section is a low-energy sandy coast with dense nearshore seagrass beds, an intertidal sandflat up to $1 \mathrm{~km}$ wide, a sandy shell grit beach backed by a very low-gradient coastal plain with an extensive salt marsh (Figure 6.5a) and numerous sabkhas. ${ }^{35}$ There are no rivers along this section of coast and, apart from tidal creeks, most drainage channels are blocked by the ridges or dunes and do not break through to the sea.

North of Light Beach and immediately southeast of Port Prime, a distinctive curvilinear series of beach ridges (Figure 6.5b), similar to the Le Fevre Peninsula beach ridge sequence discussed in Chapter Two, indicates a period of rapid coastal sedimentation. The close spacing of these ridges indicates a rapid sand/shell grit infill of the southwest-facing bay in a low-energy environment. The ridge sequence is widest

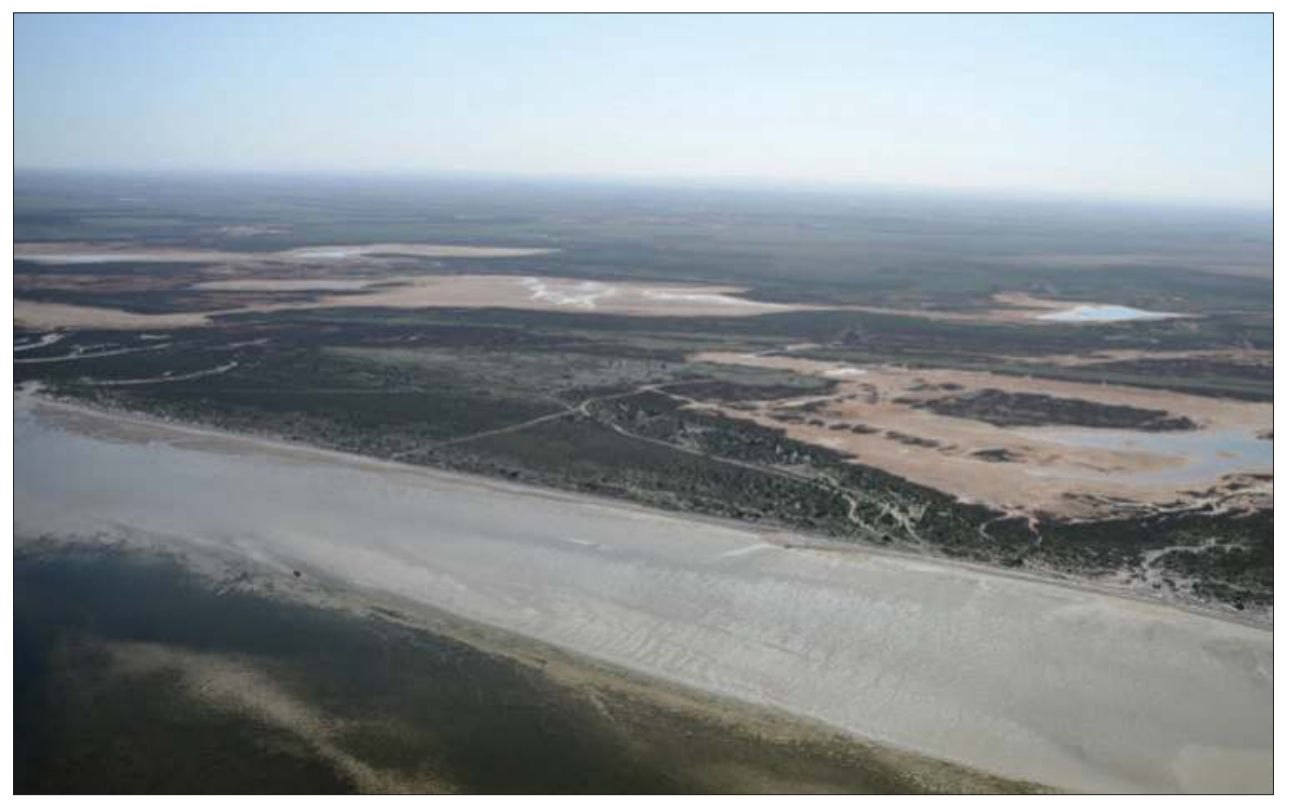

Figure 6.5a Light Beach, showing a wide intertidal sandflat, a sandy shell grit beach backed by a very low-gradient coastal plain with extensive salt marsh and sabkhas in background. Source: Reproduced with permission of the Coast Protection Board, 2014. 


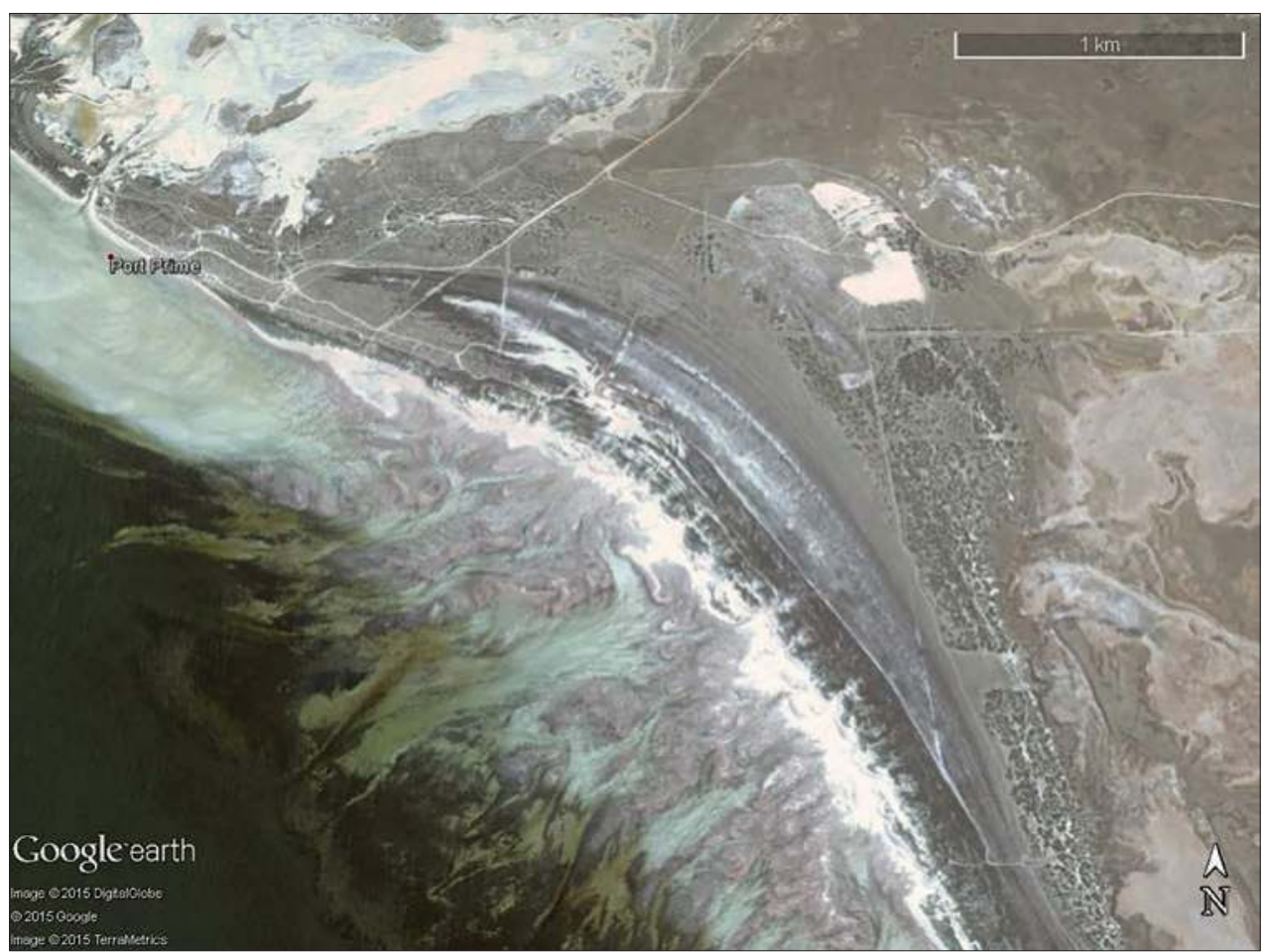

Figure 6.5b This Google Earth image of north of Light Beach shows a distinctive curvilinear series of beach ridges. The close spacing of these ridges indicates a rapid sand/shell grit infill of the southwest-facing bay in a low-energy environment. The ridge sequence is widest toward the Prime Beach road but becomes narrower toward the south.

Source: Google Earth image @ 2015 Google.

toward the Prime Beach road, but narrows towards the south. Behind the beach ridges, large areas of supratidal samphire and sabkhas or bare saline flats extend along the coast. ${ }^{36}$ Farther inland, some aeolian dunes, possibly of last glacial maximum times (about $20 \mathrm{ka}$ ), and which align with Pleistocene arid wind phase directions, are not related to current coastal processes. ${ }^{37}$ However, these dunes formed when the present gulf was exposed as dry land at a time of lower sea level, and the dune sand would have been incorporated into the coastal sediments as the sea rose to its present level.

The juxtaposed subtidal dense seagrass beds and a wide low intertidal sand- and mudflat, with stretches of bare sandflats, extend north to Port Prime (Figure 6.6), Thompson Beach and Great Sandy Point. ${ }^{38}$ The sandflat is flanked by a fairly steep and narrow sandy/shelly beach backed by low dune/beach ridges and an extensive salt marsh plain with cheniers up to $2 \mathrm{~m}$ high. The sandy/shelly dunes in places reach up to $300 \mathrm{~m}$ inland. North of Port Prime, in a section of coast around Thompson Beach (Figure 6.7) and Great Sandy Point, there are no direct tidal inlets, and the supratidal 


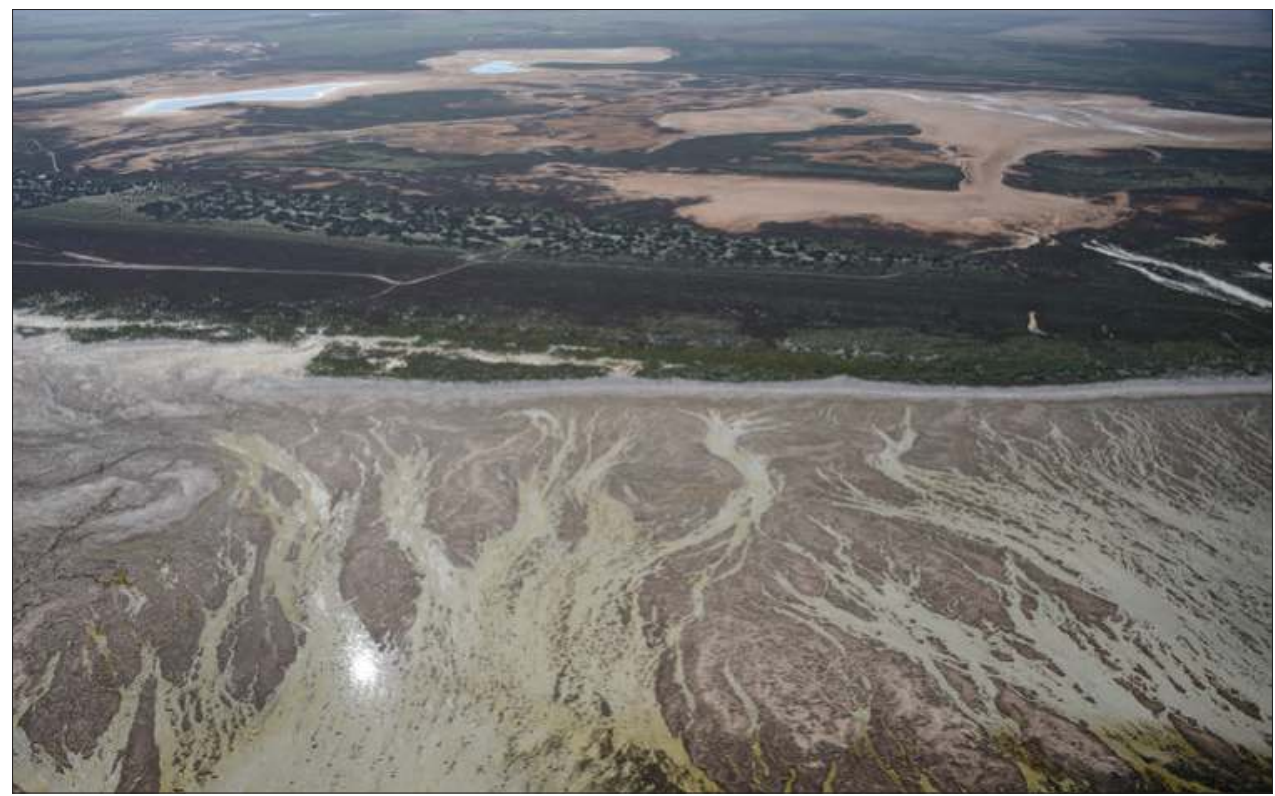

Figure 6.6 Port Prime, showing wide low-tide mudflats, a well-vegetated beach ridge system, and samphire swamps with sabkhas (saline coastal flats occasionally flooded during high tides) in middle distance.

Source: Reproduced with permission of the Coast Protection Board, 1997.

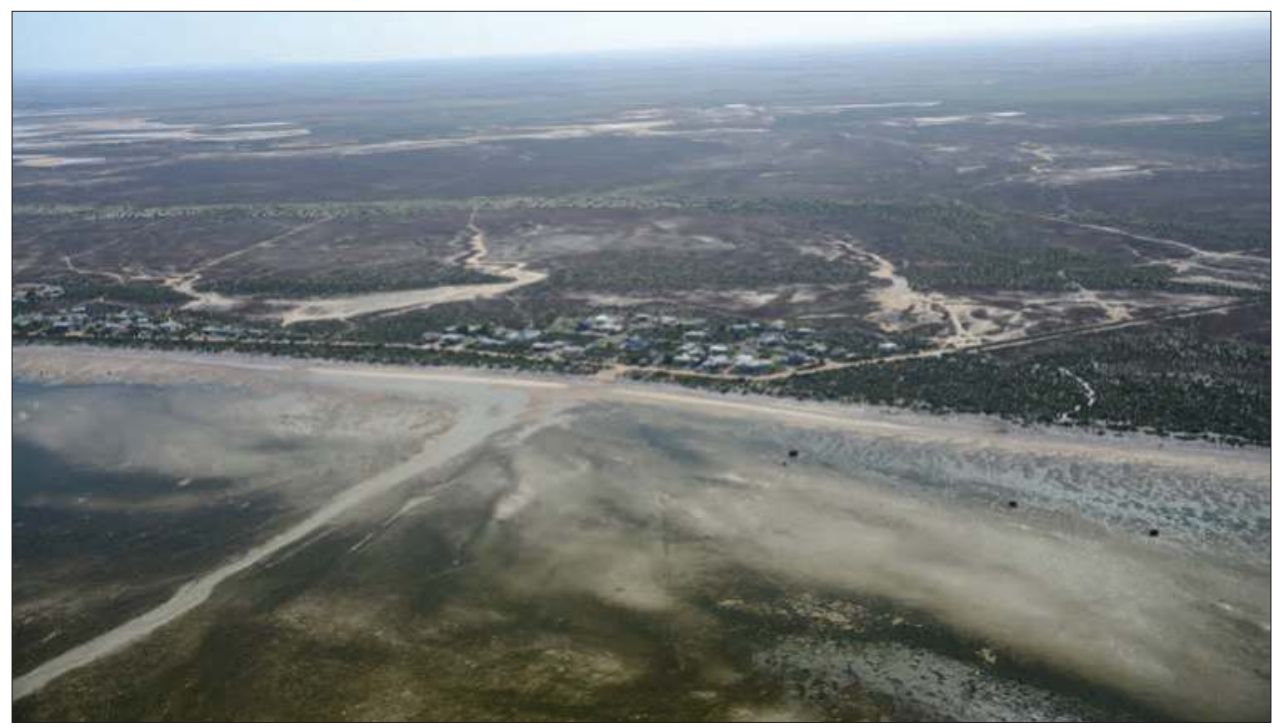

Figure 6.7 Thompson Beach, showing extensive subtidal seagrass beds (foreground), holiday homes built along the beach ridge, and a shell grit/sand ridge in the middle distance. Source: Reproduced with permission of the Coast Protection Board, 2008. 
samphire survives on tidal inundation from both the north and south. Two small tidal creeks dissect the dunes between Thompson Beach and Port Prime, allowing tidal flow to the southern part of the salt marsh, while another, Baker Creek, facilitates tidal access to the north between Great Sandy Point and Webb Beach.

The intertidal sand- and mudflat is narrow between Great Sandy Point and Baker Creek but widens towards Webb Beach (Figure 6.8) and Parham, and has some ridge and runnel features, characteristic of moderate-energy sandflats, where the runnels or gutters cut through ridges facilitate tidal exchange. The innermost chenier/beach ridges south of Baker Creek are recurved, indicating sedimentary infilling of an older embayment. There is also a significant amount of detrital seagrass along this section of coast. The sandy, shelly dunes extend up to $600 \mathrm{~m}$ inland and are backed by salt marsh areas of samphire, saline flats and sabkhas. ${ }^{39}$

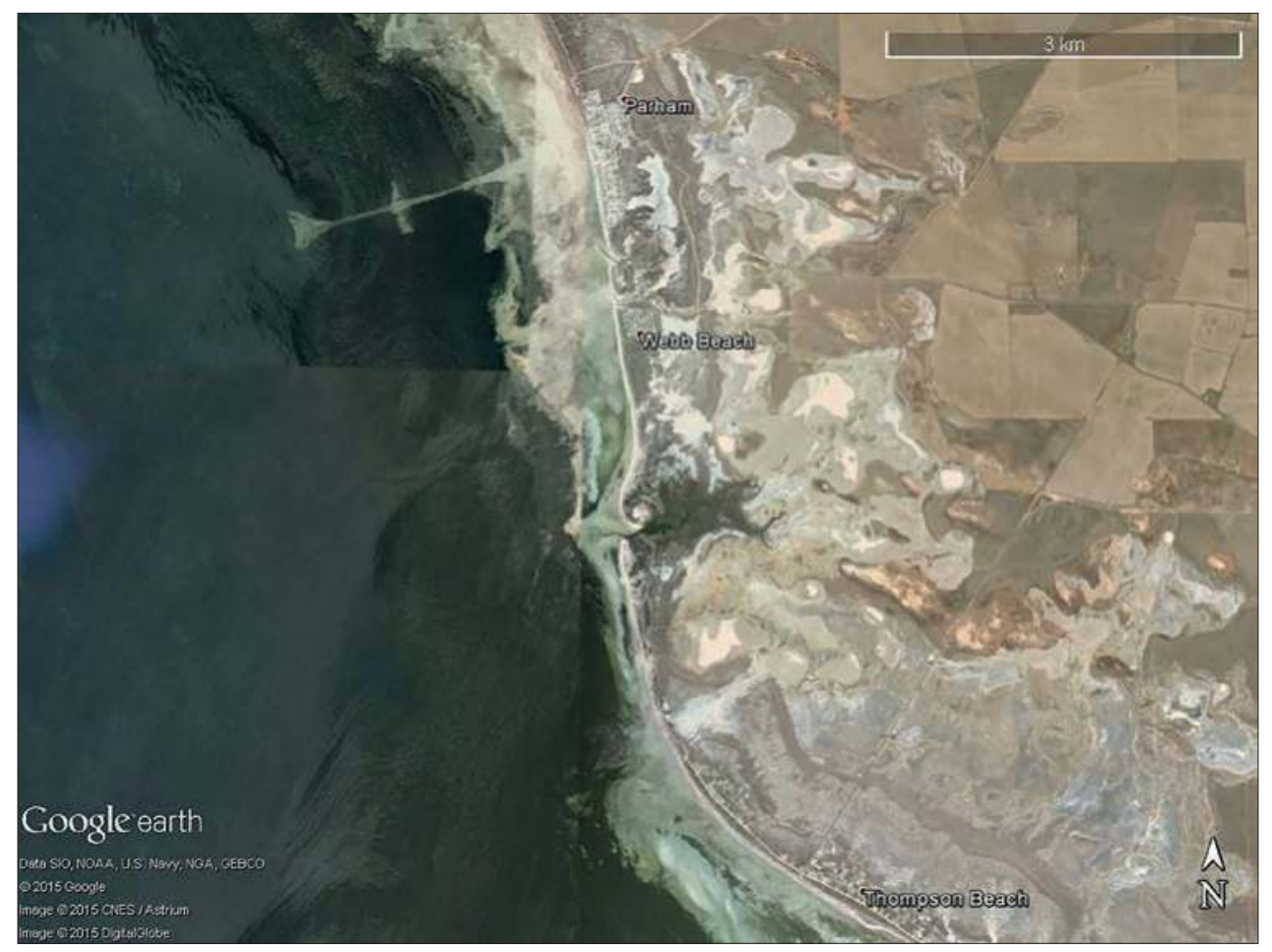

Figure 6.8 Google image, extending from Great Sandy Point in the south (lower) to just north of Parham in the north. The intertidal sand- and mudflat is narrow between Great Sandy Point and Baker Creek, but becomes wider around Webb Beach and Parham. The innermost chenier/beach ridges south of Baker Creek reveal recurved features, suggesting sedimentary infilling of an older embayment.

Source: Google Earth image @ 2015 Google. 


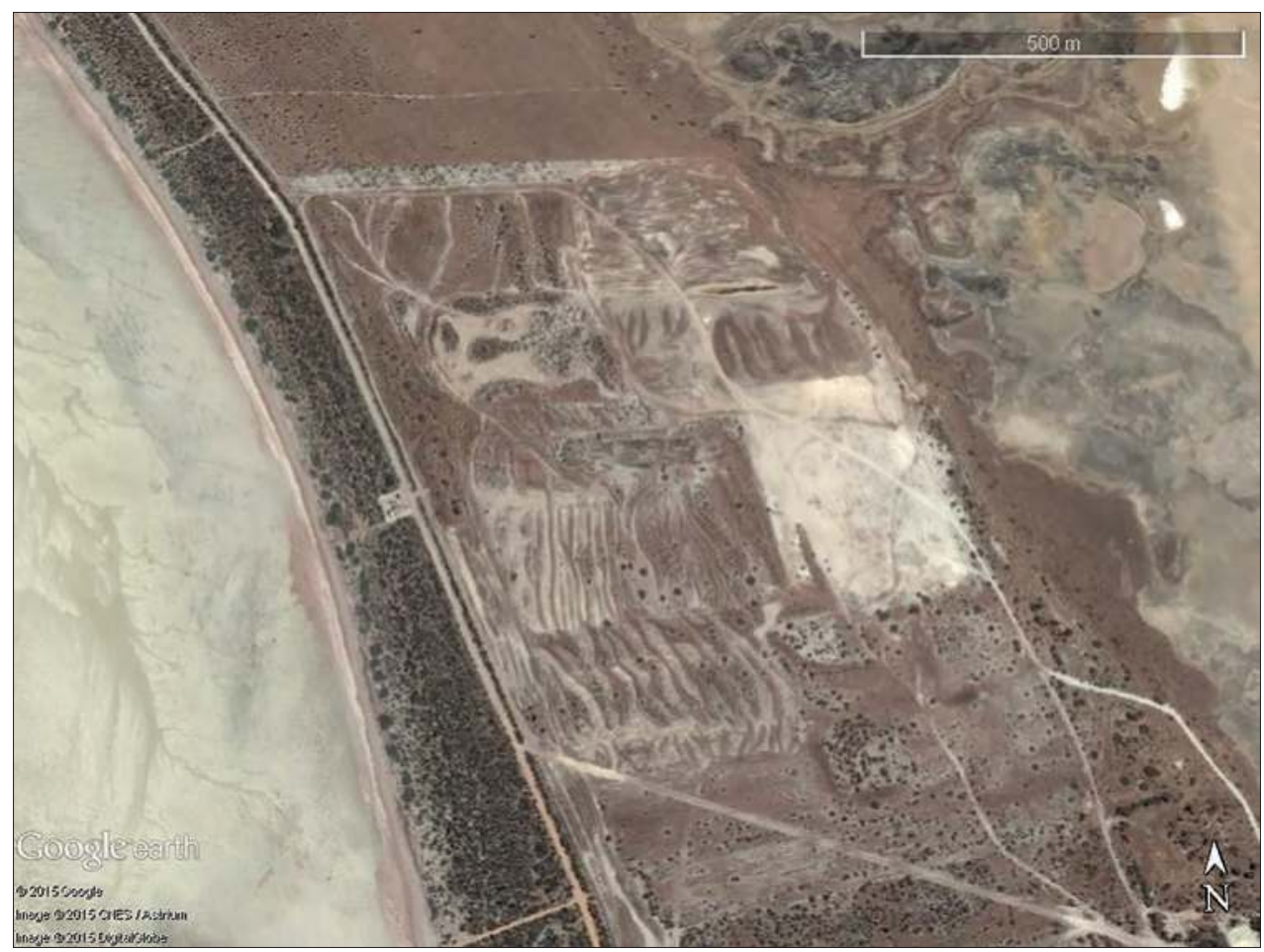

Figure 6.9 The coast north of Parham, illustrating a wide intertidal flat and a vegetated beach ridge sequence, behind which is the 'Windsor Farm' shell grit mining and rehabilitation, indicating an artificial pattern of ridge rehabilitation related to the mining process.

Source: Google Earth image @ 2015 Google.

Middle Spit, between Parham and Lorne to the north, forms a distinctive protrusion of the coastline over $8 \mathrm{~km}$ long and more than 2000 ha in area. Here, the sand and shelly foredune ridges, which extend up to $400 \mathrm{~m}$ from the shore, have been extensively mined for shell grit. Restoration of these mining activities has created a distinctive artificial pattern (Figure 6.9). At Middle Spit the wide sandflat, in places over $1.5 \mathrm{~km}$ wide, sits on an older Pleistocene substrate ${ }^{40}$, making this section of coast an ideal site for the Port Wakefield Proof Range, where test-fired ordnances can be recovered across long distances over a shallow, firm intertidal sandflat. Beyond this wide flat are dense subtidal seagrass beds.

North of Middle Spit and Lorne, the coast assumes a northwest orientation and then trends westerly toward Sandy Point, a large promontory extending $4 \mathrm{~km}$ into the northern GSV. This is a low-energy section of coast with wide intertidal sand- and 


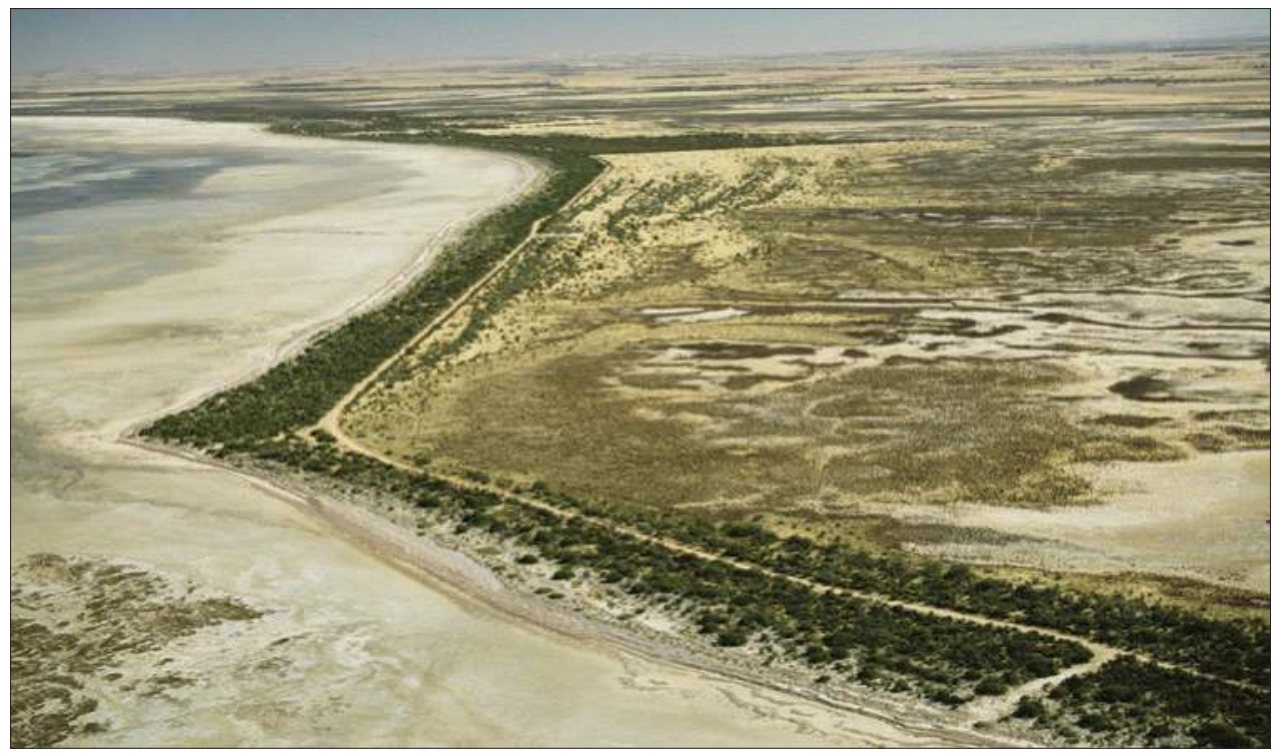

Figure 6.10 Middle Spit, illustrating the wide sandflat, in places over $1.5 \mathrm{~km}$ in width. The beach is backed by a wide beach ridge sequence of which only a narrow strip at the coast remains vegetated.

Source: Reproduced with permission of the Coast Protection Board, 2005.

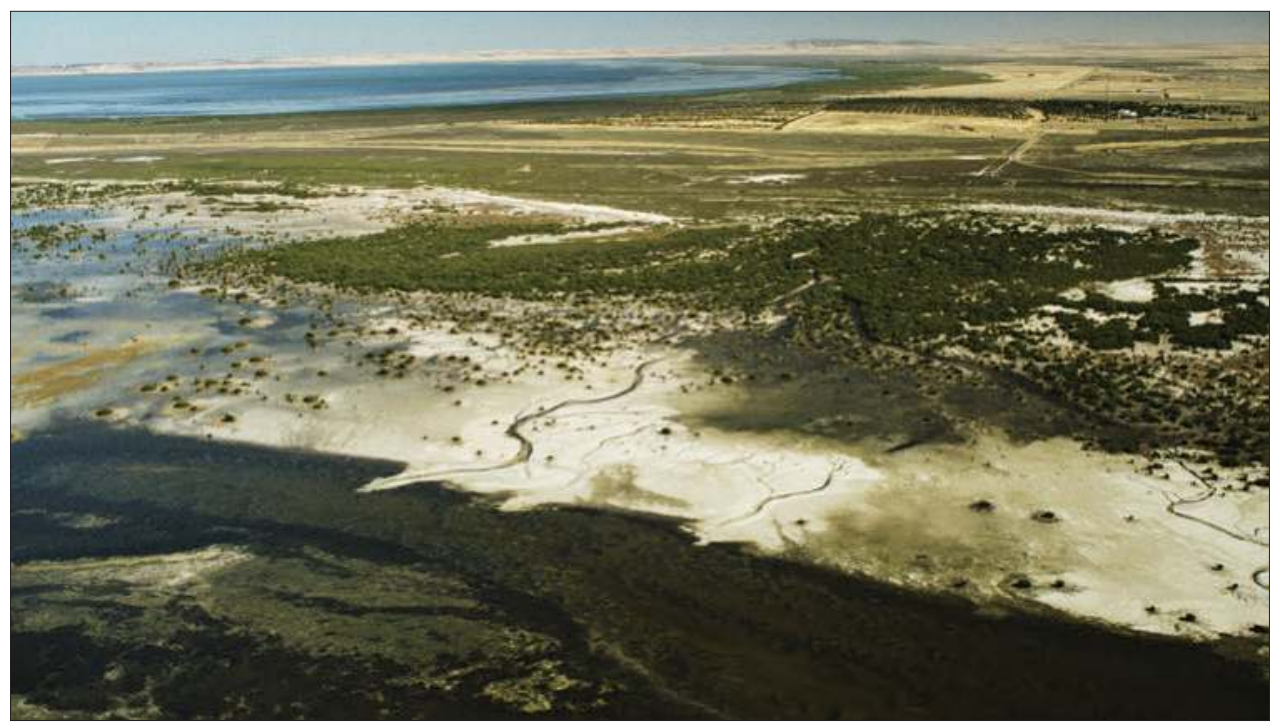

Figure 6.11 Bald Hill Beach, a very low-energy, south-facing beach with a wide sandflat and nearshore seagrass beds (in the lower part of this picture). Mangroves appear in front of the ridges and across parts of the intertidal flat.

Source: Reproduced with permission of the Coast Protection Board, 2005. 
mudflats and a narrow shelly beach backed by chenier/dune ridges forming a recurved progradational sequence to the east of Bald Hills Beach. ${ }^{41}$ Bald Hill Beach is a very lowenergy, south-facing beach with a wide sandflat. ${ }^{42}$ Along this section of coast, mangroves appear in front of the ridges and across parts of the intertidal flat (Figure 6.11).

\subsection{Sandy Point to Mangrove Point}

Mangroves occur on both sides of Sandy Point, grading from a less dense intermittent woodland on the south to a more continuous mangrove woodland on the northern side (Figure 6.12). The coastline extends into the most sheltered and lowest-energy part of GSV, with extensive intertidal sand- and mudflats along the predominantly mangrove coastline, backed by a flat salt marsh plain with expanses of stranded samphire. ${ }^{43}$

The continuous mangrove woodland extends north to Port Wakefield and the Wakefield River. This predominantly tidal inlet carries freshwater flows in wet years. Southeast of Port Wakefield, last interglacial (Glanville Formation) shoreline deposits

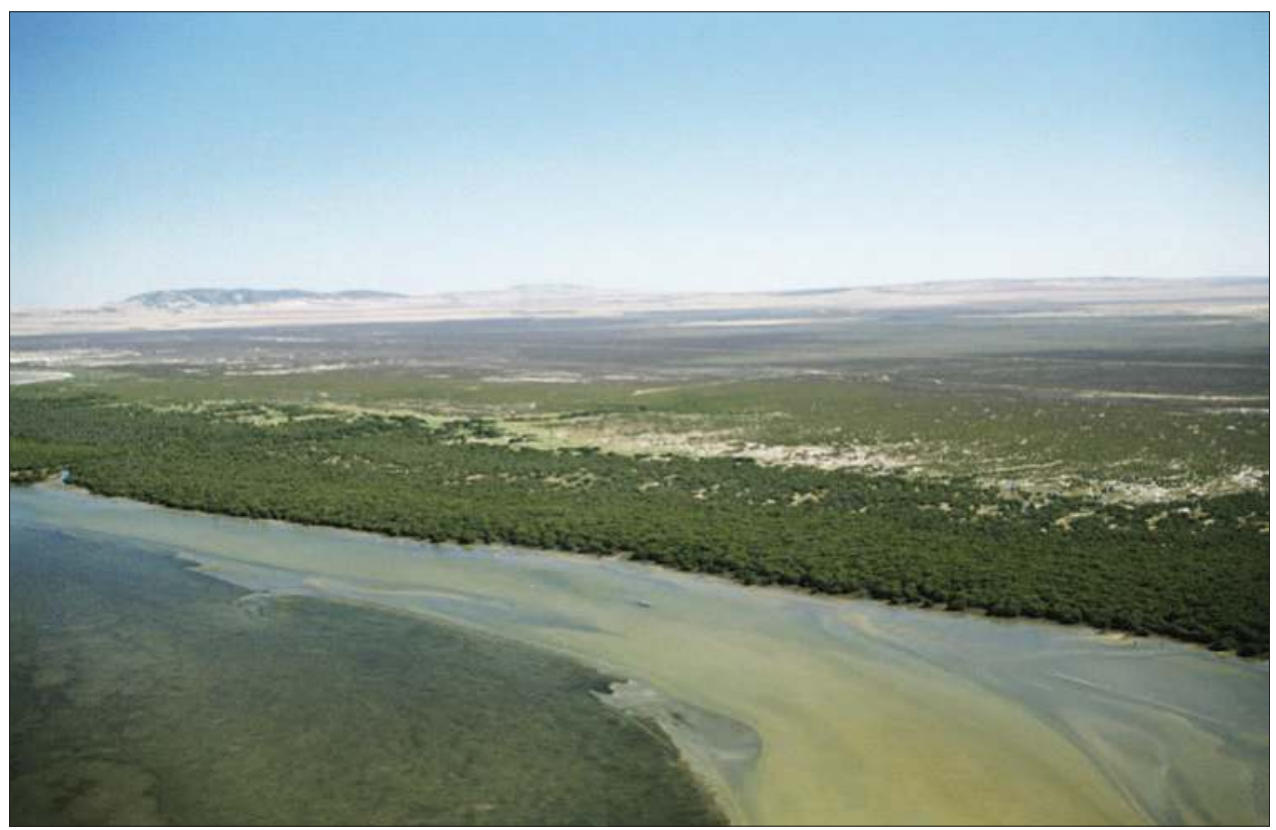

Figure 6.12 The coast south of Port Wakefield, where a very low-energy part of the GSV reveals extensive intertidal sand- and mudflats in front of a continuous mangrove coastline backed by a flat salt marsh plain. Areas of stranded samphire can be seen behind the mangroves.

Source: Reproduced with permission of the Coast Protection Board, 2005. 


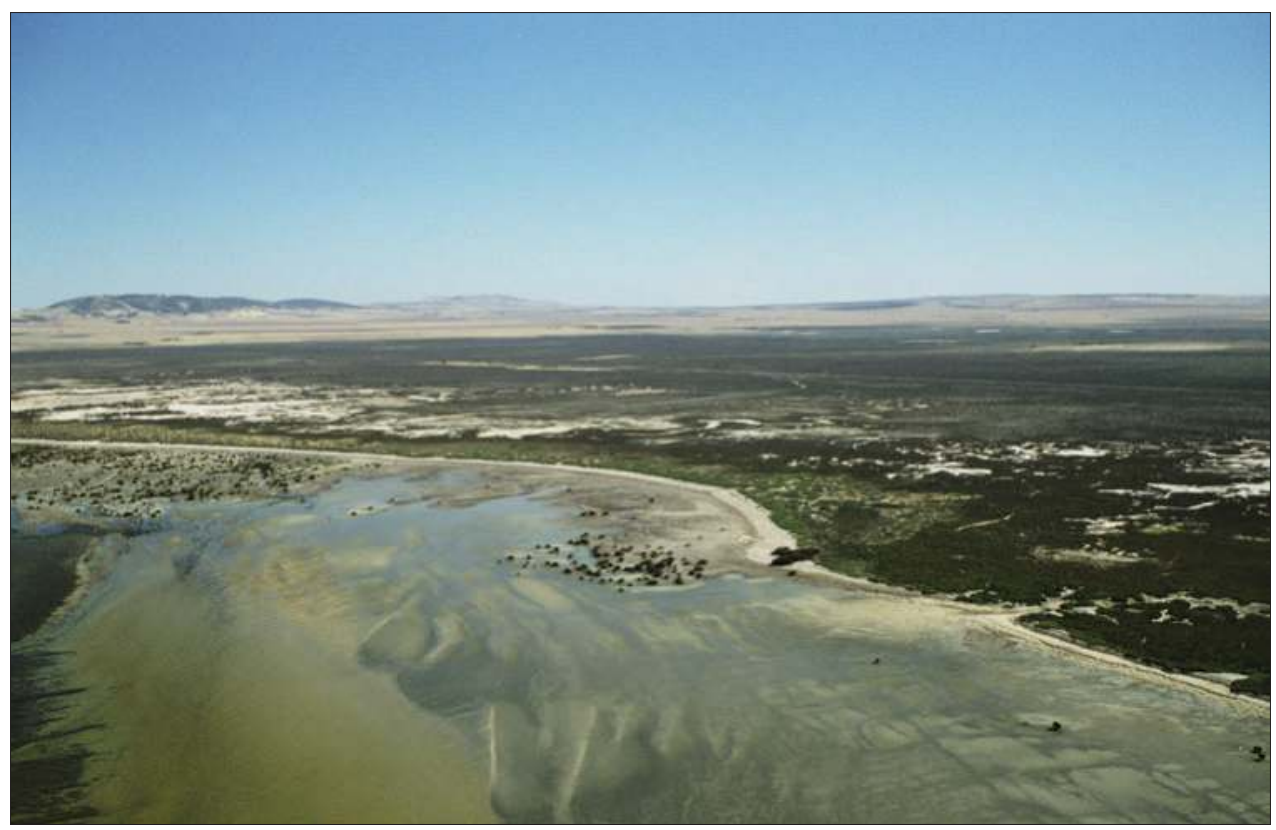

Figure 6.13 Head of Gulf St Vincent near the Clinton Conservation Park. Here, the coast has wide sandy intertidal flats with intermittent mangroves. Wide saline flats can be seen extending inland.

Source: Reproduced with permission of the Coast Protection Board, 2007.

form gravelly beach ridges, which record a relative sea level $3 \mathrm{~m}$ higher than present. ${ }^{44}$ Inland from the main mangrove woodland, an artificial swimming beach has been created at Port Wakefield by damming of the tidal creek. ${ }^{45}$ From the Wakefield River, the main fringing mangrove forest continues further up to the head of the gulf until the mangroves become intermittent across the wide sandy intertidal flats (Figure 6.13).

On the western side of the GSV mangrove, woodlands become increasingly continuous and extend down to Port Clinton, Mangrove Point, Wills Creek and Price, before giving way to a low-energy beach ridge coast towards Macs Beach. ${ }^{46}$ At Port Clinton, there is a break in the mangroves with three beaches along a stretch of sandy coast $1.5 \mathrm{~km}$ long bordered by tidal flats $1 \mathrm{~km}$ wide. At the northern end of the town, the sandy coast merges with the mangroves through a series of recurved or hooked beach ridges. To the south, the sandy beach narrows and is replaced by a mangrove coast at the northern end of Wills Creek Conservation Park, where a narrow strip of mangroves grows on a rocky platform at the base of red limestone cliffs that are 10 m high. ${ }^{47}$ 


\subsection{Summary and conclusions}

The northern GSV coast, which extends from the Port River Estuary in the south to Port Price in the northwest, is geologically part of the tectonically formed St Vincent Basin, where sedimentation began in the Paleogene-Neogene with deposition of terrestrial freshwater sediments followed by marginal marine and later marine sediments. However, the overlying Pleistocene and Holocene sediments have had the strongest influence on the shoreline of the northern GSV.

During the Last Interglacial, when sea level was at least $2 \mathrm{~m}$ higher than today, peritidal, shallow marine sediments of the Glanville Formation were deposited in the

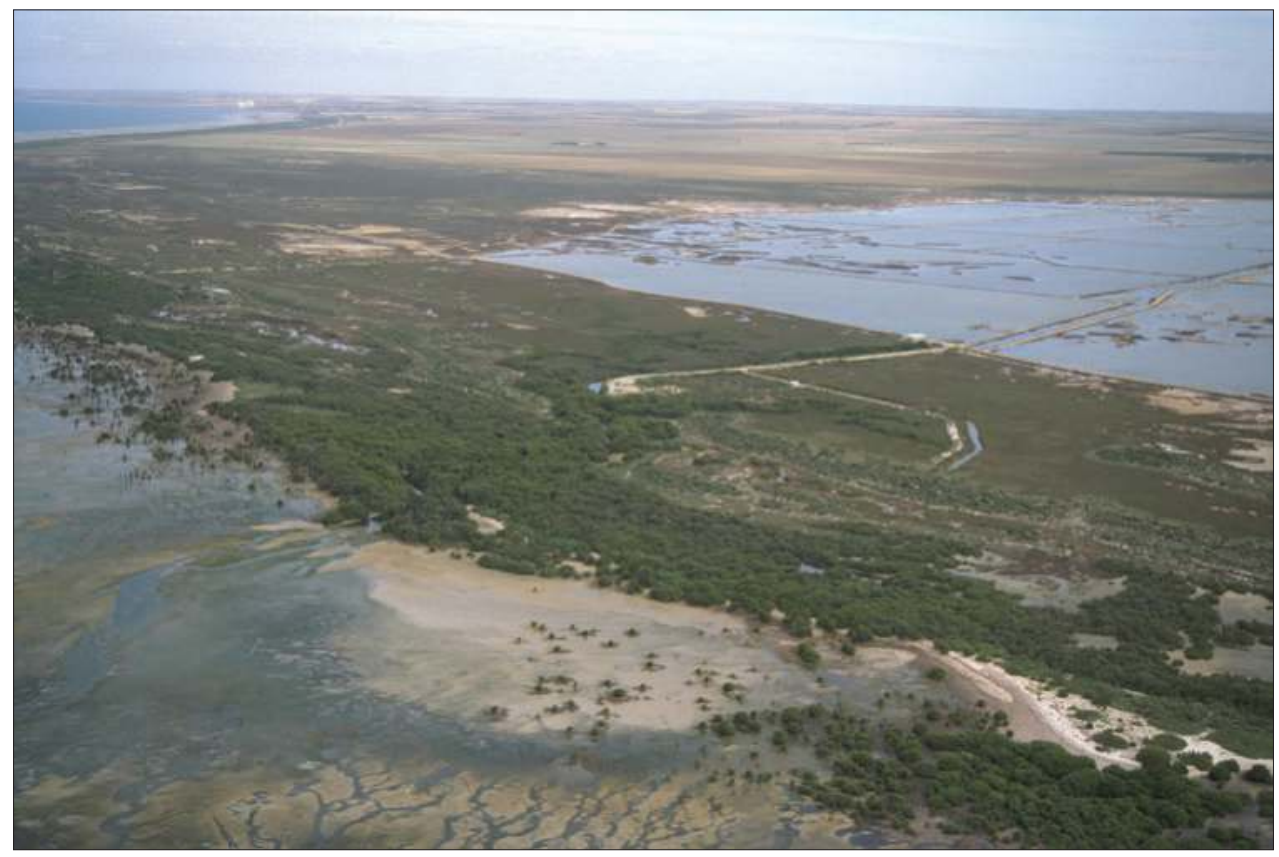

Figure 6.14 The coast south of Price on the northwestern coast of GSV, illustrating wide intertidal sandflats with seagrass beds and mangrove patches, behind which is a series of vegetated beach ridges. In the middle distance, the coast has been modified with levees to create salt evaporation ponds. To the south, the mangrove woodlands widen $(>1 \mathrm{~km})$ and become more continuous toward Wills Creek at the centre of the conservation park. ${ }^{48}$ Near the town of Price, salt marsh landward of the mangroves widens; south of Price, it has been extensively modified with levees to create salt evaporation ponds. ${ }^{49}$ On the southern side of Wills Creek, the mangroves continue from Mangrove Point to the southernmost part of the conservation park, where they give way to a sandy beach ridge coastline. A number of distinctive chenier deposits appear along this section of coast and continue to Mangrove Point. Seaward of the mangrove fringe, dense seagrass beds occur, interspersed with large sand patches.

Source: Reproduced with permission of the Coast Protection Board, 2007. 
northern GSV, forming the basic morphology of the modern coastline. Sediments of the St Kilda Formation were superimposed on this inherited framework during the Holocene; various deposits of marine origin accumulated, including coastal seagrass banks, mangrove deposits, coastal aeolian facies, coastal gypsum, and sandy beach and shell deposits. The paucity of terrestrial sediments reflects the arid climate, with little freshwater input and high evaporation rates making the GSV an inverse estuary.

The most recent phase of coastal development followed the Holocene sea level transgression, which began to flood the shallow depression of what is now Gulf St Vincent about 10000 years ago and reached its present level 7000 years ago. The upper parts of the gulf form a low-energy environment where coastal processes are dominated by tides (tidal range $-3 \mathrm{~m}$ ) and local wind waves, providing the environment for carbonate-secreting biota such as molluscs, foraminifers, bryozoans and coralline algae. Today, the whole of the northern GSV coast is defined by its lowenergy environment, dominated by wide tidal flats that are bordered by mangroves, with a peritidal sequence of sandflats, mangroves and saline marshland.

\section{Notes}

1 Fotheringham, D. \& Coleman, P. (2008). Salt marshes. In: Shepherd, S.A., Bryars, S., Kirkegaard, I., Harbison, P. \& Jennings, J.T. (Eds), Natural history of Gulf St. Vincent. Royal Society of South Australia, Inc., Adelaide, pp. 81-94.

2 Burton, T.E. (1982). Mangrove Development North of Adelaide, 1935-1982. Transactions of the Royal Society of South Australia, 106 (4), 183-189.

3 Butler, A.J. Depers, A.M., McKillup, S.C. \& Thomas, D.P. (1977). Distribution and sediments of Mangrove Forests in South Australia. Transactions of the Royal Society of South Australia. 101 (1), 35-44.

4 Burton (1982).

5 Harbison, P. (2008). Mangroves. In: Shepherd, S.A., Bryars, S., Kirkegaard, I., Harbison, P. \& Jennings, J.T. (Eds), Natural history of GulfSt. Vincent. Royal Society of South Australia, Inc., Adelaide, pp. 95-105.

6 Caton, B., Fotheringham, D., Krahnert, E., Pearson, J., Royal, M. \& Sandercock, R. (2009). Metropolitan Adelaide and Northern Coastal Action Plan. Prepared for the Adelaide and Mount Lofty Ranges NRM Board and Department for Environment and Heritage, Vols $1 \& 2$.

7 Department for Environment and Heritage (2009). Mainland Conservation Parks of Yorke Peninsula Management Plan 2009. Government of South Australia.

8 Department for Environment and Heritage (2009).

9 Fotheringham \& Coleman (2008).

10 Caton, Fotheringham, Krahnert, Pearson, Royal \& Sandercock (2009). 
11 Fotheringham \& Coleman (2008).

12 Horwitz, R.C. (1961). The geology of the Wakefield military sheet. Geological Survey of South Australia, Report of Investigation, 18, $32 \mathrm{pp}$.

13 Lindsay, J.M. \& Alley, N.F. (1995). St Vincent Basin. In: Drexel, J.F. \& Preiss, W.V. (Eds), The geology of South Australia. Vol. 2, The Phanerozoic. South Australian Department of Mines and Energy Bulletin, 54, pp. 163-172.

14 Belperio, A.P. (1985). Quaternary Geology of the Sandy Point and Outer Harbor-St Kilda areas, Gulf St Vincent. Quarterly Geological Notes, Geological Survey of South Australia, 96, 2-6.

15 Belperio (1985).

16 Belperio (1985).

17 Belperio (1985).

18 Murray-Wallace, C.V. \& Belperio, A.P. (1991). The last interglacial shoreline in Australia - A review. Quaternary Science Reviews, 10, 441-461.

19 Bourman, B., Harvey, N. \& Bryars, S. (2010). Catchments and waterways, Chapter 3. In: Daniels, C.B. (Ed.), Adelaide: Water of a city. Wakefield Press, Kent Town, SA.

20 Belperio (1985).

21 Cann, J.H. \& Gostin, V.A. (1985). Coastal sedimentary facies and foraminiferal biofacies of the St Kilda Formation at Port Gawler, South Australia. Transactions of the Royal Society of South Australia, 109 (4), 121-142; Zang, W. Cowley, W.M. \& Fairclough, M. (2006). Maitland Special, South Australia 1:250 000 geological series explanatory notes sheet SI53-12. Primary Industries and Resources, South Australia, 62 p.

22 Belperio (1985).

23 Kämpf, J. (2014). South Australia's large inverse estuaries: On the road to ruin. In: Wolanski, E. (Ed.), Estuaries of Australia in 2050 and beyond. Springer Ebook, pp. 153-167.

24 Kämpf (2014).

25 Belperio, A.P. (1993). Land subsidence and sea level rise in the Port Adelaide estuary: Implications for monitoring the greenhouse effect. Australian Journal of Earth Sciences, 40, 359-368.

26 Murray-Wallace \& Belperio (1991).

27 Belperio, A.P., Gostin, V.A., Cann, J.H. \& Murray-Wallace, C.V. (1988). Sediment organism zonation and the evolution of Holocene tidal sequences in southern Australia. In: de Boer, P.L., van Gelder, A. \& Nio, S.D. (Eds), Tide-influenced sedimentary environments and facies. Reidel, Dordrecht, pp. 475-497; Murray-Wallace \& Belperio (1991).

28 Murray-Wallace \& Belperio (1991).

29 Murray-Wallace \& Belperio (1991).

30 Kucan, U. (1979). Environmental change in the Port Adelaide - St. Kilda area. Hons Thesis, The University of Adelaide.

31 Kucan (1979); Burton (1982); Harbison (2008).

32 Caton, Fotheringham, Krahnert, Pearson, Royal \& Sandercock (2009).

33 Caton, Fotheringham, Krahnert, Pearson, Royal \& Sandercock (2009). 
34 Caton, Fotheringham, Krahnert, Pearson, Royal \& Sandercock (2009).

35 Caton, Fotheringham, Krahnert, Pearson, Royal \& Sandercock (2009).

36 Caton, Fotheringham, Krahnert, Pearson, Royal \& Sandercock (2009).

37 Caton, Fotheringham, Krahnert, Pearson, Royal \& Sandercock (2009).

38 Caton, Fotheringham, Krahnert, Pearson, Royal \& Sandercock (2009).

39 Caton, Fotheringham, Krahnert, Pearson, Royal \& Sandercock (2009); Fotheringham \& Coleman (2008).

40 Belperio, A.P. (1984). Coastal sedimentation in the vicinity of the Port Wakefield Proof Range. Rept. Bk. No. 84/87. Department of Mines and Energy, South Australia.

41 Caton, Fotheringham, Krahnert, Pearson, Royal \& Sandercock (2009).

42 Short, A.D. (2006). Beaches of the South Australian coast and Kangaroo Island: A guide to their nature, characteristics, surf and safety. Sydney University Press, Sydney, 346 pp.

43 Caton, B., Detmar, S., Fotheringham, D., Haby, N., Royal, M. \& Sandercock, R. (2007). Conservation assessment of the Northern and Yorke coast: Report. Coastal Protection Branch and Environmental Information Analysis Branch, Department for Environment and Heritage SA for the Northern and Yorke Natural Resource Management Board.

44 Belperio, A.P., Murray-Wallace, C.V. \& Cann, J.H. (1995). The last interglacial shoreline in southern Australia: Morphostratigraphic variations in a temperate carbonate setting. Quaternary International, 26, 7-19.

45 Short (2006).

46 Short (2006).

47 Harbison (2008).

48 Caton, Detmar, Fotheringham, Haby, Royal \& Sandercock (2007).

49 Harbison (2008). 


\section{The Yorke Peninsula coastline}

\subsection{Introduction}

Yorke Peninsula, with its distinctive leg-shaped form, was mapped by Matthew Flinders in 1802 and named after the First Lord of the Admiralty, Charles Philip Yorke. The peninsula covers an area of approximately $6800 \mathrm{~km}^{2}$ : from north to south, it is $240 \mathrm{~km}$ long; its width varies from $50 \mathrm{~km}$ in its northern section to $32 \mathrm{~km}$ in the south between Hardwicke Bay and Wool Bay; and the east-west trending 'foot' is $80 \mathrm{~km}$ long (Figure 7.1).

Several distinctive geographical and geological features of the peninsula have had marked influences on the present coastline. The peninsula is of low and smooth relief, with the Arthurton Trig (229 m AHD, or Australian Height Datum, which approximates mean sea level) in the central north being the highest point. Generally, land surface elevations increase northwards from $<100 \mathrm{~m}$ AHD in the south, rising gradually to $200 \mathrm{~m}$ in the north, partly reflecting tectonic tilting of the land. Elevations at the coast are well below $100 \mathrm{~m}$, restricting the potential height of coastal cliffs. No permanent streams on the peninsula and few intermittent watercourses reflect the moderate rainfall of 355 to $500 \mathrm{~mm}$, high evaporation rates associated with strong winds and hot summers, as well as the ubiquitous surface cover of rain-absorbing Cenozoic sediments with thin soil mantles, which cover more than $90 \%$ of the peninsula. ${ }^{1}$ Consequently, little continental sediment is delivered to the coast, and most beach sediment is derived from offshore sources and coastal erosion.

\subsection{Why does Yorke Peninsula resemble 'a very ill-shaped leg and foot'? ${ }^{2}$}

There is a strong structural control on the Yorke Peninsula coastline, due to tectonic activity (faulting), rock fabrics, structural factors, and varying degrees of susceptibility 


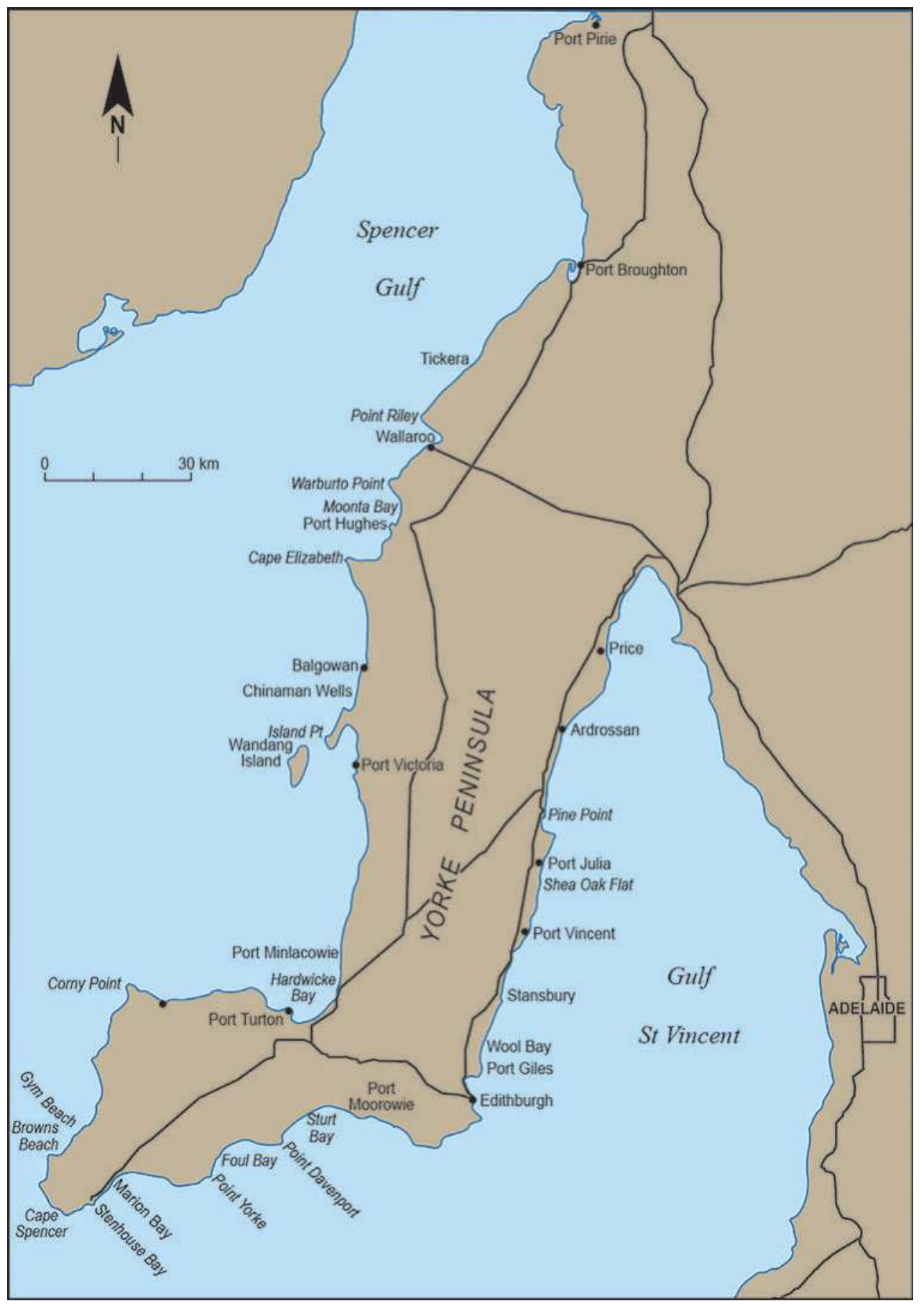

Figure 7.1 Location map of Yorke Peninsula and key locations referred to in the text. Source: Author's own work, RPB. 
of rocks to erosion. These factors, together with wind, wave and tidal actions operating during repeated migrations of sea level, help to explain the character of the coastline. The most recent rise in sea level (18 to $7 \mathrm{ka}$ ), following the Last Glacial Maximum, essentially established the modern coastline of the peninsula.

Yorke Peninsula consists of a subdued north-south ridge of ancient coarsely crystalline basement rocks linked to the west and southwest Gawler Craton, with thin mantles of younger rocks and sediment. ${ }^{3}$ The oldest Gawler Craton rocks on Yorke Peninsula are those of the Corny Point Paragneiss (1920 to $1845 \pm 6 \mathrm{Ma}) .^{4}$ Neoproterozoic sediments (850 to $545 \mathrm{Ma}$ ) of the former Adelaide Geosyncline rest on these ancient rocks with a pronounced angular unconformity. For the most part, these beds, which include Rhynie Sandstone, Sturt Tillite and Tapley Hill Formation, form part of the Spencer Shelf. ${ }^{5}$ This is a thin, mainly horizontal sequence, onlapping the Gawler Craton, west of the Torrens Hinge Zone ${ }^{6}$, which trends north-south, and marginal to the Adelaide Geosyncline. Cambrian rocks (541 to $490 \mathrm{Ma}$ ), dominantly limestones, overlie the Neoproterozoic and Gawler Craton rocks; in the central part of the peninsula, they are well preserved in broad synclines, but they are especially well preserved in the deep Stansbury Basin of the south. The resistant Gawler Craton, Neoproterozoic and Cambrian rocks inhibit erosion, thereby influencing the shape of the coast.

These rocks and sediments were deformed during the Delamerian Orogeny, which thrust them from a deep crustal setting into a significant range of mountains, following which there was extensive erosion for some $200 \mathrm{Ma}$, including erosion by the passage of a wet-based, continental ice mass during Early Permian times (299 to $290 \mathrm{Ma}$ ). ${ }^{7}$ This glaciation, which moved in a west to northwesterly direction, influences parts of the coastal morphology of Yorke Peninsula. The glaciated bedrock floor is exposed on Wardang Island, while large areas of the 'foot', 'ankle' and 'lower leg' of the peninsula have covers of glacial sediments, with minor occurrences in the north. Where exposed at the coast, and not buttressed by resistant bedrock, the generally unconsolidated Permian glacigene deposits form coastal lowlands and contribute to beach sediments.

After the Permian glaciation, there was a long break in sedimentation until the Cenozoic, when extensive terrestrial and marine sediments were deposited. These include the Middle Eocene North Maslin Sand and limestones of Late Eocene, Oligocene-Miocene and Pliocene ages, all of which are exposed in coastal cliffs. ${ }^{8}$ There are two formations deposited in the Early Pleistocene: the marine Point Ellen Formation (2.6 Ma) and the terrestrial Hindmarsh Clay. The Hindmarsh Clay is readily eroded and forms steep cliffs up to $20 \mathrm{~m}$ high, such as at Ardrossan and Balgowan.

During the Quaternary, repeated glacio-eustatic oscillations of sea level resulted in the development of stacked sequences of aeolianite assigned to the Pleistocene Bridgewater Formation. During high sea levels (interglacials), when the sea was near 
present levels, beach sand was swept landward to form dunes. During low sea levels of glacial times, when the shoreline was up to $125 \mathrm{~m}$ lower than present, the dunes were flattened by erosion and soil processes formed calcrete layers on them. Repeated sea level oscillations thus developed the layer-cake arrangement of aeolianite separated by former soils, such as at Cape Spencer, where up to 20 aeolianite-paleosol couplets occur in the cliffs, which are $70 \mathrm{~m}$ high. During the Last Interglacial, 132 to $118 \mathrm{ka}$ ago, sea level stood near $2 \mathrm{~m}$ higher than present; it is marked by the shelly and calcreted fossiliferous marine Glanville Formation, the current elevation of which can be used to demonstrate tectonic movements. At the peak of the Last Glacial Maximum (LGM) about $22 \mathrm{ka}$ ago, when the present gulfs were dry land and the peninsula was linked to Kangaroo Island, the climate was cold, dry and windy, leading to the formation of longitudinal desert dunes, which trend northwest-southeast across the peninsula and extend across the formerly subaerially exposed gulf floors. These dunes are generally light brown on the western side of the peninsula and become increasingly red towards the east. ${ }^{9}$ The dunes on the continental shelf contributed to coastal sediment as sea level rose, until by about 7000 years ago, the sea had reached near to its present position, forming the current cliffs, beaches, dunes and marshes of the coastline.

\subsubsection{Tectonic influences on the Yorke Peninsula coast}

The general north-south orientation of Yorke Peninsula reflects the influence of faults, mainly of Quaternary age ${ }^{10}$, with most escarpments trending in this direction, while there are northwest-southeast trends in the north and to the south on the 'foot' (Figure 7.2). The scarps may be fault scarps, fault line scarps eroded along the faults or monoclinal folds. Most of the peninsula's scarps face east, with gentle tilting to the west, producing tilt blocks and fault angle depressions. A major linear structural feature, the Pine Point Thrust, which dips steeply to the east, extends along much of the east coast; intensely folded and fractured sedimentary breccias of a Cambrian conglomerate were thrust over Gawler Craton rocks in pre-Cenozoic times, perhaps in the Paleozoic, and delineate the structural eastern boundary of Yorke Peninsula. ${ }^{11}$ The Pine Point Thrust links to the north with the Yaroo Thrust of Horwitz. ${ }^{12}$ Inferred faults

Figure 7.2 (right) Major faults, inferred faults, lineaments and scarps of Yorke Peninsula. Source: Modified from Zang, W., Cowley, W.M. \& Fairclough, M. (2006). Explanatory Notes of the MAITLAND Special 1:250 000 Geological Series Sheet SI53-12. Edited by J.F. Drexel. Geological Survey of South Australia. Primary Industries and Resources South Australia, 62 pp.; and Alley, N.F. \& Lindsay, J.M. (1995). Pirie Basin. In: Drexel, J.F. \& Preiss, W.V. (Eds). The geology of South Australia. Vol. 2, The Phanerozoic. Geological Survey of South Australia, Bulletin 54, pp. 175-178. Reproduced with permission of the Department of State Development's Resources and Energy Group. 


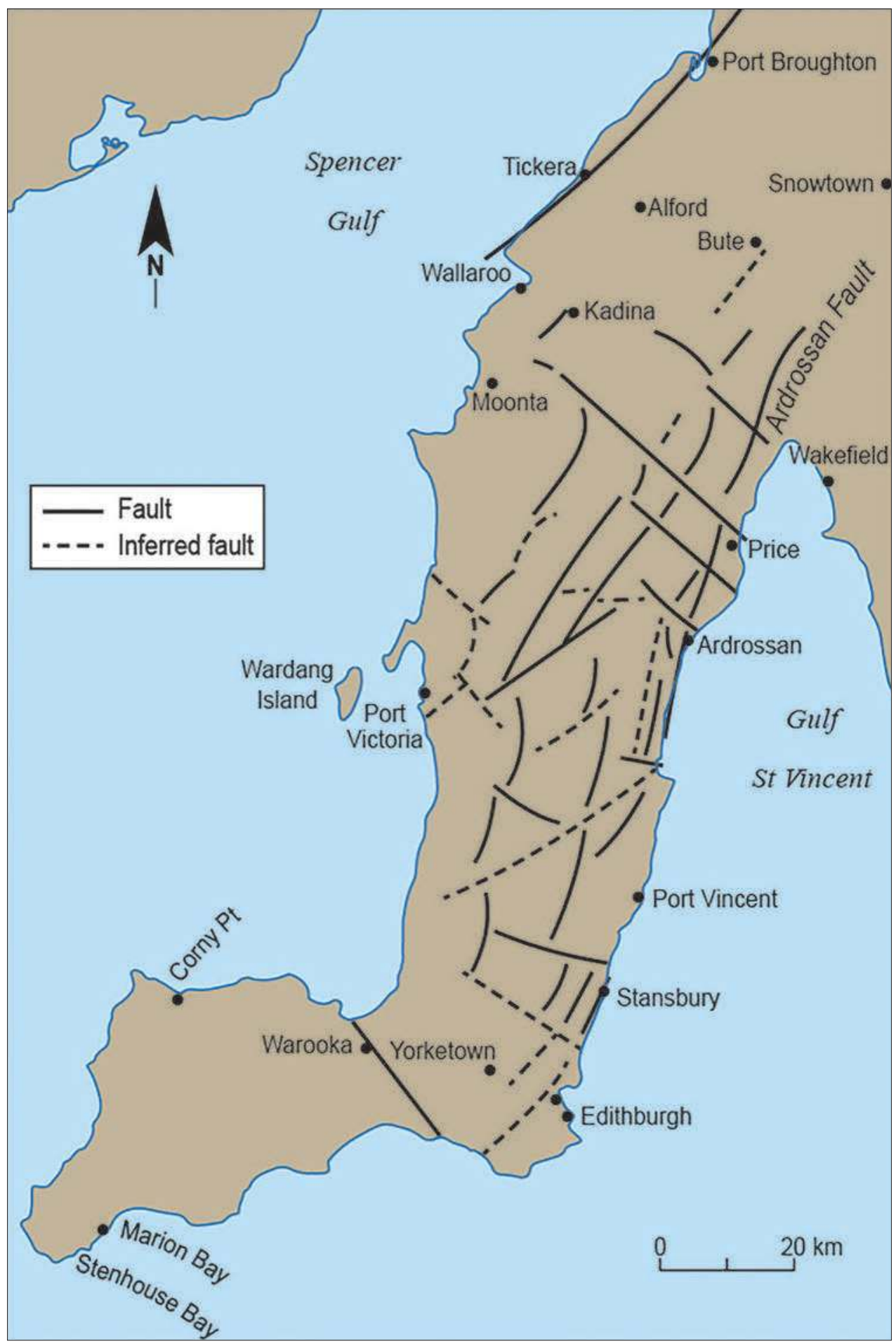


and lineaments roughly mimic the shape of the 'foot', while structural foliations in the gneissic and schistose rocks of the Gawler Craton commonly parallel the coastline.

The Ardrossan Fault and its inferred extension also follow the trend of the coastline; the fault was probably initiated in pre-Eocene times, as it controlled the deposition of Middle Eocene North Maslin Sand, now preserved in a linear northsouth paleovalley. ${ }^{13}$ However, it has also been active in Quaternary times, as exposures in the Ardrossan Quarry reveal Cambrian limestone thrust over Pleistocene Hindmarsh Clay. ${ }^{14}$ Crawford considered that although older faulting had occurred there were substantial fault movements in the Quaternary, post-dating establishment of the widespread thick Quaternary calcrete deposits. ${ }^{15}$ In the north, a pronounced fault follows the coast from near Wallaroo towards Port Broughton ${ }^{16}$, while in the south the Warooka Fault cuts across the ankle of the peninsula trending northwest-southeast.

\subsection{Divisions of the Yorke Peninsula coastline}

For the purposes of this chapter, the Yorke Peninsula coastline extends from just north of Ardrossan, where the coast is transitional to the tidally dominated mangrove environment of northern Gulf St Vincent, around to Webling Point at the southern entrance to Port Broughton, a distance of some $500 \mathrm{~km}$. Three very different sections of coastline can be distinguished: the east coast from near Ardrossan to Troubridge Hill, the south- and west-facing foot of the peninsula from Troubridge Hill to Corny Point, and the west coast.

\subsubsection{The east coast}

Despite the somewhat sheltered environment of the east coast of Yorke Peninsula, it is characterised by cliffs or bluffs, both active and abandoned, developed on various rock types. Gentle folding of the Cenozoic sediments along the coast is evident ${ }^{17}$, and depending on which sediment unit is exposed, the coast has developed in different ways. For example, if the lower part of the Hindmarsh Clay is exposed, active erosion occurs, but if the thick calcrete at the top of the sequence is warped down to the active shoreline, then it protects the shoreline. Where undermining of limestones capped by thick calcrete causes large calcrete blocks to fall to the base of the cliffs, they also protect the coast from erosion.

Old resistant rocks buttress the coast in places, but they do not dominate the shoreline; the majority of pre-Quaternary rocks along the east coast comprise Cenozoic (66 to $3 \mathrm{Ma}$ ) limestones, which may extend inland subsurface for several kilometres. Cliff erosion is most active in deposits of Hindmarsh Clay (for example, Ardrossan) and Eocene sandy limestone (for example, Point Julia). There is sporadic evidence along the east coast of the Glanville Formation ${ }^{18}$, calcreted last interglacial shell beds generally $<1 \mathrm{~m}$ thick, indicating a higher sea level $(+2 \mathrm{~m})$ at this time, when coastal 
erosion would have been enhanced. Some cliffs initiated during the Last Interglacial have been abandoned, with the present sea level failing to reach the height of this former shoreline. The townships of Port Vincent and Stansbury appear to have been built on last interglacial shoreline deposits, and fossil cliff lines back them. Stranding of the last interglacial cliffs may have been accentuated by tectonic uplift of the land. In other cases, cliffs have been abandoned due to protection by coastal sediments accumulating at the foot of the cliffs.

No aeolianite dunes of any significance occur along this coastal section, and there are few modern dunes backing sandy beaches. However, there are sandy cuspate forelands at Black Point, Port Vincent, Stansbury and Sultana Point, which have probably developed on a foundation of harder materials. In addition, $5 \mathrm{~km}$ offshore from Sultana Point, Troubridge Island, reminiscent of sandy cays of the Great Barrier Reef, has formed. Most of the sand for this section of coastline is derived from coastal erosion, offshore sources and marine organisms.

\subsubsection{The south- and west-facing coast of the 'foot'}

A spectacular change in character of the coast occurs on the south- and west-facing coast of the foot of the peninsula, which is directly exposed to large storm waves, swells and strong southwesterly winds. Resistant Precambrian and Cambrian rocks protect headlands and cliffs, which separate sandy bays and cobble beaches. Considerable thicknesses of aeolianite (up to $70 \mathrm{~m}$ ) are common in stacked sequences separated by former soils, such as at Cape Spencer and Ethel Wreck. Yellow-coloured sandy beaches and modern dunes are nourished by erosion of the aeolianite, and they represent analogues of the dunes developed during previous interglacial high sea stands. Occasionally, light brown coloured dunes occur at the coast as relicts of last glacial maximum desert dunes: they straddle the peninsula from northwest to southeast. Permian glacigene sands also contribute to the coastal sediments of Waterloo Bay.

Rocky shore platforms and reefs, developed on rocks of the Gawler Craton, are being exposed from beneath the mantle of aeolianite, while flat intertidal shore platforms have formed on aeolianite. Along the exposed south- and west-facing coast of the 'foot', there are many cliff-top dunes and transgressive dune fields, especially where there are breaks in the aeolianite cliffs. From the south coast, there are views of the Althorpe Islands and Wedge Island, which consist of bedrock-supported aeolianite. Cliffs up to $200 \mathrm{~m}$ high have been eroded on the open-ocean side of Wedge Island.

Two former seaways occupying fault structures extend across the 'arch' and 'toe' of the peninsula. Sedimentary evidence reveals a former seaway $8 \mathrm{~km}$ wide, from Sturt Bay through the Peesey Swamp to Hardwicke Bay along a tectonic depression. Seaways existed at this location during the Late Pliocene about $3 \mathrm{Ma}$ ago, the Last Interglacial $125 \mathrm{ka}$ ago, and in the Holocene 6000 years ago. ${ }^{19}$ The Peesey Swamp 
area is still subsiding, and abundant small shells of the Holocene St Kilda Formation ${ }^{20}$ provide evidence of the most recent marine transgression.

The other former shallow Quaternary seaway formed some 7000 years ago and occurred between Willyama Bay (east of Rhino Head) and Brown Beach (and possibly Dolphin Beach) through the line of salt and gypsiferous lakes that include Marion Lake (where Holocene stromatolites have formed on calcareous sediments). ${ }^{21}$ Seagrass and fossil shells mark the Holocene seaway, while Glanville Formation deposits of the Last Interglacial demonstrate the presence of a seaway $125 \mathrm{ka}_{\text {ago. }}{ }^{22}$

Point Davenport is unusual for the south coast in that it is a recent, prominent triangular spit on the south coast separating Sturt and Foul Bays. It has prograded seaward some $4 \mathrm{~km}$, impounding Tea Tree Swamp. ${ }^{23}$

\subsubsection{The west coast}

The coastline changes dramatically east of Corny Point: it is backed by relatively low, flat country and is protected from prevailing southwesterly winds and waves. Whitecoloured shelly beaches, narrow at high tide, are fronted by extensive ridged intertidal sandflats up to $700 \mathrm{~m}$ wide ${ }^{24}$ and backed by vegetated dunes and shell ridges. In turn, they commonly separate low-lying areas that were former embayments during the last interglacial high sea stand. Dunes reach up to a maximum height of $25 \mathrm{~m}$. Hardwicke Bay extends from Corny Point to near Port Victoria. It is a shallow, low-energy section of coast even when it faces due west, because of extensive intertidal sandflats, seagrass meadows and reefs, which dissipate wave energy. White sandy beaches are generally backed by vegetated sand dunes. Any former embayments have been infilled with Quaternary dunes, beach ridges and samphire swamps.

Minor headlands along the bay, such as at Fish Point (Point Turton) and Port Minlacowie, are capped by calcreted last interglacial Glanville Formation deposits containing reworked shells; these headlands are up to $5 \mathrm{~m}$ AHD. In some other localities, the headlands are formed on Pliocene Hallett Cove Sandstone (for example, Port Rickaby). Between Point Souttar and Renowden Rocks, just south of Port Victoria Township, all basement bedrock is buried beneath easily erodible Permian and Cenozoic sediments, accounting for the low, sandy character of the shoreline and the extensive intertidal sandflats. ${ }^{25}$ In addition, the tilt blocks or monoclines, which characterise the peninsula, and which tilt back gently to the west, also help to explain this observation, whereas on the east coast, the steeper uplifted part of the blocks have produced cliffs and bluffs.

The generalised geological map of pre-Quaternary rocks ${ }^{26}$ reveals that easily erodible Permian sediments underlie most of the coast from Corny Point to Point Gawler and Renowden Rocks near Port Victoria. In contrast, ancient resistant rocks of the Gawler Craton buttress the coast to the north, influencing its morphology. At Port Victoria, the generally smooth and linear character of the coastline is interrupted 
by Wardang Island and Point Pearce Peninsula. Resistant rocks of the Gawler Craton underlie both features, but this does not explain their present form. It is possible that the bedrock morphology of this area was fashioned by glacial erosion during the Permian, forming glaciated rock knobs or rochés moutonneés as parts of an irregular glaciated terrain. Subsequently, both Wardang Island and Point Pearce Peninsula have been largely stripped of Permian sediments, while marine deposits on them reveal that they were both islands during the Pliocene and the Last Interglacial. However, the eastern island was later joined to the mainland by Quaternary coastal sediments, producing the distinctive south-facing hook of Point Pearce Peninsula.

North of Port Victoria, low sandy beaches with extensive intertidal sandflats, such as at Chinaman Wells, are backed by dunes, landward of which are low-lying swamps (1 to $2 \mathrm{~m} \mathrm{AHD),} \mathrm{which} \mathrm{were} \mathrm{probably} \mathrm{last} \mathrm{interglacial} \mathrm{marine} \mathrm{embayments.}$ Small outcrops of Gawler Craton rocks maintain the general north-south orientation of the coast. There is a dramatic change in the coast at Balgowan, where steep cliffs $20 \mathrm{~m}$ high are eroded into Pleistocene sediments of the Hindmarsh Clay; the coastline resembles that of Ardrossan on the opposite side of the peninsula. Wherever the Hindmarsh Clay sediments meet the coast, rapid erosion ensues.

To the north of Balgowan, a rocky reef protects Cape Elizabeth, a triangular spit that protrudes $5 \mathrm{~km}$ into Spencer Gulf. It is formed of high, well-vegetated dunes, beach ridges and spits, while a samphire flat landward of the dunes demarks a former last interglacial embayment. North of Cape Elizabeth, which includes Tippara Bay, Moonta Bay, Warburto Point, Point Hughes, Wallaroo Bay and Point Riley, a 'headland and bay' coastline reflects the influence of sporadic outcrops of resistant Gawler Craton rocks. However, a linear section of coast from Port Riley to Port Broughton is fault controlled; in places, rocks of the Early Miocene Melton Limestone have been tilted to near-vertical positions along the coast, while the same limestone occurs at $100 \mathrm{~m}$ inland at the Melton Township. ${ }^{27}$

\subsection{Key east coast localities}

\subsubsection{Ardrossan area}

The dominant rock units underlying the east coast of Yorke Peninsula are Cenozoic limestones of Eocene to Miocene ages. ${ }^{28}$ At Ardrossan, these rocks are overlain by the red/brown terrestrial Pleistocene Hindmarsh Clay, which has been eroded to form steep cliffs up to $20 \mathrm{~m}$ high (Figure 7.3). Corresponding Hindmarsh Clay sediments occur at Redbanks on Kangaroo Island and at Sellicks Beach, where the Hindmarsh Clay has been divided, from the base upwards, into the Seaford Formation, the Ochre Cove Formation and the Ngaltinga Clay. ${ }^{29}$ The Seaford Formation overlies the Early Pleistocene Burnham Limestone (2.6 Ma), the equivalent of the Point Ellen Formation ${ }^{30}$, while paleomagnetic studies ${ }^{31}$ reveal that the weathering of the strongly iron-mottled Ochre Cove Formation occurred over at least $290 \mathrm{ka}(1.07 \mathrm{Ma}$ to <780 ka). The 


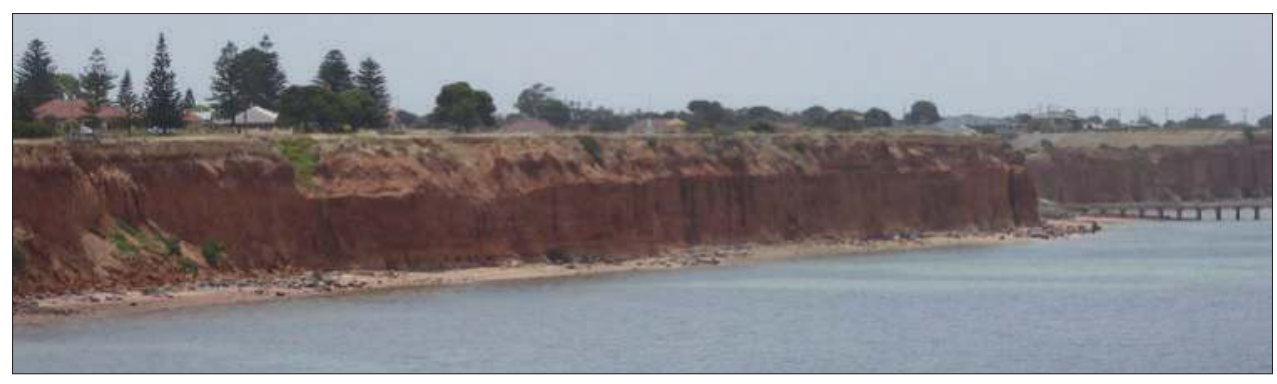

Figure 7.3 Steep cliffs up to $20 \mathrm{~m}$ high, eroded in the terrestrial Pleistocene red/brown Hindmarsh Clay, at Ardrossan.

Source: Author's own work, RPB.

uppermost layer, mainly aeolian calcareous Ngaltinga Clay, now forming a calcrete, was related to a major arid shift in regional climate 500 to $350 \mathrm{ka}$ ago. ${ }^{32}$ The Hindmarsh Clay contains bands and pods of the mineral alunite, which also requires desiccation for its formation. ${ }^{33}$

The ferruginous parts of the Hindmarsh Clay are very susceptible to erosion, and, according to local residents, remnants of these sedimentary successions occur up to $1 \mathrm{~km}$ offshore. Tepper, in 1882, noted that between Price in the north and Port Julia in the south $(40 \mathrm{~km})$, over a three-year period, the sea encroached on sand dunes and stranded beaches, sweeping away

vast masses of sand, in some cases 20 to 30 yards of permanent beach, as for example near Ardrossan', having the 'immediate effect of the waves at high tides washing parts of the cliffs ... causing falls of undermined portions to occur more frequently than before. ${ }^{34}$

Using baseline data from an 1870 map, Bourman resurveyed the cliff line, demonstrating that cliff recession over a $700 \mathrm{~m}$ length of coastline varied between a minimum of $3.6 \mathrm{~m}$ to a maximum of $32.4 \mathrm{~m}$ near the town jetty and Clay Gully. The latter is an ephemeral streamline with at least six knickpoints, or prominent drops in the stream profile, some of which were attributed to rapid coastal erosion exceeding the rate of fluvial downcutting. ${ }^{35}$

Sediment derived from coastal erosion forms an intertidal sandflat 300 m wide with megaripples and seagrass meadows. To the north, at Tiddy Widdy Beach, northwarddrifting sand has accumulated, forming dunes, which protect the now abandoned cliffs. Red beach sand also suggests sediment derivation from the Hindmarsh Clay to the south. Under conditions of high tides and southeasterly storm winds, it has been noted that fine, suspended red clay particles can stain the sea red for up to $800 \mathrm{~m}$ offshore. ${ }^{36}$ Northward longshore transport is also suggested by the presence of pebbles on 
Ardrossan Beach containing marine fossils derived from Cambrian (Archaeocyatha) and Eocene (Turritella) outcrops to the south. ${ }^{37}$ The Ardrossan Fault along this eastern coast is exposed in the dolomite quarry south of Ardrossan, revealing Cambrian rocks thrust over the Early to Middle Pleistocene Hindmarsh Clay, demonstrating reverse faulting during the Late Pleistocene. ${ }^{38}$

\subsubsection{Ardrossan to Pine Point}

South of Ardrossan through Parara Point (a sandy foreland), James Wells and Rogues Point, the eroding cliff line has been abandoned and is protected by sandy/shelly beach fill, including reworked last interglacial shells. Wide intertidal sandflats also protect the coast. Where ephemeral streams such as Pavy Creek and Rogues Gully reach the coast, there are cuspate forelands, which extend seawards for up to $250 \mathrm{~m}$ in the lee of shallow rocky reefs. This suggests that the streams are delivering some sediment to the coast and/or they are acting as hydraulic groynes, interrupting the general northerly longshore drift and causing sand accumulation. Erosion is occurring on the south side of Rogues Point, where rock and wood defences have been installed to protect houses.

From south of Rogues Point to south of Pine Point at Rocky Point, the coast consists of cliffs 20 to $30 \mathrm{~m}$ high; they are cut largely in Miocene limestone (16 to $20 \mathrm{Ma}$ old), with occasional narrow beaches and extensive intertidal sandflats, widest where Throoka Creek intersects the coast. Sporadic exposures of resistant Precambrian and Cambrian rocks, including large granite masses, at the cliff bases have been intensively weathered to form a white clay mineral (kaolinite), as in White Clay Bay. ${ }^{39}$ On the beach north of the Pine Point Township, a major fault structure, the Pine Point Thrust, occurs where Cambrian (500 Ma) rocks comprising iron-rich sandstone and breccia (Middle Cambrian Yuruga Formation) are faulted over older Mesoproterozoic basement rocks (Arthurton Granite). This fault is also exposed at Muloowurtie Point and Rocky Point ${ }^{40}$, and has probably been active since Delamerian times. At Pine Point, the cliffs are 20 to $30 \mathrm{~m}$ high and are protected by coastal sediments, while an iron-rich sandstone forms a shore platform and appears to underlie the sandy spit, which projects $200 \mathrm{~m}$ into the gulf.

\subsubsection{Black Point}

At Black Point, a large cuspate foreland resting on a basement of Cenozoic limestone juts some $3 \mathrm{~km}$ seaward, while an abandoned cliff line, the top of which is marked by the $20 \mathrm{~m}$ contour, follows the general trend of the coast. This stranded cliff line was probably the position of the coast during the Last Interglacial (132 to $118 \mathrm{ka}$ ago). Longshore transport and dune activity has formed the foreland over the past 7000 years. The sandy foreland is susceptible to erosion sometimes, necessitating the installation of protective measures. 


\subsubsection{Port Julia to Port Vincent}

Steep, red sea cliffs $20 \mathrm{~m}$ high, cut into Eocene sand, silt and limestone of the Rogue Formation some $40 \mathrm{Ma}$ old, dominate the coast at Port Julia. ${ }^{41}$ At the base of the cliffs, the Port Julia Greensand forms a distinctive layer of green glauconite up to $0.5 \mathrm{~m}$ thick (Figure 7.4). The cliffs are capped by calcrete, possibly of Pleistocene age, containing large nodules. These beds have been gently folded into a monocline, which can be traced inland as an asymmetrical ridge or escarpment. ${ }^{42}$ This gentle flexuring brings different parts of the stratigraphy into the shore zone and may be responsible for the locations of some headlands and bays. The ferruginous sediments have been eroded to form shore platforms, which reveal folding in plan as well as in section. There is evidence at Port Julia of the high last interglacial sea level, as marine shells of this age up to $3 \mathrm{~m}$ AHD were reported from here. ${ }^{43}$ The shacks farthest south at Port Julia are built on a platform related to this fossil shoreline, erosion of which has required rock protection.

The cliff line in Cenozoic limestones extends for almost $50 \mathrm{~km}$ from south of Port Julia to Wool Bay with occasional breaks, such as at Sheoak Flat, where a former last interglacial cliff line has been stranded up to $500 \mathrm{~m}$ inland; it is fronted by a sandy Holocene foreland $200 \mathrm{~m}$ long, while a large sand spit, North Spit, extends

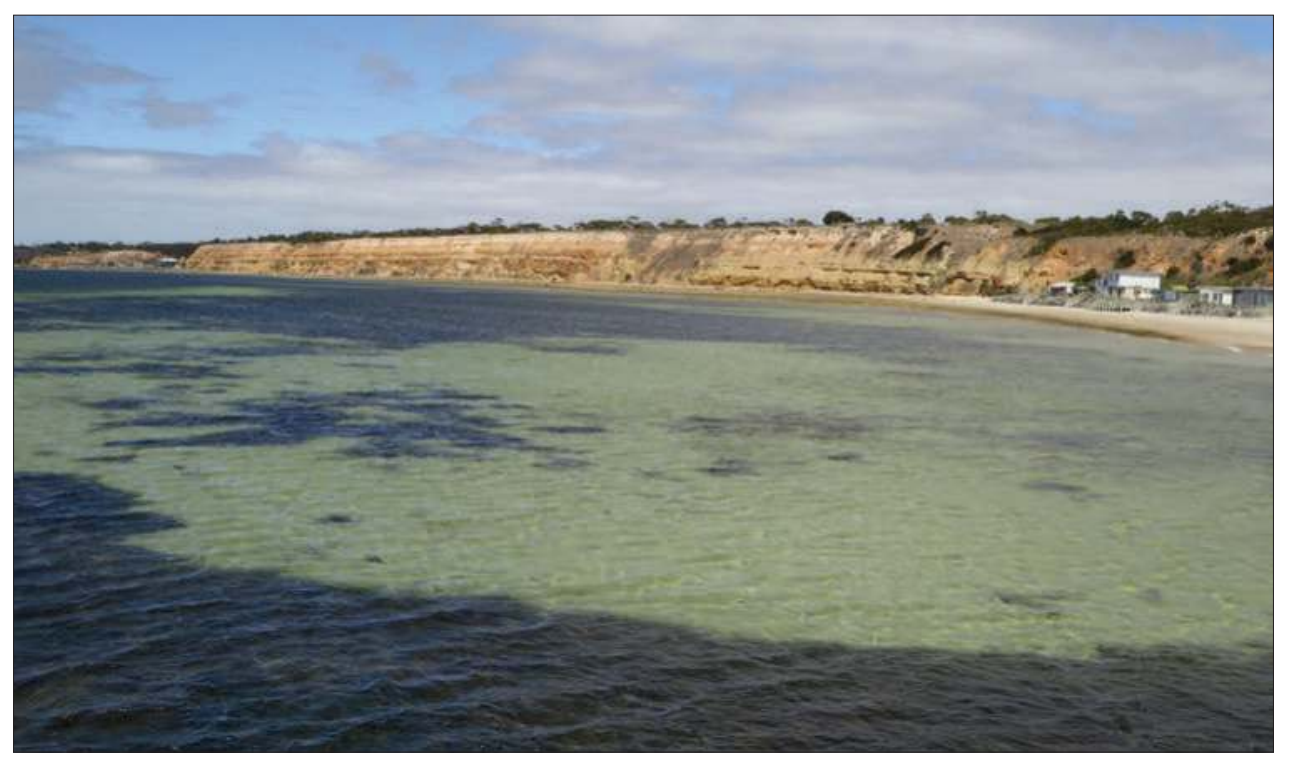

Figure 7.4 Seacliffs at Port Julia cut in Eocene sandy limestone overlain by Hindmarsh Clay. Note the gentle upfold in the strata. Shacks on the far right, protected by a rock wall, are built on a last interglacial marine bench.

Source: Author's own work, RPB. 


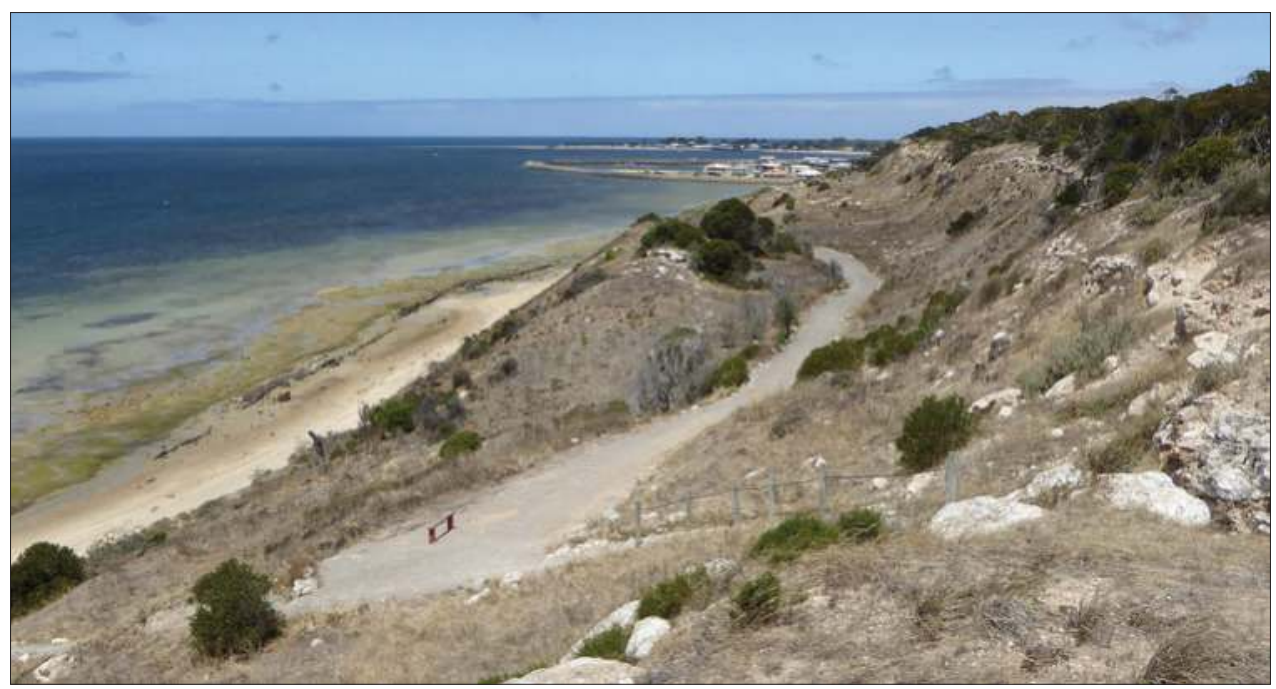

Figure 7.5 Coast at Port Vincent, showing coastal rotational landslump in the foreground, Permian glacial erratics derived from near Victor Harbor, and a band of ferruginised sandstone on the beach, with the marina and Surveyor Point, a sandy cuspate foreland, in the distance. The pathway separates the slumped Permian sediments from the backing cliffs.

Source: Author's own work, RPB.

a further $4 \mathrm{~km}$ offshore. A storm surge wall protects a low-lying flat with houses. Cliffs 20 to $30 \mathrm{~m}$ high, fronted by intertidal shore platforms, sandflats, seagrass meadows and narrow beaches, form the coast from south of Sheoak Flat to Streak Point and Dowser Bluff, where some rock groynes have been constructed to protect shacks. The coast protrudes seawards $1 \mathrm{~km}$ from the original line of the last interglacial cliffed shoreline at Port Vincent, which is largely sited on Surveyor Point, a sandy cuspate foreland formed on last interglacial sediments of the Glanville Formation. Middle Spit extends offshore for a further $4 \mathrm{~km}$ in a northeasterly direction, indicating northward longshore drift. Granite boulders transported from Encounter Bay by Permian ice occur on the beach north of the marina, while clay-rich Permian glacigene sediments, which underlie the limestone cliffs, are responsible for the rotational slumping near the marina (Figure 7.5). Iron-rich clastic sediments, probably equivalent to the Eocene North Maslin Sand, form near-vertical ridges along parts of the beach.

\subsubsection{Port Vincent to Stansbury}

This section of linear coastline $14 \mathrm{~km}$ long consists of cliffs up to $30 \mathrm{~m}$ high cut into calcreted Cenozoic limestone with pockets of Pleistocene terrestrial sediments, narrow 
sand and boulder beaches, and sandflats. Several minor short ephemeral streams, such as Devil Gully, have cut down to sea level at the coast. Near Deep Gully, red former desert dunes of last glacial maximum age (22 ka) trend northwest-southeast towards the cliff line, where there are exposures of Hindmarsh Clay containing alunite, a mineral mined for use in explosives in World War II. Evidence of the last interglacial Glanville Formation occurs at Stansbury ${ }^{44}$, and it is on this substrate that the cuspate foreland of Oyster Point has developed and continues to evolve. South Spit extends sporadically from Oyster Point for some $5 \mathrm{~km}$ to the northeast. The last interglacial cliff line stands about $1 \mathrm{~km}$ from the apex of Oyster Point, and, as with Port Vincent, outcrops of ferruginous sandstone occur on the beach, forming natural groynes in places, while artificial groynes have been erected on the north side of Oyster Point to inhibit erosion.

\subsubsection{Stansbury to Troubridge Point}

A linear cliffed section of coast 10 to $20 \mathrm{~m}$ high extends from Stansbury to Wool Bay, cut into Oligocene-Miocene limestone of the Port Willunga Formation, which in some localities dips gently to the south and has solution pipes filled with younger

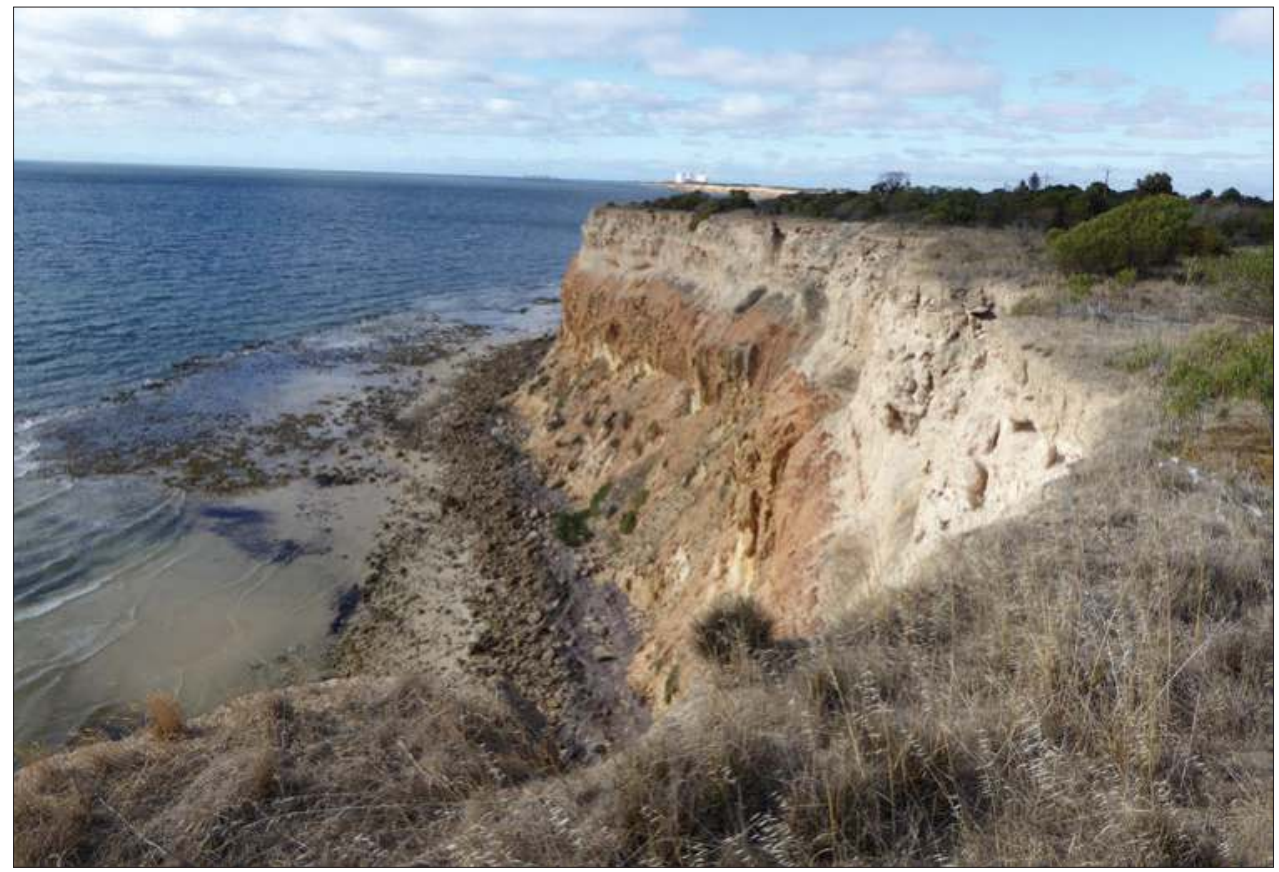

Figure 7.6 The Hindmarsh Clay is a sedimentary deposit filling a hollow eroded into limestone of the Port Willunga Formation.

Source: Author's own work, RPB. 


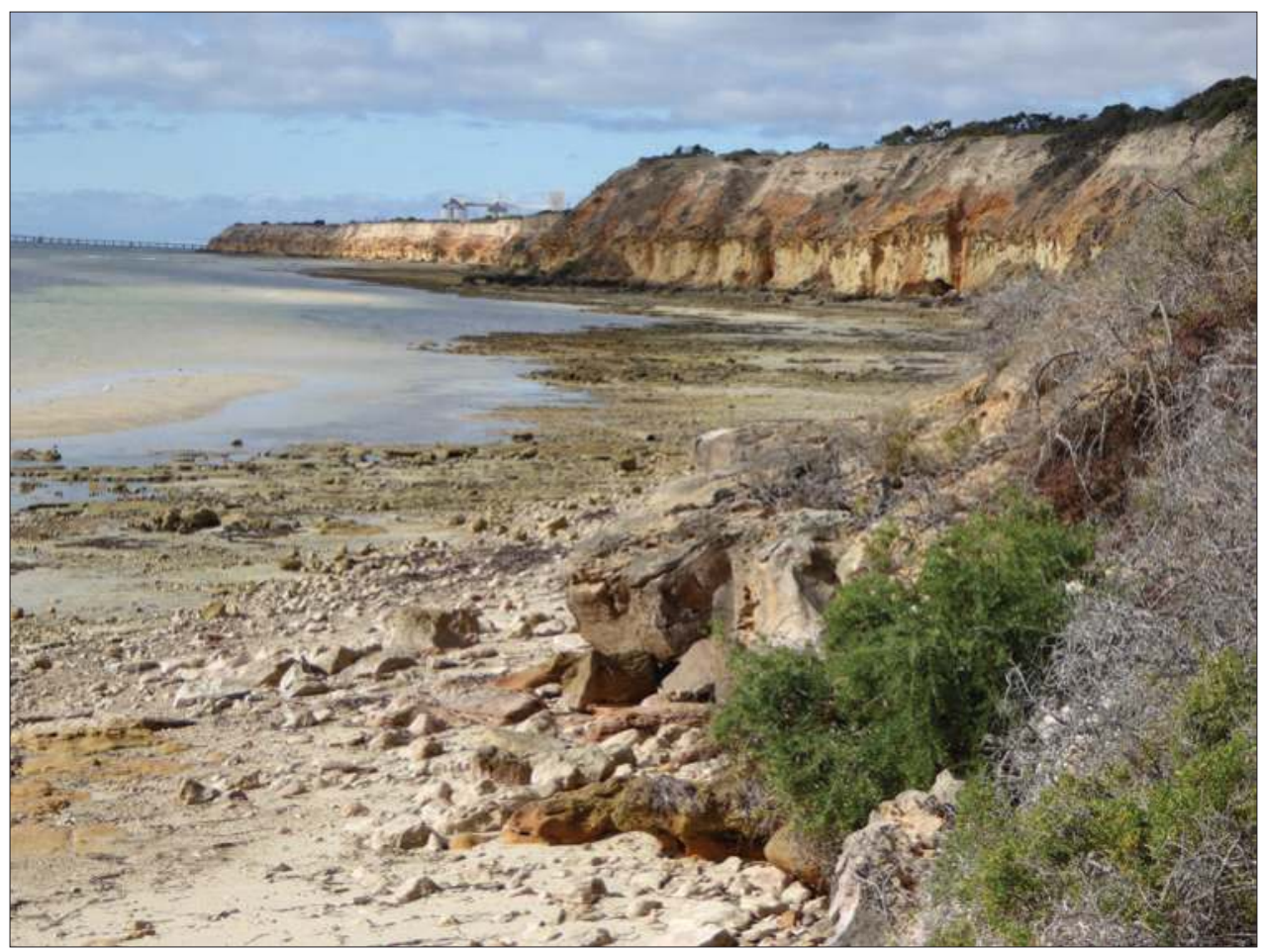

Figure 7.7 At Wool Bay, there is a sequence of light yellow limestone at the cliff base, followed by red/orange mottled sandy clays capped by calcareous sediments and calcrete. Source: Author's own work, RPB.

clays. Extending to the south, increasing amounts of Hindmarsh Clay fill hollows eroded into the Port Willunga Formation (Figure 7.6). At Wool Bay there is a sequence of light yellow limestone at the cliff base, followed by red-orange mottled sandy clays capped by calcareous sediments and calcrete (Figure 7.7), while near Klein Point steep vertical cliffs and broad shore platforms with solution pits and pans occur. Limestone of the Port Willunga Formation dips to the south until, near Port Giles, only the Hindmarsh Clay is exposed. At Port Giles, last interglacial Glanville Formation crops out at $3 \mathrm{~m}$ AHD. ${ }^{45}$ Two kilometres further south at Hickies Point, in Salt Creek Bay, Pliocene Hallett Cove Sandstone, rich in marine fossils and $1 \mathrm{~m}$ thick, is visible at low tide $^{46}$; it also occurs in the cliffs close to Edithburgh.

Salt Creek Bay, with extensive sandflats, has been eroded into the Cenozoic limestones to form a southeast-facing embayment with shallow rocky intertidal reefs and shore platforms that have led to the formation of a low-energy, seagrass-covered 


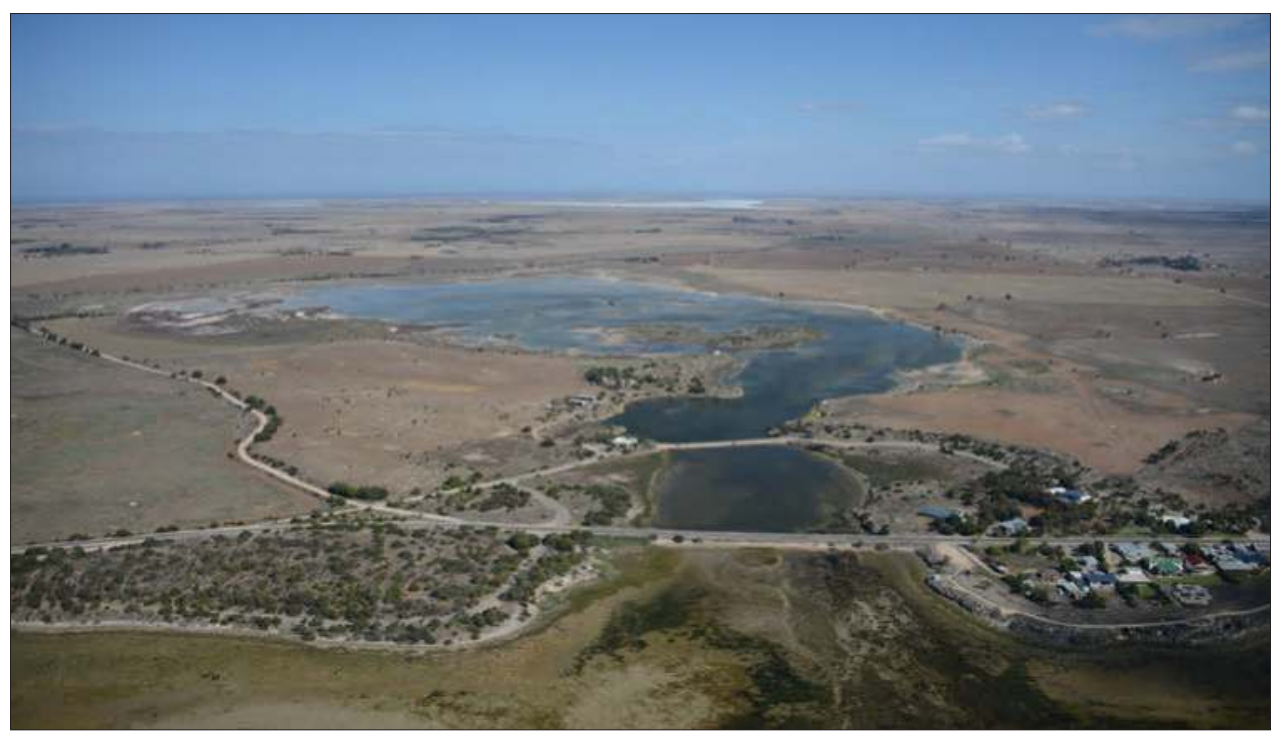

Figure 7.8 Salt Creek Bay, a southeast-facing embayment eroded into Cenozoic limestones, has extensive sandflats, shallow rocky intertidal reefs and shore platforms with a low-energy, seagrass-covered shelly beach. The causeway across the inlet initially restricted flow, but this has subsequently been reinstated.

Source: Reproduced with permission of the Coast Protection Board, 2014.

shelly beach with a backing shell ridge. Salt Swamp Creek is a tidal inlet that was a marine embayment during the Last Interglacial; it is fringed by calcreted Glanville Formation up to $3 \mathrm{~m}$ AHD. A causeway was constructed across the inlet, but flow was subsequently reinstated (Figure 7.8).

At Edithburgh, bluffs $10 \mathrm{~m}$ high form the north-south trending coast, which is fronted by rocky flats and shingle beaches. The most distinctive feature of this section of coast is a prominent cuspate foreland, Sultana Point, an accumulation of sand on a substrate of limestone of the Port Willunga Formation. Waves sweep through Investigator Strait, carrying sand derived from erosion of south coast aeolianite, building Sultana Point seawards, where it is protected by the Troubridge shoals; it has built out some $2.5 \mathrm{~km}$ into the gulf between Sultana Bay and Wattle Point. The foreland is fringed by intertidal sandflats and seagrass meadows, with sweeping wings of sand forming tidal shoals either side of the spit. The growth and development of the foreland is preserved in dunes and sand ridges, and its dynamic nature is illustrated in Figure 7.9. 
Troubridge Island, a sand island, has formed $6 \mathrm{~km}$ offshore from the apex of Sultana Point on Troubridge Shoal. When Matthew Flinders named Troubridge Shoal in 1802, Troubridge Island was merely a low-lying sand bank. ${ }^{47}$ In 1852, the feature was referred to as Troubridge Island for the first time, when it had an elevation of $60 \mathrm{~cm}$ above high-water spring tides. Thus the island had formed over a 50year period. It is now partially colonised by a low shrubland community, dominated by Nitre Bush (Nitraria billardiere), which helps to stabilise the island. Troubridge Island shares some of the characteristics of the sandy cays on the Great Barrier Reef, propellershaped sand islands on coral reefs. The Troubridge sand island rests on reefs cut across limestone and is perpetually migrating as well as being reduced in size (Figure 7.10), threatening the lighthouse and other constructions on the island.

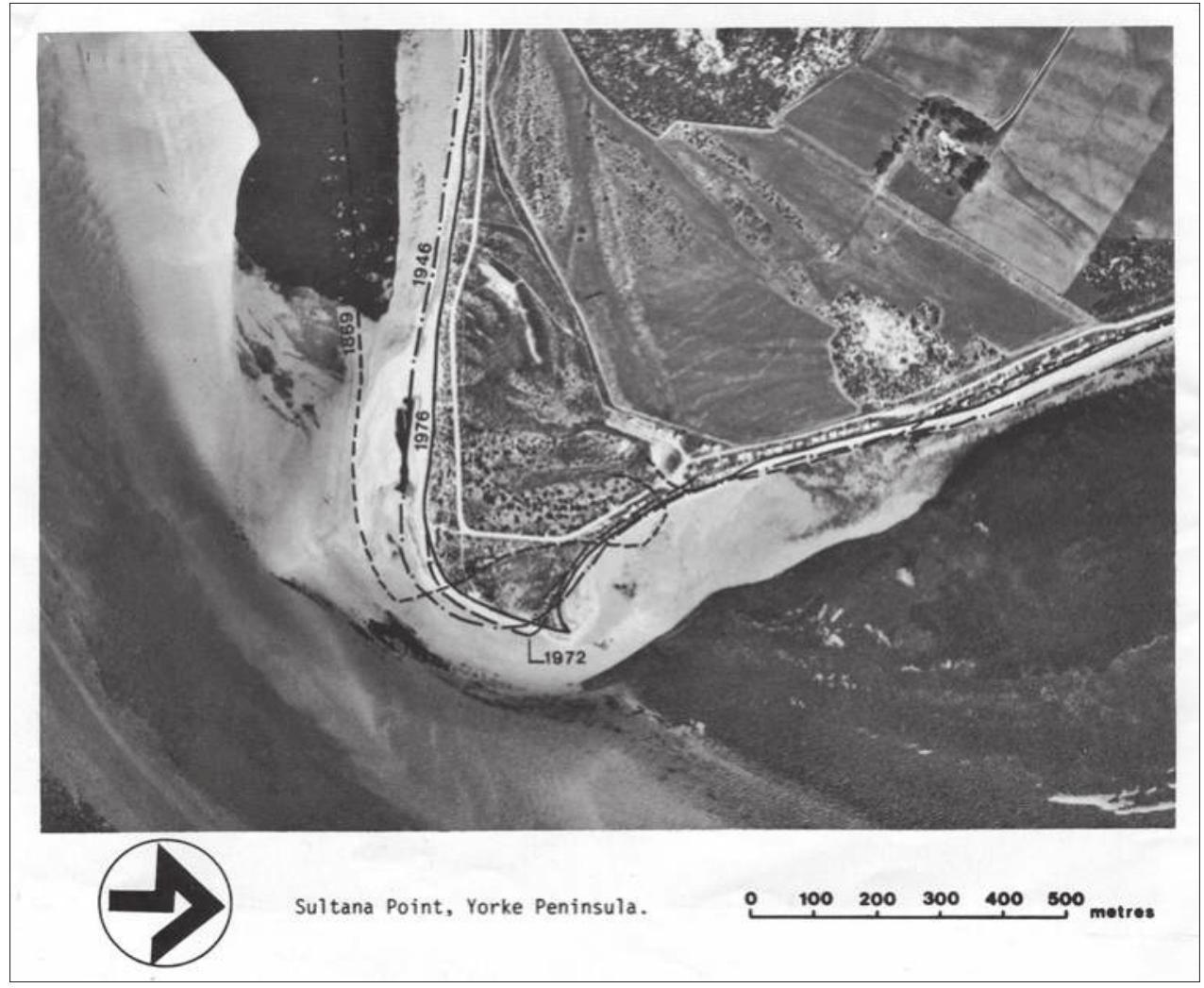

Figure 7.9 Aerial photograph, showing a complex of beach ridges and dunes on Sultana Point preserving stages in its evolution, with shoreline positions marked for 1869, 1946, 1972 and 1976.

Source: Reproduced with permission of the SA Coast Protection Board, 1977. 


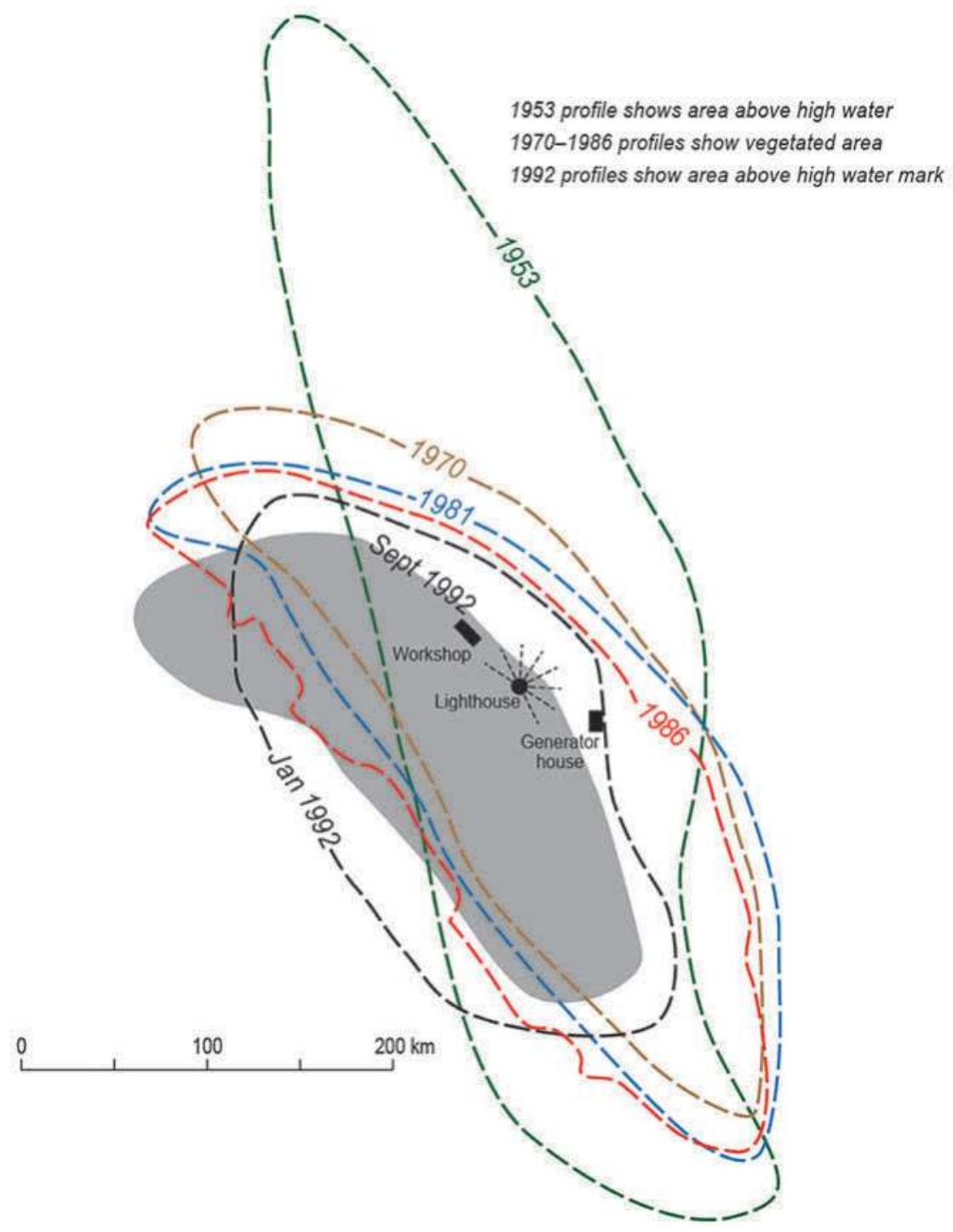

Figure 7.10 Troubridge Island, showing historical shoreline positions for 1953, 1970, 1986 and 1992.

Source: Modified and reproduced with the permission of the Department of Environment, Water and Natural Resources. <www.environment.sa.gov.au>.

Beyond Wattle Point, Sheoak Beach occupies a low-lying, southeasterly facing bay protected by intertidal reefs and extensive sandflats up to $500 \mathrm{~m}$ wide with seagrass meadows extending further offshore. The coast changes dramatically towards Troubridge Point, where there is severe undercutting of cliffs that are 6 to $10 \mathrm{~m}$ high (Figure 7.11). The backing land is very flat, comprising a thick calcrete surface, 


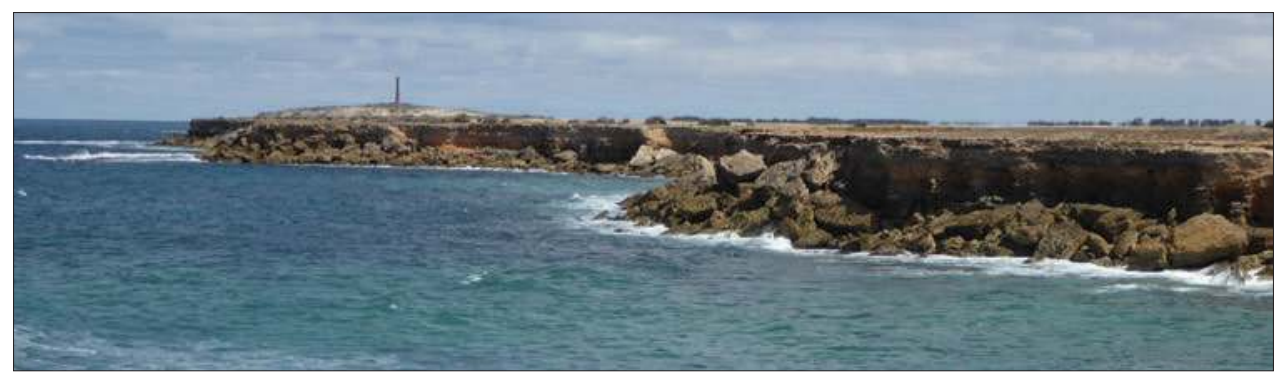

Figure 7.11 Troubridge Point, where there is severe undercutting of cliffs that are 6 to $10 \mathrm{~m}$ high. The cliffs are formed in earliest Pleistocene Hindmarsh Clay capped by calcrete. Troubridge Lighthouse sits on a younger Pleistocene aeolianite dune.

Source: Author's own work, RPB.

while the cliff line is eroded in the Port Willunga Formation ${ }^{48}$ and Hindmarsh Clay. Undercutting and subsequent cliff failure has resulted in the cliff being buttressed with huge slabs of calcrete, thereby inhibiting erosion.

\subsection{South and west coast of the 'foot'}

The coast changes from east- to south-facing at Troubridge Point; from here to Corny Point the coast is exposed to oceanic swell and storm waves from the southwest, leading to erosion and the formation of dunes, including cliff-top dunes, which are relatively rare on the east coast. This section of coastline is characterised by rocky headlands, shore platforms and cliffs developed in resistant rocks of the Gawler Craton and aeolianite deposits of the Bridgewater Formation. From Troubridge Point to Troubridge Hill (30 m AHD), the coastline is strongly crenulated and eroding in limestone bedrock. Howchin in 1900 noted that the sea near Troubridge Hill 'breaks at the base of the cliffs, which are being rapidly undermined'49, while Troubridge Hill is an aeolianite dune, originally formed as a cliff-top dune.

Permian glacigene sediments up to $31 \mathrm{~m}$ thick (claystones, clays and sands with erratics), Cenozoic limestone, Pleistocene Hindmarsh Clay (with white bands of alunite) and aeolianite of the Pleistocene Bridgewater Formation, with a calcrete capping, variably back Waterloo Bay, a bay $13 \mathrm{~km}$ wide between Troubridge Hill and Point Gilbert. ${ }^{50}$ Large erratics on the beach and pink garnetiferous beach sands indicate that they were derived from the glacigene sediments (Figure 7.12). ${ }^{51}$

Aeolianite forms a prominent headland and intertidal shore platform at Kemp Bay, but much of the cliff line near Kemp Bay is no longer actively eroding, indicated by the gentle and vegetated debris slopes on the cliff faces. The cliffs were probably 


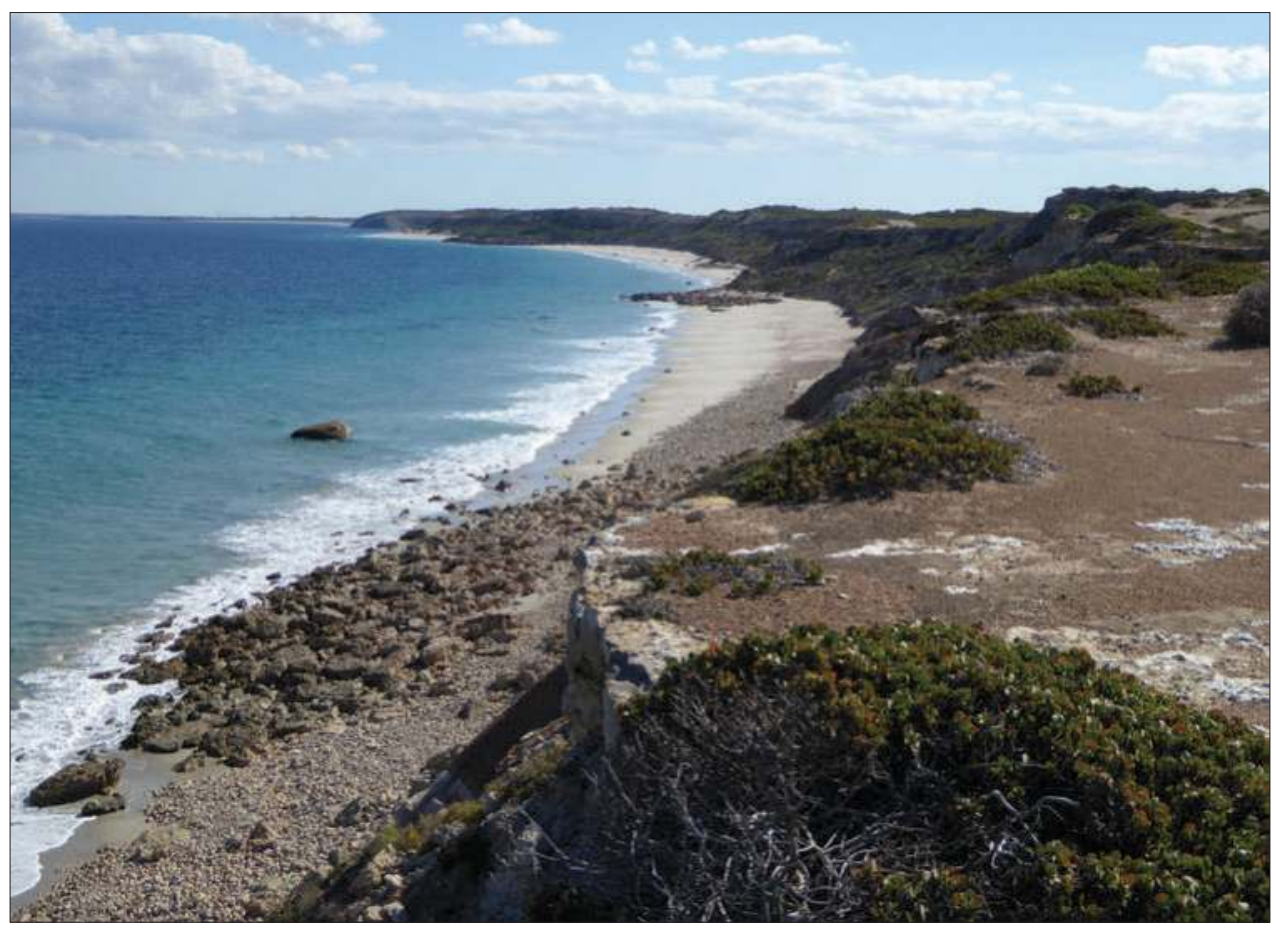

Figure 7.12 View along Waterloo Bay, with cliff formed in glacial, marine and terrestrial sediments. Note the beach cusps, the granite erratics and the purple garnet sands, indicating derivation from the Permian glacial sediments.

Source: Author's own work, RPB.

mainly eroded during the sea level of the Last Interglacial, which was $2 \mathrm{~m}$ higher than present. Cliff-top dunes are also prominent near Kemp Bay, probably forming as sand blew up sand ramps from the beach, forming precursors to the next generation of aeolianite dunes. A thin sequence of Permian glacigene sediments overlain by Port Willunga Formation limestone and mottled Hindmarsh Clay is exposed in lower cliffs at Port Moorowie and Point Gilbert, where the Pliocene Hallett Cove Sandstone also occurs. $^{52}$

Sturt Bay, a large sandy bay with backing vegetated dunes between Point Gilbert and Point Davenport, is $15 \mathrm{~km}$ wide. Permian glacial deposits and aeolianite of the Pleistocene Bridgewater Formation underlie the coastline, explaining why much of the backshore is low-lying and why, especially on the eastern side of the bay, there are extensive dunes up to $30 \mathrm{~m}$ high and more than $1 \mathrm{~km}$ wide; this reflects the effectiveness of southwesterly winds and ample supplies of sand. During Pliocene and 
last interglacial times, a seaway extended across the foot of the peninsula from Sturt Bay to Hardwicke Bay. Calcrete reefs and shore platforms, such as at Mozzie Flat, have formed on last interglacial sediments.

\subsubsection{Point Davenport}

An exception to the generally eroding nature of the south coast, with some protection from Kangaroo Island, is Point Davenport, which separates Sturt and Foul Bays as a cuspate foreland, the apex of which projects $4 \mathrm{~km}$ seaward of the general trend of the coast. It is a Holocene feature comprising lacustrine (lake) sediments and recurved sand spits; it has prograded seawards and to the east under the influence of southwesterly swells through Investigator Strait. Numerous recurved spits and sand barriers have impounded Tea Tree Swamp ${ }^{53}$ and many smaller lakes. There is no obvious influence of bedrock on the location of this feature, but it may sit on a substrate of aeolianite, while offshore reefs have subdued wave action. It is fronted by extensive sandflats and seagrass meadows, with a small triangular spit on its southwesterly side extending $400 \mathrm{~m}$ seawards.

\subsubsection{Foul Bay to Corny Point}

Foul Bay, which extends some $15 \mathrm{~km}$ from Point Davenport to Point Yorke, was possibly named after the decaying seaweed that abounds here. ${ }^{54}$ Facing the southeast, and protected from strong waves by the Point Yorke headland, offshore reefs and shoals, Foul Bay displays broad intertidal sandflats and seagrass meadows, backed by vegetated sand dunes. Towards the western end of the bay, at the boat-launching ramp, there is small, protected bay backed by a narrow high-tide beach and a stranded sea cliff $10 \mathrm{~m}$ high, the base of which coincides with a stranded cobble beach ( $2 \mathrm{~m}$ APSL) of probable last interglacial age. From western Foul Bay to Point Yorke, the shoreline is buttressed by Gawler Craton rocks, above which there are vegetated aeolianite cliffs up to $20 \mathrm{~m}$ high.

From Point Yorke to Meehan Hill, about $12 \mathrm{~km}$, the shore is more exposed and is bedrock-dominated, with overlying aeolianite, calcreted at the surface, forming headlands such as Hillock Point; cliffs and bluffs up to $40 \mathrm{~m}$ high are variably vegetated. Generally the cliff-top dunes are yellow, being derived from aeolianite. At Salmon Beach, where there is a low point between headlands, dunes have migrated landward to form cliff-top dunes. Some of the cliff-top dunes have been reactivated, while others are inactive, battered and vegetated. This section of coast is highly crenulated and is characterised by numerous sandy, structurally controlled beach compartments in between crystalline rocks and headlands, nearshore rocky reefs, rock pools (Pool Side and Coffin Beach), aeolianite shore platforms, boulder/cobble beaches (Annie's Nursery 
and Treasure Cove) and seagrass meadows. Some of the rocky shore platforms are being exhumed from beneath an aeolianite cover; large beach cusps are common on the sandy beaches. Beaches include Butlers Beach, Salmon Beach, Pool Side, Coffin Beach, Annie's Nursery, Treasure Cove and Meteor Bay. Marion Bay, which is $8 \mathrm{~km}$ wide, extends west from Meehans Lookout to the aeolianite headland at Penguin Point, which is $10 \mathrm{~m}$ high and is being undercut. Marion Bay is a large sandy bay backed by parabolic dunes, which are derived from the southwest and up to $28 \mathrm{~m}$ high on the eastern side of the bay, with a series of beach ridges at the western end. There are beach cusps of various dimensions, and cliffing of the beach berms is common. In the Marion Bay Township, a storm surge barrier to protect houses has been constructed.

The coast from Penguin Point to Gym Beach, a distance of some $40 \mathrm{~km}$ along the 'toe' of the peninsula, is occupied by Innes National Park. This coast is very spectacular; it is dominated by bedrock-protected aeolianite cliffs and headlands up to $70 \mathrm{~m}$ high, sea stacks, islands, rocky reefs, shore platforms (both on bedrock and aeolianite), numerous pocket beaches and beach compartments backed by modern dunes, and

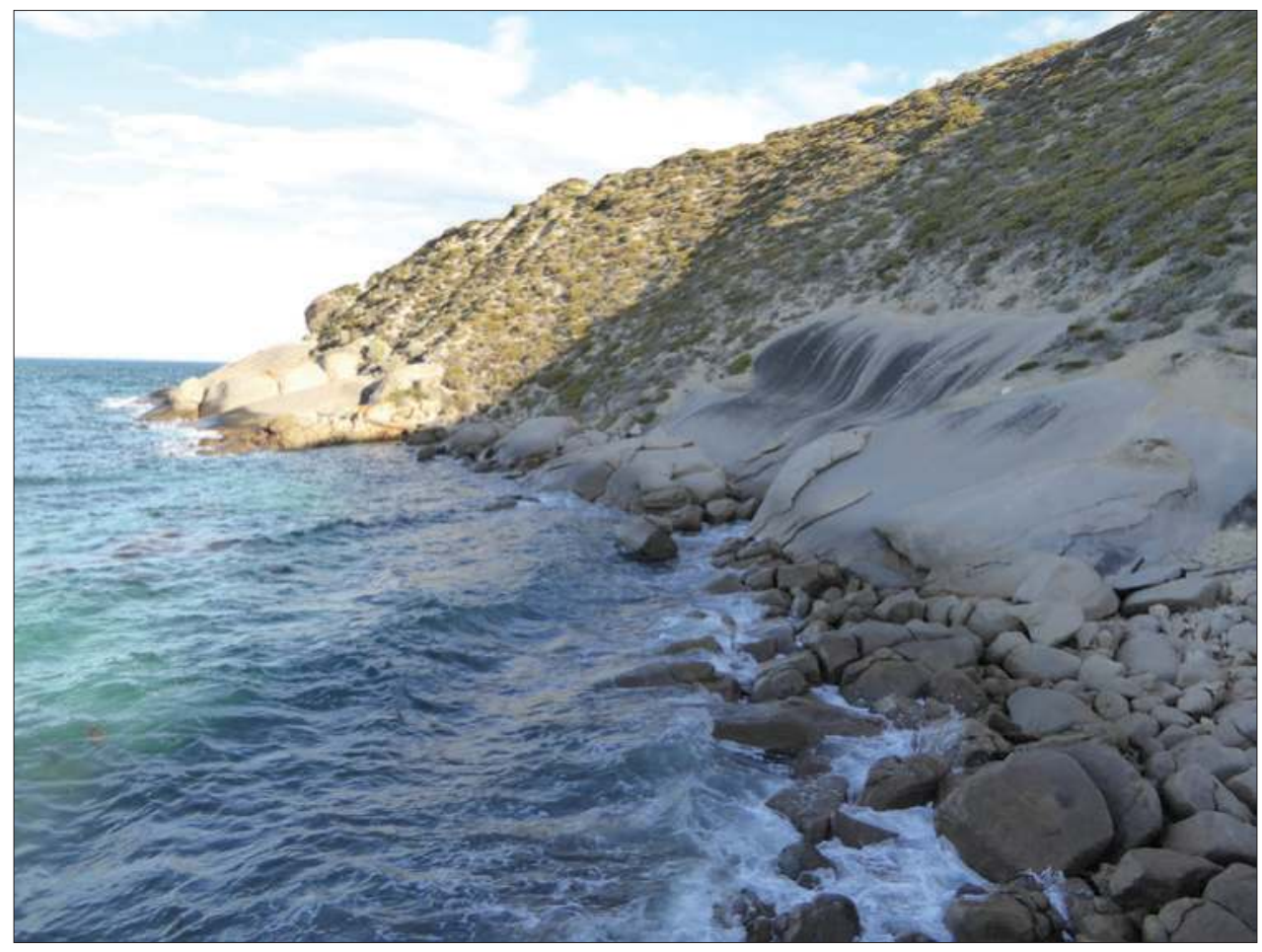

Figure 7.13 Pronounced flared slope in granite at Stenhouse Bay, which may relate to the higher sea level of the Last Interglacial.

Source: Author's own work, RPB. 


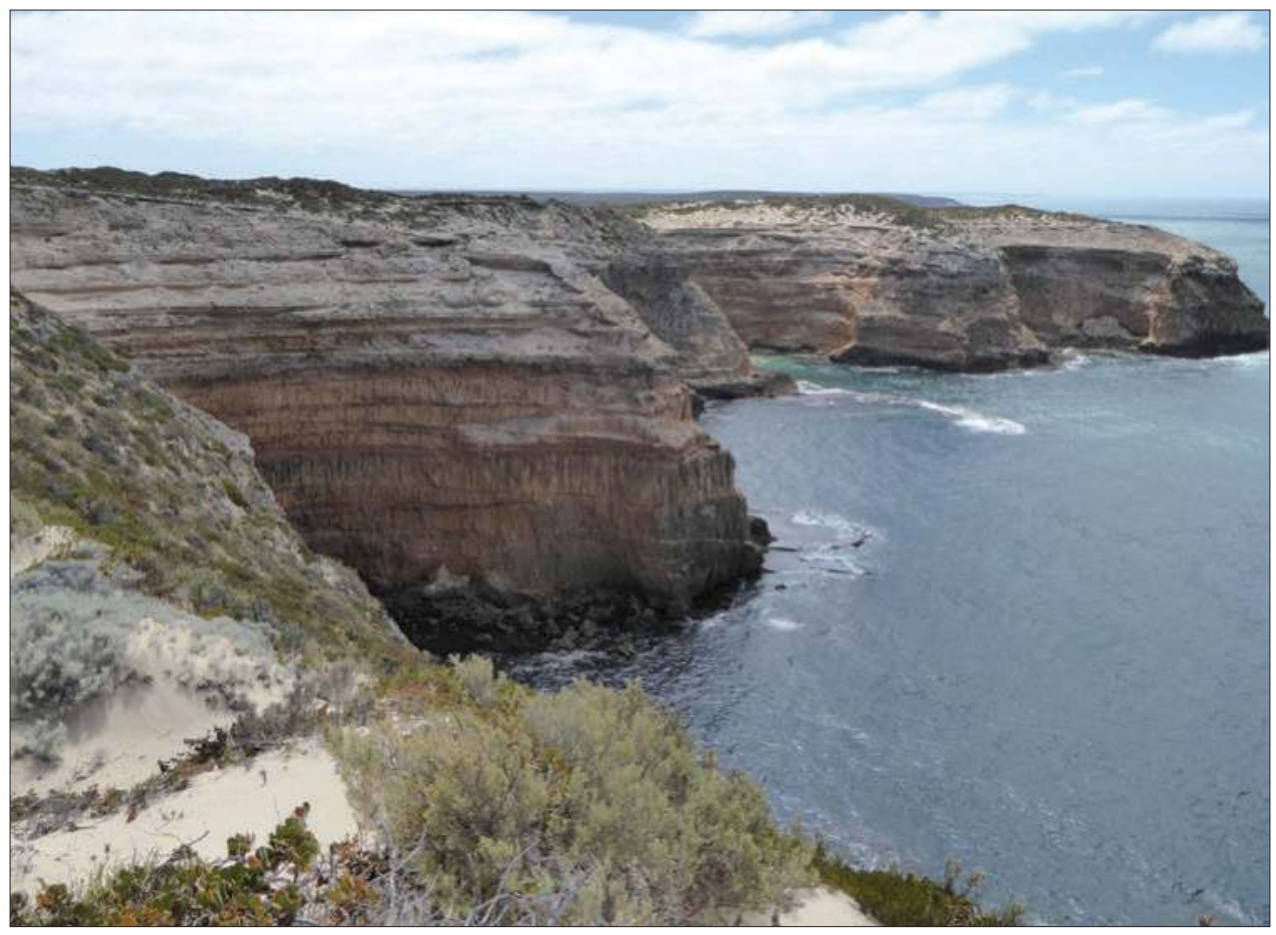

Figure 7.14 Cape Spencer. Note the multiple horizons of fossil soils separating bands of aeolianite and the current cliff-top dunes.

Source: Author's own work, RPB.

cliff-top dunes. On the west-facing section, especially at Browns Beach and at Formby Bay, fields of vegetated parabolic dunes, which are up to $60 \mathrm{~m}$ high, extend $3 \mathrm{~km}$ inland and are fronted by active dunes $1 \mathrm{~km}$ wide. Much of the dune sand has been derived from aeolianite. There is evidence of a last interglacial sea level $+2 \mathrm{~m}$ high around this coastline, which helps to explain some of the coastal features. For example, at the aptly named Rhino Head, small sea stacks and a shore platform as well as a pronounced flared slope in granite at Stenhouse Bay may relate to this higher sea level (Figure 7.13); evidence of the last interglacial Glanville Formation occurs between these two sites. ${ }^{55}$ Near the Stenhouse Bay jetty, granite boulders are being exhumed as the Bridgewater Formation continues to erode.

Between Stenhouse Bay and Cape Spencer (Figure 7.14), there are spectacular views of Chinamans Hat Island, Cable Bay, Haystack Island, Seal Island, the Althorpe Islands, Kangaroo Island and Wedge Island, the south-facing aeolianite cliffs of which are $200 \mathrm{~m}$ high (Figure 7.15). This coast is exposed to high wave and wind action and 


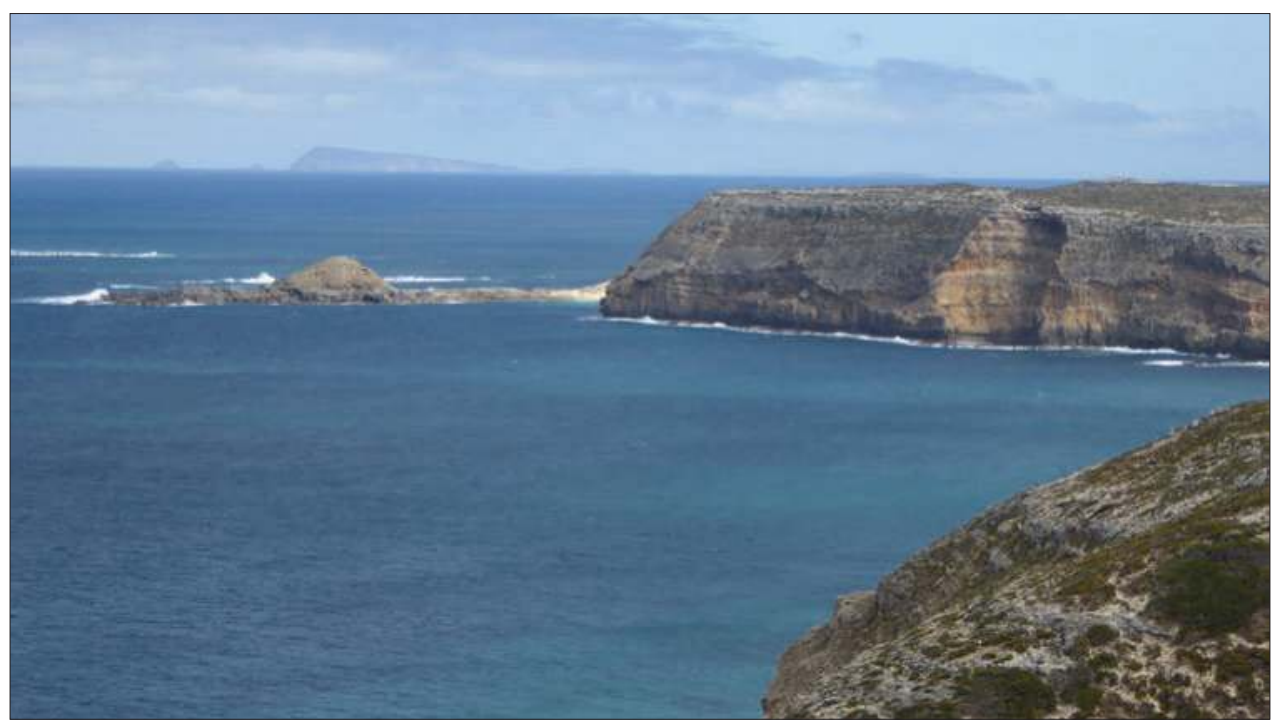

Figure 7.15 Aeolianite cliffs and islands seen from Cape Spencer. Wedge Island preserves the original backslope of the aeolianite dune form, while the south-facing side has been eroded into cliffs $200 \mathrm{~m}$ high.

Source: Author's own work, RPB.

is possibly the windiest location in South Australia. The Cape Spencer headland, which is $84 \mathrm{~m}$ high, is cut in aeolianite and is bolstered by crystalline hard rocks, as are the Althorpe Islands. Numerous calcrete and soil horizons occur within the aeolianite, indicating times of depositional quiescence of sand. Separated by the protruding Reef Head and The Gap, two linear, structurally controlled sections of coast trend to the northwest from Cape Spencer and Ethel Wreck, to the north of which there is a break in the aeolianite cliffs, allowing dunes to migrate inland to form parabolic, cliff-top dunes which extend $1 \mathrm{~km}$ inland (Figure 7.16).

The West Cape aeolianite promontory $(50 \mathrm{~m})$ is underlain by granite, which also forms numerous nearshore rocky reefs, islets and shipping hazards. Between West Cape and Gym Beach, the coast is heavily embayed with numerous islands, eroding headlands, sandy beach compartments, a tombolo at Groper Bay, incipient islands ${ }^{56}$, large parabolic dune fields and cuspate forelands opposite Middle Island and Royston Island. At Pondalowie Bay, the sea has breached an aeolianite barrier, exposing the gentle backslope of the original dune (Figure 7.17) and forming the picturesque, crescent-shaped bay, which is backed largely by vegetated parabolic dunes extending up to $1.5 \mathrm{~km}$ inland, with occasional blowouts. The coast is still subject to active erosion, evidenced by shore platforms and notches undercutting cliffs. Evidence of the sea level 125000 years ago at Pondolowie Bay ${ }^{57}$, which was $+2 \mathrm{~m}$ higher, suggests 


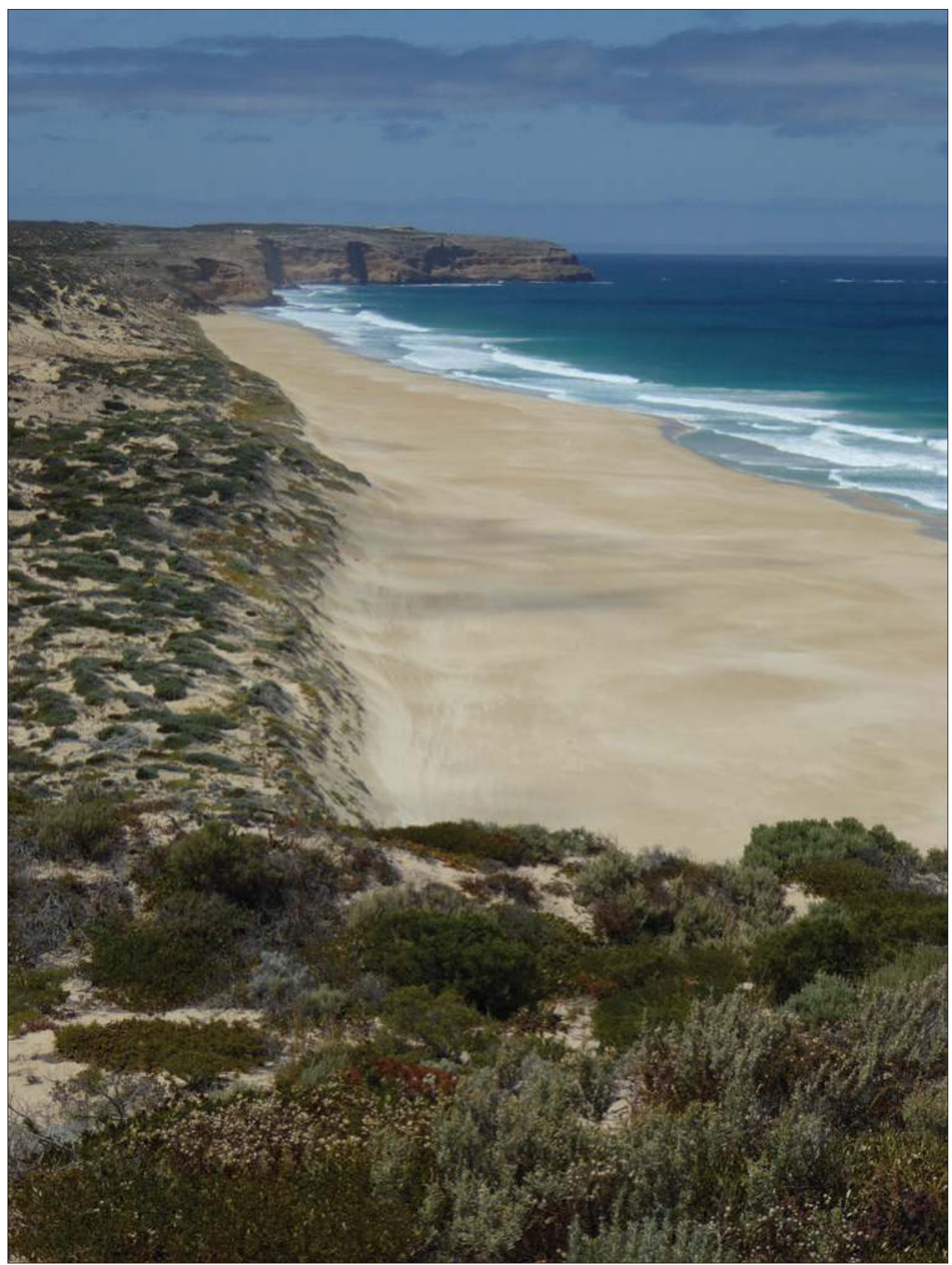

Figure 7.16 The sandy bay between West Cape and the wreck of the 'Ethel' provides a sand source for dunes that have migrated up to $1 \mathrm{~km}$ inland from the beach.

Source: Author's own work, RPB. 


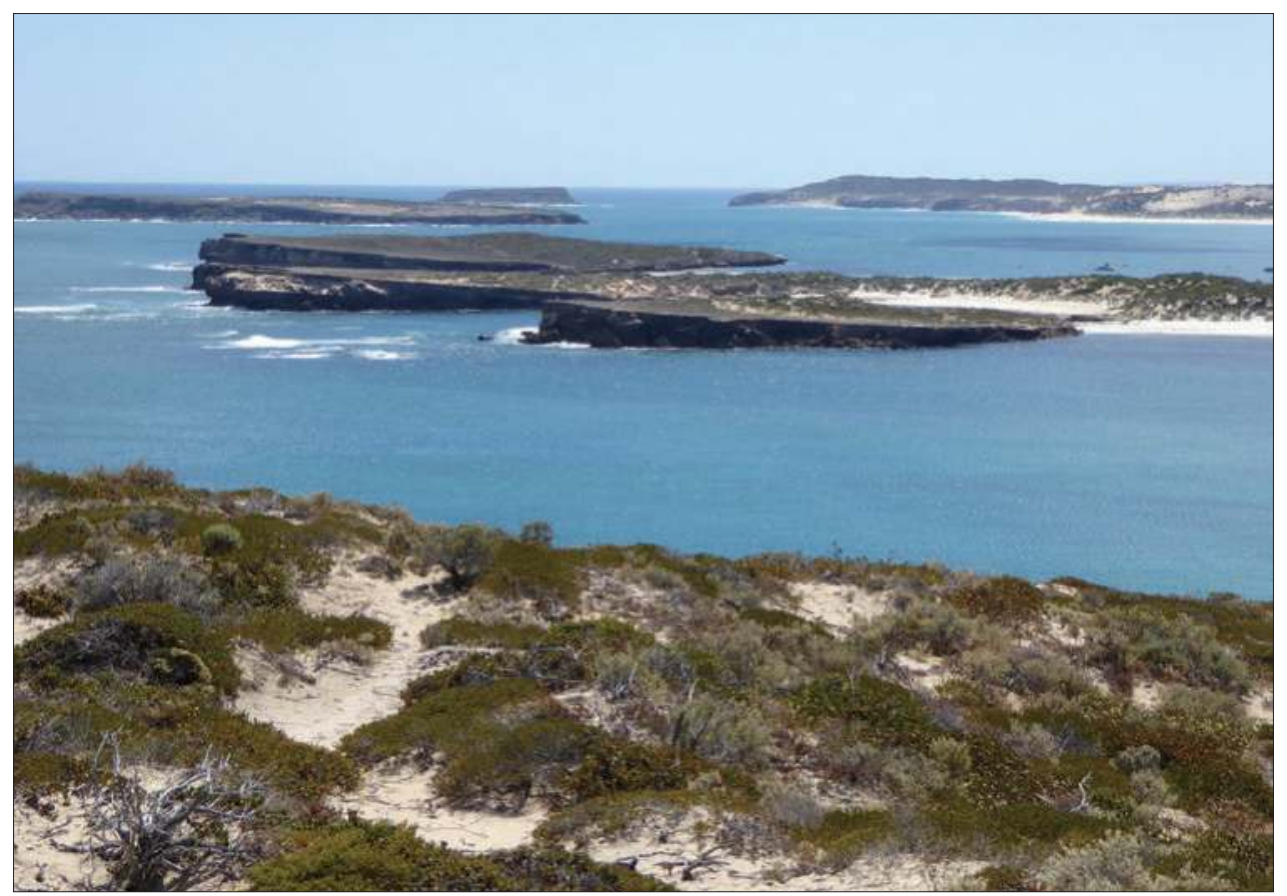

Figure 7.17 View of Pondalowie Bay, showing gentle backslope of breached aeolianite dune. Source: Author's own work, RPB.

that erosion was even more effective then, which may account for the breaching of the aeolianite dune.

From Royston Head (50 m), which is underlain by aeolianite and resistant bedrock at the base, forming prominent rock ramps, the coast is oriented to the east before trending north at Browns Beach. There are numerous rocky headlands, which control the shape of the coast, flanking sandy beach compartments backed by dunes, such as Shell Beach, the probable site of a former seaway through the Innes National Park from Marion Bay. At Dolphin Beach, whale-shaped rocks are being exhumed from beneath a cover of aeolianite. Brown Beach, in its southern section, has two nearshore calcareous reefs, which support a lagoon and protect the backing beach. Active dunes extend inland for some $500 \mathrm{~m}$, while a large field of fixed parabolic dunes up to $40 \mathrm{~m}$ high extend inland for almost $2 \mathrm{~km}$. Both the beach and dune sands are yellow in colour, suggesting derivation from aeolianite. In other localities, white sands may have been derived from weathering and erosion of granitic rocks or from shells, while brown-coloured sands indicate a source from the former desert dunes that are common on the peninsula. 
From Gym Beach to Corny Point, a similar coastline prevails with granite headlands, shore platforms, sandy bays and dune fields. Formby Bay between Point Margaret and Daly Head is a large embayment $9 \mathrm{~km}$ long and formed in aeolianite, with broad, flat, intertidal shore platforms with runnels and solution features (holes and lapiés) with notching at cliff bases. It is a high-energy bay, with some protection offered by Ella Rock and nearshore reefs. Parabolic dunes up to $50 \mathrm{~m}$ high extend landward from the centre of the bay for $3 \mathrm{~km}$, with the first kilometre of the dunes still being active.

Daly Head is a prominent bedrock headland buttressed by metamorphic rocks and Gleesons Landing Granite, forming boulder-covered shore platforms. An island, accessible at low tide, results in intense wave refraction, so that waves approach around the island from two different directions (Figure 7.18). To the north are two natural breakwaters of Gleesons Landing Granite topped with aeolianite, which separate white sandy beaches. At Gleesons Landing, north of the natural breakwaters, there are extensive flat intertidal shore platforms cut across aeolianite, which subdue wave energy. Largely vegetated dunes back the bay between Gleesons Landing and Swincer Rocks, a headland protected by old rocks, flat shore platforms, nearshore islands and reefs, all of which influence the direction of wave approach. North to Point Annie is an extensive sandy bay with vegetated dunes terminating at the aeolianite and bedrock headland, which is $20 \mathrm{~m}$ high.

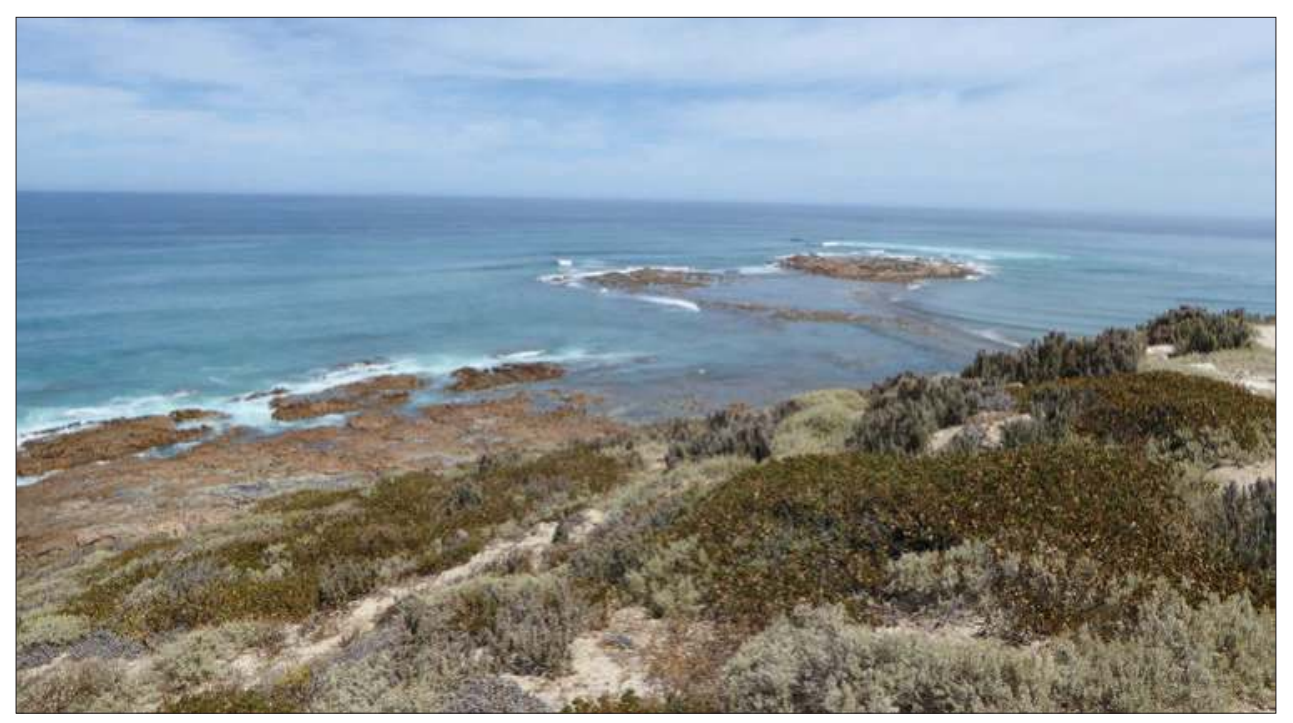

Figure 7.18 Daly Head is protected by shore platforms of resistant bedrock, which cause convergent waves to approach the headland.

Source: Author's own work, RPB. 


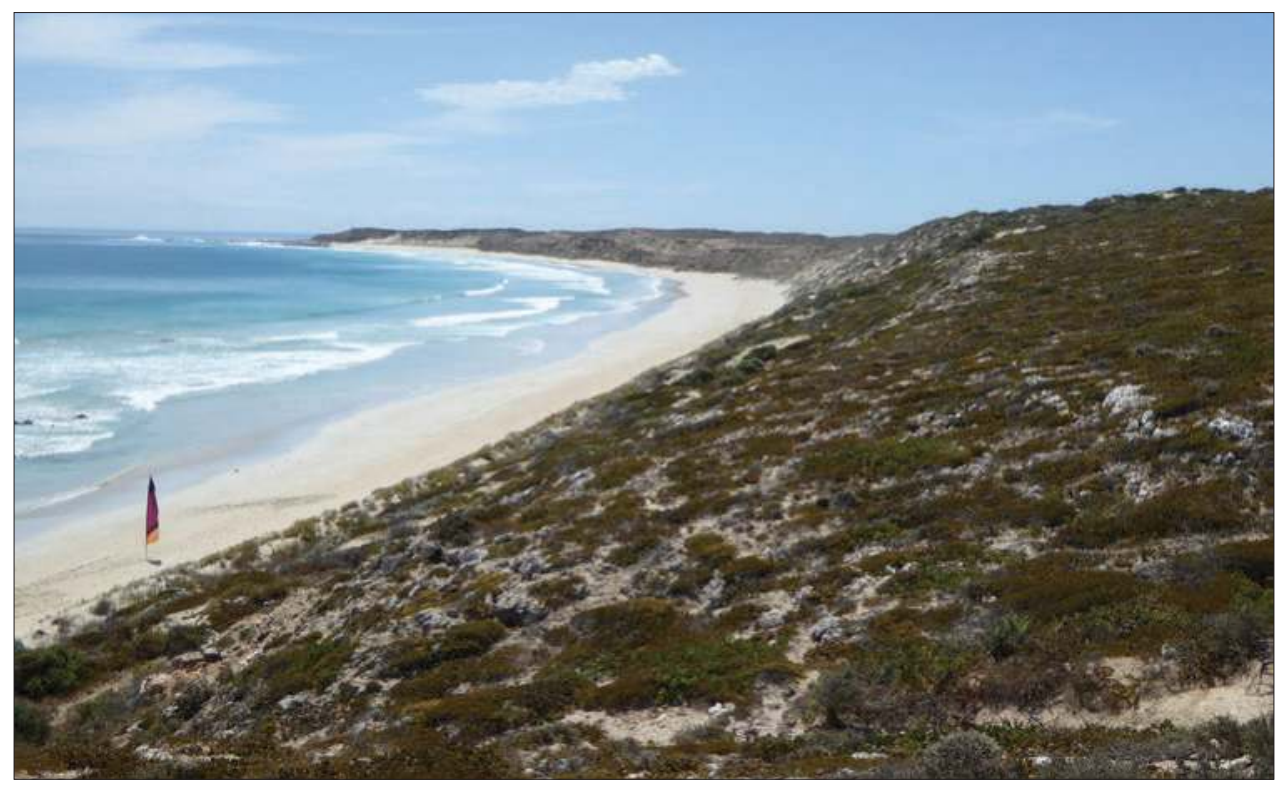

Figure 7.19 View along the northern end of the sandy Berry Bay towards the Corny Point Lighthouse.

Source: Author's own work, RPB.

Between Point Annie and southern Berry Bay, the coast consists of aeolianite cliffs and headlands $20 \mathrm{~m}$ high, protected by underlying granitic and metamorphic rocks, which produce reefs and isolated boulders. Some of the bluffs are vegetated, suggesting that they are currently not active, while many small pocket beaches occupy the bays between the headlands. The northern end of Berry Bay, West Beach comprises a sandy beach $2 \mathrm{~km}$ long with cusps and rips, backed by cliffs $20 \mathrm{~m}$ high in the south and a field of dunes $20 \mathrm{~m}$ high in the north, which merge with cliff-top dunes (Figure 7.19). These are replaced by bedrock shore platforms, reefs and aeolianite bluffs around as far as the Corny Point lighthouse, beyond which there is a dramatic change in wave energy and the character of the coast.

\subsection{The west coast}

\subsubsection{Hardwicke Bay}

Hardwicke Bay extends from Corny Point to Port Victoria on the north-facing side of the 'foot' and the west-facing part of the leg. The Corny Point rocks, which are the oldest on Yorke Peninsula, with a metamorphic age of near $1845 \mathrm{Ma}$, include gneisses (strongly metamorphosed rocks), which are intruded by the Gleesons Landing Granite. 
East of the Corny Point lighthouse, there is a horseshoe-shaped bay with headlands formed of Gawler Craton rocks. The bay is backed by cliffs cut in aeolianite, with a field of vegetated dunes. A thin bed of Point Turton Limestone has been reported from Corny Point, overlying basement rocks and overlain by a calcrete $10 \mathrm{~m}$ thick. ${ }^{58}$

The coast between the hard rocky headlands of Corny Point and Point Souttar is formed largely on aeolianite ${ }^{59}$, producing calcareous shore platforms, reefs, broad intertidal sandflats, white sandy bays, narrow high-tide beaches and vegetated sand dunes 15 to $20 \mathrm{~m}$ high, with occasional bluffs up to $20 \mathrm{~m}$ high. From Dunn Point to Burners Beach, the coast has formed largely through accretion. Former embayments of the Last Interglacial have been infilled with Holocene beach and dune ridges, causing the coast to protrude seawards at the Leven Beach Conservation Park; almost 100 ridges have built out the coastline $3 \mathrm{~km}$ during the past 7000 years (Figure 7.20). Beaches

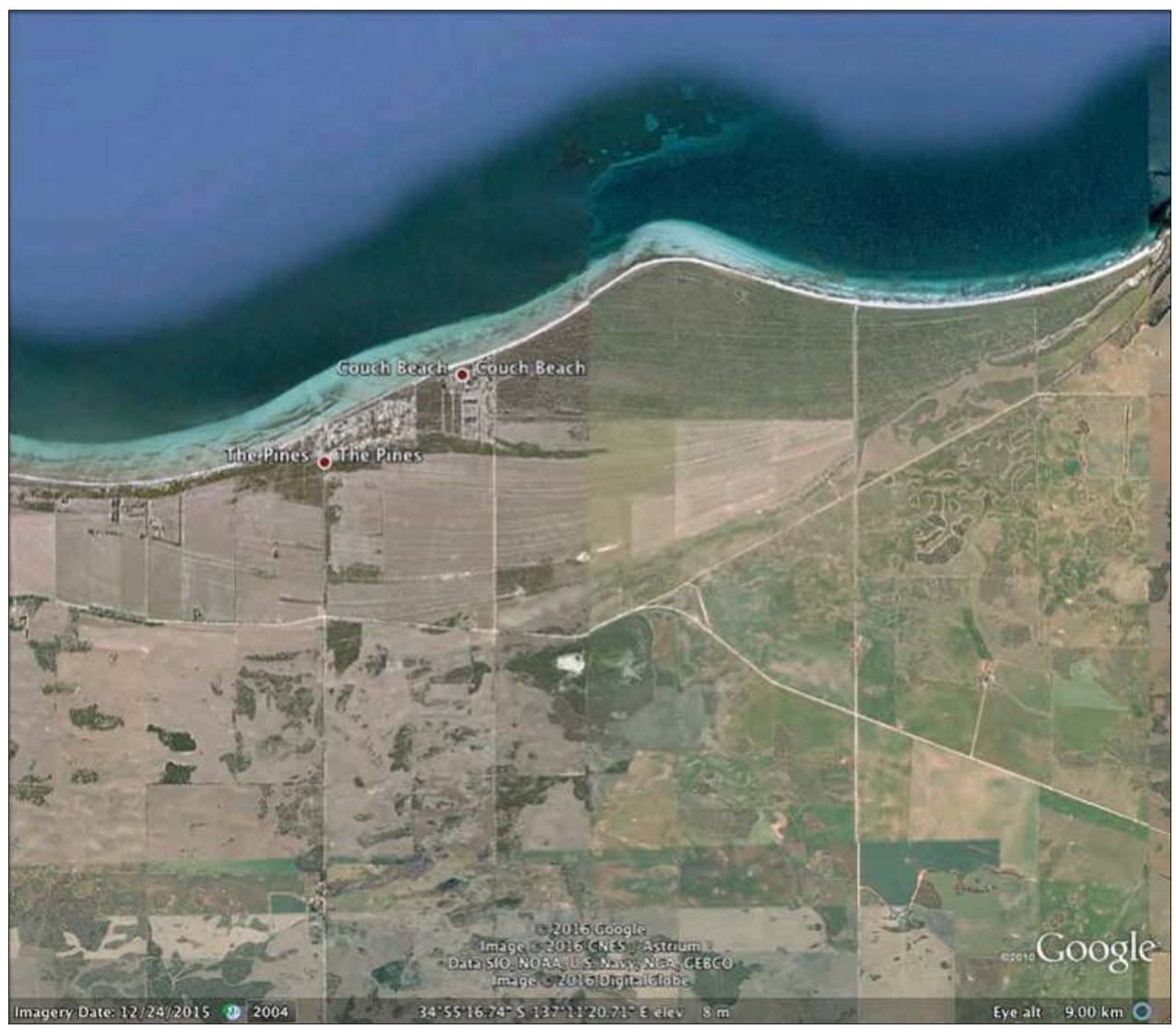

Figure 7.20 The Leven Beach beach ridge sequence of almost 100 ridges built out the coastline by $3 \mathrm{~km}$ during the past 7000 years, infilling a former last interglacial embayment. Source: Google Earth image (๑) 2015 Google. 
along this section of coast include Dairy Estate, Collins Beach, The Pines, Couch Beach and Leven Beach, all of which are fronted by broad intertidal sandflats, seagrass meadows and largely vegetated dunes. Dead seagrass often covers the sandy beaches. Despite the low wave energy, this coast of largely unconsolidated sand is vulnerable to erosion at times of high tide, so that rock revetments have been frequently used to protect infrastructure and dwellings. Towards the eastern side of Burner Bay, where there is a camping area, an abandoned sea cliff up to $30 \mathrm{~m}$ high forms the coast; it probably relates to the higher sea level of the Last Interglacial (125 ka). This inactive cliff merges to the west with the large, most inland dune backing the Leven Beach Conservation Park beach ridges.

Galway Bay is situated between structurally controlled bedrock headlands and islands, which form natural breakwaters and cause the coast to protrude as small tombolos. Gawler Craton bedrock also forms an extensive shore platform and reefs. Foredunes and thickly vegetated hind dunes back the beach, while at the eastern end of the bay there are active cliff-top dunes up to $26 \mathrm{~m}$ high overlying aeolianite and possible Point Turton limestone.

Point Souttar is a bluff $15 \mathrm{~m}$ high, underlain by aeolianite and buttressed by Gawler Craton rocks. There is a small occurrence of the earliest Pleistocene Point Ellen Formation limestone just to the southeast of Point Souttar. Between Point Souttar and Point Turton, there are sporadic outcrops of resistant Gawler Craton rocks and Point Turton Limestone, but beyond the eastern limit of the old rocks, there are possible high-level storm deposits, some of which have been derived from Point Souttar rocks, indicating west-east longshore transport. Between Point Souttar and Point Turton, low rocky bluffs and shore platforms and a sandy high-tide beach dominate the coast, with the Oligocene-Miocene Point Turton Limestone underlying the coast ${ }^{60}$ from Brutus Road to Point Turton, where the limestone rests on Permian glacial sediments; these are exposed in Magazine Bay. A fossil beach, which is 125000 years old and represented by the calcreted Glanville Formation, occurs along the coast for several kilometres to the west of Fish Point. ${ }^{61}$ An unconsolidated shell deposit, $2 \mathrm{~m}$ high, extends for a further kilometre to the west.

\subsubsection{Point Turton to Point Gawler}

Between Point Turton and Point Gawler, the coast is underlain by easily eroded Permian glacial sediments, explaining the general low-lying character of the coast, the very broad sandflats and the abundant dunes, which are rare on the east coast. Outcrops of the Hallett Cove Sandstone, at Port Rickaby ${ }^{62}$, and the last interglacial calcreted Glanville Formation, which extends up to $4.5 \mathrm{~m}$ APSL, produce headlands, extensive intertidal shore platforms and reefs along this section of Hardwicke Bay. Landward of the extensive dune systems, there is commonly low-lying land, where shells of the last interglacial shoreline occur. 


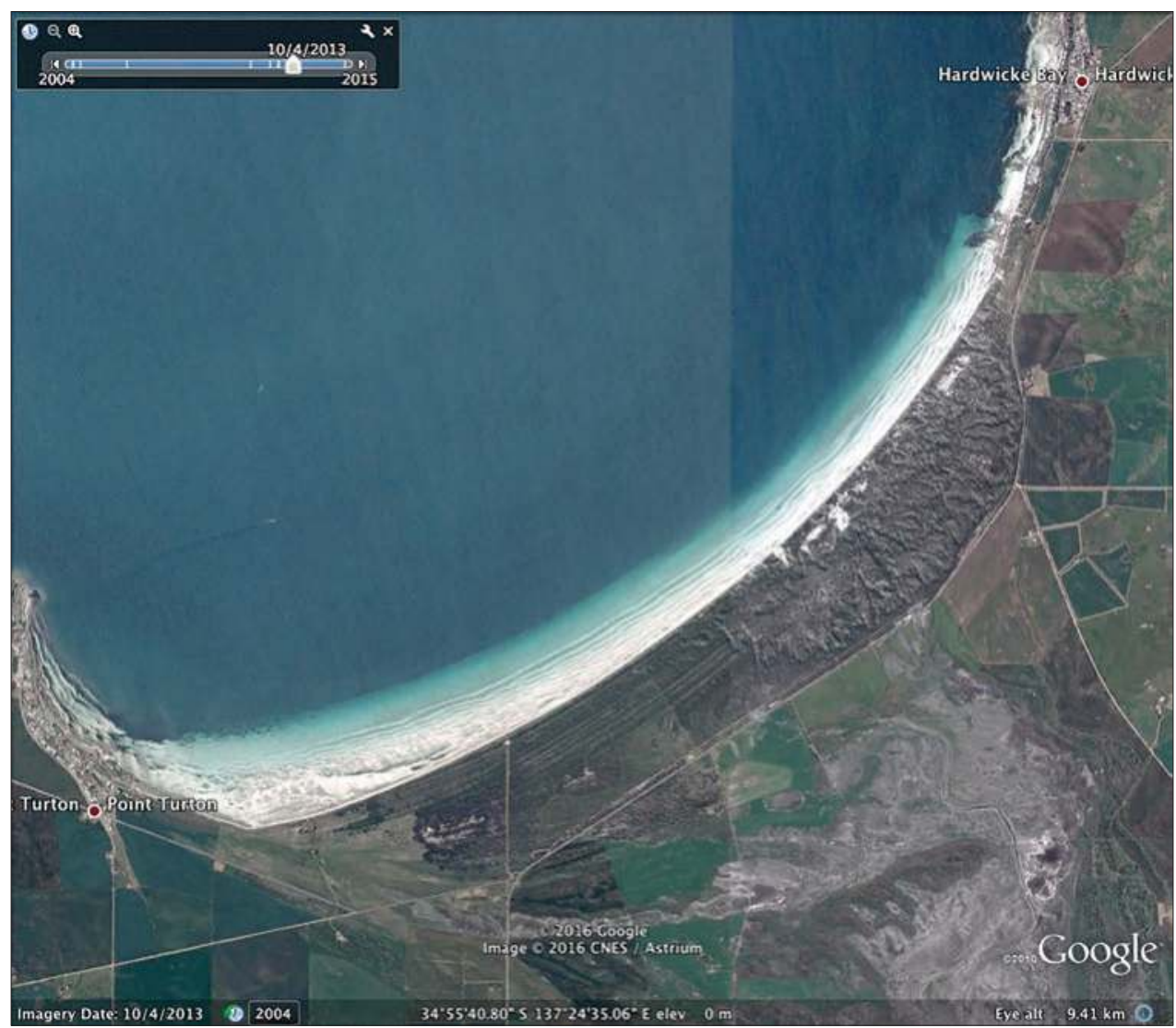

Figure 7.21 The coast between Point Turton and Hardwicke Bay township. This is a lowenergy shoreline with broad, ridged intertidal sandflats up to a kilometre wide with up to a dozen individual megaripples with patches of seagrass. A sequence of Holocene foredune ridges and dunes 2 to $2.5 \mathrm{~km}$ wide can be seen in the southwest, with an extensive dune field to the northeast.

Source: Google Earth image ( 2013 Google.

The bay between Point Turton and Hardwicke Bay Township, which is $10 \mathrm{~km}$ wide, occupies a low-energy shoreline, with rocky shore platforms at either end but with broad, ridged intertidal sandflats up to a kilometre wide in between. Up to a dozen individual megaripples with patches of seagrass can be distinguished. Flaherty Beach, the main beach in the bay, is backed by an infill of calcreted last interglacial beach ridges with Holocene foredune ridges and dunes, 2 to $2.5 \mathrm{~km}$ wide, in the southwest. A jumble of parabolic dunes in the northeast was constructed mainly by northwesterly winds. This infill marks the former location of a seaway across the peninsula to Sturt Bay 125000 years ago. 
Between Hardwicke Bay Township and Cockle Beach, the coast trends north. Along it there are numerous intertidal shore platforms in calcrete, with reefs up to $500 \mathrm{~m}$ wide, sandflats, narrow high-tide beaches and much dead seagrass (Posidonia australis). A strip of dunes up to $10 \mathrm{~m}$ high follows the shoreline northwards from Flaherty Beach, but narrows as it does so. At Port Minlacowie, calcreted shells of the last interglacial Glanville Formation at $4 \mathrm{~m}$ APSL are associated with a series of shore platforms.

Parsons Beach, which occupies the area between Cockle Beach and Brown Point (The Bluff), is a white, sandy bay $8 \mathrm{~km}$ long. North of Cockle Beach, the sand dunes increase in height and width, reaching up to $25 \mathrm{~m}$ and extending inland for up to $500 \mathrm{~m}$. In places they are brownish in colour, suggesting that they have been derived from pre-existing desert dunes. Some of the dunes are active, as for example at Watson Beach, where there are mobile transgressive dunes with nubbins of vegetated dunes (nebkhas) on their summits. At Brown Point and The Bluff, very rocky, calcareous shore platforms, headlands and bluffs up to $10 \mathrm{~m}$ high are most likely formed on sediments of last interglacial age. Dwellings built on the foredune at Bluff Beach have a rock wall for protection. The rocky shoreline continues to Barker Rocks, where there is a small break in the reefs, with the majority of the shoreline to Port Rickaby consisting of sandflats, seagrass meadows and dunes up to $25 \mathrm{~m}$ high.

A large sandy bay forms the section of coast between Port Rickaby and Renowden Rocks, which is $15 \mathrm{~km}$ long. Here, the first exposure of Gawler Craton rocks since Point Souttar forms a resistant barrier that has produced a sandy tombolo. This bay includes individually named narrow high-tide beaches: Bushes Beach, Bamboo Beach, Kemps Beach and Wauraltee Beach. Holocene shell flats and ridges occur sporadically along this coast. The southern section of the sandy bay is characterised by broad, calcareous shore platforms up to $500 \mathrm{~m}$ wide, while in the north, sandflats and seagrass meadows dominate, reflecting the northward transport of sand along the beach. Dunes 10 to $20 \mathrm{~m}$ high are a major feature of this entire coastal section, and in the north, between Wauraltee Beach and Renowden Rocks, the dunes widen to $2 \mathrm{~km}$, suggesting that sand has been derived from the south. The dunes are generally stabilised by vegetation, with rare areas of drifting sand. Landward of the dune fields, there is commonly low-lying and sometimes swampy land, which probably formed embayments during the Last Interglacial when the sea level was $2 \mathrm{~m}$ higher than present; excavations, wombat burrows and debris around posts reveal abundant evidence of marine shells underlying the flats.

North of Renowden Rocks, outcrops of resistant Gawler Craton rocks (basalt, gneisses, pegmatites and amphibolite dykes) form rocky shores and headlands separating sandy beaches backed by dunes such as Second Beach, Rifle Butts Beach and around Port Victoria beyond Point Gawler. Calcrete-capped benches along the shore 
between Port Gawler and the Port Victoria jetty may relate to the high last interglacial sea level. There are many rocky islets and reefs in Port Victoria harbour.

\subsubsection{Port Victoria}

The general smooth and linear character of the coastline is interrupted near Port Victoria Township by Wardang Island and Point Pearce Peninsula. Resistant rocks of the Gawler Craton underlie both features, but this does not explain their present form. It is possible that the bedrock morphology of this area was fashioned by glacial erosion during Permian times, when an ice mass of continental proportions, more than $1 \mathrm{~km}$ thick, moved in a northwesterly direction across Yorke Peninsula. Glacial sediments occur at Port Victoria Township and on Wardang Island, where there is grooved and polished bedrock on the south coast of the island, as well as erratics of Encounter Bay Granite. ${ }^{63}$ As with Fleurieu Peninsula, the bedrock subsurface topography on Yorke Peninsula is considerable; at Stansbury, Permian glacigene sediments occur $300 \mathrm{~m}$ BPSL, and at Minlaton, they extend almost $500 \mathrm{~m}$ BPSL. ${ }^{64}$ Thus Wardang Island and Point Pearce Peninsula as former rochés moutonneés represent a high portion of the irregular glaciated Permian terrain. During the Pliocene and the Last Interglacial, both were islands, but Point Pearce Peninsula was later attached to the mainland by Quaternary coastal sediments.

\subsubsection{Wardang Island (Wauraltee Island)}

Wardang Island, with a high point of $29 \mathrm{~m}$, covers an area of some $20 \mathrm{~km}^{2}$ and lies $9 \mathrm{~km}$ offshore from Port Victoria Township. It is underlain by resistant basement rocks of the Gawler Craton, metamorphosed porphyry, a volcanic rock, which is interbedded with sediments and conglomerates, and intruded by volcanic dykes. ${ }^{65}$ Permian ice transgressed the island, as glacial till and pebbly sandstone containing exotic rocks occur around the southern coastline ${ }^{66}$, resting on glacially smoothed basement rocks, which carry grooves trending south-southeast to north-northwest. ${ }^{67}$ Further evidence for this direction of ice movement is provided by the presence of granite erratics, derived from Encounter Bay. ${ }^{68}$ It is likely that the bedrock topography of Wardang Island and Point Pearce Peninsula was fashioned by ice, forming asymmetrical glaciated rock knobs, subsequently covered with Neogene and Pleistocene sediments.

Both were originally islands, but Point Pearce Peninsula was later joined to the mainland by coastal sediments. A sequence of Pliocene Hallett Cove Sandstone $4.2 \mathrm{~m}$ thick occurs on the south coast of the island at Fossil Beach. ${ }^{69}$ Rocky headlands, cliffs with large caves and rock overhangs, shore platforms, islets and bays with occasional sandy beaches such as Bikini Beach fringe the exposed rugged western half of the island, from where sand dunes $20 \mathrm{~m}$ high extend up to $2 \mathrm{~km}$ inland. In contrast, the eastern side of the island consists of a low-lying swamp marsh with 
tidal channels and seagrass meadows; it is a classic prograding barrier beach, growing seawards at a rate of $25 \mathrm{~cm}$ per year. ${ }^{70}$ Bird Point, which protrudes seaward, continues as an intertidal sand spit into Port Victoria Bay. Aeolianites of the Bridgewater Formation occur extensively on the northern and western sides of the island with intervening calcrete horizons; one prominent, continuous calcrete horizon is traceable for some kilometres. $^{71}$

Evidence of higher sea levels on Wardang Island includes shore platforms and coastal sediments. The Hallett Cove Sandstone at about $10 \mathrm{~m}$ AHD indicates the level of the sea in the Pliocene. The last interglacial shoreline at $2 \mathrm{~m}$ AHD is represented by beach ridges on the east coast and a fossiliferous limestone overlying truncated aeolianite on the north coast, with a probable Holocene shoreline $1 \mathrm{~m}$ APSL marked by shell hash beds in the eastern salt marsh. ${ }^{72}$ Calcareous mobile dunes of fine shell sand on the south of the island were mined for use as a flux and by the 1960s had been totally removed, but 15 years later, mobile longitudinal dunes of this material were re-establishing. ${ }^{73}$

\subsubsection{Point Pearce Peninsula to near Tickera}

North of Point Pearce Peninsula and in the lee of Reef Point, the coast to Balgowan Point is very subdued, tidally dominated, with extensive intertidal sandflats up to $3 \mathrm{~km}$ wide, low foredunes and narrow high-tide beaches marked by seagrass banks (Figure 7.22). At Chinamans Wells, a dune field up to $23 \mathrm{~m}$ high and $1.5 \mathrm{~km}$ wide separates the beach from low-lying swampland that marks the position of the shoreline 125000 years ago. Despite the shallow, protected nature of the coast, rock walls are required to defend shacks built on the foredune.

South of Balgowan Point, a small headland with Warrenne Lookout situated on it, the coast is characterised by calcareous shore platforms and reefs, as well as sandy beaches backed by sparsely vegetated foredunes with well-vegetated hind dunes. To the north, a pronounced cliff line 10 to $20 \mathrm{~m}$ high (Figure 7.23) extends for some $5 \mathrm{~km}$ to Tippara Rocks, diminishing in elevation as it does so. The cliffs are cut into the Hindmarsh Clay as are those at Ardrossan, directly opposite on Gulf St Vincent, suggesting former continuity between the two sites. The Hindmarsh Clay appears to have been gently folded, and the calcrete horizon at the top dips to the north and eventually coincides with the shoreline, where it acts as protection against erosion. Tippara Rocks have been mapped as Gawler Craton rocks ${ }^{74}$, although they may be formed of the calcrete horizon in the Hindmarsh Clay. The cliff top is crenulated in plan, reflecting active erosion. Blocks of undercut calcrete have tumbled from above, temporarily protecting the cliff base from erosion. Because of the soft nature of the sediments, the cliffs are also vulnerable to rain and gully erosion. 


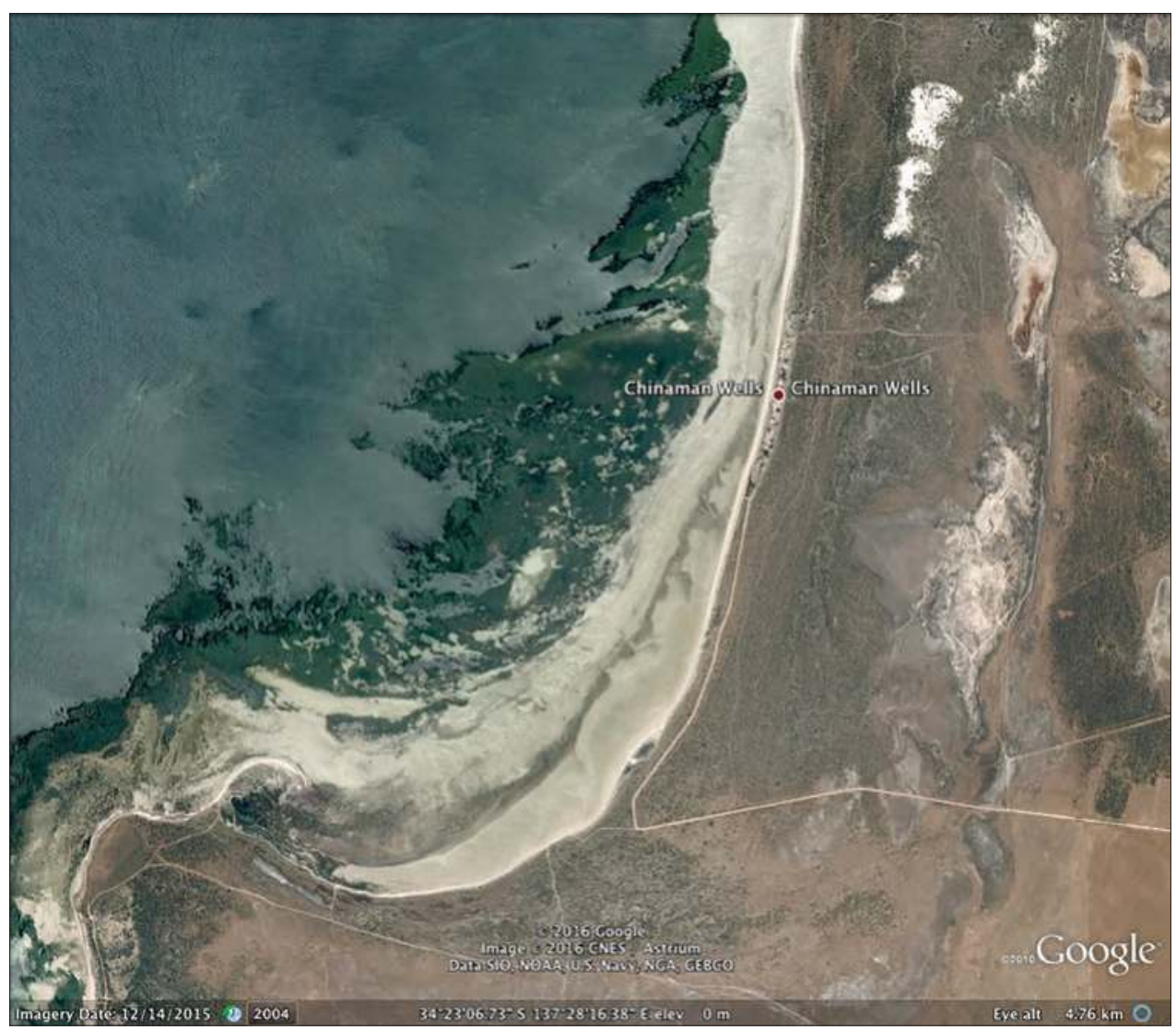

Figure 7.22 The coast at Chinaman Wells. Note the extensive intertidal platform and the broad sandy beach. Despite these features, at high tides, coastal erosion is a problem requiring rock protection for the houses.

Source: Google Earth image () 2015 Google.

Cliff-top dunes surmount the eroding cliffs. These are not coastal dunes but former linear, brown desert dunes formed some 20000 years ago during the low sea level of the Last Glacial Maximum. Between Balgowan and Tiparra Rocks, they have been stranded on the cliff top by sea level rise and coastal erosion. In a few places, where sand has accumulated at the foot of the cliffs, erosion is inhibited and the cliff faces are vegetated.

Several bays north of Tippara Rocks formed as intertidal shore platforms and sandflats, between rocky headlands, with low calcrete-topped cliffs topped by dunes up to $10 \mathrm{~m}$ high (Figure 7.24). The Bamboos Beach area, $3.4 \mathrm{~km}$ north of Tippara 


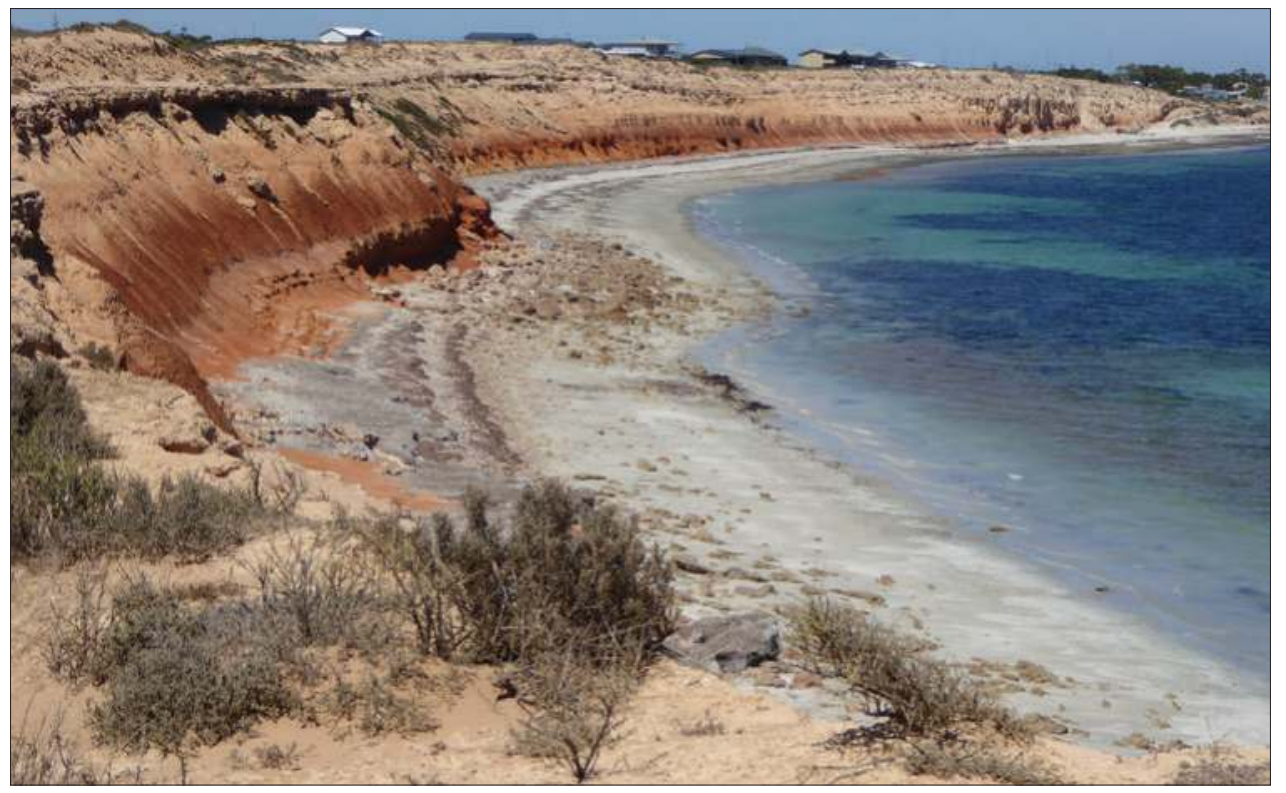

Figure 7.23 Cliffs at Balgowan, revealing a sequence of Pleistocene sediments. At the base of the cliff are the orange/brown-coloured Ardrossan clays and sand rock (equivalent in age to the Hindmarsh Clay on the east coast of GSV). Above this is a layer of up to $10 \mathrm{~m}$ of calcareous windblown loess (or parna) interspersed with calcreted horizons. The loess relates to the drying out of the Australian continent over the past $500 \mathrm{ka}$.

Source: Author's own work, RPB.

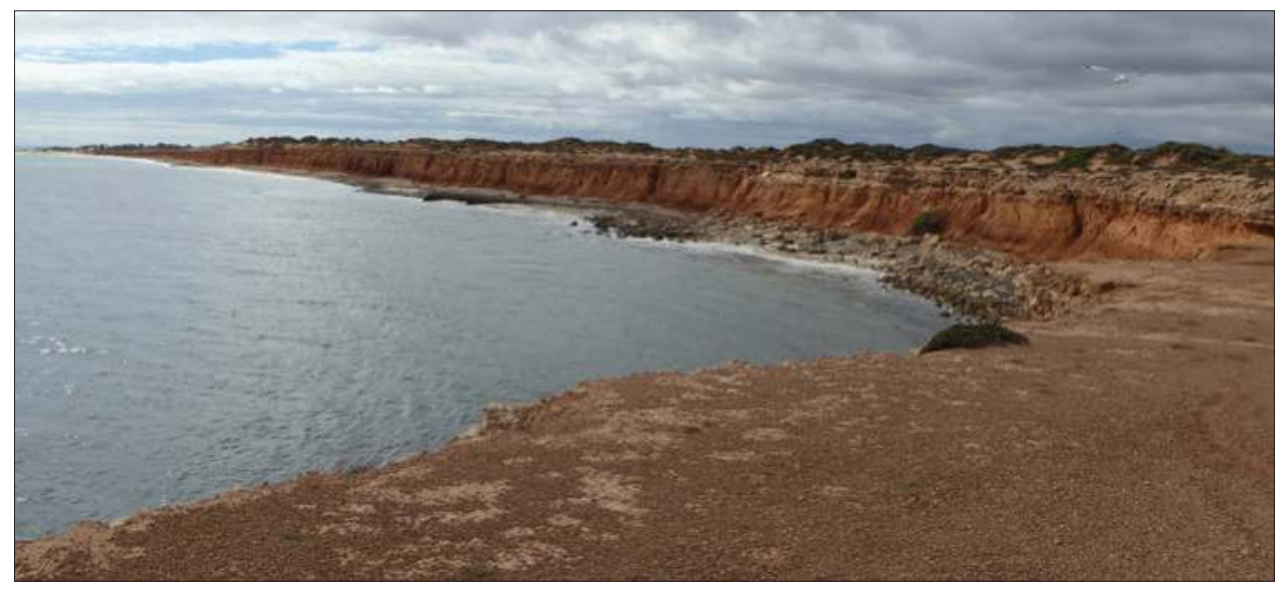

Figure 7.24 View of North Balgowan Beach towards Tippera Rocks, where backing dunes extend up to $400 \mathrm{~m}$ inland. Tippara Rocks is the start of a rocky reef, which extends for about $6 \mathrm{~km}$ north to The Gap, where there is also a break in the dunes.

Source: Author's own work, RPB. 
Rocks, is marked by high dunes, some of which are active. They afford fine views along the coast. The Gap is a low point in the persistent dunes between Balgowan and Cape Elizabeth; here the beach comprises sandflats and calcareous shore platforms, while a shore platform $+2 \mathrm{~m}$ high forms a natural breakwater.

Cape Elizabeth is a large cuspate foreland, which protrudes seawards some $7 \mathrm{~km}$ and forms the southern extremity of Tiparra Bay (Figure 7.25). It is formed of unconsolidated Holocene sediments, but is buttressed by rocky reefs, which form natural breakwaters. The southwest-facing side of the foreland consists of parabolic dunes 10 to $20 \mathrm{~m}$ high, some of which are active and have been blown inland for up to $2 \mathrm{~km}$ by prevailing southwesterly winds. The dunes are well vegetated, including

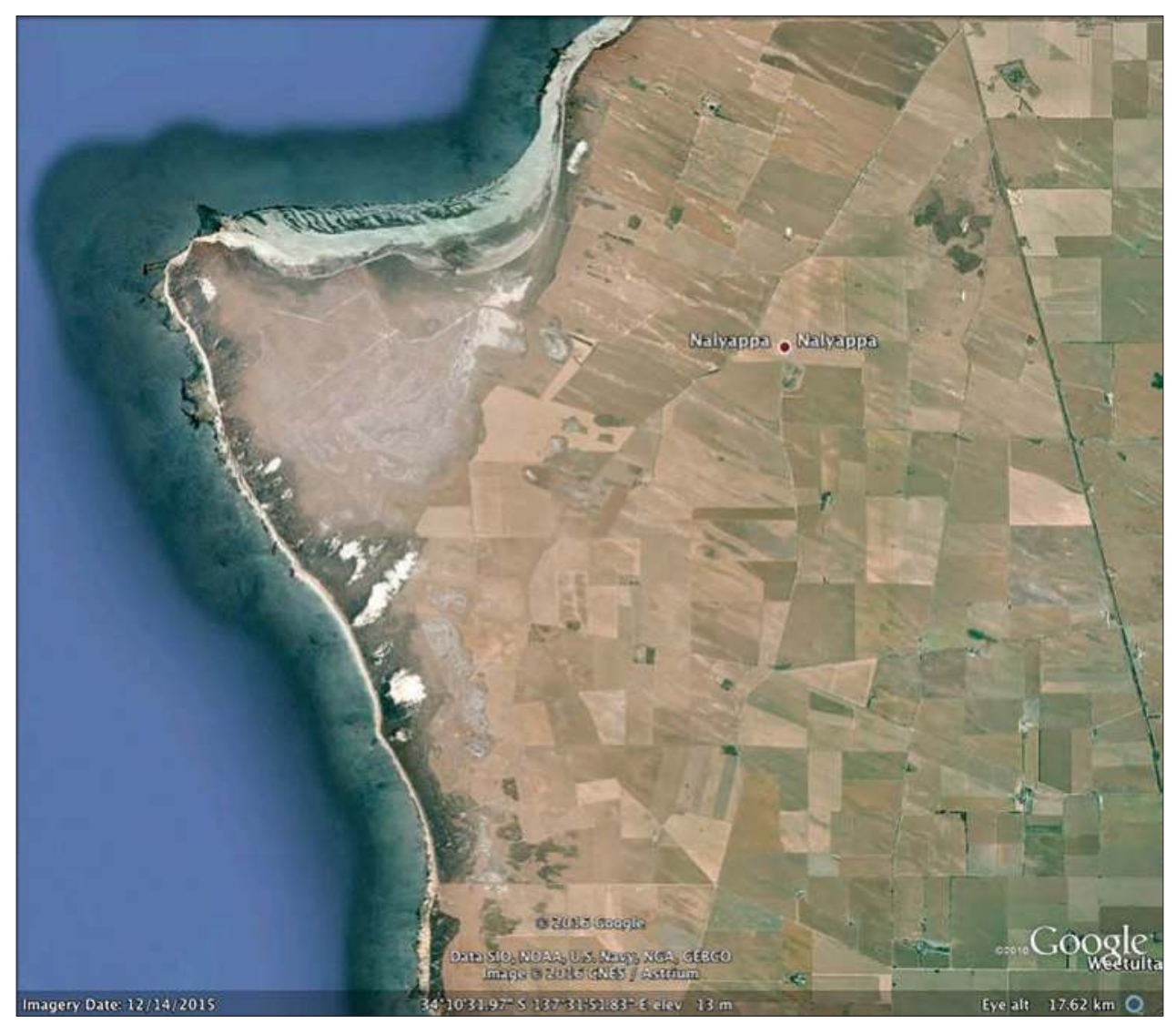

Figure 7.25 Cape Elizabeth protrudes $7 \mathrm{~km}$ into the gulf. Southwest-facing beaches are exposed to strong waves, and dunes extend up to $2 \mathrm{~km}$ inland. The north coast is a wide low-energy shoreline with sandflats up to $1 \mathrm{~km}$ wide containing bars and incipient spits offshore. Near the Cape are remnant vegetated spits behind the modern beach. In the central part of the Cape Elizabeth are $15 \mathrm{~km}^{2}$ of salt marsh and stranded tidal samphire.

Source: Google Earth image @ 2015 Google. 
some large trees such as casuarinas. These dunes impound low-lying samphire swamps, which would have been inundated by the last interglacial sea. The north-facing side of the foreland is constructed of sand spits and up to 25 beach and sand ridges, fronted by a broad, ridged intertidal sandflat and seagrass meadows (Figure 7.25). At Coopers Beach on the south side of Tiparra Bay, an abandoned Holocene sandflat backs the coast. Landward, the maximum impact of foreland construction is marked by the truncation of fields of desert dunes trending northwest-southeast, which back the coastline up to Port Hughes.

The basal Cambrian conglomerate (Winulta Formation), which crops out extensively at Port Hughes, north of the Moonta jetty and at Warburto Point ${ }^{75}$, is resistant to erosion, forms broad, rocky shore platforms and influences the general morphology of Moonta Bay between these localities. The entire bay has broad intertidal sandflats, which widen to the north. The Tickera Granite appears just south of the jetty. ${ }^{76}$ For about $3 \mathrm{~km}$ north of Port Hughes, the coast is composed of Hindmarsh Clay, which forms steep cliffs that are $20 \mathrm{~m}$ high and eroded by marine undercutting and gullying from rainfall. Some attempts are being made to stabilise the cliffs using vegetation. Between Port Hughes and the Moonta jetty, there are minor headlands at Harry Point, Sims Cove and Rossiters Point, producing hook-shaped sandy beaches with rocky shore platforms and reefs. The basal beds of the Hindmarsh Clay are exposed near the Moonta jetty, while to the north of the jetty the last interglacial Glanville Formation occurs. ${ }^{77}$ The northern half of Moonta Bay is backed by sand dunes up to $16 \mathrm{~m}$ high; these separate the sea from low-lying salt swamps inland, where shells indicate that it is a former embayment of the sea. The bay terminates at Warburto Point, a cuspate foreland in the lee of hard rocks and supporting mangrove woodland (Figure 7.26).

The coastline north of Warburto Point is scalloped, forming a series of bays with broad intertidal sandflats and calcrete shore platforms, backed by low-lying land composed of hooked sand spits and shell and beach ridges infilling former larger bays. At Coopers Beach, an outcrop of resistant Emeroo Quartzite ${ }^{78}$ has produced the shoals of Bird Island Conservation Park, with its tidal channels and mangroves. Several small outcrops of the Miocene Melton Limestone occur at the coast towards Point Hughes, where there are extensive calcrete shore platforms.

Wallaroo Bay between Point Hughes and Point Riley is protected by outcrops of resistant bedrock of the Kulpara Limestone, Doora Schist and Tickera Granite ${ }^{79}$, which form headlands, boulder and cobble beaches, rocky reefs, and shore platforms in the bay with its wide intertidal sandflats. Between Point Hughes and Wallaroo, low red bluffs of Hindmarsh Clay are protected at headlands by underlying hard rocks, but in places rock walls are necessary to protect built assets. Much of this coast is taken up by harbour and marina infrastructure. Between Wallaroo and North Beach, a former last 


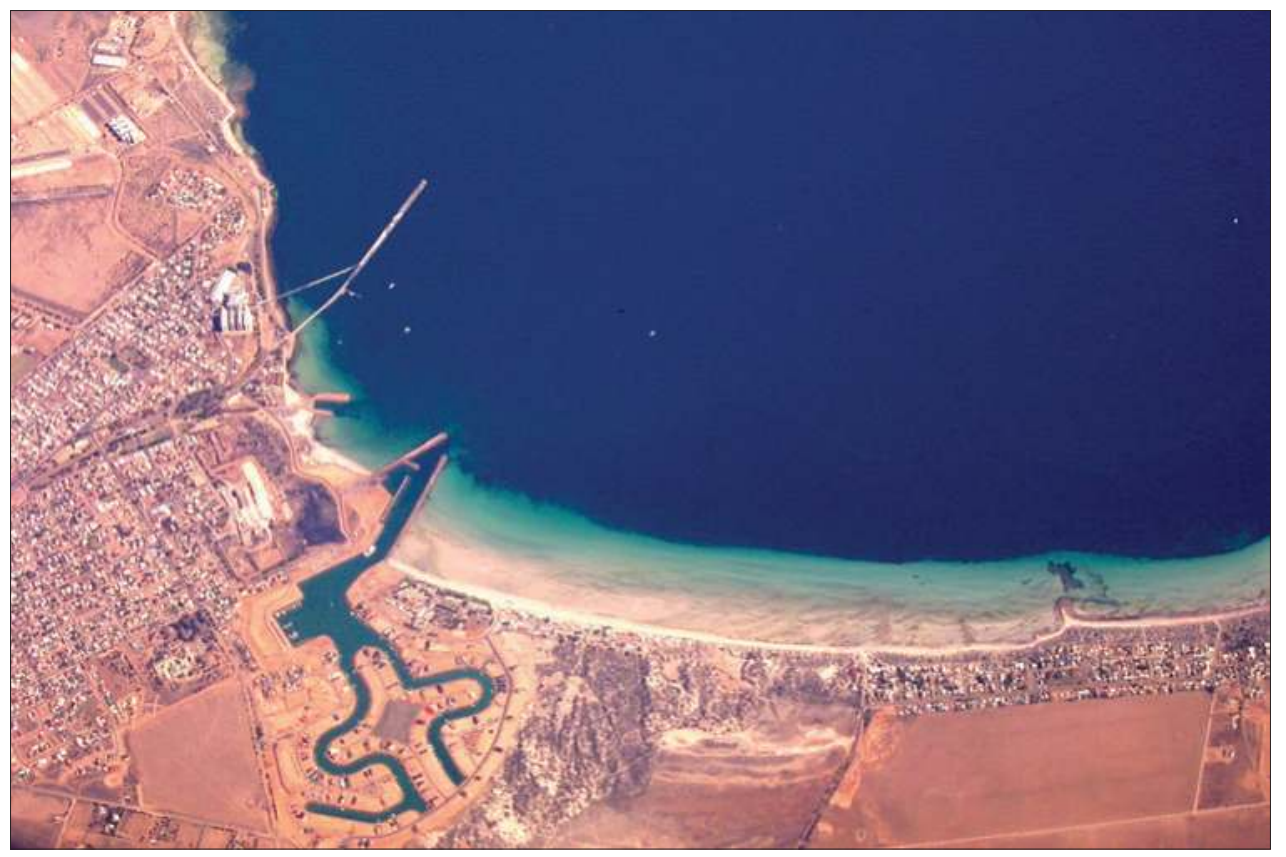

Figure 7.26 Aerial photograph of Wallaroo to North Beach, where a former last interglacial embayment has been infilled by low-lying salt marsh and fronted by Holocene dunes. Marina construction has significantly altered the salt marsh environment and impacted on the dunes. At North Beach (right of photo) a tombolo is linked to a rocky islet.

Source: Author's own work, NH.

interglacial embayment is now occupied by low-lying salt marsh fronted by Holocene dunes (Figure 7.27). At North Beach, a rocky islet has been linked to the coast by a tombolo.

A cliffed coast up to $30 \mathrm{~m}$ high trends in a linear fashion from Point Riley to the northeast and, in broad view, is structurally controlled; a major fault extends from Point Riley towards Port Broughton. ${ }^{80}$ The fault dislocates the Miocene Melton Limestone ${ }^{81}$, which occurs along the shoreline but has been uplifted about $100 \mathrm{~m}$ APSL inland. ${ }^{82}$ Rocky headlands, cobble beaches and wide rocky shore platforms are common; some of the cliffs have been abandoned, suggesting that they were mainly formed during the last interglacial high sea level. Numerous short streams about $1 \mathrm{~km}$ long flow to the sea along the coast between Point Riley and Tickera, following pre-Pleistocene paleovalleys cut into the underlying Tickera Granite and infilled with the easily eroded Pleistocene Hindmarsh Clay. 


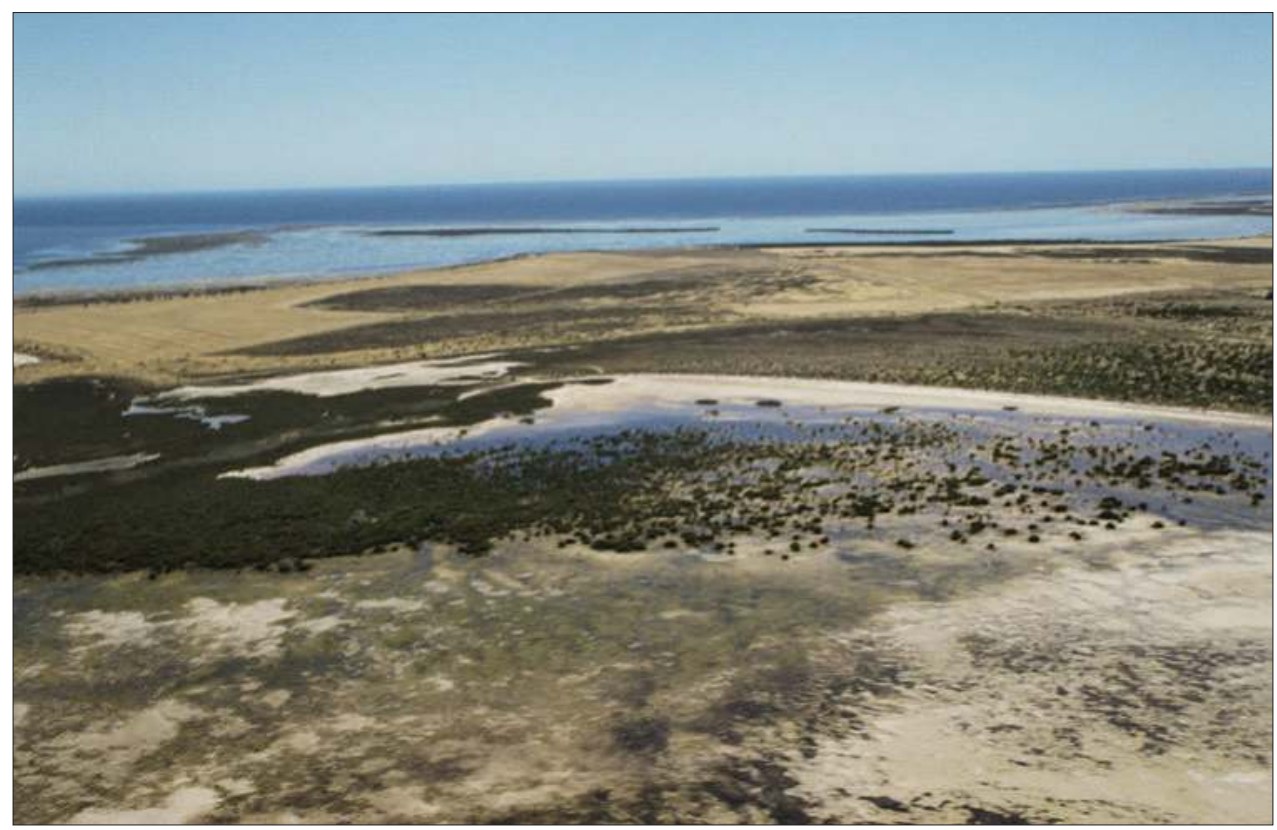

Figure 7.27 Warburto Point, showing a tidal flat about $1 \mathrm{~km}$ wide and samphire and mangroves growing close to the shore. Dense seagrass beds are located beyond the tidal flats. On the northern side of the point is a curved sandy beach with migrating sand spits at both the southern and northern ends.

Source: Reproduced with permission of the Coast Protection Board, 2005.

At Myponie Point, Melton Limestone and Hindmarsh Clay overlie Tickera Granite at the base, but in places the cliffs are formed entirely of Hindmarsh Clay. The cliffs just south of Tickera consist of strongly weathered granite, possible Permian fluvioglacial sediments and cross-bedded aeolianites, which are rare in this area. North of Tickera, where there are intertidal shore platforms and sandflats up to $1 \mathrm{~km}$ wide, a large section of the coast is formed solely of Hindmarsh Clay. Former last glacial maximum desert dunes, truncated by sea level rise and coastal erosion, cap the coastline from Point Riley to Webling Point near Port Broughton.

North of Tickera the coast transitions into the northern Spencer Gulf, which is characterised by low wave energy, high tidal ranges, broad sandflats, extensive seagrass meadows and mangroves. The Yorke Peninsula coastline terminates at the protruding Webling Point, composed of the faulted Early Miocene Melton Limestone ${ }^{83}$ south of the entrance to Port Broughton. 


\subsection{Summary and conclusions}

Yorke Peninsula provides examples of diverse coastal landforms and features, which can be explained in terms of the nature of the rocks, sediments and geological structures in contact with the shoreline during migrations of sea level, and the currently operating processes related to the wind, wave and tidal regimes.

Three very different sections of coast fringe Yorke Peninsula. The linear east coast is determined by prominent north-south faults and is marked by cliffs and bluffs cut into hard Cambrian rocks, Cenozoic limestones and Quaternary alluvial deposits. Cliff erosion was accentuated during the Last Interglacial when sea level was $2 \mathrm{~m}$ higher than present. Some of the cliffs have been protected from coastal erosion by tectonic uplift of the land or by a fall in sea level, thereby placing the cliff base above the erosion level of waves. In other instances, the accumulation of sediment at the cliff base protects them from erosion. Cliff erosion currently occurs where the backing cliffs are easily eroded, as at Ardrossan. Other erosion risk zones occur where dwellings have been placed on foredunes: even though there is not a high tidal range, and extensive intertidal sandflats subdue waves, erosion may occur during high tides and storm events. Dunes are not extensive, but there are several prominent cuspate forelands along the east coast.

The exposed south- and southwest-facing coast of the 'foot' is dominated by resistant granitic rocks of the Gawler Craton on which aeolianite of the Bridgewater Formation was deposited during past interglacials; it became lithified and was subsequently eroded to form spectacular cliffs and islands. Recycling of aeolianite sand provides much of the beach and dune sediment for this coastal section, although Permian glacial sediments also make significant contributions; parabolic and cliff-top dunes are prominent features. The eastern side of the foot, which is partly sheltered by Kangaroo Island, assisted the formation of Point Davenport, a large cuspate foreland. Two seaways formerly extended across the foot of the peninsula during the Last Interglacial (125 ka) and the Holocene (6 ka) through the Peesey Swamp and Marion Lake areas.

Broad sandflats, shore platforms and reefs attenuate wave action on the west- and north-facing shoreline, which typically has narrow high-tide beaches backed by largely vegetated dunes. Resistant Gawler Craton sequences at Corny Point, Point Souttar, Port Victoria and beyond provide the backbone for this section of coast; easily eroded Permian glacial sediments underlie much of the coast, which is generally lower than the east and south coasts. Embayments formed during the high sea level of the Last Interglacial are now infilled with Glanville Formation and Holocene beach ridges and dunes. Minor headlands and shore platforms have formed on calcreted sediments overlain by last interglacial shell beds. Wardang Island and Point Pearce Peninsula are partly relics of Permian glacial erosion of Gawler Craton rocks, which assume a greater 
influence on the coast to the north of Port Victoria. Eroding cliffs in Hindmarsh Clay occur at Balgowan and to the north. A major fault line controls the linear coastline between Point Riley and Port Broughton, where the coast merges into the tidally dominated shoreline of the northern Spencer Gulf.

\section{Notes}

1 Crawford, A.R. (1965). The geology of Yorke Peninsula. Geological Survey of South Australia, Bulletin, 39, 96 pp.; Gravestock, D.J. (1995). Chapter 7, Early and Middle Palaeozoic, In: Drexel, J.F. \& Preiss, W.V. (Eds), The geology of South Australia. Vol. 2, The Phanerozoic. Geological Survey of South Australia, Bulletin 54, pp. 218-281; Zang, W., Cowley, W.M. \& Fairclough, M. (2006). Explanatory Notes of the MAITLAND Special 1:250 000 Geological Series Sheet S153-12. Edited by J.F. Drexel. Geological Survey of South Australia. Primary Industries and Resources South Australia, $62 \mathrm{pp}$.

2 Flinders, M. (1814). A voyage to Terra Australis. Undertaken for the purpose of completing the discovery of that vast country and prosecuted in the years 1801, 1802 and 1803, in His Majesty's ship, the 'Investigator; and subsequently in the armed vessel 'Porpoise' and schooner 'Cumberland'. G \& W Nicol, London.

3 Crawford (1965).

4 Zang, Cowley \& Fairclough (2006).

5 Sprigg, R.C. (1952). Sedimentation in the Adelaide Geosyncline and the formation of the continental terrace. In: Glaessner, M.F. \& Sprigg, R.C. (Eds), Sir Douglas Mawson Anniversary Volume. The University of Adelaide, Adelaide. pp. 153-159; Drexel, J.F., Preiss, W.V. \& Parker, A.J. (1993). The geology of South Australia. Vol. 1, The Precambrian. Geological Survey Bulletin of South Australia, Bulletin 54, pp. 33-49.

6 Gravestock (1995).

7 Alley, N.F. \& Bourman, R.P. (1995). Troubridge Basin. Chapter 8, Late Palaeozoic. In: Drexel, J.F. \& Preiss, W.V. (Eds), The geology of South Australia. Vol. 2, The Phanerozoic. Geological Survey of South Australia, Bulletin 54, pp. 65-70.

8 Zang, Cowley \& Fairclough (2006).

9 Corbett, D. (Ed.) (1976). A field guide to the geology of Yorke Peninsula. Field Geology Club of South Australia, 65 pp.

10 Crawford (1965).

11 Crawford (1965).

12 Horwitz, R.C. (1961). The geology of the Wakefield military sheet. Geological Survey of South Australia, Report of Investigation, 18, 32 pp.

13 Pain, A.M., Valentine, J.T. \& Hayball, A. (1992). Reconaissance drilling of construction sand deposits, northern Yorke Peninsula, South Australian Department of Mines and Energy, Report Book, 92/56.

14 Zang, Cowley \& Fairclough (2006). 
16 Alley, N.F. \& Lindsay, J.M. (1995). Pirie Basin. In: Drexel, J.F. \& Preiss, W.V. (Eds), The geology of South Australia. Vol. 2, The Phanerozoic. Geological Survey of South Australia, Bulletin 54, pp. 175-178.

17 Crawford (1965).

18 Zang, Cowley \& Fairclough (2006).

19 Corbett (1976); Zang, Cowley \& Fairclough (2006).

20 Zang, Cowley \& Fairclough (2006).

21 von der Borch, C.C., Bolton, B. \& Warrn, J.K. (1997). Environmental setting and microstructure of sub-fossil lithified stromatolites associated with evaporates: Marion Lake, SA. Sedimentology, 24, 693-708.

22 Zang, Cowley \& Fairclough (2006).

23 Short, A.D. (2006). Beaches of the South Australian coast and Kangaroo Island: A guide to their nature, characteristics, surf and safety. Sydney University Press, Sydney, 346 pp.

24 Short (2006).

25 Crawford (1965); Corbett (1976).

26 Crawford (1965).

27 Lindsay, J.M. (1970). Melton Limestone: Multiple Mid-Tertiary Transgressions, SouthEastern Gawler Platform. Quarterly Geological Notes, Geological Survey of South Australia, $33,2-10$.

28 Crawford (1965); Stuart, W.J. Jnr (1970). The Cainozoic stratigraphy of the eastern coastal area of Yorke Peninsula, South Australia. Transactions Royal Society of South Australia, 94, 151-178; Zang, Cowley \& Fairclough (2006).

29 Ward, W.T. (1966). Geology, geomorphology and soils of the southwestern part of County Adelaide, South Australia. CSIRO Soil Publication, 23. Commonwealth Scientific and Industrial Research Organization, Australia, Melbourne, 115 pp.

30 Ludbrook, N.H. (1983). Molluscan faunas of the Early Pleistocene Point Ellen formation and Burnham Limestone, South Australia. Transactions of the Royal Society of South Australia, 107, 37-50; May, R.I. \& Bourman, R.P. (1984). Coastal landslumping in Pleistocene sediments at Sellicks Beach, South Australia, Transactions of the Royal Society of South Australia, 108 (2), 85-94.

31 Pillans B.J. \& Bourman, R.P. (1996). The Bruhnes/Matuyama Polarity transition (0.78 Ma) as a chronostratigraphic marker in Australian regolith studies. Australian Geological Survey Organisation, Journal of Geology and Geophysics, 16 (3), 289-294.

32 Pillans, B. \& Bourman, R.P. (2001). Mid Pleistocene arid shift in southern Australia, dated by magnetostratigraphy. Australian Journal of Soil Research, 39, 89-98.

33 Wilson, C.C. (1991). Geology of the Quaternary Bridgewater Formation of southwest and central South Australia. Unpublished PhD thesis, Flinders University of South Australia.

34 Tepper, J.J.O. (1882). Sketch of a geological and physical history of Hundred Cunningham and neighbouring regions. Transactions of the Royal Society of South Australia, 4, 61-70, here p. 65.

35 Bourman, R.P. (1979). Geomorphological contributions to Coastal Management. In: 
Corbett, D. \& Sibly, J. (Eds), Southern heritage: Proceedings of the Conference Focus on our southern heritage. Conservation Council of South Australia and the Department of Continuing Education, The University of Adelaide, pp. 80-88.

36 Pappageorgiou, D.B. (1973). Cliff morphology and processes along the Ardrossan coastline, on eastern Yorke Peninsula. Unpublished BA Hons Thesis, Flinders University of South Australia.

37 Corbett (1976).

38 Zang, Cowley \& Fairclough (2006).

39 Corbett (1976).

40 Zang, Cowley \& Fairclough (2006).

41 Stuart (1970).

42 Crawford (1965).

43 Gill, E.D. \& Bourman R.P. (1972). Research on Quaternary Shorelines in Australia and New Zealand - a summary report of the ANZAAS Quaternary Shorelines Committee. Report for South Australia. Search, 3 (4), 103-104.

44 Stuart (1970).

45 Zang, Cowley \& Fairclough (2006).

46 Corbett (1976).

47 Troubridge Island Conservation Park Management Plan. Yorke Peninsula, South Australia (1993). Department of Environment and Land Management, South Australia, 19 pp.

48 Foster, C.B. (1974). Stratigraphy and palynology of the Permian at Waterloo Bay, Yorke Peninsula, South Australia. Transactions of the Royal Society of South Australia, 98, 29-42; Zang, Cowley \& Fairclough (2006).

49 Howchin, W. (1900). Evidences of extinct glacial action in Southern Yorke Peninsula. Transactions of the Royal Society of South Australia, 24, 71-80, here p. 71.

50 Foster (1974).

51 Foster (1974).

52 Crawford (1965).

53 Short, A.D. (2006). Beaches of the South Australian coast and Kangaroo Island: A guide to their nature, characteristics, surf and safety. Sydney University Press, Sydney, 346 pp.

54 Short (2006).

55 Corbett (1976); Zang, Cowley \& Fairclough (2006).

56 Corbett (1976).

57 Corbett (1976).

58 Corbett (1976).

59 Zang, Cowley \& Fairclough (2006).

60 Zang, Cowley \& Fairclough (2006).

61 Clark, E.V. (1928). A Recent raised beach near Point Turton, Yorke Peninsula. Transactions of the Royal Society of South Australia, 52, 189-190.

62 Zang, Cowley \& Fairclough (2006). 
63 Bone, Y. (1985). Wardang Island. Bulletin of the Field Geology Club of South Australia, 14, 3-9.

64 Alley \& Bourman (1995).

65 Bone (1985).

66 Bone, Y. (1984). The Wardang Volocanics, Wardang Island, Yorke Peninsula. Quarterly Geological Notes, Geological Survey of South Australia, 89, 2-7.

67 Bone (1985).

68 Bone (1985).

69 Bone (1985).

70 Bone (1984).

71 Bone (1985).

72 Bone (1985).

73 Bone (1985).

74 Zang, Cowley \& Fairclough (2006).

75 Zang, Cowley \& Fairclough (2006).

76 Zang, Cowley \& Fairclough (2006).

77 Zang, Cowley \& Fairclough (2006).

78 Parker, A.J. \& Fanning, C.M. (1998). Explanatory Notes of the WHYALLA 1:250 000 Geological Series Sheet S153-8. Edited by J.F. Drexel. Geological Survey of South Australia. Primary Industries and Resources South Australia, 52 pp.

79 Parker \& Fanning (1998).

80 Alley \& Lindsay (1995).

81 Parker \& Fanning (1998).

82 Lindsay (1970).

83 Parker \& Fanning (1998). 



\section{The northern Spencer Gulf coast}

\subsection{Introduction}

Northern Spencer Gulf encompasses the coastline that extends north from Whyalla to Port Augusta on the eastern Eyre Peninsula and from Port Augusta to Port Broughton on Yorke Peninsula (Figure 8.1). Northern Spencer Gulf is an inverse or negative estuary where evaporation exceeds freshwater input, with salinities (34 to $49 \mathrm{ppt}$, or parts per thousand) increasing in the northernmost portion of the gulf. Water temperatures are also elevated, ranging between 13 to $28^{\circ} \mathrm{C}$. ${ }^{1}$ The gulf thus provides a refuge for plants and animals that colonised during warmer water conditions of the past, such as coralline algae near the bridge crossings at Port Augusta. Protected from the ocean swell, these northernmost gulf areas also experience diminished wave heights but amplified tidal ranges. The tidal ranges typical of the gulf are 2.5 to $3 \mathrm{~m}$, but a maximum tidal range of $4.1 \mathrm{~m}$ has been recorded at Port Augusta, which is just into the macrotidal range. ${ }^{2}$ There are regular dodge tides every two weeks, when for 1 to 2 days there is no tidal movement due to the two main semi-diurnal tides, $\mathrm{M}_{2}$ and $\mathrm{S}_{2}$, cancelling each other out. ${ }^{3}$

Tidal processes dominate the northern Spencer Gulf ${ }^{4}$, and the coastline is characterised by thick seagrass meadows, wide intertidal sandflats, mangrove woodlands and supratidal saline marshland. ${ }^{5}$ Coastal development is intimately related to the massive production and accumulation of biogenic materials including algae, seagrass, molluscs and bryozoans; the site is a 'major carbonate factory', sequestering much $\mathrm{CO}_{2}{ }^{6}$ Algal mats, seagrass meadows and mangrove woodlands are highly productive environments for the growth of rich and diverse marine organisms that promote the rapid accumulation of skeletal, calcareous, bioclastic debris when they die. ${ }^{7}$ Intertidal sandflats produce vast numbers of molluscs that also contribute to the vertical accretion and seaward progradation of the shoreline (Figure 8.2 ). ${ }^{8}$ These processes have been enhanced by a fall 


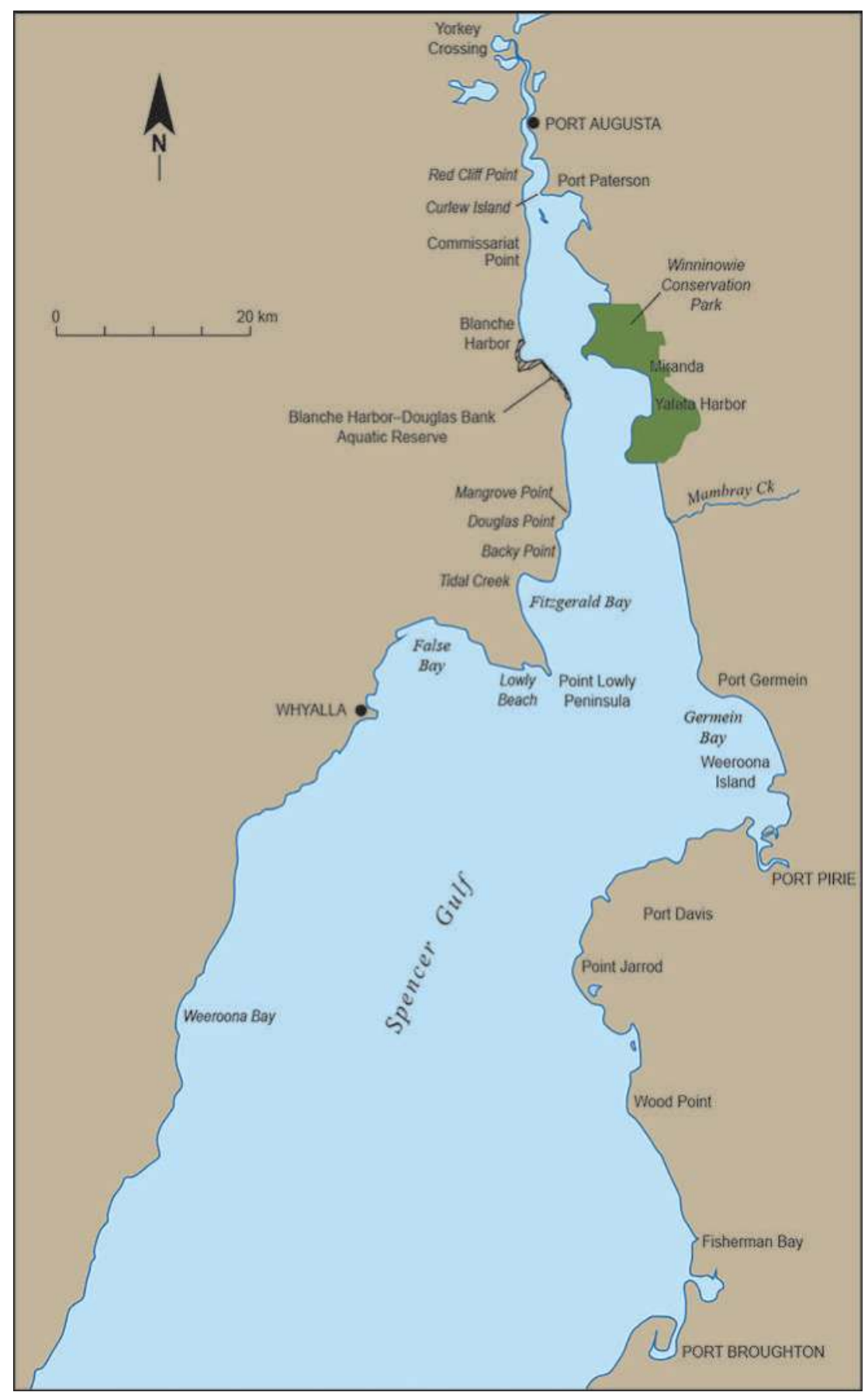

Figure 8.1 Location map of northern Spencer Gulf, showing the key locations referred to in the text.

Source: Authors' own work, RPB. 


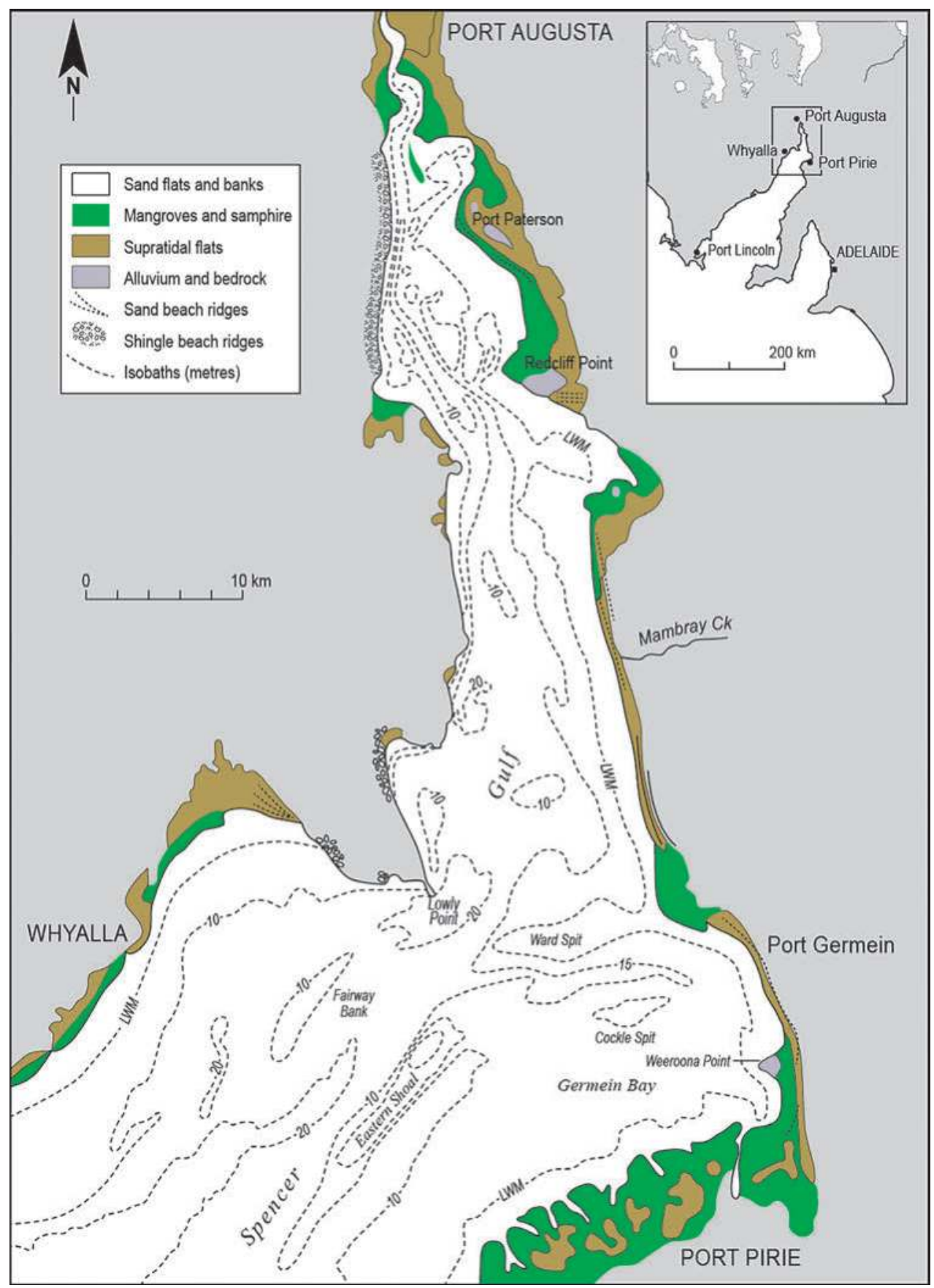

Figure 8.2 Coastal sediments of the northern Spencer Gulf.

Source: Modified from Belperio, A.P., Hails, J.R. \& Gostin, V.A. (1983). Holocene sea levels of Upper Spencer Gulf, South Australia. Australian sea levels in the last 15000 years: A review. Australian Report for IGCP 61 (Ed. D. Hopley) Department of Geography, James Cook University of North Queensland, pp. 48-53. 
in relative sea level over the past 5000 years, stranding shell ridges and supratidal flats, which accumulate gypsum, dolomite and salt. ${ }^{?}$

\subsection{Geological setting}

Between Whyalla and Port Augusta, the basic shape of the shoreline reflects bedrock geology; resistant Proterozoic rocks form shore platforms and headlands that shelter sandy bays. From Point Lowly to Port Augusta, the coast is closely aligned with the Torrens Hinge Zone (see Figure 9.1), a major complex fault that separates the eastern side of the Gawler Craton from the rocks of the Adelaide Geosyncline. The Geosyncline contained a thick sequence of sediments 850 to $520 \mathrm{Ma}$ old, which were folded during the Delamerian Orogeny; the deformation commenced at $514 \pm 3 \mathrm{Ma}^{10}$ and was followed by protracted erosion. Tectonic uplift over the past $50 \mathrm{Ma}$ formed the Mount Lofty and Flinders Ranges. ${ }^{11}$ The Tent Hill Formation, equivalent in age to the folded ABC Range Quartzite of the Flinders Ranges, is little deformed and forms flat-topped hills on the western side of the gulf as part of the Stuart Shelf. ${ }^{12}$ There are locations where bedrock outcrops do not immediately abut the shoreline, but alluvial and colluvial sediments, derived from higher, backing country, influence the detailed position of the coast and have provided pebbles and cobbles for the production of shingle ridges.

Fitzgerald Bay, on the eastern margin of the Gawler Craton, has been stable for about $1400 \mathrm{Ma}$ and marks the western edge of an ancient rift valley in which the sediments of the Adelaide Geosyncline accumulated. ${ }^{13}$ Volcanic outpourings accompanied the rifting. The coastline between the head of Fitzgerald Bay and Blanche Harbor, which stretches for a distance of $20 \mathrm{~km}$, protrudes into the gulf where the Torrens Hinge Zone bifurcates either side of volcanic and granitic rocks, the erosion of which produces rounded hills near Backy Point. ${ }^{14}$

On the eastern side of the northern gulf, the geological and structural control is less direct, although faults associated with the western side of the Hummocks and Flinders Ranges define the eastern margins of the Pirie Basin, which encompasses the whole of the northern Spencer Gulf. ${ }^{15}$ However, the alluvial sediments washed to the coast from the tectonically uplifted Flinders Ranges explain the detailed morphology of the coastline, especially at Port Pirie, where the River Broughton delta protrudes seawards. At Weeroona Island, resistant rocks of the Flinders Ranges (Proterozoic cross-bedded sandstone and quartzite of the Tent Hill Formation) crop out and impact on coastal morphology, forming an 'island' $40 \mathrm{~m}$ high, which is linked to the mainland by a causeway. Other outcrops of the Tent Hill Formation occur close to the coastline at Mount Grainger (65 m), Mount Gullet (46 m) and Mount Mambray (29 m), providing a broad control on coastal orientation. The Paleogene to Neogene deposits on the eastern side of the Pirie Basin have similarities with those in the Cowell Basin on the western side and with sediments of the St Vincent Basin. 
Sediment studies from the northern gulf demonstrate the importance of Pleistocene and Holocene shallow estuarine coastal processes in shaping the modern gulf coastline, particularly on the eastern coast. Numerous alternating periods of sedimentation and subaerial exposure throughout the Pleistocene occurred in response to changing sea levels, although there is only evidence for two major interglacial episodes in Spencer Gulf. Coastal sediments containing the subfossil Anadara trapezia, of the Penultimate Interglacial (Marine Isotope Stage 7, approximately 240 to $210 \mathrm{Ma}$ old), occur both subsurface in the gulf and around its margins. ${ }^{16}$ Amino acid racemisation dating techniques gave an age of near 200000 years for specimens of Anadara trapezia recovered from depths between 90 to $135 \mathrm{~cm}$ inland from Redcliff Point ${ }^{17}$, while the last interglacial Glanville Formation (125 ka) was deposited in the northern gulf on the Pleistocene Hindmarsh Clay, near to the present level of the sea. Following the Last Interglacial, shoreline and lagoonal sediments (the False Bay and Lowly Point Formations) were deposited in the deeper parts of the gulf during low sea levels, and were overlain by unnamed Marine Isotope Stage 3 (MIS 3) sediments, 60 to 25 ka old. ${ }^{18}$

An expanse of Holocene bioclastic sediment (molluscs, bryozoans, foraminifers and coraline algae), exceeding $6 \mathrm{~m}$ in places and locally associated with massive seagrass beds, now rests on the foundation of the above marine transgressive units ${ }^{19}$; this sediment has accumulated since the sea reached its present level near 6600 years ago. Thus the detailed position of the shoreline evolved as biogenic material aggraded and prograded throughout the Holocene.

\subsection{Whyalla to Blanche Harbor}

Beaches at Whyalla are enclosed by seawall structures and Hummock Hill. ${ }^{20}$ Construction of the Whyalla boat harbour involving new breakwaters reclaimed 2.63 ha of land, using $1500 \mathrm{~m}^{3}$ of dredged material. A new beach was created on the northern side of the boat harbour, using $-600^{3} \mathrm{~m}$ of dredged sand. ${ }^{21}$ South of the jetty, the beach is backed by a seawall and fronted by extensive intertidal sandflats up to $1 \mathrm{~km}$ wide. Beyond the seawall, mangrove woodland is interspersed with small sandy beaches, sand spits, ridges and tidal creeks, which fringe the coast for $5 \mathrm{~km}$. An extensive supratidal flat is underlain by terrestrial red/brown alluvium of the last interglacial Pooraka Formation and shelly sand. At the shore, mangroves and tidal creeks separate samphire swamps 1 to $2 \mathrm{~km}$ wide from intertidal sandflats up to $1 \mathrm{~km}$ wide.

False Bay is a large bay, $14 \mathrm{~km}$ wide and situated between outcrops of Precambrian cross-bedded sandstone/quartzite bedrock at Black Point and the Hummocks at Whyalla. Much of the southern half of the bay is heavily impacted by harbour, industrial (smelting and salt) and recreational works. The bay is characterised by lowgradient sandflats, numerous beach ridges, barrier islands, sand spits, tidal channels and mangroves. False Bay would have been a much larger embayment during the 


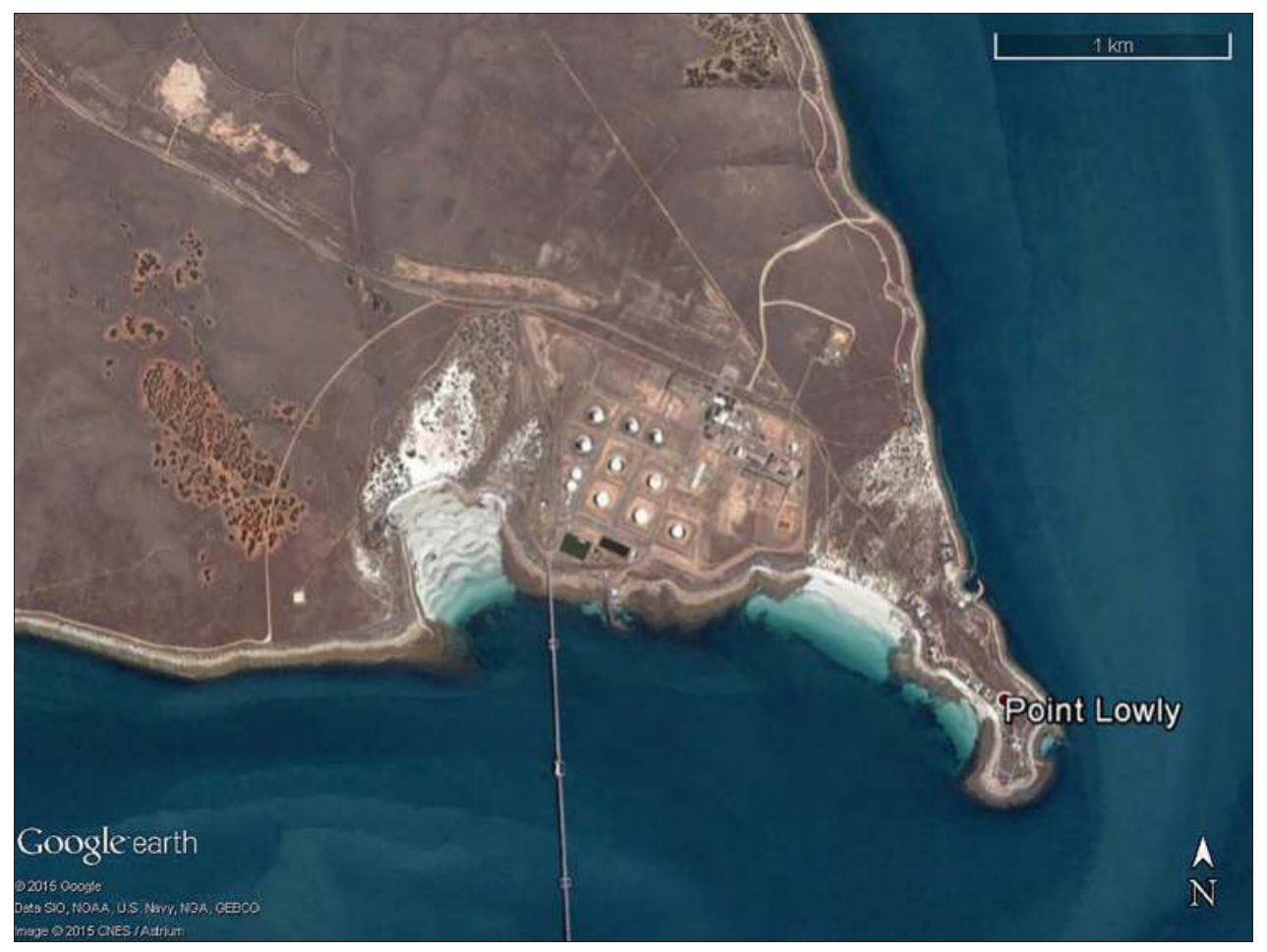

Figure 8.3 Point Lowly-Port Bonython area, showing Weeroona Bay, from which sand has blown to form two largely fixed parabolic dune fields extending inland for up to $200 \mathrm{~m}$ and $400 \mathrm{~m}$ and oriented from the south-southwest. Another dune field, sourced from Lowly Beach, has migrated $1 \mathrm{~km}$ across the Point Lowly Peninsula to form anomalously placed dunes on top of the rocky, cliffed, east-facing shoreline.

Source: Google Earth image () 2015 Google.

Last Interglacial (125 ka ago), as former shoreline deposits, including boulder beaches 2 to $3 \mathrm{~m}$ APSL, are exposed in gullies on the road to Black Point.

From Black Point to Stony Point, there are shore platforms with small stacks and cliffs $20 \mathrm{~m}$ high developed on rocks of the Tent Hill Formation; these dip gently towards the east. Erosion of this slabby bedrock shoreline has provided a source of sediments for some of the Holocene shingle ridges that infill the northern part of False Bay.

A small bay, Weeroona Bay immediately east of Stony Point, traps sand, which has blown inland to form two largely fixed parabolic dune fields oriented from the south-southwest (Figure 8.3). These dunes extend inland for up to $200 \mathrm{~m}$ and $400 \mathrm{~m}$, with parts of them still active. Another dune field, sourced from Lowly Beach on the western side of the Point Bonython jetty, has migrated $1 \mathrm{~km}$ across the Point Lowly 
Peninsula to form anomalously placed dunes on top of the rocky, cliffed, east-facing shoreline. Freshwater soaks occur in the dunes.

Point Lowly Peninsula has developed in Ediacaran rocks of the Tent Hill Formation. The headland of Point Lowly with its distinctive lighthouse is mantled with fossil shells that are mainly rocky shoreline species. At an elevation of $2 \mathrm{~m}$, portions of Point Lowly could represent a platform of the Last Interglacial. It is part of the Rebecca Plateau, which slopes downwards from a maximum elevation of about $125 \mathrm{~m}$ APSL, $13 \mathrm{~km}$ north-northwest of Point Lowly. Just offshore, the plateau drops suddenly to $-26 \mathrm{~m}$, making it the deepest point in the northern part of Spencer Gulf, producing a strong current. The rocky shoreline near Point Lowly is ideal for the breeding of cuttlefish, for which the area is world-famous. ${ }^{22}$

The mix of unique marine environments and industrial development is a source of potential conflict. ${ }^{23}$ For example, on 30 August 1992, the Tanker 'Era' was ruptured by the tug 'Turmoil' in 25-knot winds, creating the largest spill of coastal oil in Australia's maritime history until that time. Approximately 300 tonnes of bunker fuel damaged mangroves and small creeks on the opposite side of the gulf, southwest of Port Pirie. There was also significant loss of birdlife along the coast. There are future environmental threats to the area with the development of a proposed desalination plant. ${ }^{24}$

Fitzgerald Bay (Figure 8.4) extends for $15 \mathrm{~km}$ from Point Lowly to Backy Point (50 m APSL). It is a crenulated coast with small bays at valley mouths.

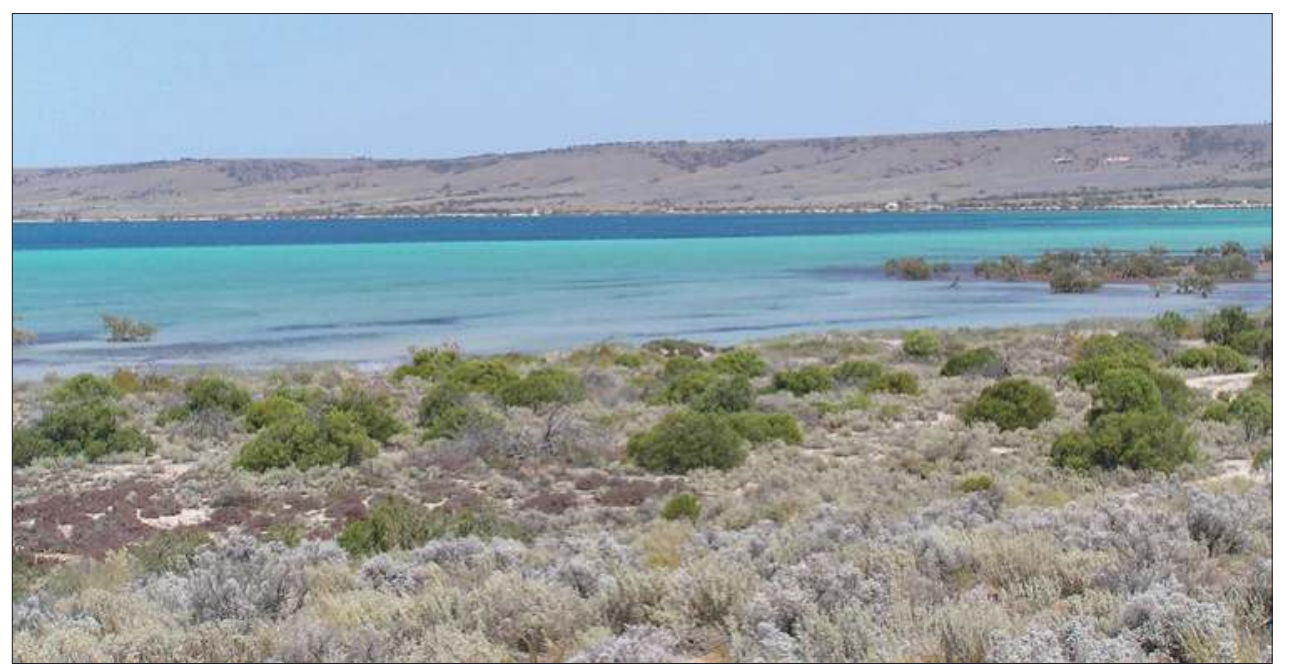

Figure 8.4 View to the south across Fitzgerald Bay, showing seagrass, sandflat, mangrove, samphire and supratidal vegetation.

Source: Author's own work, RPB. 


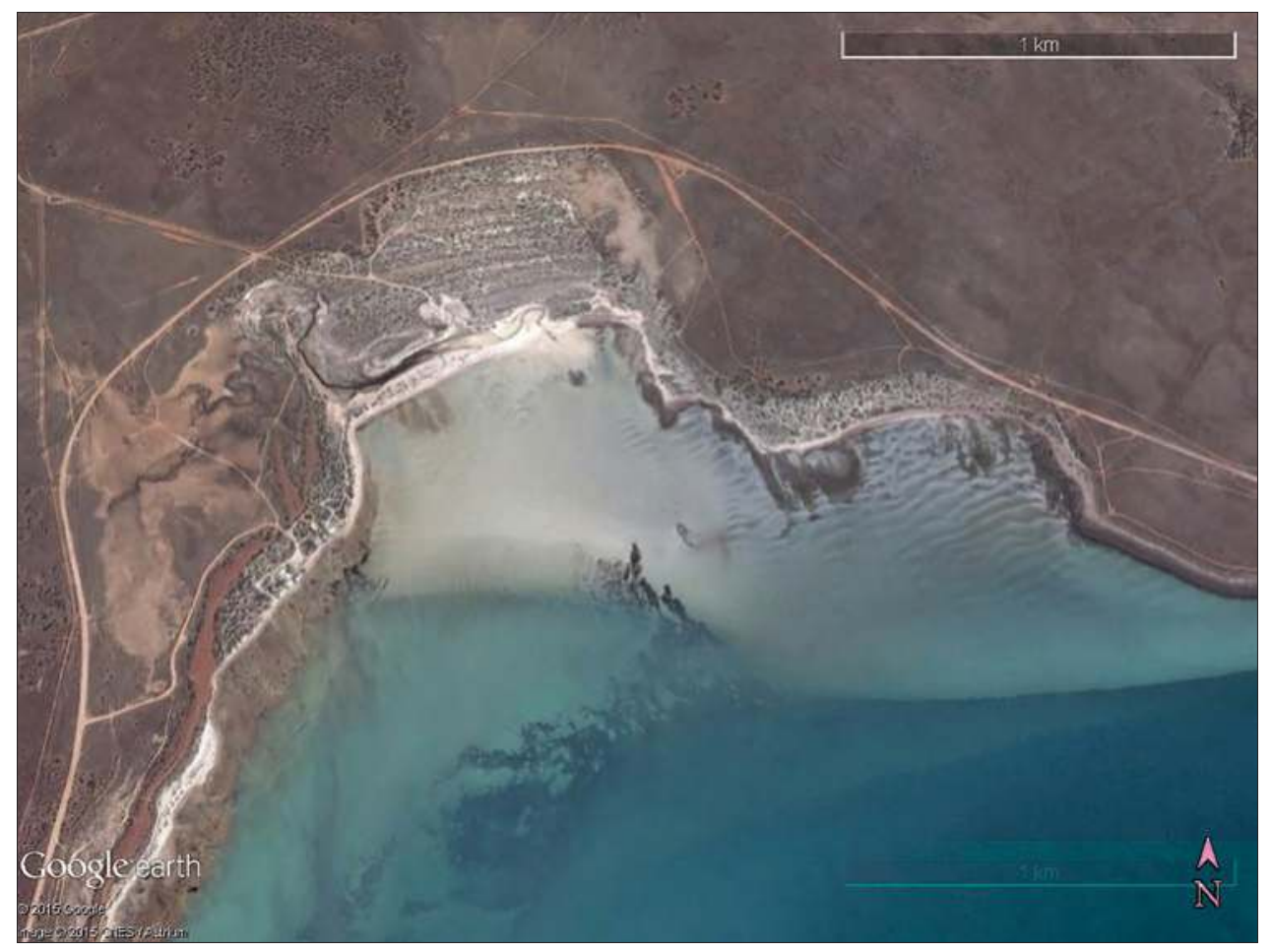

Figure 8.5 Tidal creek at the head of Fitzgerald Bay with multiple Holocene beach ridges infilling a former last interglacial embayment. Note the shingle ridge parallel to the coast on the western side.

Source: Google Earth image (๑) 2015 Google.

Boulder, shingle and gravel deposits occur along the shoreline. In places, cemented shingles, including shells, form conglomerate at the back of some beaches. Isolated mangroves are colonising the shingle beaches in the intertidal zone, but they are not flourishing. The east-facing shore of the bay is backed by steep bedrock country between 60 to $100 \mathrm{~m}$ high, producing rocky shorelines.

A short distance north, the rocky shoreline is replaced with shingle, where numerous short, non-perennial streams debouch at the coast; some 30 streams occur within $10 \mathrm{~km}$, delivering coarse sediment to the coastline. Several of the valleys have their outlets blocked by multiple shingle ridges up to $5 \mathrm{~m}$ APSL, some of which have not been disturbed for quite a while as they are covered with lichen and vegetation. The shingle ridges consist of Proterozoic sandstone and quartzite clasts with red/brown staining of iron oxides. The ridges also contain shells, including abraded and reworked valves of the subfossil Anadara trapezia. ${ }^{25}$ 
The only major tidal creek between Whyalla and Port Augusta occurs at the head of Fitzgerald Bay (Figure 8.5), where a major drainage basin from the north approaches the coast. River action has carved out a broad open depression, flanked in places by cliffs cut into river alluvium. The cliffs were probably sea cliffs abandoned after the withdrawal of the last interglacial seas. Subsequently, the embayment has been filled with more than 20 Holocene beach/shell ridges. The tidal creek meanders through the ridges from a swamp up to $1 \mathrm{~km}$ inland, while its mouth is deflected to the northwest by longshore drift.

The northern shore of Fitzgerald Bay abuts a small coastal range, which protrudes a maximum of $5 \mathrm{~km}$ into the gulf at Backy Point, and extends for $20 \mathrm{~km}$ to the north from the Point $(50 \mathrm{~m})$ to Blanche Harbor. Granitic and volcanic rocks underlie the Coastal Range, producing a bedrock-dominated shoreline oriented north-south, with small rocky bays and sandy and shingle pocket beaches. High points in the range include Grag Point (104 m), Gordon Hill (174 m), Monument Hill (144 m) and Douglas Hills $(204 \mathrm{~m})$. Elevations drop north of Douglas Hills, and low-lying areas are covered with salt marsh, mangroves and sandflats, either side of the bedrockdefended Two Hummock Point. Two Hummock Point is located within the centre of the Blanche Harbor-Douglas Bank Aquatic Reserve. Further north, near Blanche Harbor (Figure 8.6), mangrove woodlands re-emerge, along with associated sandflats

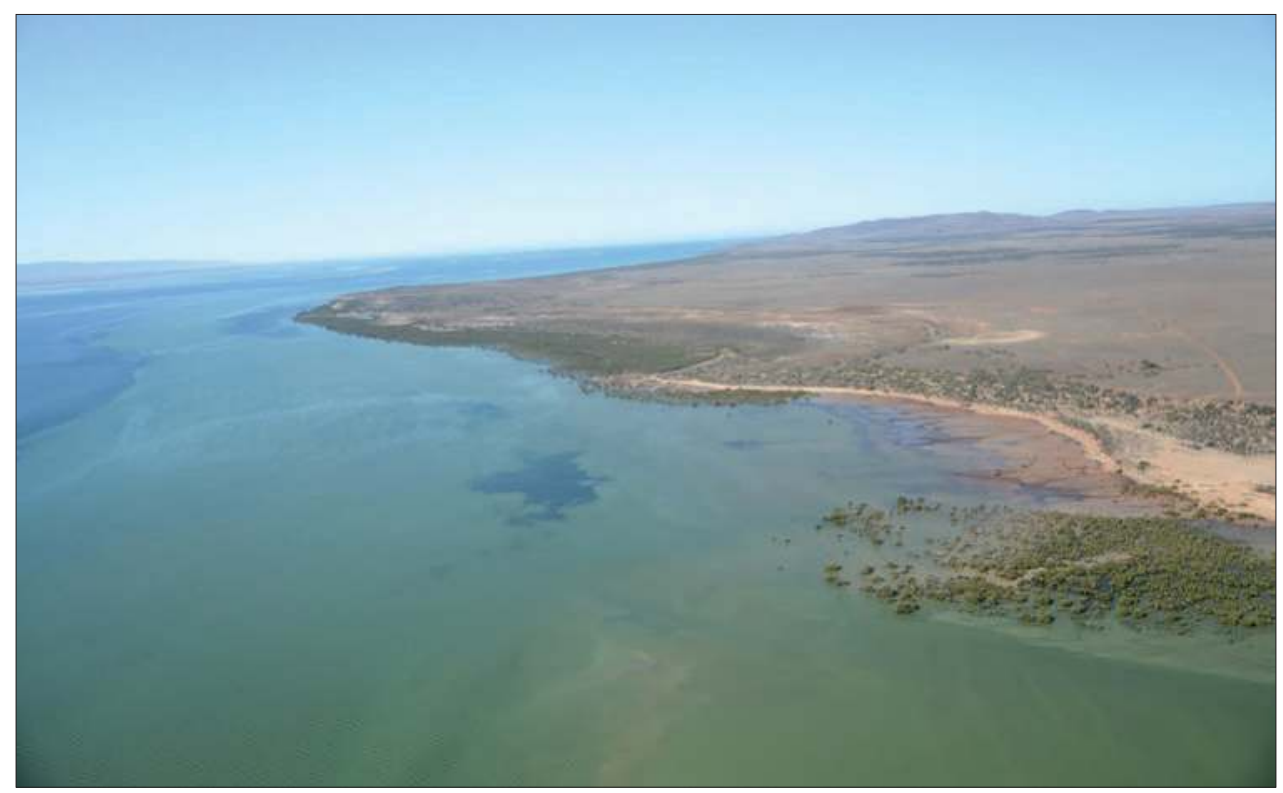

Figure 8.6 Blanche Harbor-Douglas Bank Aquatic Reserve, illustrating a low-lying coast with salt marsh, mangroves and sandflats.

Source: Reproduced with permission of the Coast Protection Board, 2013. 
and salt marshes. The southern boundary of the marine reserve at Douglas Point is also the furthest point accessible on the coastal road north of Point Lowly. Here, possible last interglacial elevated shells set in calcrete occur above the high water line, while lithified shingle and shells, including Anadara trapezia, form shore platforms ${ }^{26}$; the coast is backed by a high-level Holocene shell ridge landward of a lower modern ridge.

\subsection{Blanche Harbor to Port Augusta coast}

Blanche Harbor (Figure 8.7) is a tidally dominated, mangrove-filled embayment with low wave energy extending from Mangrove Point, where the gulf is only $5 \mathrm{~km}$ wide, to Blanche Harbor settlement. ${ }^{27}$ At Mangrove Point, sandflats front a series of recurved spits colonised by mangroves and backed by samphire flats. ${ }^{28}$

Between Blanche Harbor and Port Augusta, the bedrock-dominated coastline, which trends north-south, mirrors the orientation of the eastern escarpment of the flat-topped hills developed on rocks of the Tent Hill Formation. ${ }^{29}$ The upland is $300 \mathrm{~m}$ high and only 1 to $2 \mathrm{~km}$ (Figure 8.8) from the shoreline; within a distance of $20 \mathrm{~km}$, some 45 short, dry stream valleys debouch at the coast. The streams have formed small deltas, delivering coarse sediment derived from the alluvial fan sediments of Middle and Late Pleistocene ages. These deltas front the ranges and provide cobbles

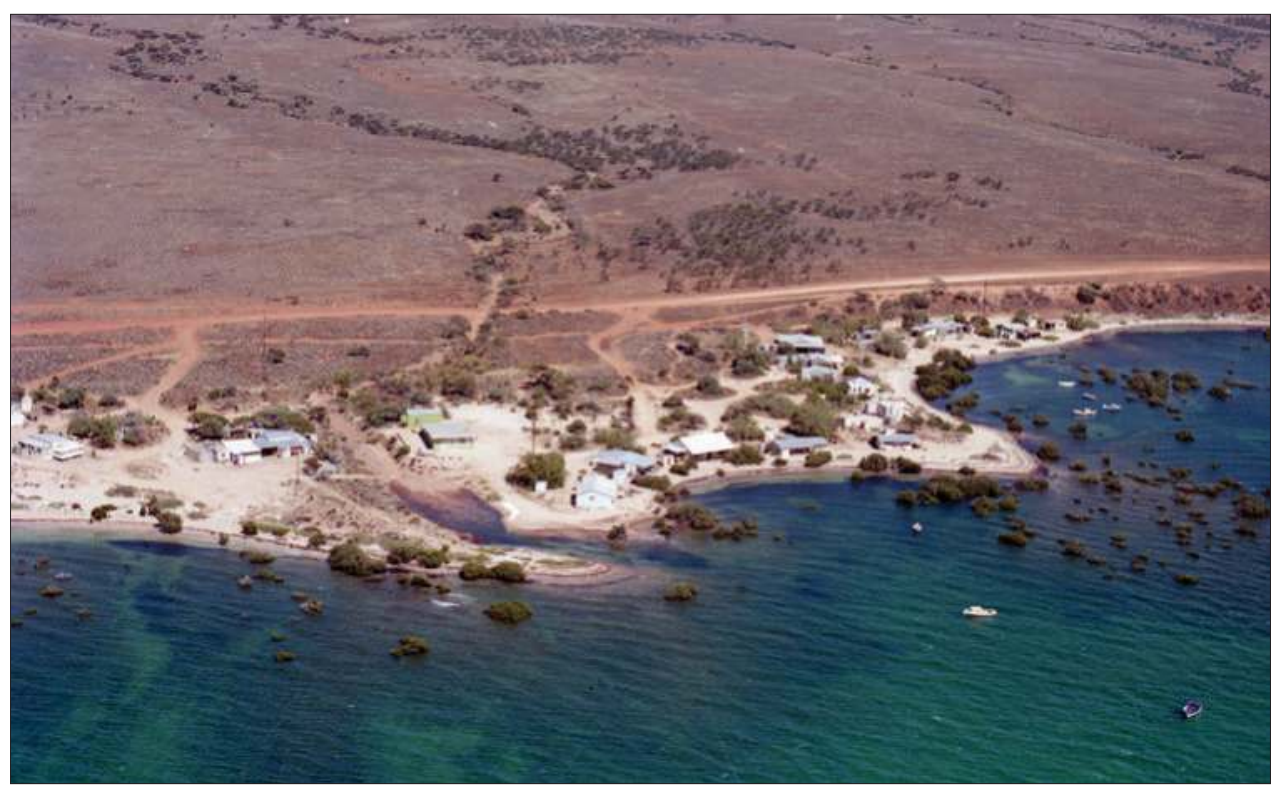

Figure 8.7 Blanche Harbor shacks, illustrating the close proximity of the shacks to the current intertidal mangrove and seagrass environment.

Source: Reproduced with permission of the Coast Protection Board, 2013. 


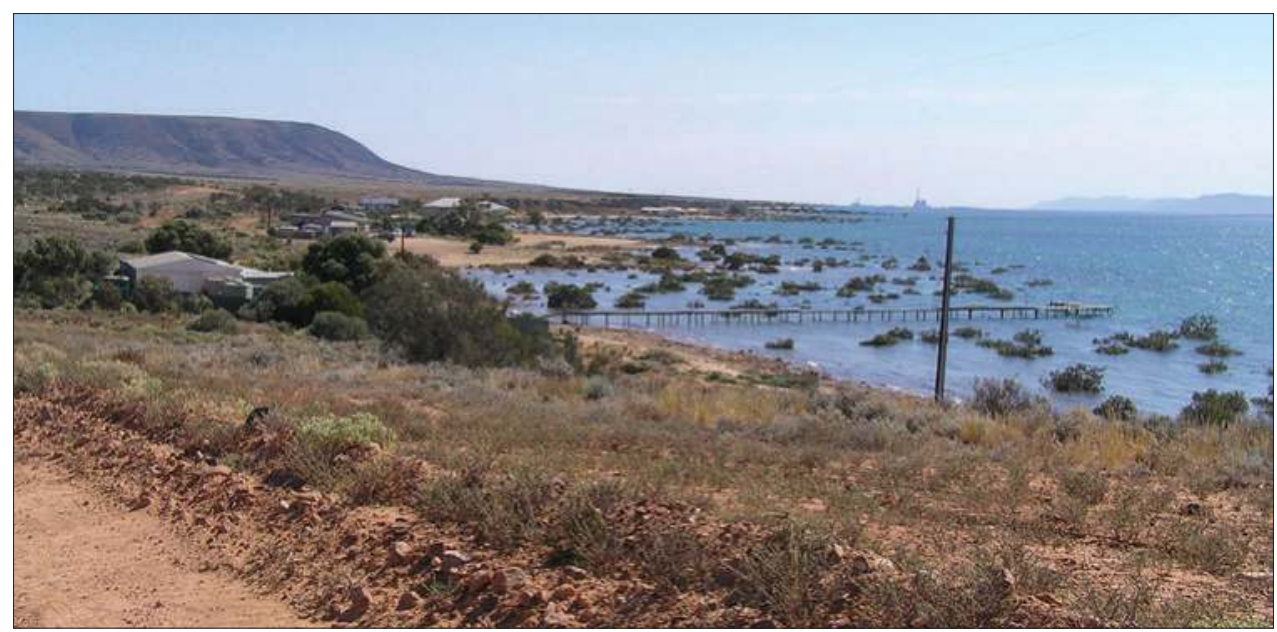

Figure 8.8 Blanche Harbor looking north, illustrating shacks adjacent to mangroves. Note the break in the slope of escarpment in the distance and the alluvial fan at the piedmont junction to shoreline.

Source: Author's own work, RPB.

for shingle ridge development. Cobble and sand beaches spotted with occasional mangroves occupy small bedrock bays, while there are extensive sandflats and seagrass meadows seawards. There are numerous beach shacks along this section of coastline.

The northern part of Spencer Gulf is tidally dominated. In stark contrast, however, is the enigmatic presence of stranded, shingle beach deposits (Figure 8.9) that occur over a range of $50 \mathrm{~km}$ from Stony Point north of Whyalla to within $8 \mathrm{~km}$ of Port Augusta. ${ }^{30}$ Apart from these occurrences, shingle and cobble beaches and ridges are relatively rare in Spencer Gulf. A small shingle ridge occurs at Lipson Cove; shingle beaches front steep colluvial deposits between Port Lincoln and North Shields, and also occur at The Knob near Cowell. There are other spasmodic occurrences of small cobble beaches along the coast, but none approach the dimensions of those in northern Spencer Gulf.

The shingle ridges, which strongly resemble the ballast stone of railway lines (Figures $8.10 \mathrm{a}$ and $8.10 \mathrm{~b}$ ), are usually between 3 to $5 \mathrm{~m}$ APSL and $15 \mathrm{~m}$ wide, with rare ridges up to $75 \mathrm{~m}$ wide at their bases. The shingles consist of moderately sorted clasts of Proterozoic bedrock, varying from large tabular cobbles to smaller subrounded pebbles. The shingle ridges are restricted to localities where there are relatively steep slopes developed on Proterozoic sandstone and quartzite, and are particularly well developed where there are steep alluvial and colluvial fans that contain numerous 


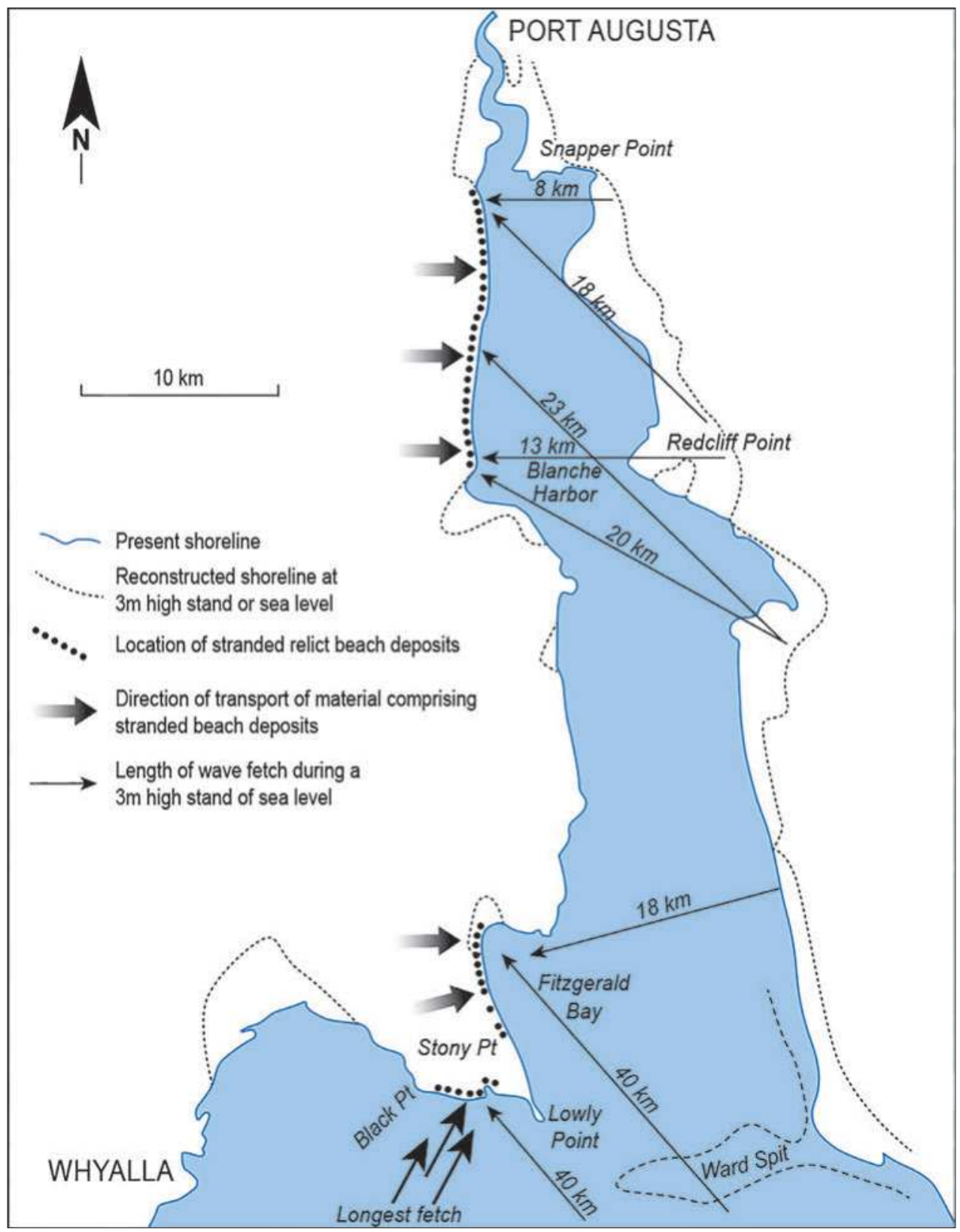

Figure 8.9 Locations of stranded shingle beach ridges between Whyalla and Port Augusta. Source: Modified from Hails, J.R. \& Goston, V.A. (1978). Stranded shingle beach ridges, Upper Spencer Gulf, South Australia: Evidence for high wave energy dissipation during the Late Pleistocene. Transactions of the Royal Society of South Australia, 102 (6), 169-173. 


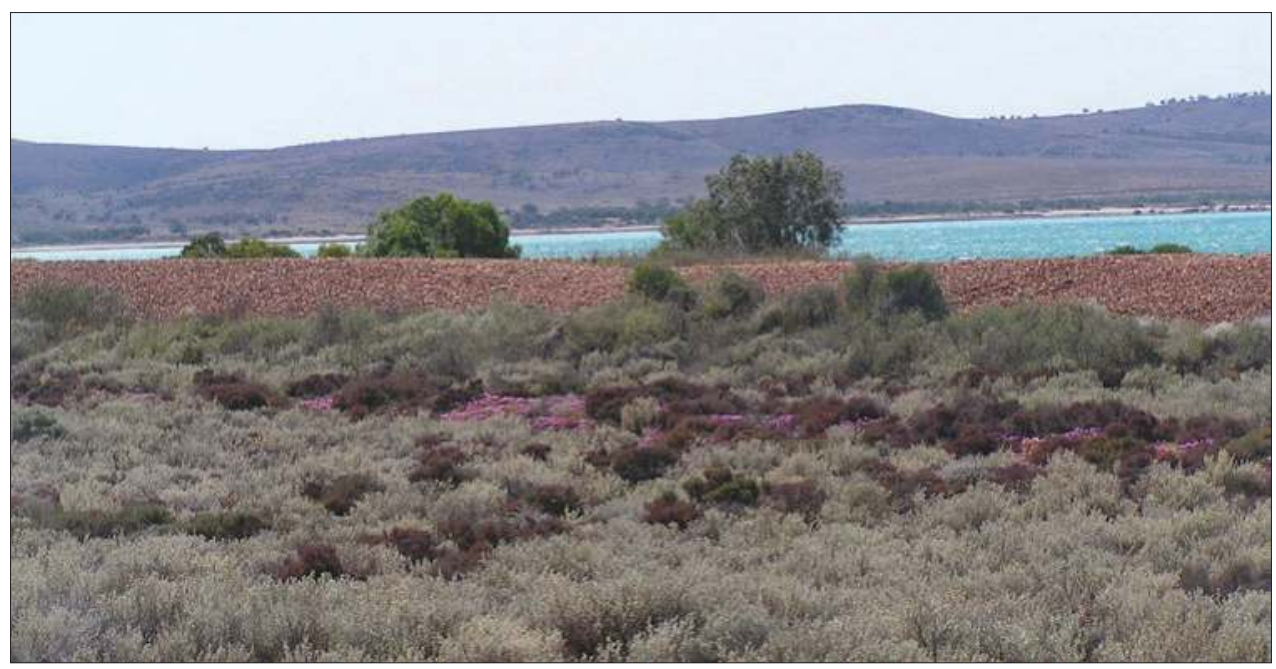

Figure 8.10a A stranded shingle ridge a few metres high, extending parallel to, but set back from, the current coastline on the western shore of Fitzgerald Bay. Note the lack of vegetation on the shingle ridge.

Source: Author's own work, RPB.

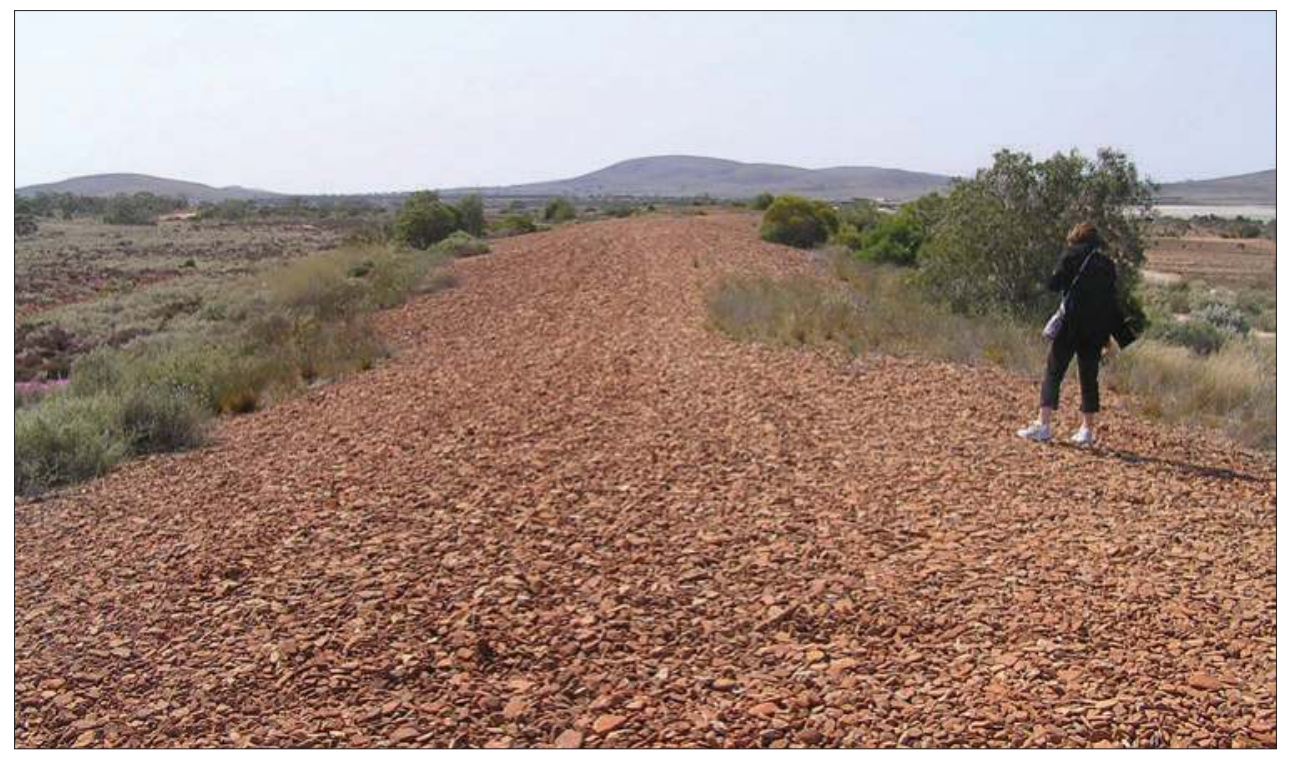

Figure 8.10b A view along the crest of a shingle beach ridge on Fitzgerald Bay. The ridge is at least 15 metres in width (note person for scale). The shingle consists of tabular and rounded cobbles.

Source: Author's own work, RPB. 
cobbles, boulder and pebbles. ${ }^{31}$ These deposits provided the main source of the shingle for the ridges, although some, no doubt, derived from erosion of the shore platforms developed on slabby, tabular sheets of bedrock such as at Stony Point. The main locations of ridges front the Pleistocene alluvial aprons of sediment fringing the western shore of Fitzgerald Bay and the area from Blanche Harbor settlement towards Port Augusta.

In some instances, large flat areas landward of the shingle ridges are suggestive of lateral movement of shingle along the shoreline. Remnants of various fossil shells occur within the shingle and include highly abraded valves of the subfossil species Anadara trapezia, characteristic of local intertidal estuarine environments during the Last Interglacial about $125 \mathrm{ka} \mathrm{ago}^{32}$, when conditions were warmer than present. Their tidally dominated habitat would have been totally out of harmony with the conditions of high wave energy required to build the Holocene shingle ridges into which these subfossils have been incorporated.

Although the surfaces of the shingle ridges reach up to 3 to $5 \mathrm{~m} \mathrm{APSL}$, their formation does not demand that the sea was at that level during their formation ${ }^{33}$; however, it does require an abundant source of shingle and a climate of high-energy waves to throw shingle up to form the ridges..$^{34}$

The formation of the ridges would have been enhanced by a sea level higher than today, which would have increased wave effectiveness. During the Last Interglacial $125 \mathrm{ka}$ ago, sea level was $2 \mathrm{~m}$ higher than at present, but the ridges contain highly abraded shells of the last interglacial species Anadara trapezia, indicating an estuarine environment ${ }^{35}$ and suggesting reworking of these deposits. After this high sea level, the sea drained from the gulf as the continental ice caps grew, and alluvial sediments containing pebbles and cobbles were carried seawards, only to be swept back inland by the rising seas as the ice sheets melted out between 18 to $7 \mathrm{ka}$ ago, incorporating last interglacial shells into the Holocene deposits. ${ }^{36}$

A higher sea level during the mid-Holocene, a high tidal range $(4.1 \mathrm{~m})$ and higher wave energies may have further eroded colluvial sediments and piled the cobbles into ridges. ${ }^{37} \mathrm{~A}$ higher sea level would have increased the fetch (the distance of open water over which the wind builds up waves). It is possible that the ridges have been uplifted since their formation, as an expression of hydro-isostasy; nevertheless, powerful wave action is required to explain their formation. There is evidence of spectacular wave activity at the foot of the peninsula at Whalers Way, where large boulders have been thrown up at least $20 \mathrm{~m}$ APSL. The size of such waves would have been amplified up the narrowing gulf and may have impacted on the shingle ridges.

North of Commissariat Point on the east coast, the gulf narrows into a tidal estuary stretching up to tidal flats near Yorkeys Crossing, about $8 \mathrm{~km}$ north of Port Augusta (Figure 8.11 ). The estuary is only $300 \mathrm{~m}$ wide at the Port Augusta road bridges, where 


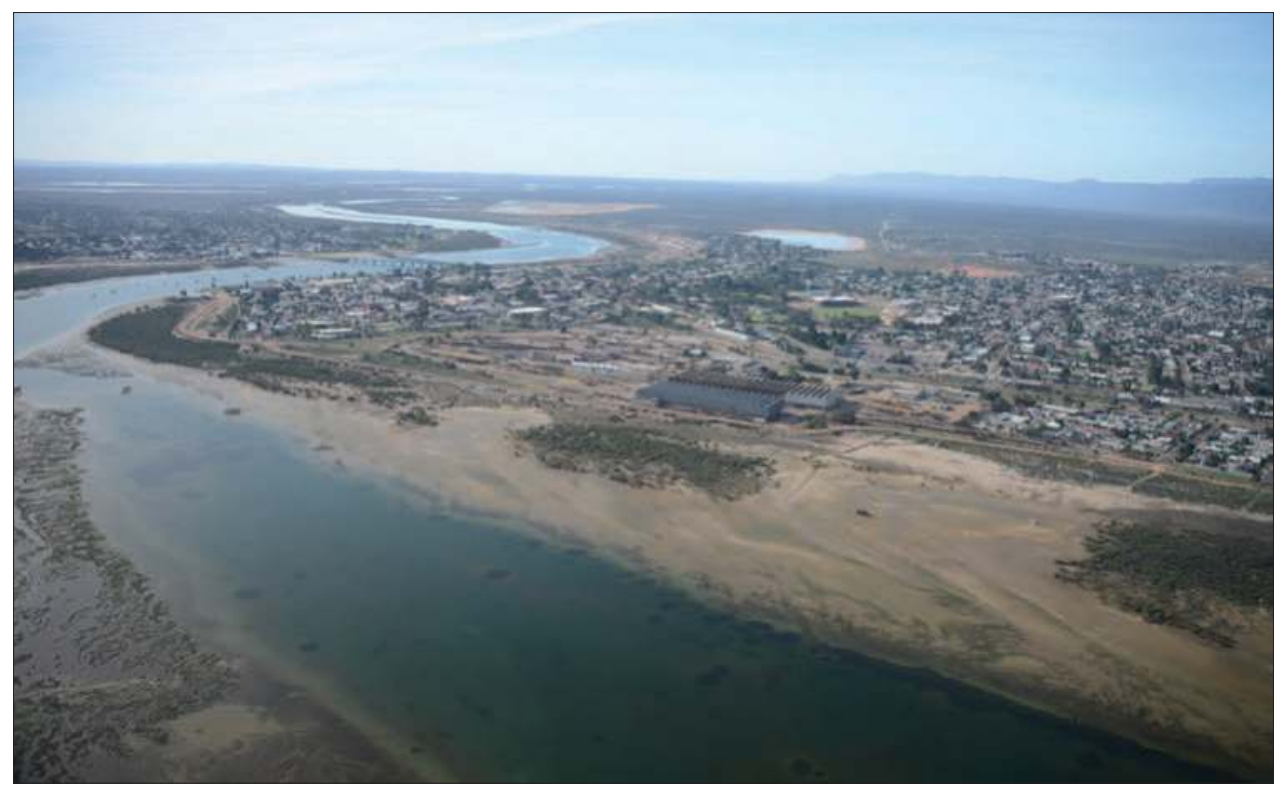

Figure 8.11 Port Augusta coast, illustrating a narrow estuary a few hundred metres wide with extensive sandflats and mangroves. The Port Augusta road bridges can be seen in the middle distance, where the estuary is $300 \mathrm{~m}$ wide.

Source: Reproduced with permission of the Coast Protection Board, 2014.

there are three small sandy beaches. ${ }^{38}$ Sandflats, seagrass, mangroves and samphires dominate this part of the coast, which has the largest tides in South Australia. ${ }^{39}$ A cliffed section on the eastern bank of the estuary to the north of the township at Red Cliff, near Flinders Lookout, reveals brightly coloured red/brown alluvial sediments of Late Pleistocene age, possibly 60 to 25 ka old.

\subsection{Port Augusta to Point Paterson}

The mangroves fringing the northern part of the estuary become denser to the south, developing into extensive mangrove woodlands. Curlew Point and Curlew Island form part of a protrusion of samphire, mangroves, and tidal sandflats extending $2 \mathrm{~km}$ from the western side of the gulf. Slightly further south on the eastern side is Port Paterson, a shallow embayment surrounded by mangroves and tidal flats up to $2 \mathrm{~km}$ wide. ${ }^{40}$ A southwest-facing beach on the north shore of this embayment is fronted by tidal flats $0.5 \mathrm{~km}$ wide, which are backed by recent beach ridges and older dunes. ${ }^{41}$ On the eastern side is a line of storm ridge deposits behind the mangrove fringe. These mangroves give way to a wide intertidal sandflat at Point Paterson in the south. 


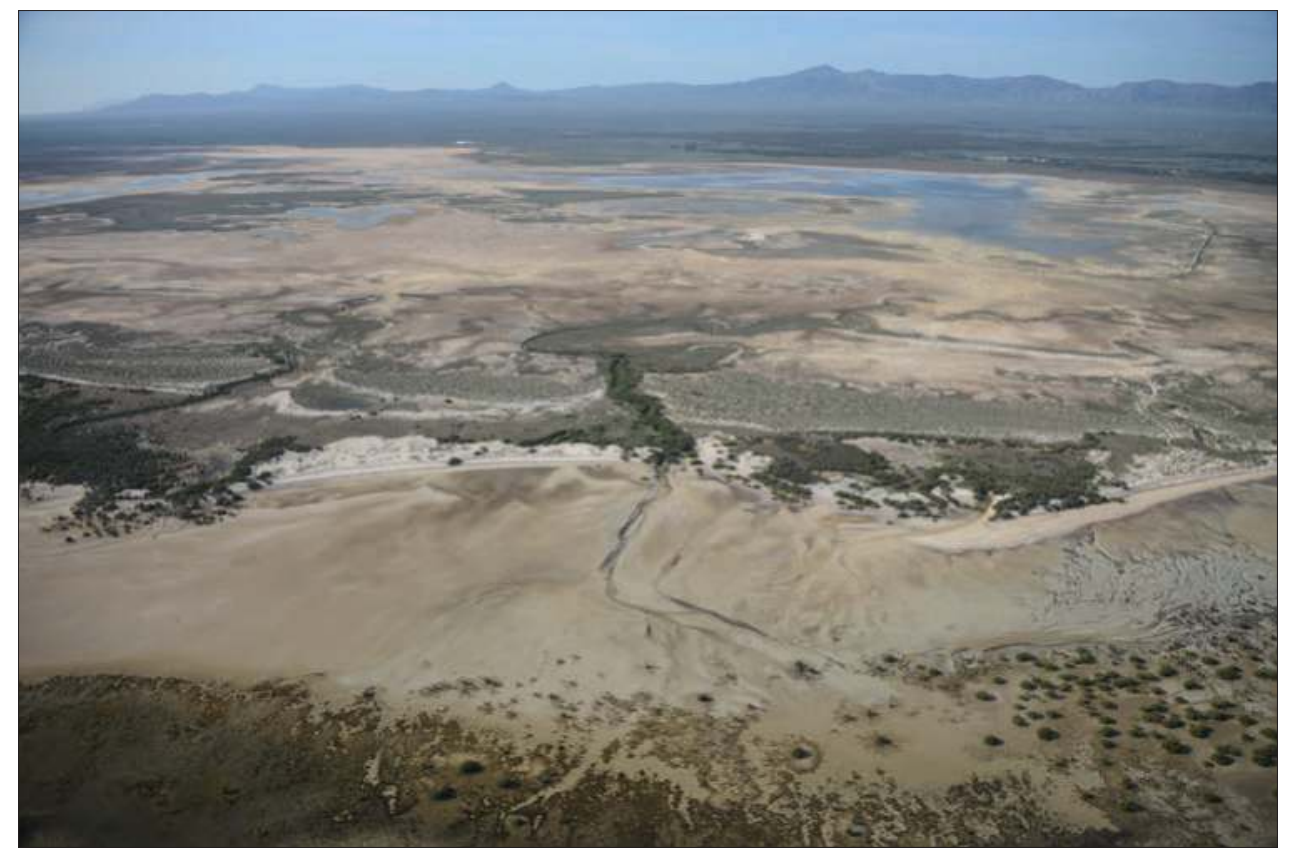

Figure 8.12 Point Patterson coastal plain, looking towards the southern Flinders Ranges in the distance. This illustrates a very low-energy coastal plain with extensive sandflats, along with intertidal and supratidal samphire flats and mangroves in a number of tidal creeks. There are also sand and shell ridge deposits behind the mangrove fringe.

Source: Reproduced with permission of the Coast Protection Board, 2014.

At Point Paterson, the gulf is about $4 \mathrm{~km}$ wide, with the Point protruding into the gulf up to $5 \mathrm{~km}$ from the alignment of the main coastline, due to the accretion of sediments of the Holocene St Kilda Formation, which comprises sands, shells, silts and clays of the mangrove swamps and littoral lagoons. A large proportion of Point Paterson is made up of bare high-tide and supratidal flats (Figure 8.12), producing a very low-energy coastal plain with extensive sandflats, as well as intertidal and supratidal samphire flats. These give way to mangroves with numerous tidal creeks on the southwest-facing coast ${ }^{42}$, extending some $6 \mathrm{~km}$ to the northern lee side of Redcliff Point, which protrudes seawards for $-3 \mathrm{~km}$. Along this coastal section, discontinuous shore-parallel sand and shell ridge deposits occur landward of the mangrove fringe between small tidal creeks.

\subsection{Point Paterson to Yatala Harbor}

South of Point Paterson, the intertidal zone narrows and there is a distinct zonation between dense mangrove forest and gently sloping samphire and supratidal flats. ${ }^{43}$ 
Much of this coastal section is in the Winninowie Conservation Park, which extends south past Yatala Harbor. It contains a high proportion of remnant vegetation, of which some $75 \%$ is salt marsh. ${ }^{44}$ Nearshore seagrass beds front the mangroves, which are protected from waves by the East Banks, a series of large sand islands. ${ }^{45}$

On the southern side of Redcliff Point, the coast faces southwest and is less protected; this $9 \mathrm{~km}$ stretch of beach is fronted by intertidal sandflats, which are $1 \mathrm{~km}$ wide and grade into dense seagrass beds. ${ }^{46}$ In this area, some supratidal springs of saline non-marine groundwater have isolated and stranded mangroves, cyanobacterial marshes and gypsum fans. ${ }^{47}$ Immediately south of the Point, a beach stretches for just over $5 \mathrm{~km}$ to the southeast toward Mt Grainger, a point on the coast ${ }^{48}$ which is $65 \mathrm{~m}$ high and formed of resistant sandstone and quartzite. The beach is backed by a low foredune ridge, which in part is backed by a low relict cliff of older dune material. In the southeast, a series of beach ridges extends inland for over $1 \mathrm{~km}$, indicating rapid sediment deposition and shoreline progradation in the Holocene. At their southeastern end, the ridges are cut by tidal creeks, they become discontinuous, and their alignment curves to the south, indicating earlier Holocene stages of embayment infill.

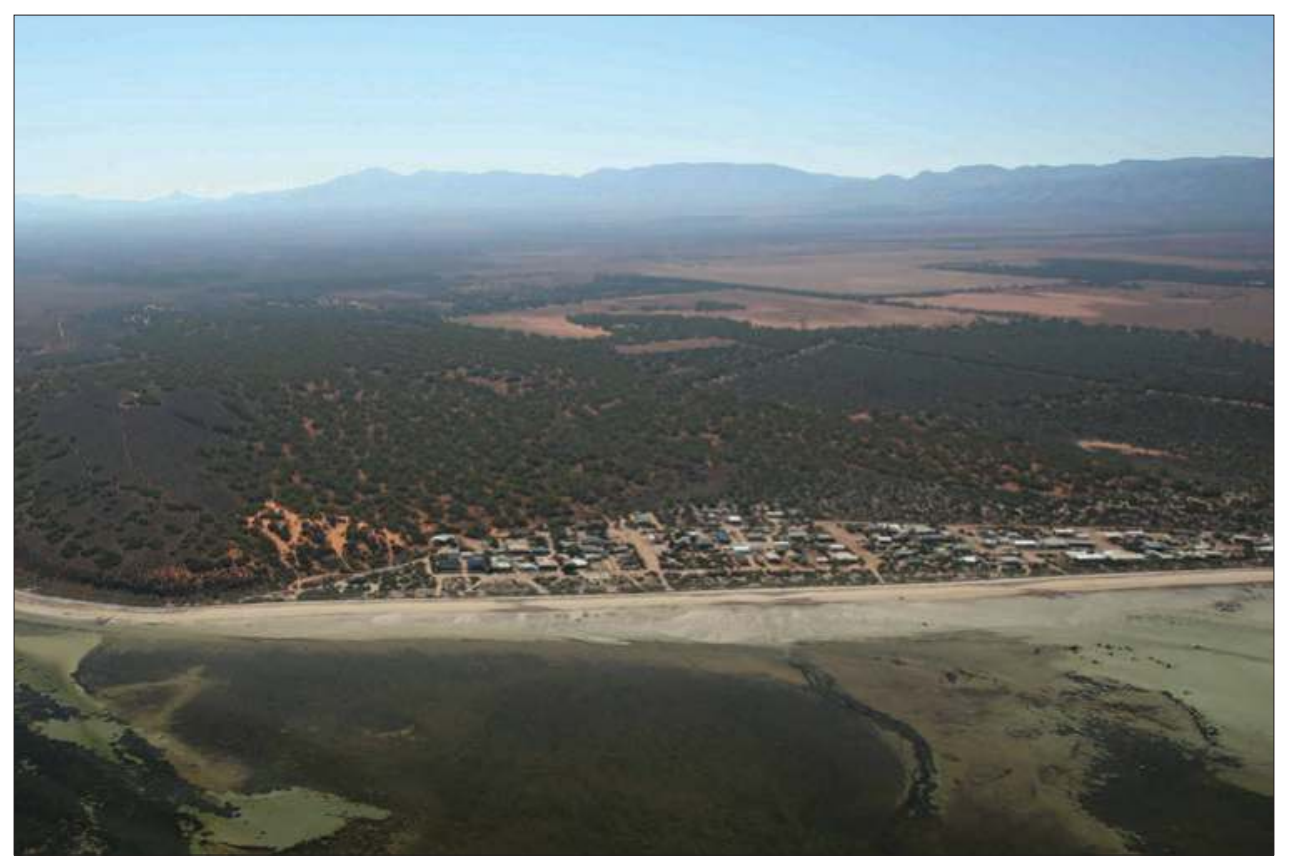

Figure 8.13 Miranda Beach, looking toward the lower Flinders Ranges in the distance. This is a very low-energy, southwest-facing beach just over $3.5 \mathrm{~km}$ in length, protected from waves by extensive sand banks and shoals to the southwest. A narrow sandflat adjacent to seagrass beds at the eastern end of the beach, near the Miranda township, expands to a width of $2 \mathrm{~km}$ towards the east (right).

Source: Reproduced with permission of the Coast Protection Board, 2014. 


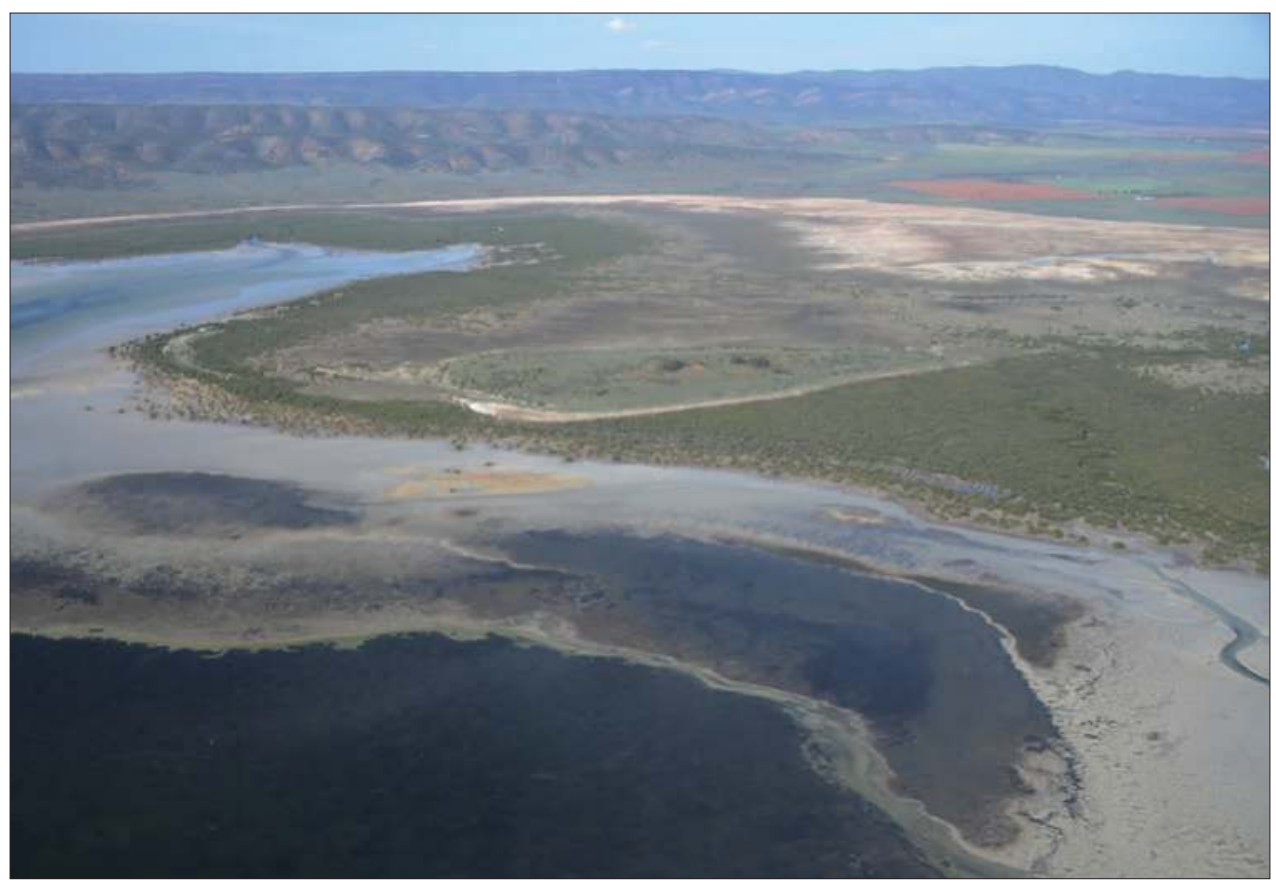

Figure 8.14 The southern part of Yatala Harbor (part of Winninowie Conservation Park), looking towards the southern Flinders Ranges in the distance. The whole embayment is fringed by mangroves, intertidal and supratidal samphire, and saline flats. In the middle distance is a relict sand island about 300 to $400 \mathrm{~m}$ in length abutting mangroves on its western shore. These mangroves extend westwards toward the sandflats and shoals (foreground).

Source: Reproduced with permission of the Coast Protection Board, 2014.

Mount Grainger and Mount Gullet, resistant bedrock outcrops, flank the inlet of Yatala Harbor, a west-facing sheltered embayment that is $4 \mathrm{~km}$ wide and is designated an aquatic reserve (Figure 8.14). Between Mount Grainger and Yatala Harbor, a very low-energy, southwest-facing beach, $3.5 \mathrm{~km}$ long (Figure 8.13), is protected from wave attack by extensive sand banks and shoals to the southwest. A narrow sandflat adjacent to seagrass beds at the eastern end of the beach, near the Miranda Township, expands to a width of $2 \mathrm{~km}$ towards Yatala Harbor. The beach is backed by a narrow foredune, both of which give way to mangroves at the northern end of Yatala Harbor.

At this transition zone, the sandy deposits appear as discontinuous sand and shell ridges landward of the mangroves and samphire flats. Mangroves, intertidal and supratidal samphires, and saline flats fringe the entire embayment. Yatala Harbor is a very low-energy environment due to its protection from the west and southwest by extensive sand and shoal areas. A relict sand island about 300 to $400 \mathrm{~m}$ in length 
at the southern entrance to the harbour abuts mangroves on its western shore. These mangroves extend westwards toward the sandflats and shoals, but finish abruptly where the coast is oriented to the south.

\subsection{Yatala Harbor to Weeroona Island}

A relatively linear section of sandy coast extends $25 \mathrm{~km}$ south from Yatala Harbor to a mangrove coast in the lee of Ward Point (Figure 8.15). The alignment of outcrops of hard rock at Mount Grainger, Mount Gullet, Mount Mambray and Weeroona Island suggests a structural influence on the broad orientation of the coast. Near Yatala Harbor, the sandflats extend up to $4 \mathrm{~km}$ offshore but narrow to $1.5 \mathrm{~km}$ in the south. The northern section of this coast has wide intertidal sandflats fronting a narrow beach and foredune, behind which are extensive intertidal and supratidal samphire flats drained by a number of tidal creeks. These flats narrow at Mambray Creek, where a series of low beach ridges dominates. The line of beach ridges about $300 \mathrm{~m}$ in width

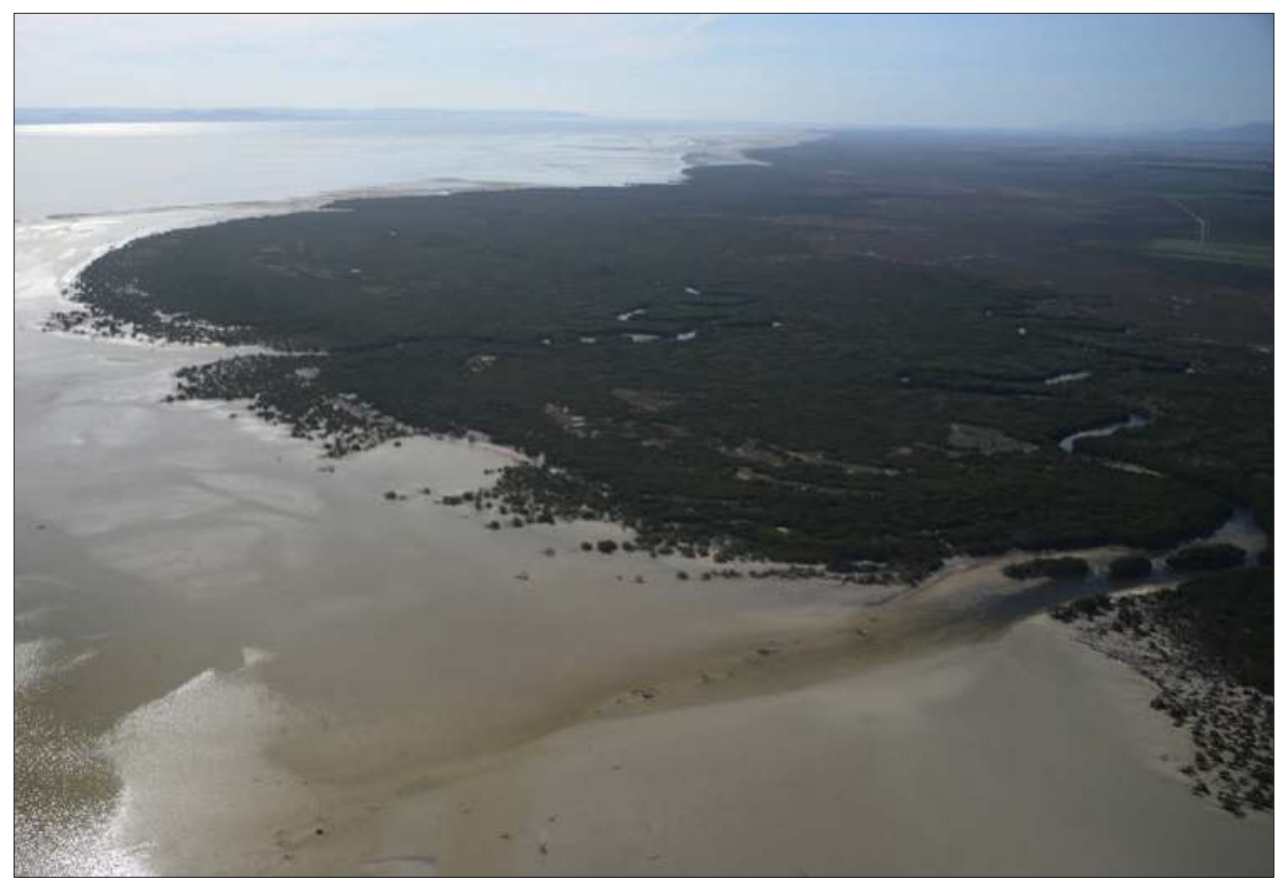

Figure 8.15 Ward Point, showing mangroves fringing the protected eastern end of the spit and around the whole of Ward Point. Here, dense woodland occurs behind the frontal beach ridge, while more scattered mangroves have developed on the seaward side. A small deltaic plain drained by a number of tidal estuaries shows a zonation between mangroves, intertidal and supratidal samphire flats. There are also isolated ridge deposits in and behind the mangroves.

Source: Reproduced with permission of the Coast Protection Board, 2014. 
continues south toward Ward Point, where the ridges narrow, break up and become discontinuous across a plain of supratidal samphire flats.

At Ward Point, a sand spit approximately $10 \mathrm{~km}$ long stretches westward toward Point Lowly on the western side of the gulf (see Figure 1.10). The spit has developed in response to low-energy conditions related to wave and currents in northern Germein Bay. The extension of this spit has most likely built on bioclastic sediments derived locally from prolific biota associated with seagrass meadows. ${ }^{49}$ Mangroves fringe the protected eastern end of this spit (Figure 8.15), including the coast of Ward Point, where dense mangrove forest occurs behind the frontal beach ridge, while more scattered mangroves have developed on the seaward side. There is a small deltaic plain with a clear zonation between mangroves, intertidal and supratidal samphire flats. ${ }^{50}$ The plain is drained by a number of tidal estuaries, which cut through the beach ridge deposits. Some isolated ridge deposits lie in and behind the mangroves.

South of Ward Point, the west-facing Germein Bay contains the settlement of Port Germein, which has been built across a wide beach ridge plain. North of the town jetty, a sandy beach almost $1.5 \mathrm{~km}$ long has built up alongside the artificial jetty structure.

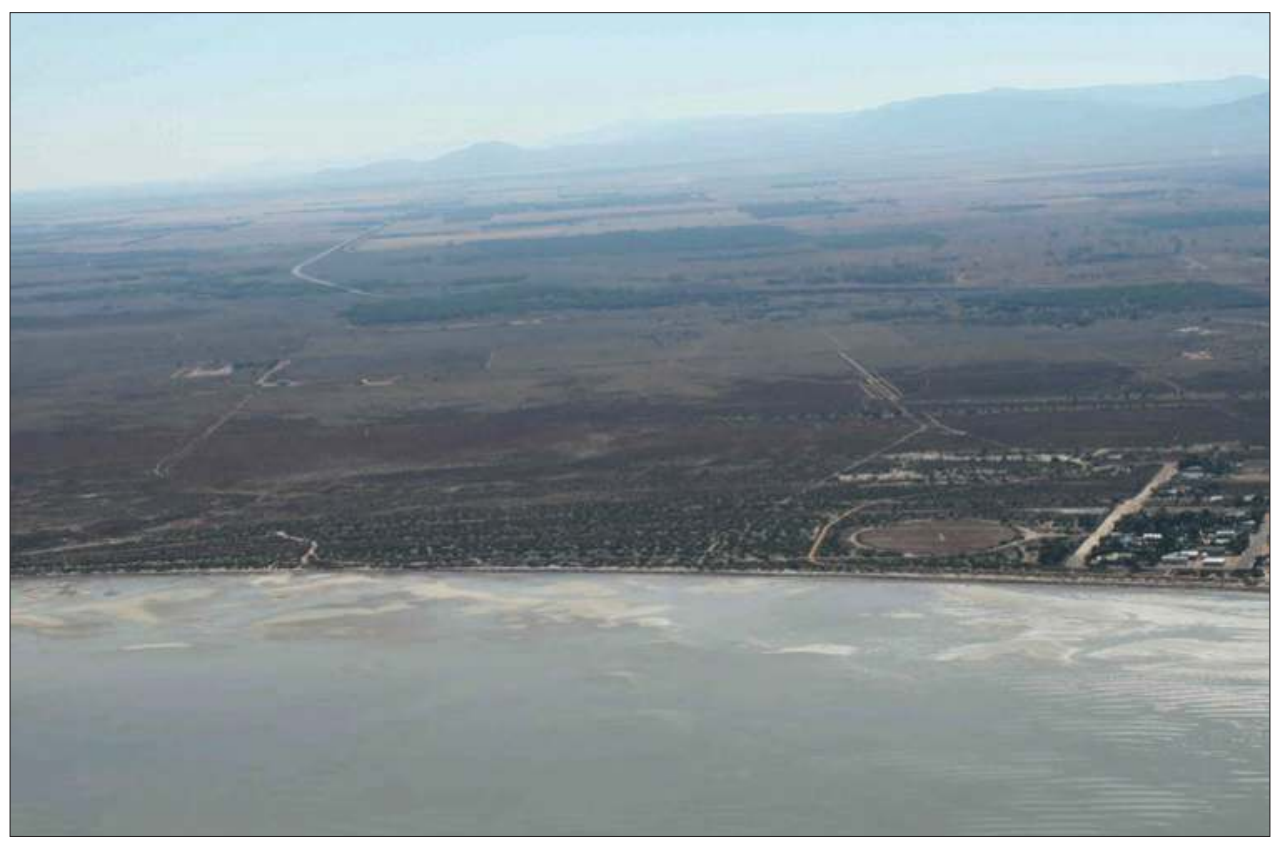

Figure 8.16 The beach north of Port Germein, fronted by sandflats almost $1 \mathrm{~km}$ in width. The beach is backed by a series of low sand ridges.

Source: Reproduced with permission of the Coast Protection Board, 2014. 
This beach is fronted by sandflats almost $1 \mathrm{~km}$ wide, which contain numerous low sand ridges (Figure 8.16). South of the jetty, the beach extends for over $1.5 \mathrm{~km}$ to a tidal creek, which cuts through recurved beach ridges. South of the creek, a sandy beach extends for $7.5 \mathrm{~km}$ to the northwest of Weeroona Island. The beach is backed by a series of low beach ridges and fronted by a tidal flat with multiple sand ridges; the tidal flat is $1 \mathrm{~km}$ wide and abuts dense seagrass beds. There are numerous sand shoals and spits in the northern gulf; one of these, Cockle Spit in Germein Bay, is of interest in that it is used at low tides to host occasional cricket matches between the yacht clubs of Whyalla and Port Pirie.

Weeroona Island, which consists of an outcrop of cross-bedded sandstone and quartzite of the Tent Hill Formation of Proterozoic age, similar to that in the Flinders Ranges, contains the last of the sandy beaches on the predominantly west-facing coast stretching from Germein Bay up to Yatala Harbor. The Weeroona beach extends for just over $1.5 \mathrm{~km}$ on the western side of the island, whereas mangrove woodland occupies its sheltered eastern side. An artificial causeway across the intertidal and supratidal samphire flats provides access to the island, which is $40 \mathrm{~m}$ high. ${ }^{51}$

\subsection{Port Pirie to Port Broughton}

A prominent protrusion of the coast between Port Pirie and Port Broughton some $20 \mathrm{~km}$ seaward from the general alignment of the coast resembles a classic arcuate delta, such as that of the River Nile. This attribute, along with other factors, was used by some as evidence for a western outlet of the River Murray before uplift of the Mount Lofty/Flinders Ranges. ${ }^{52}$ Others, however, believed that the ranges existed before the lower course of the river from Morgan to Goolwa was established ${ }^{53}$, and it has also been suggested that the mouth of the River Murray was located in Western Victoria until about $1 \mathrm{Ma}$ ago. ${ }^{54}$ Not only is it unlikely that the bulging coast at Port Pirie is a paleodelta of the River Murray, but the size of the drainage basin of the River Broughton $\left(5761 \mathrm{~km}^{2}\right)$ is also compatible with the dimensions of the 'delta'. ${ }^{55}$ Accretion from river floods continues today, as do spillover lobes of intertidal sandflat sediments onto the supratidal zone by storm waves. ${ }^{56}$ Former desert dunes of the Last Glacial Maximum were also incorporated into the Holocene coastal sediments as sea level rose. $^{57}$

From Weeroona Island to Port Davis, the coast of Germein Bay faces the northwest, providing a very low-energy environment for mangrove development. This entire section is a very low-gradient, low-energy, prograding coast up to $7 \mathrm{~km}$ wide (Figure 8.17). There is a distinct zonation in both vegetation and associated geomorphology from the subtidal seagrass beds, through to an intertidal sandflat up to $1 \mathrm{~km}$ wide, a mangrove fringe up to $1 \mathrm{~km}$ wide, extensive intertidal and supratidal samphire flats and bare supratidal saline flats. This section of coast contains numerous 


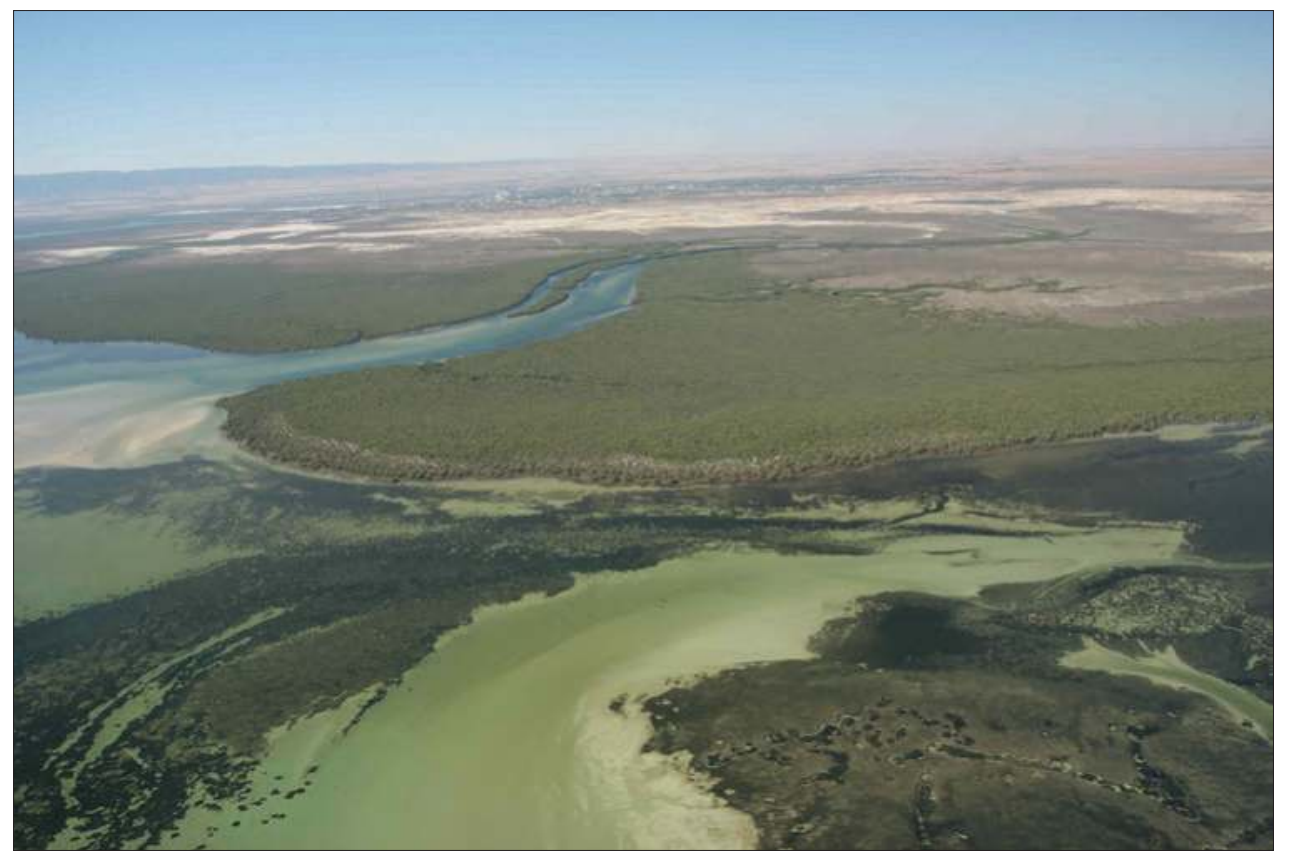

Figure 8.17 Mangrove coast between Port Pirie and Port Davis, illustrating a very lowgradient, low-energy, prograding coast of up to $7 \mathrm{~km}$ in width. The photo illustrates a zonation in vegetation and associated geomorphology from the subtidal seagrass beds, through to an intertidal sandflat up to $1 \mathrm{~km}$ wide, a mangrove fringe up to $1 \mathrm{~km}$ wide, extensive intertidal and supratidal samphire flats and bare supratidal saline flats.

Source: Reproduced with permission of the Coast Protection Board, 2014.

tidal creeks, the largest of which are the Port Pirie River south of Weeroona Island and Port Davis Creek in the southwest. Geological studies in the Port Pirie coastal zone reveal a rapidly prograding and aggrading sedimentary sequence, indicating a hydroisostatically uplifting coast over the past 6700 years. ${ }^{58}$

This has produced relict tidal channels ${ }^{59}$ and has caused a local relative fall in sea level. These Holocene deposits overlie up to $150 \mathrm{~m}$ of Paleogene, Neogene and Quaternary alluvial sediments derived from the Flinders Ranges.

Near Port Pirie, tidal influences dominate the coastline, with the widespread development of mesotidal inlets (spring tides vary between 2 and $4 \mathrm{~m}$ ), while wave activity is restricted by limited fetches of 25 to $30 \mathrm{~km}$. In marked contrast, the southwesterly facing coast, where the Broughton River enters the sea, has a fetch of more than $200 \mathrm{~km}$, causing this section of coast to be wave-dominated. Here the mangroves disappear, and the coast comprises intertidal sandflats up to $4 \mathrm{~km}$ wide, high-tide beaches backed by beach ridges, and salt flats containing gypseous clay. ${ }^{60}$ Point Jarrod, 

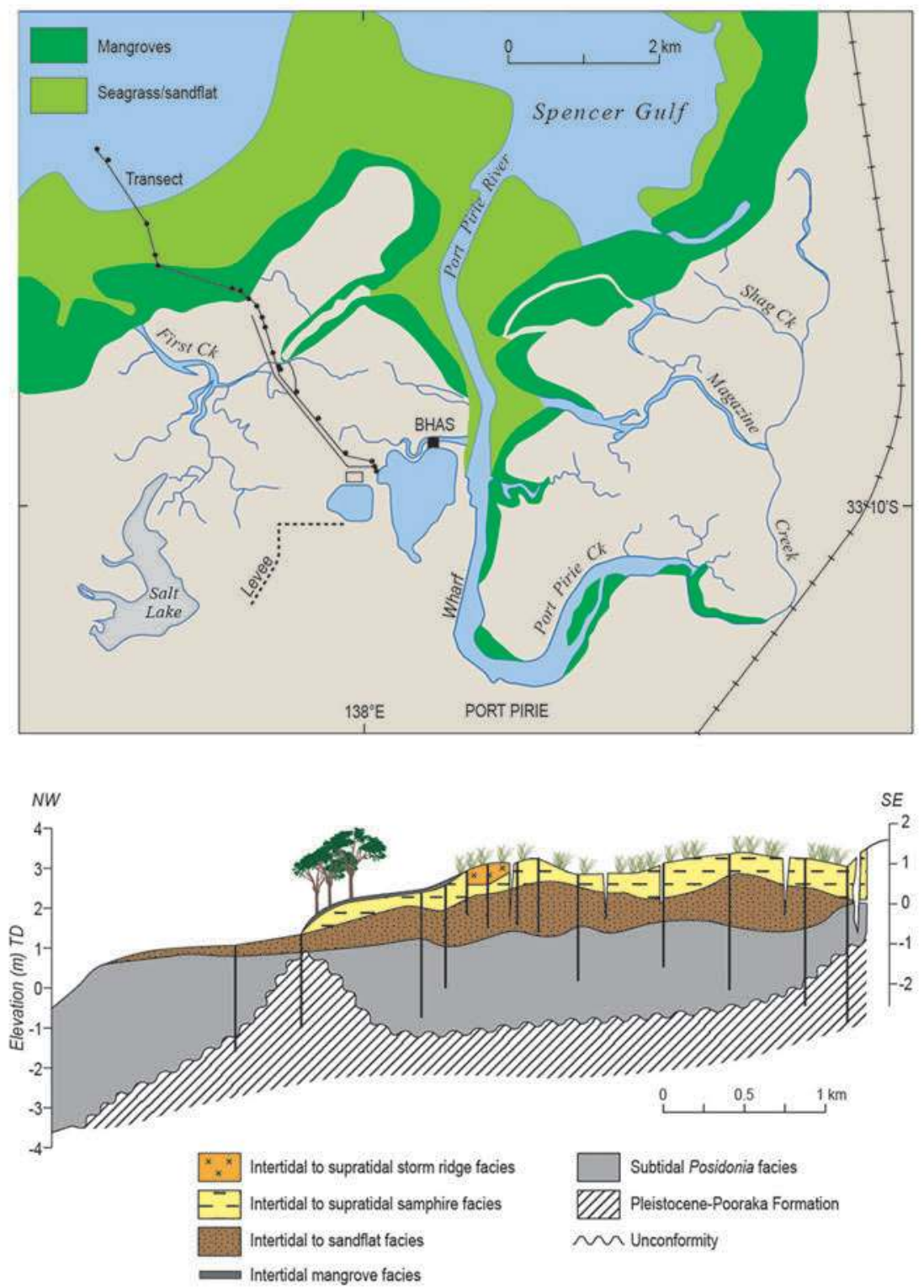

Figure 8.18 The coastline around Port Pirie, illustrating the wide prograding coast with extensive mangroves, sandflat and seagrass beds. The transect reveals a prograding coastal wedge of seaward-inclined subtidal, intertidal and supratidal layers. Cores reveal an underlying erosional Pleistocene/Holocene boundary on the terrestrial Pooraka Formation. A smooth contact between the Posidonia facies and the sandflat facies falls $1 \mathrm{~m}$ in elevation over $5 \mathrm{~km}$. Much of the subsurface is masked by samphire facies with occasional storm ridges. Mangrove facies are spatially restricted.

Source: Harvey, N., Barnett, E.J., Bourman, R.P. \& Belperio, A.P. (1999). Holocene sealevel change at Port Pirie, South Australia: A contribution to global sea-level rise estimates from tide gauges. Journal of Coastal Research, 15 (3), 607-615. 


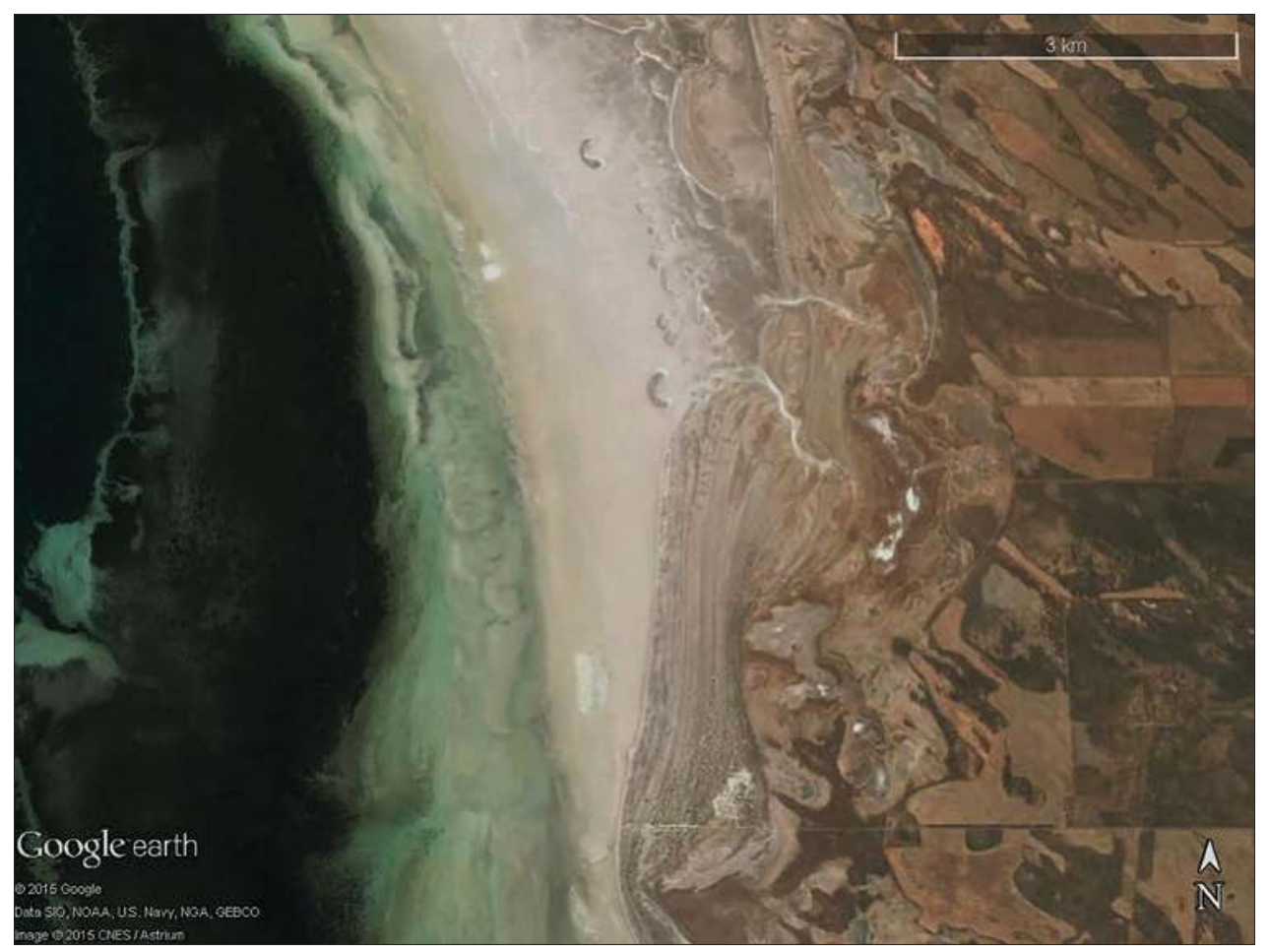

Figure 8.19 Vertical aerial photograph, illustrating a disjointed series of spits and beach ridges 5 to $6 \mathrm{~km}$ south of Point Jarrod, which indicate phases of rapid coastal progradation during the Holocene.

Source: Google Earth image () 2015 Google.

immediately south of the Port Davis Creek, has a high-tide beach $7 \mathrm{~km}$ long, fronted by intertidal sandflats $3 \mathrm{~km}$ wide and backed by a series of low beach ridges that are 200 to $300 \mathrm{~m}$ wide and grade into extensive salt flats. ${ }^{61}$ The presence of a disjointed series of spits and beach ridges for 5 to $6 \mathrm{~km}$ south of Point Jarrod ${ }^{62}$ indicates phases of rapid coastal progradation during the Holocene (Figure 8.19). Continuing southwards, beach ridge development (Figure 8.20) is more regular, with up to 25 ridges stretching north-south for some $18 \mathrm{~km}$, including the protruding coastline of Wood Point. ${ }^{63}$ Here, sandflats up to $3 \mathrm{~km}$ wide abut dense seagrass beds and are backed by wide supratidal salt flats with cyanobacterial mat development. At the southern end of this wide beach ridge plain, the sandflat narrows, and there is a west-facing beach $3.5 \mathrm{~km}$ long with a low backing foredune.

The northern Spencer Gulf terminates at the two embayments of Fisherman Bay and Port Broughton, which mark the northern end of Yorke Peninsula. A distinctive 
feature of the hypersaline Fisherman Bay is that it is a site where iron oxides, derived from iron-rich continental groundwater, accumulated in Holocene carbonate sediments ${ }^{64}$, forming hard crusts, red clays and biscuit-like forms containing up to $36 \%$ iron oxides as hematite, goethite and ferrihydrite. ${ }^{65}$

Fisherman Bay and Port Broughton are complex tidal inlets that were much bigger embayments during the Last Interglacial (125 ka ago), when sea level was some $2 \mathrm{~m}$ higher than at present. Fossil molluscs of last interglacial age occur on the fringes of the embayments. The open shoreline enclosing Fisherman Bay and Port Broughton (Hamilton Lagoon and Mundoora Arms) consists of calcreted deposits of Miocene Melton Limestone ${ }^{66}$, which were breached, allowing tidal waters to occupy low-lying land behind this coastal barrier. Melton Limestone also underlies Shag Island, while the coast protrudes slightly where there is a small outcrop of resistant sandstone just north of the entrance to Port Broughton. A series of recurved spits has formed at the inlet to Hamilton Lagoon as sand has drifted northwards along the coast to be transported into the embayment. Intricate systems of dendritic tidal channels occupy both embayments, which are slowly being infilled with flood tide deposits, mangroves and samphire vegetation.

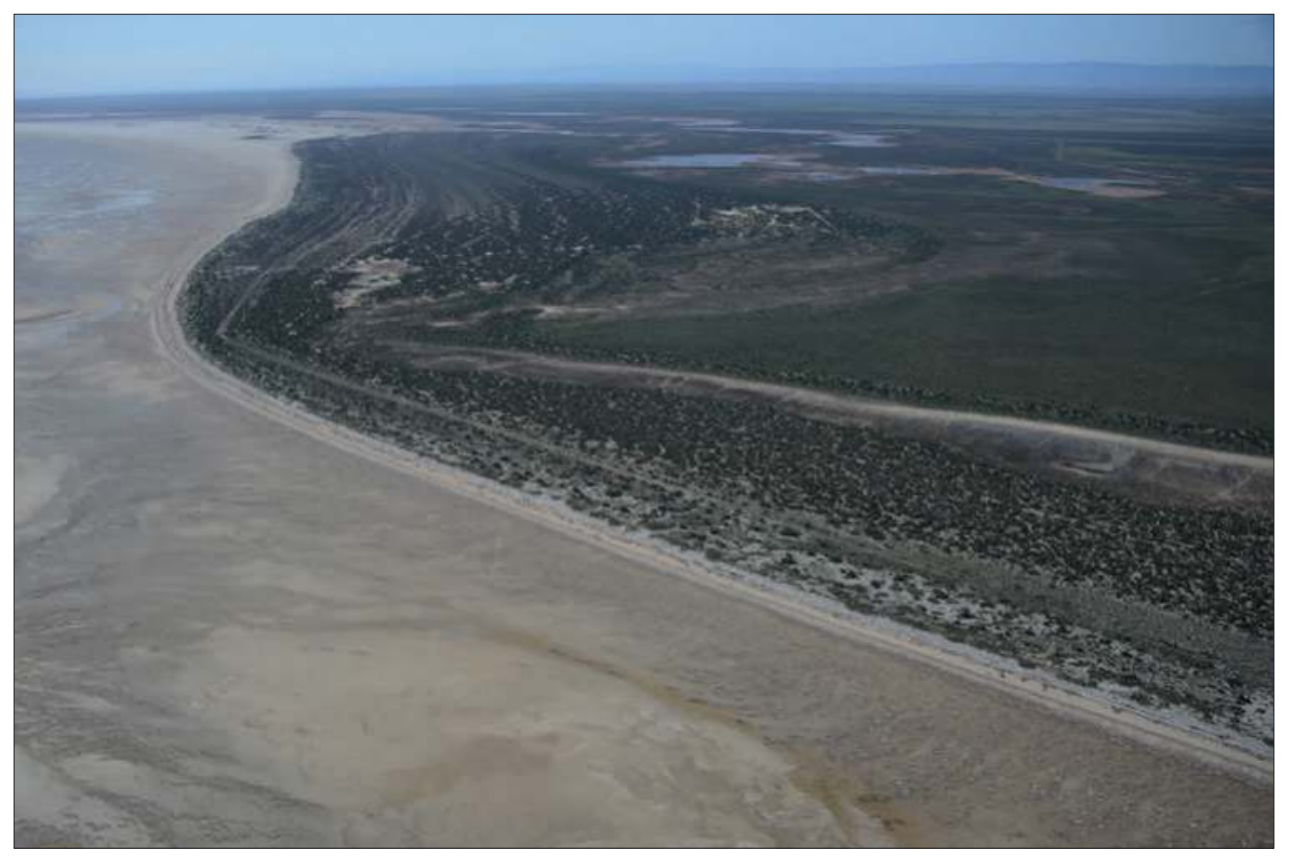

Figure 8.20 A regular pattern of beach ridge development south of Wood Point with up to 25 ridges stretching north-south for around $18 \mathrm{~km}$. The sandflats here are up to $3 \mathrm{~km}$ wide, abutting dense seagrass beds.

Source: Reproduced with permission of the Coast Protection Board, 2014. 


\subsection{Summary and conclusion}

Northern Spencer Gulf is located within the Paleogene to Neogene Pirie Basin, where structural controls are evident on the western coast and the shoreline reflects bedrock topography. There is an anomalous Holocene shingle beach ridge complex on the northwestern coast, significant because of its uniform elevation at about $5 \mathrm{~m}$ APSL, implying regional uplift of the area in the past few thousand years since ridge formation. They also suggest that there was a relatively higher sea level and a high-energy wave environment during their construction.

The eastern coast has less structural control, but it is dominated by Pleistocene and Holocene marine sedimentation. The northern gulf is an inverse or negative estuary with elevated salinity and temperatures in a protected wave environment with amplified tidal ranges of up to $4.1 \mathrm{~m}$. Consequently, tidal processes dominate the northern gulf. The coastline has thick seagrass meadows, wide intertidal sandflats, mangrove woodlands and supratidal saline marshland. There is a massive production and accumulation of biogenic materials that include algae, seagrass, molluscs and bryozoans, characterising the area as a 'major carbonate factory'. Peritidal coastal environments such as the northern Spencer Gulf are flood-prone because of their broad and gently sloping coasts. However, mapping of the various biogeomorphic units, subtidal seagrass meadows, intertidal sandflats, mangroves and samphires, and supratidal zones provides an accurate, rapid and inexpensive approach for determining threats of marine inundation such as at False Bay, Port Pirie, Port Augusta and Blanche Harbor. ${ }^{67}$

\section{Notes}

1 Drexel, J.F. \& Preiss, W.V. (Eds) (1995). The geology of South Australia. Vol. 2, The Phanerozoic. South Australian Department of Mines and Energy Bulletin, 54, pp. 178-186.

2 Schluter, C., Bye, J.A.T. \& Harbison, P. (1995). The most vigorous SA tide. Transactions of the Royal Society of South Australia, 119, 123-132.

3 Kämpf, J., Payne, N. \& Malthouse, P. (2010). Marine Connectivity in a large inverse estuary. Journal of Coastal Research, 26 (6), 1047-1056; Nunes Vaz, R.A. (2014). Chapter 4, Physical characteristics of Spencer Gulf. In: Shepherd, S.A., Madigan, S.M., Gillanders, B.M., Murray-Jones, S. \& Wiltshire, D.J. (Eds), Natural history of Spencer Gulf, Royal Society of South Australia Inc., Adelaide, pp. 44-68.

$4 \quad$ Bye, J.A.T. \& Harbison, I.P. (1991). Transfer of inland salts to the marine environment at the head of Spencer Gulf, South Australia. Paleogeography, Paleoclimatology, Paleoecology, 84, 357-368; Kämpf, Payne \& Malthouse (2010).

5 Gostin, V.A., Belperio, A.P. \& Cann, J.H. (1988). The Holocene non-tropical coastal and shelf carbonate province of southern Australia. In: Nelson, C.S. (Ed.), Non-tropical shelf 
carbonates - Modern and ancient. Sedimentary Geology, 60, 51-70.

$6 \quad$ Drexel \& Preiss (1995); Gostin, V.A., Hails, J. R. \& Belperio, A.P. (1984). The sedimentary framework of northern Spencer Gulf, South Australia. In: Hails, J.R. \& Gostin, V.A. (Eds), The Spencer Gulf Region. Marine Geology, 61, 111-138; Gostin, Belperio \& Cann (1988).

7 Belperio, A.P., Hails, J.R., Gostin, V.A. \& Polach, H.A. (1984). The stratigraphy of coastal carbonate banks and Holocene sea levels of northern Spencer Gulf, South Australia. In: Hails, J.R. \& Gostin, V.A. (Eds), The Spencer Gulf Region. Marine Geology, 61, 297-313; Cann, J.H., Belperio, A.P. \& Murray-Wallace, C.V. (2000). Late Quaternary palaeosealevels and palaeoenvironments inferred from foraminifera, Northern Spencer Gulf, South Australia. Journal of Foraminiferal Research, 30 (1), 29-53.

8 Belperio, Hails, Gostin \& Polach (1984); Gostin, Belperio \& Cann (1988).

9 Belperio, Hails, Gostin \& Polach (1984); Cann, Belperio \& Murray-Wallace (2000); Drexel \& Preiss (1995).

10 Foden, J., Elburg, M., Dougherty-Page, J. \& Burtt, A. (2006). The timing and duration of the Delamerian Orogeny: Correlation with the Ross Orogen and implications for Gondwana assembly. Journal of Geology, 114, 189-210.

11 Thomson, B.P. (1969). Precambrian Basement Cover: The Adelaide System. In: Parkin, L.W. (Ed.), Handbook of South Australian geology. Geological survey of South Australia, Adelaide, pp. 49-83.

12 Gostin, Hails \& Belperio (1984); Thomson (1969).

13 Drexel, J.F., Preiss, W.V. \& Parker, A.J. (1993). The geology of South Australia. Vol. 1, The Precambrian. Geological Survey of South Australia, Bulletin 54, 242 pp.

14 Drexel, Preiss \& Parker (1993).

15 Drexel \& Preiss (1995).

16 Gostin, V.A. and Hill, S.M. (2014). Spencer Gulf: Geological setting and evolution, Chapter 2. In: Shepherd, S.A., Madigan, S.M., Gillanders, B.M., Murray-Jones, S. \& Wiltshire, D.J. (Eds), Natural history of Spencer Gulf, Royal Society of South Australia Inc., Adelaide, pp. 21-35.

17 Murray-Wallace, C.V., Kimber, R.W.L., Gostin, V.A. \& Belperio, A.P. (1988). Amino acid racemisation dating of the 'Older Pleistocene marine beds', Redcliff, northern Spencer Gulf, South Australia. Transactions of the Royal Society of South Australia, 112, 51-56.

18 Gostin \& Hill (2014).

19 Gostin \& Hill (2014).

20 Short, A.D. (2006). Beaches of the South Australian coast and Kangaroo Island: A guide to their nature, characteristics, surf and safety. Sydney University Press, Sydney, 346 pp.

21 Harvey, N. (1993). Sensitivity of South Australian environments to Marina Construction, Chapter 20. In: Thomas, D.S.G. \& Allison, R.J. (Eds), Landscape sensitivity. John Wiley and Sons, Chichester, pp. 327-342.

22 Dupavillon J.L. \& Gillanders, B.M. (2009). Impacts of seawater desalination on the giant cuttlefish Sepia apama in the upper Spencer Gulf, South Australia. Marine Environment Research, 67, 207-218.

23 Kämpf, J. (2014). South Australia's large inverse estuaries: On the road to ruin. In: Wolanski, E. (Ed.) Estuaries of Australia in 2050 and Beyond. Springer Ebook, Dordrecht, pp. 153-167. 
24 Kämpf (2014).

25 Hails, J.R. \& Gostin, V.A. (1978). Stranded beach ridges, Upper Spencer Gulf, South Australia: Evidence for high wave energy dissipation during the late Pleistocene. Transactions of the Royal Society of South Australia Inc., Vol. 102, pp. 169-173.

26 Hails \& Gostin (1978).

27 Short (2006).

28 Short (2006).

29 Gostin, Hails \& Belperio (1984).

30 Hails \& Gostin (1978).

31 Hails \& Gostin (1978).

32 Hails \& Gostin (1978); Gostin, Hails \& Belperio (1984).

33 Belperio, Hails, Gostin \& Polach (1984).

34 Hails \& Gostin (1978).

35 Hails \& Gostin (1978).

36 Belperio, Hails, Gostin \& Polach (1984).

37 Belperio, A.P., Harvey, N. \& Bourman, R.P (2002). Spatial and temporal variability in the Holocene sea-level record of the South Australian coastline. Sedimentary Geology, 152, 153-169.

38 Short (2006).

39 Cann, J.H., Belperio, A.P. \& Murray-Wallace, C.V. (2000). Late Quaternary palaeosealevels and palaeoenvironments inferred from foraminifera, Northern Spencer Gulf, South Australia. Journal of Foraminiferal Research, 30 (1), 29-53.

40 Short (2006).

41 Short (2006).

42 Caton, B., Detmar, S., Fotheringham, D., Haby, N., Royal, M. \& Sandercock, R. (2007). Conservation assessment of the Nothern and Yorke coast: Report. Coastal Protection Branch and Environmental Information Analysis Branch, Department for Environment and Heritage SA for the Northern and Yorke Natural Resource Management Board.

43 Gostin, Hails \& Belperio (1984).

44 Caton, Detmar, Fotheringham, Haby, Royal \& Sandercock (2007).

45 Caton, Detmar, Fotheringham, Haby, Royal \& Sandercock (2007).

46 Short (2006).

47 Burne, R.V. \& Colwell, J.B. (1982). Temperate carbonate sediments of Northern Spencer Gulf, South Australia: A high salinity 'foramol' province. Sedimentology, 29, 223-238.

48 Short (2006).

49 Gostin \& Hill (2014).

50 Caton, Detmar, Fotheringham, Haby, Royal \& Sandercock (2007).

51 Short (2006).

52 Williams, G.E. \& Goode, A.D.T. (1978). Possible western outlet for an ancient Murray River in South Australia. Search, 9 (12), 443-447. 
53 Gostin, V.A. \& Jenkins, R.J.F. (1980). Possible western outlet for an ancient Murray River in South Australia-an alternative viewpoint. Search 11 (7-8), 225-226; Harris, W.K., Lindsay, J.M. \& Twidale, C.R. (1980). Gostin, V.A. \& Jenkins, R.J.F. (1980). Possible western outlet for an ancient Murray River in South Australia - A discussion. Search, 11 (7-8), 226-227.

54 McLaren, S., Wallace, M.W., Gallagher, S.J., Miranda, J.A., Holdgate, G.R., Gow, L.J., Snowball, I. \& Sandgren, P. (2011). Palaeogeographic, climatic and tectonic change in southeastern Australia: The Late Neogene evolution of the Murray Basin. Quaternary Science Reviews, 30, 1086-1111.

55 Murray-Wallace, C.V. (1983). Quaternary sea-levels and coastal evolution, Broughton River 'Delta', Northern Spencer Gulf, South Australia. Unpublished BA Hons thesis, The University of Adelaide.

56 Murray-Wallace, C.V. (1984). Holocene coastal development - Broughton River Mouth Taminga, 21, 74-89.

57 Murray-Wallace (1984).

58 Barnett, E.J., Harvey, N., Belperio, A.P. \& Bourman, R.P. (1997). Sea-level indicators from a Holocene, tide-dominated coastal succession, Port Pirie, South Australia. Transactions Royal Society of South Australia, 121 (4), 125-135; Cann, J., Harvey, N., Barnett, E.J., Belperio, A.P. \& Bourman, R.P. (2002). Foraminiferal biofacies eco-succession and Holocene sea levels, Port Pirie, South Australia. Marine Micropaleontology, 44, 31-55; Harvey, N. (2006). Holocene coastal evolution: Barriers, beach ridges, and tidal flats of South Australia. Journal of Coastal Research, 22 (1), 90-99.

59 Murray-Wallace (1984).

60 Short (2006).

61 Short (2006).

62 Short (2006).

63 Short (2006).

${ }^{64}$ Ferguson, J., Burne, R.V. \& Chambers, L.A. (1984). Iron mineralisation of peritidal carbonate sediments by continental groundwaters, Fisherman Bay, South Australia. Sedimentary Geology, 34, 41-57.

65 Bourman, R.P. (1989). Investigations of ferricretes and weathered zones in parts of southern and southeastern Australia - a reassessment of the 'laterite' concept. Unpublished PhD. The University of Adelaide, 495 pp.

66 Parker A.J. \& Fanning, C.M. (1998). Explanatory Notes of the WHYALLA 1:250 000 Geological Series Sheet S153-8. Edited by J.F. Drexel. Geological Survey of South Australia. Primary Industries and Resources South Australia, 52 pp.

67 Harvey, N., Belperio, A.P., Bourman, R.P. \& Bryan, B. (1999). Regional coastal vulnerability assessment using Holocene geological mapping of the northern Spencer Gulf, South Australia. Asia Pacific Journal on Environment and Development, 6 (2), 1-25. 



\section{The Gulf Coast of Eyre Peninsula}

\subsection{Introduction}

This chapter describes the coastline between Port Lincoln and Whyalla, the southern section of the Gulf Coast of Eyre Peninsula; the coast between Whyalla and Port Augusta is included in Chapter Eight on the northern Spencer Gulf shoreline. The eastern, sheltered Gulf Coast of Eyre Peninsula has a subdued morphological character in comparison with the exposed rugged, open ocean Bight Coast due to restrictions on oceanic swell, a much calmer wind and wave regime, and greater tidal influences. This has resulted in less development of modern sand dunes and aeolianite (lithified sand dunes), which on the Bight Coast are widespread and have been eroded into spectacular high cliffs. Ancient coarse crystalline rocks of the Gawler Craton, which underlie Eyre Peninsula and most of the Gulf Coast, have been essentially stable for millions of years. ${ }^{1}$ Tectonic deformation has been restricted to widespread uplift of the peninsula as a single unit, with more localised downfaulting near its eastern margin.

The shape and origin of Spencer Gulf is associated with many long-lived basement faults (Figure 9.1). The orientation of the coast southwest to northeast from Port Lincoln to Port Augusta is broadly related to tilted blocks and associated observed and inferred faults expressed in low escarpments. These are up to $70 \mathrm{~km}$ long with displacements of 100 to $150 \mathrm{~m}$, separating uplands from coastal plains. Faulting has uplifted parts of the peninsula, such as the Lincoln and Cleve Uplands and the Blue Range, which merge with the eastern coastal plain that provides the backdrop to the coastline. ${ }^{2}$ In some locations, such as the shores of Boston Bay, the shoreline closely follows the Lincoln Fault. The faults are oriented to the northeast or to the east, and 


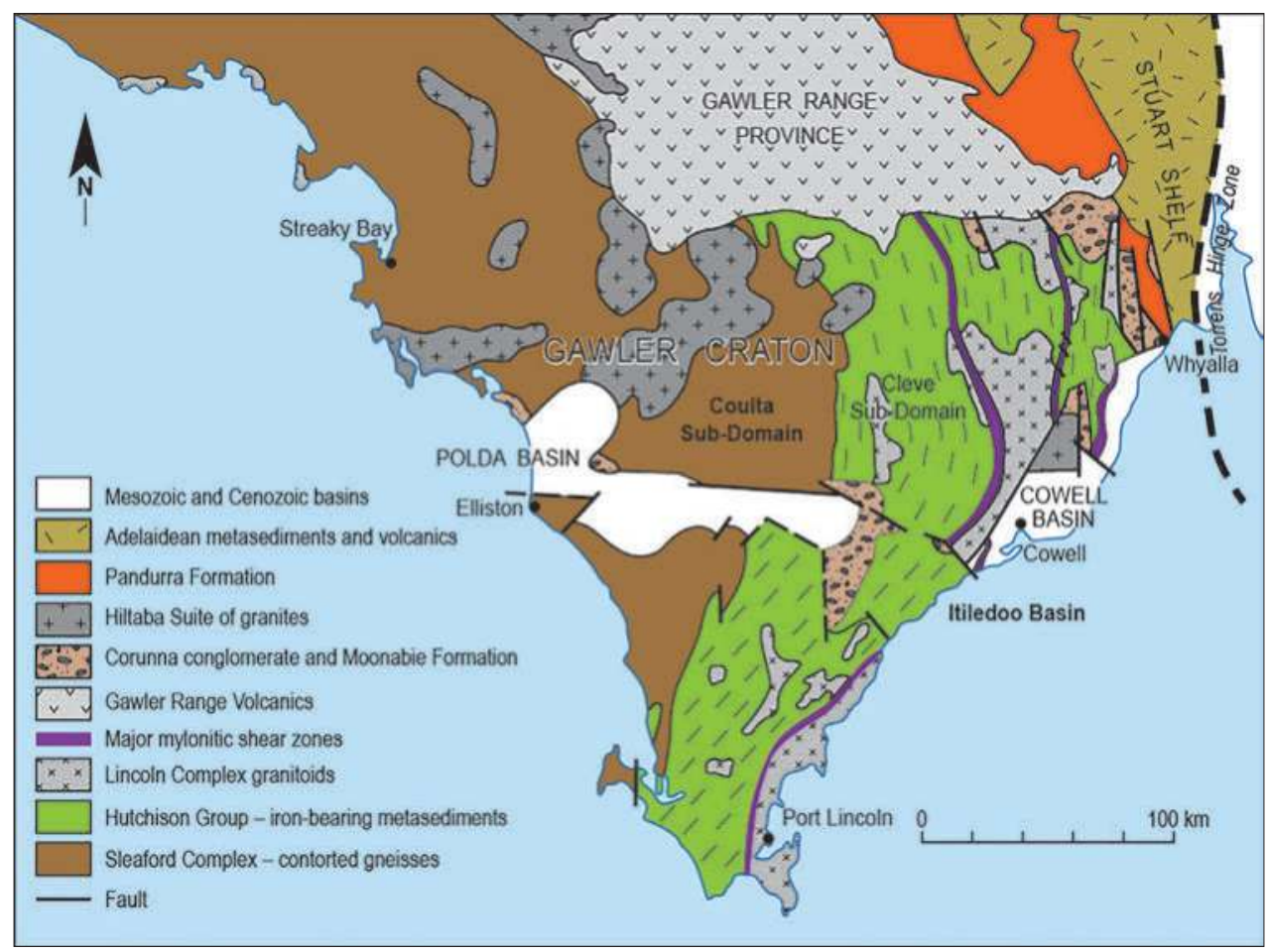

Figure 9.1 Tectonic and structural map of Eyre Peninsula.

Source: Natural History of Eyre Peninsula. Royal Society of South Australia.

ancient structural features influence some of them. Faulting is continuing, as revealed by offset of the Late Pleistocene Pooraka Formation; there is also ongoing seismic activity. In places, faults are coincident with the coastline, whereas in others there is only an indirect influence, as the shoreline position is determined by the location of alluvial sediments derived from the fault-bounded uplands.

Most of the coastal plain comprises alluvial deposits overlying resistant Proterozoic rocks, which also produce rocky headlands and help to explain the more detailed character of the coastline (Figure 9.1). Weathering of the resistant rocks has added diversity to the coastline. Occasionally, high cliffs occur, but more commonly the gentle topography gives rise to low, rounded outcrops, sometimes fronted by rocky shore platforms. Between the headlands, coastal erosion and sea level rise has developed a crenulated coast with sequences of broad open sandy bays backed by dune systems. Coastal samphire marshes fronted by mangroves and extensive sandflats occur on shores such as those of Franklin Harbor. Elsewhere, disconnected saline lagoons 


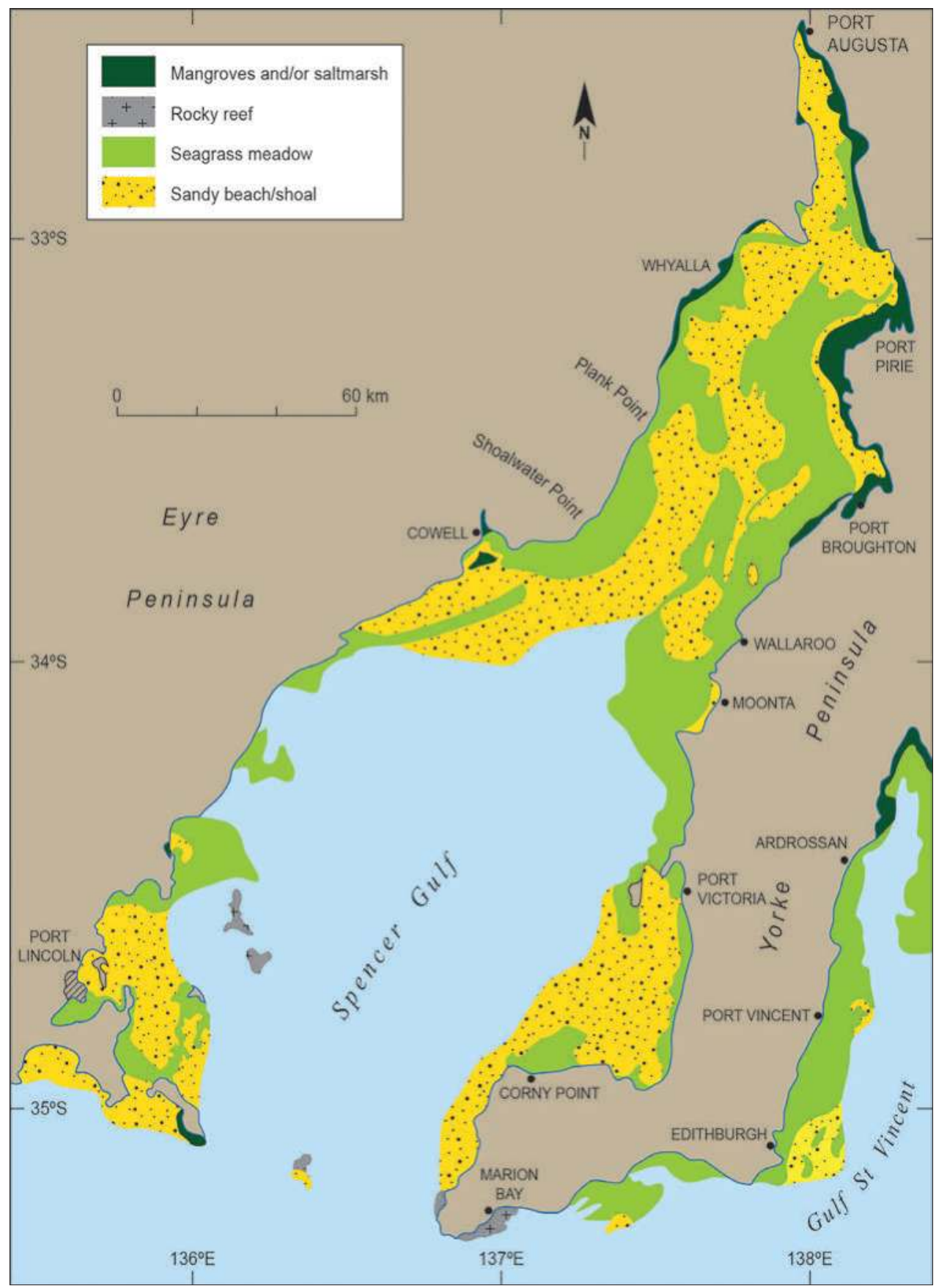

Figure 9.2 Dominant coastal environments of Spencer Gulf: rocky reefs, sandflats, seagrass meadows and mangroves.

Source: Modified and reproduced with the permission of Primary Industries and Regions South Australia. $<w w w$.pir.sa.gov.aus. 
and samphire swamps are isolated from the sea by dune barriers. The major coastal environments are shown in Figure 9.2.

Spencer Gulf has been inundated by the sea and drained many times over the past $3 \mathrm{Ma}$, as global ice caps have waxed and waned. During the Last Interglacial $(125 \mathrm{ka})$, sea level stood at least $2 \mathrm{~m}$ higher than at present. Following that event, sea level fell progressively as the ice caps grew. At $100 \mathrm{ka}$, sea level had fallen by $8 \mathrm{~m}$; it fell another $14 \mathrm{~m}$ by $80 \mathrm{ka}$, and between 40 to $30 \mathrm{ka}$ ago it had fallen to at least 22 to $30 \mathrm{~m}$ below present sea level (BPSL). During the Last Glacial Maximum about 21 ka ago, global sea level reached a maximum low of $125 \mathrm{~m}$ BPSL, when the whole of the gulf was exposed as land, and was occupied by non-perennial streams and longitudinal desert dunes. Sea level rose rapidly from about $17 \mathrm{ka}$, reaching to near its present level $7 \mathrm{ka}$ ago.

\subsection{Jussieu Peninsula}

Jussieu Peninsula (Figure 9.3) contains Lincoln National Park, Memory Cove Wilderness Protection Area and Sleaford Mere Conservation Park. It is the eastern fluke of the 'anchor' forming the southern tip of Eyre Peninsula. The densely vegetated peninsula, with an area of about $270 \mathrm{~km}^{2}$ and with high points exceeding $200 \mathrm{~m}$, has a foundation of ancient resistant granitic bedrock, much of which is calcrete-covered and mantled by many generations of dunes. Once an archipelago of islands, the peninsula formed as the islands and the mainland were linked together by Pleistocene sand dunes, later lithified (turned into rock) and consolidated by calcrete. A narrow neck of land, $2 \mathrm{~km}$ wide, separates the head of Proper Bay and Sleaford Mere, which is dammed back by active sand dunes. Last interglacial shells set in calcrete at the head of Proper Bay and at Stamford Beach are $2 \mathrm{~m}$ APSL, suggesting that at this time, $125 \mathrm{ka}$ ago, a seaway separated the peninsula and the mainland.

Jussieu Peninsula includes the most southerly part of mainland Eyre Peninsula and occupies the transitional area between the Bight and Gulf Coasts, and consequently exhibits marked variations in coastal environments. The peninsula begins at Fishery Bay with headlands and cliffs of calcreted aeolianite buttressed by Paleoproterozoic bedrock. The youngest Oligocene limestone, $25 \mathrm{Ma}$ old, possibly an equivalent of the Abrakurrie Limestone ${ }^{3}$, which occurs in the Nullarbor cliffs, occurs in the cliffs at Fishery Bay as well as nearby at Cape Wiles and Thistle Island. A younger, unnamed, possibly Late Pliocene thin limestone remnant also occurs at Fishery Bay. An inactive, fossil sea cliff at the back of Fishery Bay (Figure 9.4) probably developed during a former higher sea level, but it is currently being buried by white sand drifting from the beach. A small pebble beach occurs on the eastern side of the bay. West of Fishery Bay 


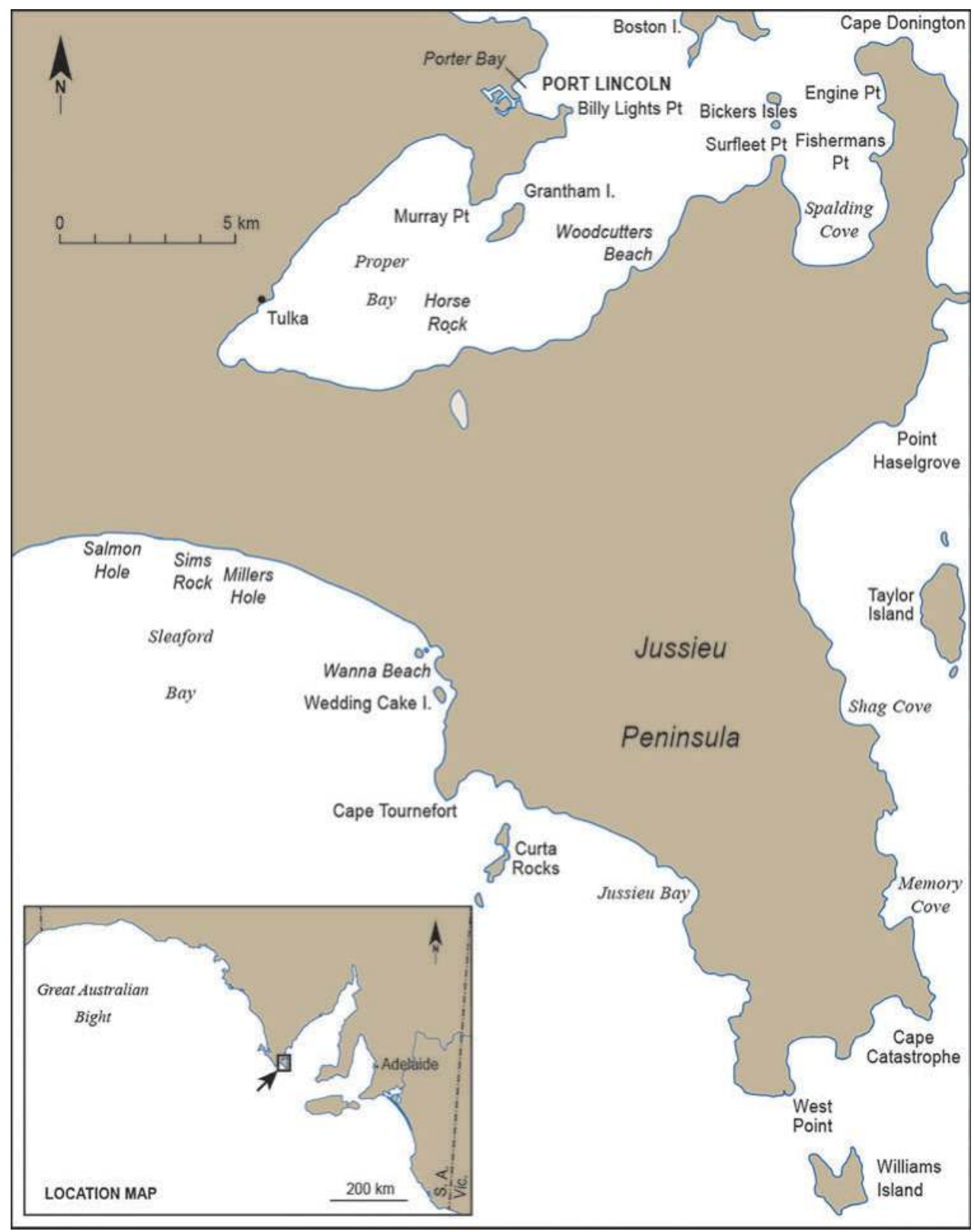

Figure 9.3 Jussieu Peninsula, showing the locations of sites mentioned in the text. Source: Author's own work, RPB. 


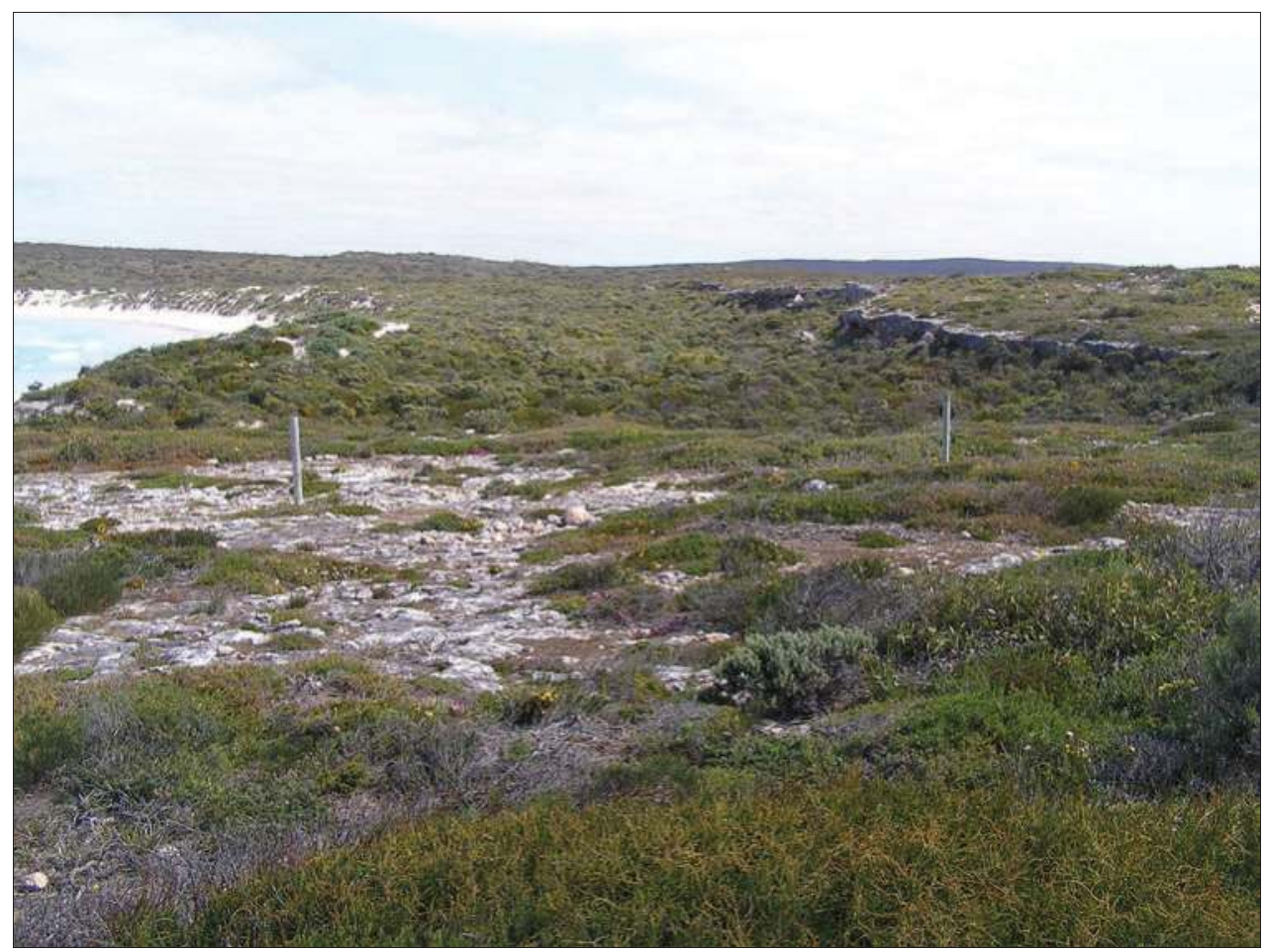

Figure 9.4 Fossil sea cliff at the back of Fishery Bay. The cliff, which was probably eroded in the Last Interglacial, is now protected from wave attack by accumulated dune sand. Source: Author's own work, RPB.

near Lone Pine, the basement rocks have been variably weathered and ferruginised, producing strongly coloured cliffs with surface accumulations of ironstone gravels. ${ }^{4}$

A rocky cliffed shoreline interspersed with large fields of active calcareous dunes up to $200 \mathrm{~m}$ high has formed over $45 \mathrm{~km}$ between Sleaford Mere and Cape Catastrophe. This southwesterly facing coastline is exposed to high-energy swell, winddriven waves and strong winds that have produced transgressive fields of parabolic dunes inland from Sleaford Bay $\left(25 \mathrm{~km}^{2}\right)$ and between Cape Tournefort and Jussieu Bay $\left(18 \mathrm{~km}^{2}\right)$ (Figure 9.5). Modern dunes have migrated some $2 \mathrm{~km}$ landward, but older dunes now fixed with calcrete or vegetation reach more than $5 \mathrm{~km}$ inland. Highenergy waves at Wanna on the eastern end of Sleaford Bay have eroded sea cliffs up to $50 \mathrm{~m}$ high and have exposed the bedrock/aeolianite unconformity, thus forming shore platforms (Figure 9.6). 
The east-facing shoreline between Cape Catastrophe and Cape Donington is less exposed. Ancient crystalline Lincoln Complex rocks ${ }^{6}$ produce a bedrock-dominated cliffed coast with numerous small coves, some with beaches and backing dunes, as at Memory Cove, Taylors Landing and MacLaren Point. In strong contrast, the northern shoreline from Cape Donington to Tulka West is well protected; cliffs are lower, and sandflats, seagrasses and beaches, such as at Spalding Cove, are more common. With less erosion on the northern shore, there is more preservation of weathered bedrock and Pleistocene sediments capped by calcrete. Spectacular views of the coast are available from the summit of Stamford Hill $(145 \mathrm{~m})$ on the north coast of the peninsula.

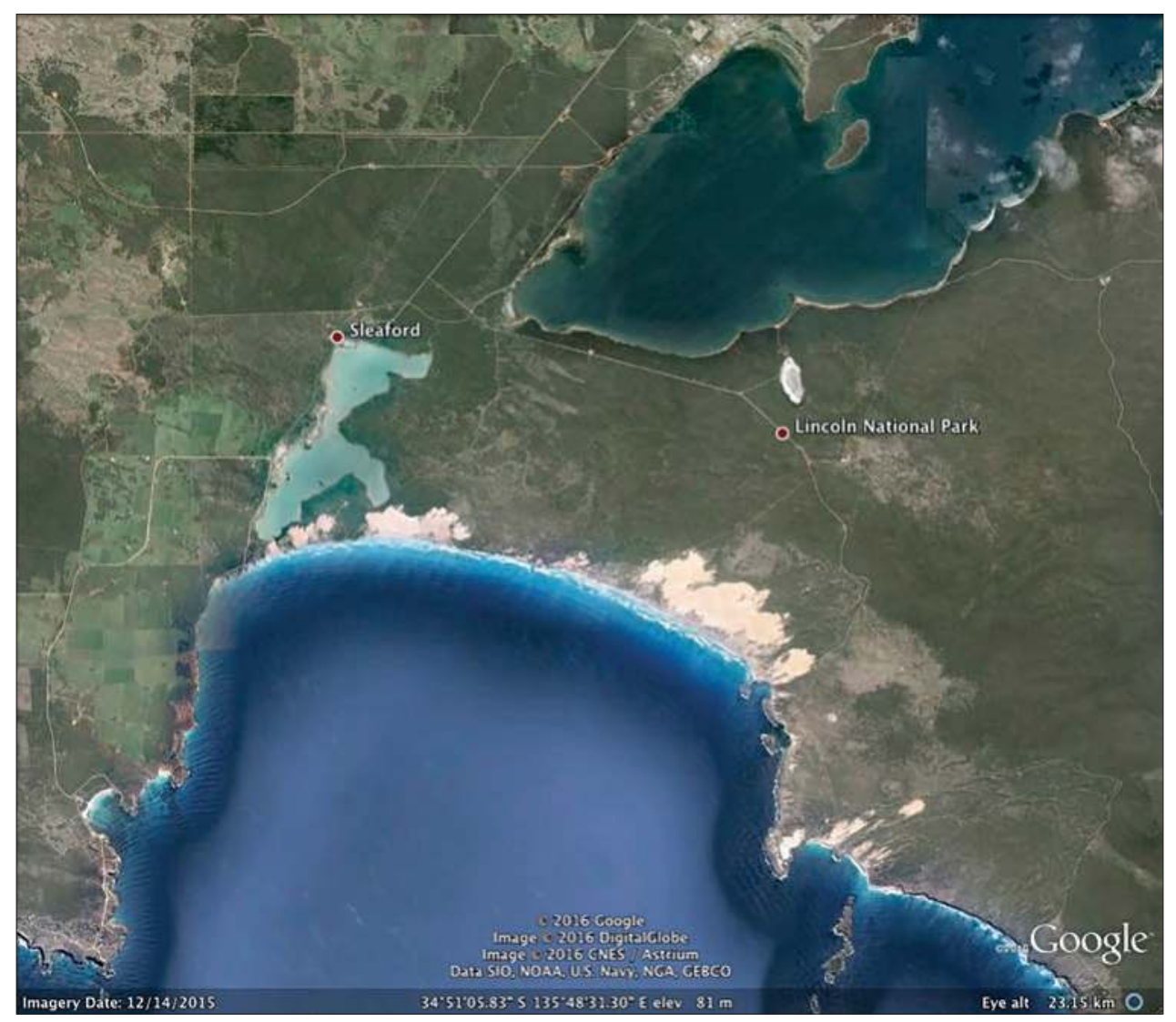

Figure 9.5 The neck of Jussieu Peninsula. Note Sleaford Mere, which has stromatolites on its shore ${ }^{5}$, the active and vegetated dunes derived from the shores of Sleaford Bay, the eroded cliff line with islands and stacks on the far right of the bay, and Pillie Lake near the northern shore above Lincoln National Park.

Source: Google Earth image ( 2013 Google. 


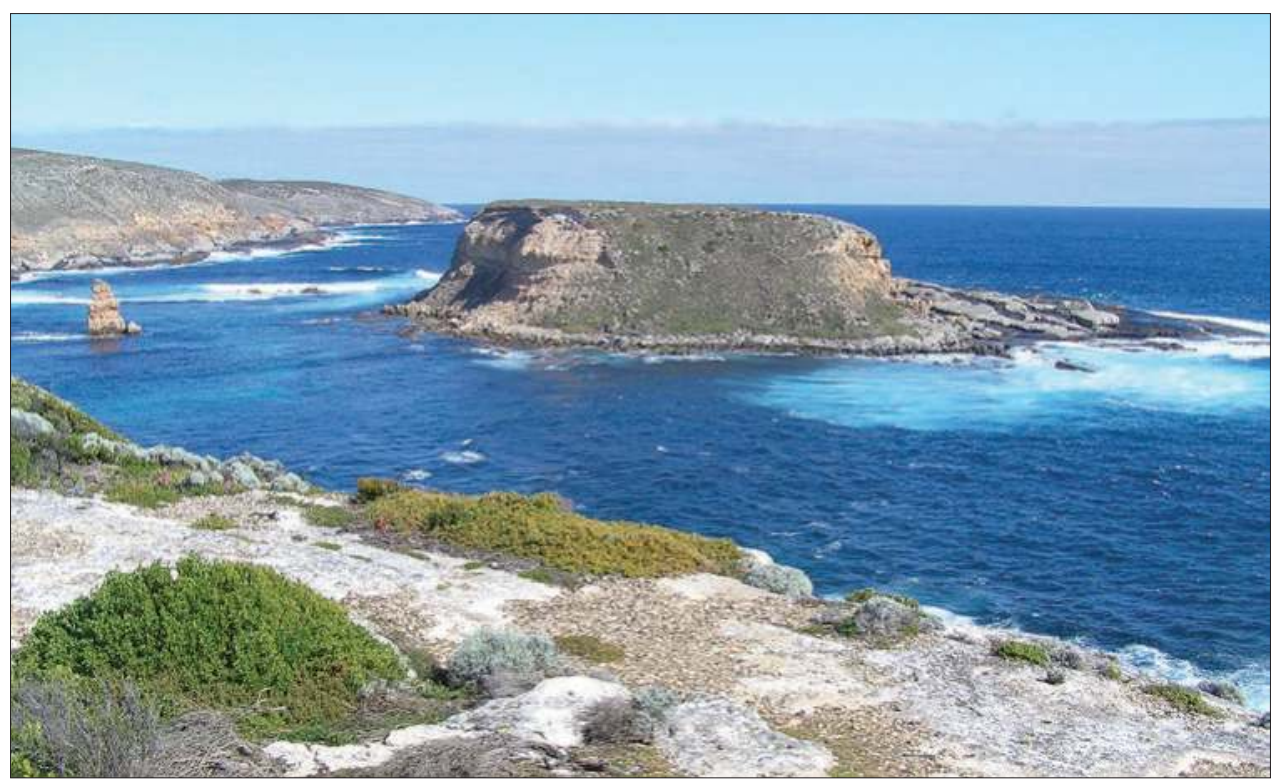

Figure 9.6 Wedding Cake Island at Wanna eroded from aeolianite at the far eastern end of Sleaford Bay. Note the underlying bedrock platform being exhumed on the right-hand side of the island.

Source: Author's own work, RPB.

\subsubsection{Pillie Lake}

Pillie Lake (Figure 9.7) is an ephemeral, carbonate lake on Jussieu Peninsula located in a Pleistocene interdune depression 1 to $2 \mathrm{~m}$ APSL. Microfossils reveal that dolomite formed in the lake, both under permanent and ephemeral water conditions, and that there was a general decrease in water salinity, probably related to a fall of sea level over the past 6000 years. Footprints of humans, birds and other animals are preserved in the surface encrustations of the lake deposits. ${ }^{7}$

\subsection{Proper Bay}

The northwestern shore of Proper Bay, which is backed by rounded hills and low rocky bluffs, is remarkably linear and may relate to a geological structure. At Tulka West, calcreted outcrops of the last interglacial Glanville Formation make up the shoreline and suggest a former link through this point to the open ocean (Figure 9.8). Further along the coast, at Tulka, a small delta of sands, rocks and boulders has formed at the coast by Duck Ponds Creek. Low cliffs comprise weathered, red breccia (angular 


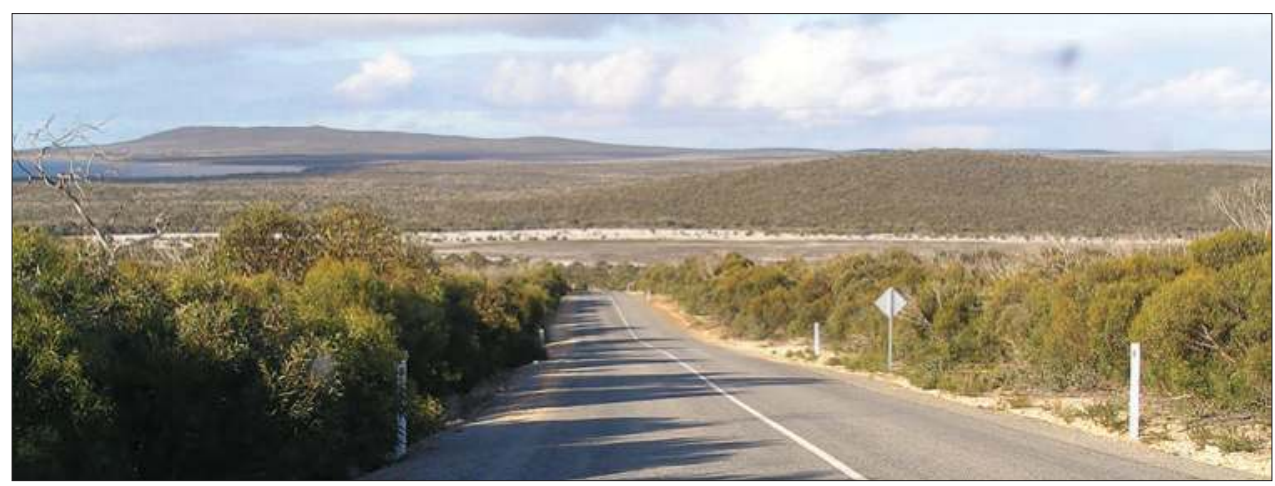

Figure 9.7 Pillie Lake in the foreground with Mount Stamford in the background. Source: Author's own work, RPB.

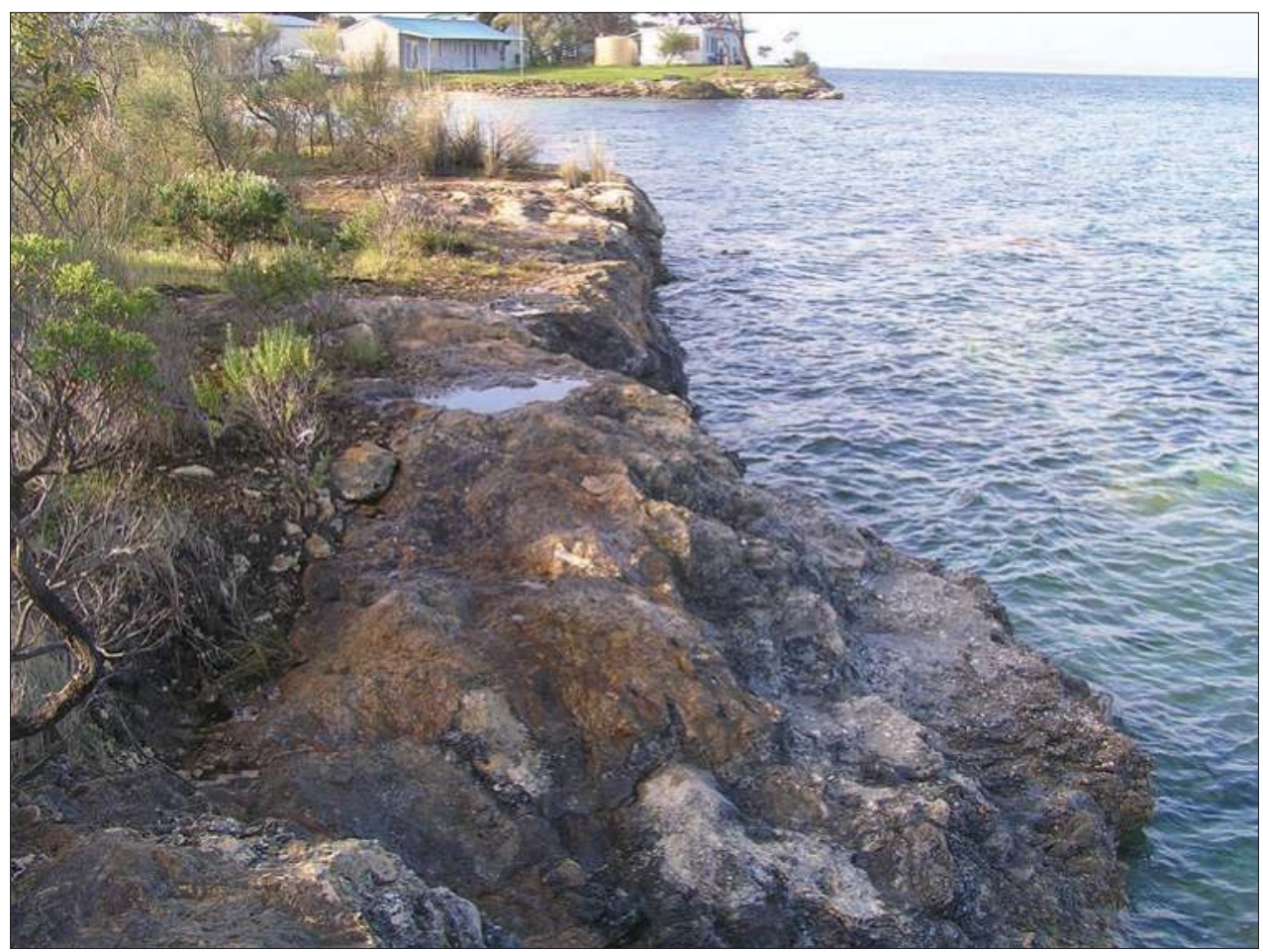

Figure 9.8 Calcreted last interglacial shells, $125 \mathrm{ka}$ old, of the Glanville Formation at Tulka 2 m APSL, at the head of Proper Bay, which probably linked with Sleaford Mere at this time.

Source: Author's own work, RPB. 


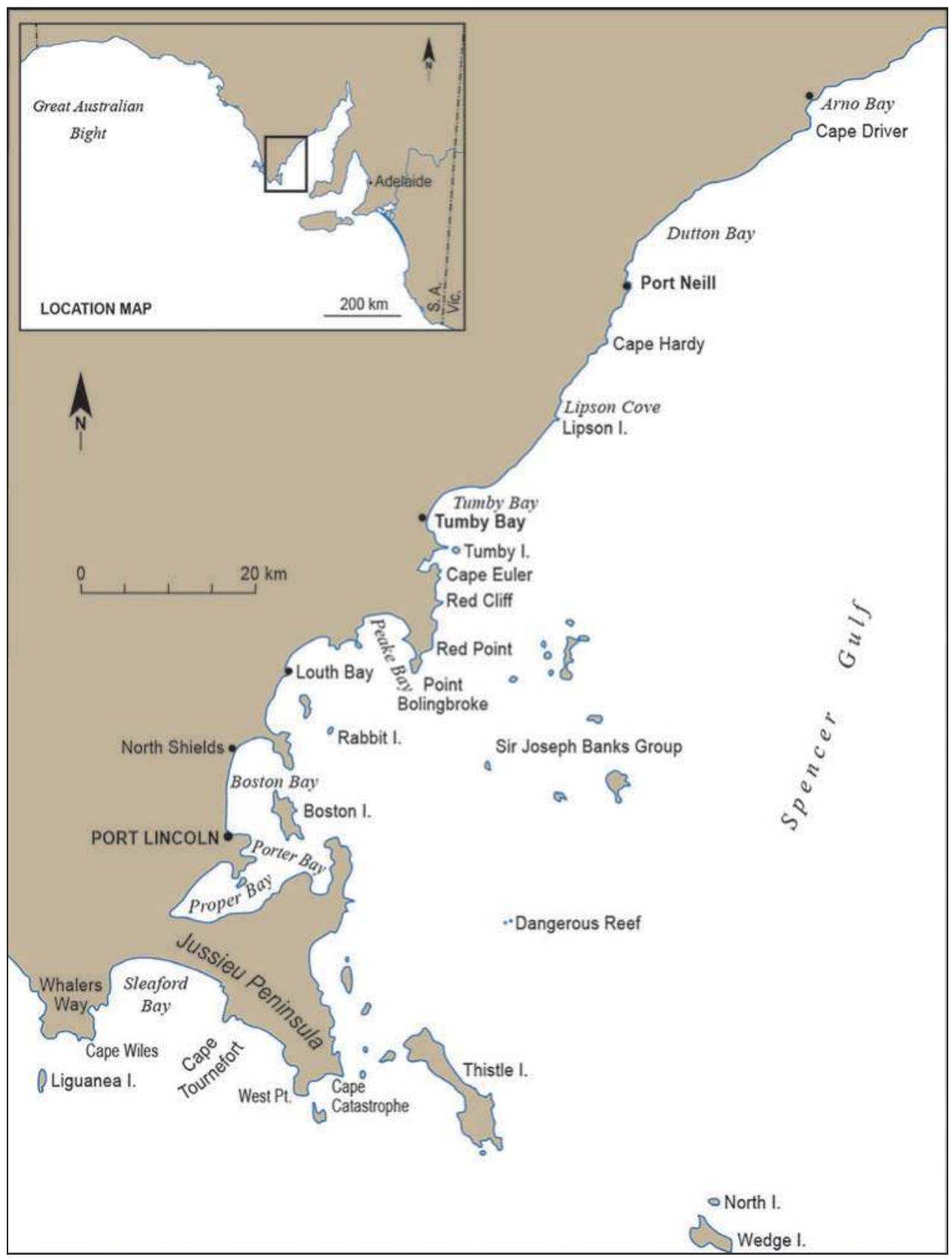

Figure 9.9 Lower eastern Eyre Peninsula coastline, showing localities referred to in the text. Source: Author's own work, RPB. 
boulders cemented together), probably delivered by the same creek in the past. A bench $2 \mathrm{~m}$ APSL has formed on the breccia, and this is overlain by $2 \mathrm{~m}$ of beach sand and calcrete rubble containing calcified tree roots and trunks.

At the northern head of Proper Bay, a large south-facing bay is formed by calcretecovered, weathered bedrock outcrops at Murray Point (Figure 9.3). The headland from Murray Point to Billy Lights Point and the shores of Porter Bay are up to $20 \mathrm{~m}$ APSL and are underlain by weathered, ferruginised bedrock mantled by calcrete. This headland may have been an island 6000 years ago, when sea level was probably $1 \mathrm{~m}$ higher than present, linking the tidal flats of the Lincoln Cove Marina on Porter Bay with the low-lying racetrack area of Proper Bay; here extensive deposits of Holocene shells have infilled the former waterway.

Rounded cliffs in weathered Proterozoic bedrock with corestones and iron-rich weathering products form the northern shoreline of Proper Bay. Irregular weathering of the bedrock produces an undulating surface that is capped in places by dune sand and calcrete. At Billy Lights Point, a shore platform has developed in gneiss, a coarsely crystalline, banded metamorphic rock. The overlying, more weathered rock has been removed by coastal erosion, producing shore platforms of the Old Hat variety. This formation occurs where the contact between weathered and unweathered rock occurs in the intertidal zone and the 'brim' forms a shore platform on unweathered rock, while the 'crown' consists of weathered rock in the eroding backing cliff. Around Kirton Point, headlands, sandy bays and shore platforms are developed on Proterozoic basement rocks as at Shelly Beach and Snapper Point.

\subsection{Boston Bay}

The Port Lincoln shoreline (Figure 9.9) is structurally controlled with outcrops of basement bedrock providing the template for the bays and islands; there is a strong north-south orientation of the bedrock-based Boston Island, Point Boston Peninsula and Louth Island. On this framework, sandy bays, beaches, dune fields, sand spits and back-barrier lagoons have developed.

North of Port Lincoln, the western coastline of Spencer Gulf closely follows the Lincoln Fault ${ }^{8}$, producing steep slopes up to $100 \mathrm{~m}$ high. These sediments are inherently unstable when oversteepened, and engineering works have been required to stabilise road cuts. At the foot of the steep escarpment, angular and rounded pebbles, cobbles and boulders have accumulated by gravity as colluvium. These Pleistocene, coarse-grained sediments have been variably weathered, contain iron-rich mottles and gravels, and are undergoing erosion by the sea, forming cliffs up to $30 \mathrm{~m}$ high. Extensive shore platforms have developed in these materials; near Tiatukia Township, the shore platform extends for more than $50 \mathrm{~m}$ offshore. 


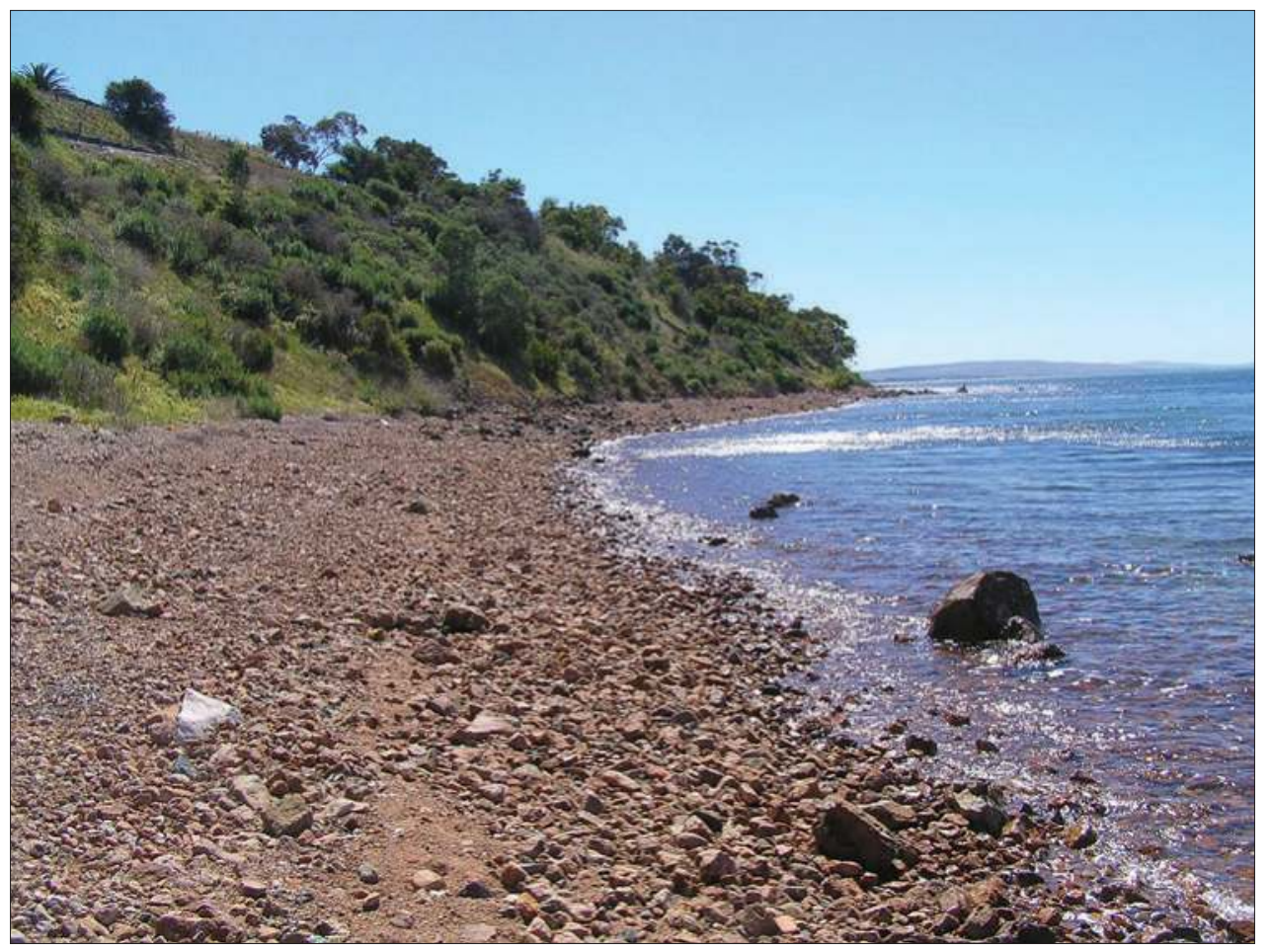

Figure 9.10 Cobble and shingle beach north of Port Lincoln backed by coarse, bouldery alluvial and colluvial sediments derived from the backing escarpment by undercutting and collapse.

Source: Author's own work, RPB.

As the coast is eroded, the sediments become unstable and collapse onto the shore; fine sediment is selectively removed and washed offshore, while the coarse boulders and cobbles remain as steep shingle beaches (Figure 9.10). Where streams flow to the coast, such as at the Lions Picnic Reserve near the Boston Township, valleys have been carved out, cliffs are lower, and terraces have developed on river alluvium. The lower river terraces are sometimes associated with stranded cobble beaches and shells. At these stream localities, the cobbles on the beach are varied and rounded, as they have been transported considerable distances by streams, which have constructed small protruding deltas at their outlets. At Stinky Creek, for example, there is a delta of large boulders and sand where the creek enters the sea. As the coast diverts from the alignment of the fault escarpment, the sea cliffs decrease in height to less than $10 \mathrm{~m}$, but they are still underlain by Middle Pleistocene gravels and cobbles. 
At North Shields, the coastline makes a large sweeping curve to the east, linking up with the hard rocks of Point Boston Peninsula. The North Shields coast consists of actively eroding alluvial deposits of Middle and Late Pleistocene ages (1.3 Ma to $125 \mathrm{ka}$ in age), forming cliffs up to $5 \mathrm{~m}$ high. This section of coast is exposed to swell waves approaching between Boston Island and Point Boston, perhaps explaining the erosion here, which has required the installation of rock walls. Longshore drift is from North Shields towards Point Boston, transporting beach sediments from this locality to the east, where the beach increases in width and ridged sandflats become extensive. Backbarrier lagoons and beach/shell ridges also back the beach.

Fluvial and coastal processes have collectively formed the isthmus, which links Point Boston Peninsula to the mainland. The Tod River and Meadows Creek have constructed an extensive Late Pleistocene alluvial flat, which grades to a sea level slightly higher than at present. The streams have abandoned their former flood plains, developing river terraces as they have cut back down through their own deposits. A small delta has formed at the mouth of the Tod River and mangroves are colonising the estuary. Longshore transport of sediment has added further sediments from the mainland to the isthmus, as have dune sands blown from the beaches. Extensive Holocene shell ridges up to $3 \mathrm{~m}$ APSL have also contributed to the infill, separating low-lying lagoons from the sea.

\subsection{Louth Bay}

Louth Bay extends for $25 \mathrm{~km}$ from Point Boston Peninsula to Peake Point (Figure 9.9). Low rocky headlands of gneiss and granite are interspersed with sandy bays, low dunes and back-barrier swamps. Deeply weathered bedrock is exposed in the cliffs, with ironrich gravels at the surface occurring both on the mainland and on Louth Island. The deeply weathered material is being stripped to form headlands and shore platforms of the Old Hat type. There are also alluvial fans sweeping down to the coast from the faulted uplands. Louth Bay Township is sited on the prominent headland of Point Warna, which divides the bay into two main sections. In the northern section of Louth Bay, a series of smaller bays with white sandy beaches is separated by headlands of gneiss exposed from beneath deeply weathered bedrock. The bay is low-lying (less than $4 \mathrm{~m}$ ) between the bedrock headlands, which are up to $10 \mathrm{~m}$ high. Dunes and shell ridges dam back lagoons and swamps.

In the far north of the bay, there are two shore platforms developed on very resistant gneiss with a spectacular array of weathering pits, pans and armchair-shaped hollows (Figure 9.11). These gnammas are only developed in the area affected by waves and tides, and they may be on the summits of buried domed inselbergs. The term 'gnamma' has an Aboriginal derivation, referring to depressions in solid rock, which 


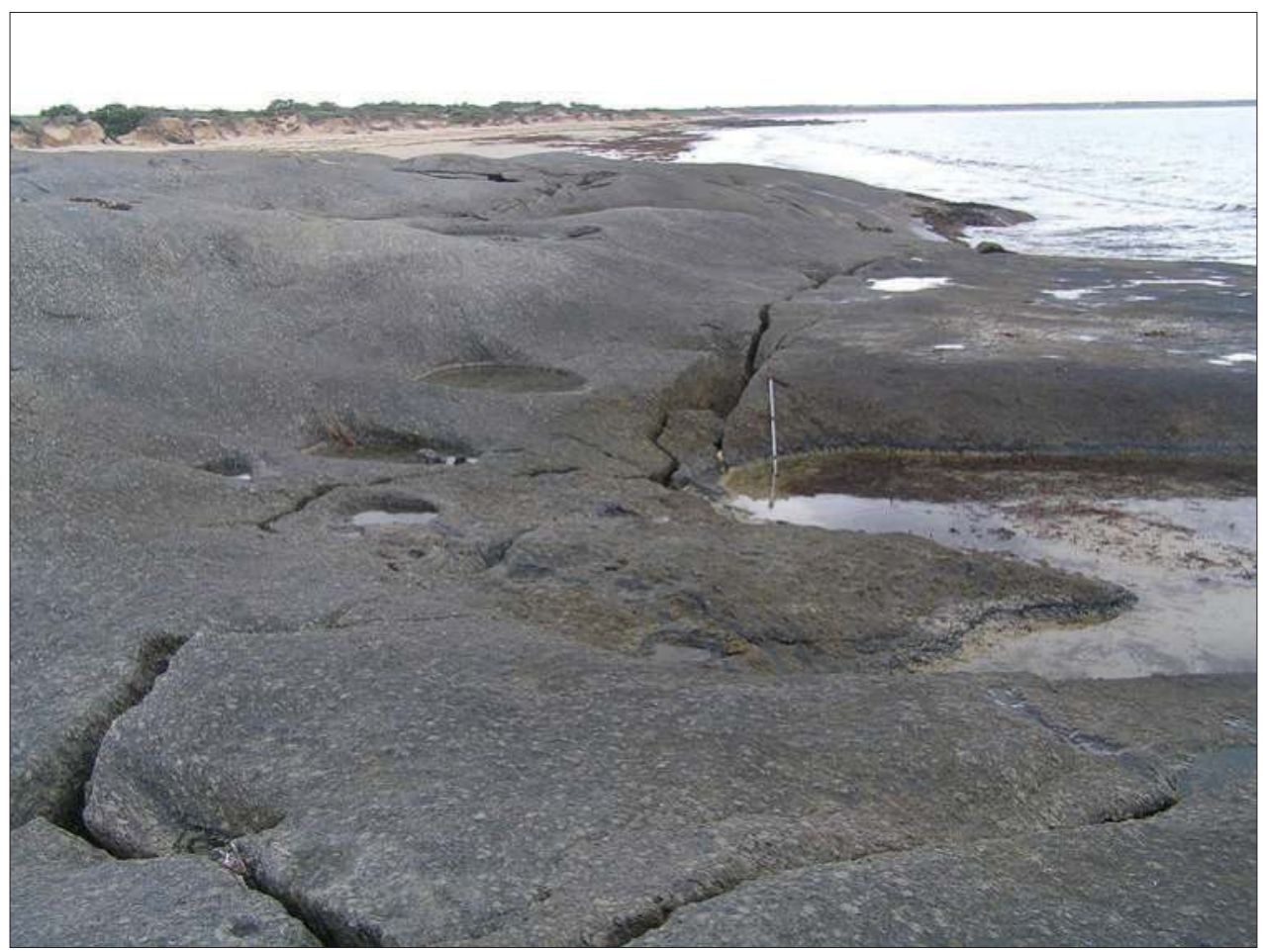

Figure 9.11 Gnammas (weathering pits) in granitic bedrock at Louth Bay. A similar outcrop occurs further along the shore. The fractures through the rock may be related to earthquake activity. A hiking stick provides a scale.

Source: Author's own work, RPB.

commonly hold water. ${ }^{9}$ Nearby, there is a fossil sea cliff, abandoned by the sea and now fronted by an accumulation of dune sand.

\subsection{Peake Bay}

Peake Bay is a large, sheltered south-facing sandy bay between headlands at Peake Point $(10 \mathrm{~m})$ and Bolingbroke Point $(20 \mathrm{~m})$. The Bolingbroke Peninsula is covered with vegetated longitudinal dunes, related to the more arid and windier conditions of the Last Glacial Maximum, $21 \mathrm{ka}$ ago. At the shoreline, weathered bedrock and Pleistocene alluvial sediments form shore platforms and cliffs up to $7 \mathrm{~m}$ high, capped by calcrete and cliff-top dunes in places. Shells of possible last interglacial age occur on the western side of the peninsula at about $1 \mathrm{~m} \mathrm{APSL}$.

The east-facing shoreline of Bolingbroke Peninsula to Cape Euler contains a variety of bays, such as Massena Bay, between headlands of weathered bedrock and 
Pleistocene alluvial gravels (Figure 9.12). Eroding cliffs are up to $11 \mathrm{~m}$ high, but most of the coast is more subdued. Shore platforms have been cut into bedrock, and sandy bays are backed by dunes and fronted by seagrasses.

\subsection{Tumby Bay}

Tumby Bay occupies an arc-shaped coastal plain extending $30 \mathrm{~km}$ north-south and up to $15 \mathrm{~km}$ inland to the backing Lincoln Uplands. Numerous streams from the uplands, such as Mine Creek and Salt Creek, have built up extensive alluvial plains of Pleistocene sediments. The general form of the coastline reflects a gently undulating weathered land surface intersected by a rising sea level. This gave rise to headlands on weathered Proterozoic bedrock protected by underlying fresh bedrock, forming shore platforms on the higher parts of the landscape. Sandy, dune-backed bays occupy the lower parts of the original landscape.

The coastline protrudes seawards opposite Tumby Island (Figure 9.13). Between the mainland and the island are shallow, subtidal sandflats that may one day permanently join the mainland and the island together; the two are presently connected at low tides. Both the island and the headland are underlain by resistant

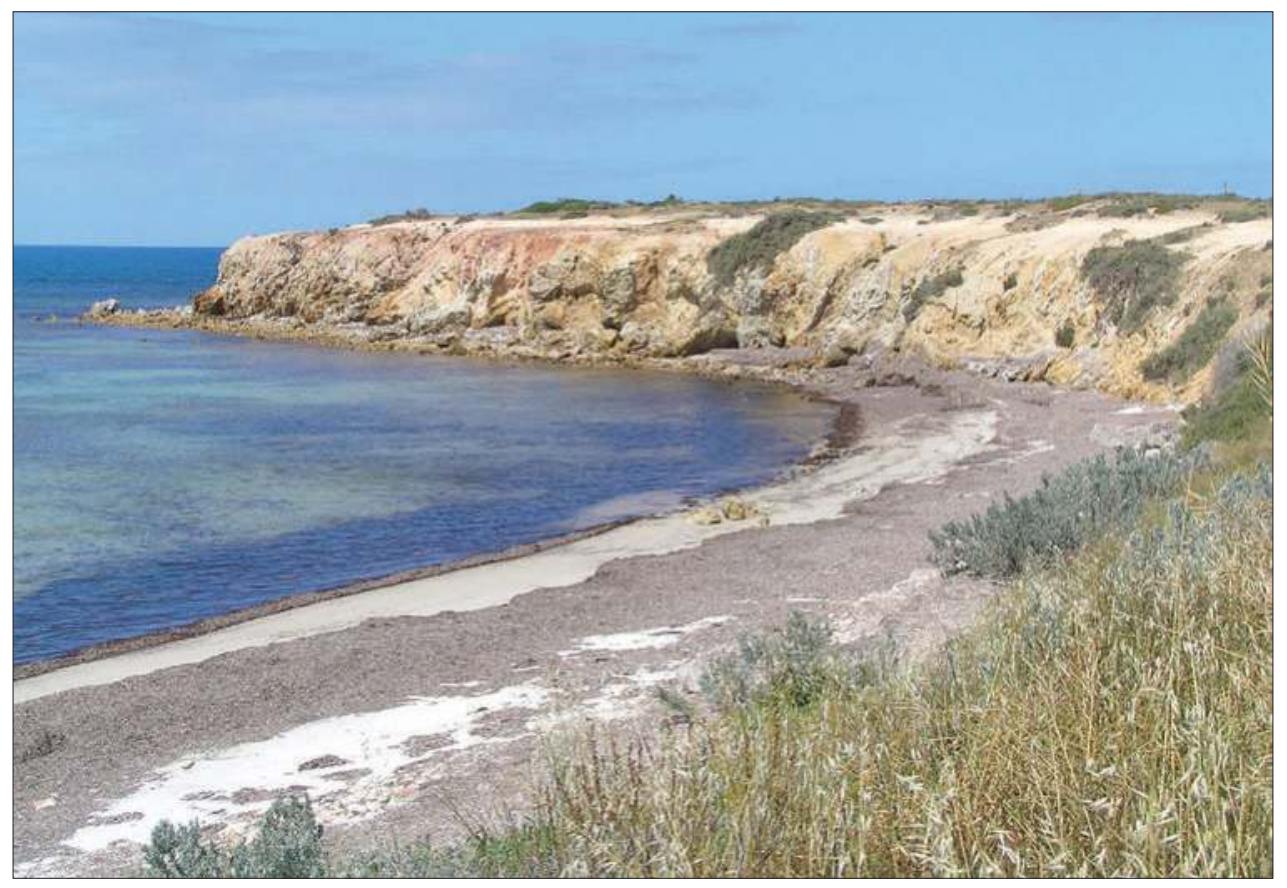

Figure 9.12 Eroding weathered cliffs on Bolingbroke Peninsula. The bladed leaf Posidonia australis seagrass is in the foreground, backing the beach.

Source: Author's own work, RPB. 


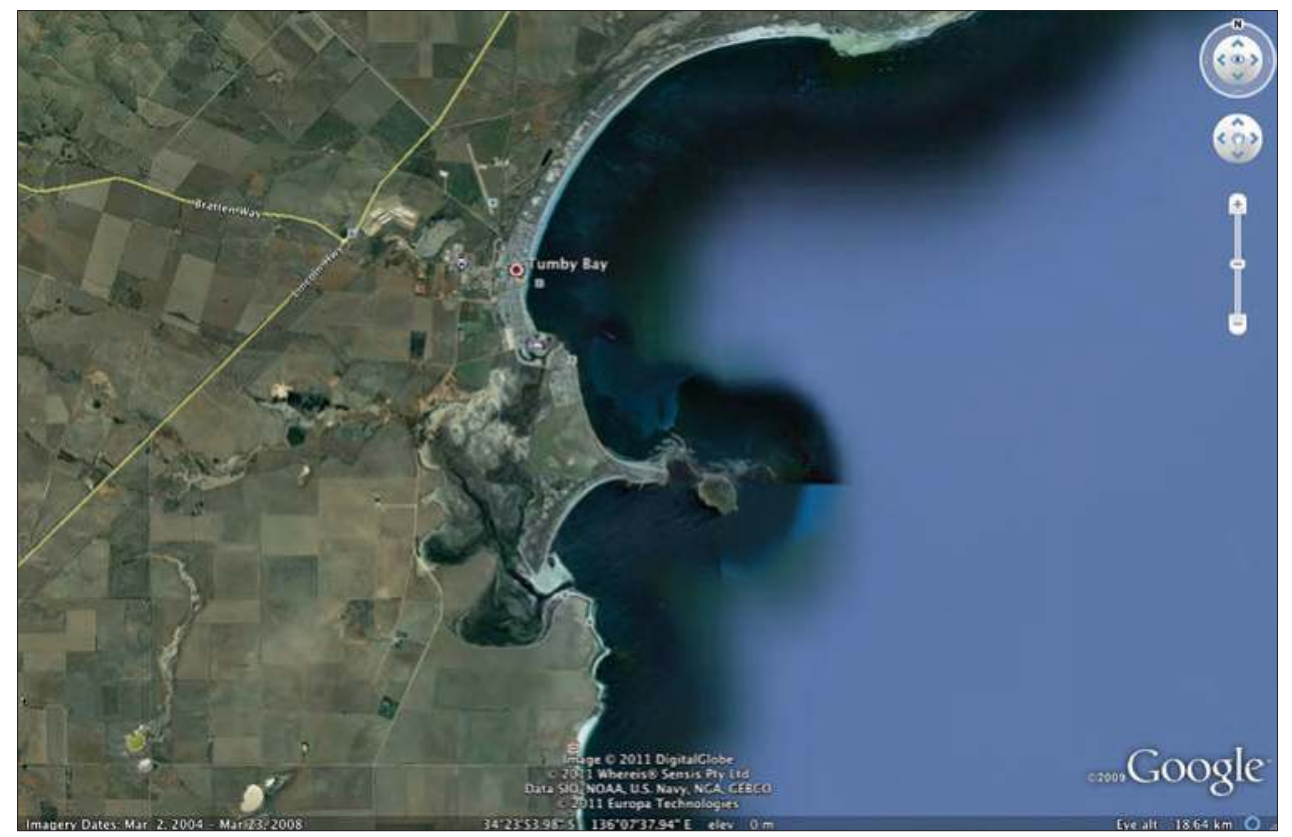

Figure 9.13 The Tumby Bay coastline.

Source: Google Earth image (c) 2008 Google.

bedrock, weathered bedrock, calcreted rubble with iron-rich pisoliths (pea-sized spherical particles), Pleistocene sandy sediments and dune sand. This material forms the headland and extends along the coast for $2 \mathrm{~km}$ to the marina. It is overlain in places by a series of dune ridges. Both the land surface and sediments tilt to the north beneath Tumby Bay, explaining the location of the bay. A complex tidal inlet with sandflats, mangroves and samphire occurs behind this protective section of coast, linking Tumby Bay with the inlet near Cape Euler. These tidal inlets would have been united as a continuous waterway during the Last Interglacial, when Tumby Headland would have been an island. Evidence for this is provided by the presence of the last interglacial shell-rich and calcreted Glanville Formation up to $2 \mathrm{~m}$ APSL, with some articulated shells, occurring on the point opposite Tumby Island. Furthermore, during dredging of the tidal area for a marina, last interglacial shells were found.

Beyond the marina, the shallow Tumby Bay curves around to beyond the outlet of Salt Creek, forming a sandy beach with beach ridges and dunes, which in turn are backed by ephemeral saline supratidal playa lakes and lagoons. Alluvium delivered to the coast by Salt Creek has caused several kilometres of coastal progradation and 
is responsible for the current bulge of the shoreline $400 \mathrm{~m}$ seaward about its outlet. Sandflats and seagrasses front most of the sandy shoreline. For $8 \mathrm{~km}$ north of Salt Creek, low-lying country, dunes and lagoons back the coast until it intersects higher bedrock country, peaking at Oswald Trig $(70 \mathrm{~m})$. For $5 \mathrm{~km}$ from here to Lipson Cove, a relatively straight and steep-cliffed coastline is marked by a series of short stream valleys, manifested at the coast by small inlets or bays occupied by sandy beaches and rocky reefs.

\subsection{Sir Joseph Banks Group of Islands}

Seventeen granite-based islands lie about $20 \mathrm{~km}$ offshore from Bolingbroke Peninsula. They are capped by Pleistocene aeolianite, and Reevesby Island, the largest of the group, consists of several islands linked by sand spits known as tombolos (Figures 9.9 and 9.14).

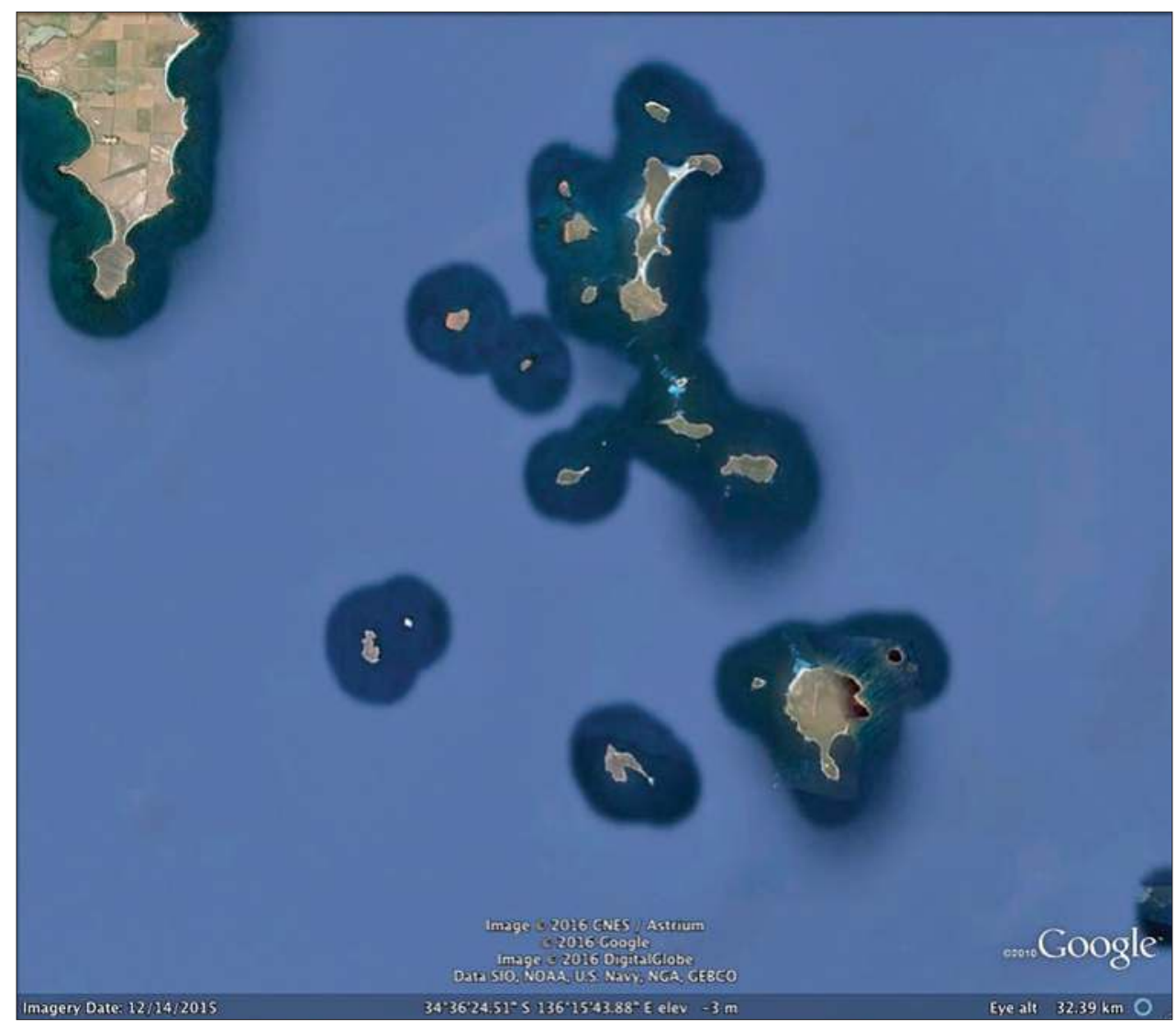

Figure 9.14 The Sir Joseph Banks Group of islands offshore from Bolingbroke Peninsula. Source: Google Earth image $\odot 2015$ Google. 


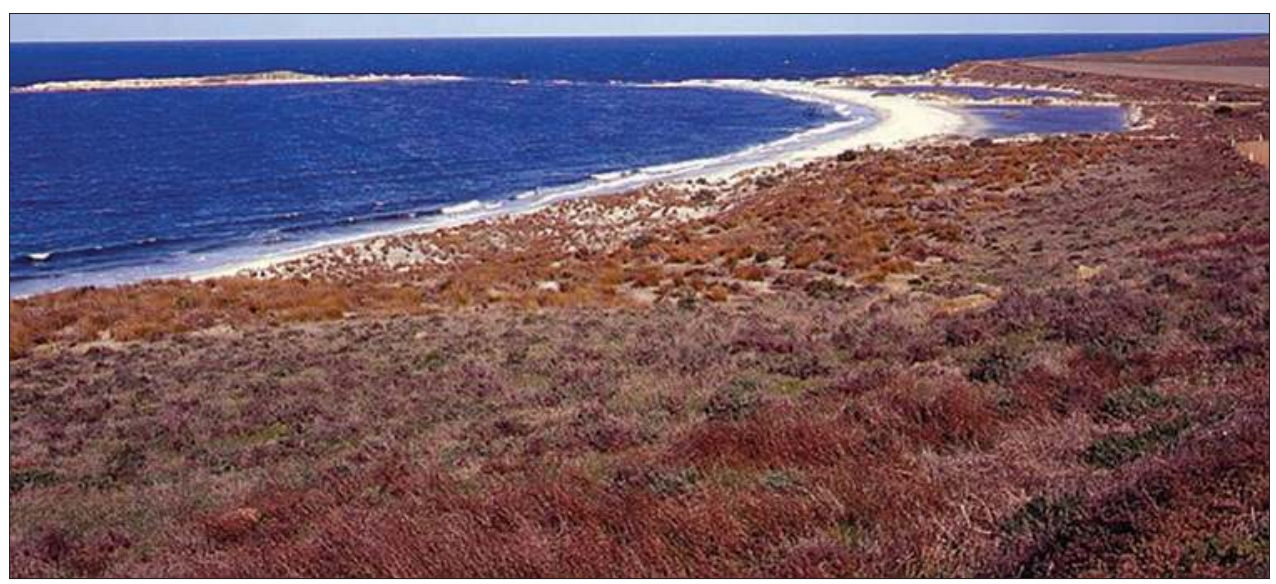

Figure 9.15 Lipson Cove, with a cuspate foreland in the lee of Lipson Island, and an ephemeral lagoon behind the beach.

Source: Author's own work, RPB.

\subsection{Lipson Cove}

Lipson Cove occupies a valley cut into bedrock cliffs 20 to $30 \mathrm{~m}$ high; red/brown Pleistocene alluvium grades down to the shoreline. Protected by Lipson Island and a small outcrop of hard rock, a triangular sand spit or cuspate foreland has formed, linking the island to the mainland (Figure 9.15). At low tides, it is possible to walk to the island. A sandy beach with dunes occurs on the landward side of the island. Beach cusps commonly occur on the main beach face and a dune-covered stranded shingle ridge containing shells and shell fragments occurs at the back of the beach. ${ }^{10}$ The shingle ridge is essentially a fossil feature, suggesting a change in relative sea level or wave activity, although the front of the ridge may still be within reach of the current highest storm waves. A high ridge or berm at the back of the beach forms a shallow ephemeral lagoon, divided by a roadway that leads to an abandoned jetty. Sandflats in the south and dunes in the north back the Lipson Cove shoreline. An older grey/brown sand deposit occurs behind the modern white dunes.

\subsection{Lipson Cove to Cape Burr (Port Neill)}

This is a highly crenulated, bedrock-controlled coast $20 \mathrm{~km}$ long (Figure 9.16), with relatively high, dissected granite country abutting the coast; some of the bluffs and headlands, such as Cape Hardy, are up to $20 \mathrm{~m}$ high. Small rocky bays and sandy pocket bayhead beaches with occasional granite boulders and cobbles have developed 
where more than a dozen stream valleys intersect the coast. Red/brown Late Pleistocene alluvium of the Pooraka Formation infills the valleys and grades down to the coast at $2 \mathrm{~m}$ APSL, the level of the last interglacial shoreline; this shoreline may also be preserved in some coastal benches, such as at Cowleys Beach and Ponto Creek. Dunes, ephemeral lagoons and bay mouth bars occur in some bays.

\subsubsection{Carrow Wells}

Until 1928, Carrow Wells, sited in the dunes, were the main water supply for Port Neill Township, some $6 \mathrm{~km}$ to the north. Near Carrow Wells, there are four sandy bays separated by rocky headlands up to $10 \mathrm{~m}$ high and further protected by shore platforms, reefs and a couple of small islands. The main beach, which infills a former valley, exceeds $1 \mathrm{~km}$ in length. The sandy beaches commonly have well-developed

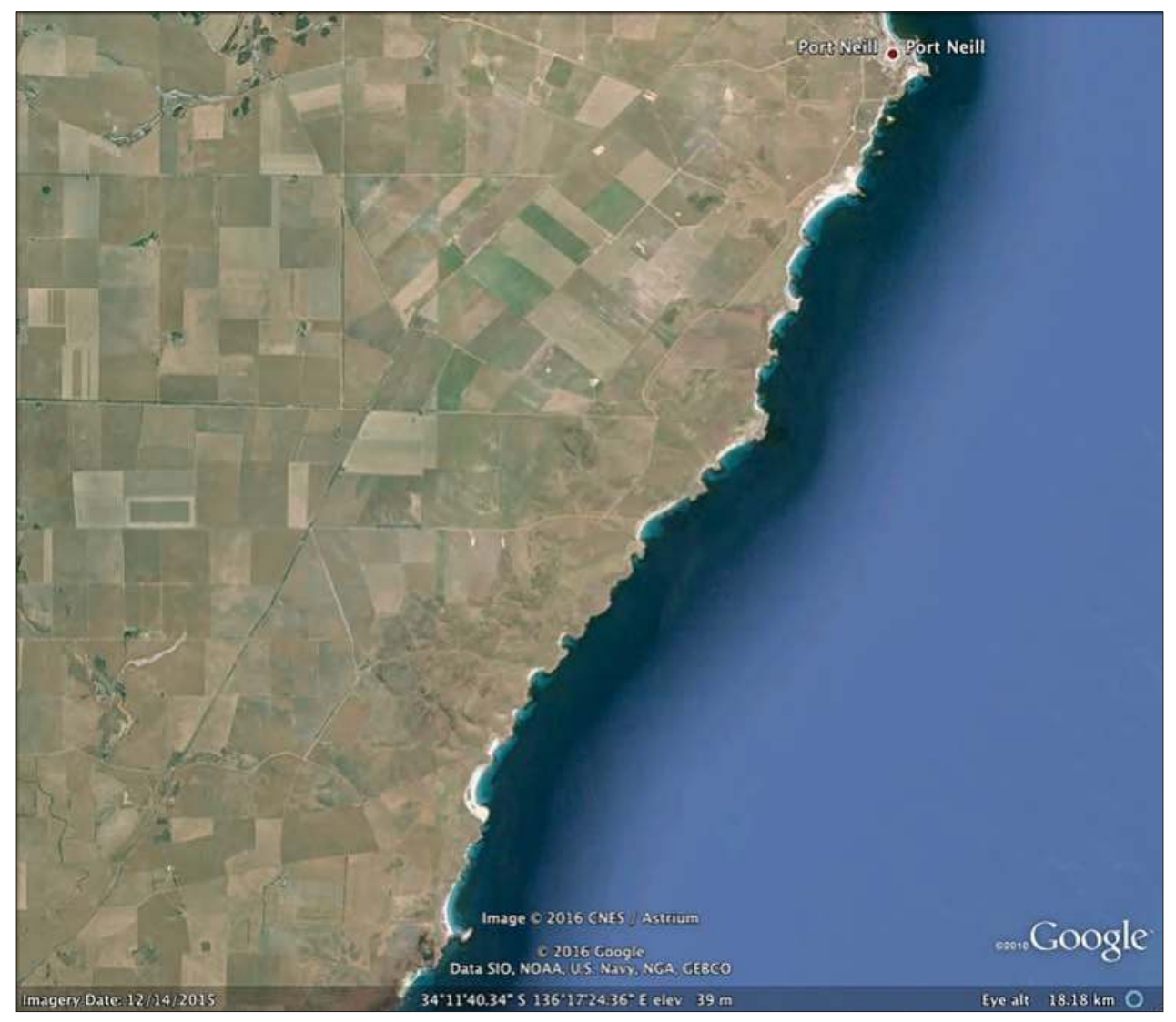

Figure 9.16 The bedrock-controlled crenulated coast between Lipson Cove and Port Neill. Source: Google Earth image (๑) 2015 Google. 


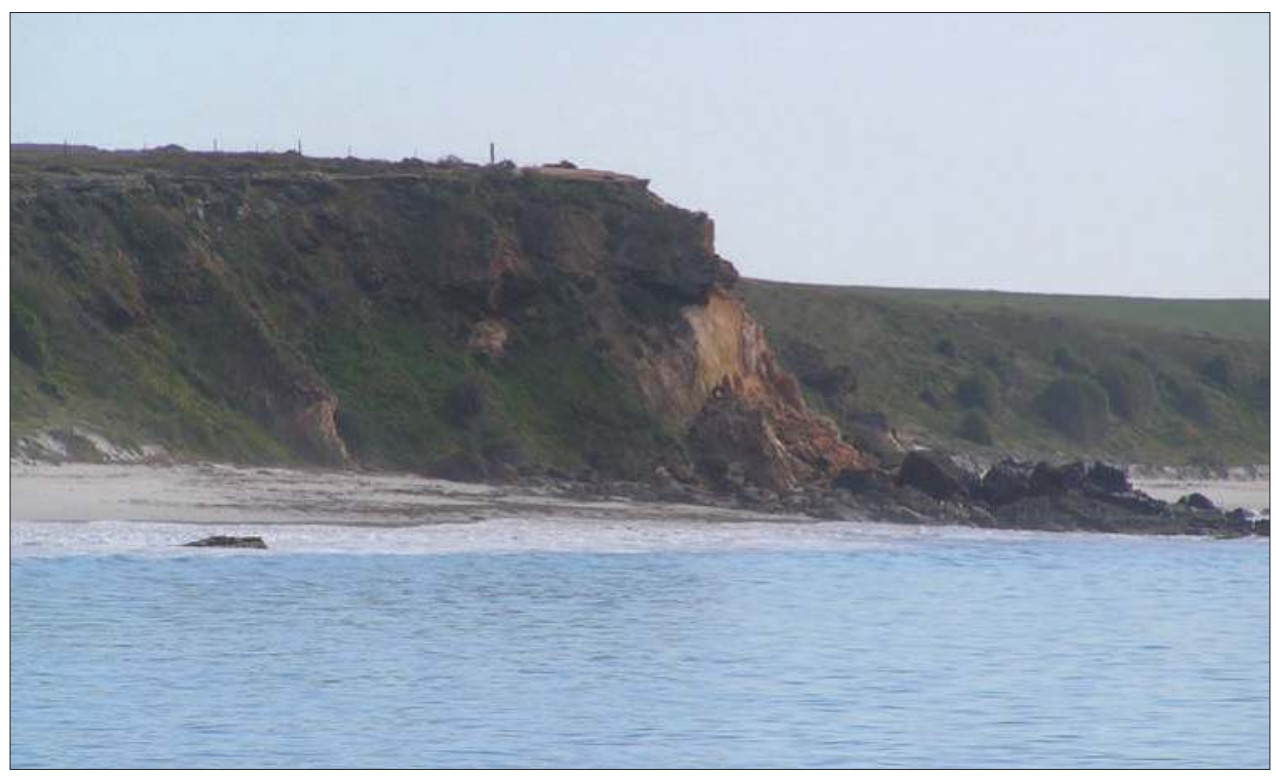

Figure 9.17 The northern headland of Byrne Bay, formed of weathered Proterozoic rocks overlain by ferruginous Pleistocene sediments.

Source: Author's own work, RPB.

arrays of beach cusps, and they have spawned dunes that have migrated to cliff tops, extending inland for $1 \mathrm{~km}$ and up to $30 \mathrm{~m}$ APSL across a calcreted surface.

\subsection{Dutton Bay}

This coastline trends southwest-northeast and is $30 \mathrm{~km}$ long. It has a relatively smooth form between Cape Burr $(10 \mathrm{~m})$ near Port Neill and Cape Driver $(10 \mathrm{~m})$, south of Arno Bay. Around Cape Burr, there are granitic rocky headlands, shore platforms and boulder and sandy beaches. Back Beach lies south of Cape Burr, where there are two sandy beaches separated by a tombolo linked to a rocky outcrop.

At Port Neill, north of the cape, Mottled Cove extends for a couple of kilometres to a lookout point $25 \mathrm{~m}$ high. Sand accumulating, especially in the northern section of the cove, has produced a sweeping sandy bay, backed by dunes and a back-barrier swampy depression. Byrne Bay extends $2 \mathrm{~km}$ north from the Pioneer Lookout to a prominent headland $20 \mathrm{~m}$ high; this has captured another sandy beach with a foredune at the base of the cliff, where there are also high shingle beaches. Cliffs on the south side of the bay have a tough calcrete capping. The northern headland of Byrne Bay 
(Figure 9.17) comprises weathered mottled Proterozoic rocks, unconformably overlain by dark red, iron-rich Pleistocene grits, gravels and sands, which closely resemble the Seaford Formation at Sellicks Beach, where the base of the unit has been dated at $-2.6 \mathrm{Ma} .{ }^{11}$ This pattern of ancient granitic rocks overlain by younger deposits continues well to the north of the Dutton River outlet, forming a rocky cliffed coastline up to $20 \mathrm{~m}$ high. In the central part of Byrne Bay, a stream debouches at the coast. Yellow last glacial maximum dunes intersect the coast and are being eroded to form beach sands.

The outlet of Dutton River (Figure 9.18), $7.5 \mathrm{~km}$ north of Port Neill, is usually blocked by a sand bar and dune barrier, which form small lagoons. South of the outlet, there is an abandoned, dead cliff line and a long narrow bay, infilled with a series of beach ridges. Dutton River, one of the few reasonably large Eyre Peninsula creeks, has

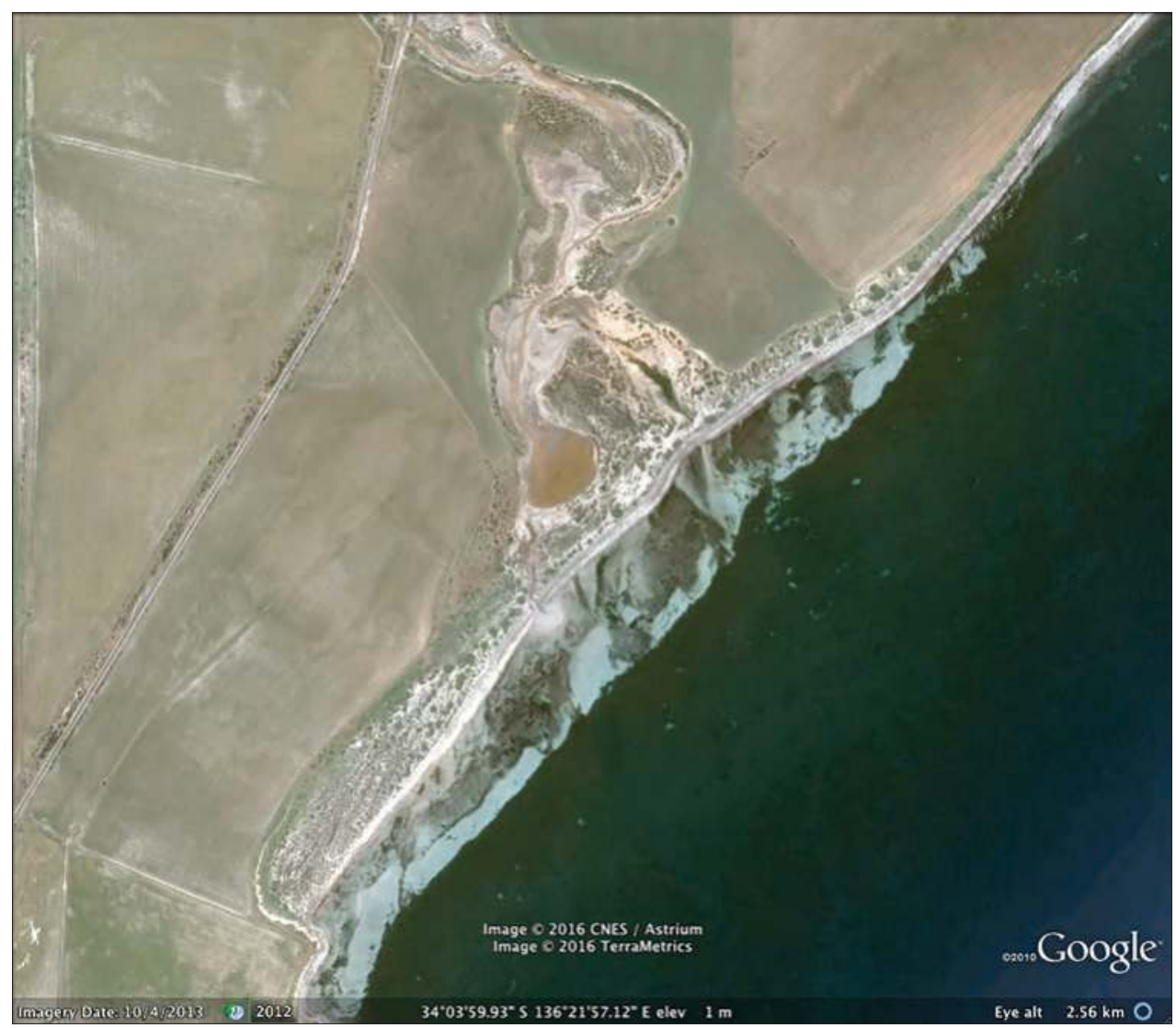

Figure 9.18 Where Dutton River meets the coast.

Source: Google Earth image (๑) 2015 Google. 
delivered sediment to the coast, contributing directly to the beach, sand ridges and intertidal sand shoals that front the beach.

From the mouth of Dutton River, a linear section of coastline $9 \mathrm{~km}$ long, with cliffs and bluffs 10 to $20 \mathrm{~m}$ high and underlain by granitic rocks capped by Pleistocene gravelly sediments, extends to Mokami Beach; it resumes beyond to Cape Driver. Around Mokami Beach, there is a break in the bedrock shoreline occupied by a long sandy beach backed by salt flats, longitudinal dunes and low bluffs. Driver River enters the coast at Mokami, delivering sediment to the coast and forming a small sand delta. It no doubt contributed to the build-up of a wide series of beach/dune ridges for several kilometres south of the mouth.

\subsection{Arno Bay}

Arno Bay (Figure 9.19) is west-facing between headlands of fresh and weathered granitic bedrock fronted by rocky shore platforms and reefs, such as at the boat harbor on the north side of the bay. Cape Driver is a prominent headland south of Arno Bay proper. It is $10 \mathrm{~m}$ high and it comprises weathered granitic bedrock overlain by alluvial and aeolian Pleistocene deposits. An extensive samphire swamp occupying some 4 to $5 \mathrm{~km}^{2}$ in area backs the bay. It was a large embayment of the sea during the Last Interglacial (125 ka), when sea level was $2 \mathrm{~m}$ higher than present.

There are mangrove woodlands along the tidal channels of Salt Creek, which are accessible by boardwalks. The outlet of the creek is subject to migration where there is currently a south-pointing sand spit. The mangroves are separated from the sea by sandy beaches, dunes and ridges, with a sandy ebb tidal delta at the mouth of Salt Creek at low tide. Longitudinal dunes trending from the northwest abut the coast; they are contributing sand to the beaches as they are eroded, and they form cliff-top dunes in places. The dunes, which are about $20 \mathrm{ka}$ old, have been truncated by tidal action at the back of the samphire swamp; this process would have been accelerated during the mid-Holocene (6 to $4 \mathrm{ka}$ ), when sea level was perhaps a metre higher than at present.

A causeway across the low-lying samphire flats links the main town to the houses built on a coastal sand barrier fronting the bay. The Yeldulknie Creek, which drains from the Cleve Hills, enters the sea via the swamp and is responsible for the occasional flooding of the samphire swamps and isolation of the two parts of the town.

\subsection{Red Banks to Point Gibbon}

This section of coastline is $10 \mathrm{~km}$ long and is characterised by actively eroding cliffs up to $15 \mathrm{~m}$ high, which have developed in red, weathered bedrock, overlain in places 


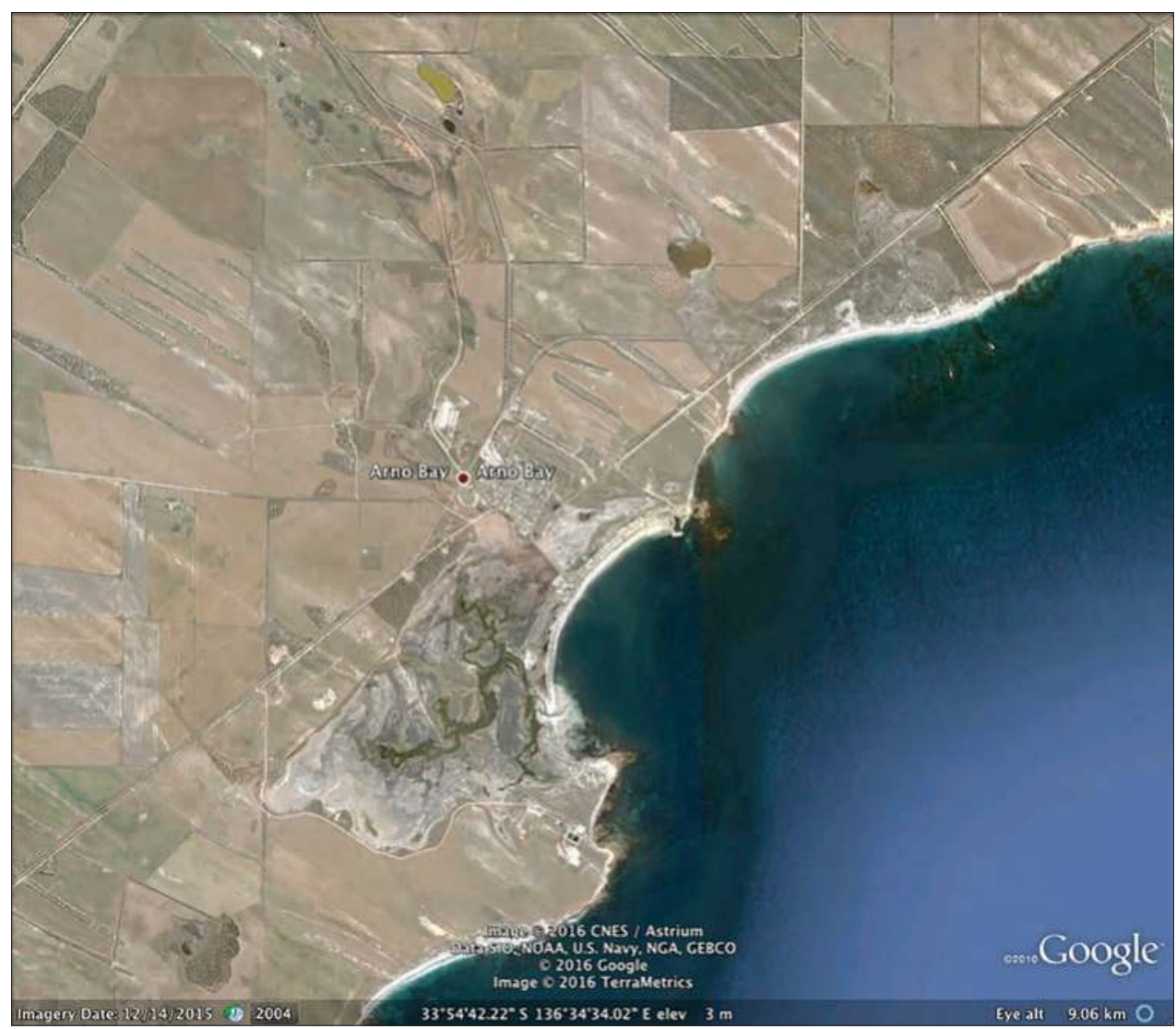

Figure 9.19 The Arno Bay coastline. Note the prominent last glacial maximum longitudinal dunes trending northwest-southeast.

Source: Google Earth image @ 2013 Google.

by Pleistocene alluvial sediments, known locally as the Port Gibbon Beds. ${ }^{12}$ Much of the cliff top is markedly crenulated in plan, a result of the eroding nature of the coast, developing notches, caves, steep undercut bluffs, protruding headlands and extensive shore platforms and reefs as well as beach sediments.

The Pleistocene alluvial sediments are intensely weathered, displaying strong ironrich colouring (Figures 9.20 and 9.21). They were derived by stream action from the highlands that back the coastline. At Red Banks, the sediments dip to the south, where they are overlain by Holocene sand dunes, and plunge beneath Arno Bay but reappear further south at Cape Driver, forming a broad, gentle syncline that is occupied by 


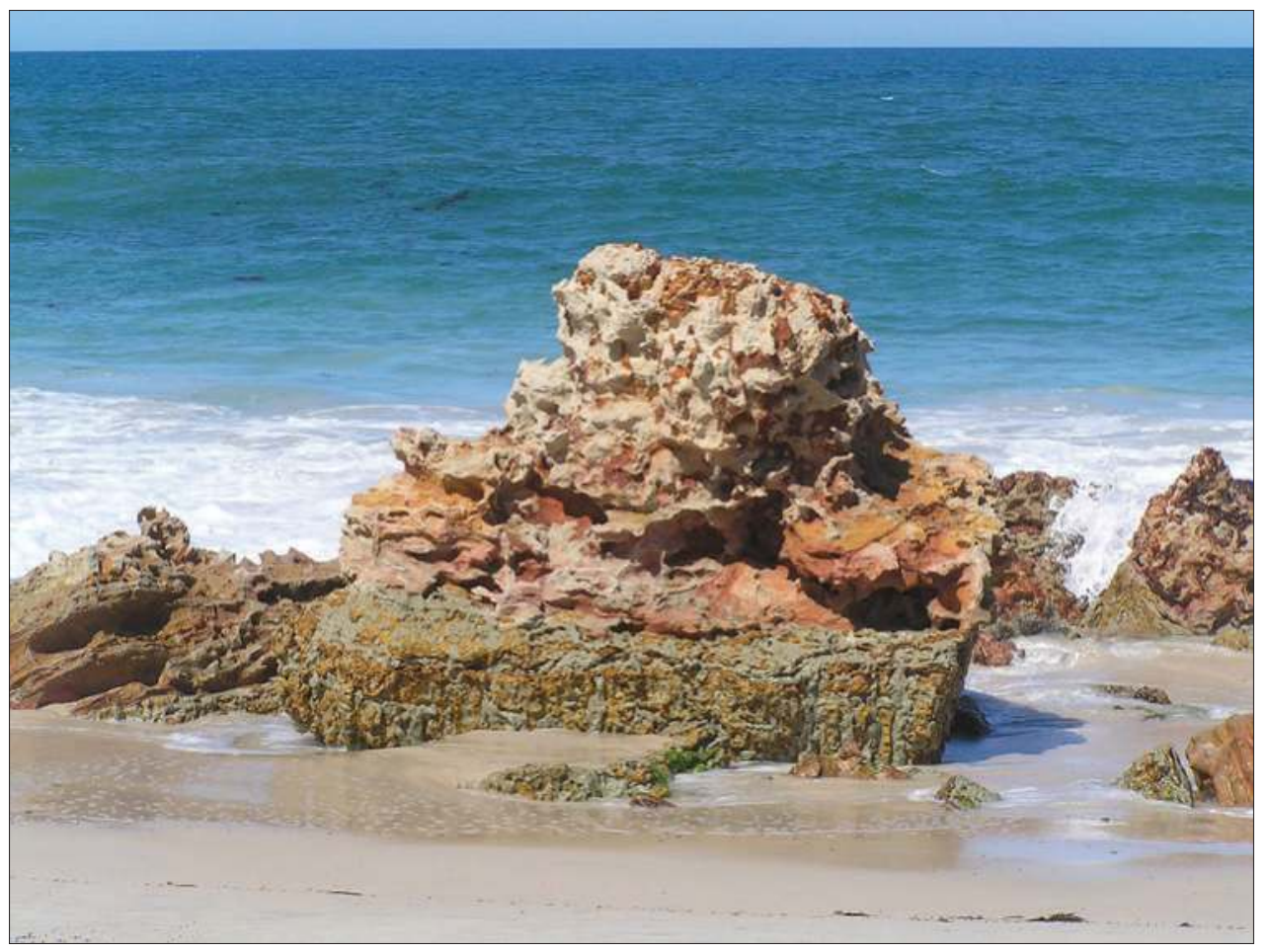

Figure 9.20 Red Banks sediments of Pleistocene age, which closely resemble the Seaford Formation at the base (Early Pleistocene) and the Ochre Cove Formation with strong red mottles at the top (Middle Pleistocene) in the Sellicks Beach area. The exposure is $3 \mathrm{~m}$ high. Source: Author's own work, RPB.

Arno Bay. A light-coloured calcreted boulder layer in the sediments separates the Late Pleistocene Pooraka Formation from the older Pleistocene beds beneath. Desert dunes of last glacial maximum age sporadically cap the cliff line, forming cliff-top dunes. Small and younger, brown-coloured dunes also form cliff-top dunes in places. About halfway between Red Banks and Poverty Bay, there is a protruding sandy cuspate foreland anchored on a boulder-covered, broad rocky shore platform, which continues to Poverty Bay.

Poverty Bay, which is about $1 \mathrm{~km}$ wide, occupies a stream valley bordered by gneissic bedrock shore platforms, reefs and cliffs up to $15 \mathrm{~m}$ high, overlain by younger Pleistocene sediments. Windittie Creek enters the bay through the sand dunes that back the generally sandy bay; some shingle occurs on the southern side of the bay and boulders mantle some of the shore platforms. 


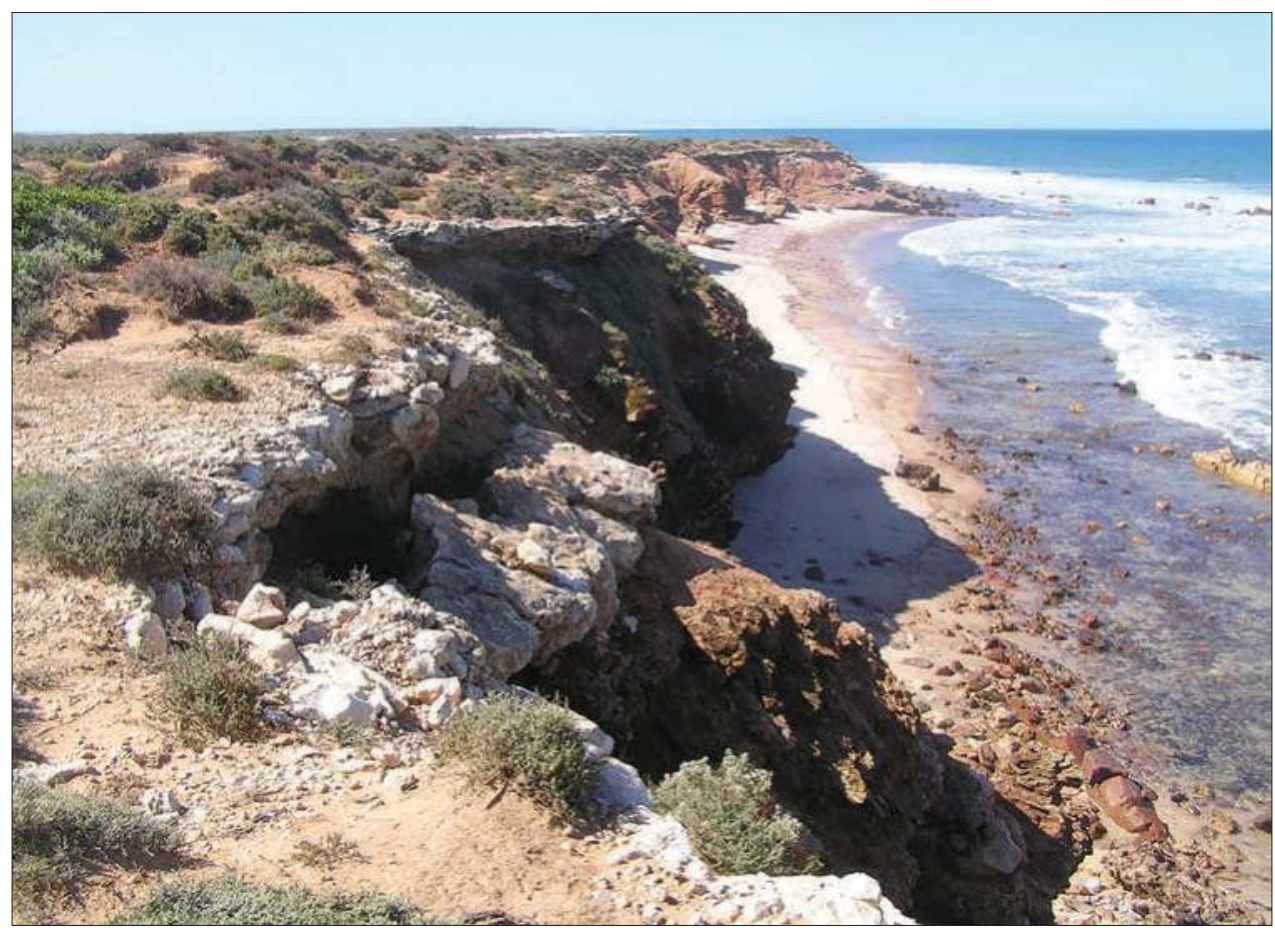

Figure 9.21 Cliffs, $15 \mathrm{~m}$ high, eroded in Pleistocene alluvial deposits at Red Banks. Source: Author's own work, RPB.

\subsubsection{Mills Beach}

Mills Beach is a south-facing sandy beach $5 \mathrm{~km}$ long and backed by foredunes, which feed active, transgressive dunes up to $20 \mathrm{~m}$ high; these extend inland for some $600 \mathrm{~m}$. These Point Price sandhills comprise the most extensive dune field on the northern Gulf Coast of Eyre Peninsula, with their orientation resulting in exposure to wave action and southerly winds. The dune sands were probably sourced from the floor of the gulf, being swept landward during the most recent period of sea level rise. The dunes also provide a barrier to drainage, damming back a swampy area to landward. The most westerly kilometre of the beach is fronted by bedrock outcrops, which also form the headland of Point Gibbon (Figure 9.22).

\subsubsection{Point Gibbon}

A most dramatic feature of Point Gibbon is an active dune field up to $20 \mathrm{~m}$ high and covering almost $2 \mathrm{~km}^{2}$, which has migrated from Mills Beach, across the promontory, anomalously producing sandy beaches and dunes on a rocky shoreline. The rocky 


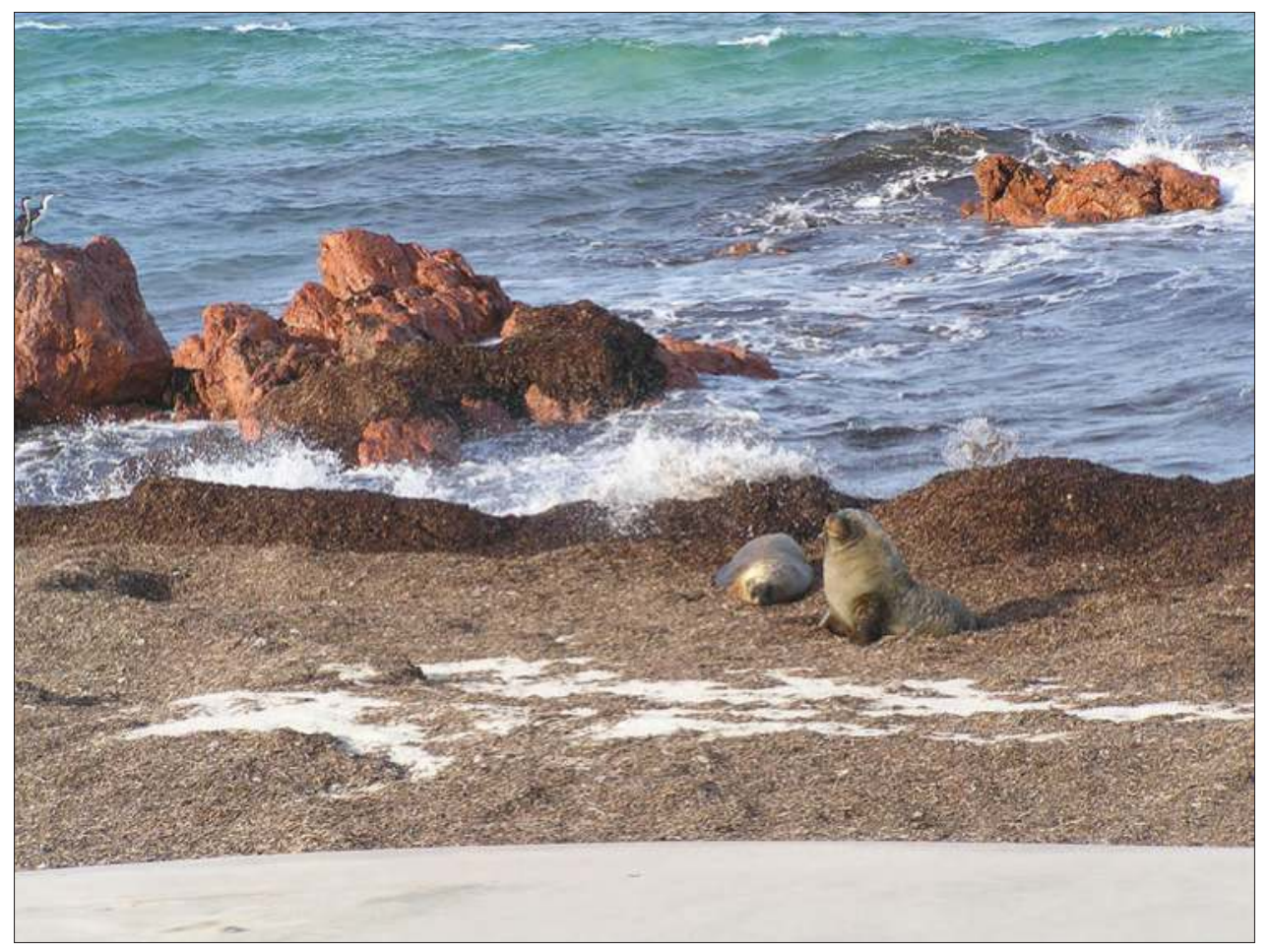

Figure 9.22 Point Gibbon, protected by resistant rocks of the Blue Range Beds. Source: Author's own work, RPB.

headland of Point Gibbon is underlain by interbedded sandstone and conglomerate of the Blue Range Beds, which are 1.55 billion years old (Mesoproterozoic) and also crop out on the Bight Coast at Talia Caves. The Blue Range Beds occur in a large tectonic depression up to $50 \mathrm{~km}$ wide, the Itledoo Basin, which extends across Eyre Peninsula from south of Cowell to north of Elliston and beyond..$^{13}$ There are also older metamorphic rocks in the Point Gibbon area, as well as younger Pleistocene sediments capped by a resistant calcrete layer containing ferruginous pisoliths and rock fragments. Calcareous rhizomorphs resembling fossilised plant roots also occur on the calcreted land surface. Such hard calcrete sheets up to $1 \mathrm{~m}$ thick mantle much of the landscape, commonly underlain by up to $1.5 \mathrm{~m}$ of rubbly, nodular calcrete. They are not related to aeolianite dunes, as on the Bight Coast, but the carbonate was wind-derived and probably represents a Middle Pleistocene drying of the Australian continental climate. $^{14}$ 


\subsubsection{Port Gibbon}

At Port Gibbon, steep, eroding cliffs 8 to $15 \mathrm{~m}$ high have been cut into alluvial deposits known as the Gibbon Beds (Figure 9.23). These consist of iron-mottled, cross-bedded gravels, conglomerates, sands and clays, and range in age from about Late Pliocene to Late Pleistocene in age (3 Ma to $120 \mathrm{ka}$ ). ${ }^{15}$ The sediments are dominantly fluviatile beds derived from backing uplands such as the Cleve Hills, although they have a calcrete mantle, the calcium carbonate for which was probably wind-derived. The Port Gibbon Beds are well exposed in Yabmana Creek, which enters the sea at Port Gibbon, cutting a valley and reducing the heights of the sea cliffs on the valley sides. Pleistocene marine shells are also exposed in the lower Yabmana Creek. Much of the coast from Port Gibbon to Flat Rocks is protected by low calcreted headlands and shore platforms with intervening white sandy beaches.

The Port Gibbon Beds are prone to erosion by undercutting and collapse, forming notches, headlands and protruding bluffs. Active erosion is marked by a scalloped cliff line and collapse, but in some places the cliffs are more stable, where the base of the cliff is protected by a temporary build-up of dune sand and vegetation. The interaction

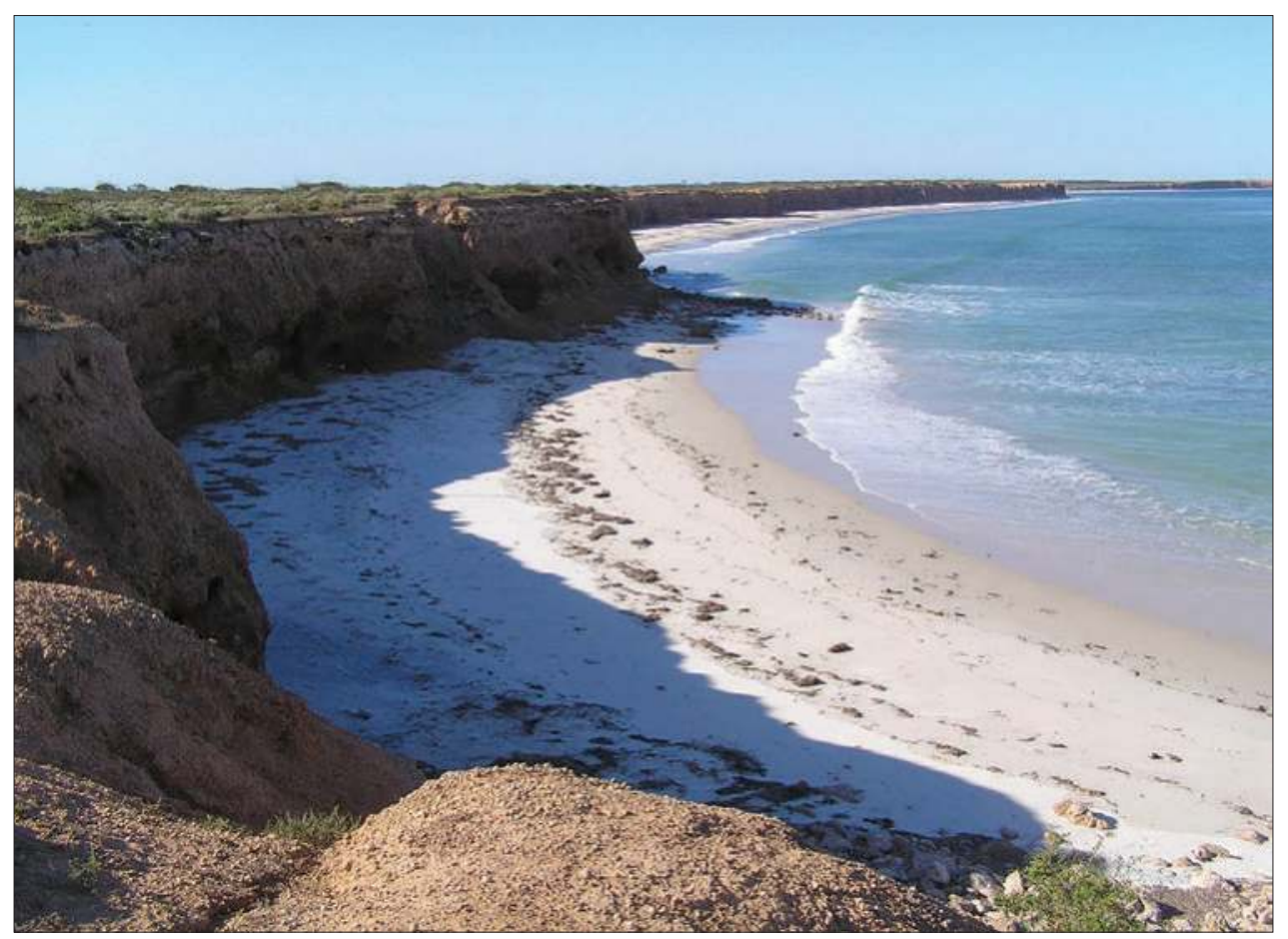

Figure 9.23 Port Gibbon Beds being actively eroded, producing cliffs $15 \mathrm{~m}$ high. Source: Author's own work, RPB. 
of the land and coast is well illustrated by the devastation of land-based flooding on the Carlaw Boathouse south of Port Gibbon, where all of the buildings were destroyed and boats were washed out to sea in 1946 .

\subsection{Franklin Harbor to Whyalla}

\subsubsection{Franklin Harbor}

Franklin Harbor (Figures 9.24 and 9.25) is an almost completely landlocked body of water, $48 \mathrm{~km}^{2}$ in area, with a narrow access to the sea. In fact, Flinders did not recognise the entrance and regarded Franklin Harbor as a large lagoon. A former open bay during the higher sea level of the Last Interglacial, the mouth of the bay has been largely closed by the progressive longshore growth of recurved sand spits from the low rocky calcreted bench at The Knob. There are 11 prograded shingle ridges exposed at The Knob related to deposition by storm wave activity, with ridge heights diminishing seawards, possibly in response to a falling sea level. ${ }^{16}$ After formation, the ridges were buried by dunes and later re-exposed by deflation; some of the dunes are still active. The ridges contain a wide range of rock types. At the shore, there are calcreted shore platforms also containing cobbles and shingle.

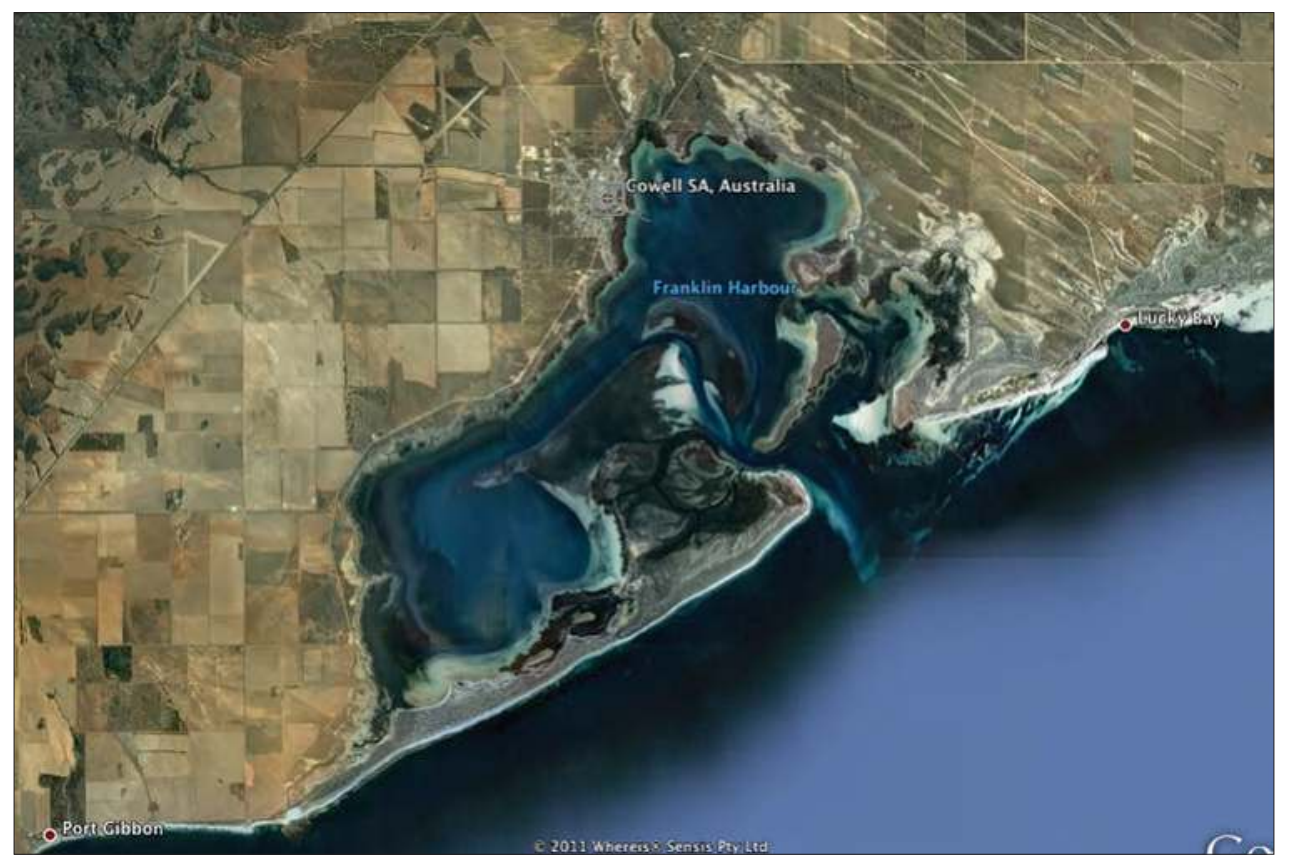

Figure 9.24 Franklin Harbor at Cowell.

Source: Google Earth image @ 2011 Google. 


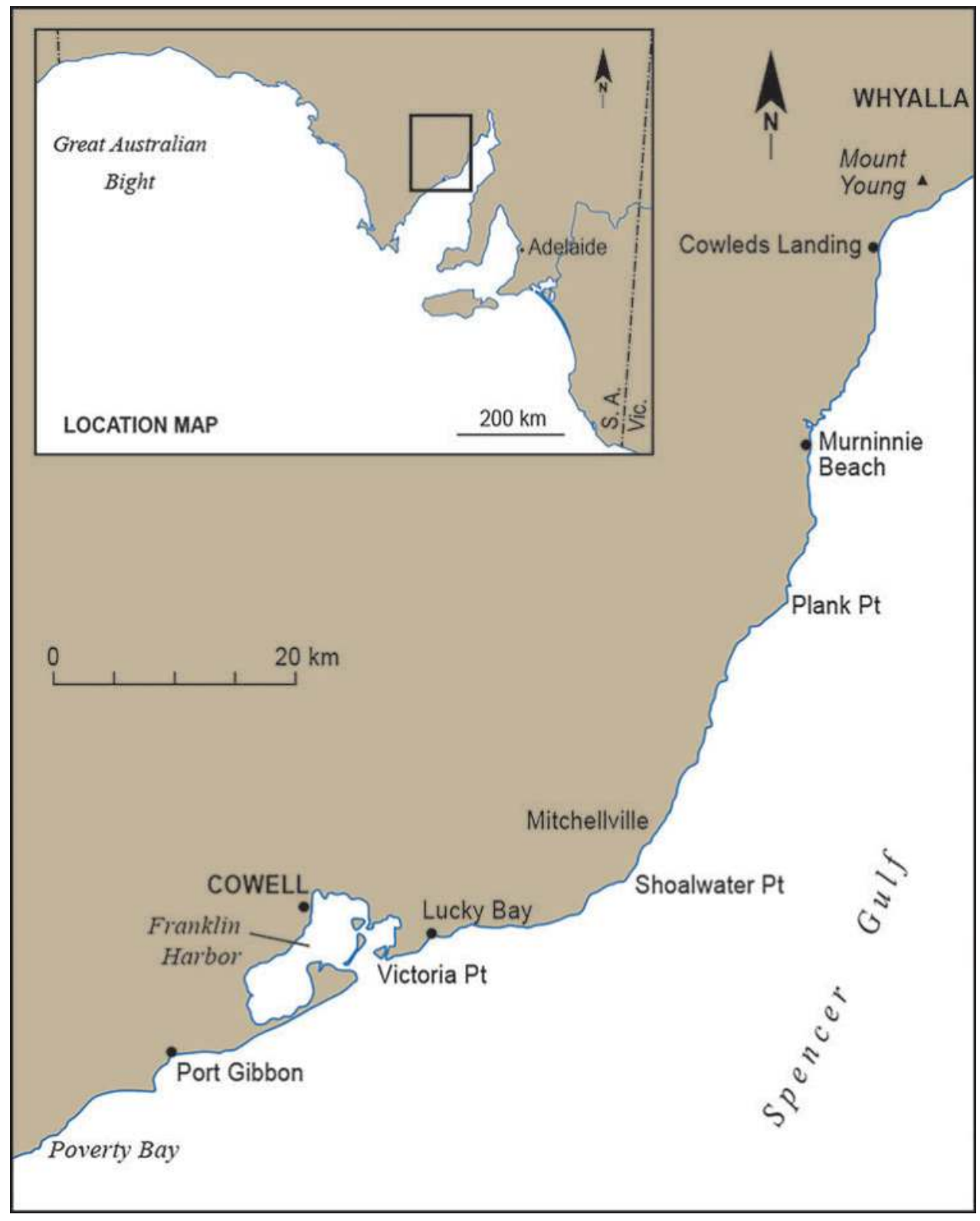

Figure 9.25 The northern Spencer Gulf, showing localities of sites mentioned in the text. Source: Author's own work, RPB. 
Windmill Beach fronts the sand spit, which is $13 \mathrm{~km}$ long and terminates at Germein Point. The sand spit has not only grown northward but has also prograded seawards. The northern portion of the spit was established at $3220+80 \mathrm{yr}$ BP, after which the spit prograded seaward another $250 \mathrm{~m} .{ }^{17}$ Currently a foredune $5 \mathrm{~m}$ high has developed landward of the modern beach. Red Cliff and Victoria Point form the northern entrance to the harbour as a series of sand shoals, beaches and recurved spits, which extend into the harbour. The extensive ebb tidal delta of Franklin Harbor, particularly visible at low tide, lies offshore from Red Cliff beach, extending to the east as a low sand spit about $4 \mathrm{~km}$ long and 100 to $200 \mathrm{~m}$ wide.

Within the harbour, there are numerous sand spits (for example, Howard Spit, Observation Point), and flood tidal deltaic sediments that form distinctive shoals. The landward margins of the harbour comprise Pleistocene alluvial sediments, derived from the backing uplands and the distinctive longitudinal dunes trending northwestsoutheast, which intersect the northern side of the harbour and extend into it. These former desert dunes of the Last Glacial Maximum (21 ka) would have provided much sand for the coastal sediments. The position of their truncation by the sea, such as at Lucky Bay, reveals the amount of coastal progradation that has occurred since sea level reached near to its present position 7000 years ago. Sandflats, seagrasses and mangroves ${ }^{18}$ abound in the harbour, backed by samphire flats and shell ridges. Some of the shell ridges are up to $3 \mathrm{~m}$ high and contain largely Holocene shells, but they also contain some much older, reworked ones. The internal structure of some of the shell ridges suggests that they may have formed during single storm events. A causeway constructed for the main highway across the intertidal area has restricted tidal flushing and has impacted on the health of the mangroves landward of the causeway.

The dominant processes of coastal development in the protected, tidally dominated waters of the northern Gulf Coast are related to the massive production and accumulation of biogenic skeletal carbonate fragments derived from corraline algae, foraminifers, molluscs and bryozoans; the site is a 'major carbonate factory', sequestering much $\mathrm{CO}_{2}$. Algal mats, seagrass meadows and mangrove woodlands are highly productive environments for the growth of rich and diverse marine organisms, and they promote the rapid accumulation of skeletal, calcareous, bioclastic debris when they die. Intertidal sandflats produce vast numbers of molluscs that also contribute to the aggradation (vertical accretion) and seaward progradation of the shoreline. ${ }^{19}$ These processes have been enhanced by a fall in relative sea level over the past 5000 years, stranding shell ridges and supratidal flats, which accumulate gypsum, dolomite and salt.

\subsubsection{Lucky Bay}

The Lucky Bay settlement is built on a prograding, protruding sand spit about $3 \mathrm{~km}$ long and $100 \mathrm{~m}$ wide, forming a sandy cuspate foreland. Relict longitudinal desert 
dunes $20 \mathrm{ka}$ old intersect the coast and provide a clue to the amount of coastal progradation that has occurred since sea level reached its present position $7 \mathrm{ka}$ ago. The dunes have been truncated up to $1 \mathrm{~km}$ from the present shore, suggesting that the coast has built out this distance over the last 7000 years. The shoreline is backed by a series of up to eight low sand and shell ridges interspersed with samphire swamps and a tidal channel. ${ }^{20}$ There is a wide intertidal sandflat with large seagrass banks. The shacks built on the spit are in danger of being undermined, a problem that may be increased by the new harbour, which may deprive the shoreline of sand. It is a very low-lying and fragile section of coast, and the shacks have been built up on fill material protected by stone revetments. There is a great mound of debris derived from dredging of the harbour, which contains innumerable shells that are probably of last interglacial age as some are set in calcrete, typical of the Glanville Formation.

\subsubsection{Shoreline between Franklin Harbor and Whyalla}

Much of the coastline from Franklin Harbor to near Whyalla (Figure 9.25), which is $110 \mathrm{~km}$ long, is a beach ridge plain formed on expansive $100 \mathrm{~km}^{2}$ intertidal sandflats. Relatively low-lying Pleistocene alluvial deposits ( $<10 \mathrm{~m}$ APSL), derived from higher country to the west, form the backing coastal plain, which is mantled in places with former desert dunes. The geomorphology of this coast is dominated by shell ridge plains backed by salt flats, seagrass meadows and debris, samphire flats, extensive sandflats, sandy forelands, lagoons, mangrove woodlands with tidal channels and multiple northward-trending recurved spits, all of which contribute to coastal stability of this sedimentary shoreline. Additional protection is provided by recent beach ridges, which occupy the hollows between the desert dunes at the shoreline.

Despite the predominance of tidal action and the low wave energy of this section of coastline, the presence of prograding beach and chenier ridges overlying sandflats and mudflats attests to the episodic operation of occasional high-energy waves, which have swept shells and sand into ridges over the past 6000 years, with most ridges having formed between 4000 and 2000 years ago. ${ }^{21}$ The more recent ridges contain greater amounts of shells, highlighting the importance of biogenic processes in providing sediment for the ridges. ${ }^{22}$

There is a broad protrusion of the shoreline over a distance of some $40 \mathrm{~km}$ from Lucky Bay to near Plank Point (Figure 9.26). The coastal plain is underlain by Pleistocene and younger sediments, and there is no obvious influence of older harder rocks influencing the morphology of the coast, although there is a submerged rocky reef 10 to $20 \mathrm{~km}$ offshore (Figure 9.2). Shoalwater Point, the most easterly point of the coastal protrusion, is fronted by a very broad, tidally dominated sandflat, up to $2 \mathrm{~km}$ wide, and experiences only subdued wave activity. Near Glensea, about $10 \mathrm{~km}$ north of Shoalwater Point, there are at least eight wave-deposited beach 


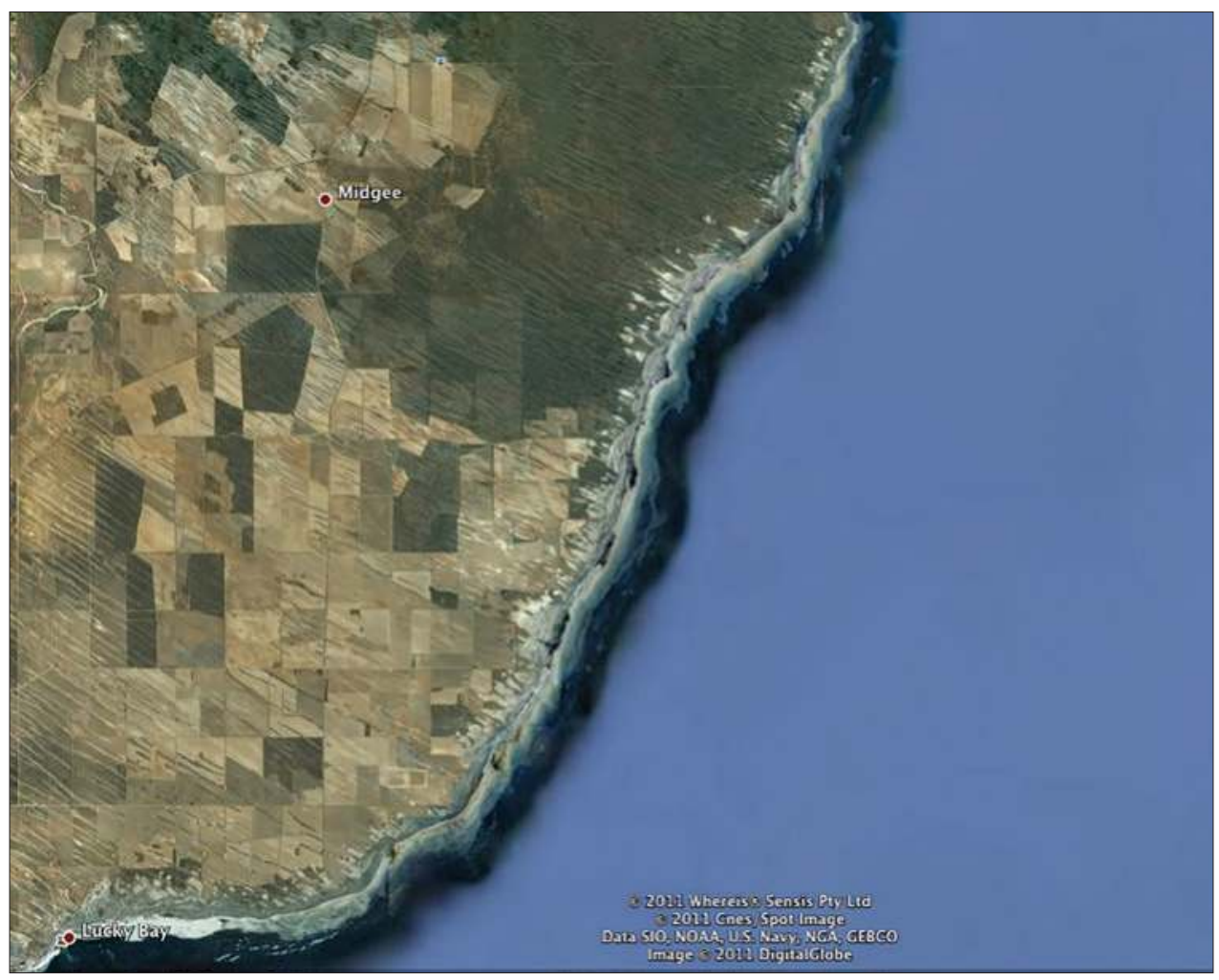

Figure 9.26 The protruding shoreline between Lucky Bay and Plank Point, with southeasttrending desert dunes intersecting the coastline.

Source: Google Earth image (๑) 2011 Google.

ridges, all of which formed over the past 2600 years. ${ }^{23}$ The recent beach ridges and their intervening swales slope seawards, possibly in response to a fall in sea level of $1 \mathrm{~m}$, which would have added further stability to the shoreline.

Along this section of coastline, a field of relict longitudinal desert dunes trending northwest-southeast abuts the shoreline at right angles. They formed when sea level was lower than present, as they are partially submerged in places. The dunes, which consist of yellow/brown sand, with powdery carbonate cores, almost certainly formed during the drier, colder and windier times of the Last Glacial Maximum, 21 ka ago. At this time sea level was up to $125 \mathrm{~m}$ lower than present and dunes would have spread across much of the then dry gulf. As sea level rose between $18 \mathrm{ka}$ and $7 \mathrm{ka}$ ago, sand from the dunes would have been incorporated into the shoreline sediments, sandflats 
and shoals. Thus it appears that the shoreline is protected by extensive shoals and sandflats derived from redistribution of sand derived from biogenic processes and from the former desert dunes.

North of Plank Point, beach ridge plains up to $1 \mathrm{~km}$ wide back onto saline samphire flats and former desert dunes. The plains are fronted by intertidal sandflats almost $2 \mathrm{~km}$ wide, before terminating at the edge of seagrass meadows. There are occasional mangroves, including some dead ones, such as at the end of Mitchellville Road and at Murninnie Beach.

\subsubsection{Whyalla}

Beaches at Whyalla have been trapped by seawall structures and Hummock Hill. South of the jetty, the beach is backed by a seawall and fronted by extensive intertidal sandflats up to $1 \mathrm{~km}$ wide. Beyond the seawall, mangrove woodland interspersed with small sandy beaches, sand spits, ridges and tidal creeks fringes the coast for $5 \mathrm{~km}$. A very extensive supratidal flat is underlain by red/brown alluvium of the Pooraka Formation and shelly sand nearer the coast. The mangroves and tidal creeks separate samphire swamps 1 to $2 \mathrm{~km}$ wide from intertidal sandflats up to $1 \mathrm{~km}$ wide. Mount Young $(-140 \mathrm{~m})$ stands island-like above the low-lying $(<10 \mathrm{~m})$ alluvial plain (Figure 9.27).

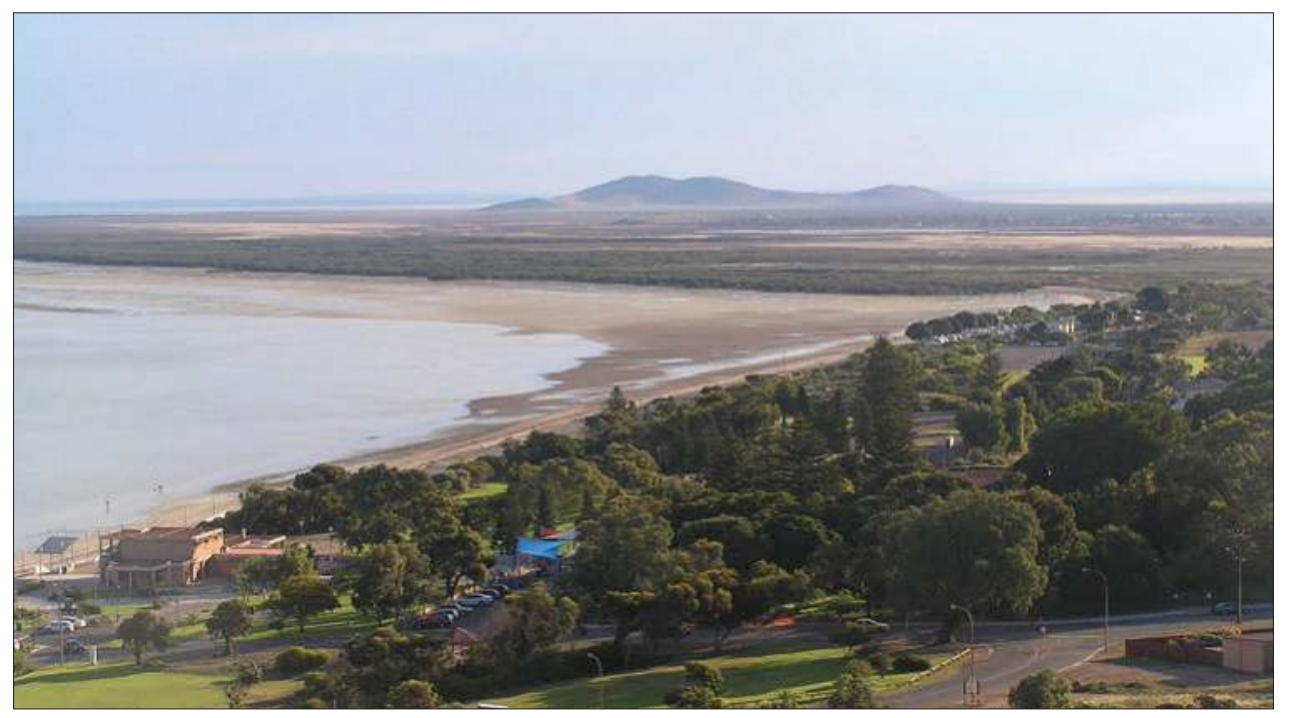

Figure 9.27 The coastline south of Whyalla, with Mount Young prominent in the distance. Source: Author's own work, RPB. 


\subsection{Summary and conclusions}

The coast between Port Lincoln and Whyalla is basically fault-controlled, as a series of southeast-northwest faults, such as the Lincoln Fault, separate the Gawler Craton from the downfaulted Spencer Gulf. Outcrops of basement rock, forming headlands and islands, structurally control the Port Lincoln coast and produce the framework for the development of sandy bays, beaches, dune fields, sand spits and back-barrier lagoons. Islands during higher sea levels of the Last Interglacial and Holocene have sometimes been linked to the mainland by coastal sediments, while former last interglacial embayments (for example, Arno Bay and Tumby Bay) are often marked by tidal inlets, samphire flats, mangroves and large sand spits.

Headlands, cliffs and islands, formed in aeolianite and resting on Gawler Craton rocks, occur in the south on Jussieu Peninsula, and shore platforms arise where unconformities are exposed or where weathered bedrock has been removed to expose near-horizontal, fresh rock surfaces. Further north, actively eroding cliffs have formed on iron-rich Pleistocene sediments (Gibbon Beds) at Red Banks and Port Gibbon. Between Lucky Bay and Whyalla, the coastline is low-lying and dominated by beach ridges, intertidal sandflats and seagrass meadows. Modern active dune fields extend up to $5 \mathrm{~km}$ inland in the south, but these are rare in the north except for Mills Beach, while aeolianite is restricted to the southern coast.

In detail, shoreline positions have been influenced by the accumulation of alluvial and colluvial fans sourced from the uplands bordering the gulf or by the seaward growth (progradation) of the coast, forming sandflats and beach and shell ridges, the sediments for which have largely resulted from biogenic processes. Relict desert dunes also provided a large source of terrestrial sand for the coast as they occupied the exposed gulf during the Last Glacial Maximum, 21 ka ago, and were swept landwards as the sea rose to its present level some $7 \mathrm{ka}$ ago.

\section{Notes}

1 Drexel, J.F., Preiss W.V. \& Parker, A.J. (Eds) (1993). The geology of South Australia. Vol. 1. The Precambrian. Geological Survey of South Australia, Bulletin 54, 242 pp.

2 Johns, R.K. (1961). Geology and mineral resources of southern Eyre Peninsula. Geological Survey of South Australia, Bulletin 37, 102 pp.

3 Benbow, M.C., Lindsay, J.M. \& Alley, N.F. (1995). Chapter 1, Eucla Basin and palaeodrainage. In: Drexel, J.F. \& Preiss, W.V. (Eds), The geology of South Australia. Vol. 2, The Phanerozoic. South Australian Geological Survey Bulletin, 54, pp. 178-186.

4 Bourman, R.P. (1989). Investigations of ferricretes and weathered zones in parts of southern and southeastern Australia — a reassessment of the 'laterite' concept. Unpublished PhD 
thesis, The University of Adelaide, $495 \mathrm{pp}$.

5 Schwartz, M.P. (2003). Explanatory Notes for the Lincoln 1:250 000 geological map. Geological Survey of South Australia, Sheet SI5311.

6 Parker, A.J., Daly, S.J., Flint, D.J., Flint, R.B., Preiss W.V. \& Teale, G.S. (1993). Chapter 4, Palaeoproterozoic. In: Drexel, J.F., Preiss W.V. \& Parker, A.J. (Eds), The geology of South Australia. Vol. 1, The Precambrian. Geological Survey of South Australia, Bulletin 54, pp. 51-104.

7 De Deckker, P., Bauld, J. \& Burne, R.V. (1982). Pillie Lake, Eyre Peninsula, South Australia: Modern environment and biota, dolomite sedimentation and Holocene history. Transactions of the Royal Society of South Australia, 106, 169-182.

8 Johns (1961).

9 Fenner, C. (1944). Gnamma holes. In: Fenner, C., Mostly Australian. Georgian House, Melbourne, pp. 113-115.

10 Short, A.D. (2006). Beaches of the South Australian coast and Kangaroo Island: A guide to their nature, characteristics, surf and safety. Sydney University Press, Sydney, 346 pp.

11 Pillans B. \& Bourman, R.P. (1996). The Bruhnes/Matuyama Polarity transition (0.78 Ma) as a chronostratigraphic marker in Australian regolith studies. Australian Geological Survey Organisation, Australian Journal of Geology and Geophysics, 16 (3), 289-294.

12 Parker, A.J. (1998). Explanatory notes for the WHYALLA, South Australia: 1:250 000 geological series: sheet SI53-8. Geological Survey of South Australia.

13 Flint, R.B. (1993). Chapter 5, Itledoo basin. Blue Range Beds. In: Drexel, J.F., Preiss W.V. \& Parker, A.J. (Eds), The geology of South Australia. Vol. 1, The Precambrian. Geological Survey of South Australia, Bulletin 54, p. 142.

14 Pillans, B. \& Bourman, R.P. (2001). Mid Pleistocene arid shift in southern Australia, dated by magnetostratigraphy. Australian Journal of Soil Research, 39, 89-98.

15 Parker, A.J. \& Flint, R.B. (Compilers) (1983). WHYALLA map sheet. Geological Atlas 1: 250000 Series. Geological survey of South Australia, sheet S153-8.

16 Short, A.D., Buckley, R.C. \& Fotheringham, D.G. (1989). Preliminary investigations of beach ridge progradation on Eyre Peninsula and Kangaroo Island. Transactions of the Royal Society of South Australia, 113, 145-162.

17 Short, Buckley \& Fotheringham (1989).

18 Butler, A.J. Depers, A.M., McKillup, S.C. \& Thomas, D.P. (1977). Distribution and sediments of Mangrove Forests in South Australia. Transactions of the Royal Society of South Australia, 101 (1), 35-44.

19 Belperio, A.P. (1995). Quaternary. In: Drexel, J.F. \& Preiss, W.V. (Eds), The geology of South Australia. Vol. 2, The Phanerozoic. South Australian Department of Mines and Energy, Bulletin 54, pp. 219-280.

20 Short (2006).

21 Short, Buckley \& Fotheringham (1989).

22 Short, Buckley \& Fotherinham (1989).

23 Short, Buckley \& Fotheringham (1989). 



\section{The Bight Coast - West coast of Eyre Peninsula}

\subsection{Introduction}

Extending from the Western Australian border near Wilson Bluff to Cape Carnot and Cape Wiles, south of Port Lincoln, this section of coast covers approximately $1400 \mathrm{~km}$. Although it is the longest section of coastline described in this book, it has sufficient integrity to consider it a discrete unit. The west coast of Eyre Peninsula forms the eastern side of the Great Australian Bight, the general shape of which was inherited from the continental rifting and separation from Antarctica some $43 \mathrm{Ma}$ ago. ${ }^{1}$ There is not a perfect jigsaw fit of the current Australian and Antarctic coasts, but if the edges of the continental shelves, which separate continental and oceanic crust, are used, then the fit is much better. All of the coastline is underlain by crystalline rocks (granites, gneisses, volcanic rocks and metamorphosed sediments) of the ancient and highly stable Gawler Craton (Figure 10.1). ${ }^{2}$

The Bight coastline has remained tectonically stable during the Pleistocene. On Eyre Peninsula there is no spectacular sequence of Pleistocene coastal dune barriers as in the southeast of South Australia, where the land has been progressively uplifted to record successive interglacial high sea levels. The stability of the Gawler Craton, which underlies Eyre Peninsula, caused succeeding interglacial high sea levels to merge, rework and overlap with the previous ones. ${ }^{3}$ However, distinct Eocene shorelines ${ }^{4}$ in the Eucla Basin are marked by coastal barrier systems similar to the modern Murray Mouth and Coorong, forming relict strandlines, lagoons, estuaries, coastal barriers and extensive coastal sand dunes and beach ridges some $300 \mathrm{~km}$ inland of the modern coastline (Figure 10.2). 


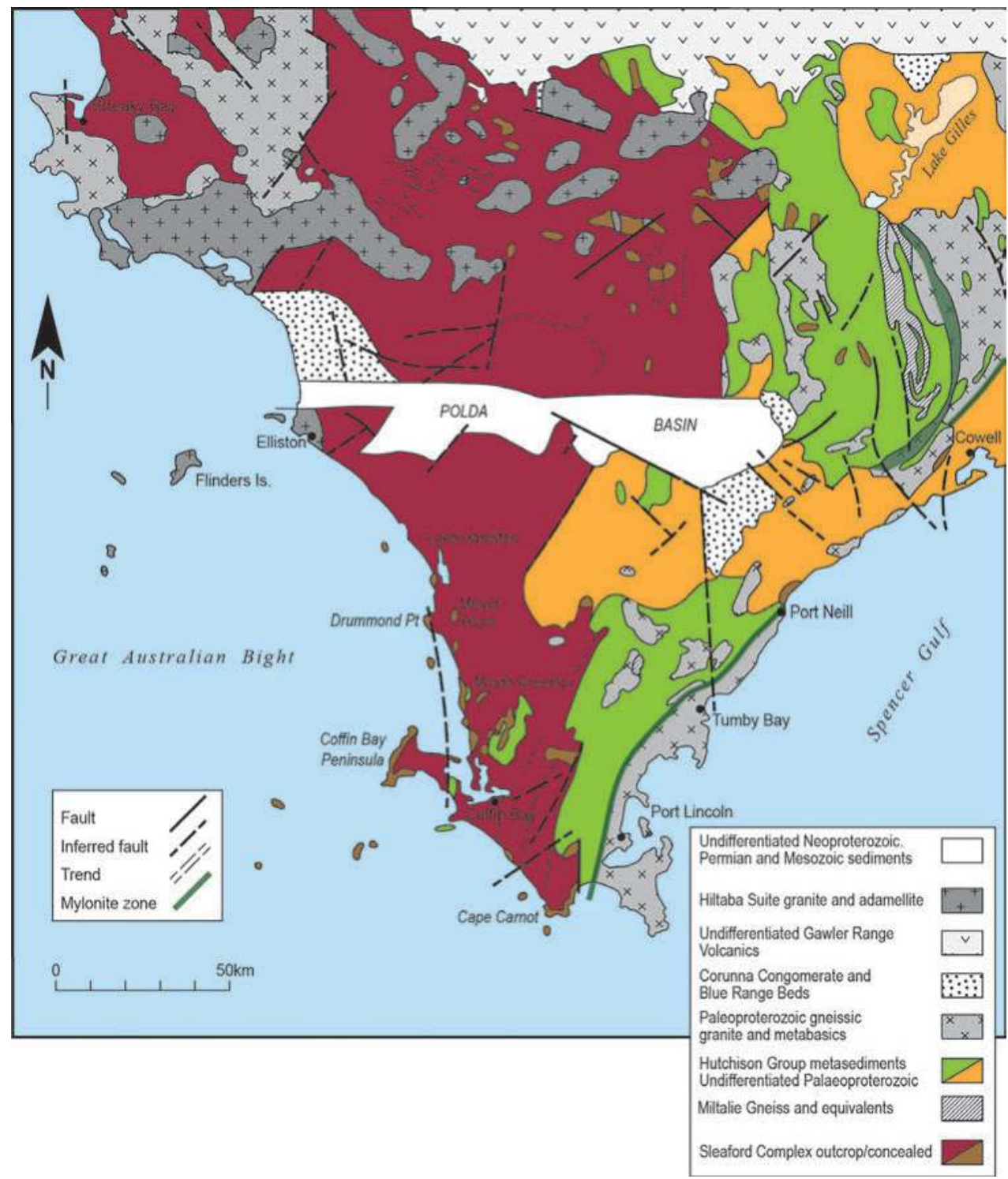

Figure 10.1 Geological map of Eyre Peninsula, showing the various ancient rocks of the Gawler Craton. These have a marked influence on the character of the coastline by providing resistant headlands and bluffs to the processes of coastal erosion and also by providing a platform for younger sediments that give the coast its variability.

Source: Daly, S.J. \& Fanning, C.M. (1993). Chapter 3, Archaean. In: Drexel, J.F., Preiss, W.V. \& Parker, A.J. (Eds), The geology of South Australia. Vol. 1, The Precambrian. Geological Survey of South Australia, Bulletin 54, pp. 33-50. Modified and reproduced with permission of the Department of State Development's Resources and Energy Group. 
Ongoing stability of the coast since the Last Interglacial (132 to $118 \mathrm{ka}$ ) is indicated by the constant elevation of marine shells of that age along the shoreline. ${ }^{5}$ Marine shells including the subfossil Anadara trapezia occur at a consistent height of near $2 \mathrm{~m}$ APSL, so they have been little affected by land movements, as they have in other parts of the State. The presence of Anadara indicates that inner shelf waters were warmer, accentuated by an enhanced Leeuwin Current, which moves south along the western side of Australia before flowing easterly along the Great Australian Bight.

Aeolianite (dune calcarenite) blankets the landscape along the coast and well inland. Aeolianite consists of former coastal sand dunes up to $100 \mathrm{~m}$ high which have been lithified (that is, turned into a harder rock). The calcrete assists the development of steep cliffs eroded into the former dunes, as it reduces erosion from above, protecting the underlying softer aeolianite. Occasionally, isolated ridges formed independently and now contain near-coastal lakes, such as Lake Hamilton.

There are no significant streams that impact on the entire coastline of western Eyre Peninsula, due to the arid to semi-arid climate and the porous nature of the aeolianite and other limestones. Occasional, small V-shaped valleys at the coast have been left hanging by coastal erosion, which operates faster than downcutting by surface runoff. The overriding source of sand for the modern-day beaches and dunes is from offshore sources (broken-up marine shells) and from the reworking of pre-existing dunes and marine deposits.

During the Pleistocene, particularly during the last 1 million years, global sea level has successively fallen and risen as ice sheets have waxed and waned over periods of 100000 years. With every ice age, sea level fell to about $125 \mathrm{~m}$ below present sea level, and as the ice melted (an interglacial event) sea level rose to approximately the present level. Successive sea level rises encroached on a nearly stable landmass, sweeping sediment across the exposed continental shelf landwards as it did so. Consequently, these events caused huge volumes of sand to amass at the shoreline, from where the sand was blown inland, blanketing the landscape.

During the Last Interglacial (132 to $118 \mathrm{ka}$ ago), along the South Australian coast, sea level rose to $2 \mathrm{~m}$ higher than present sea level, when the sea flooded into interdune depressions, tidal inlets and rare stream valleys. Sandflats, mangrove forests and samphire swamps now occupy these former inlets, many of which are being infilled with bioclastic debris. Sometimes recent sand dunes have blocked these inlets, forming coastal lakes. The elevated last interglacial shoreline focused erosion on headlands and islands, providing sediment for sandy beaches and sand dunes. Last interglacial shoreline successions have been identified in many places, such as Lake Newland, Venus Bay and Waterloo Bay at Elliston.

The most recent rise in sea level occurred after the Last Glacial Maximum, 21 ka ago, when the shoreline was as much as $125 \mathrm{~m}$ below present sea level. Much of the 
continental shelf was exposed, allowing plants and animals to establish themselves on hills that were later to become islands. Sea level rose rapidly at a rate near $1 \mathrm{~cm}$ per year between 20 to $7 \mathrm{ka}$ ago, when it stabilised at close to its present elevation. There is an ongoing debate as to whether global sea level stood up to $1 \mathrm{~m}$ higher than present some 6 to $4 \mathrm{ka}$ ago during the mid-Holocene Hypsithermal. The sea level rise following the Last Glacial Maximum submerged pre-existing depressions, forming islands, headlands and bays of varying dimensions, thereby establishing the basic form of the present-day coastline. Cliffed headlands formed on hard outcrops of old rocks of the Gawler Craton or more resistant zones in the coastal aeolianite. Bays occupied intervening areas, especially in last interglacial inlets or where coastal aeolianite barriers were breached. Extensive Holocene shell ridges up to $2 \mathrm{~m}$ APSL occur around the margins of many bays.

Sand dunes, distinctive features of the Bight Coast, vary from small blowouts to huge transgressive dune fields, and vary in colour depending on the sand source. White dunes have derived from modern shell fragments or granitic bedrock, yellowish dunes from reworked, slightly weathered aeolianite deposits and brown dunes from weathered bedrock or relict desert dunes. Cliff-top dunes ${ }^{6}$, separated from the nearby beach by cliffs up to $100 \mathrm{~m}$ high, are common. These dunes have mainly developed by sand accumulating at the cliff foot, forming a ramp for the sand to migrate to the cliff top, after which coastal erosion removed the ramp, leaving the dune perched on the cliff top. Such dunes may also form by dunes migrating from an upwind beach across a headland to a cliff top on the other side of the peninsula, such as on Point Lowly (Chapter Nine). Cliff-top dunes may also form during a high sea level, only to be stranded as sea level falls or as the land is uplifted. This situation does not apply to the stable western coast of Eyre Peninsula, as the sea level during recent times has not been sufficiently high to account for the elevation of the stranded dunes. Reworking of older aeolianite dunes or former desert dunes some $21 \mathrm{ka}$ old, which intersect the coast, might also result in cliff-top dune formation. During the Last Glacial Maximum, when sea level was low $(-125 \mathrm{~m})$ and conditions were cold and arid, parallel longitudinal desert sand dunes oriented northwest-southeast developed over much of Eyre Peninsula.

Preceding the separation of Australia and Antarctica, downwarping developed basins such as the Eucla Basin province, which were subsequently infilled with sediments including marine deposits. The entire coast of western Eyre Peninsula occurs within the Eucla Basin (Figure 10.2). Most importantly, sediments deposited include the limestones that, after regional uplift, have been eroded to form the spectacular cliffed coastline of the Nullarbor Plain (See Figure 1.13). Following the separation of Australia and Antarctica, a seaway developed, forming the south coast of Australia. Sediments up to $300 \mathrm{~m}$ thick accumulated in the downwarped Eucla Basin during Paleogene and Neogene times between $45 \mathrm{Ma}$ and $4 \mathrm{Ma}$ years ago, when the coastline stood up to $300 \mathrm{~km}$ inland of the present coast. Half of the full length of the Eucla 


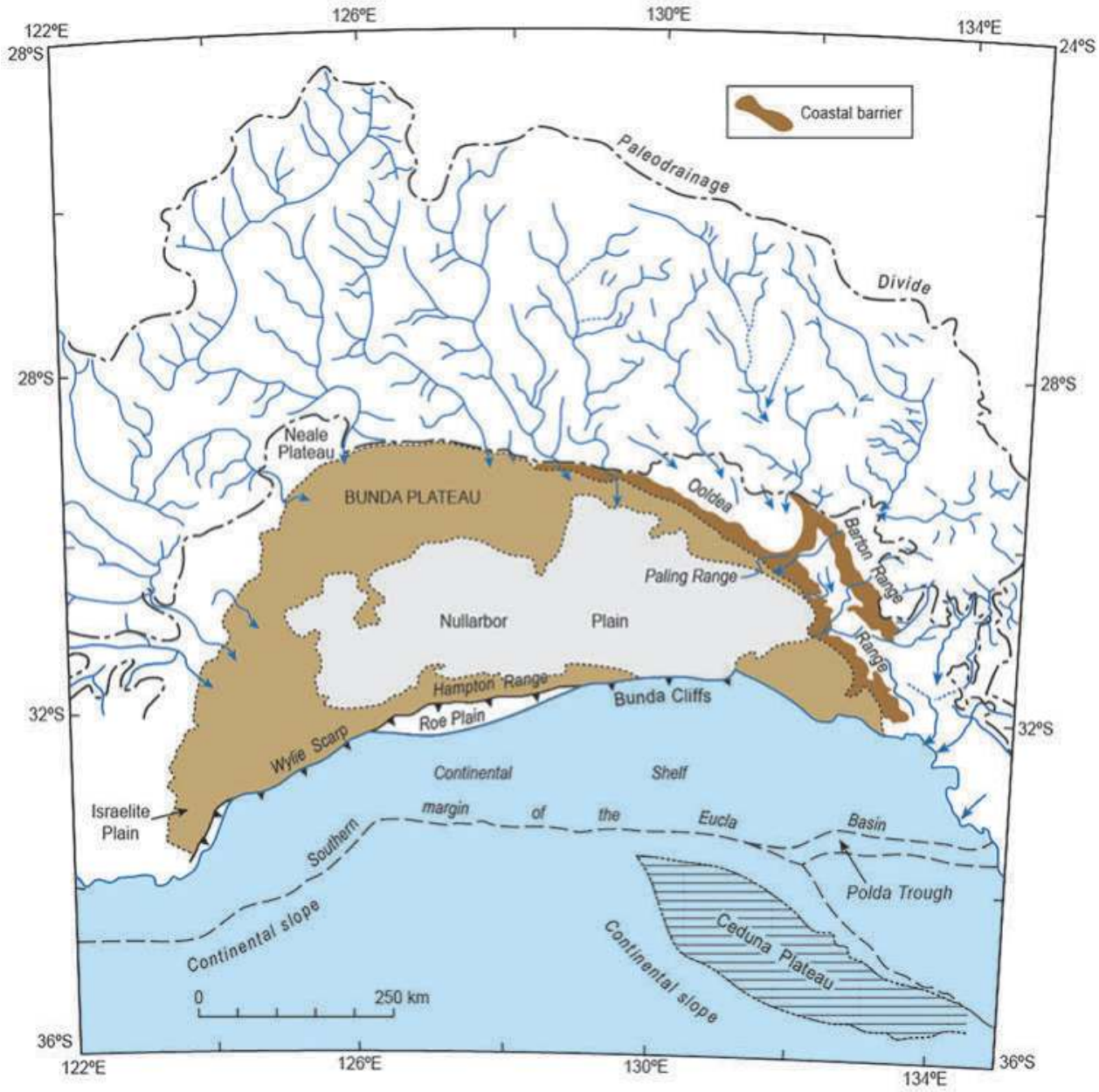

Figure 10.2 The Eocene Eucla Basin, which formed after the separation of Australia and Antarctica. Note the position of the Eocene coastline, the fossil valleys draining to it, the modern shoreline, the continental shelf and the continental slope. The evolution of the South Australian coastline began after the initial separation of the Australian and Antarctic continents and the ingress of the Eocene seas some $50 \mathrm{Ma}$ ago, forming the Great Australian Bight. This beginning is best illustrated by the position of the $2000-\mathrm{km}$ long Eocene coastline in the Eucla Basin that straddles the WA/SA border, extending to Port Lincoln in South Australia.

Source: Daly, S.J. \& Fanning, C.M. (1993). Chapter 3, Archaean, In: Drexel, J.F., Preiss, W.V. \& Parker, A.J. (Eds), The geology of South Australia. Vol. 1, The Precambrian. Geological Survey of South Australia, Bulletin 54, pp. 33-50. Modified and reproduced with permission of the Department of State Development's Resources and Energy Group. 


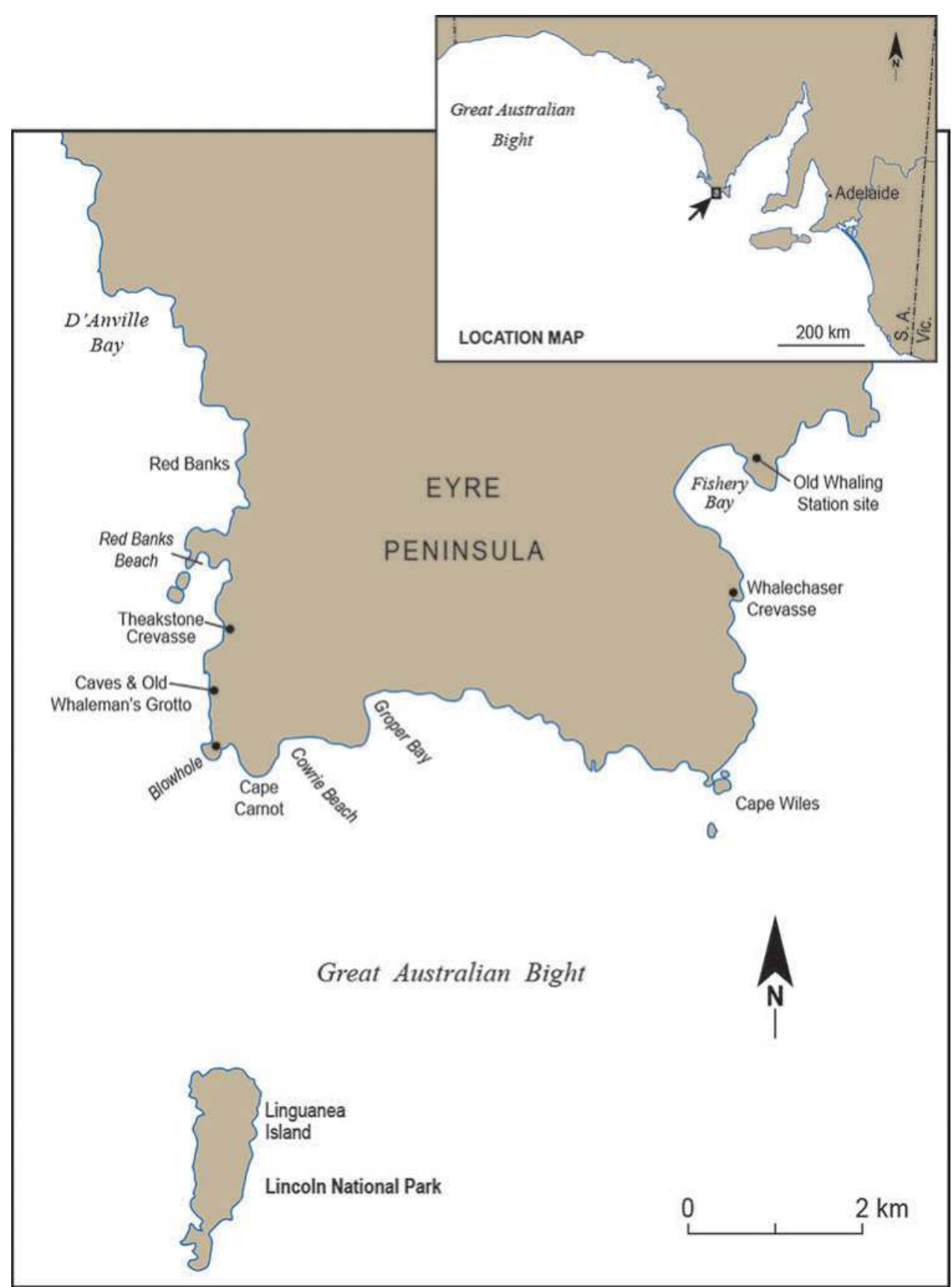

Figure 10.3 Map of the Whalers Way coastline. Aeolianite-capped cliffs, headlands and islands are buttressed by resistant crystalline rocks.

Source: Author's own work, RPB. 
Basin coastline of $2000 \mathrm{~km}$ lies in South Australia. Although no major river systems impact on the coastline today, during the Paleogene and Neogene many streams, now paleochannels, entered the sea via coastal barrier systems (Figure 10.2).

This chapter presents a regional description of the Bight Coast from Whalers Way in the south to the Nullarbor cliffs in the far west. It includes Whalers Way; Coffin Bay Peninsula and Coffin Bay; Frenchman Bluff to Elliston; Avoid Bay, Lake Newland, Talia Beach and Venus Bay to Baird Bay; Streaky Bay area; Smoky Bay and the Ceduna coastline; Point Peter to Rocky Point; Fowlers Bay; Fowlers Bay to the Head of the Bight; and the Bunda Cliffs of the Nullarbor.

\subsection{Whalers Way}

The most southerly section of the Bight Coast of Eyre Peninsula is Whalers Way, some $32 \mathrm{~km}$ south of Port Lincoln (Figure 10.3). It is a spectacular coast, displaying classic features of erosion due to the highly active wave and swell climate from the open ocean. Cliffs, cut in Pleistocene aeolianite (Figure 10.4) and up to $130 \mathrm{~m}$ high,

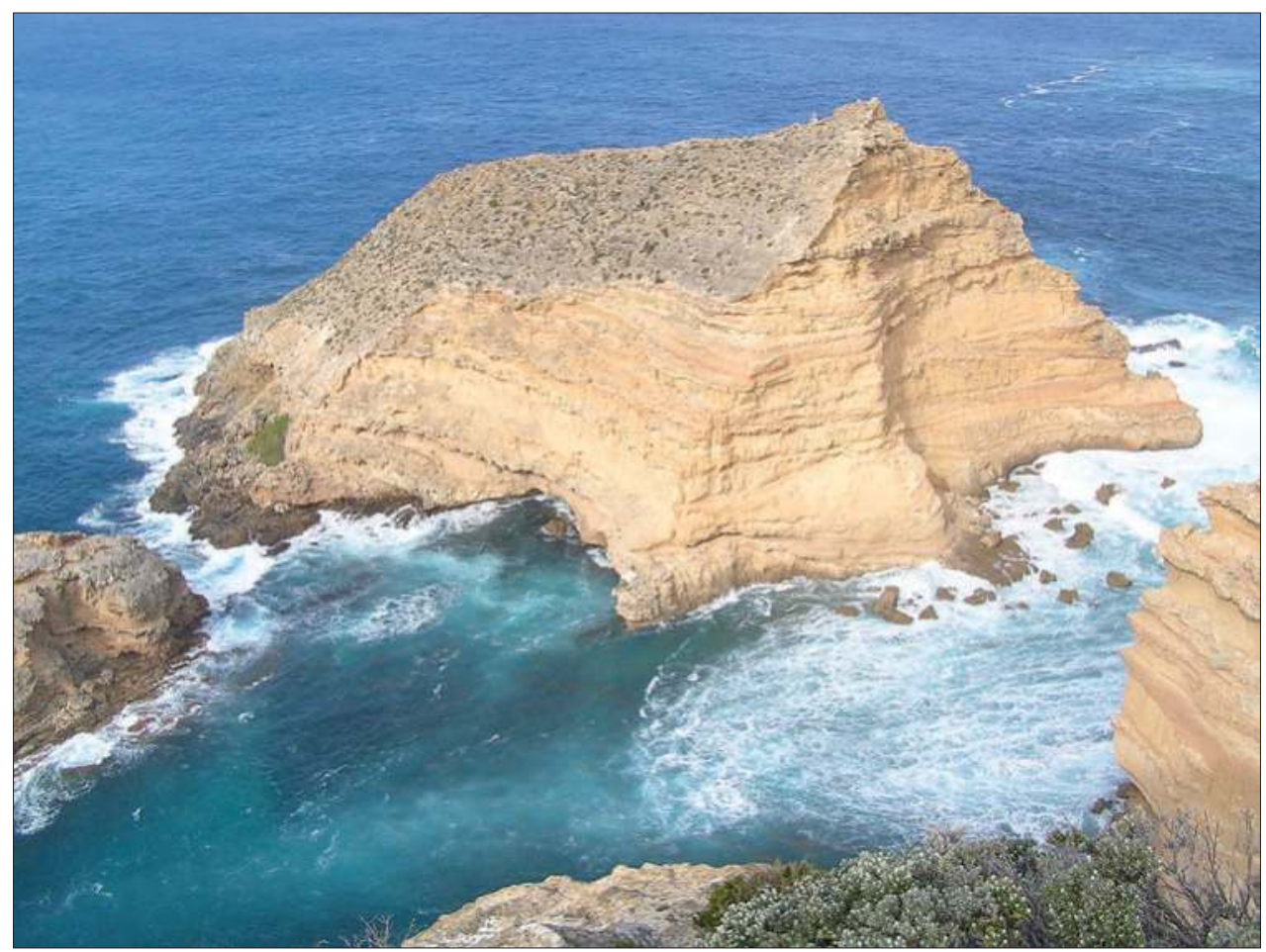

Figure 10.4 Sea stack cut in aeolianite deposits near Cape Wiles. The stack rests on old crystalline rocks of the Gawler Craton.

Source: Author's own work, RPB. 


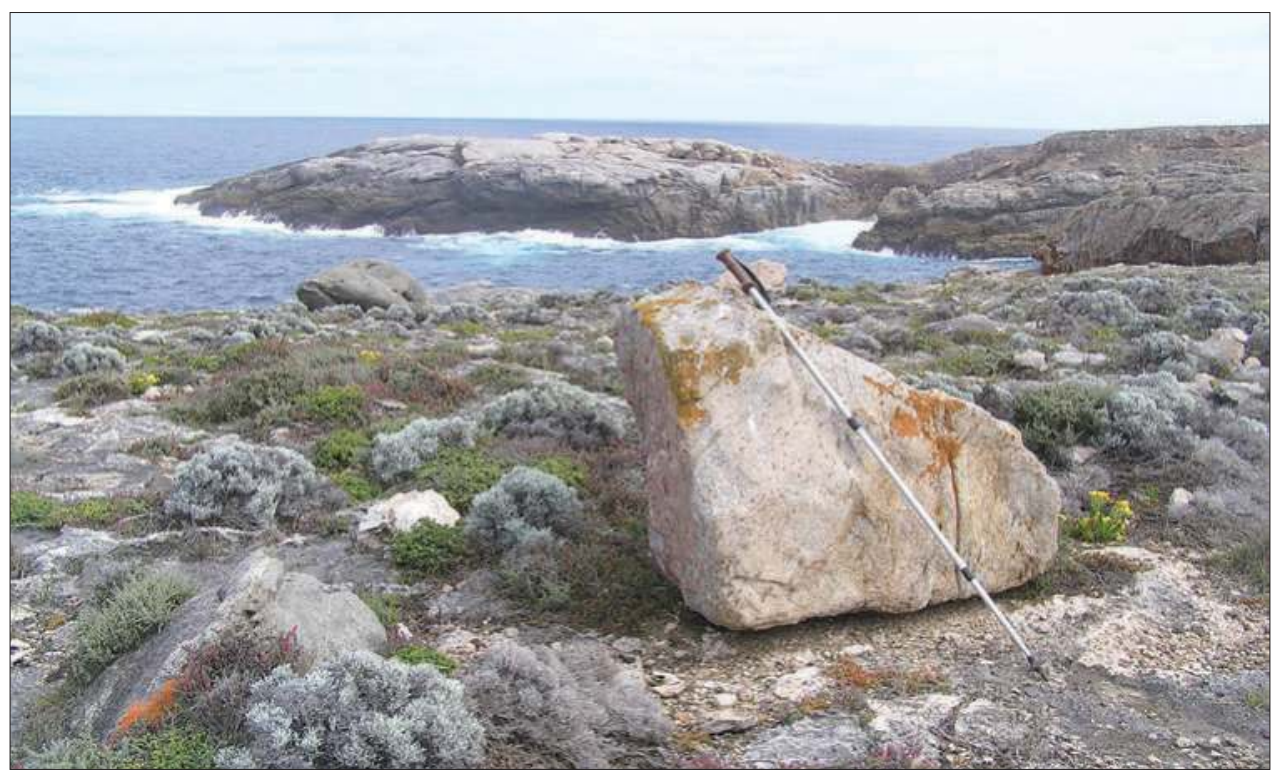

Figure 10.5 Large boulder of gneiss at Cape Carnot, resting on last interglacial calcrete about $20 \mathrm{~m}$ APSL, thrown up by a megawave. The hiking stick provides a scale.

Source: Author's own work, RPB.

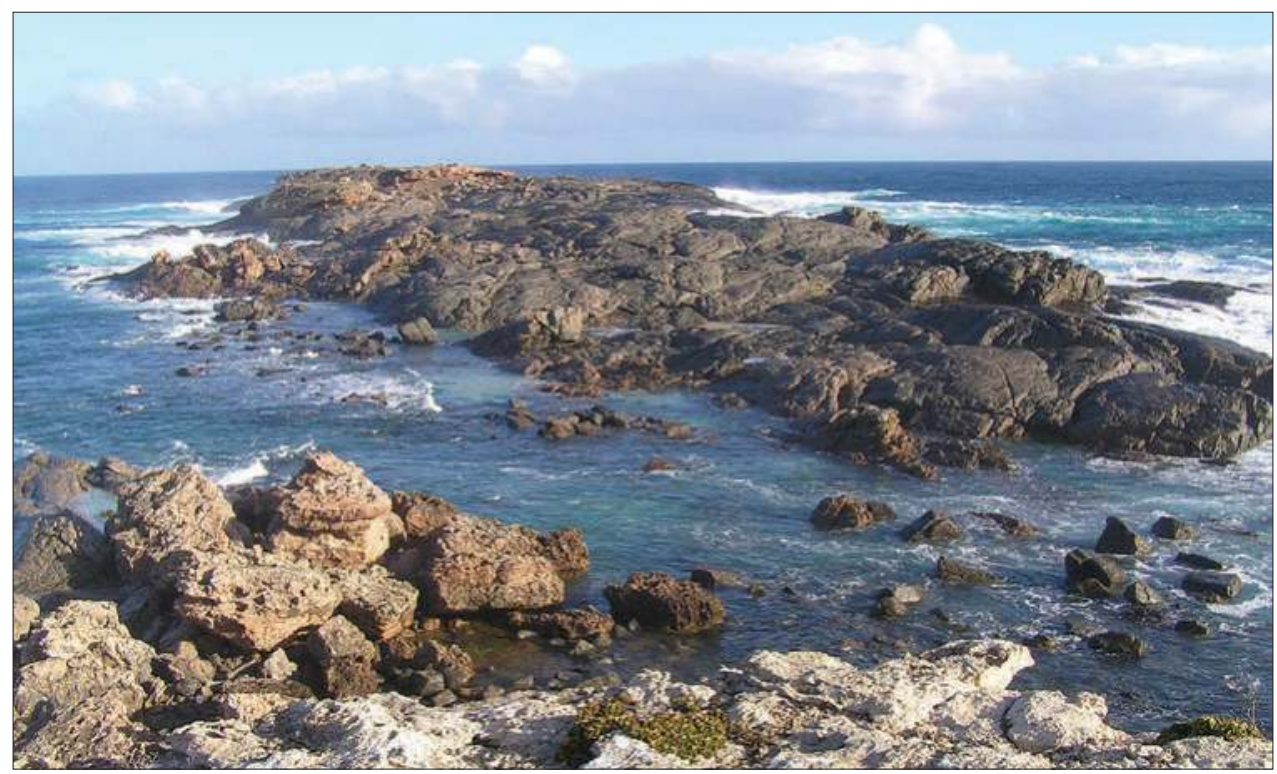

Figure 10.6 This granitic domed inselberg is being resurrected from beneath its aeolianite cover at Red Banks Beach. Aeolianite is still present at the far end of the inselberg.

Source: Author's own work, RPB. 


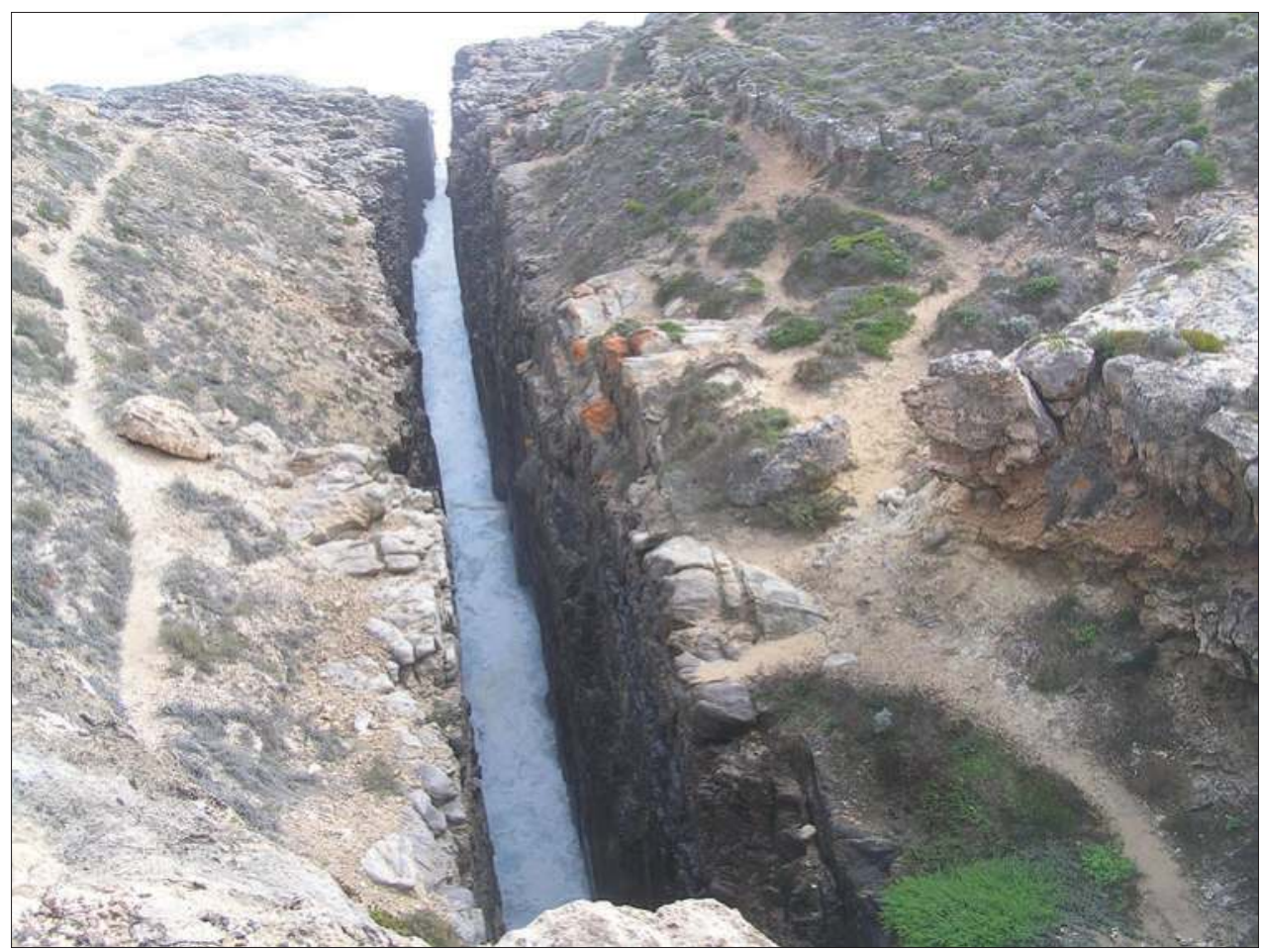

Figure 10.7 A remarkable cleft, the Theakstone Crevasse has been eroded into the ancient crystalline rock along a rock structure, possibly a former, more easily eroded dyke. The crevasse becomes a cave, which extends $30 \mathrm{~m}$ underground. The walls of the crevasse are almost $10 \mathrm{~m}$ high.

Source: Author's own work, RPB.

fringe the coastline, but the highly resistant ancient crystalline basement rocks, on which aeolianite has been deposited, determine the basic shape of the coastline. Many generations of former sand dunes now cemented with calcium carbonate are distinguishable by multiple buried fossil soils (paleosols). Collectively, such sequences are referred to as the Bridgewater Formation, and they vary in age from 125 ka to more than $2 \mathrm{Ma}$. Landform assemblages of this actively eroding coast include cliffs, caves, sea stacks, islands, crevasses, shore platforms, rock holes, coves, blowholes and small embayments. Large boulders of Gawler Craton gneiss, some weighing up to a quarter of a tonne and up to $18 \mathrm{~m}$ above sea level occur on Cape Carnot, enigmatically overlying much younger aeolianite about 125 ka old (Figure 10.5). In some other parts of the world, the positions of such boulders have been attributed to powerful storm waves or to tsunamis. ${ }^{7}$ 


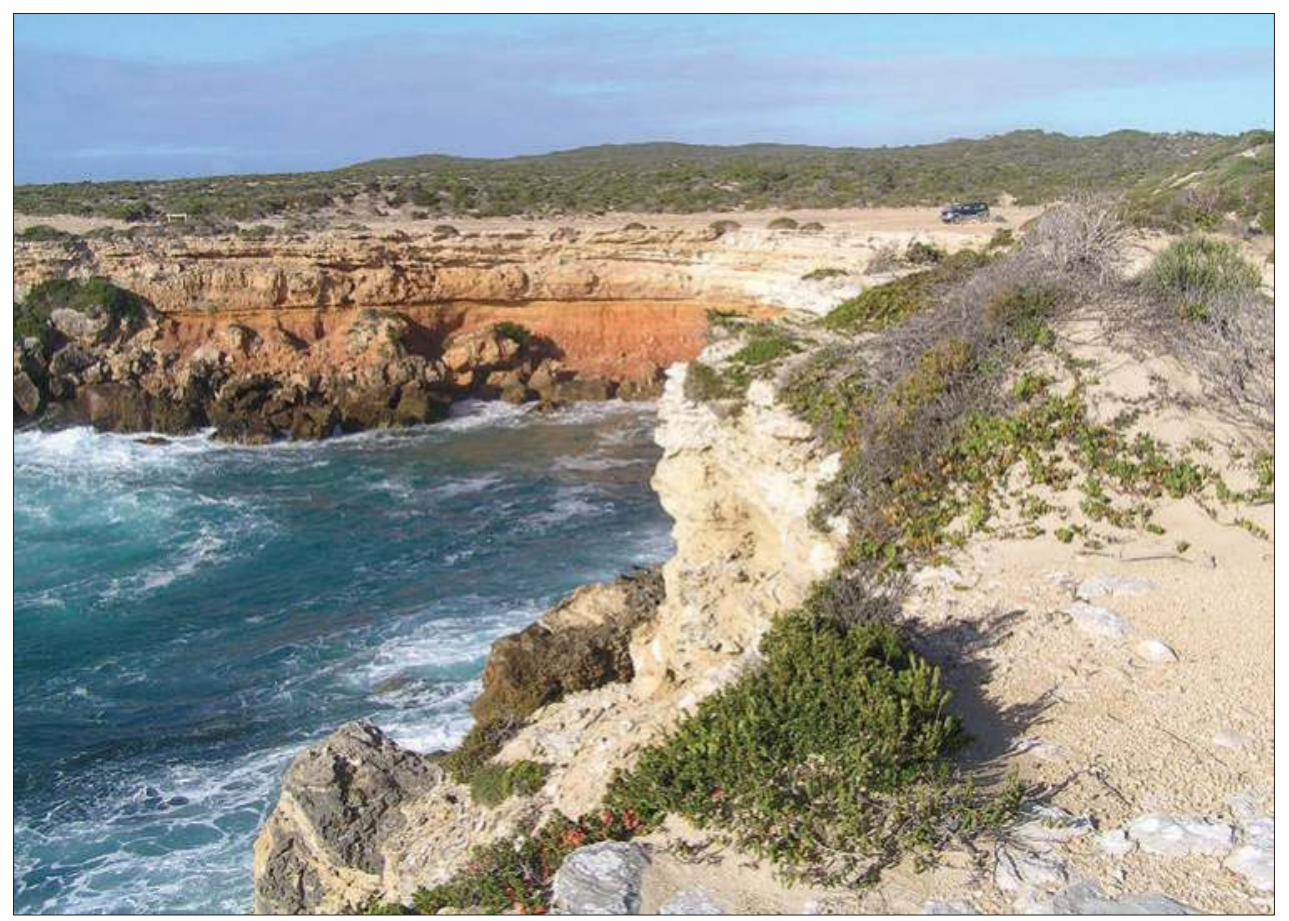

Figure 10.8 An iron-enriched weathered zone at Red Banks is overlain by aeolianite. Source: Author's own work, RPB.

Aeolianite of the Bridgewater Formation overlies crystalline shield rocks of the Gawler Craton, and where the unconformity between the two is close to present sea level they are being eroded to reveal the older basement rocks (Figure 10.6). The rocks at Cape Carnot, the most southwesterly point on Eyre Peninsula, were once regarded as the oldest rocks in South Australia at 2.64 billion years, but the current record now goes to rocks 3.15 billion years old near Iron Knob. ${ }^{8}$ A spectacular cleft has been eroded into them at Theakstone Crevasse (Figure 10.7). In places, the rocks have been weathered, such as at Redbanks, forming an iron-rich regolith (Figure10.8), which is more easily eroded than the unweathered rock.

\subsection{Coffin Bay Peninsula}

Coffin Bay Peninsula forms the western fluke of the 'anchor', which makes up the southern portion of Eyre Peninsula (Figure 10.9). Jussieu Peninsula is the eastern fluke, and Whalers Way the crown of the 'anchor'. The coastline from Red Banks at Whalers Way to Shoal Point $(20 \mathrm{~km})$ consists of aeolianite cliffs over $120 \mathrm{~m}$ in places, sporadically buttressed by resistant basement rocks that form shore platforms. This section of coast is being actively eroded: it is extremely crenulated, with dozens of small 
bays, headlands and promontories. Cliff-top dunes extend out from the bay heads. The Cathedral Rocks Wind Farm has been built on this high-energy section of coast, taking advantage of the persistent southwesterly winds. Coffin Bay is sheltered from the open ocean by Coffin Bay Peninsula and other smaller peninsulas, but the south and westerly shores of Coffin Bay Peninsula are very exposed to extreme events: indeed, the southwest-facing shoreline is fronted by the appropriately named Avoid Bay. There is a marked contrast between the exposed and sheltered shores of the peninsula.

From just beyond Shoal Point to Point Avoid, the coastline assumes a smoother appearance. Rocky cliffs are replaced by a sandy beach, which is $15 \mathrm{~km}$ long and backed by an enormous field of sand dunes of many generations. These include Pleistocene aeolianites and vegetated Holocene dunes as well as a currently active dune field that extends up to $10 \mathrm{~km}$ inland. The dune field is generally 20 to $60 \mathrm{~m}$ APSL, but has

Figure 10.9 Coffin Bay Peninsula, showing localities referred to in the text. Source: Author's own work, RPB.
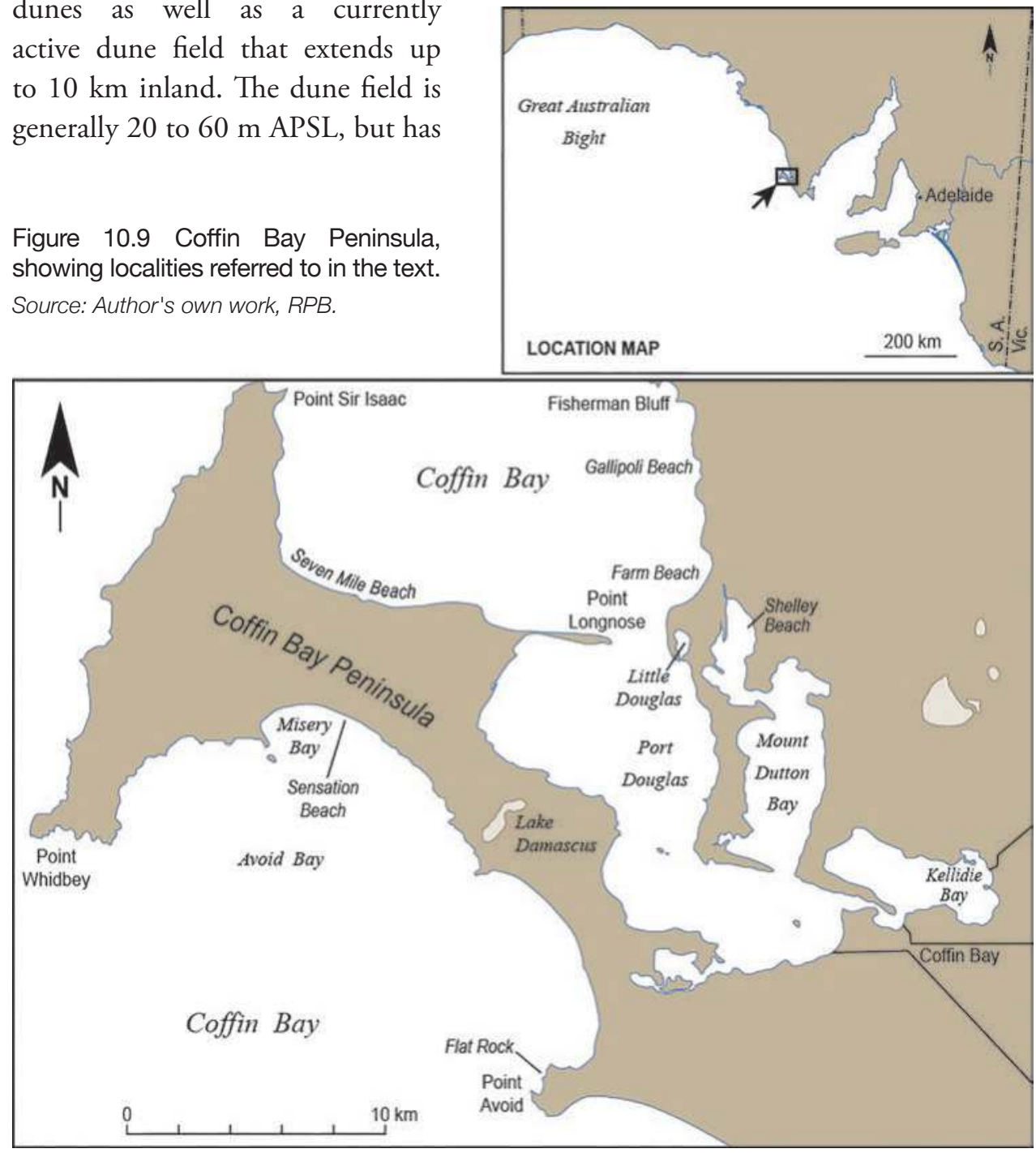


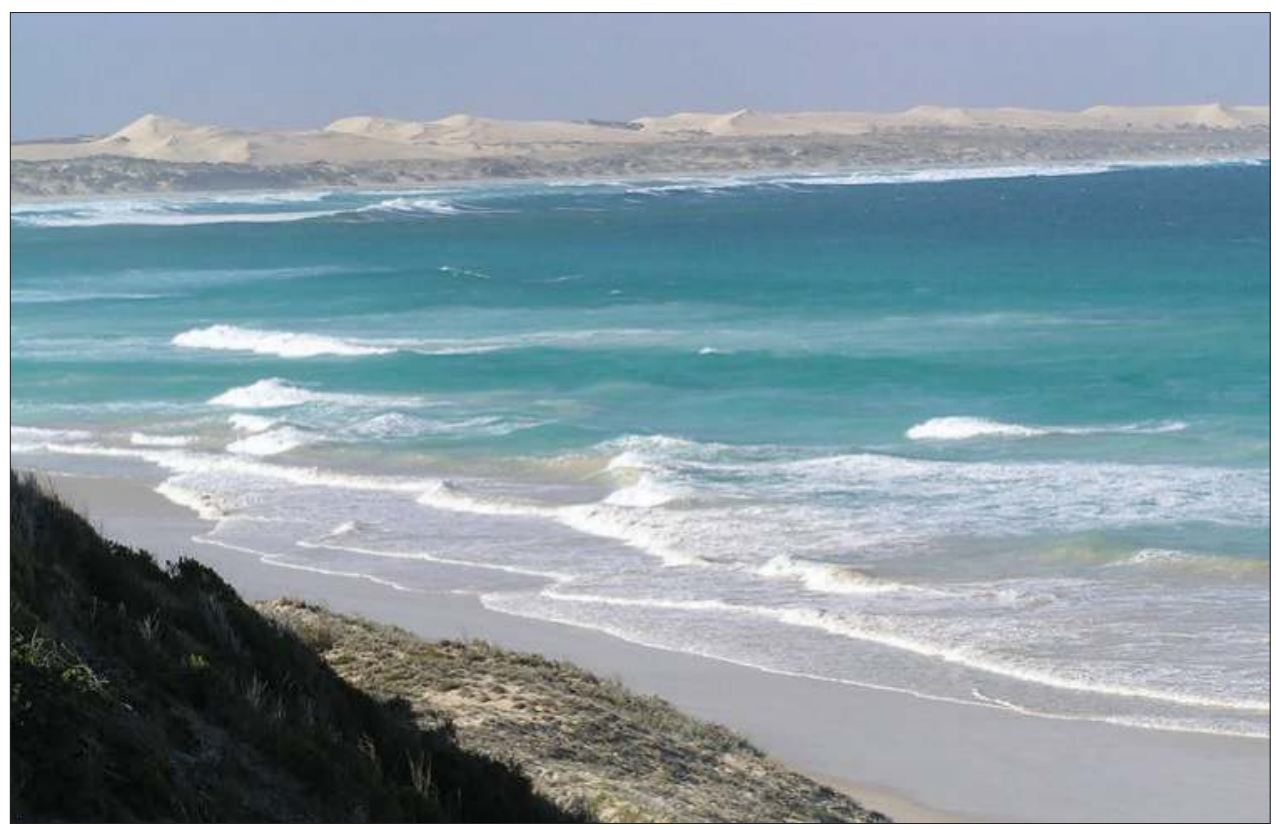

Figure 10.10 The western end of Gunyah Beach (Almonta Beach), with a vegetated foredune and high active dunes behind.

Source: Author's own work, RPB.

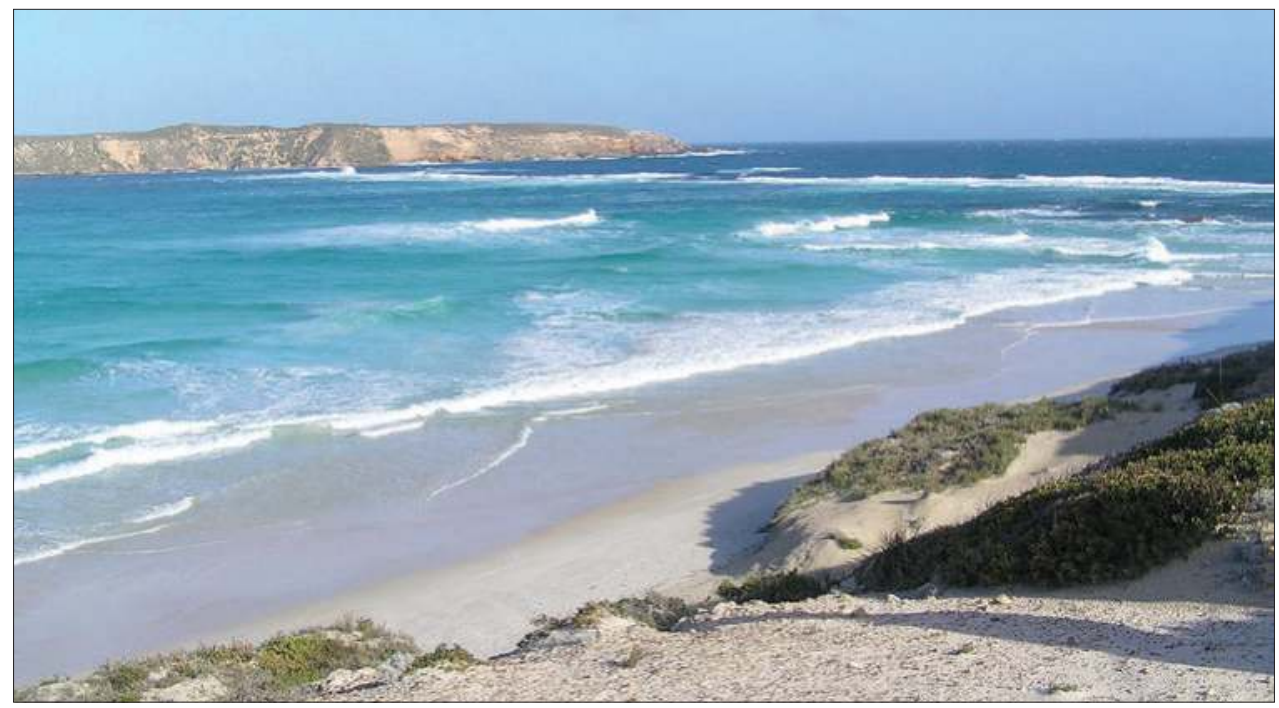

Figure 10.11 Golden Island, which lies off from the Point Avoid headland, causes waves to refract and approach the shore at right angles to each other. Other nearby islands include Price Island and the Whidbey Isles.

Source: Author's own work, RPB. 


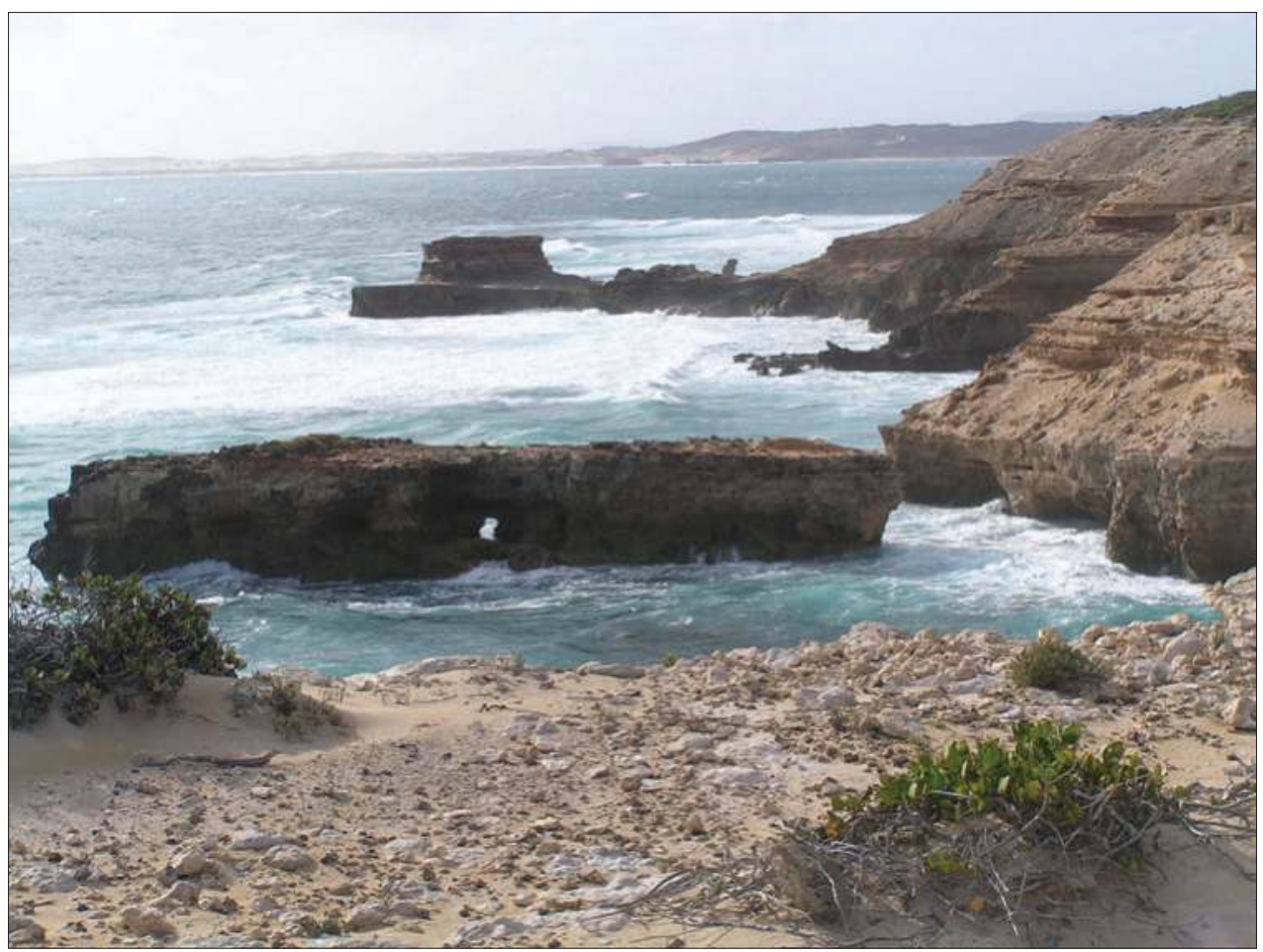

Figure 10.12 Coastal landforms of erosion at Flat Rocks on the northern side of the Point Avoid headland.

Source: Author's own work, RPB.

high points of up to $160 \mathrm{~m}$. Gunyah Beach (Figure 10.10), which fronts the dune field, is one of the highest-energy beaches in South Australia and is characterised by a double offshore bar and trough system broken by huge rips. ${ }^{9}$

\subsection{Avoid Bay}

Avoid Bay extends from Point Avoid to Point Whidbey. Within Avoid Bay, there are several smaller bays separated by hard basement rock outcrops and aeolianite, either as islands (for example, Golden Island, Figure 10.11) or headlands (for example, Flat Rocks, Figure 10.12) The first two bays within Avoid Bay are each about $10 \mathrm{~km}$ long and exhibit similar characteristics. The southern portions comprise aeolianite cliffs interspersed with small beaches, whereas the more northerly parts of the bays have trapped sand, forming more extensive beaches such as at Misery Bay and Sensation Beach as well as opposite Black Rocks. Holocene dunes fixed with vegetation extend across the peninsula, and current mobile dunes are well on the way (Figure 10.13). Rocky outcrops separating small beaches dominate Whidbey Beach, the section of coast which is east of Point Whidbey is $6 \mathrm{~km}$ long. 


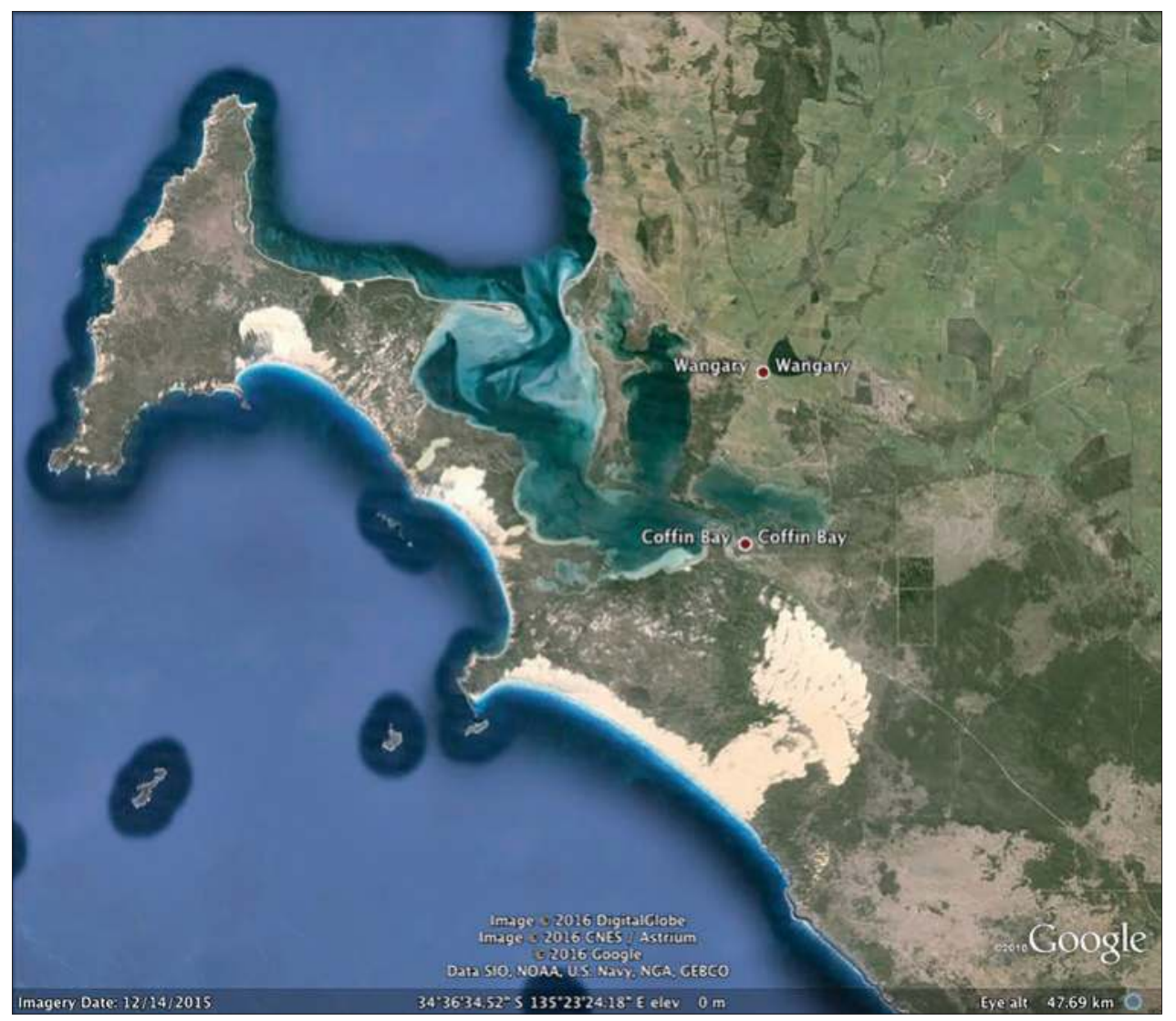

Figure 10.13 The Coffin Bay Peninsula. The dune field in the bottom right-hand corner covers $30 \mathrm{~km}^{2}$, is highly calcareous and has been mined for use as a flux in steel making. Some dunes, now fixed by vegetation, have migrated across the peninsula to the sheltered waters of Coffin Bay.

Source: Google Earth image () 2015 Google.

The west coast of the peninsula, with prominent headlands such as Point Whidbey, Reef Point and Point Sir Isaac, is formed of resistant bedrock capped by aeolianite, while sections of the coastline are draped between rocky headlands up to $40 \mathrm{~m}$ high. Steep aeolianite cliffs and bluffs are interspersed with sandy beaches. Climbing and cliff-top dunes are also present.

\subsection{Coffin Bay}

A series of bays occurs in the more sheltered waters of the northern shore of Coffin Bay Peninsula (Figure 10.9), in strong contrast to the coasts of the west and south, which 
experience high wave energy. Dune sand of many generations, both mobile and fixed, is the major constituent of the peninsula, with the large Lake Damascas occurring in an interdune depression close to sea level.

Sand dominates the shoreline in this protected environment with low wave energy; Point Burgess is a rare bedrock outcrop. This section of protected coast is one of deposition, with bars, dunes, beaches, sandflats and spits leading to the progradation of the shoreline seawards. The sand for Seven Mile Beach has been sourced from now largely vegetated dunes that migrated across the peninsula from Sensation Beach on the south coast. From the eastern end of Seven Mile Beach Point, Longnose has built out some $2 \mathrm{~km}$, separating Coffin Bay from Port Douglas (Figure 10.14).

Sand spits have played a large role in the development of the inner bays of Coffin Bay. The distinctive double-legged shapes of Kellidie and Horse Peninsulas

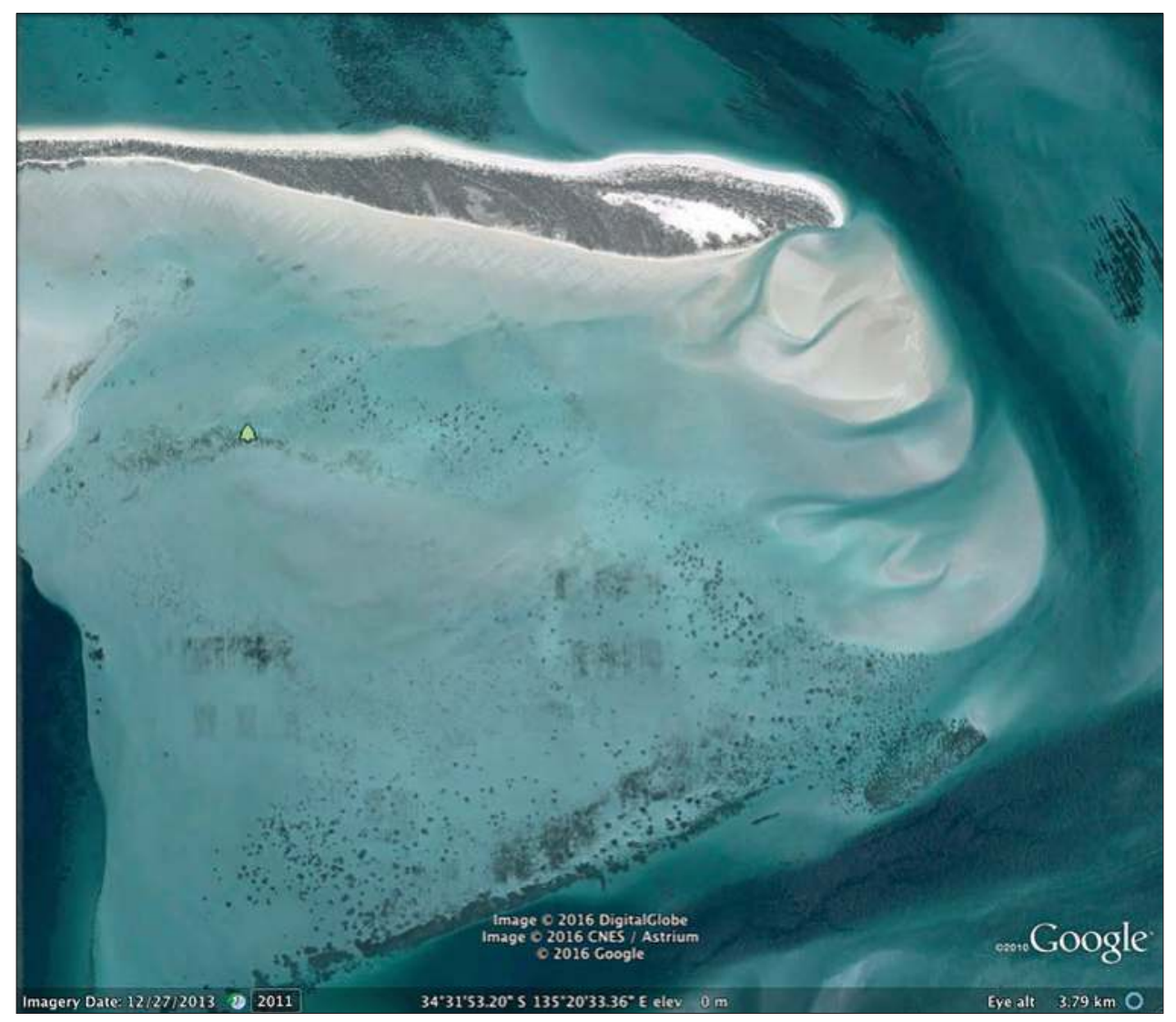

Figure 10.14 Point Longnose, a complex sand spit with truncated ridges of former recurved spits and beach ridges, sandflats and dunes; sand is progressively accumulating at the distal (eastern) end of the spit.

Source: Google Earth image () 2013 Google. 
enclose Kellidie and Mount Dutton Bays (Figures 10.9 and 10.13). These peninsulas, now calcreted and of Pleistocene age, have been built up by dune action and wave activity. They are probably of last interglacial age $(125 \mathrm{ka})$, formed when sea level was $2 \mathrm{~m}$ higher than at present. A smaller recent spit, building from the north, has formed the bay at Little Douglas, and others have contributed to the formation of Big Yangie Bay and Little Yangie Bay. Coffin Bay is relatively shallow (2 to $6 \mathrm{~m}$ deep), tidal action is restricted and numerous sand bars are contributing to its infilling as more sand is moved into the bays than is removed. Numerous sandflats and islands occur within the shallow bays. On the eastern side of the inlet there are low cliffs on eroding sections of the dune calcarenite deposits.

An intriguing feature is the presence of Holocene seashells, forming ridges at the head of Dutton Bay West and around most of the shoreline of Kellidie Bay. The shells are probably about 5000 years old and in places extend up to $1 \mathrm{~m}$ above sea level. Furthermore, some of the shells are paired, suggesting that they have not been thrown up by waves but were deposited during a sea level slightly higher than at present.

\subsection{Frenchman Bluff to Elliston}

The coastline between Frenchman Bluff and Elliston has a near south-north orientation to Point Drummond, generally following the elongated shapes of resistant basement rock outcrops of Mount Greenly, Franklin Lookout, Mount Drummond and Mena Hill. An inferred fault line from Coffin Bay to Point Drummond (Figure 10.1) also parallels this section of coastline. Beyond Point Drummond, which is a prominent seaward protrusion about $4 \mathrm{~km}$ long, the coast trends more to the northwest towards Elliston and has a smoother form in outline. The detailed morphology of the coast is related to the variable elevations and positions of the aeolianite deposits and the underlying resistant bedrock, which fortuitously intersect the shoreline, as well as the blanketing cover of sand dunes.

From Frenchman Bluff, a bedrock-dominated coast extends towards Coles Point, where greater exposure results in higher wave energies. This coast is $6 \mathrm{~km}$ long, with abrupt cliffs and bluffs up to $50 \mathrm{~m}$ high cut into aeolianite. Calcarenite and occasional cliff-top dunes overlie basement rock headlands, with beach cusps occurring on the sandy beaches at the coastal extremities. Greenly Beach, backed by dunes that extend up to $1 \mathrm{~km}$ inland, occurs immediately north of Coles Point between rocky headlands (Figure 10.15). Unusually, the beach sand is brown and may have derived from weathered aeolianite or relict desert dunes. A rocky, crenulated, cliffed coastline with reefs and cliffs $40 \mathrm{~m}$ high extends for $10 \mathrm{~km}$ to Convention Beach.

Beyond Greenly Beach, the next prominent headland is Point Drummond, which is underlain by ancient crystalline granite rocks and aeolianite cliffs $30 \mathrm{~m}$ high. Granite usually produces narrow, steep shorelines as at Coles Point, but at Point Drummond very broad and flat shore platforms have developed. This is because the granitic rocks 


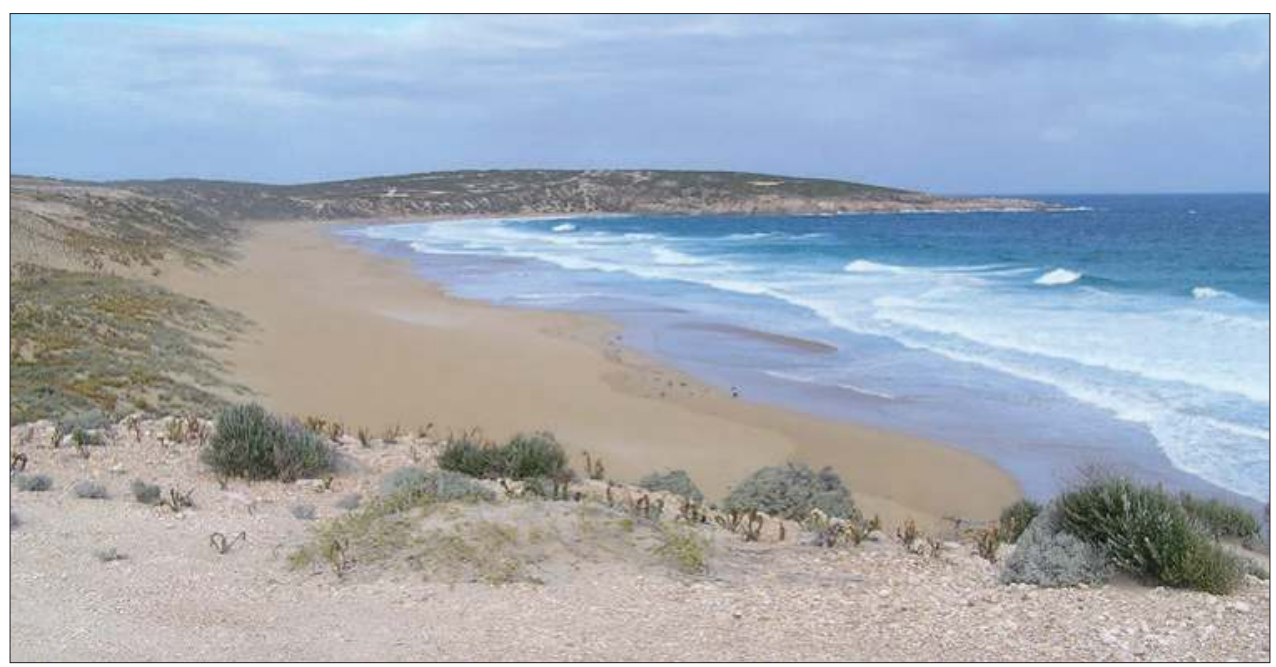

Figure 10.15 View over Greenly Beach towards the rocky headland at Coles Point. Source: Author's own work, RPB.

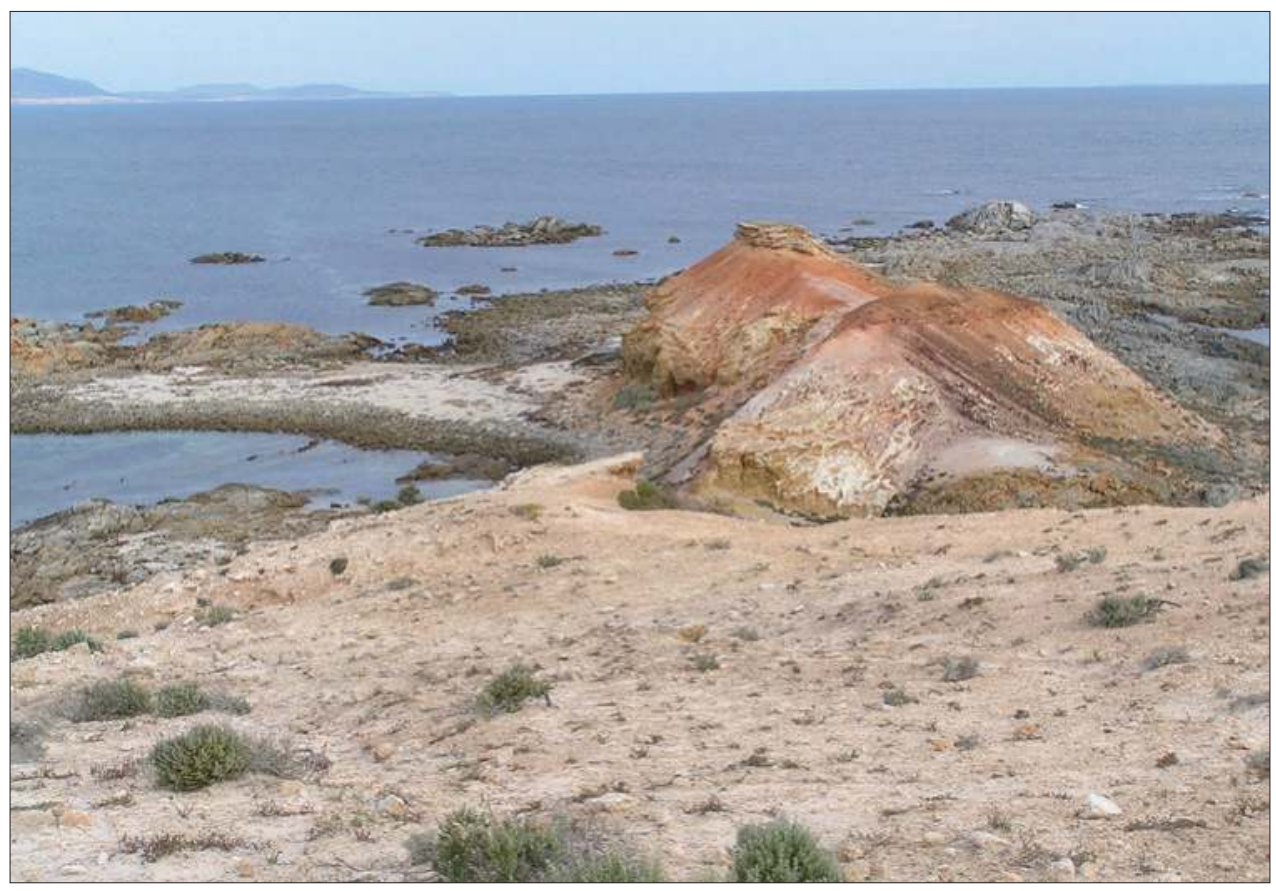

Figure 10.16 Weathering profile $20 \mathrm{~m}$ thick at Point Drummond South, capped by thin beds of aeolianite. Fresh bedrock in the intertidal zone has formed an extensive shore platform as erosion exposes the contact between fresh and weathered bedrock.

Source: Author's own work, RPB. 


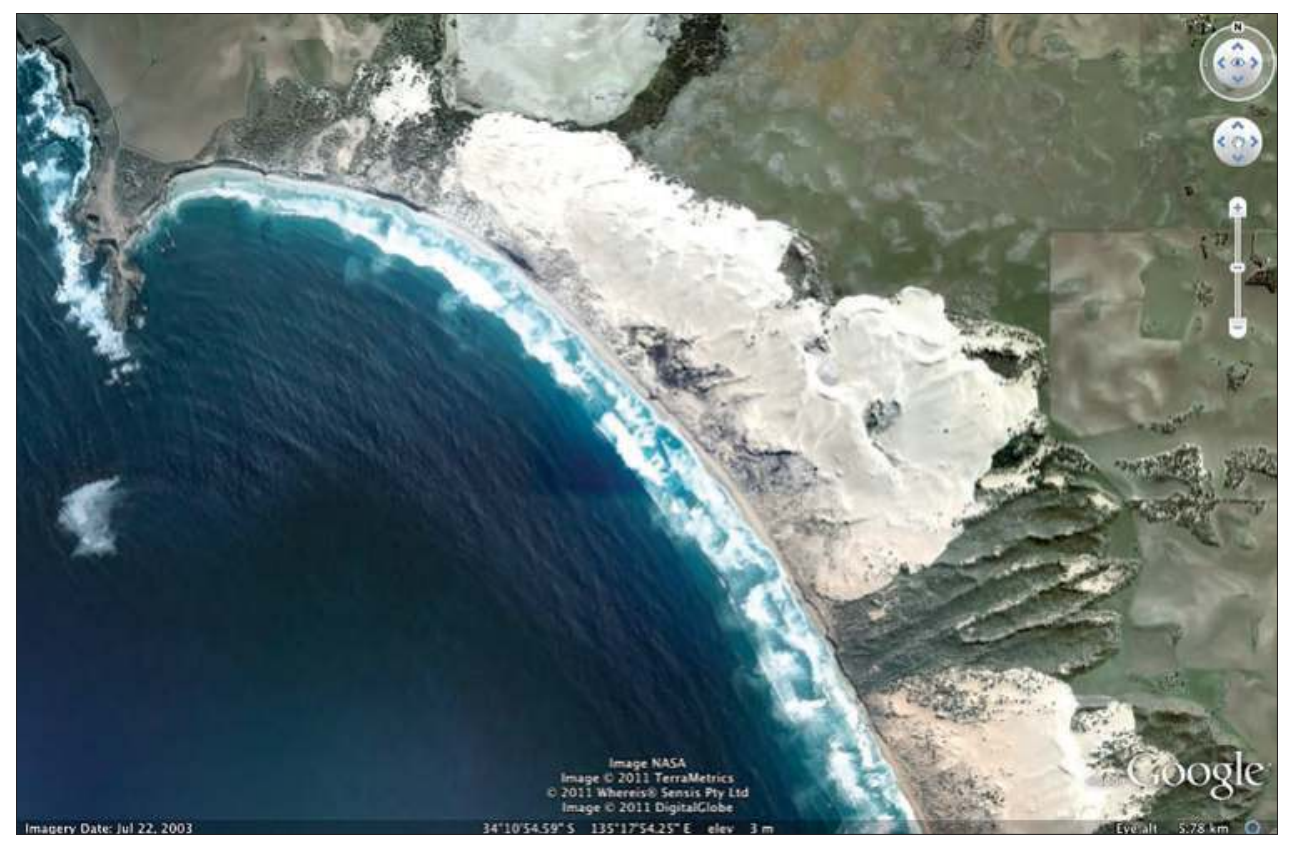

Figure 10.17 Picnic Beach in the lee of Point Drummond South. Note the bare white dunes up to $70 \mathrm{~m}$ high migrating inland from the southwest, the older vegetated parabolic dunes in the bottom right-hand corner and the hummocky stony rises of older calcreted Pleistocene dunes inland of these. Coastal erosion has resulted in some of these dunes becoming clifftop dunes, which extend $12 \mathrm{~km}$ south to Convention Beach.

Source: Google Earth image @ 2003 Google.

have been extensively weathered and the junction between weathered and unweathered rock is coincident with the intertidal zone.

Stripping of the weathered regolith exposing fresh bedrock has produced the extensive shore platforms (Figure 10.16). Such platforms have been termed 'Old Hat' shore platforms after a classic example in the Bay of Islands, New Zealand. ${ }^{10}$ Picnic Beach (Figure 10.17), protected by Point Drummond, sweeps to the south, displaying both active and fixed parabolic dunes, some of which block off a saline depression from the coast.

The bedrock-protected headland of Point Drummond extends into Hill Bay and beyond, where small islands and shore platforms are developed in basement rocks, with rare boulder beaches and cliff-top dunes. A bedrock reef provides a protected anchorage in an otherwise exposed coastline. The aeolianite, cliffed coastline, which is 30 to $50 \mathrm{~m}$ high, extends to Blackfellows Point, Kiana Beach and beyond, with occasional pocket beaches forming between aeolianite bluffs. A narrow neck of 
land, $500 \mathrm{~m}$ wide, separates the sea from Lake Hamilton, which is about $12 \mathrm{~km}$ long and up to $3 \mathrm{~km}$ wide (Figure 10.18). Lake Hamilton is a salt lake fed by rainfall and seepage from the ocean; it contains several islands of aeolianite and sand. It has formed in an interdune corridor between separate Pleistocene dunes.

Sheringa Beach occupies a prominent bay $6 \mathrm{~km}$ wide between bold aeolianite headlands. Older, vegetated dunes flank bare, mobile, white dunes, which are up to $40 \mathrm{~m}$ high and extend more than $1 \mathrm{~km}$ inland. There is a great diversity of vegetation on the foredune, which backs the beach. The beach occupies an embayment of last interglacial age, which has now been filled with sand dunes, effectively damming Sheringa Lagoon and separating it from the open ocean.

North of Sheringa Beach, the aeolianite cliffed and crenulated coastline continues along a near-linear path as far as Cape Finniss and the Waldergrave Islands, with cliffs 10 to $100 \mathrm{~m}$ high, in places mantled with several generations of cliff-top dunes, occasional caves, numerous small bays, rocky reefs and many short stream valleys

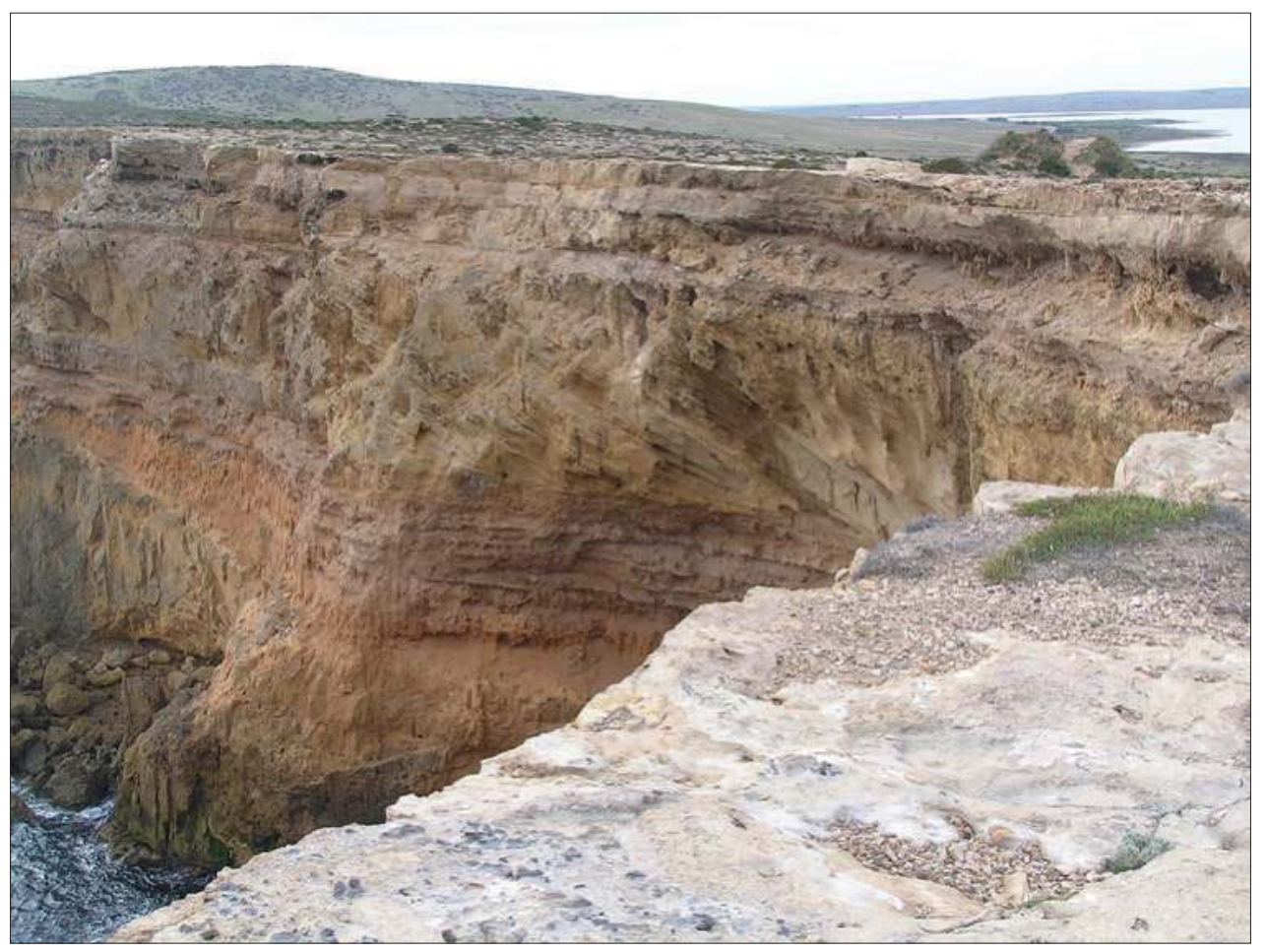

Figure 10.18 Narrow neck of land at Cummings Monument, separating the ocean from Lake Hamilton in the background. Note the cross-bedding in the aeolianite cliff, the fossil soils and the calcreted upper surface. The cliff is about $50 \mathrm{~m}$ high.

Source: Author's own work, RPB. 


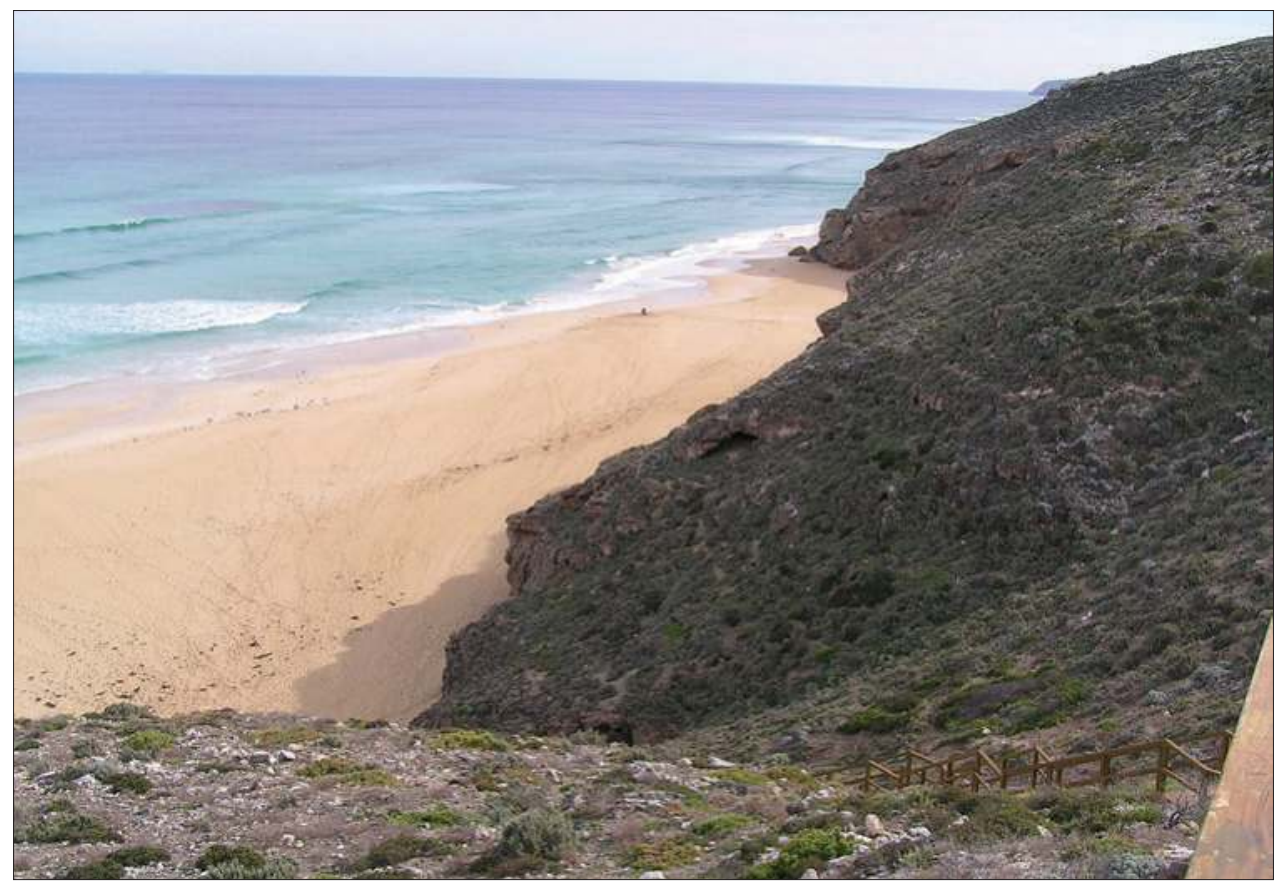

Figure 10.19 View of Locks Well Beach set within a coastline dominated by aeolianite cliffs, which are up to $90 \mathrm{~m}$ high.

Source: Author's own work, RPB.

incised into the aeolianite. Some of these valleys reach the shore, but many have been truncated by coastal erosion and form dry hanging valleys. Access to the coast is fairly restricted, but at Locks Well Beach a staircase provides a safe approach to the shore (Figure 10.19).

\subsection{Elliston area}

This cliffed linear coastline, which trends southeast-northwest, is broken at Elliston by Waterloo Bay, a horseshoe-shaped bay, flanked by the prominent aeolianite headlands of Wellington Point and Salmon Point (Figure 10.20). The bay mouth is almost $2 \mathrm{~km}$ wide and extends inland for $1.7 \mathrm{~km}$. The entrance is dotted with rocky reefs and small islands, remnants of the once continuous coastal dune barrier that forms the headlands. It has been suggested that the circular nature of Waterloo Bay may reflect its origin either as a doline, a rounded hollow formed by solution weathering of underlying calcareous rocks, or as a meteor impact crater, but it is more likely to 
have evolved by wave action ${ }^{11}$, after breaching of the cliffed coastal dune barrier during or before last interglacial times, $125 \mathrm{ka}$ ago. It was an embayment during the Last Interglacial because marine shells of this age occur in back-barrier positions around the margins of swampy areas well inland of the modern shoreline. Such swamps include those due east of Elliston, Lake Hemp and the swamp due north of the bay. The lowlying area northwest of this area to Anxious Bay was also a back-barrier lagoon during this time when sea level was $2 \mathrm{~m}$ higher than at present. Thus much of the present Waterloo Bay has formed by infilling of a former, much bigger, embayment. The reefs at the bay mouth diminish wave attack and disperse the waves through refraction to mould the regular shape of the bay. Within the bay, low rocky aeolianite bluffs separate sandy beaches.

The dramatic aeolianite cliffs facing the ocean are up to $50 \mathrm{~m}$ high and provide splendid examples of actively eroding coastlines from the cliff-top drives (Figure 10.21). Cliffs, notches, caves, shore platforms, stacks and small bays are all present. Any last interglacial beach system would have long been eroded, but remnants of last interglacial dunes probably form part of the cliff line, which reveals multiple fossil soils covered by successive dune advances.

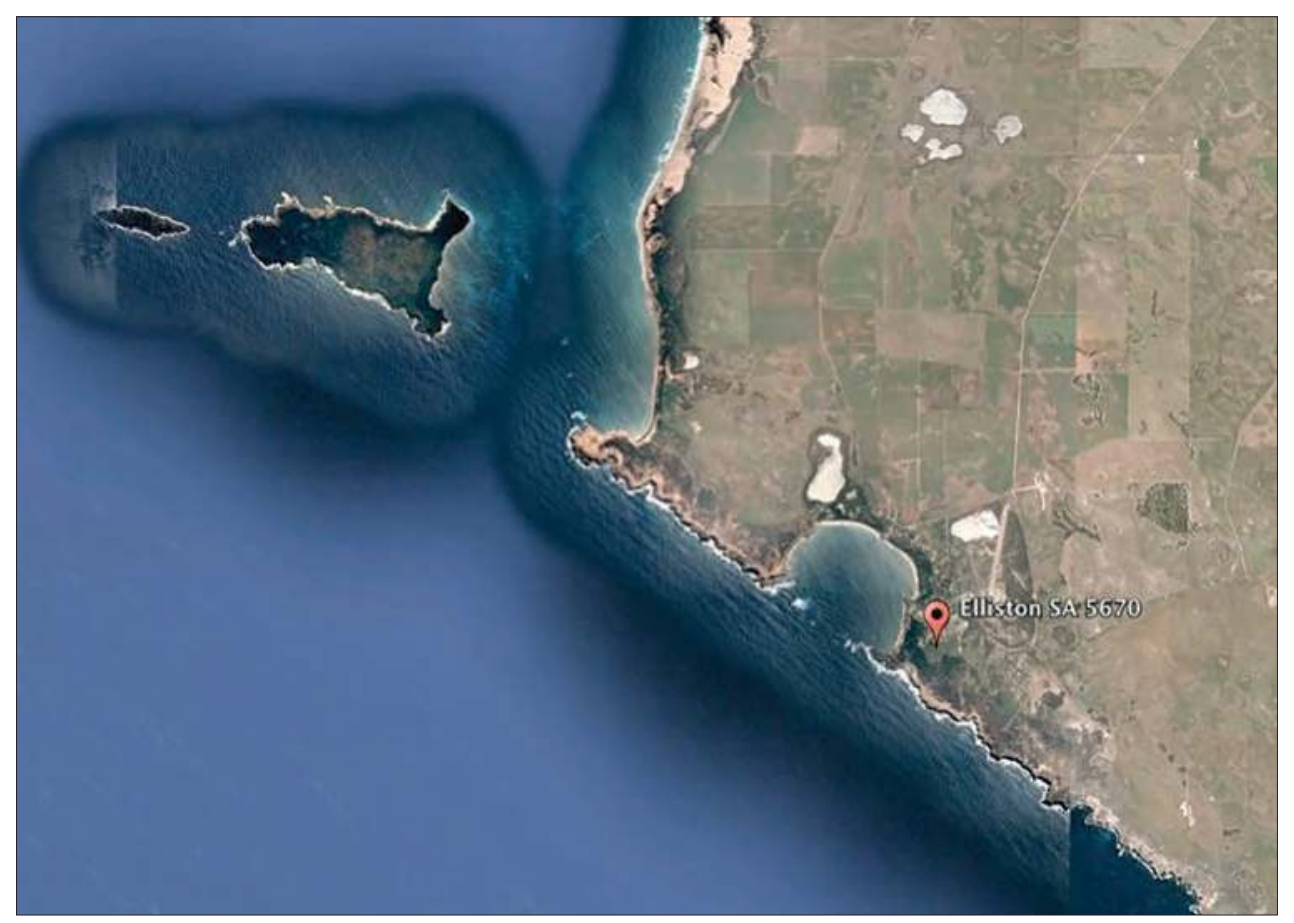

Figure 10.20 Waterloo Bay at Elliston and the Waldergrove Islands Conservation Park. Source: Google Earth image () 2015 Google. 


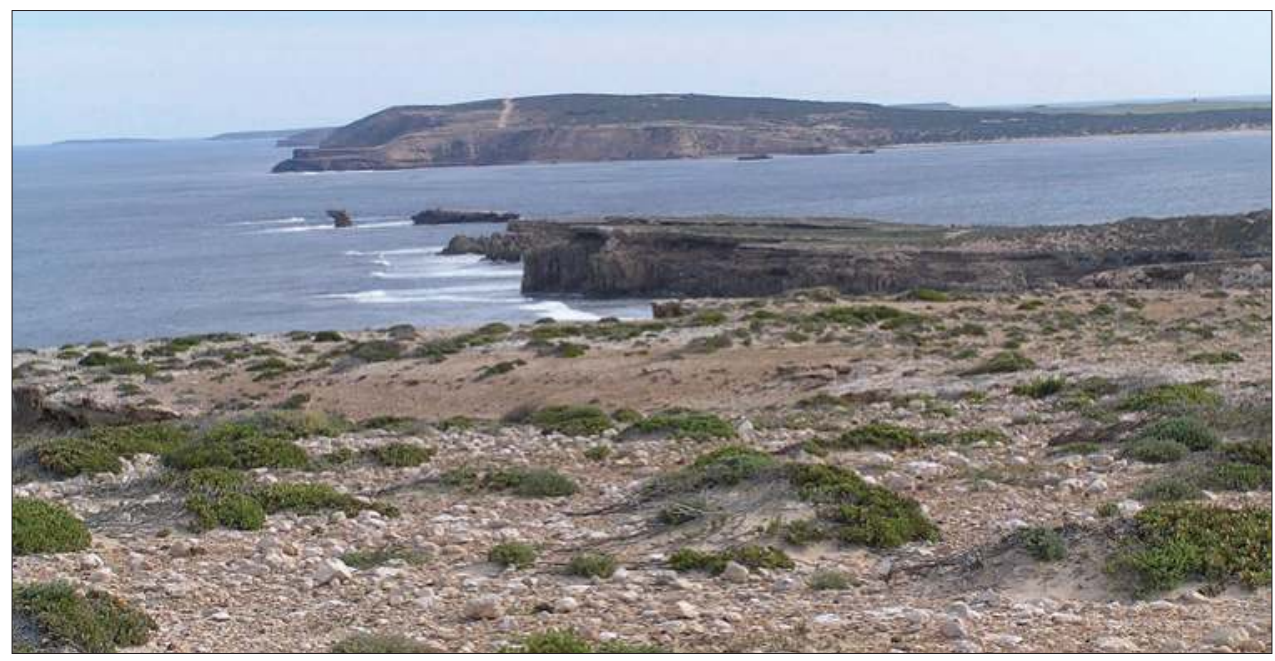

Figure 10.21 View to the north across the entrance to Waterloo Bay. Note the preserved backslope of the breached aeolianite dunes. The Waldergrave Islands appear in the background.

Source: Author's own work, RPB.

This section of straight coastline ends abruptly at Cape Finniss, a headland $40 \mathrm{~m}$ high, which is protected by hard granitic bedrock and also forms the foundation for the Waldergrave Islands to the north. Flinders Island, the largest in the Investigator Group, lies about $40 \mathrm{~km}$ to the west of Waterloo Bay. It is shaped a little like an arrowhead, about $12 \mathrm{~km}$ long in a southwest-northeast direction, with a maximum width of $6 \mathrm{~km}$. Ancient crystalline rocks protect the shoreline and explain its survival. Numerous headlands, cliffs up to $50 \mathrm{~m}$ high, granite shore platforms, bays, dunes and cliff-top dunes surround the island.

\subsection{Anxious Bay}

Anxious Bay extends from Cape Finniss near Elliston to Cape Radstock at the tip of Calca Peninsula, a distance of some $85 \mathrm{~km}$ (Figure 10.22). Most of the coastline is backed by calcreted Pleistocene sand dunes of the Bridgewater Formation, extending far inland, in places almost $100 \mathrm{~km}$. The former dune fields, now lithified, are marked by calcreted hummocky rises. Where these occur at the coast they form rocky cliffs, headlands and reefs. From the granite-protected aeolianite headland of Cape Finniss, the coast trends north to Walkers Rocks, with a protuberance opposite the Waldergrave 
Islands, which offer protection to the coast, and in the lee of which a cuspate foreland or triangular spit has accreted. Small aeolianite bluffs separate beach compartments backed by both vegetated and active sand dunes, some of which extend inland for $1 \mathrm{~km}$ and are up to $10 \mathrm{~m}$ high.

\subsection{Lake Newland}

From Walkers Rocks to Talia Beach (Figure 10.22), a remarkably smooth section of coast $25 \mathrm{~km}$ long follows the orientation of the last interglacial shoreline between resistant aeolianite at Walkers Rocks and hard rock outcrops at Talia. Nearshore reefs of aeolianite also sporadically parallel the sandy shoreline. It is noteworthy that an

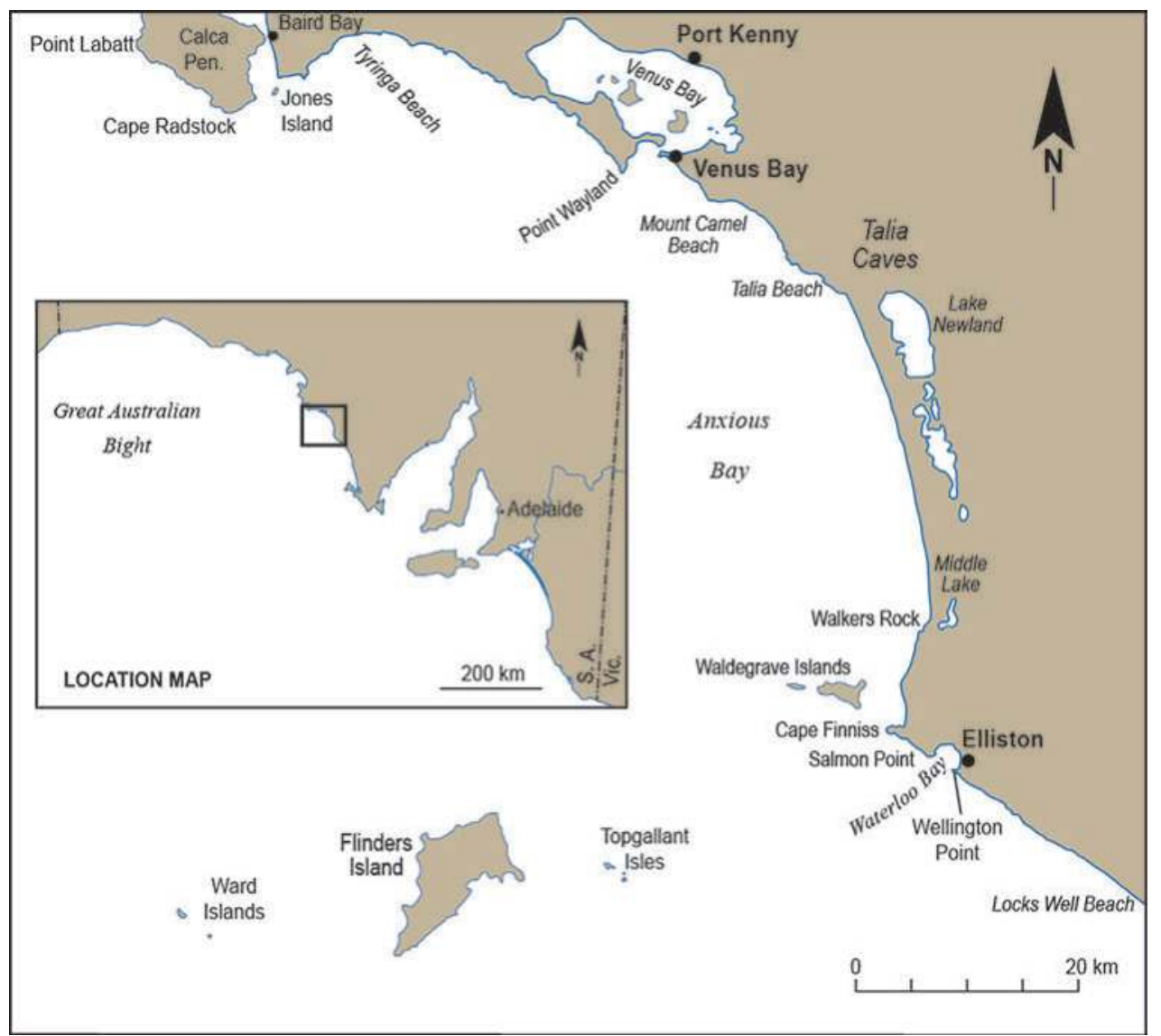

Figure 10.22 Localities along the Anxious Bay coastline from Cape Finniss to Cape Radstock.

Source: Author's own work, RPB. 
ancient downfaulted linear depression, filled with sediments ranging back to the Blue Range Beds approximately 1.55 billion years old and tectonically rejuvenated to form the younger Polda Basin (Figure 10.1), crosses the modern shoreline at this location and may influence its character. ${ }^{12}$

This coastal section is paralleled inland by Lake Newland, which at $20 \mathrm{~km}$ long is the largest of the coastal lakes on Eyre Peninsula. The modern-day beach $(25 \mathrm{~km})$ is reputedly also the longest beach. Middle Lake, inland of Walkers Rocks, is probably an extension of the original Lake Newland. Lake Newland has similar characteristics to those of the Coorong in the southeast of the State, as a long, narrow lagoon parallel to the shoreline occupying a back-barrier lagoon. However, unlike the Coorong, Lake Newland does not have a direct link to the ocean, but depends on runoff from the land and seepage of ocean water through the dune system to maintain water levels. The lake is blocked off from the sea by fields of transgressive sand dunes up to $20 \mathrm{~m}$ high; the dunes continue to migrate and contribute to infilling of the lake. Parts of the dune fields are mobile, while others are well vegetated with fixed parabolic dunes trending from the southwest.

Along the landward shoreline of Lake Newland, which abuts an earlier Pleistocene aeolianite dune, marine shells of last interglacial age (125 ka) occur at an elevation of $2 \mathrm{~m}$ APSL. These shells include Anadara trapezia, which is characteristic of backbarrier coastal lagoons. At the time of their growth, there was probably a break in the coastal barrier to allow water circulation and provision of nutrients from the ocean. Some of the shells are paired or articulated, indicating that they are in their original intertidal life positions; thus they provide reliable evidence of the position of the shoreline $125 \mathrm{ka}$ ago.

\subsection{The Talia coast}

North of Talia Beach, the coast takes on a markedly different character, where resistant coarse-grained sandstone is overlain by aeolianite; a smooth, sweeping sandy shoreline backed by dunes is replaced by $5 \mathrm{~km}$ of a spectacular rocky cliffed coastline. The underlying reddish-brown cross-bedded sandstone, containing occasional thin layers of finer grained siltstone, is approximately 1.55 billion years old (Mesoproterozoic), and is part of the Blue Range Beds. ${ }^{13}$ The aeolianite, part of the Bridgewater Formation, is less than 2 million years old. Differential erosion is stripping away and undercutting the softer aeolianite, producing bedrock ramps of gently dipping sandstone (Figure 10.23) sculptured by coastal processes, and forming caves such as the Woolshed Cave, the roof of which is being supported by a tougher calcrete capping. Erosion along lines of weakness in the underlying sandstone and undercutting of the aeolianite has developed cliffs, caves, blowholes, crevasses, small crenulated bays, headlands and bluffs. Solution operating from above has also influenced coastal erosion, producing features such 


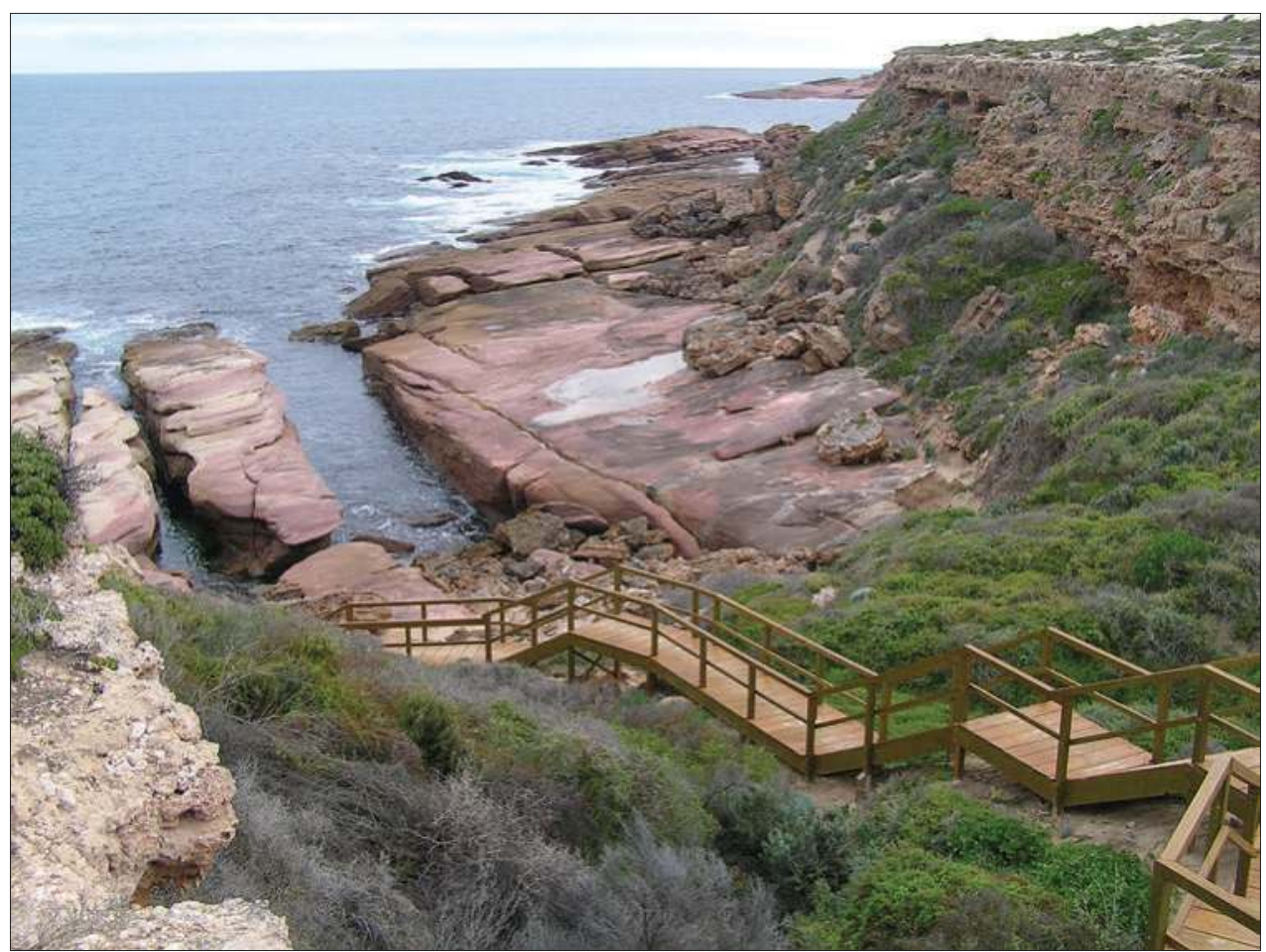

Figure 10.23 Shore platforms at Talia developed on ancient coarse-grained reddish sandstone of the Blue Range Beds being exhumed from beneath a cover of much younger aeolianite with a resistant calcrete capping. The contact between the old and young rocks is an unconformity, representing a time gap of at least 1.5 billion years. Crevasses, also known as geos, are being eroded out along lines of weakness such as joints in the underlying sandstone.

Source: Author's own work, RPB.

as 'The Tub', a large circular doline or pit in aeolianite with a bedrock foundation (Figure 10.24, overleaf). Coastal erosion is also attacking the doline from below.

\subsection{Mount Camel}

Beyond the Talia coast, aeolianite cliffs up to $40 \mathrm{~m}$ high dominate the shoreline. They are often backed by cliff-top dunes, with the base of the cliffs protected by the same reddish-brown sandstone at Talia, until about $5 \mathrm{~km}$ from the entrance to Venus Bay. The beaches at Mount Camel are set in the centre of a broad bay $7 \mathrm{~km}$ long, which is backed by steep aeolianite cliffs with cliff-top dunes. 


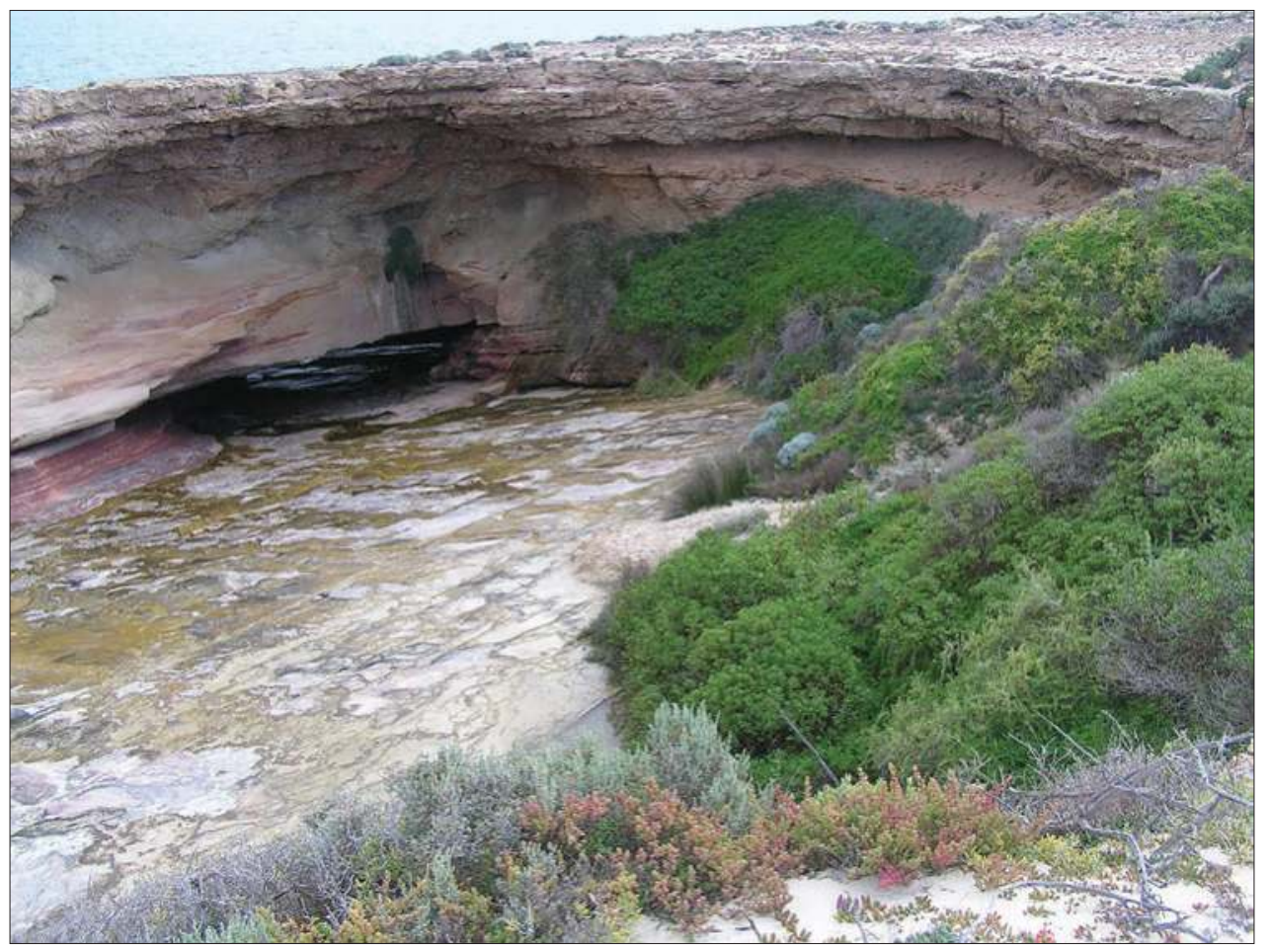

Figure 10.24 'The Tub', a doline about $10 \mathrm{~m}$ deep, which developed in aeolianite, and is now being enlarged by wave action and weathering processes. Waves access 'The Tub' via a tunnel between the aeolianite and bedrock.

Source: Author's own work, RPB.

\subsection{Venus Bay}

Venus Bay is a protected bay some $75 \mathrm{~km}^{2}$ in area, set within a much larger, broader embayment, Anxious Bay on the southwest-facing west coast of Eyre Peninsula (Figure 10.25). The entry to Venus Bay is quite restricted at about $300 \mathrm{~m}$, but is reasonably deep. The western side of the bay and the South Head Peninsula on which Venus Bay Township is sited are both composed of aeolianite of probable last interglacial age $(125 \mathrm{ka})$. Typical landforms of coastal erosion such as cliffs, notches, stacks, arches (Needle Eye), bays, shore platforms and reefs characterise the open ocean coast. Calcreted back-barrier lagoonal shells, including Anadara of the last interglacial Glanville Formation, occur on the eastern shore of the bay near the rifle range at Port Kenny. These shells were deposited in a lagoon protected from the open ocean waves and swell by a beach and dune barrier, now consolidated into aeolianite. Any evidence 
of a shelly beach facies on the open ocean side of the barrier has now been removed, as this part of the peninsula protecting Venus Bay has been severely eroded, forming a cliff line varying in height between between 50 and $100 \mathrm{~m}$.

Dunes occur sporadically along the cliff. They probably formed by climbing up a sand ramp to the cliff top, after which the ramp was eroded. A sand dune is currently blowing in a north-northwesterly direction from a small embayment over cliffs up to $60 \mathrm{~m}$ high, about $2.5 \mathrm{~km}$ southeast of 'The Narrows', which is a section of the Point Weyland Peninsula that is only $400 \mathrm{~m}$ wide. The dune sand, red/orange in colour, probably derived from the aeolianite cliffs and accumulated in the small erosional bay from where it was blown inland. The dune now migrates to the edge of Venus Bay and is contributing sediment to the infilling of the bay.

Point Weyland Peninsula and the several islands of Venus Bay are all part of the Venus Bay Conservation Park. A narrow neck of land links a former island up to $30 \mathrm{~m}$ high in the central part of the bay to the peninsula as a tombolo. Outcrops of resistant calcareous rocks form small protrusions along the shoreline, and sand spits of various sizes have grown out from some of the points.

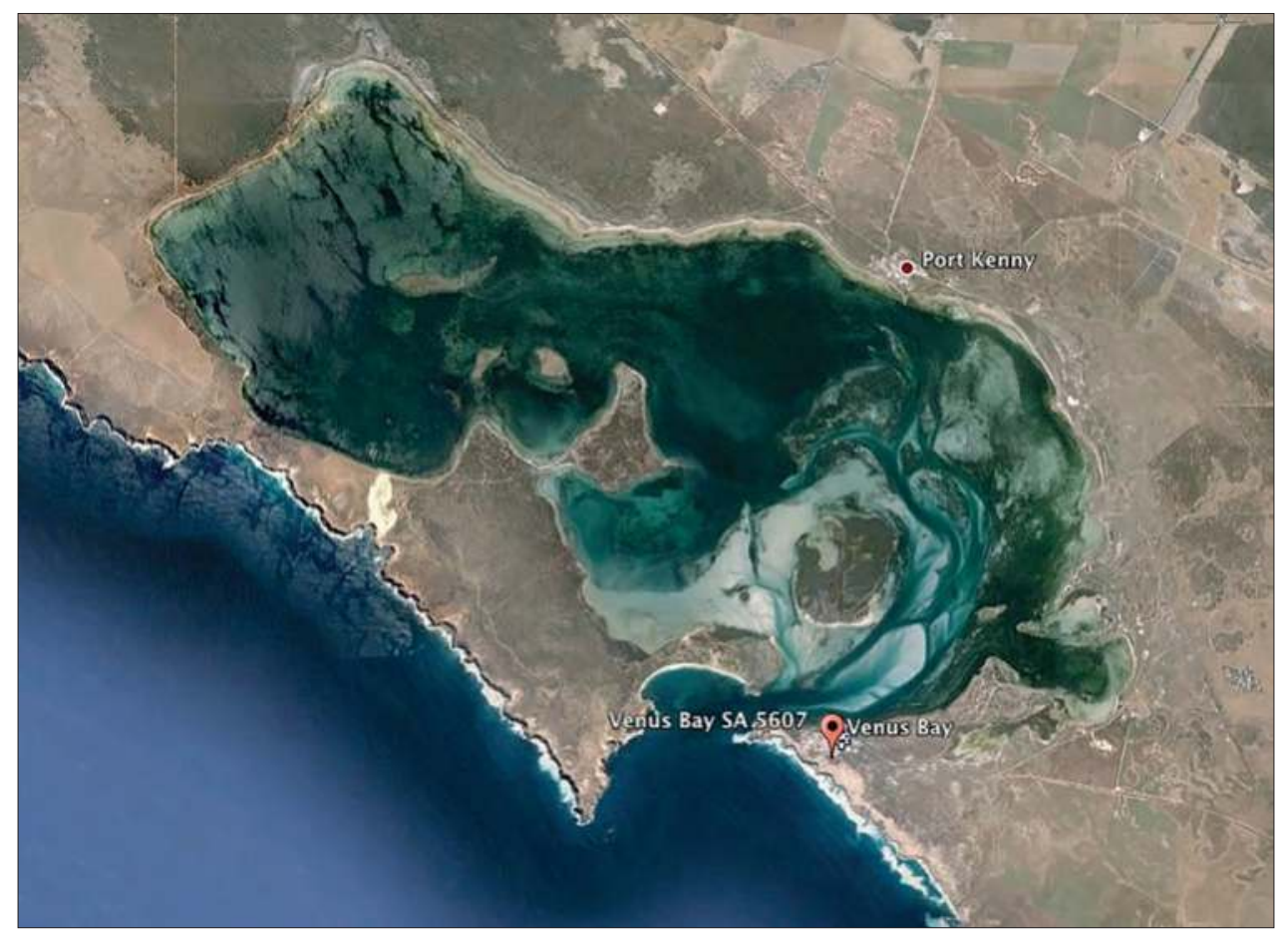

Figure 10.25 Venus Bay, showing narrow inlet, flood tidal delta and eroding open ocean cliffs. Source: Google Earth image () 2011 Google. 
Venus Bay is filling in; up to $4 \mathrm{~m}$ of sediment has accumulated in the bay over the past $6.5 \mathrm{ka}$. Unconsolidated shell ridges developed over this time flank the northeastern, northern and some of the eastern shores of the bay. There are up to five shell ridges, with the highest and furthest inland ridges resting on truncated calcrete of the last interglacial Glanville Formation. The shells are mostly unpaired but occasionally are articulated or paired, suggesting that they have not moved far from their original living positions in an intertidal zone. Venus Bay warrants further detailed investigation. The last interglacial Glanville Formation, which was deposited during a sea level $2 \mathrm{~m}$ higher than present, contains truncated calcreted tree stumps. On this platform Holocene shells, some of which are articulated, form deposits up to $2 \mathrm{~m}$ thick.

It is possible that storm waves were responsible for constructing these ridges to levels of more than $2 \mathrm{~m}$ above present sea level. However, it is difficult to envisage this mechanism alone being responsible, given the fact that some of the shells are paired, and given also the shallow nature of the bay, the restricted inlet into the bay, and the short fetch over which waves can build up. In contrast to the sections of the bay fronted with shell ridges, and surprisingly, given their protected position, parts of the southwestern shore of Venus Bay are bordered by low aeolianite cliffs, attesting to former enhanced erosion. Hydro-isostasy alone does not appear adequate to account for these preliminary observations.

Infilling of the bay is proceeding by production of biogenic sediment within the bay, by shell ridge progradation, and by sand blowing from the open ocean shoreline across the peninsula at 'The Narrows' and over the northern side of the bay entrance. Here, sand spits have accreted, providing an ideal environment for mangroves. In addition, calcareous sandy sediments have been swept in through the entrance by flood tides forming a flood tidal delta and extensive sand shoals, especially in the southern half of the bay and along the northern shore. The ebb tide is not large enough to evacuate these sediments. The sand has been derived from reworking of the aeolianite coastal cliffs and from nearshore shelf waters. A large sand island covering about $1 \mathrm{~km}^{2}$, Germein Island has formed as part of the flood tidal delta immediately inland of the bay entrance. The southern section of the island is composed of a sand dune up to $10 \mathrm{~m}$ high, backed by low-lying swamp fringed with mangroves.

\subsection{Venus Bay to Baird Bay}

A cliffed coastline formed in aeolianite over bedrock extends from Venus Bay to the entrance to Baird Bay, with the cliffs notably reducing in height in the last $10 \mathrm{~km}$. Along this coastal sector there are numerous bays, such as Horseshoe Bay and Tyringa Bay, some with beaches, backing dunes and cliff-top dunes. Highly siliceous beach sand occurs south of the Baird Bay settlement at Silica Beach. The composition of 
the beach sand suggests derivation from the nearby granite of the Hiltaba Suite. ${ }^{14}$ In addition to quartz, the sand contains minor amounts of felspar and shell fragments.

\subsection{The Streaky Bay area}

This section of coast covers the area between Baird Bay and Point Brown. It includes Searcy Bay, Sceale Bay, Corvisart Bay, Blanche Port, Streaky Bay and Gascoigne Bay (Figure 10.26).

\subsubsection{Baird Bay}

This is a narrow inlet, $15 \mathrm{~km}$ long and between $1 \mathrm{~km}$ and $3 \mathrm{~km}$ wide, bordered on the west by the Calca Peninsula, a Pleistocene coastal barrier shoreline complex that is $20 \mathrm{~km}$ long. The bay occupies a Pleistocene interdune corridor with a limestone and sand substrate; it has an average depth of $2 \mathrm{~m}$ and a total area of $38 \mathrm{~km}^{2}$. Broad, flat shore platforms occur sporadically along its western side, occasionally covered with sand. The bay is narrowest opposite the township of Baird Bay $(300 \mathrm{~m})$, where sandflat formation and growth of sand spits and ridges is encouraged by protection from waves by Jones Island and some reefs; this encourages the growth of extensive seagrass meadows, specifically Posidonia australis, Zostera mucronata and Hormosira banksii. The bay contains fossils of the Glanville Formation, revealing a last interglacial shoreline some $2 \mathrm{~m}$ higher than at present. Remnants of a relatively higher sea level during the mid-Holocene 6 to $4 \mathrm{ka}$ ago also occur in Baird Bay towards its head, and the Baird Bay Township is built on Holocene shell flats, which also occur extensively at Kalca.

\subsubsection{Calca Peninsula}

Cape Radstock, at the end of the Calca Peninsula, which is $20 \mathrm{~km}$ long, consists of up to $120 \mathrm{~m}$ of Bridgewater Formation aeolianite resting on resistant bedrock. The peninsula is up to $9 \mathrm{~km}$ wide on a line between Point Labatt and Baird Bay Township and narrows to less than $1 \mathrm{~km}$ to the north. The wide section of the peninsula consists dominantly of Holocene infill. High aeolianite bedrock-protected cliffs with occasional cliff-top dunes extend to Point Labatt, where there is a classic sequence of several generations of aeolianite resting on resistant granite bedrock, forming reefs that extend up to $600 \mathrm{~m}$ offshore. As at Point Drummond, the extensive, flat and smooth shore platform in granite has resulted from the etching away of weathered granite, which is sandwiched between an irregular fresh bedrock surface and the overlying aeolianite close to present sea level (Figure 10.27). The smooth granite platforms are favoured by sea lion colonies. 


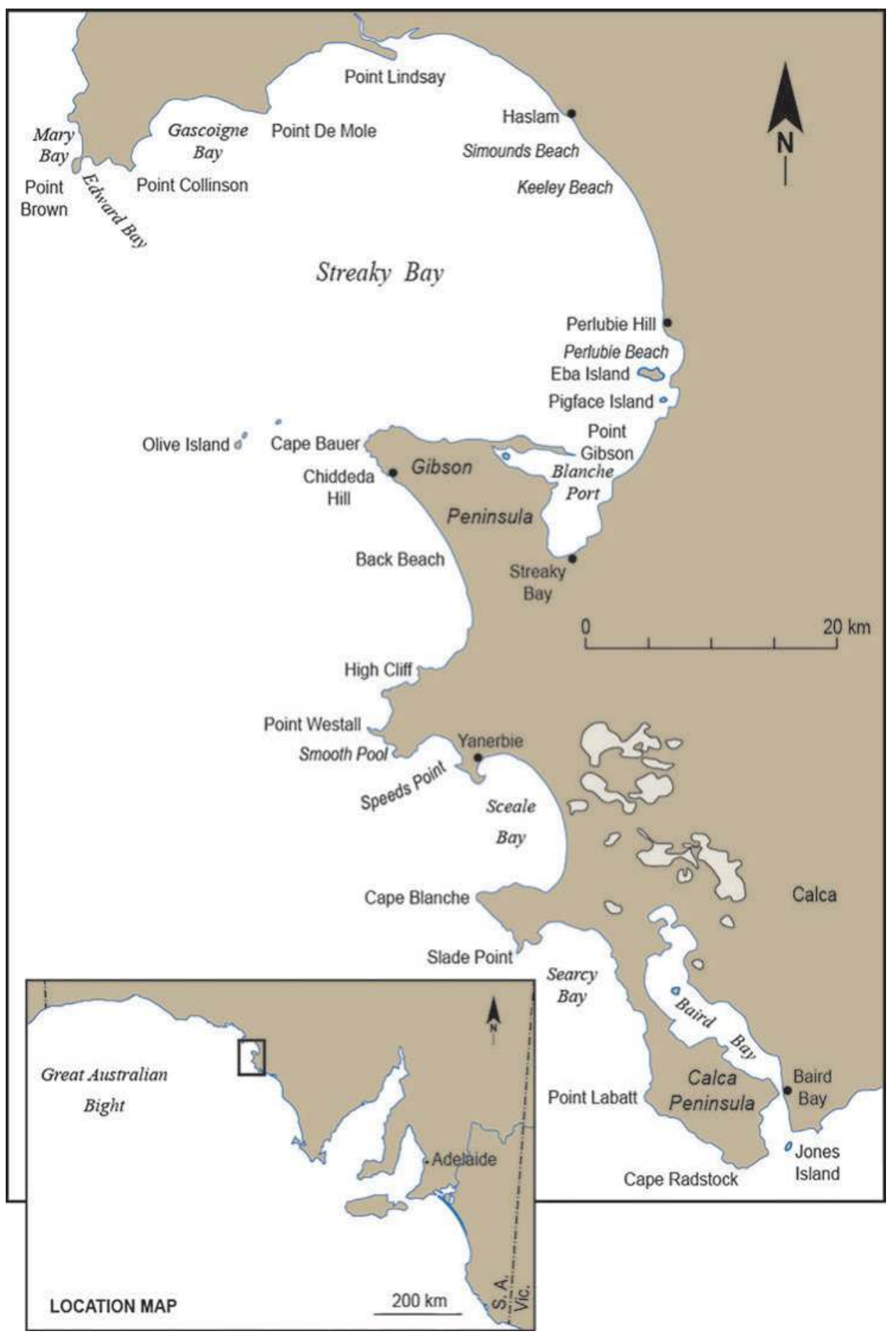

Figure 10.26 The Streaky Bay area: the coastline between Baird Bay and Point Brown. Source: Author's own work, RPB. 


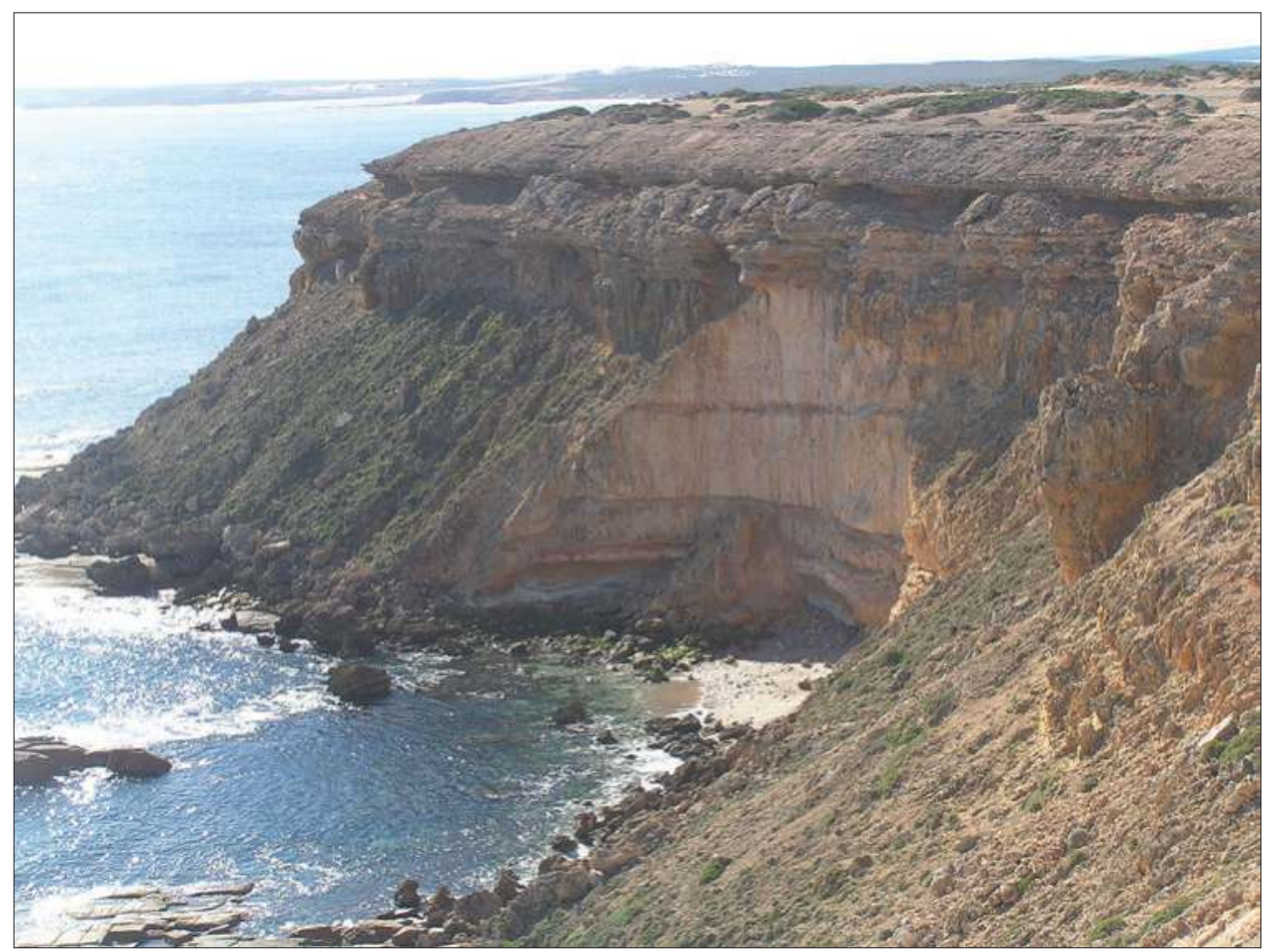

Figure 10.27 Coastal erosion at Point Labatt has exposed bleached, iron-mottled, weathered granite bedrock in the lowest $4 \mathrm{~m}$ of the $40 \mathrm{~m}$ high cliffs, which consist dominantly of aeolianite. A thin layer of nodular iron-rich crust occurs at the base of the aeolianite. A rock fall is visible at the base of the cliffs. The fall occurred in the 1990s and it is slowly being eroded away. Parts of the flat granite shore platforms are visible at sea level.

Source: Author's own work, RPB.

\subsubsection{Searcy Bay}

This bay extends from Point Labatt for about $25 \mathrm{~km}$ to Slade Point, a rocky and reefstrewn section of coastline with bedrock-protected aeolianite cliffs 10 to $50 \mathrm{~m}$ high, cliff-top dunes, bluffs, and intervening pocket beaches with well-developed cusps. In the northeastern section of the bay, a reef-protected beach, $3 \mathrm{~km}$ wide, is backed by active white sand dunes up to $40 \mathrm{~m}$ high. Older vegetated dunes extend even further inland.

The linear promontory between the headlands of Slade Point $(50 \mathrm{~m})$ and Cape Blanche $(90 \mathrm{~m})$ is $23 \mathrm{~km}$ long, bedrock-based and aeolianite-capped; it separates Searcy and Sceale Bays. This southwest-facing coastal section is crenulated with numerous small rocky bays backed by cliff-top dunes. At Slade Point, a sandy spit is accumulating in the lee of a rocky reef, forming a tombolo. 


\subsubsection{Scaele Bay}

Scaele Bay has accumulated sand driven northwards by southwesterly winds in the lee of the rocky headland of Speed Point and Yanerbie. Several small lakes have formed as the accreting sand has blocked off direct access to the ocean and from the head of Baird Bay. The White Sands of Yanerbie cover an area of about $12 \mathrm{~km}^{2}$, extend inland for about $5 \mathrm{~km}$ and are up to $30 \mathrm{~m}$ high. They have migrated over a last interglacial backbarrier embayment. Near the Yanerbie settlement, seagrass meadows have developed in a wave-protected zone.

The cliffed coastline of Point Westall Peninsula is protected by aeolianite-capped granite bedrock. Broad, smooth shore platforms in granite are prominent at Smooth Pool and Point Westall, where the abrupt contact between deeply weathered and unweathered granite occurs at present sea level and is easily exploited, producing extensive, flat, granite bedrock surfaces. There are rare boulder beaches. Some granite reefs extend up to $1 \mathrm{~km}$ seawards, while other landforms of coastal erosion have developed in the aeolianite, producing the distinctive Dreadnoughts, sea stacks that resemble battleships (Figure 10.28). Landward of the Dreadnoughts is a low-lying depression with samphire, blocked off from the sea by dunes.

\subsubsection{Corvisart Bay}

Corvisart Bay sweeps from the Dreadnoughts to Cape Bauer. Lying athwart the westerly winds and swell, reef-protected but eroding aeolinite cliffs up to $40 \mathrm{~m}$ high dominate the shoreline. They are commonly mounted by cliff-top dunes and fronted by narrow beaches. Steep undercut cliffs, bluffs, notches, shore platforms at various levels, whistling rocks and blowholes attest to the active erosion of this section of coast.

\subsubsection{Streaky Bay}

Streaky Bay is flanked by the bedrockprotected aeolianite headlands of Point Brown $(30 \mathrm{~m})$ in the north and Cape Bauer $(80 \mathrm{~m})$ in the south. Olive Island, which lies offshore in the south, is surrounded by reefs and shore platforms (Figure 10.26).

Within Streaky Bay, the major headlands and shallow reefs protect a series of smaller bays. The entrance

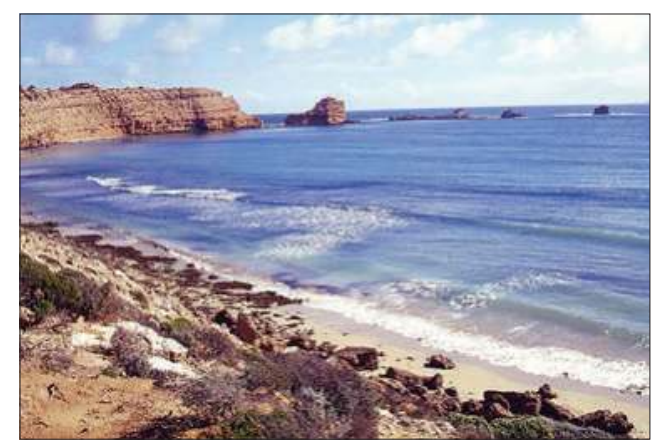

Figure 10.28 The Dreadnoughts, a sequence of sea stacks and shore platforms offshore from the cliff at the southern end of Corvisart Bay; the cliff is $50 \mathrm{~m}$ high.

Source: Author's own work, RPB. 
to the semicircular bay is about $26 \mathrm{~km}$ across. A large sand spit, Gibson Spit, which extends to the east some $7 \mathrm{~km}$ from Gibson Peninsula, protects Blanche Port, on which the township of Streaky Bay is situated. Gibson Spit is a complex feature comprising several spits and cuspate forelands onto which the main spit has been attached. It has grown by accretion of sediment derived from Cape Bauer to the west. Smaller spits south of Gibson Spit have had their sand supply cut off, but they contribute to the sheltered environment, which has favoured the establishment of a mangrove woodland. The entrance to Blanche Port, between Gibson Spit and the Perforated Rocks (Little Islands) near the mainland, is $3 \mathrm{~km}$ wide.

The smoothly curving shoreline of Streaky Bay is affected only by low-energy waves; resistant outcrops of aeolianite, which form low bluffs and islands, such as Pigface and Eba Islands, have impacted on the detailed morphology of the shoreline. At Eba Island, a sand spit has built seawards in the lee of the island, forming a tombolo, which links to the island at low tide. Perlurbie Beach, backed by active sand dunes that extend almost $0.5 \mathrm{~km}$ inland, has also developed in the lee of the island. Much of the shoreline is backed by sand dunes up to $10 \mathrm{~m}$ high, while multiple beach ridges up to $1 \mathrm{~km}$ wide back parts of the shoreline. Near Haslam, a cuspate foreland protrudes seawards some $200 \mathrm{~m}$, where the shore is protected by a sand shoal; and north of Haslam, aeolianite cliffs $10 \mathrm{~m}$ high extend for $6 \mathrm{~km}$ to the reef-protected Flagstaff Landing.

\subsubsection{Acraman Creek}

A large mangrove woodland in Streaky Bay, Acraman Creek, which occurs along a section of shoreline that is $10 \mathrm{~km}$ long, has evolved through episodic growth of recurved spits in conjunction with seaward progradation of multiple beach ridges. These ridges have grown seaward up to $3 \mathrm{~km}$ in the past 6000 years, effectively impounding the creek area (Figure 10.29). ${ }^{15}$ Low barrier islands and sandflats occupy the mouth of the creek, and Point Lindsay, which is $5 \mathrm{~km}$ long, is a composite recurved sand spit that protrudes into the bay. The area occupied by Acraman Creek was an embayment during the Last Interglacial; paired shells of Anadara trapezia $125 \mathrm{ka}$ old occur on the landward side of the tidal creek network. They were deposited when sea level was $2 \mathrm{~m}$ higher than present. Shell rock at Point Collinson, about $1.5 \mathrm{~m} \mathrm{APSL}$, is almost certainly of the same age.

In the northern section of Streaky Bay, headlands such as Point De Mole, Point Collinson and Point Brown are fringed by bedrock reefs of etch origin; they protect the shoreline to the east, where the development of sandflats and seagrass meadows is favoured. Bays between the headlands contain steep-faced beaches with prominent beach cusps. Vegetated cliff-top dunes are being reactivated and degraded in places, producing prominent nubbins of vegetated sand (nebkhas). 


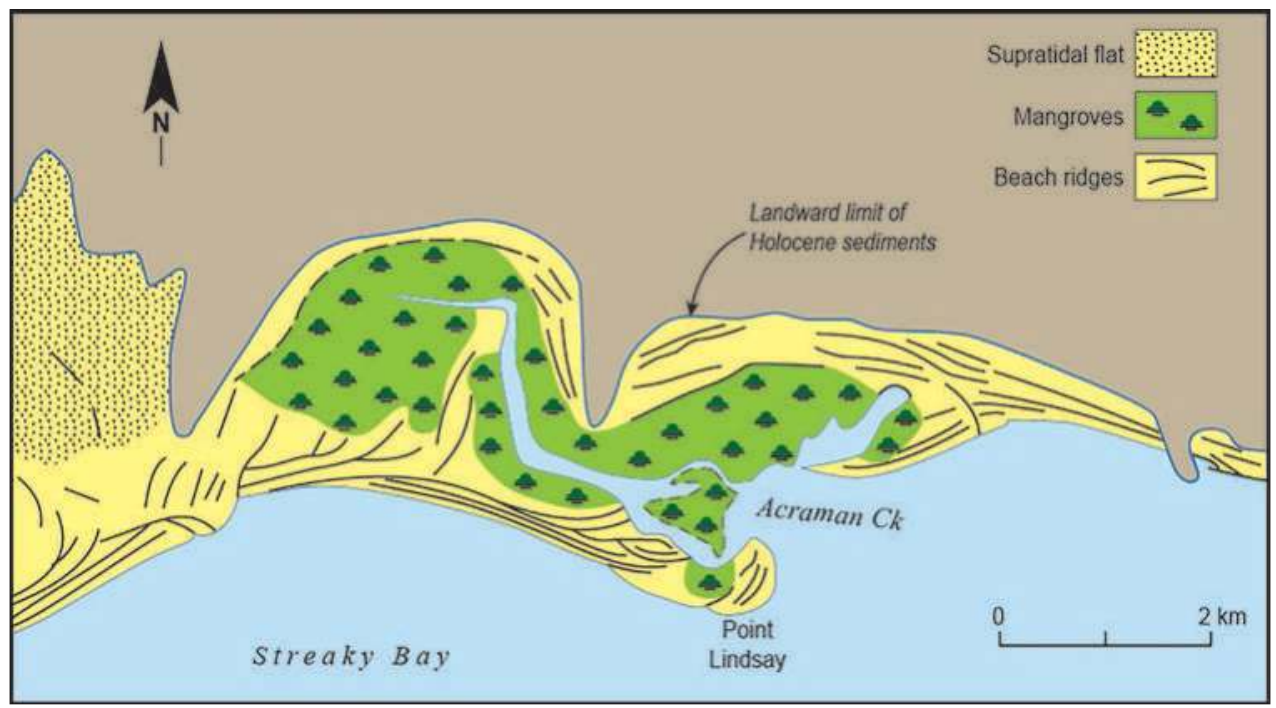

Figure 10.29 Map of tidal Acraman Creek, showing complex beach ridges, sand spits, a supratidal sandflat and mangroves. A radiocarbon age of $5650 \pm 90$ BP was obtained from shells at the landward limit of the Holocene sediments.

Source: Modified from Short, A.D., Buckley, R.C. \& Fotheringham, D.G. (1989). Preliminary investigations of beach ridge progradation on Eyre Peninsula and Kangaroo Island. Transactions of the Royal Society of South Australia, 113, 145-161.

\subsection{The Ceduna coastline}

The shoreline between Point Brown and Rocky Point is intricately embayed and extends up to $30 \mathrm{~km}$ landwards from a line drawn between these two headlands (Figure 10.30). Furthermore, the coast here is much protected by the Isles of St Francis, the Franklin Islands and the islands of the Nuyts Archipelago. The high, dramatic aeolianite bluffs and headlands to the south are replaced by a more subdued section of coastline, with generally lower calcareous bluffs separating numerous bays, beaches and backing dunes. Given the relatively low wave energy along this coastal sector, there are numerous seagrass meadows, sandflats, mangroves and samphire swamps, where the shoreline is tidally dominated.

This section of coast extends from Point Brown to Point Bell and includes Smoky Bay, Laura Bay, Decres Bay, Denial Bay, Murat Bay and Tourville Bay. ${ }^{16}$ The coastline trends northwards from Point Brown to Cape Missiessy. Largely bedrock- and reefprotected aeolianite cliffs and bluffs, interspersed with bays and beaches with active dunes, such as St Mary Bay, comprise the coast south of Cape Missiessy, where the shoreline becomes one of barrier accretion. Accreting beach ridges and multiple 
recurved spits, with sediment being derived from the south and from offshore, have built both northwards and eastwards into Smoky Bay, providing a wave-sheltered environment for sandflat, mangrove and samphire development. Destabilisation of the vegetated ridges by stock has resulted in the development of an active dune area of some $6 \mathrm{~km}^{2}$, with dunes up to $10 \mathrm{~m}$ high migrating into the mangroves. Cape Missiessy almost links up with Eyre Island, but tidal flushing maintains a relatively deep channel between the two.

\subsubsection{Eyre Island}

This island covers an area of $12 \mathrm{~km}^{2}$ and partially blocks Smoky Bay; it is the only unconsolidated sand island along the exposed Bight Coast. However, protection afforded by other islands of the Nuyts Archipelago and aeolianite reefs further offshore has aided the accretion of multiple recurved sand spits, beach ridges and fringing sandflats, which have been colonised with seagrasses, samphire and mangrove woodland

Figure 10.30 The coastline of the Ceduna area, showing localities referred to in the text.

Source: Author's own work, RPB.
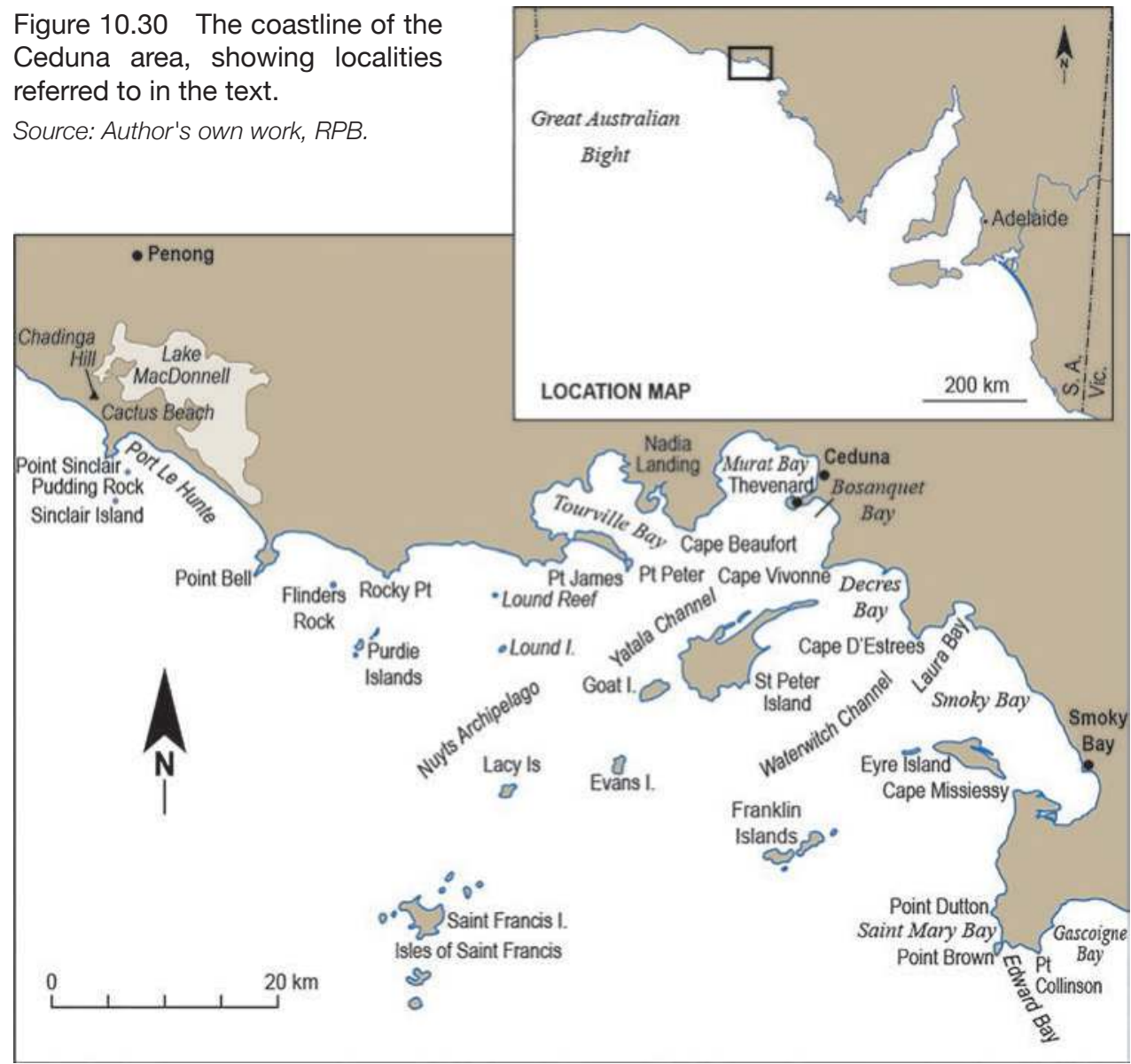
during the period from 3.8 to $1.4 \mathrm{ka} \mathrm{BP} .{ }^{17}$ The main period of accretion seems to have passed, but ongoing erosion and reworking of the sand island is contributing to its landward movement and the infilling of the southern section of Smoky Bay.

\subsubsection{Smoky Bay}

Due to the presence of Eyre Island, associated sand shoals and the Franklin Islands, Smoky Bay has a subdued wave climate. Much of the shoreline of Smoky Bay consists of tidally dominated sandflats up to $0.5 \mathrm{~km}$ wide, mangroves and seagrass meadows. The bay was much larger during the Last Interglacial (125 ka), as shells of this age are present well above the modern shoreline. Much of the township of Smoky Bay appears to be built on shell ridges of Holocene age, probably about $4 \mathrm{ka}$ old.

\subsubsection{Laura Bay}

At the northern end of Smoky Bay is Laura Bay, a small bay with mangroves backed by samphire swamps. It is a protected arcuate bay with backing tidal channels, shelly beaches, mangroves and samphire swamps. The area of samphire swamps indicates the former extent of the bay during the Last Interglacial.

\subsubsection{Decres Bay}

Decres Bay is flanked by Cape De'Estrees $(20 \mathrm{~m})$ and Cape Vivonne and sheltered by the large nearby St Peter Island, the largest island on the Bight Coast, along with associated sand shoals, spits and bedrock reefs. Although Decres Bay faces west and southwest, nearshore islands protect it so that seagrass meadows and sandflats abound. The southeasterly section of the bay contains aeolianite cliffs up to $20 \mathrm{~m}$ high, but elsewhere the shore is formed of low aeolianite rises with sandflats. An aeolianite promontory, Wittelbee Point, protrudes seawards almost $1 \mathrm{~km}$ into the bay, providing a sand sink for the formation of rippled sandflats and dunes.

\subsubsection{Bosanquet Bay}

Bosanquet Bay is located between the headlands of Cape Vivonne and Cape Thevenard, both of which are about $10 \mathrm{~m}$ high and underlain by variably weathered granite bedrock. Cliffs and bluffs of calcareous rock interspersed with pocket beaches comprise the flanks of the bay. Sandflats and mangroves occur in the sheltered head of the bay, where the main sandy beach is backed by vegetated sand dunes that extend $0.4 \mathrm{~km}$ inland. Strongly rippled, white sandflats, widest on the western side of the bay, strongly contrast with the dark colours of the seagrass meadows. Shells derived from the intertidal sandflats comprise large proportions of the beach sediment, such as at Shelly Beach. 


\subsubsection{Murat Bay}

The headlands of Cape Thevenard and Matts Point are $10 \mathrm{~m}$ high and separated from each other by a distance of $5.5 \mathrm{~km}$; they enclose the shoreline of Murat Bay, which is $22 \mathrm{~km}$ long. Most of the coastline of Murat Bay is subdued; relatively low cliffs and small headlands 2 to $5 \mathrm{~m}$ high are underlain by fresh bedrock, weathered and ironenriched bedrock and at least two horizons of calcrete. ${ }^{18}$ Some of the calcrete is related to the last interglacial sea level, as shells of this age have been observed in the calcareous cappings. Sandflats with seagrass meadows fringe much of the bay, while mangroves occupy inlets and sheltered areas, such as at the Denial Bay Township. South of Ceduna Waters, there are low cliffs in calcareous sediments capped by calcrete.

\subsubsection{Tourville Bay}

The occurrence of the last interglacial Glanville Formation deposits reveals that Tourville Bay was much larger $125 \mathrm{ka}$ ago, and during the Holocene it was up to $100 \mathrm{~km}^{2}$ in area. It now contains a tidal creek, Davenport Creek, and a mangrove woodland. Largely a result of highly productive intertidal and subtidal ecosystems, a 'carbonate factory' has resulted in aggradation and progradation, effectively filling Tourville Bay and other sheltered bays with bioclastic sediments over the past 3000 years. ${ }^{19}$ At Nardia Landing on the northeastern shore of Tourville Bay, an extensive ridge mainly of Holocene shells has been constructed up to $3 \mathrm{~m}$ ASPL on calcareous sediments of possible last interglacial age.

\subsection{Point Peter to Rocky Point}

West of Point Peter, the coastline changes dramatically, being much more exposed to ocean waves and swell. Point Peter is a bedrock-buttressed aeolianite headland $25 \mathrm{~m}$ high, which may become linked to the mainland by a sand spit. Active dunes up to $30 \mathrm{~m}$ high are migrating more than $1 \mathrm{~km}$ from the smooth ocean shoreline into the mangroves bordering Davenport Creek, producing an irregular northern shoreline. Bedrockprotected aeolianite headlands, bluffs, cliffs with cliff-top dunes and embayments of various sizes extend to Rocky Point, producing a sequence of capes and bays along the coast with dunes backing the bays. A beach west of Point James is $5 \mathrm{~km}$ long and has nourished the active transgressive dune field of Bielamah Sandhills; these sandhills cover $6 \mathrm{~km}^{2}$ and reach elevations of up to $50 \mathrm{~m}$. Rocky Point is buttressed with old hard rocks, and shore platforms are evolving by stripping of the aeolianite cover.

\subsection{Rocky Point to Fowlers Bay area}

This section of coastline is characterised by major headlands such as Point Bell, Point Sinclair, Eyre Bluff and Point Fowler (Figure 10.31), all of which are protected by hard 
rocks and mantled by aeolianite that forms cliffs up to $50 \mathrm{~m}$ high. Cuspate, bluffbounded beaches, sea stacks, shore platforms and reefs are common features of this coastline. Point Bell separates fine white beach sand to the east from coarser brown sand on the west. Between the prominent headlands of Points Bell and Sinclair, the Cantaby and Shelly Beaches have formed and spawned active dunes, which have blown inland for distances of between one to several kilometres, separating Lake MacDonnell from the ocean (Figure 10.32). A slight cuspate foreland has formed in the lee of Pudding Rock, which lies $3 \mathrm{~km}$ offshore.

At Clare Bay, east of Eyre Bluff, footprints of humans, along with the tracks of native animals, have been recognised in calcareous muds on the shore of a small salt lake. ${ }^{20}$ Preserved for some 5000 years, these are trace fossils or indirect evidences of past life, as opposed to the preservation of the life forms themselves.

\subsection{Fowlers Bay to the Head of the Bight}

\subsubsection{Point Fowler area}

Point Fowler projects seawards to the southeast for some $5 \mathrm{~km}$, providing a shelter from the dominant southwesterly waves on its northern side (Figure 10.33). This has favoured the development of a mobile sand spit, which is migrating towards the jetty as waves refract around the headland. The spit has prograded more than $1000 \mathrm{~m}$ from a former sea cliff

Figure 10.31 The coastline from Rocky Point to the Fowlers Bay area.

Source: Author's own work, RPB.

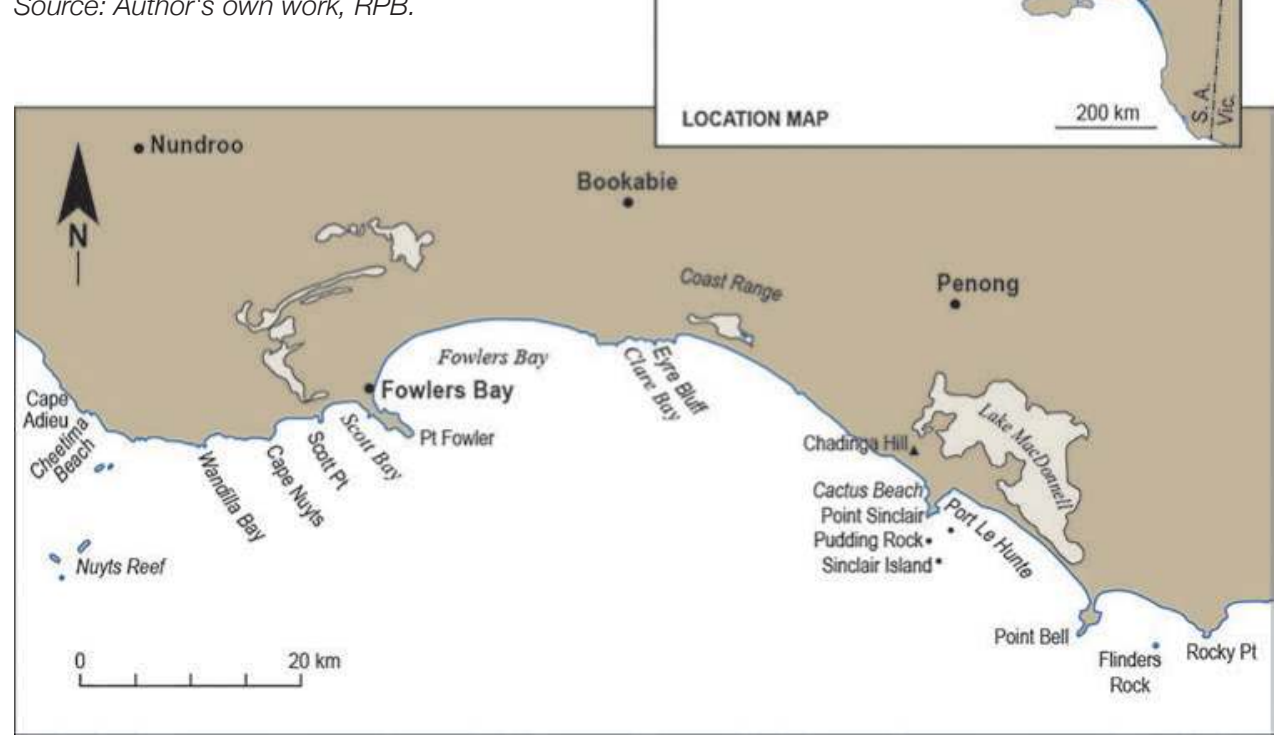




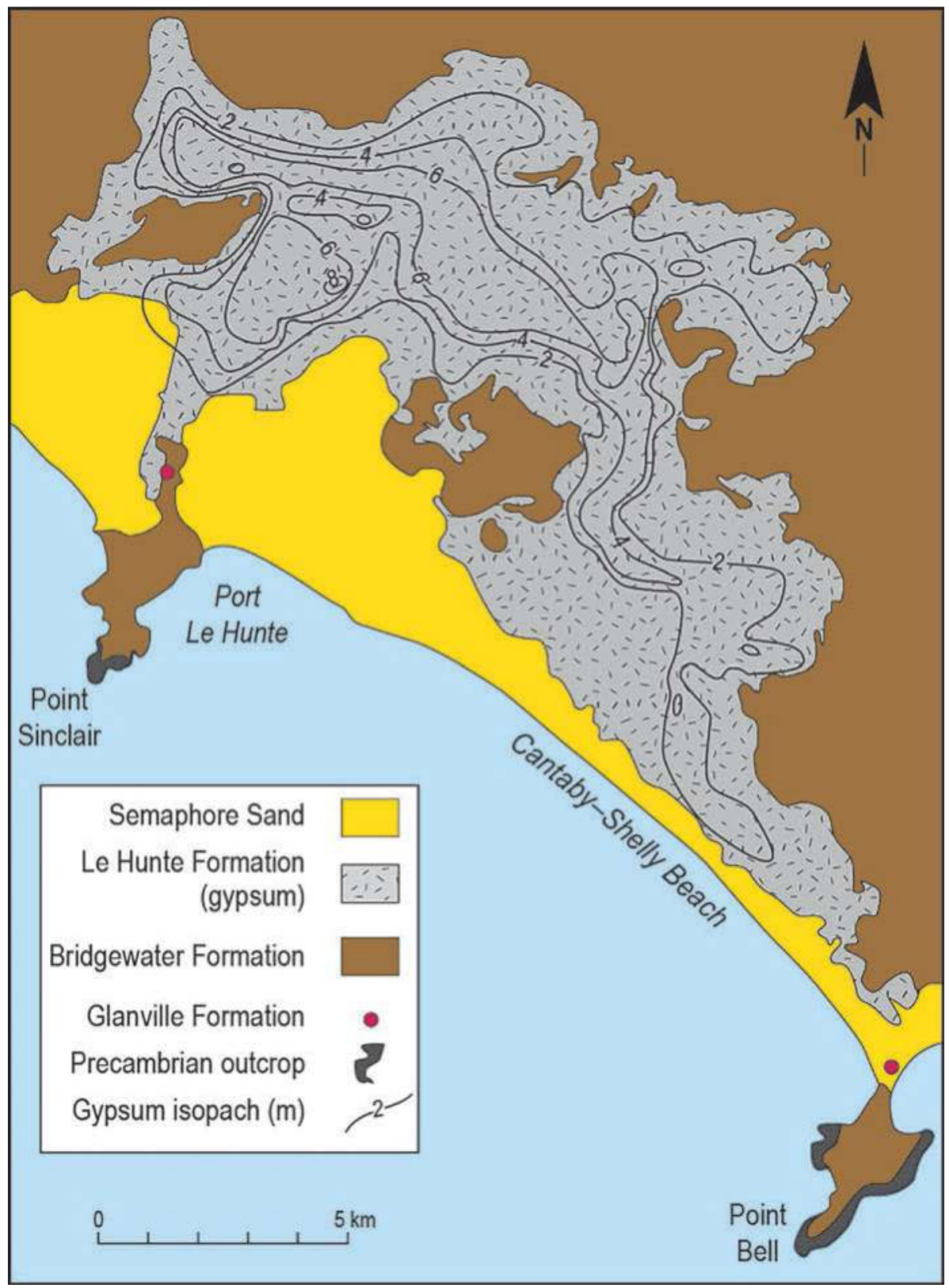

Figure 10.32 Lake MacDonnell and its gypsum deposits formed as sea water seeped into a pre-existing coastal depression through the coastal sand dunes to evaporate and precipitate gypsum. The lake was probably a marine embayment during the Last Interglacial. The isopachs indicate the thickness of gypsum in the lake.

Source: Belperio, A.P. (1995). Coastal and marine sequences, in Chapter 11, Quaternary. In: Drexel, J.F. \& Preiss, W.V. (Eds), The geology of South Australia. Vol. 2, The Phanerozoic. Geological Survey of South Australia, Bulletin 54, pp. 219-240. Modified and reproduced with permission of the Department of State Development's Resources and Energy Group. 


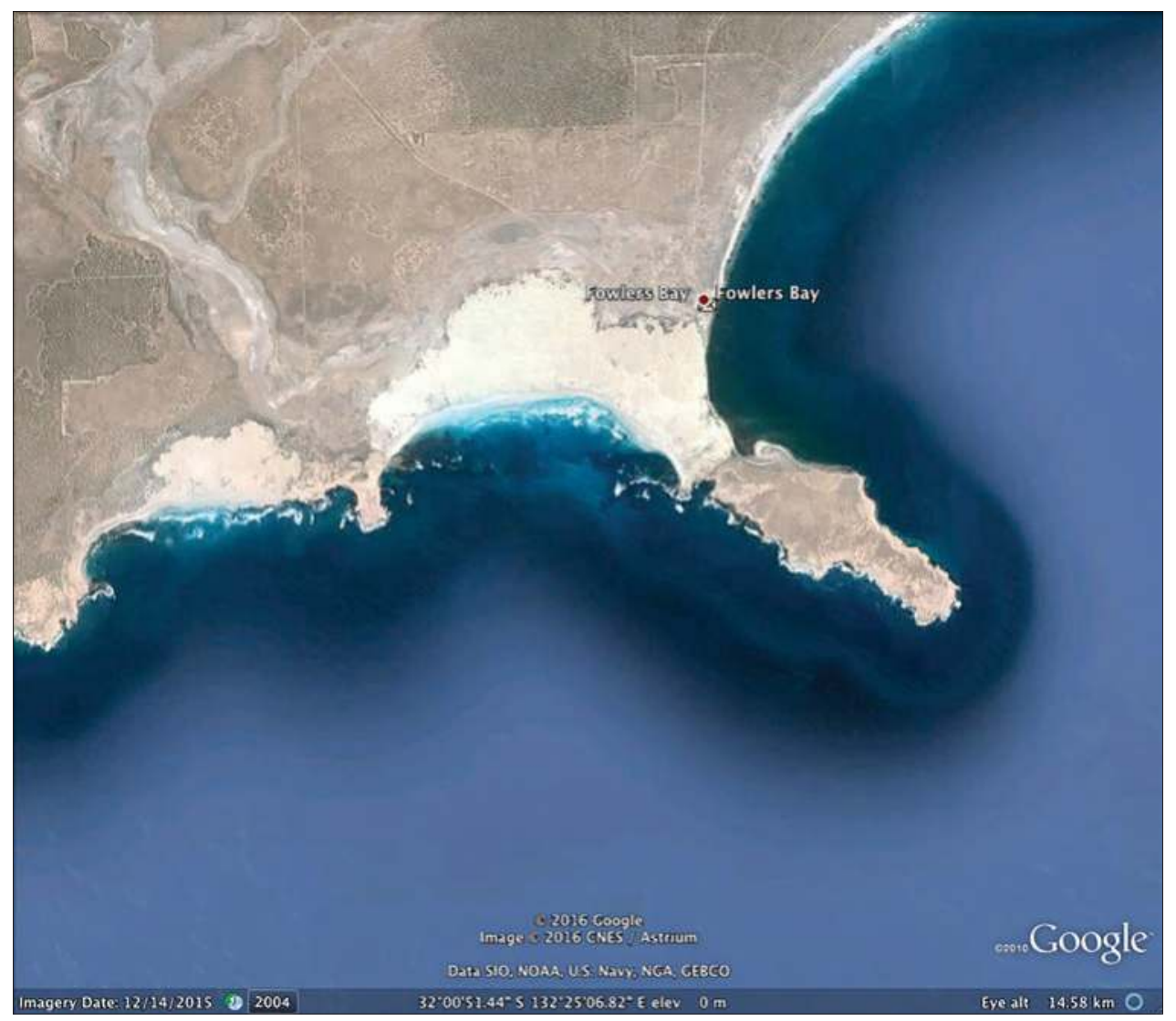

Figure 10.33 Fowlers Bay area, with the prominent headland of Point Fowler, developed in aeolianite over bedrock. The active sand dunes are migrating from Scott Bay over the headland into Fowlers Bay, blocking drainage and forming a swamp. During the higher sea level of the Last Interglacial, this swamp was an arm of the sea, while Cape Fowler was an island.

Source: Google Earth image () 2015 Google.

and has landlocked an abandoned whaling station, leaving the station $100 \mathrm{~m}$ inland. A large, low-lying samphire swamp occurs landward of Fowlers Bay. This was a back-barrier lagoonal embayment during the Last Interglacial. The modern active sand dunes, which sweep in from Scott Bay across the headland, have blocked off free drainage to the sea, burying some of the early buildings and threatening to engulf Fowlers Bay Township. This process of headland bypassing is a major supplier of sand to Fowlers Bay. Strong winds and a plentiful supply of sand has led to the development of extensive coastal dunes in the Fowlers Bay area (Figure 10.34).

Between Point Bell and the Head of the Bight, the shoreline is backed by a series of at least three former separate Pleistocene dune barrier systems of the Bridgewater 
Formation $^{21}$, in addition to the modern beach/dune barrier. Because of the tectonic stability of the area during the Pleistocene, the deposits of successive interglacial high sea levels merge and are indistinguishable. However, in a few places it has been possible to distinguish separate dune ranges associated with discrete former shorelines, such as the last interglacial (125 ka) Nundroo Range and the penultimate interglacial $(250 \mathrm{ka})$ Bookabie Ranges. An older Early Pleistocene range has also been identified (Figure 10.35). Each dune developed during an interglacial period of relatively high sea level.

The coastline between Cape Adieu and the Head of Bight is $110 \mathrm{~km}$ long and relatively straight; it is in alignment with the consolidated Pleistocene dunes of the Last Interglacial. Low reefs and intertidal shore platforms, developed in aeolianite and beachrock, are interspersed with sandy beaches; they occasionally form lagoons between the reef and shore. Breaks in the reefs lead to the development of curved sandy bays with backing dunes. Cliffs and bluffs 10 to $30 \mathrm{~m}$ high front the coast, except

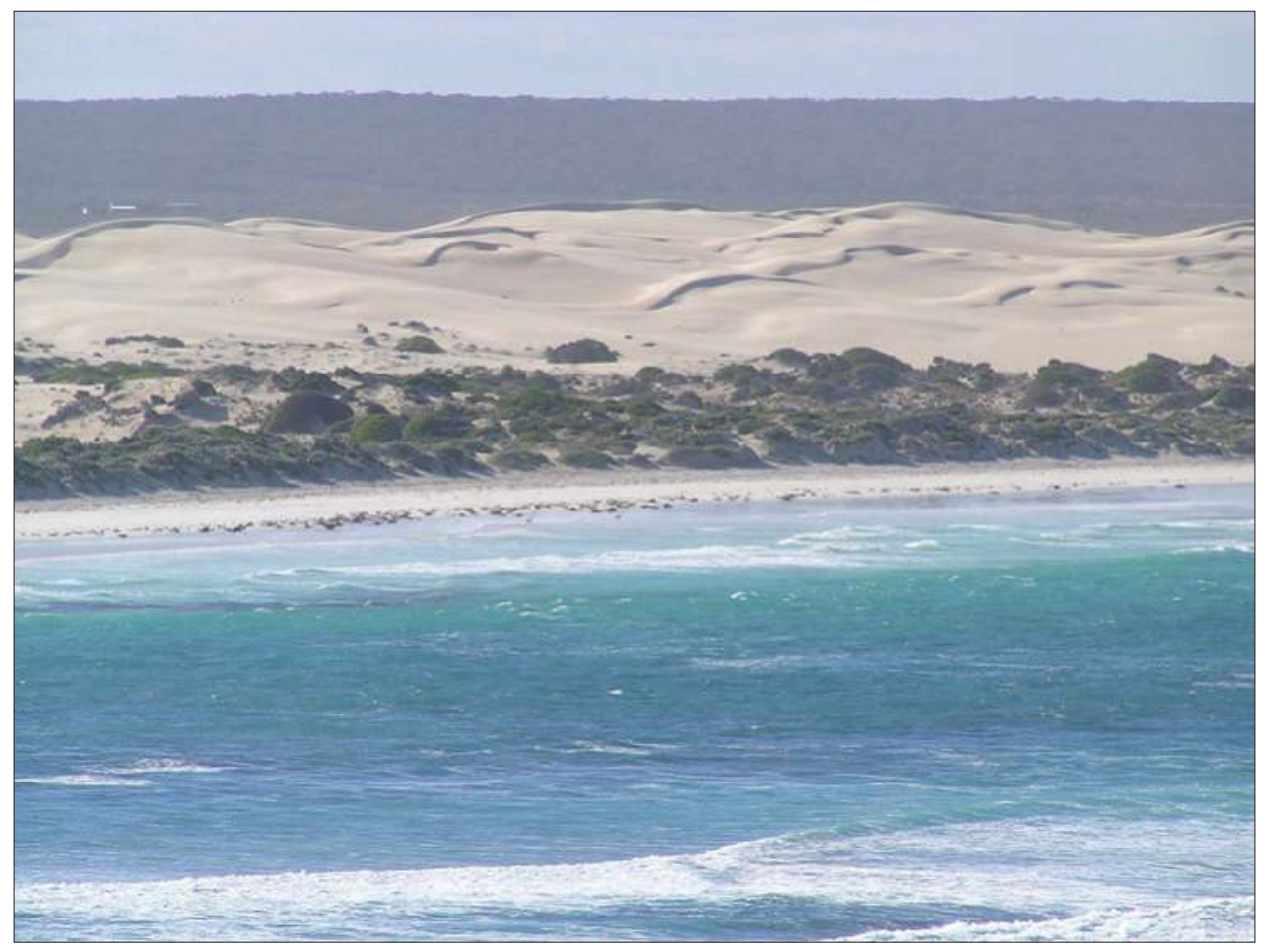

Figure 10.34 Active sand dunes near Fowlers Bay with vegetated foredunes. The migrating crests of the mobile dunes vary depending on wind strength and direction. In this instance, they are migrating seawards, as indicated by the orientation of the sharp slip faces.

Source: Author's own work, RPB. 

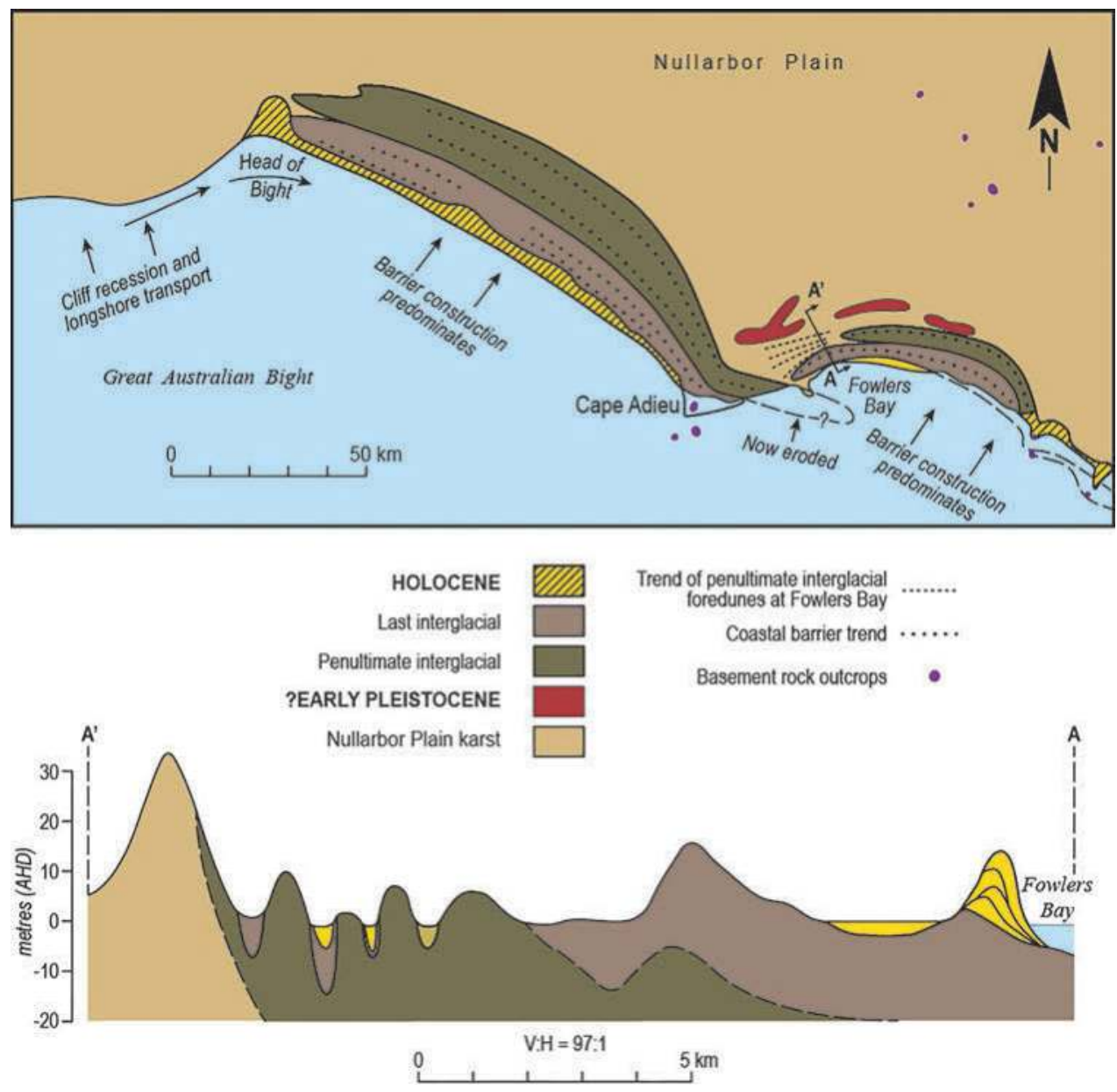

Figure 10.35 The coastline between the Head of Bight and Rocky Point is backed by up to three Pleistocene beach/dune barriers. The orientation of the modern coastline largely mimics that of the older barriers.

Source: Belperio, A.P. (1995). Coastal and marine sequences, in Chapter 11, Quaternary. In: Drexel, J.F. \& Preiss, W.V. (Eds), The geology of South Australia. Vol. 2, The Phanerozoic. Geological Survey of South Australia, Bulletin 54, pp. 219-240. Modified and reproduced with permission of the Department of State Development's Resources and Energy Group.

where they are obscured by fields of hummocky, alveolar or net-shaped dunes, both mobile and fixed with vegetation. Some large blowouts occur, such as the Tchalingaby Sand dunes, which cover $10 \mathrm{~km}^{2}$, reach a maximum height of $70 \mathrm{~m}$ and extend inland for $3 \mathrm{~km}$.

The shape of the coast in plan is due to outcrops of resistant Precambrian basement rocks, such as at Cape Adieu, Cactus Beach, Point Sinclair, Point Bell, Rocky Point and beneath the aeolianite at Fowlers Bay. The Nuyts Reef, comprising old resistant 
rocks partly mantled with aeolianite, lies offshore from Cape Adieu, and Mexican Hat forms an island near Cape Nuyts. Reefs, shore platforms at various levels, sea stacks and cliffs formed in aeolianite are ubiquitous.

At the Head of Bight, sediment derived from erosion of the Bunda Cliffs has accumulated, forming a sandy beach and providing the sand for a massive transgressive dune field, the Yalata Dune field, which has migrated inland some $8 \mathrm{~km}$ (Figure 10.36).

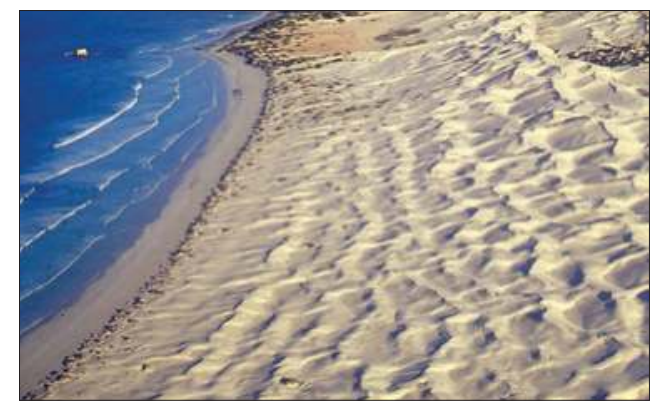

Figure 10.36 The Yalata Dune field at the Head of Bight. A sea stack, Twin Rocks, lies offshore from the dune field.

Source: Author's own work, RPB.

\subsection{Head of the Bight to the West Australian border}

\subsubsection{The Nullarbor (Bunda) Cliffs}

The Nullarbor or Bunda Cliffs, which are formed in Paleogene-Neogene limestone, are up to $100 \mathrm{~m}$ in height and are reputed to form the longest unbroken cliff line in the world. The two main units exposed in the cliffs are the whitish-coloured Wilson Bluff Limestone of Middle to Late Eocene age ( 43 to $35 \mathrm{Ma}$ ) at the base, and the light brown Nullarbor Limestone of Middle to Late Miocene age to Early Pliocene age (16 to $6 \mathrm{Ma}$ ) (Figure 10.37). ${ }^{22} \mathrm{~A}$ thin but persistent band of yellow/ brown limestone, the Abrakurrie Limestone, separates the two. In South Australia, the Bunda Cliffs extend some $210 \mathrm{~km}$ from the Head of the Bight, near the settlement of Nullarbor, to the border, near Wilson Bluff. Calcrete at the surface of the cliff tops presents a resistant capping to erosion, which is also affected by the paucity of rainfall, the majority of which evaporates or disappears into the underground limestone.

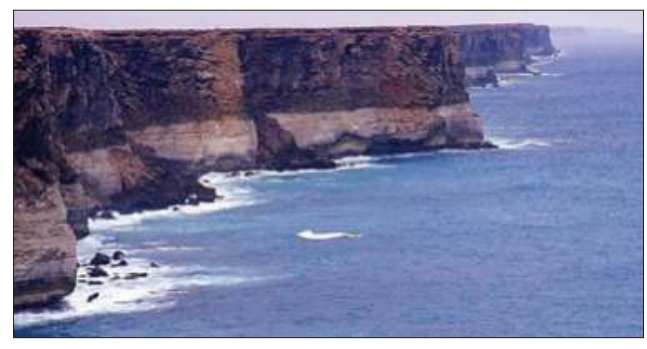

Figure 10.37 The eroding Bunda cliffs at the Head of Bight.

Source: Author's own work, RPB.

Bearing the brunt of high-energy waves approaching an uplifted and erodible landmass, the cliff line has a spectacular scalloped plan, a feature characteristic of highly eroding coastlines. Undercutting and collapse of the cliff are indicated by fresh scars on the cliff face and temporary accumulations of fallen rocks at the cliff base. Cliff collapse is common, with local operators of scenic flights reporting collapses on a weekly basis. 
In some localities, sand dunes sit atop the cliffs (cliff-top dunes), attesting to the former presence of sand ramps at the base of the cliffs, which allowed the sand to migrate onto the Nullarbor plateau. Subsequent erosion has removed the sand ramp, leaving the dunes perched on the cliff top. A currently active ramp that is forming cliff-top dunes occurs at the Merdayerrah Sandpatch, where, in places along $20 \mathrm{~km}$ of the Bunda Cliffs, modern dunes are migrating onto the cliff top, which is $90 \mathrm{~m}$ high.

\subsection{Summary and conclusions}

The evolution of the Bight Coast of Eyre Peninsula began with the separation of Australia and Antarctica $43 \mathrm{Ma}$ ago, when the broad arcuate shape of the coastline was established. During higher sea levels of the Late Eocene (37 to $34 \mathrm{Ma}$ ), the coast stood several hundred kilometres landward of its present location, and numerous streams flowed to the coast through coastal barrier systems. Tectonic subsidence of the Eucla Basin resulted in the deposition of limestones during the Oligocene and Miocene, later uplifted and eroded to form the spectacular Bunda Cliffs of the Nullarbor.

Two geological features, in particular, influence the nature of the Bight Coast: the ancient, stable and resistant crystalline rocks of the Gawler Craton, and the presence of vast, consolidated coastal dunes (aeolianite), which are biogenically produced and derived from the continental shelf during numerous Pleistocene excursions of sea level. The aeolianites are primarily composed of marine carbonate, reflecting the absence of streams delivering terrestrial, quartzose sediments to the coast. Reworking of the aeolianite deposits, coupled with strong onshore winds, has spawned numerous modern dune fields and cliff-top dunes.

The tectonic stability of the Gawler Craton, especially during the Pleistocene, provides a datum to establish the level of the last interglacial sea ( $125 \mathrm{ka}$ ), which stands consistently at some $2 \mathrm{~m}$ APSL along the coast. The resistant Gawler Craton rocks also provide a buttress to coastal erosion and protect the weaker aeolianite deposits, which form spectacular cliffs and headlands in an environment of pronounced swell and storm wave activity. Despite the highly erosive potential along this coast, there are sheltered bays and inlets, many of which were larger during the Last Interglacial; these bays and inlets hold sandflats, mangroves, samphire swamps, beach ridges and sand spits.

\section{Notes}

1 Veevers, J.J., Powell, C. Mc. A. \& Roots, S.R. (1991). Review of sea floor spreading around Australia. 1. Synthesis of patterns of spreading. Australian Journal of Earth Sciences, 38, 373-389. 
2 Preiss, W.V. (1987). The Adelaide Geosyncline: Late Proterozoic stratigraphy, sedimentation, palaeontology and tectonics. Geological Survey of South Australia, Bulletin 53, D.J. Woolman, Government Printer, South Australia, Adelaide, 438 pp.

3 Milnes, A.R. \& Ludbrook, N.H. (1986). Provenance of microfossils in aeolian calcarenites and calcretes in southern South Australia. Australian Journal of Earth Sciences, 33, 145-159.

4 Hou, B., Alley, N.F., Frakes, L.A., Gammon, P.R. \& Clarke, J.D.A. (2003). Facies and sequence stratigraphy of Eocene palaeovalley fills in the eastern Eucla Basin, South Australia. Sedimentary Geology, 163, 111-130; Hou, B. \& Warland, I. (2005). Heavy mineral sands potential of the Eucla Basin in South Australia. MESA Journal, 37, 4-12.

5 Murray-Wallace, C.V. \& Belperio, A.P. (1991). The last interglacial shoreline in Australia - A review. Quaternary Science Reviews, 10, 441-461.

6 Jennings, J.N. (1957). Cliff-top dunes. Australian Geographical Studies, 5, 40-49.

7 Bryant, E. (2001). Tsunami: The underrated hazard. Cambridge University Press, Cambridge, 320 pp.

8 Fraser, G., Foudoulis, C., Neumann, N., Sircombe, K., McAvaney, S. Reid, A. \& Szpunar, M. (2008). Foundations of South Australia discovered. Aus Geo News, 92, 10-11.

9 Short, A.D. (2006). Beaches of the South Australian coast and Kangaroo Island: A guide to their nature, characteristics, surf and safety. Sydney University Press, Sydney, 346 pp.

10 Bartrum, J.A. (1916). High water rock platforms: A phase of shoreline erosion. Transactions of the New Zealand Institute, 48, 132-143; Kennedy, D.M., Paulik, R. \& Dickson, M.E. (2011). Subaerial weathering versus wave processes in shore platform development: Reappraising the Old Hat Island evidence. Earth Surfaces Processes and Landforms, 36, 686-694.

11 Twidale, C.R. \& Campbell, E.M. (1985). Chapter 4, The form of the landsurface. In: Twidale, C.R., Tyler, M.J. \& Davies, M. (Eds), Natural history of Eyre Peninsula. Royal Society of South Australia, pp. 57-76.

12 Flint, R.B. (1995). Itledoo Basin, Blue Range beds. In: Drexel, J.F. \& Preiss, W.V. (Eds), The geology of South Australia, Vol. 2, The Phanerozoic, Geological Survey of South Australia, Bulletin 54, p. 142.

13 Flint (1995).

14 Keeling, J.L. (1990). The provenance and accumulation of coarse-grained sand on Silica Beach, Baird Bay, Eyre Peninsula. Quarterly Geological Notes, Geological Survey of South Australia, 114, 8-17.

15 Short, A.D., Buckley, R.C. \& Fotheringham, D.G. (1989). Preliminary investigations of beach ridge progradation on Eyre Peninsula and Kangaroo Island. Transactions of the Royal Society of South Australia, 113, 145-161.

16 Short, Buckley \& Fotheringham (1989).

17 Short, Buckley \& Fotheringham (1989).

18 Bourman, R.P. (2006). A composite regolith profile at Ceduna, South Australia. Transactions of the Royal Society of South Australia, 131 (2), 197-205.

19 Short, Buckley \& Fotheringham (1989).

20 Belperio, A.P. \& Fotheringham, D.G. (1990). Geological setting of two Quaternary footprint sites, western South Australia. Australian Journal of Earth Sciences, 40, 423-426. 
21 Belperio, A.P. (1995). Coastal and marine sequences, in Chapter 11, Quaternary. In: Drexel, J.F. \& Preiss, W.V. (Eds), The geology of South Australia, Vol. 2, The Phanerozoic. Geological Survey of South Australia, Bulletin 54, pp. 219-240.

22 James, N. P. \& Bone, Y. (2011). Neritic carbonate sediments in a temperate realm. Springer, Dordrecht, $254 \mathrm{pp}$. 


\section{Kangaroo Island}

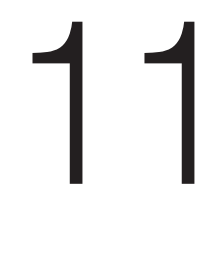

\subsection{Introduction}

Kangaroo Island, Australia's third-largest island after Tasmania and Melville Island, is approximately $140 \mathrm{~km}$ long (east-west) and $55 \mathrm{~km}$ wide (north-south), with a coastline of some $458 \mathrm{~km}^{1}$, and a land area of approximately $3890 \mathrm{~km}^{2} .^{2}$ Coastal cliffs that developed on pre-Cenozoic bedrock, Paleogene-Neogene limestones and Pleistocene aeolianite (dune limestone) comprise approximately $66 \%$ of the island's coastline, while the remaining $34 \%$ of the coastline consists of sandy beaches. The island has 218 beaches, which average only $700 \mathrm{~m}$ in length. ${ }^{3}$ Kangaroo Island is separated from the mainland by Backstairs Passage, a stretch of water about $14 \mathrm{~km}$ wide between Dudley Peninsula, on the easternmost portion of the island, and Fleurieu Peninsula, on the mainland. In places, Backstairs Passage is an oversteepened bedrock depression formed by glacial erosion during the Early Permian (299 to $290 \mathrm{Ma}$ ). ${ }^{4}$ In the central portion of the passage, water depth exceeds $40 \mathrm{~m}$; and closer to the island's coast, approximately $2 \mathrm{~km}$ to the east of Cape St Albans, it exceeds $80 \mathrm{~m}$ (Figure 11.1). In this region, an elongate bedrock depression trends in a northwesterly direction. The north coast of the island is separated from southernmost Yorke Peninsula by Investigator Strait, a stretch of water $50 \mathrm{~km}$ long and less than $55 \mathrm{~m}$ deep on the easternmost Lincoln Shelf.

With its long axis trending east-west, the island attenuates the impact of high-energy swell waves on Gulf St Vincent. The northwestern coastline of the island is bounded by the Lincoln Shelf, and its southern and eastern coastlines are bordered by the Lacepede Shelf (Figure 11.1). The edge of the continental shelf is approximately $60 \mathrm{~km}$ south of the island, where a spectacular series of submarine 


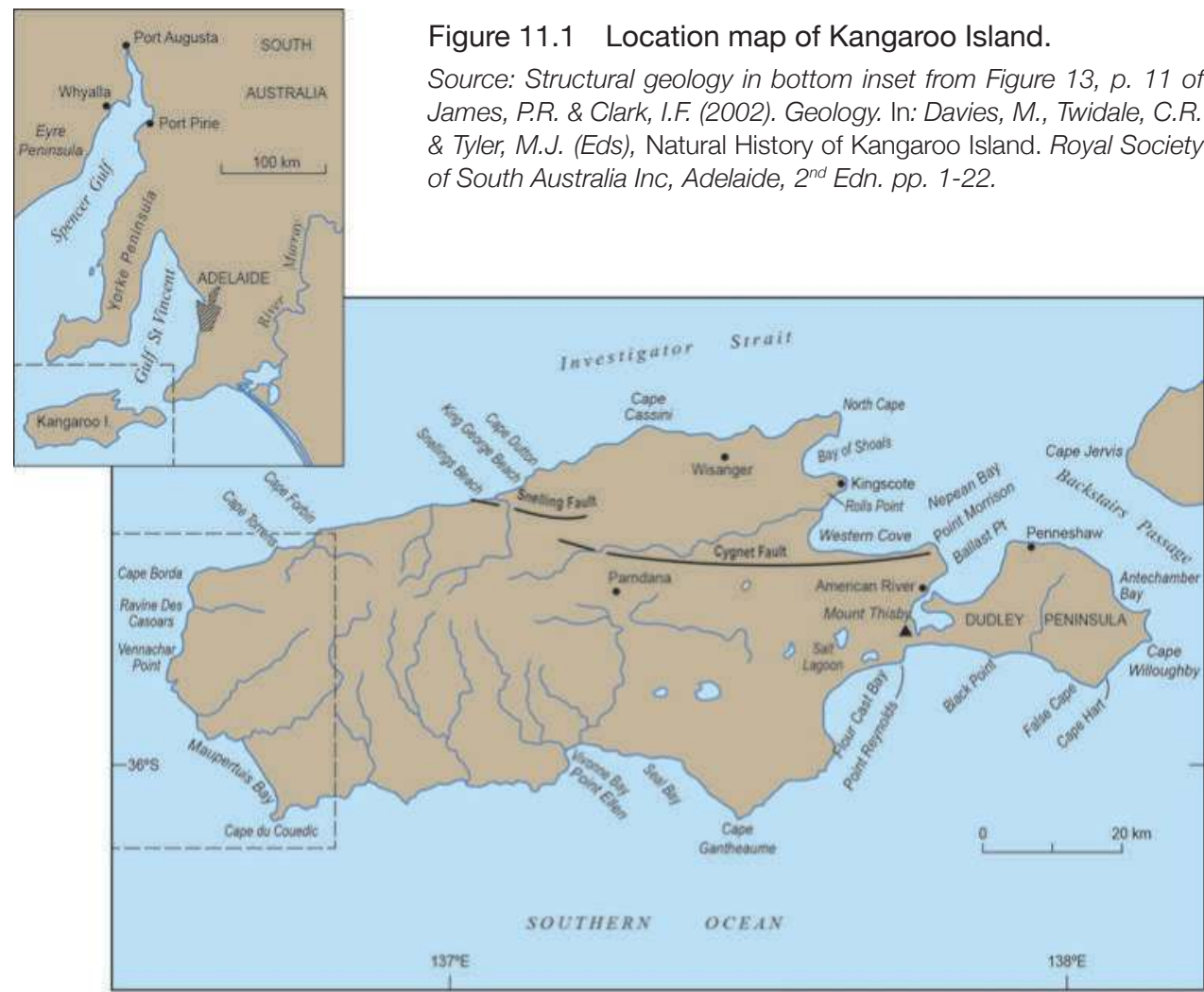

canyons (Murray Canyons Group) occurs. Some of these are among the largest in the world and remain active conduits for the transportation of continental shelf sediment to the deep sea. ${ }^{5}$ In contrast, the west-facing coastline between Cape Borda and Cape du Couedic is bounded by a narrow shelf, less than $10 \mathrm{~km}$ wide.

\subsection{Regional geological setting}

The regional landscape of Kangaroo Island comprises a weathered, partially dissected plateau surface mantled by deeply weathered regolith, including ferricrete developed on pre-Cenozoic bedrock. The plateau surface has been differentially uplifted and tilted with higher relief (250 m APSL) in the northwest of the island compared with the southeast, where the plateau surface is $50 \mathrm{~m}$ APSL. On the southern coastline, between Hanson and Vivonne Bays, the regional, structurally controlled drainage pattern flows from the 
north, reflecting the tilt of the plateau surface. Cygnet River, the island's longest river, is approximately $50 \mathrm{~km}$ long and trends broadly east-west, draining into Western Cove in Nepean Bay (Figure 11.1). The dominance of aeolianite on the eastern half of the island between Vivonne Bay and Dudley Peninsula partly explains the lack of surface drainage and the extensive occurrence of lagoons. The gently undulating land surface of southern Dudley Peninsula is largely composed of Pleistocene aeolianite, while the American River to Pelican Lagoon region was a seaway during Pleistocene high sea level stands, before being constricted by aeolianite.

Kangaroo Island is an extension of the Mount Lofty Ranges. It trends eastwest due to regional-scale structures within the Neoprotereozoic and Cambrian bedrock, which forms the central core of the island. The Adelaide Rift Complex (that is, the Adelaide Geosyncline and Kanmantoo Trough, which was an actively subsiding marine basin 850 to $-550 \mathrm{Ma}$ ago, in the Neoproterozoic to Cambrian), is now formed of folded and regionally metamorphosed strata. At the macroscale, this defines a 'lazy-S structure', which extends north along the Mount Lofty and Flinders Ranges to the Olary Province. Kangaroo Island is the southernmost portion of this folded terrain. The rock successions include folded and metamorphosed sedimentary rocks of the widespread Cambrian (541 to $486 \mathrm{Ma}$ ) Kanmantoo Group, which form bedrock-dominated coastal cliffs around substantial parts of the island's coastline. Between Western River Cove and Kingscote (Figure 11.1) along the central northern coastline, the Cambrian Kangaroo Island Group, a succession of shallow marine (platform) sedimentary rocks, crops out along the coastal cliffs. The southern limit of this succession is bounded by the Kangaroo Island Shear Zone ${ }^{6}$, a structural feature generally coincident with the younger Cygnet and Snelling Faults, which have northfacing scarps and form a topographic divide (fault-bounded depression) between the low northern plains of the Nepean Lowlands and the higher-level central plateau surface.

The oldest outcropping strata on the island of Adelaidean age (850 to $541 \mathrm{Ma}$ ) are confined to northeastern Dudley Peninsula, east of Bald Hill. ${ }^{7}$ The Adelaidean (latest Neoproterozoic) spans a time interval in which the Earth experienced a major continental glaciation during the Cryogenian Period (850 to $635 \mathrm{Ma}$ ) and the appearance of the first multicellular organisms during the Ediacaran Period (635 to $541 \mathrm{Ma}$ ). Occurring between two shear zones, these successions show a higher degree of metamorphism than do equivalent formations to the south of Adelaide, and they also form an overturned anticline.

Along the southwestern coastline, granites of Cambro-Ordovician age $(514$ to $485 \mathrm{Ma}$ ) give rise to imposing coastal cliffs and other landforms, such as Remarkable Rocks. The Cape Willoughby Granite, a related granite, occurs along some seven kilometres of coastline between Moncrieff Bay and Windmill Bay, and also crops out at Cape Willoughby (Figure 11.1). Collectively, these granite plutons 
were intruded during the Delamerian Orogeny, a protracted interval of crustal deformation, regional metamorphism and mountain building, which created a fold mountain range, the Delamerides. ${ }^{8}$ This mountain range underwent substantial erosion, and up to $10 \mathrm{~km}$ of regional landscape-lowering occurred between the Lower Ordovician (485 Ma) and the beginning of the Permian (299 Ma). The erosion exposed upper parts of the granite plutons, such as at Windmill Bay, where a horizontal shore platform formed between 5 to $6 \mathrm{~m}$ APSL and is now overlain by aeolianite of the Pleistocene Bridgewater Formation. ${ }^{9}$

There is a major gap in the geological record both in the Adelaide region and on Kangaroo Island: Silurian (443 to $419 \mathrm{Ma}$ ), Devonian (419 to $359 \mathrm{Ma}$ ) and much of the Carboniferous (359 to $299 \mathrm{Ma}$ ) Periods of geological time are not represented. Surface exposures of Permian unlithified glacial sediments, deposited when Australia was part of the supercontinent Gondwana and extensively covered by a continentalscale ice sheet, are confined to the north coast at Smith Bay, Boxing Bay, Kingscote and Christmas Cove (Figure11.1). Christmas Cove is a bedrock depression formed by ice movement and glacial scouring during the Permian, and preserves erosional features such as striated bedrock surfaces, erratics (boulders of granite derived from other locations) and a roche moutonnée (asymmetric knoll of rock) on the western side of the cove. ${ }^{10}$ Glaciated bedrock and elongate clasts within lodgement tills reveal a general northwest direction of ice flow, while glacial ice was funnelled through a preexisting east-west bedrock depression, forming the proto-Backstairs Passage. ${ }^{11}$

Volcanic activity during the Middle Jurassic (c. $170 \mathrm{Ma}$ ) erupted the Wisanger Basalt, which crops out in the Kingscote area and forms the basalt-capped plateau of the Gap Hills near Wisanger. The volcanism was associated with tension within the Earth's crust, associated with the early rifting phase during the separation of Australia and Antarctica. ${ }^{12}$ The basalt is part of a sheet-like deposit, shows well-developed columnar jointing and is commonly 15 to $20 \mathrm{~m}$ thick, with a maximum thickness of $30 \mathrm{~m}$.

Development of the Southern Ocean heralded a new phase in the geological history of the region, with the onset of vigorous carbonate sediment production on the continental shelves of southwestern and southern Australia. ${ }^{13}$ Widespread deposition of marine limestones accompanied major rises in global sea level (transgressions). The Kingscote Limestone, a succession of echinoid, bryozoan and molluscan carbonates, was deposited in the Eocene (c. 56 to $34 \mathrm{Ma}$ ), and sediments of similar age occur at Maslin Bay, south of Adelaide (Maslin Sand and Tortachilla Limestone). The upper portion of the limestone succession, which is of Oligocene age ( -34 to $23 \mathrm{Ma}$ ), comprises crossbedded calcareous sands (calcarenite). Shallow marine sedimentation continued with the deposition of the Early Miocene Mannum Limestone, which occurs as an isolated exposure $17 \mathrm{~km}$ west of Kingscote. The Mannum Limestone occurs extensively in the Murray Basin, and the presence of an isolated remnant of this succession on Kangaroo 
Island confirms that the region was subjected to marine inundation during the Early Miocene.

Substantial portions of the west and southern coasts of Kangaroo Island are blanketed by successions of aeolianite (dune limestone or calcarenite) of Pleistocene age, attaining thicknesses of up to $100 \mathrm{~m} .{ }^{14}$ The sediments comprise sand-size particles of skeletal carbonate derived from the physical breakdown of marine invertebrates such as molluscs, bryozoans, echinoids, foraminifers and coralline algae from the adjacent continental shelf. These 'blanket-like' deposits of dune limestone are predominantly of windblown origin and are stacked on top of each other and separated in places by relict soil profiles (paleosols) formed during periods of landscape stability, lower sea levels and reduced sand supply. In places, isolated relict beach deposits interbedded with the dune units, formed during intervals of higher sea level. Lithologically similar sedimentary successions occur on southwestern Yorke Peninsula, western Eyre Peninsula and the Coorong and Limestone Coasts in the southeast of South Australia, and have collectively been mapped as correlatives of the Pleistocene Bridgewater Formation ${ }^{15}$, which was originally defined at Bridgewater Bay in western Victoria. ${ }^{16}$

Aeolianite crops out over half of Dudley Peninsula, and from Cape Gantheaume on the south coast these successions extend some $17 \mathrm{~km}$ inland. The bioclastic sediment comprising these deposits was generated on the highly productive inner-continental shelf environments of the Lincoln and Lacepede Shelves. The sediment was moved landwards by waves and shallow water currents and ultimately onto the land by wind. ${ }^{17}$ The vast deposits of aeolianite on Kangaroo Island attest to the high bioproductivity of the surrounding continental shelf environments; they are part of the world's largest aeolianite province, which extends from western Victoria to the north of Shark Bay in Western Australia. ${ }^{18}$

Deposition of the aeolianite successions has occurred since at least latest Early Pleistocene time, with the aeolianite from Kelly Hill Caves yielding a whole-rock (skeletal carbonate sand) amino acid racemisation age of $835 \pm 194 \mathrm{ka}$ and an optically stimulated luminescence age on quartz sand grains of $1.3 \pm 0.1 \mathrm{Ma} .{ }^{19}$ These analytical results support the mapping by Sprigg ${ }^{20}$, who demonstrated that the host rocks to Kelly Hill Caves are Pleistocene aeolianite. Geochronological evidence reveals that the aeolianite units were deposited at a time of Pleistocene high sea level stands during full interglacial conditions or during warm interstadials ${ }^{21}$, rather than following a regression after the Middle Miocene. ${ }^{22}$ This latter interpretation was based on the identification of reworked Early Miocene foraminifers within the aeolianite successions.

Another phase in the geological evolution of Kangaroo Island is represented by stranded beaches and terraces of Early Pleistocene and Holocene ages, which indicate deposition at times of higher eustatic (global) sea levels, as well as the influence of tectonic uplift. Their contained molluscan faunas provide insights into the nature 
of coastal environments and processes at the time of deposition, particularly in the enhanced strength of ocean currents and the warmer temperature of the inner shelf waters surrounding the island.

Numerous high-level benches, presumed to have formed by marine abrasion processes at times of higher sea level during the Pliocene and Pleistocene, have been reported from Kangaroo Island. ${ }^{23}$ These features were interpreted to be of marine origin and were identified based on correlation with the Mediterranean scheme of Quaternary sea level changes, in which it was held that evidence for successively younger interglacials occurred at lower elevations within coastal landscapes. ${ }^{24}$ Bauer identified an extensive terrace at an elevation of $122 \mathrm{~m}$ APSL on the weathered ferricrete plateau surface north of Vivonne Bay and at several locations on the north of the island, which he considered to be of Pliocene age. ${ }^{25}$ Several younger terraces of presumed Pleistocene age were identified at 57 to $47 \mathrm{~m}, 33 \mathrm{~m}, 25$ to $17 \mathrm{~m}, 8 \mathrm{~m}$ and 5 to $3 \mathrm{~m}$ APSL. The traditional glacio-eustatic Mediterranean scheme of Quaternary sea level change has been discredited, as the high shoreline elevations have been shown to be due to tectonism. ${ }^{26}$ However, a stranded cobble beach at Kingscote, now shown to be of last interglacial age, correlates with the terrace at the 5 to $3 \mathrm{~m} \mathrm{level.}{ }^{27} \mathrm{~A}$ shingle beach deposit at Admiral's Arch is also a likely correlative of the Kingscote deposit.

Kangaroo Island became isolated from the mainland with the most recent phase of sea level rise following the demise of the continental ice sheets at the end of the Last Glacial Maximum, 16000 years ago. The present form of Kangaroo Island was broadly established 7000 years ago, at the culmination of the most recent postglacial rise in sea level. Previously, during many earlier glacial events, the island had been connected to the mainland; this occurred at least eight times during the past 800000 years, based on understanding of relative changes in sea level at the global scale. ${ }^{28}$

The coastline of Kangaroo Island is exposed to the full force of the Southern Ocean and experiences high wave energy conditions, particularly along its western and southern coasts. Southwesterly swell waves are less than $2 \mathrm{~m}$ for approximately half the year, with wave heights of 2 to $4 \mathrm{~m}$ for 30 to $45 \%$ of the year, exceeding $4 \mathrm{~m}$ for at least $5 \%$ of the year on average. Tides are microtidal, with the highest tides $(1.4 \mathrm{~m})$ recorded in the Kingscote region. ${ }^{29}$ In broad view, the regional coastal morphology is in part a function of these contrasting wave regimes; accordingly, the western and southern coasts are dominated by actively eroding cliffs and pocket beaches. The northern and eastern coastal sectors are characterised by high cliffs (due to uplift of resistant bedrock) and pocket beaches, while tidal inlets and mudflats occur in the more protected sectors of the northeastern coastline. The island experiences a Mediterranean-style climate with hot, dry summers and cool, wet winters. In this chapter, the landforms of the modern coastal landscapes of Kangaroo Island are described in a clockwise direction around the island, beginning at Kingscote. 


\subsection{Modern coastal landscapes of Kangaroo Island}

The modern coastline of Kangaroo has a diverse range of coastal landforms that include coastal cliffs and shore platforms developed on a range of rock types of contrasting resistance to erosion; relict beach deposits associated with Pleistocene interglacial sea levels; boulder, cobble and sandy beaches; and, in sheltered settings, sandflats, such as in the Cygnet River Delta in Western Cove, Nepean Bay. Overall, the island has a coastline dominated by bedrock cliffs, with the Pelican Lagoon region representing the only major estuarine coastal waterway on the island. A few, smaller estuarycoastal lagoons occur landward of small coastal barriers around the island, such as at Harriet River (Vivonne Bay), Stun Sail Boom River and South West River at Hanson Bay on the southern coastline, and Middle River at Snelling Beach on the northern coastline (Figure 11.1). Another pervasive feature of Kangaroo Island is the extensive occurrence of aeolianite (dune limestone) exposed in coastal cliffs and forming shore platforms principally along the southern and western coasts; more restricted examples of these sedimentary successions on the northern coast occur, particularly on North Cape Peninsula between Emu Bay, North Cape and Cape Rouge (Figure 11.1). The coastline between Kingscote jetty and the Old Government Quarry is formed on unstable Permian glacigene sediments, which are very vulnerable to coastal erosion, and which have required protective works to inhibit coastal collapse and retreat.

\subsubsection{Stranded cobble shoreline, Kingscote}

At Kingscote, between The Bluff and Rolls Point (Figure 11.1), there is a stranded shoreline succession, comprising strongly indurated basalt cobbles set in a shelly matrix cemented by calcium carbonate. ${ }^{30}$ The stranded beach deposit crops out along a small coastal cliff, which typically stands up to $3 \mathrm{~m}$ high (Figure 11.2). The clasts are predominantly well-rounded pebbles and cobbles of basalt, with additional clasts of limestone and quartz. The basalt clasts are derived from the Jurassic Wisanger Basalt, which crops out to the north of the town of Kingscote. Twenty species of fossil marine shells have been identified within the stranded beach deposit, with the genera Katelysia sp., Anapella cycladea and Mactra australis being the most common. ${ }^{31}$ The presence of the megascopic foraminifer Marginopora vertebralis indicates warmer water temperatures at the time of deposition of the beach deposit due to an intensified Leeuwin Current, which delivered warmer, lower-salinity ocean surface waters from Western Australia across the Great Australian Bight. ${ }^{32}$ The stranded cobble beach rests unconformably on a karst weathered bench $2 \mathrm{~m}$ APSL, which developed on the Paleogene Kingscote Limestone. The landward 'feather edge' of the relict beach deposit occurs up to approximately $3 \mathrm{~m}$ APSL and would have formed under moderately high wave energy conditions at a time of a slightly higher sea level (possibly up to $2 \mathrm{~m}$ APSL). A fossil coral Goniopora lobata from the succession provided an age of $122 \pm 1 \mathrm{ka}$, demonstrating a last interglacial age for the deposit. ${ }^{33}$ 


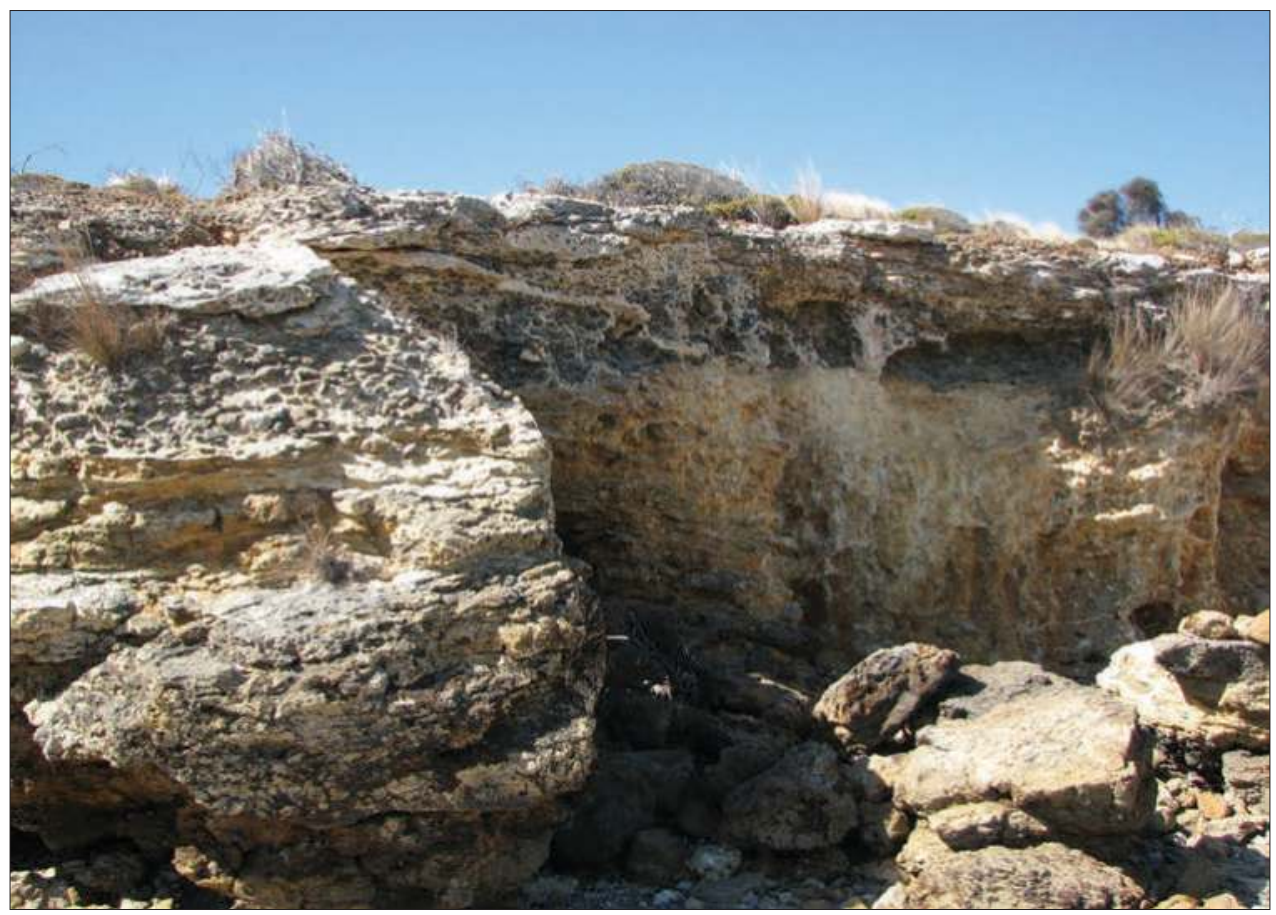

Figure 11.2 A last interglacial (125 ka) stranded beach deposit with basalt cobbles and pebbles, near Kingscote.

Source: Courtesy of Terry Lachlan.

\subsubsection{Western Cove to Redbank, Nepean Bay}

The Western Cove coastline is one of the few low-relief portions of coast on the entire island and is an extension of the Nepean Lowlands. The marshlands of the Western Cove area formed as a bay-head delta of the Cygnet River in a protected portion of Western Cove. The delta plain has prograded (advanced seaward) by about $1 \mathrm{~km}$ during the past 7000 years, as indicated by several shelly sand beach ridges, which mark the positions of successively younger shorelines. Samphire sandflats are exposed at low tide and extend some $400 \mathrm{~m}$ from the main shoreline. Numerous tidal creeks drain this coastal lowland. At the northern margin of the delta, there are up to seven beach ridges, while to the south of Cygnet River, two of the landward ridges have yielded radiocarbon ages of $2650 \pm 60 \mathrm{yr}$ BP (radiocarbon laboratory code Wk-840) and $2290 \pm 50$ yr BP (Wk-841). ${ }^{34}$ These beach ridge coastlines are particularly vulnerable to flooding from storm surges, and a storm surge barrier has been constructed fronting Brownlow Beach along The Parade and Links Road. Similar works may be required at the Western Cove settlement. 
The coastline from Western Cove to Point Morrison is broadly arcuate in plan, with a cuspate foreland in the Nepean Bay Conservation Park. The cuspate foreland represents $1.5 \mathrm{~km}$ of coastal progradation in the past few thousand years, marked by several well-defined beach ridges. The cuspate foreland has formed by longshore sediment transport from the east. Fossil shell from one of the most landward swales between the beach ridges has yielded a radiocarbon age of $4580 \pm 70 \mathrm{yr}$ BP (Wk-839), indicating that the cuspate foreland is younger than that age. ${ }^{35}$

Nepean Bay occurs as a result of the easterly downtilting of the fault block north of the Snelling-Cygnet Fault. The basic form of the coastline from Western Cove to Point Morrison, and Ballast Head to American River, is therefore structurally controlled and broadly parallels two major southeasterly dipping thrust faults that define the eastward continuation of the Kangaroo Island Shear Zone. ${ }^{36}$ Between Western Cove and Point Morrison, the coast follows the eastern continuation of the Snelling-Cygnet Fault. The fault follows a prominent break in slope from the narrow coastal plain up to a plateau surface some $70 \mathrm{~m}$ APSL immediately south of the cuspate foreland. East of the cuspate foreland, the higher relief and steeper slopes define the coastline for the easternmost $8 \mathrm{~km}$ of the peninsula. Clearly visible from Kingscote, this coastal sector is formed of red cliffs (20 to $30 \mathrm{~m}$ APSL) cut in Pleistocene alluvium. In places, the vertical cliff faces are fronted by low-energy beaches and sandflats. Part of the Pleistocene alluvium contains magnetically susceptible minerals that reveal reverse magnetisation, indicating that a portion of the sedimentary succession was deposited before the Brunhes-Matuyama geomagnetic reversal at $780 \mathrm{ka} \mathrm{ago}^{37}$, while the upper part of the cliffs is formed of calcareous windblown sediment, a possible indicator of the progressive drying of the Australian continent over the past $500 \mathrm{ka}^{38}$

The sector of coastline from Point Morrison to Ballast Head is $4 \mathrm{~km}$ long and trends in a southeasterly direction. It is dominated by coastal cliffs up to $60 \mathrm{~m}$ high with small pocket sandy beaches and boulders offshore in the shallow subtidal zone. The resistant bedrock comprises the Early Cambrian Tapanappa Formation, a succession of grey-coloured sandstones. The northernmost section of Point Morrison consists of the slightly younger Early Cambrian Tunkalilla Formation, a series of dark blue/grey, iron-stained phyllites and siltstones.

\subsubsection{Dudley Peninsula}

Dudley Peninsula, the easternmost portion of Kangaroo Island (Figure 11.1), extends from the American River-Pelican Lagoon area to Cape Willoughby for some $30 \mathrm{~km}$. Episodically an island, the modern peninsula formed by deposition of aeolianite during the Pleistocene, principally along the southern shore of the peninsula, effectively establishing a land link between the regional bedrock highs of the Point MorrisonBallast Head and Kangaroo Head-Cape Willoughby sectors of coast. Skeletal carbonate sand ( 0.063 to $2 \mathrm{~mm}$ ), derived from the adjacent shallow continental shelf (Lacepede 


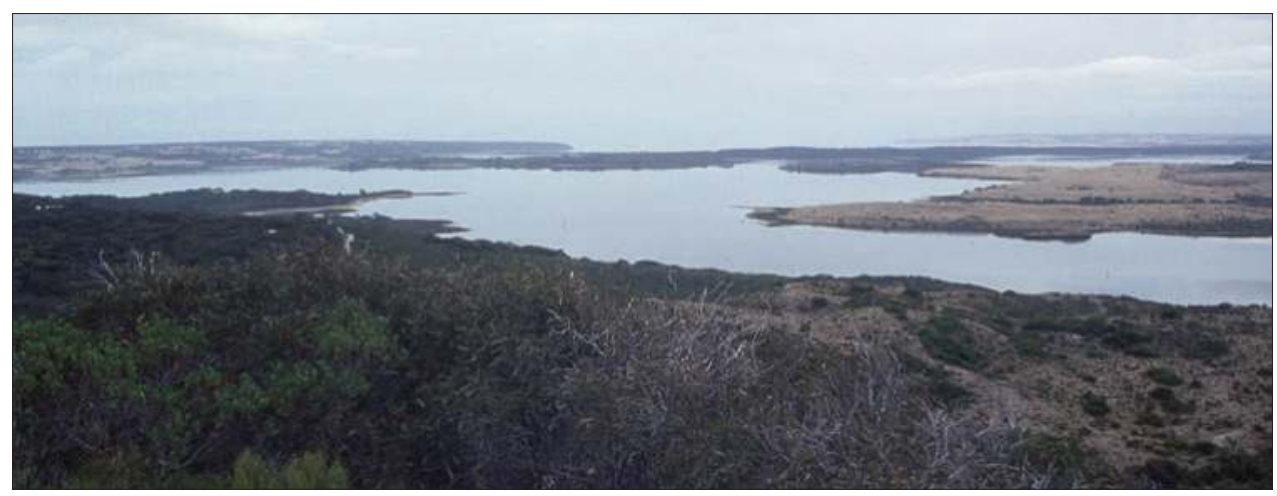

Figure 11.3 View looking northeast from Mt Thisby (Prospect Hill) towards Pelican Lagoon and American River, the largest estuarine coastal waterway on Kangaroo Island.

Source: Author's own work, CMW.

Shelf) to the southeast of the island, was the source for these sands, which now form extensive blanket-like deposits of aeolianite across the peninsula. Dune cross-bedding representing the slip faces of advancing aeolian dunes reveals that they migrated in a north-northwesterly direction. ${ }^{39}$ The gently undulating land surface, which developed on the aeolianite successions as seen at Pennington Bay, represents the original form of the dune landscape, which has been preserved through pervasive calcrete development. On the northern portion of the peninsula, the aeolianite successions unconformably overlie metasandstones of the Early Cambrian Tapanappa Formation of the Kanmantoo Group. Before deposition of the aeolianite, the Kanmantoo Group rocks would have formed a separate, small eastern island.

American River and Pelican Lagoon comprise the only major coastal-estuarine waterway on Kangaroo Island (Figures 11.1 and 11.3). American River extends some $7 \mathrm{~km}$ south from Eastern Cove, across the narrow neck of Dudley Peninsula; inland, to the east, it joins with Pelican Lagoon, a shallow lagoon some $4 \mathrm{~km}$ long (eastwest) and $2.5 \mathrm{~km}$ wide (north-south). The western side of Eastern Cove is bounded by the Early Cambrian Tapanappa Formation, giving rise to coastal cliffs and bluffs in solid bedrock. These strata continue along the western bank of American River. In the southern portion of American River, the Tapanappa Formation is blanketed by aeolianites of the Pleistocene Bridgewater Formation. Mount Thisby, originally named Prospect Hill by Matthew Flinders, is a high point on the southern coast in the American River-Pelican Lagoon area and is situated $1 \mathrm{~km}$ due west of the southernmost section of American River (Figure 11.1). Matthew Flinders climbed this 'eminence' to gain a further impression of the landscapes of the interior of the island and was surprised 
to see that the open ocean was only $1 \mathrm{~km}$ to the south. ${ }^{40}$ Mount Thisby is developed on Pleistocene aeolianite and covered with a veneer of younger Holocene dune sand. The southern portion of American River and all of Pelican Lagoon is bounded by Pleistocene aeolianite of the Bridgewater Formation.

Relict estuarine sediments of the Late Pleistocene Glanville Formation occur to the east of Pelican Lagoon, a former estuary entrance which was located on the eastern side of Eastern Cove near Rocky Point (Figure 11.1). The Glanville Formation developed during the Last Interglacial Maximum some 125000 years ago at a time of higher sea level. Sediments of equivalent age on Eyre Peninsula indicate that sea level was at least $2 \mathrm{~m}$ APSL at this time. The sediments at Eastern Cove contain a diverse molluscan fauna and are capped by a strongly indurated laminar calcrete (Figure 11.4). The Glanville Formation preserves elements of warmer-water fauna that no longer live in the coastal waters of South Australia; these include the Sydney blood cockle Anadara trapezia, the Shark Bay pearl oyster Pinctada carchariarum, the conical-fusiform gastropod Euplica bidentata and the megascopic foraminifer Marginopora vertebralis. ${ }^{41}$ Their presence is a function of the warmer waters brought across the Great Australian Bight during the Last Interglacial Maximum. ${ }^{42}$ The relatively narrow entrance to

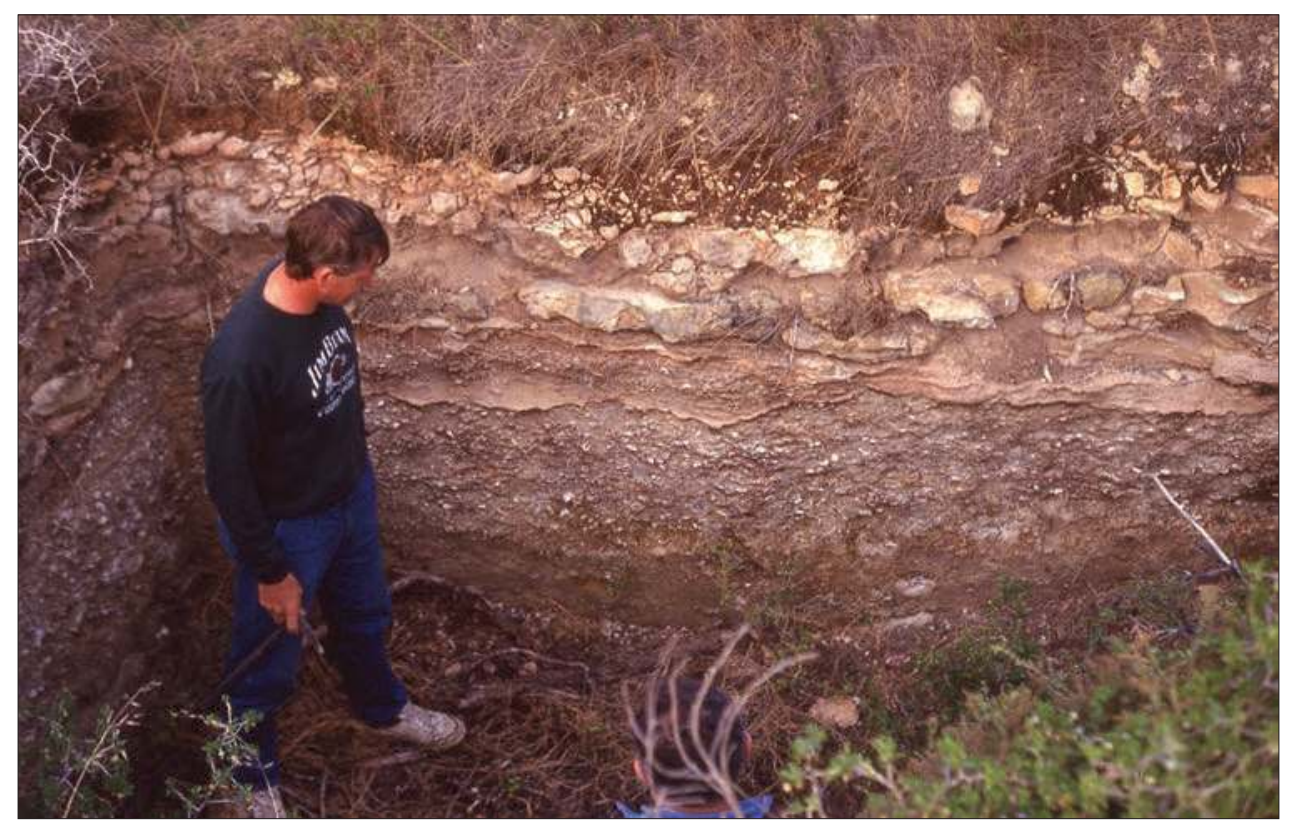

Figure 11.4 An exposure of the last interglacial (125 ka) Glanville Formation to the east of Pelican Lagoon, Dudley Peninsula. The excavation reveals an in situ shell bed overlain by laminar, blocky and rubbly calcrete horizons.

Source: Author's own work, CMW. 
American River is flanked by Buick Point and Strawbridge Point. Buick Point is a triangular spit largely underlain by shells of probable last interglacial age. Strawbridge Point is also a spit and shell ridge.

Several well-defined sandy beaches occur on the eastern sector of Eastern Cove from Rocky Point to American Beach (Figure 11.1). They are situated in more protected settings with low wave energy, and consequently sand bars and sandflats up to $100 \mathrm{~m}$ wide in places front the beaches. These beaches are backed by welldeveloped foredunes, and, farther inland, by coastal bluffs developed on the Pleistocene Bridgewater Formation. At the northern end of American Beach, the coastline trends in a northerly direction for $4 \mathrm{~km}$ and is backed by steep coastal cliffs developed on sandstones of the Cambrian Tapanappa Formation that extend up to $100 \mathrm{~m}$ APSL. From Kangaroo Head east to the Chapman River mouth at the northern end of Antechamber Bay, coastal cliffs and steep rocky slopes, up to $160 \mathrm{~m} \mathrm{APSL}$ and formed principally on the Early Cambrian Tapanappa Formation, dominate the coastline. Between Cuttlefish Bay and Sprigg Inlet $(2.5 \mathrm{~km}$ ) (Figure 11.1), the coast is formed on Late Neoproterozoic strata, the oldest rocks exposed in coastal cliffs on the island. ${ }^{43} \mathrm{~A}$ few inaccessible beaches, occupying small structurally controlled coves less than $200 \mathrm{~m}$ wide, occur along this stretch of coast. The sand in the coves was entrained landwards from the western Lacepede Shelf during sea level rise at the end of the Last Glacial Maximum.

Situated between the bedrock headlands of Cape Coutts and Cape St Albans towards the eastern end of Dudley Peninsula, Antechamber and Red House Bays (Figure 11.1) are broad, open, northeasterly facing, low-energy beaches backed by prominent foredunes up to $10 \mathrm{~m}$ high. The bays occur between resistant bedrock highs to the northwest (Tapanappa Formation) and southeast (Middleton Sandstone). The Chapman River mouth at the northern end of Antechamber Bay is commonly blocked by a sand spit. Antechamber Beach is $4.2 \mathrm{~km}$ long and is separated from the beach of Red House Bay by a prominent bluff up to $50 \mathrm{~m}$ high, developed on the Early Cambrian Balquhidder Formation, a grey biotite-laminated, lithic metasandstone. ${ }^{44}$ Red House Bay is a low-energy sandy beach $2.3 \mathrm{~km}$ long, with seagrass meadows offshore, as represented by the bladed leaf seagrass Posidonia australis.

Cape St Albans is a triangular-shaped protuberance developed on the Middleton Sandstone and capped by the Pleistocene Bridgewater Formation. On the Red House Bay sector of the cape, aeolianite successions of the Pleistocene Bridgewater Formation crop out along the coastline. On the easternmost portion of the island is Cape Willoughby, a headland $50 \mathrm{~m}$ high which formed on the granite of CambroOrdivician age. The Cape Willoughby Granite is a coarse-grained equigranular granite with quartz, microcline and plagioclase felspar and minor biotite. Xenoliths (inclusions of country rock) of Kanmantoo Group metasandstone are common within these rocks. At Pink Bay, masses of granite boulders have been rounded by wave action 
and have been closely packed together to form a spectacular granite boulder beach. ${ }^{45}$ The coastline from Cape Willoughby southwest to Cape Heart is bedrock-dominated, with sheer coastal cliffs between 60 to $80 \mathrm{~m}$ high formed on Cambrian Kanmantoo metasediments. Halfway along this coastline, dolerite dykes are locally exposed within the bedrock cliff exposures.

From False Cape to Point Reynolds (Figure 11.1), the southern coastline of Dudley Peninsula broadly trends east-west and is dominated by aeolianite, which crops out in sheer coastal cliffs up to $60 \mathrm{~m}$ high. At Black Point (Figure 11.1), the Cambrian Middleton Sandstone crops out $500 \mathrm{~m}$ along the coastline, forming a prominent headland in an otherwise linear sector of coast. The sandstone is medium-grained with large-scale tabular cross-beds between 1 to $3 \mathrm{~m}$ thick. The Wilson River, the only major river along this sector of coast, has cut a V-shaped valley over $80 \mathrm{~m}$ deep; this has partially infilled with river, beach and dune sediments, forming the well-developed Mouth Flat Beach, which is some $300 \mathrm{~m}$ long. Well-developed foredunes back the beach.

At the westernmost portion of Dudley Peninsula, Pennington Bay is a southfacing sector of coast up to $1.3 \mathrm{~km}$ long (Figure 11.1). From a prominent headland near the Cave Sandhills west to Pennington Bay, cliffs $20 \mathrm{~m}$ high, which developed on the Pleistocene Bridgewater Formation, front the coast. Local outcrops of the Early Cambrian Petrel Cove Formation, a succession of interbedded sandstones and mudstones, give rise to prominent headlands.

\subsubsection{The southern coastline: Point Reynolds to Cape du Couedic}

The south-facing sector of coast from Point Reynolds to Cape du Couedic is dominated by coastal cliffs developed on Pleistocene aeolianite, with D'Estrees Bay and Vivonne Bay representing two particularly prominent arcuate bays, backed by dune limestone and modern dune sands (Figures 11.1 and 11.5). In detail, the coastline between Point Ellen (on the western side of Vivonne Bay) west to Cape du Couedic appears more irregular in plan, with numerous promontories developed on Cambrian Kanmantoo metasandstones, Middle Cambrian granites such as the Stun Sail Boom Granite $\left(505 \pm 7 \mathrm{Ma}\right.$ ), and the Early Cambrian Middleton Sandstone. ${ }^{46}$ In places, high cliffs have developed on granites, which have a broad dome-like form, particularly at Remarkable Rocks. Pleistocene aeolianite covers much of the Paleozoic rocks, which are more resistant to coastal erosion, thus slowing the rate of cliff recession in aeolianite along this sector of coast.

D'Estrees Bay is an arcuate bay that faces southeast, with a beach up to $18 \mathrm{~km}$ long (Figure 11.1). ${ }^{47}$ The bay is backed by an aeolianite complex, which extends some $4 \mathrm{~km}$ inland, representing relict coastal barrier dune deposits of Middle and Late Pleistocene age. Salt Lake, a large back-barrier coastal saline lake up to $2 \mathrm{~km}$ long, is 


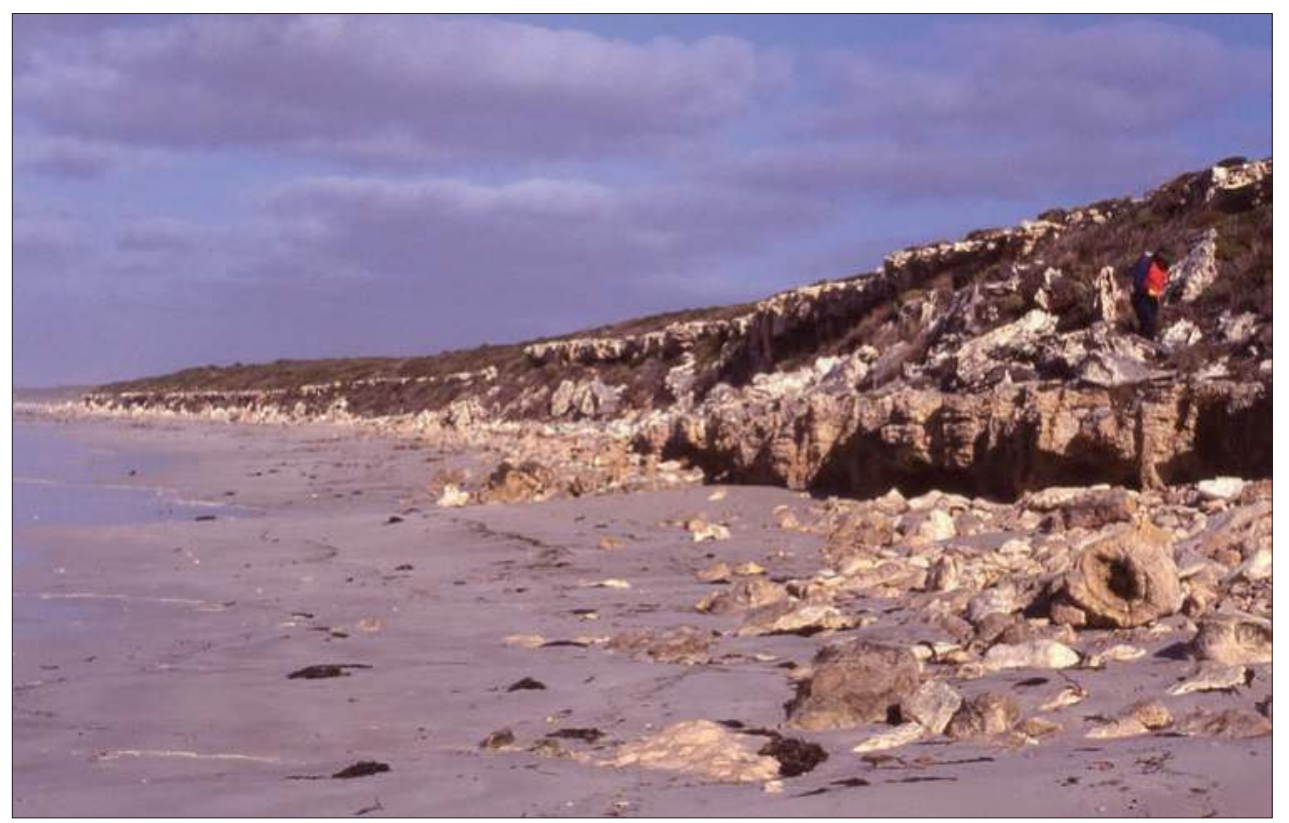

Figure 11.5 D'Estrees Bay, southeastern Kangaroo Island. The subdued coastal cliffs in this location comprise aeolianite (dune limestone) with a pervasive and laterally persistent calcrete horizon. The aeolianite has well-developed solution pipes, resulting from karst weathering processes. The cliff is undergoing active erosion, as seen in the detached blocks of limestone. Holocene coastal dunes covered by vegetation occur above the calcrete horizon.

Source: Author's own work, CMW.

actively precipitating gypsum $1 \mathrm{~km}$ inland from Flour Cask Bay (Figure 11.1). To the southwest of Salt Lake, the aeolianite successions bifurcate into two well-defined coastal barrier structures, and a series of small coastal lagoons occurs between these two barriers. At Point Reynolds, which defines the eastern limit of D'Estrees Bay, the aeolianite successions form steep coastal cliffs up to $50 \mathrm{~m}$ high (Figure 11.6). At this location, the aeolianite rests unconformably on Late Eocene and Pliocene limestones. At Table Rock near Point Reynolds, a high-level shore platform or bench has developed on these older limestones. ${ }^{48}$ The aeolianite successions are preserved as multiple-stacked, 'blanket-like' deposits of dune limestone with laterally persistent paleosols (relict soils) separating some of the major sedimentary units. Aeolianite cliffs up to $30 \mathrm{~m}$ high back the easternmost $6 \mathrm{~km}$ of the embayment, Flour Cask Bay. A narrow beach has developed in this region and at high tide water laps up against the coastal cliffs, which are rapidly eroding. A prominent bluff of aeolianite separates Flour Cask Bay from the rest of D'Estrees Bay. 
A southwest-trending, bedrock-dominated coastline, developed on steeply dipping beds of the Early Cambrian Middleton Sandstone, occurs between Point Tinline at the southern extremity of D'Estrees Bay across to Cape Gantheaume, the southernmost point of Kangaroo Island (Figure 11.1). Along this coastal sector, steeply dipping beds (up to $80^{\circ}$ southeast) of Middleton Sandstone give rise to serrated surfaces on the shore platforms at the base of the coastal cliffs and, in detail, control the orientation of the rocky coastline. This sector of coast is $18 \mathrm{~km}$ long and backed by cliffs 40 to $100 \mathrm{~m}$ high, developed on Pleistocene aeolianite. The cliffs have precipitous slopes and are embayed, with some bays backed by narrow and inaccessible sandy beaches. The aeolianite, which rests unconformably on the sandstone, extends north up to $17 \mathrm{~km}$ inland from Cape Gantheaume, attesting to the strength of the southwesterly onshore winds at the time of dune formation. The northern inland margin of these aeolianite successions extends across the island from D'Estrees Bay to Vivonne Bay.

From Cape Gantheaume west to Bales Beach, the coastline is strikingly linear in form and trends to the northwest for about $10 \mathrm{~km}$. It is dominantly a rocky coastline

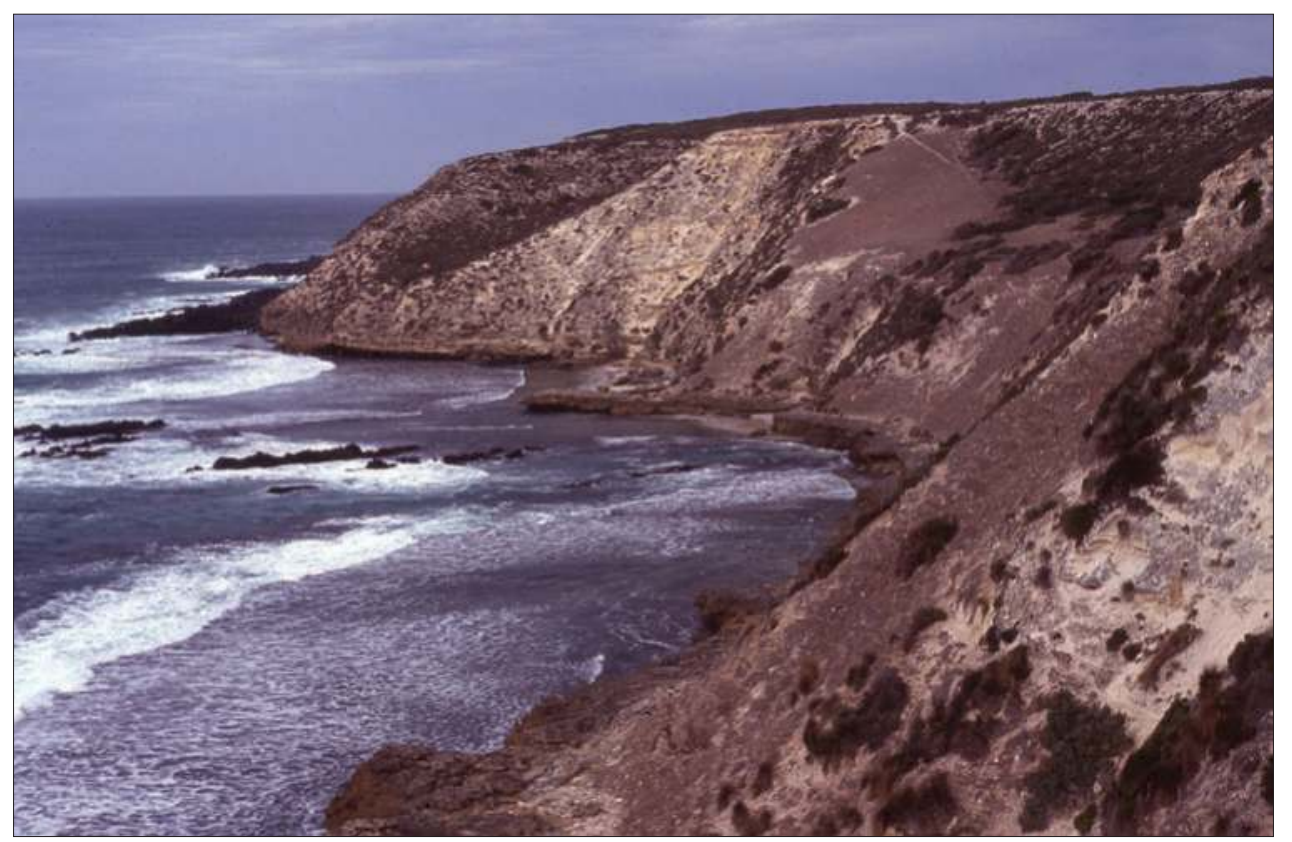

Figure 11.6 Outcrops of aeolianite (dune limestone) in steep coastal cliffs at Point Reynolds at the western end of D'Estrees Bay. The cliffs are up to $50 \mathrm{~m}$ APSL. At the top of the cliff in the middle distance, a fluvially influenced, gently undulating hill slope is evident, whereas the steep slopes developed in aeolianite are due to geologically rapid marine erosion. The structural bench is developed on horizontally bedded Late Eocene and Pliocene limestones. The offshore 'reefs' are formed on Kanmantoo Group metasediments.

Source: Author's own work, CMW. 
with shore platforms developed on Cambrian metasandstone with dolerite intrusions of Cambro-Ordovician age, while coastal cliffs are developed on aeolianite. This is a particularly exposed sector of coast and an extensive sand drift of Holocene age, comprising partially stabilised cliff-top parabolic dunes, has developed within the region. In the Cape Gantheaume Wilderness Protection Area, the dunes, which reach up to $100 \mathrm{~m}$ APSL, have migrated up to $11 \mathrm{~km}$ inland and show a pronounced southwestnortheast orientation, reflecting the dominant wind regime of the area. The Holocene dune sediment, largely derived from erosion of Pleistocene aeolianite deposits, was mapped as the Gantheaume Sand Member. ${ }^{49}$ In the westernmost portion of the Cape Gantheaume Wilderness Protection Area and landward of Bales Beach, the dunes are more siliceous in composition and are regarded as equivalents of the Semaphore Sand Member of the Holocene St Kilda Formation of the Adelaide area. ${ }^{50}$ These sediments $^{2}$ differ in composition from the Gantheaume Sand Member and comprise unconsolidated white, fine- to coarse-grained bioclastic quartz-carbonate sand characteristic of modern beaches. The dunes extend up to $5 \mathrm{~km}$ inland in a northeasterly direction from Bales Beach. Several larger well-defined embayments occur in the Bales Beach to Seal Bay sector of coast, backed by Pleistocene aeolianite. Three well-developed embayments occur at Bales Beach and range from $850 \mathrm{~m}$ to $1.9 \mathrm{~km}$ in length. ${ }^{51}$

Seal Bay is a popular tourist destination, providing the opportunity to observe the Australian Sea Lion, Neophoca cinerea, and the New Zealand Fur Seal, Arctocephalus forsteri. ${ }^{52}$ The Bay is approximately $700 \mathrm{~m}$ long and is backed by vertical cliffs that range in height from 20 to $40 \mathrm{~m}$, developed on Pleistocene aeolianite (Bridgewater Formation). The bay is in part an erosional depression cut into aeolianite and has partially infilled with unconsolidated Holocene coastal dune sand, providing a habitat for seals. Offshore, the Middleton Sandstone gives rise to shallow reefs and platforms. Nobby Island, a prominent erosional landform some $2 \mathrm{~km}$ to the west of Seal Bay, is predominantly aeolianite resting on Middleton Sandstone. The island is $60 \mathrm{~m}$ high, with a well-developed shore platform up to $50 \mathrm{~m}$ wide about its margins, also developed on aeoliante.

Vivonne Bay is an arcuate sandy beach $5 \mathrm{~km}$ long, which primarily faces south. Its eastern section is characterised by a higher wave energy and has well-developed offshore bars. ${ }^{53}$ On its western margin, the shoreline trends in a northerly direction and is relatively sheltered. The Eleanor River debouches at the central portion of Vivonne Bay, but is commonly constricted due to the large volumes of marine-sourced sand, locally reworked and trapped in this coastal compartment by high-energy waves. Extending some $4 \mathrm{~km}$ to the northeast, inland from Vivonne Bay, a field of active coastal dunes, the 'Little Sahara', has developed (Figure 11.7). The sand has been mapped as the Semaphore Sand Member, a succession of unconsolidated, white, 


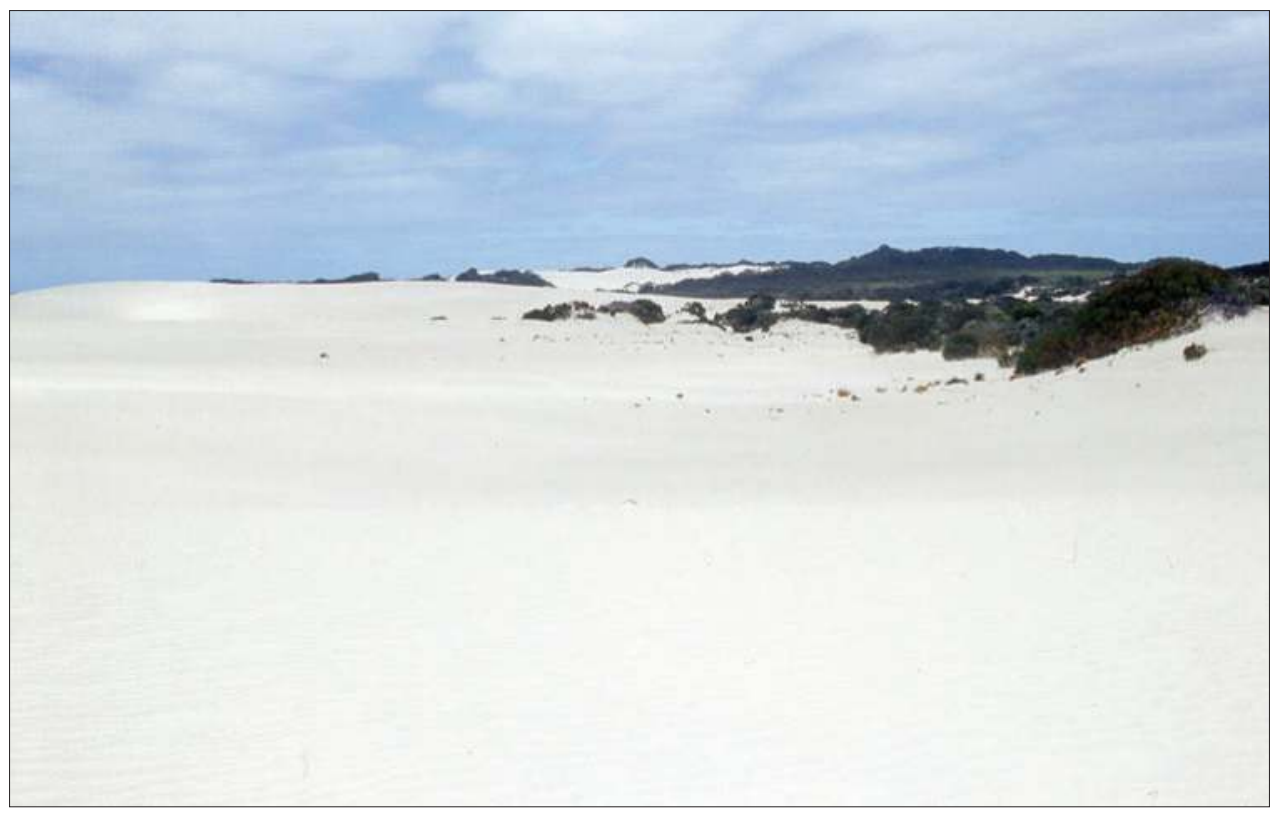

Figure 11.7 Active and partially vegetated dunes of the Little Sahara, which have migrated $4 \mathrm{~km}$ inland from Vivonne Bay.

Source: Author's own work, CMW.

bioclastic quartz carbonate sand that characterises modern beaches and transgressive dune fields. ${ }^{54}$ Although in places the dunes are partially vegetated by Coastal Wattle (Acacia longifolia sp) and Black Tea Tree (Melaleuca sp), they remain active and, at times, the vegetation is blanketed by locally advancing dunes. In broad view, however, the overall dune field appears relatively stable and is not actively migrating inland.

At Point Ellen on the western side of Vivonne Bay, richly fossiliferous shelly limestone and coquina (sediment comprising predominantly shell and other fossil marine invertebrates) are exposed in actively eroding, subdued cliffs. ${ }^{55}$ The shelly deposit rests unconformably on an irregular erosion surface on Kanmantoo metasediments extending up to $2 \mathrm{~m}$ APSL. The sediments, assigned to the Early Pleistocene Point Ellen Formation, contain up to 51 species of fossil molluscs, the most common fossil being the small gastropod Nerita milnesi. ${ }^{56}$ Sediments of presumed equivalent age also crop out at Table Rock, Point Reynolds (10 m APSL) and Cape Willoughby (10 m APSL), as well as on the mainland at Cape Jervis, where the base of the succession is at $50 \mathrm{~m}$ APSL, reflecting ongoing differential uplift of the 
southern Fleurieu Peninsula since deposition of the succession. An Early Pleistocene age was assigned to this succession, based on the presence of the biostratigraphically significant marine gastropod Hartungia dennanti chavani. ${ }^{57}$ Amino acid racemisation ages on the foraminifer Elphidium rotatum $(1.3 \pm 0.4 \mathrm{Ma})$ and the mollusc Katelysia scalarina $(1.1 \pm 0.2 \mathrm{Ma})$ also support an Early Pleistocene age for the Point Ellen Formation. ${ }^{58}$

West from Point Ellen to Kirkpatrick Point near Remarkable Rocks (Figure 11.1), the rocky coastline is characterised by outcrops of igneous rocks, such as the Stun Sail Boom Granite, and high-grade metamorphic rocks of the Kanmantoo Group metasediments, which have been locally heated and deformed by the granite intrusions. Collectively, these rock units give rise to well-developed bays and headlands. They are covered by thick successions of Pleistocene aeolianite.

A field of Holocene parabolic dunes, derived mainly from reworked Pleistocene aeolianite, occurs on the eastern side of Hanson Bay in the Cape Bouguer Wilderness Protection Area, extending south to Cape Bouguer. The dunes have been mapped as the Gantheaume Sand Member; similar dune fields of reworked aeolianite occur at discrete localities across the entire southern coastline of the island (for example, at Maupertuis, Vivonne, Seal, and Pennington Bays; see Figure 11.1).

\subsubsection{Remarkable Rocks}

Imposing outcrops of Stun Sail Boom Granite (505 $\pm 7 \mathrm{Ma}$ ) and Remarkable Granite of Middle Cambrian age, related to the Delamerian Orogeny ${ }^{59}$, form outcrops along the southwestern coastline of Kangaroo Island between Cape Kersaint and Kirkpatrick Point (Figure 11.1). The Stun Sail Boom Granite is medium-grained, comprising grey porphyritic quartz-plagioclase-biotite with felspar megacrysts, and shows deformation features, with flow banding and xenoliths of country rock (recrystallised metasediments of the Early Cambrian Kanmantoo Group) near the margins of the intrusions. The Remarkable Granite is a medium-grained, grey, equigranular, biotite-rich granite with minor xenoliths of metasediment. ${ }^{60}$ Both suites of granites were emplaced at moderate crustal depths of 5 to $10 \mathrm{~km}$ below the surface of the Earth. Their large crystals indicate a slow history of cooling ${ }^{61}$, while their presence at the Earth's surface reflects a prolonged history of denudation (landscape lowering).

The Remarkable Rocks granite outcrop, which extends from Kirkpatrick Point to Sanderson Bay within Flinders Chase National Park (Figures 11.8 and 11.9) ${ }^{62}$, formally belongs to a group of landforms known as castellated inselbergs or castle koppies, which are steep-sided, joint-bounded blocks of granite resting on granite domes. The granite shows major curvilinear rock masses called sheeting planes, resulting from unloading and pressure release as many kilometres of the overlying rocks were eroded. 


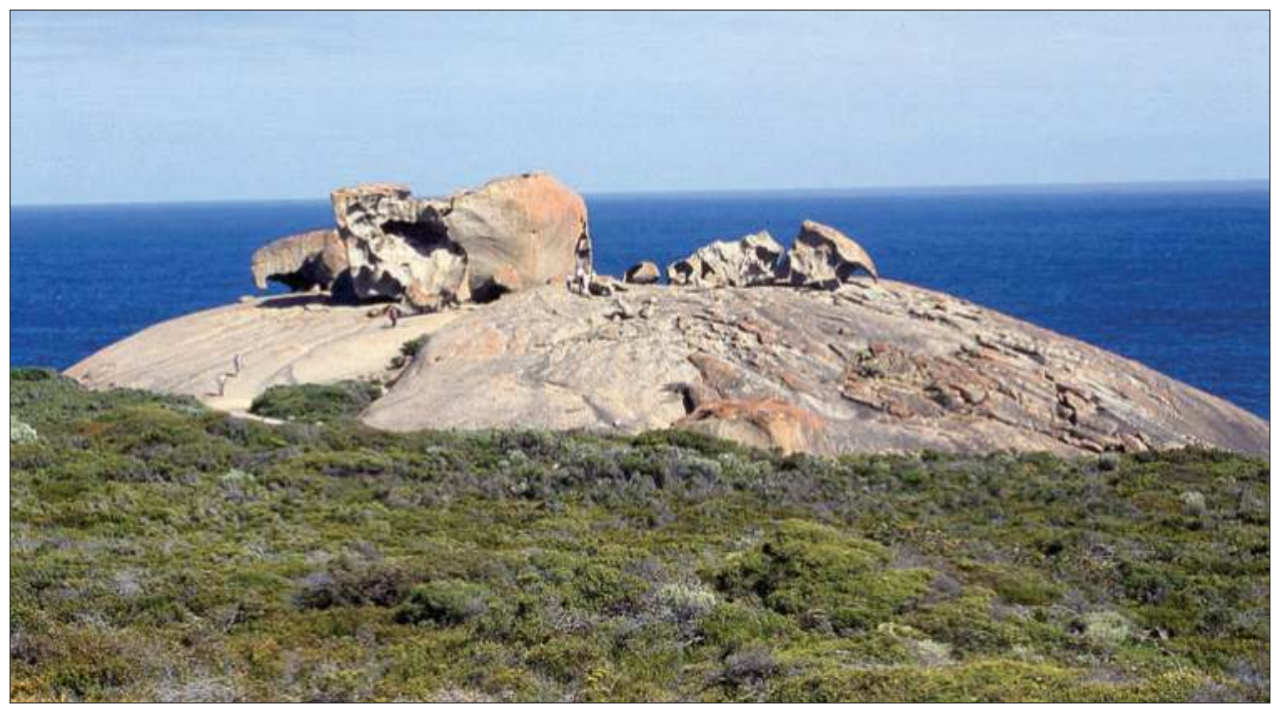

Figure 11.8 View looking south towards outcrops of the Remarkable Granite at Remarkable Rocks, southwestern Kangaroo Island. The domal structure of the granite is clearly evident, showing granite boulders up to $30 \mathrm{~m}$ high with well-developed cavernous weathering (tafoni), representing remnants of a former sheet structure in the granite. Gutters radiating out from near the apex of the feature are visible on the left-hand side of the feature, and thinner slabs of granite sheeting structures can be seen on the right-hand side of the photograph.

Source: Author's own work, CMW.

At the apex of the granite dome, several large remnants of a granite sheet structure are preserved in the form of tafoni-weathered angular residual blocks (castle koppies); these are up to $30 \mathrm{~m}$ high and in places show rillen (vertical grooves). ${ }^{63}$ Tafoni is a cavernous form of weathering common in granite landforms. ${ }^{64}$ The granite is well jointed, and preferential weathering has occurred along the joints, forming elongate gutters and clefts. Numerous granite boulders are scattered across the landscape and concentrated within an elongate depression on the southern portion of the outcrop, as well as along the shoreline. The principal mechanism for the development of this landform is subsurface weathering of the granite, with subsequent removal of the more easily weathered rock, leaving the residual blocks in higher relief at the crest of the dome.

On the northern sector of Remarkable Rocks, a blanket-like deposit of aeolianite covers the granite and is progressively being eroded, re-exhuming the granite. The presence of the aeolianite on the upper slopes of the granite dome implies that much of the dome was covered by aeolianite during the Pleistocene. 


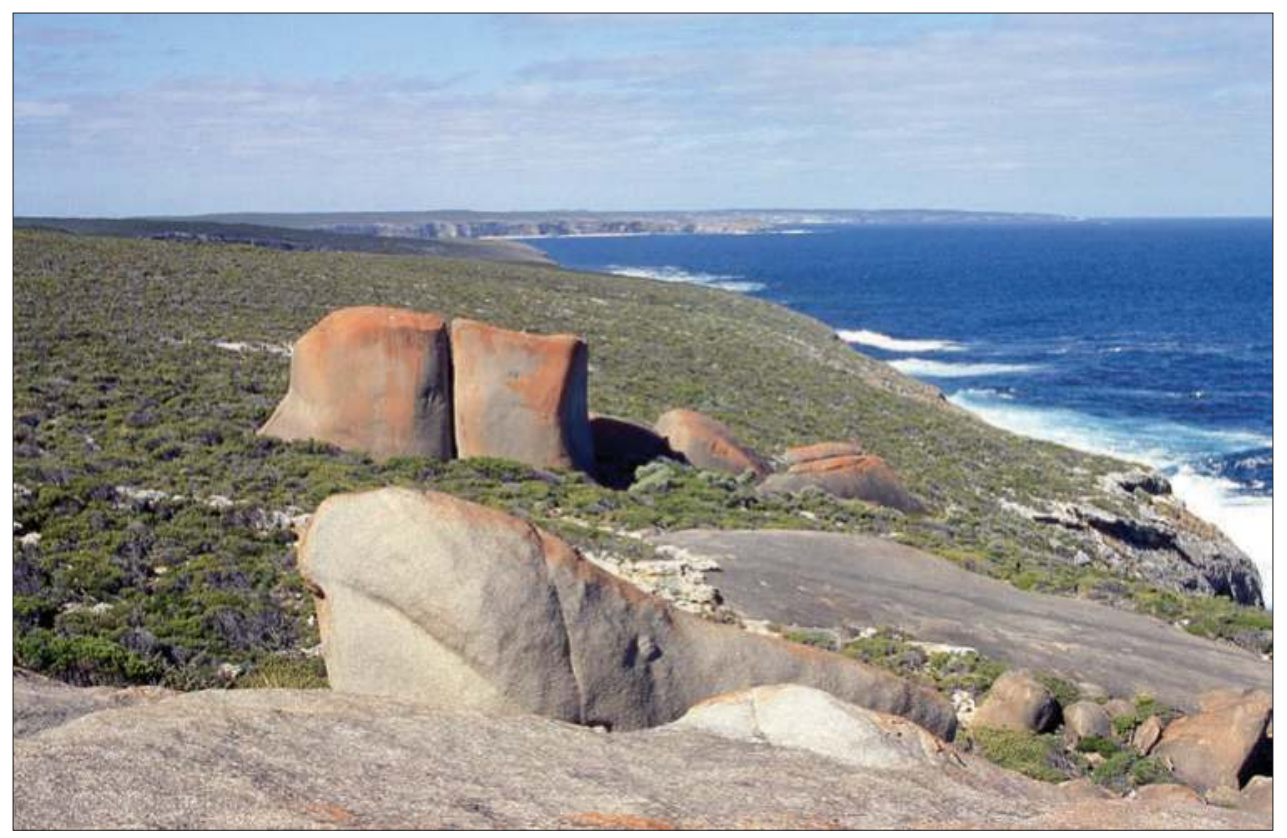

Figure 11.9 View looking east of part of Remarkable Rocks, with Sanderson Bay and Cape Younghusband in the horizon. Pleistocene aeolianite covering the surface of the granite can been seen to the right near the top of the cliff. Two large granite boulders with a welldeveloped joint cleft are visible in the middle distance.

Source: Author's own work, CMW.

\subsubsection{Admiral's Arch}

Admiral's Arch at Cape du Couedic, southwestern Kangaroo Island, is a former sea cave developed in aeolianite of the Pleistocene Bridgewater Formation (Figure 11.10), which rests unconformably on low angle ( $20^{\circ}$ southwest), seaward-dipping beds of the Middleton Sandstone. The arch has formed through the combined effects of solutional weathering processes along the contact between the sandstone and limestone, and subsequent excavation by coastal processes. A shingle beach deposit within the arch, plastered against the aeolianite and resting on the Middleton Sandstone, attests to a marine origin for the arch. The arch is partly supported by a hardened calcrete layer formed on the upper surface of the aeolianite. Rhizoliths, plant root replacement features due to solution and redeposition processes in former soil profiles, radiate from the roof of the arch. 


\subsubsection{The western coast - Cape du Couedic to Cape Borda}

Cliffs that extend up to $100 \mathrm{~m}$ APSL dominate the west-facing coastline from Cape du Couedic north to Cape Borda. This coastal sector, $50 \mathrm{~km}$ long, reveals the influence of older geological structures on long-term coastal development. Five regional-scale folds in the Cambrian Kanmantoo bedrock have been mapped along this coastline plunging to the southwest. ${ }^{65}$ The folds are regional structures that extend across the island to the Kangaroo Island Shear Zone. Cape du Couedic may be a structurally controlled feature coinciding with the less well-jointed core of the southwesterly-trending Cape du Couedic syncline. ${ }^{66}$ The regional folds produced steeply dipping beds in the Middleton Sandstone, now exposed in coastal outcrops. The fold axis of the Maupertuis Anticline is located approximately midway along the length of Maupertuis Beach. Sandy Beach Syncline appears to coincide with the location of the embayment that bears its name as well as with the lower portion of the Sandy River, indicating that these features may also be structurally controlled. The axis of the West Bay-Sandy Beach Anticline is approximately $2.5 \mathrm{~km}$ south of West Bay, and the axis of the accompanying BordaWest Bay Syncline is approximately $3 \mathrm{~km}$ north of West Bay. From Vennachar Point to

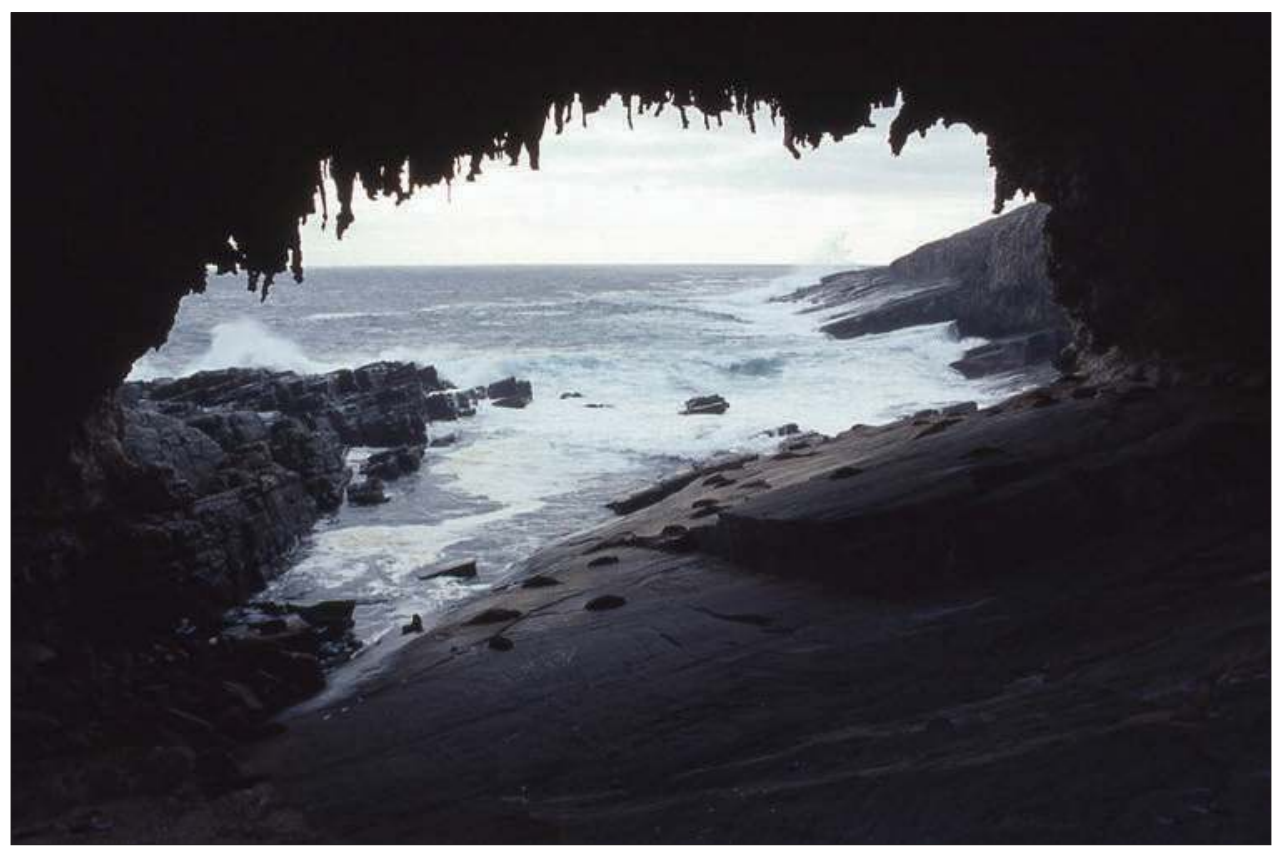

Figure 11.10 Admiral's Arch, a former sea cave in aeolianites of the Pleistocene Bridgewater Formation.

Source: Author's own work, CMW. 
Cape Borda, the coastline follows a northeasterly to northerly trend and is dominated by steep coastal cliffs.

Five rivers traverse the plateau in a broadly southwesterly direction along the coast between Cape du Couedic and Vennachar Point, with their general courses controlled by regional-scale fold structures. Ravine des Casoars is a deeply incised valley $3 \mathrm{~km}$ long and up to $100 \mathrm{~m}$ deep, trending in a west-northerwesterly direction. At its mouth, the valley is V-shaped, and some $600 \mathrm{~m}$ up-valley from the present shoreline it is infilled with a well-defined beach, backing dunes and a coastal lagoon. The valley fill is dominated by marine-sourced sands of Holocene age from the adjacent narrow shelf; little sediment appears to have been derived from erosion of the surrounding plateau surface. The southern valley side slope is covered by climbing dunes, which extend up to $100 \mathrm{~m}$ APSL, resulting from the strong westerly onshore winds.

Only 10 beaches occur along the coastline from Cape du Couedic to Cape Borda; they are confined to small embayments near the mouths of rivers or creeks. The seaward portions of the Rocky, Sandy and Breakneck Rivers, as well as the Ravine des Casoars, are relatively deeply incised. A long geological history has been responsible for the erosional development of these bedrock valleys, in which beach sand has accumulated by coastal processes. ${ }^{67}$ For much of the coastline, the Early Cambrian Middleton Sandstone of the Kanmantoo Group metasediments crops out, giving rise to narrow shore platforms and irregular rocky outcrops close to sea level. The metasediments represent a more erosion-resistant base on which extensive blanket-like deposits of aeolianite occur. Lamprophyre of Middle Ordovician age forms the headland south of Sandy Beach towards the northern end of Maupertuis Bay (Figure 11.1). Lamprophyre is a grey to green, ultramafic igneous rock of serpentinised olivine, augite and biotite phenocrysts (larger crystals that formed earlier through prolonged cooling of magma) in a matrix of augite, olivine, nepheline and dolomite. Rocks from these outcrops have been dated at $469 \pm 9 \mathrm{Ma}^{68}$ Aeolianite of the Pleistocene Bridgewater Formation extends along this entire sector of coast and rests unconformably on the Middleton Sandstone; the unconformity represents a time gap in the geological record of over $500 \mathrm{Ma}$.

Maupertuis Bay is a cliffed coastline trending north-northwesterly for some $16 \mathrm{~km}$, with cliffs that reach up to $100 \mathrm{~m}$ towards Cape du Couedic and up to $60 \mathrm{~m}$ near the mouth of Rocky River. The fold axis of the Maupertuis Anticline (arch-shaped fold) trends at right angles to the coastline and forms steeply dipping beds of Middleton Sandstone. ${ }^{69}$ Along the northern sector of this coast, $2 \mathrm{~km}$ south of Rocky River in Flinders Chase National Park, a dune field of Holocene Semaphore Sand extends up to $2.5 \mathrm{~km}$ inland from the coastline, with active parabolic dunes. The sand accumulation has resulted from strong southwesterly winds entraining sand landwards during the Early to Middle Holocene some 7000 years ago, in the final stages of postglacial sea level rise. At this time, the regional landscape was in the final stages of a major transition from a largely exposed continental shelf, at a time of glacial 
low sea level, to a flooded shelf that resulted from the meltwaters of the continental ice sheets returning to the world oceans.

Aeolianite of the Pleistocene Bridgewater Formation occurs along the entire length of Maupertuis Bay and is in turn overlain by cliff-top dunes and sand spreads locally reworked from the erosion of the Bridgewater Formation, termed the Gantheaume Sand Member of the Holocene St Kilda Formation. ${ }^{70}$ Thus the sands differ in origin from the shelf-sourced sands closer to Rocky River.

\subsubsection{Cape Borda to Cape Dutton}

The sector of coast between Cape Borda and Cape Dutton (Figure 11.1) is characterised by steep, high, rocky cliffs with small, inaccessible pocket beaches. Between Cape Borda and Cape Torrens, the cliffs commonly reach up to $200 \mathrm{~m}$ APSL, forming the island's highest coastal cliffs. The highest point along this sector, $9.5 \mathrm{~km}$ east of Cape Borda, is $261 \mathrm{~m}$ APSL, with a boulder beach backing the base of the cliff. The regional drainage along this coastal sector flows away from the coastline and ultimately reaches Ravine des Casoars. The regional bedrock comprises Kanmantoo metasediments, which commonly show evidence of deep weathering on the plateau surface, producing kaolinitic and iron-rich (ferricrete) profiles. The ferricrete has well-developed pisoliths and is veneered by clean siliceous sands over mottled red and yellow sandy clay regolith with iron-rich concretions. Massive ferricrete is also present, with pebble-sized pisoliths of maghemite cemented by goethite. The sector of coast between Cape Torrens and Cape Forbin (Figure 11.1) is $8 \mathrm{~km}$ long and is characterised by broad arcuate-shaped bays backed by cliffs 150 to $200 \mathrm{~m}$ high.

Between Cape Forbin and Cape Dutton, the coast is more serrated in plan view, with numerous small coastal promontories. A major change in rock type is evident at Cape Forbin, where en echelon thrust faults have brought fine-grained quartzitic phyllonites (metamorphic rocks rich in the micaceous mineral muscovite) in contact with Kanmantoo Group metasediments. The fine-grained quartzitic phyllonites crop out along the coastline between Cape Forbin and Waterfall Creek (Figure 11.1), along the western extension of the Kangaroo Island Shear Zone. ${ }^{71}$ This rock relationship also extends from Western River Cove in a broadly arcuate shape eastward across the island to the western portion of Dudley Peninsula near American River. Accordingly, the Kangaroo Island Group of shallow marine platform sediments of Cambrian age form the bedrock of the entire mid-northern coastline of the island from Western River Cove to American River.

Snelling Beach (Figure 11.1) is one of the more popular and accessible beaches on the north coast. It is backed by a large coastal foredune complex and back-barrier lagoon. A wide bedrock valley carved out in the lower reaches of the Middle River was infilled with coastal barrier and estuarine sediments during and since the postglacial 
rise in sea level. This northwest-facing beach is up to $660 \mathrm{~m}$ long and maintains a surf zone $100 \mathrm{~m}$ wide with waves typically $1 \mathrm{~m}$ high. ${ }^{72} \mathrm{~A}$ common feature of the stream valleys near the coast is that they have been infilled with grey/black alluvial/estuarine sediments that form flood plain/low terrace surfaces. There is no clear evidence of higher terraces formed on red/brown-coloured alluvial deposits of the Late Pleistocene Pooraka Formation, which are common on Fleurieu Peninsula. The bedrock valleys are fairly restricted and any Pooraka sediments may have been eroded during the prolonged period of lower sea level during the Last Glacial Cycle (118 to $12 \mathrm{ka}$ ago) when sea level was at least $60 \mathrm{~m} \mathrm{BPSL} .^{73}$

\subsubsection{King George Beach}

This is a narrow bedrock bay where King George Creek strikes the coast. Boulders and shingle-forming terraces and ridges up to $4 \mathrm{~m}$ APSL appear to be still active, but even higher shingle deposits, which extend up to 8 to $10 \mathrm{~m}$ APSL, are clearly relict features.

\subsubsection{Cape Dutton to Point Marsden}

The coastline between Cape Dutton and Cape Cassini is backed by coastal bluffs and cliffs developed on Cambrian strata of the Mt McDonnell Formation, a succession of siltstones and mudstones, and the Stokes Bay Sandstone, a red/brown arkose (feldspathic sandstone).$^{74}$ In detail and in plan view, this sector of coastline is markedly serrated in shape, due to the intersection of the coastline with the strike of these resistant lithologies. The coastal cliffs at Cape Dutton are up to $60 \mathrm{~m}$ APSL, and between Cape Dutton and Knob Point they commonly range between 20 to $50 \mathrm{~m}$ APSL.

From Cape Cassini to Point Marsden, the coastline trends broadly east-west and is characterised by three large bays, Dashwood, Smith and Emu Bays (Figure 11.1), which are bounded by laterally persistent capes backed by coastal cliffs. Dashwood Bay is a north-facing bay $2.5 \mathrm{~km}$ wide, which has formed by fluvial incision by the Duncan River, particularly during lower sea levels. The lateral migration of the river has carved a wide valley, subsequently infilled during and following the sea level rise after the Last Glacial Maximum.

Smith Bay (Figure 11.1), located approximately $2 \mathrm{~km}$ east of Dashwood Bay, is $5 \mathrm{~km}$ wide. On its margins, Smith Bay is backed by coastal cliffs up to $100 \mathrm{~m}$ APSL, formed on the Cambrian Stokes Bay Sandstone. The central backing slopes of Smith Bay are developed on the Cape Jervis Formation, a succession of diamictites (very poorly sorted sediments comprising small, gravel-sized clasts within silts) deposited by glacial processes during the Permian glaciation. ${ }^{75}$ Prominent boulder beaches occur along much of the bay. At Smith Bay, glaciated bedrock surfaces on Cambrian metasiltstone at $-7 \mathrm{~m}$ APSL are overlain by some $18 \mathrm{~m}$ of Permian tillite ( 299 to $290 \mathrm{Ma}$ old). ${ }^{76}$ In turn, this is overlain by $2 \mathrm{~m}$ of a stranded pebble/cobble beach deposit with fossil 
marine shells of the genera Mactra sp. and Irus sp. (Figure 11.11). ${ }^{77}$ This succession appears to have formed from the reworking of Permian glacigene sediments. ${ }^{78}$

Amino acid racemisation dating of abraded shell fragments from the beach unit yielded an age of $1 \pm 0.2 \mathrm{Ma}{ }^{79}$ Paleosea-level evidence from the Coorong Coastal Plain suggests that, for the past $1 \mathrm{Ma}$, interglacial sea levels have not deviated by more than $6 \mathrm{~m}$ from levels obtained during the current Holocene interglacial ${ }^{80}$; thus the Smith Bay stranded beach deposit implies local uplift by at least $21 \mathrm{~m}$ during the past $1 \mathrm{Ma}$. This contrasts markedly with the view of Bauer ${ }^{81}$, who claimed that there was no evidence of uplift since the Late Miocene; he attributed evidence of high sea levels to global glacio-eustatic fluctuations.

Emu Bay is a northwest-facing bay $8 \mathrm{~km}$ wide, bounded by Cape D'Estaing in the west and White Point to the east (Figure 11.1). The main, rectilinear portion of the bay, some $5 \mathrm{~km}$ long, is backed by laterally persistent and substantial foredunes between 10 to 20 m APSL. ${ }^{82}$ Situated between White Point and North Cape, the most northerly point on the island, Boxing Bay is a north-facing bay $2.5 \mathrm{~km}$ wide, backed by rocky slopes up to $60 \mathrm{~m}$ APSL, which have formed on sandstones of the Early Cambrian Boxing Bay Formation. The sandstones are responsible for the higher relief

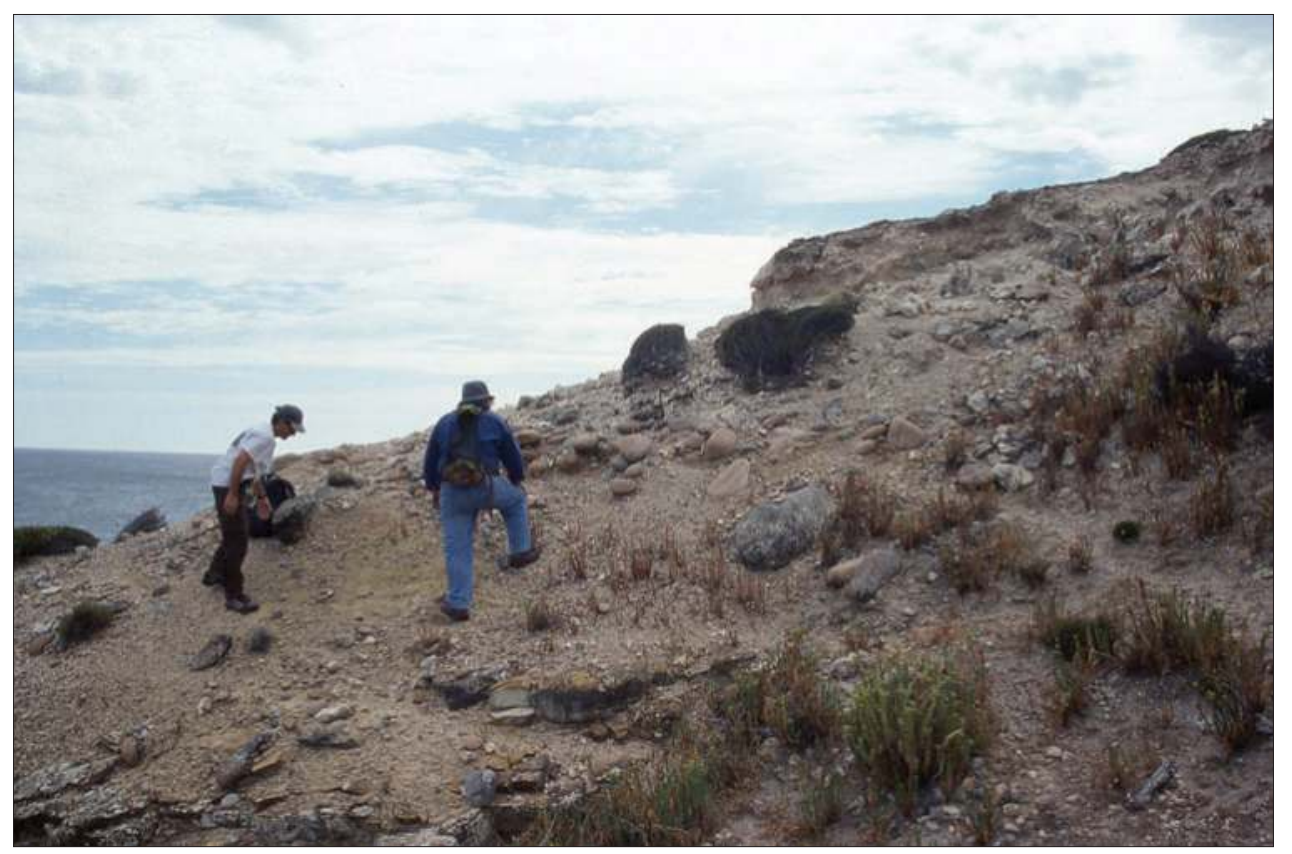

Figure 11.11 Stranded beach deposit at Smith Bay. The rounded clasts are reworked from Permian-age glacigene sediments.

Source: Author's own work, CMW. 
in this region. Permian glacigene sediments and striated bedrock surfaces occur in Boxing Bay. ${ }^{83}$ To the south of North Cape a cuspate foreland, which extends to Cape Rouge, developed during the Last Interglacial; outcrops of Glanville Formation occur near Cape Rouge (Figure 11.1). Much of the peninsula from Emu Bay eastwards to Point Marsden is covered by Pleistocene aeolianite.

The Bay of Shoals is an east-facing, circular-shaped bay with a mouth $5 \mathrm{~km}$ wide and with $16 \mathrm{~km}$ of shoreline. ${ }^{84}$ Given its protected setting, the bay experiences relatively low wave energy and consequently has been infilled with marine-sourced, flood tidal delta sands, particularly along the southern portion of the bay, where sandflats up to $200 \mathrm{~m}$ occur. Seagrass meadows within the bay promote sedimentation by further baffling wave energy. Vegetation has created more or less permanent islands, such as Busby and Beatrice Islets, which are associated with a large recurved spit, known as 'The Spit' 85 , extending from near Point Marsden to east of Kingscote, across the mouth of the Bay of Shoals. A small islet that had been anchored by the exotic African boxthorn, Lycium ferocissmum, was washed away following removal of the exotic plants. The southern portion of the bay is backed by Permian glacigene sediments of the Cape Jervis Formation, which are more susceptible to weathering and erosion than the Cambrian sandstones elsewhere on the island, and accordingly may also contribute to the sediments within the Bay of Shoals.

\subsection{Summary and conclusions}

The modern coastline of Kangaroo Island is a legacy of numerous long-term geological processes, some of which extend back to the very early mountain-building events of the Cambro-Ordovician, Delamerian Orogeny (514 to $485 \mathrm{Ma}$ ). During this prolonged episode, basement rocks were deformed and metamorphosed, with the development of numerous regional-scale geological structures such as faults, joints, cleavage, folds and the emplacement of numerous granitic intrusions at intermediate levels within the Earth's crust $(<10 \mathrm{~km}$ below the former land surface). With regional landscape lowering since the Paleozoic, these structural features have ultimately influenced aspects of the long-term development of the island's coastline at a range of spatial scales. The influence of structural control on portions of the coastal landscape is evident from the trend of some coastal sectors coinciding with the direction of geological structures in resistant basement rocks, such as the dip of bedding in the Middleton Sandstone southwest of Point Tinline. Similarly, the Sandy Beach Syncline on the west coast coincides with the embayment that bears its name, as well as the lower portion of the Sandy River. The un-roofing of the granitic intrusions at Remarkable Rocks and other locations on the island has also locally influenced the shape of the coastline.

The deposition of younger sedimentary successions has also influenced the coastline in some regions. For example, Permian glacigene sediments have influenced 
local hillslope development in the Smith Bay region and formed the template for the natural harbour at Christmas Cove.

Prolonged erosion produced a subdued planation surface, which was differentially uplifted to form a gently inclined plateau surface with a greatest elevation in the northwest. Coastal erosion of the uplifted resistant rocks and aeolianite deposits explains the extensive coastal cliffs that bound much of the island.

Changes in relative sea level during the Quaternary were instrumental in promoting the deposition of extensive blanket-like deposits of aeolianite, principally on the southern and western sectors of the island. Sea level changes have also been instrumental in reworking previously deposited sediment, so that the sedimentary record is in part palimpsest in nature. At Smith Bay, for example, glacially deposited sediment in the form of lodgement till has been reworked in the Early Pleistocene, giving rise to a high-level boulder beach deposit. In a similar manner, coastal erosion over multiple glacial cycles has reworked aeolian sand, so that the dune limestones contain a significant proportion of reworked skeletal carbonate sand. Evidence for active coastal erosion and reworking of previously deposited sediment is also seen in the numerous transgressive dune fields such as at 'Little Sahara' and other areas on the island.

Kangaroo Island most recently became an island again, with the culmination of the most recent postglacial sea level rise some 7000 years ago, associated with the demise of the Northern Hemisphere continental ice sheets. At least eight similar islandforming events have occurred in the past 800000 years.

\section{Notes}

1 Short, A.D. (2006). Beaches of the South Australian coast and Kangaroo Island: A guide to their nature, characteristics, surf and safety. Sydney University Press, Sydney, 346 pp.

2 Northcote, K.H. (2002). Soils. In: Davies, M., Twidale, C.R. \& Tyler, M.J. (Eds), Natural history of Kangaroo Island. Royal Society of South Australia, $2^{\text {nd }}$ Edn, pp. 36-42.

3 Short (2006).

4 Bourman, R.P. (1987). A review of controversial issues related to the late Palaeozoic glaciation of southern South Australia. In: Gardiner, V. (Ed.), International Geomorphology 1986, Part II, John Wiley and Sons Ltd., Chichester, pp. 725-742.

5 Von der Borch, C.C. (2002). Giant Submarine Canyons. In: Davies, M., Twidale, C.R. \& Tyler, M.J. (Eds), Natural History of Kangaroo Island. Royal Society of South Australia, $2^{\text {nd }}$ Edn, pp. 43-46; Sprigg, R.C. (1947). Submarine canyons of the New Guinea and South Australian coasts. Transactions of the Royal Society of South Australia, 71, 296-310; Schmidt, S., De Deckker, P., Etcheber, H. \& Caradec, S. (2010). Are the Murray Canyons offshore southern Australia still active for sediment transport? In: Bishop, P. \& Pillans, B. (Eds), 
Australian landforms. Geological Society, London, Special Publication, 340, 43-55.

6 Natural history of Kangaroo Island. Royal Society of South Australia, $2^{\text {nd }}$ Edn, pp. 2-22.

7 James \& Clark (2002); Daily, B., Milnes, A.R., Twidale, C.R. \& Bourne, J.A. (1979). Geology and geomorphology. In: Tyler, M.J., Twidale, C.R. \& King, J.K. (Eds), Natural history of Kangaroo Island. Royal Society of South Australia, 1 ${ }^{\text {st }}$ Edn, pp. 1-38.

8 Daily, Milnes, Twidale \& Bourne (1979).

9 Twidale, C.R., Bourne, J.A. \& Twidale, N. (1977). Shore platforms and sea level changes in the Gulfs region of South Australia. Transactions of the Royal Society of South Australia, 101, 63-74.

10 Bourman, R.P. \& Alley, N.F. (1999a). Christmas Cove. In: Barker, S. \& McCaskill, M. (Eds), Discover Kangaroo Island. Royal Geographical Society of South Australia, Adelaide, pp. 16-17.

11 Alley, N.F. \& Bourman, R.P. (1995). Troubridge Basin. In: Drexel, J.F. \& Preiss, W.V. (Eds), The geology of South Australia Vol. 2, The Phanerozoic Geological Survey of South Australia, Bulletin 54, pp. 65-70; Bourman, R.P. \& Alley, N.F. (1999b). Permian glaciated bedrock surfaces and associated sediments on Kangaroo Island, South Australia: Implications for local Gondwanan ice-mass dynamics. Australian Journal of Earth Sciences, 46, 523-531; Alley, N.F., Bourman, R.P. \& Milnes, A.R. (2013). Late Paleozoic Troubridge Basin sediments on Kangaroo Island, South Australia. MESA Journal, 70 (3), 18-37.

12 Milnes, A.R., Cooper, B.J. \& Cooper, J.A. (1982). The Jurassic Wisanger Basalt of Kangaroo Island, South Australia. Transactions of the Royal Society of South Australia, 106, 1-13.

13 James, N.P. \& Bone, Y. (2011). Neritic carbonate sediments in a temperate realm. Springer, Dordrecht; Murray-Wallace, C.V. (2014). The continental shelves of SE Australia. In: Chiocci, F.L. \& Chivas, A.R. (Eds), Continental shelves of the world: Their evolution during the last glacio-eustatic cycle. Memoirs 41. The Geological Society, London, pp. 273-291.

14 Bauer, F.H. (1959). The regional geography of Kangaroo Island, South Australia. Unpublished PhD thesis, Australian National University, Canberra, 2 Vols; Bauer, F.H. (1961). Chronic problems of terrace study in southern Australia. Zeitschrift für Geomorphologie, Suppl.-Band 3, 57-72; Brooke, B.P. (2001). The distribution of carbonate eoliante. Earth-Science Reviews, 55, 135-164; Lachlan, T.J. (2011). Aminostratigraphy and luminescence dating of the Pleistocene Bridgewater Formation, Kangaroo Island, South Australia: An archive of long term climate and sea-level change. PhD Thesis, University of Wollongong, $712 \mathrm{pp}$.

15 Lachlan (2011); Belperio, A.P. (1995). Quaternary. In: Drexel, J.F. \& Preiss, W.V. (Eds), The geology of South Australia Vol 2, The Phanerozoic Geological Survey of South Australia, Bulletin 54, pp. 218-280.

16 Boutakoff, N. (1963). The geology and geomorphology of the Portland area. Memoirs 22. Victoria, Geological Survey, $172 \mathrm{pp}$.

17 James \& Bone (2011).

18 James \& Bone (2011); Brooke (2001); Murray-Wallace, C.V. (2002). Pleistocene coastal stratigraphy, sea-level highstands and neotectonism of the southern Australian passive continental margin - A review. Journal of Quaternary Science, 17, 469-489; Playford, P.E., Cockbain, A.E., Berrry, P.E., Roberts, A.P., Haines, P.W. \& Brooke, B.P. (2013). The 
geology of Shark Bay, Geological Survey of Western Australia, Bulletin 146, 281 pp.

19 Lachlan (2011).

20 Sprigg, R.C. (1979). Stranded and submerged sea-beach systems of Southeast South Australia and the aeolian desert cycles. Sedimentary Geology, 22, 53-96.

21 Lachlan (2011).

22 Milnes, A.R. \& Ludbrook, N.H. (1986). Provenance of microfossils in aeolian calcarenites and calcretes in southern South Australia. Australian Journal of Earth Sciences, 33, 145-159.

23 Bauer (1959; 1961).

24 Zeuner, F.E. (1949). Dating the past. Methuen, London. 474 pp.

25 Bauer (1959; 1961).

26 Murray-Wallace, C.V. \& Woodroffe, C.D. (2014). Quaternary sea-level changes: A global perspective. Cambridge University Press, Cambridge, 484 pp.

27 Milnes, A.R., Ludbrook, N.H., Lindsay, J.M. \& Cooper, B.J. (1983). The succession of Cainozoic marine sediments on Kangaroo Island, South Australia. Transactions of the Royal Society of South Australia, 107, 1-35; Nicholas, W.A. (2012). Aminostratigraphy of semienclosed basins. PhD thesis, University of Wollongong, $285 \mathrm{pp}$.

28 Murray-Wallace \& Woodroffe (2014).

29 Short, A.D. \& Fotheringham, D.G. (1986). Coastal morphodynamics and Holocene evolution of the Kangaroo Island Coast, South Australia. Coastal Studies Unit Technical Report 86/1, Coastal Studies Unit, Department of Geography, University of Sydney, 112 pp.

30 Milnes, Ludbrook, Lindsay \& Cooper (1983).

31 Lachlan (2011).

32 Cann, J.H. \& Clarke, J.D.A. (1993). The significance of Marginopora vertebralis (Foraminifera) in surficial sediments at Esperance, Western Australia, and in last interglacial sediments in northern Spencer Gulf, South Australia. Marine Geology, 111, 171-187; Murray-Wallace, C.V., Beu, A.G., Kendrick, G.W., Brown, L.J., Belperio, A.P. \& Sherwood, J.E. (2000). Palaeoclimatic implications of the occurrence of the arcoid bivalve Anadara trapezia (Deshayes) in the Quaternary of Australasia. Quaternary Science Reviews, 19, 559-590.

33 Nicholas (2012).

34 Short, A.D., Buckley, R.C. \& Fotheringham, D.G. (1989). Preliminary investigations of beach ridge progradation on Eyre Peninsula and Kangaroo Island. Transactions of the Royal Society of South Australia, 113, 145-161.

35 Short, Buckley \& Fotheringham (1989).

36 James \& Clark (2002).

37 Pillans, B. \& Bourman, R. P. (2001). Mid Pleistocene arid shift in southern Australia dated by magnetostratigraphy. Australian Journal of Soil Research, 39, 89-98.

38 Fujioka, T. \& Chappell, J. (2010). History of Australian aridity: Chronology in the evolution of arid landscapes. In: Bishop, P. \& Pillans, B. (Eds), Australian landscapes. Special Publication 346. Geological Society, London, pp. 121-139.

39 Lachlan (2011); James \& Bone (2011).

40 Flinders, M. (1814). A voyage to Terra Australis: Undertaken for the purpose of completing 
the discovery of that vast country and, prosecuted in the years 1801, 1802 and 1803, in His Majesty's Ship, the Investigator, 2 Volumes and Atlas. G. \& W. Nicol, London; Cumpston, J.S. (1986). Kangaroo Island 1800-1836. Roebuck Society Publication No. 1, Roebuck Book, Canberra, 218 pp.

41 James \& Bone (2011); Murray-Wallace (2002); Ludbrook, N.H. (1984). Quaternary molluscs of South Australia. Handbook No. 9. South Australia, Department of Mines and Energy, 327 pp; Belperio, A.P., Murray-Wallace, C.V. \& Cann, J.H. (1995). The last interglacial shoreline in southern Australia: Morphostratigraphic variations in a temperate carbonate setting. Quaternary International, 26, 7-19.

42 Cann \& Clarke (1993); Murray-Wallace, Beu, Kendrick, Brown, Belperio \& Sherwood (2000).

43 James \& Clark (2002).

44 Fairclough, M.C. (2008). Kingscote Special map sheet, South Australia, Geological Survey. Geological Atlas 1:250 000 Series, Sheet SH 53-16. Department of Primary Industries and Resources South Australia, Adelaide.

45 Bauer (1959).

46 Fairclough (2008).

47 Short (2006).

48 Milnes, Ludbrook, Lindsay \& Cooper (1983).

49 Fairclough (2008).

50 Fairclough (2008).

51 Short (2006).

52 Ling, J.K. (2002). Marine mammals. In: Davies, M., Twidale, C.R. \& Tyler, M.J. (Eds), Natural history of Kangaroo Island. Royal Society of South Australia, $2^{\text {nd }}$ Edn, pp. 80-87.

53 Short (2006).

54 Fairclough (2008).

55 Milnes, Ludbrook, Lindsay \& Cooper (1983); Ludbrook, N.H. (1983). Molluscan faunas of the Early Pleistocene Point Ellen Formation and Burnham Limestone, South Australia. Transactions of the Royal Society of South Australia, 107, 37-49.

56 Ludbrook (1983).

57 Ludbrook (1983).

58 Lachlan (2011).

59 Fairclough (2008).

60 Fairclough (2008).

61 Daily, Milnes, Twidale \& Bourne (1979).

62 Bourman, R.P. \& Alley, N.F. (1999c). Remarkable Rocks. In: Barker, S. \& McCaskill, M. (Eds), Discover Kangaroo Island. Royal Geographical Society of South Australia, Adelaide, pp. 14-15; Twidale, C.R. \& Vidal Romaní, J.R. (2005). Landforms and geology of granite terrains. Balkema, Leiden, $351 \mathrm{pp}$.

63 Twidale, C.R. \& Bourne, J.A. (2002). The Land Surface. In: Davis, M., Twidale, C.R. \& Tyler, M.J. (Eds), Natural history of Kangaroo Island. Royal Society of South Australia, $2^{\text {nd }}$ 
Edn, pp. 23-35.

64 Twidale \& Vidal Romaní (2005); Gutiérrez, M. (2013). Geomorphology. CRC Press, London, 1017 pp.

65 James \& Clark (2002).

66 James \& Clark (2002).

67 Short (2006).

${ }^{68}$ Fairclough (2008).

69 James \& Clark (2002).

70 James \& Clark (2002).

71 James \& Clark (2002).

72 Short (2006).

73 Murray-Wallace \& Woodroffe (2014).

74 Fairclough (2008).

75 Alley, Bourman \& Milnes (2013); Fairclough (2008).

76 Bourman \& Alley (1999b).

77 Lachlan (2011).

78 Alley, Bourman \& Milnes (2013).

79 Lachlan (2011).

80 Murray-Wallace \& Woodroffe (2014); Murray-Wallace, C.V., Brooke, B.P., Cann, J.H., Belperio, A.P. \& Bourman, R.P. (2001). Whole-rock aminostratigraphy of the Coorong Coastal Plain, South Australia: Towards a 1 million year record of sea-level highstands. Journal of the Geological Society, London, 158, 111-124.

81 Bauer (1959; 1961).

82 Short (2006).

83 Alley, Bourman \& Milnes (2013).

84 Short (2006).

85 Eardley, C.M. (1945). Plant colonisation of a sandspit, Kangaroo Island. The South Australian Naturalist, 23 (2), 2. 



\section{Explaining the coastal landscapes of South Australia - A synthesis}

\subsection{Introduction}

South Australia is notable for a remarkable diversity of coastal landscapes, many of which are of national and global significance. Numerous landscape-forming processes have influenced the evolution of this coastline. The current shape of the coastline relates to geological processes operating on a wide range of geological timescales that extend as far back as Archaean time ( $>2.5$ billion years). As well as possessing many scenic wonders, the South Australian coastline presents numerous opportunities for scientific investigators to unravel the evolution of the coastline, with national and international implications.

As the broader continental-scale features of Australia influence the coastal landscapes of South Australia, the coastline should not be viewed in isolation from its hinterland. Australia in many respects is an old, flat and highly denuded continent, with the lowest topographical relief of all continents. ${ }^{1}$ Its intra-plate setting, high degree of tectonic stability, regional aridity, inland drainage (up to half the continent) and absence of major mountain ranges have significantly reduced the supply of terrigenous sediment to much of the coastline of South Australia. Few rivers reach the sea along the entire coastline of South Australia. Much of the State's drainage trends inland, and therefore the production of temperate sedimentary carbonates on the surrounding continental shelves is enhanced. ${ }^{2}$ Even on the Adelaide Plains, when the principal rivers (Little Para, Gawler, Light, Wakefield) do flow vigorously, their waters tend to temporarily exceed bankfull discharge and flood the adjacent flood plains, rather than reach Gulf St Vincent. ${ }^{3}$ 
Desert dune fields related to intensified aridity and the latitudinal expansion of the arid zone during successive glacial events ${ }^{4}$ occur throughout extensive regions of inland Australia and along parts of the coastal margin. At times of glacial low sea level, when South Australia's gulfs were dry land, longitudinal dune fields extended across this broad region. On the northern Adelaide Plains, and to the east of Lake Alexandrina and the northern Coorong Lagoon (Big Desert), as well as on Eyre and Yorke Peninsulas, the dunes are very notable features of the regional landscape, sometimes dramatically truncated at the coast. They have contributed to coastal sediments.

\subsection{General overview}

\subsubsection{The modern coastline: A general overview}

The modern coastline was broadly established some 7000 years ago with the culmination of the most recent phase of postglacial sea level rise. ${ }^{5}$ The Holocene coastline that continues up to the present day, when viewed in terms of the longer-term geological record, is a transitory feature, representing the latter part of a succession of coastlines that formerly occupied the broader region of the State of South Australia since the separation of Australia and Antarctica some $43 \mathrm{Ma}$ ago. ${ }^{6}$ In this sense, the coastline represents a palimpsest feature, where evidence of former shorelines has been erased or superimposed upon. In a Late Quaternary context the coastal zone can be regarded as a broad zone extending inland from the elevated position of the last interglacial shoreline to near the edge of the continental shelf some $125 \mathrm{~m}$ BPSL, at times of glacial low sea levels. Depending on local shelf gradients, these sea level fluctuations imply the lateral shift of coastlines over distances of 100 to $300 \mathrm{~km}$.

During the past $125 \mathrm{ka}$, the mean position of sea level was some $60 \mathrm{~m} \mathrm{BPSL}$, and present sea level was only attained about 7000 years ago (5.6\% of Late Quaternary time; see Figure 12.1). As a result of this geologically rapid rise in sea level, many coastal sectors are still establishing a new equilibrium, such as at Robe where the aeolianite cliffs have eroded landward by about $1.5 \mathrm{~km}$ in the past 7000 years. Other areas experiencing ongoing adjustment include sites on Eyre Peninsula (for example, North Shields), Yorke Peninsula (for example, Ardrossan), and the eroding Pleistocene alluvial fan successions at Middleton, Tunkalilla Beach and Sellicks Beach, as well as on Kangaroo Island, west of Kingscote jetty, where Permian glacial sediments are prone to erosion.

\subsubsection{Current sea level trends}

Tide gauges on the South Australian coastline reveal varying sea level trends, but there is little doubt that the level of the sea is rising. Ongoing global sea level rise, which may be associated with an enhanced greenhouse effect due to the combustion of fossil fuels, will influence the future behaviour of the coastline. Estimates of a globally averaged 


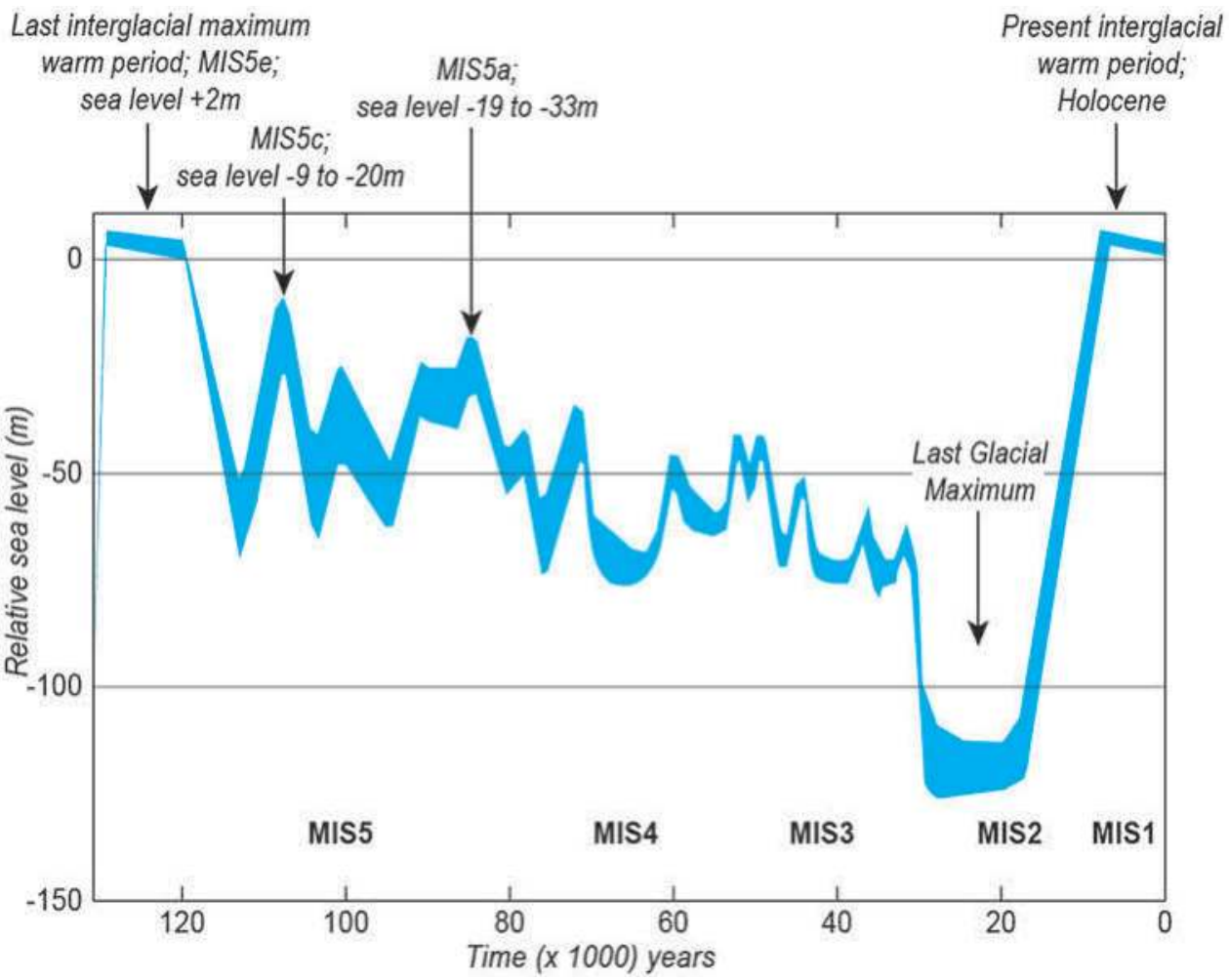

Figure 12.1 Sea level curve from the Last Interglacial to the present.

Source: Modified after Lambeck, K. \& Chappell, J. (2001). Sea level change through the last glacial cycle. Science, 292, 679-686.

rise in sea level suggest that by the year 2100, at a global scale, sea level could rise between 0.26 to $0.98 \mathrm{~m} \mathrm{APSL}$, based on a range of modelled scenarios. ${ }^{7}$ Irrespective of the level of uncertainty, the local effects of sea level rise along the South Australian coastline will be enhanced coastal erosion and landward migration of the shoreline along some more vulnerable sectors of the coastline. The mangrove woodlands of the gulfs' region, for example, will migrate landward; cliffs in unconsolidated alluvium and dune limestone will experience new phases of erosion, but many of the resistant, bedrock-cliffed coastlines should experience less dramatic change.

\subsubsection{Geology}

The broad outline and shape of much of the coastline at a macroscale $(\geq 100 \mathrm{~km})$ is due to geological inheritance, partly related to older bedrock structures such as the regional 
trends of bedding or foliation as well as faults and joints. These features, formed during earlier geological events, have set the stage for the embayed coastline of the faultbounded graben depressions of Gulf St Vincent and Spencer Gulf ${ }^{8}$ and the formation of the uplifted horst fault blocks of the Mount Lofty Ranges and Yorke Peninsula. The Ardrossan Fault, for example, defines much of the eastern coastline of Yorke Peninsula and western Gulf St Vincent.

The final separation of southern Australia from Antarctica about 43 Ma ago, with the subsequent development of the Southern Ocean, was a decisive geological event, influencing the broad shape of the current coastline, particularly the Great Australian Bight, which relates to the most recent Wilson Cycle of continental fragmentation and plate tectonic movement of continents across the globe. ${ }^{9}$

Examples of distinctive coastal landscapes that have resulted from a series of longterm geological events include the Coorong Lagoon and Younghusband Peninsula, which are fronted by Australia's longest beach, some $194 \mathrm{~km}$ long; the coastal cliffs that developed on Paleogene-Neogene limestones (for example, the Bunda Cliffs of the eastern Nullarbor Plain); the plunging cliffs on Neoproterozoic and Cambrian bedrock of Fleurieu Peninsula; and the geographically extensive successions of aeolianite (dune limestone) up to $200 \mathrm{~m}$ high, which fringe much of the open ocean coastlines of mainland South Australia, Kangaroo Island and the State's smaller islands, such as Wedge Island at the entrance to Spencer Gulf.

\subsubsection{Geological history}

Some of the principal geological events, which have left their mark on the coastline and influenced the Quaternary development of the coastline at a macroscale, include:

1. the formation of the rocks and structures of the Gawler Craton ( $>2.5$ to 1.45 billion years), with the latter age indicating the last time that these rocks were significantly deformed on Eyre Peninsula

2. the development of the Adelaide Geosyncline ${ }^{10}$ and the subsequent deformation of its contained strata during a mountain-building event, the Delamerian Orogeny (approximately 1 billion to 500 million years ago)

3. a major continental glaciation during Early Permian times (299 to 290 million years ago), which affected all of the southern continents plus the Indian subcontinent, when they were joined together in the super-continent of Gondwana

4. the tectonic uplift of the Mount Lofty and Flinders Ranges, initiated some time before the separation of Australia and Antarctica, with early rifting some 100 million years ago and subsequent ongoing separation for the last 43 million years ${ }^{11}$, over which time Australia has drifted $3000 \mathrm{~km}$ to the north. 
5. the deposition of shallow marine limestones within broad, epicontinental basins from about 46 million years ago

6. the continued differential uplift and subsidence of major structural domains such as the Mount Lofty Ranges and the Murray Basin (post-65 million years ago) ${ }^{12}$

7. numerous oscillations of sea level throughout the past 2.6 million years of the Quaternary, driven by global glacial/de-glacial events

8. the demise of the continental ice sheets of the Last Glacial Maximum (21000 years ago), accompanied by sea level rise from $-125 \mathrm{~m}$ at 16000 years ago to near its present position about 7000 years ago, at a rate of almost $14 \mathrm{~mm} / \mathrm{yr}$.

\subsubsection{Coastal processes}

During the past 125000 years (Late Quaternary), the combined effects of wave, tidal and inner-shelf ocean surface currents, as well as biological, climatic and tectonic processes, have forged the morphology of the current coastline.

Spectacular contrasts in the modern coastal systems are provided by comparisons of open-ocean, wave- and storm-dominated coastlines with those experiencing tidally dominated processes, such as in the northern portions of the gulfs and protected inlets. These major environmental contrasts affecting the style of deposition have resulted in the widespread formation of coastal barriers, with substantial coastal dunes and back-barrier lagoonal environments on the open ocean coastlines, but broad tidal flats with extensive sand- and mudflats, displaying low topographical relief within the downfaulted areas occupied by the sheltered Spencer Gulf and Gulf St Vincent.

Tidally dominated environments are marked by distinctive subtidal, intertidal and supratidal vegetation associations of seagrasses, mangroves, samphires and salttolerant bushes, with each different vegetation zone producing contrasting sediments. These biological facies variations in fossil form have been used as indicators of former sea levels ${ }^{13}$ and relict coastlines.

\subsubsection{Climatic influences}

Three principal climatic zones occur along the coastline of South Australia: Temperate, Semi-arid (Grassland) and Arid (Desert). Low rainfall and few streams entering the coast mean that little sediment on the coast is derived from the land; much coastal sediment has been sourced from offshore. Nevertheless, an arid climate has assisted the preservation of spectacular cliffs such as those of the Nullarbor Plain, while the seasonally wet and dry climate of South Australia with moderate to low rainfall has 
favoured the formation of calcrete, which caps and preserves many fossil shoreline features such as beach/dune barriers.

Contrasting regional climates have had a nuanced expression on coastal landform development. In the wetter southeast of the State, for example, active solution processes have resulted in the formation of a variety of enclosed depressions (dolines) within the coastal plain near Mount Gambier, and a karstified land surface representing a former marine abrasion surface on the Oligo-Miocene Gambier Limestone near Mount Schank. In contrast, in the drier and hotter semi-arid region of much of the northern gulfs, gypseous clays and dolomite are commonly precipitated in the upper portions of bare supratidal flats. ${ }^{14}$

A strong southwesterly wind regime and the semi-arid climate, which favours surface heating, drying and reduced vegetation cover, have generated some remarkable dune fields as a result of widespread sand drift.

\subsubsection{Wind and wave regimes}

A strong west to southwesterly wind regime dominates the South Australian shoreline, and, as much of the coast is at right angles to this pattern, numerous dunes, both current and fossil, lie inland of beaches.

The wave regime on the South Australian coastline (the frequency, wave height, wavelength and duration of wave sets) is also closely related to the wind regime and the season, with generally larger waves occurring in winter. Swell waves, initiated by distant storms, approach predominantly from the west and southwest. They have a periodicity of 10 to 16 seconds and wave heights of 2 to $3 \mathrm{~m}$. Storm waves driven by local storms, also predominantly from the southwest, have a shorter wavelength (periodicity of 6 to 8 seconds) with wave heights up to $5 \mathrm{~m}$. Swell waves tend to push sand onto beaches, whereas storm waves typically scour them. Sheltered areas with limited fetch are affected by local winds, which generally produce short, choppy waves.

The highest average waves in the world, which occur in the Southern Ocean, impact on the South Australian coastline and produce waves $3 \mathrm{~m}$ high for $40 \%$ of the year, $4 \mathrm{~m}$ high for $15 \%$ of the year and $5 \mathrm{~m}$ high for about $5 \%$ of the year. ${ }^{15}$ The west coast of Eyre Peninsula in particular experiences pronounced swell and storm wave activity.

\subsection{What is especially significant about the South Australian coastline?}

Geological and geomorphological studies not only provide some fascinating insights into the evolution of the South Australian coastline, but also have ramifications for coastlines globally. The coastline preserves a record of former climatic, biological, tectonic and sea level events, as well as the impacts of wind, wave and tidal processes. 


\subsubsection{The last interglacial shoreline}

\subsubsection{The Gawler Craton}

The coastline of South Australia is internationally significant, in that the tectonically highly stable Gawler Craton, which underlies much of the western half of the State and all of Eyre Peninsula, provides an important datum for establishing the eustatic worldwide sea level during the Last Interglacial Maximum (132 to $118 \mathrm{ka}$ ago). This datum contributes to an understanding of the global problem of how high sea level reached during the Last Interglacial. ${ }^{16}$ Southern Australia is located far from Pleistocene ice sheets and thus was not directly influenced by glacio-isostatic adjustments (crustal compensation and uplift due to accretion and melting of glacial ice). It is remote from tectonic plate boundaries and it is characterised by only a modest hydro-isostatic signature (about $0.5 \mathrm{~m}$ along the entire open ocean coastline), which results from loading and unloading of the continenal shelf by oceanic water. Consequently, the area is affected by fewer processes than elsewhere, which may otherwise complicate the interpretation of ancient sea levels. For over $500 \mathrm{~km}$ of the western Eyre Peninsula coastline, coastal barrier landforms with associated back-barrier estuarine sediments indicate a consistent sea level of at least $2 \mathrm{~m}$ APSL for the Last Interglacial Maximum. ${ }^{17}$

The Last Interglacial Maximum left a significant stamp on the coastline of South Australia. Away from Eyre Peninsula, coastal deposits and landforms of this age are consistently preserved at higher levels in the landscape and up to several kilometres inland of Holocene and modern equivalents. ${ }^{18}$ To the south of Port Wakefield in the northern Gulf St Vincent, for example, modern/Holocene supratidal flats occupy areas that were formerly intertidal flats during the Last Interglacial Maximum at 125000 years ago.

\subsubsection{The last interglacial shoreline as a tectonic indicator}

Last interglacial shoreline successions also provide evidence for long-term differential earth movements. Studies of last interglacial deposits and landforms reveal that Gulf St Vincent has progressively subsided during the past 125000 years, while the Mount Lofty Ranges have risen ${ }^{19}$, the Murray Lakes region has subsided, and the southern Coorong and Limestone Coast has been uplifted. Throughout this time Eyre Peninsula has remained stable.

\subsubsection{The last interglacial deposits as a climatic indicator}

Coastal sedimentary successions of last interglacial age within the region preserve molluscan and foraminiferal faunas, which indicate warmer water temperatures on the inner-continental shelf at the time of deposition. This was due to an enhanced Leeuwin Current, a southerly flowing ocean-surface current along the Western 
Australian coastline, which during warmer interglacials penetrated across the Great Australian Bight. ${ }^{20}$

\subsubsection{The Southeast Coastal Plain: A unique record of sea level movements during the Quaternary}

The uplifting southeast of the State (Coorong Coastal Plain and Limestone Coast) has preserved a globally unique stairway of former beach-dune barrier shorelines resulting from the interplay of slow $(70 \mathrm{~mm} / \mathrm{ka})$, monotonic, epeirogenic uplift and glacioeustatic sea level changes during the Quaternary Period of the past 2.59 Ma, and was particularly striking during the past 1 million years. ${ }^{21}$ These processes resulted in a series of emerged coastal barrier shoreline successions that chronicle successive interglacial highstands of sea level, and show that in the most general sense the interglacial sea levels during the Middle and Late Pleistocene (the past 800000 years) flooded the continental shelves and returned to a broadly common level close to $\pm 6 \mathrm{~m}$, which approximates the present sea level.

The record of postglacial relative sea level following the Last Glacial Maximum is also internationally significant. The sea level records from South Australia provide a rigorous framework for quantifying more precisely the loading effect of variable water masses at different points on the continental shelf. ${ }^{22}$ The progressive rise in the elevation of Early Holocene highstand shoreline successions in a northerly direction within the South Australian gulfs, away from the shelf edge, is one of the world's more significant natural laboratories to quantify hydro-isostasy and provides an important empirical framework for calibrating geophysical models of mantle rheology. ${ }^{23}$ The Early Holocene sea level highstand rises from $0.5 \mathrm{~m}$ APSL near Port Lincoln to approximately $4.5 \mathrm{~m} \mathrm{APSL}$ at the northern apex of Spencer Gulf. ${ }^{24}$

\subsubsection{Inherited features on the South Australian coastline}

The most spectacular examples of inherited coastal topography on the South Australian coast are those related to the extensive continental-scale glaciation that occurred during the Early Permian (299 to $290 \mathrm{Ma}$ ago) in South Australia, when Australia was part of the super-continent Gondwana. Numerous distinctive ice-related features that occur on Fleurieu Peninsula include glacial valley-side slopes in the Inman Valley, erratics, rochés moutonnées and striated bedrock surfaces. In Encounter Bay, the upper portions of a granite pluton were exposed during the Permian glaciation and now form numerous granitic islands and headlands. The proliferation of granitic erratics, sediments for beaches and remnants of the Permian glacial topography persist on the coastlines of Fleurieu Peninsula, Hallett Cove, Yorke Peninsula and Kangaroo Island, where Christmas Cove, formerly a Permian glacial basin, is a sheltered natural harbour. The bedrock depression of Backstairs Passage, which separates Kangaroo Island from 
Fleurieu Peninsula, was originally a glacial trough, with The Pages being glaciated rock knobs. The morphology of the coast at Wardang Island and Point Pearce Peninsula on Yorke Peninsula also reflects the impacts of the Permian glaciation.

Another inherited feature influencing coastal morphology and development is deep weathering of resistant bedrock. On Eyre Peninsula, in particular, there are many examples of extensive bedrock shore platforms having formed where sea level is coincident with the near-horizontal weathering front. The weathered material is easily stripped away, exposing the unweathered rock beneath. In some other instances, resistant bedrock platforms have been exhumed from beneath covers of younger sediments, such as aeolianite.

A minor, but interesting, example of inheritance occurs at Lady Bay on Fleurieu Peninsula, where an ancient boulder conglomerate, originally separating Gawler Craton and Adelaide System rocks, is now contributing to present-day beach pebbles and boulders.

\subsubsection{Part of the world's largest temperate carbonate factory}

The coastline of South Australia is part of the world's largest aeolianite (dune limestone) temperate sedimentary carbonate province, which extends from western Victoria to north of Shark Bay, Western Australia. ${ }^{25}$ The aeolianite deposits attest to the high calcium carbonate bioproductivity of the surrounding continental shelf environments. The dune successions formed predominantly during numerous interglacials of the past 1 million years at times of high sea stands, although not all reached quite as high as at present. The sand-sized particles of calcium carbonate derived from the mechanical abrasion of marine invertebrates were entrained landwards by inner-shelf currents, and subsequently brought on land by aeolian processes to form thick dune deposits, which are interbedded with relict soil profiles (paleosols) that formed during periods of lower sea levels. The presence of aeolianite reflects the prolonged history of aridity of the Australian continent and the paucity of terrigenous-clastic sediment delivered to much of the coastline of southern Australia.

\subsubsection{The estuary of Australia's largest exoreic river system, the Murray-Darling}

The Murray-Darling River is Australia's largest exoreic river system, which drains approximately one-seventh of the continent (1 $062530 \mathrm{~km}^{2}$ ). Despite the extensive area of this drainage basin, the river has failed to produce a delta during its geological history. ${ }^{26}$ The limited sediment brought to this region since late Middle Pleistocene time has been either rapidly incorporated into aeolianite barrier shoreline successions during sea level highstands, or transported to the edge of the continental shelf (the Lacepede Shelf offshore from the mouth of the River Murray) during glacial low sea levels. Consequently, the majority of the sediments associated with the estuary have 
largely been derived from marine sources by wave and tidal action. Former quartz desert dunes, which extended across the exposed continental shelf during the Last Glacial Maximum (21 000 years ago), were also incorporated into the coastal sediments as sea level rose to near its current position 7000 years ago.

The terminal lakes of the River Murray, Lake Alexandrina and Lake Albert comprise the largest estuarine-lagoonal environment on the South Australian coastline. The River Murray drains into Lake Alexandrina and has produced only a small digitate delta on the lake's northeastern margin. Although Lake Alexandrina has an average water depth of only $3 \mathrm{~m}$, the lake is $39 \mathrm{~km}$ (east-west) and $20 \mathrm{~km}$ (north-south). In a similar manner, Lake Albert has an average water depth of about $2 \mathrm{~m}$ but is approximately $13 \mathrm{~km}$ (east-west) by $18 \mathrm{~km}$ (north-south). The areas occupied by the lakes were eroded at times of low sea level, forming broad depressions that were flooded at the culmination of the most recent postglacial sea level rise 7000 years ago.

In their natural state, Lakes Alexandrina and Albert were predominantly fresh ${ }^{27}$, the Goolwa Channel and the Coorong Lagoon were marine, while a migrating brackish mixing zone occurred between the two at 'The meeting of the waters'. This natural variability formed a vibrant and highly productive estuarine environment. However, as more water was abstracted upstream, by the 1860 s and 1870 s the system was deteriorating. ${ }^{28}$ Increasing salinity levels in the estuary eventually led to the construction of a system of five barrages, completed in 1940, across the southern extremity of the lakes to retain fresh water and to exclude sea water. While there are calls from time to time to remove the barrages and to return the estuary to its 'natural state', the reduction of freshwater flow by 75 to $80 \%$ means that the former freshwater lakes would be converted into marine embayments. The calculated original natural freshwater flow to the sea was approximately 2000 megalitres (ML) per day for more than $95 \%$ of the time, but the present median annual flow to the sea is only $27 \%$ of this former natural flow. ${ }^{29}$

While the barrages dramatically reduced tidal exchange, which previously had also helped to clear the Murray Mouth, the estuary was originally fluvially dominated, and the reduction in freshwater flow is mainly responsible for the growth and consolidation of a flood tidal delta that has formed Bird Island since barrage completion in $1940 .{ }^{30}$ The growth of Bird Island, which is $1 \mathrm{~km}$ in diameter, and its colonisation by more than 80 plant species, stand as permanent testaments to river management strategies.

\subsubsection{Fossil shorelines inland of the modern coast}

\subsubsection{Ooldea Range}

Paleoshorelines even older than those of the Southeastern Coastal Plain extend several hundred kilometres inland from the modern coastline along the northeastern sector of the Eucla Basin ${ }^{31}$, where coastal barrier landforms of Late Eocene age (37 to $34 \mathrm{Ma}$ ), 
relating to higher sea levels, occur. The Ooldea Range, and associated Paling and Barton Ranges, are fossil coastal landforms that extend laterally for over $650 \mathrm{~km}$ on the eastern margin of the Nullarbor Plain, and between 25 to $300 \mathrm{~km}$ inland of the present coastline (see Figure 10.2).

\subsubsection{Kanawinka Escarpment}

The Kanawinka Escarpment represents another notable ancient shoreline in the southeast of the State. The Kanawinka Escarpment is a former sea cliff partly coincident with an uplifted fault block ${ }^{32}$ and one of the most prominent and laterally persistent landscape features in southeastern Australia. ${ }^{33}$ The escarpment can be traced from near the Mount Lofty Ranges in South Australia to near Portland in western Victoria, a distance of some $600 \mathrm{~km}$. The portion of the escarpment in South Australia has also been termed the Marmon-Jabuk Scarp. ${ }^{34}$ The escarpment ranges from 30 to $100 \mathrm{~m}$ APSL. The Kanawinka Escarpment is one of the most laterally persistent abandoned sea cliffs in the world. The formation of the Kanawinka Escarpment occurred some time after $5 \mathrm{Ma}$ (the age of the youngest Loxton-Parilla Sands strandline preserved above the escarpment) and before around 1.2 Ma (the youngest Werrikoo Limestone ages).

\subsubsection{Nullarbor Cliffs - Part of the largest unbroken cliff line in the world}

The Nullarbor Cliffs are part of the largest unbroken cliff line in the world, and have resulted from the erosion of the limestones of the Eucla Basin, which are 43 to 23 million years old. ${ }^{35}$ The Bunda Cliffs, which are 40 to $90 \mathrm{~m}$ high, are approximately $200 \mathrm{~km}$ long in westernmost South Australia. They extend inland as subaerially modified, relict sea cliffs backing the Roe Plain $(290 \mathrm{~km})$ and join the Baxter Cliffs (c. $165 \mathrm{~km}$ ) near the western limit of the Nullarbor Plain. The rocks that give rise to the precipitous cliffs are part of the world's largest karst landscape, which has developed on these Paleogene-Neogene limestones.

\subsubsection{Spectacular submarine canyons of South Australia}

Spectacular submarine canyons traverse the steep continental margin of South Australia. These include the Ceduna Canyon, the Murray Group of Canyons and the Bridgewater Group in the southeast, which is associated with the Beachport Terrace. ${ }^{36}$ The Ceduna Canyon lies about $420 \mathrm{~km}$ south of Ceduna and is associated with the gently sloping Ceduna Terrace, which covers an area of $70000 \mathrm{~km}^{2}$ between depths of 500 and $2500 \mathrm{~m} \cdot{ }^{37}$ Broad and shallow submarine valleys cut into Paleogene and Neogene sediments form distributary patterns, feeding steeper, walled canyons on the lower slopes. The largest of the canyons here, Ceduna Canyon, is $4 \mathrm{~km}$ wide, $600 \mathrm{~m}$ deep, steep-sided and asymmetrical, with a steeper eastern wall. ${ }^{38}$ 
The Murray Group of Canyons, the largest group, contains some of Australia's most spectacular landforms; they are up to $80 \mathrm{~km}$ long, extend over a distance of $400 \mathrm{~km}$ on the continental slope, and are among the biggest in the world. For example, Sprigg Canyon is more than $2 \mathrm{~km}$ deep and exceeds the dimensions of the Grand Canyon of the Colorado River. The canyons lie about $60 \mathrm{~km}$ offshore from Kangaroo Island and extend from the margin of the continental shelf at $180 \mathrm{~m}$ to depths of $5 \mathrm{~km}$. They are linked with former courses of the River Murray, which flowed across the wide continental shelf (Lacepede Shelf) during episodes of low sea level (Figure 12.2). ${ }^{39}$ It has been suggested that the Murray Group of Submarine Canyons, discovered by Reg Sprigg, may have been initiated by fault-controlled river erosion before subsidence of the continental margin. This followed the rifting of Antarctica and Australia about $43 \mathrm{Ma}^{\mathrm{ago}}{ }^{40}$, with Jurassic-Cretaceous Rift structures trending west-northwest influencing the morphology of the central canyons. ${ }^{41}$

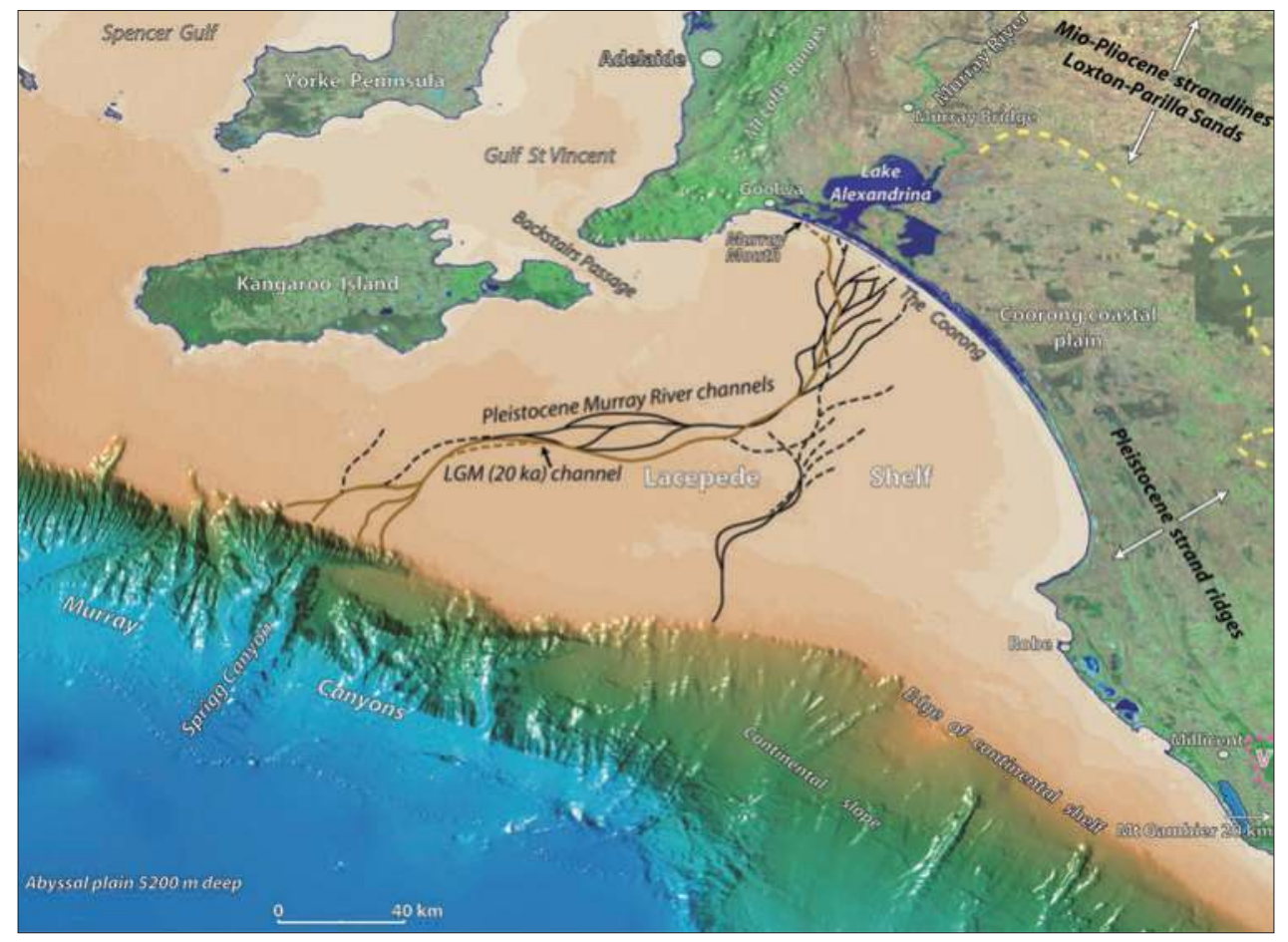

Figure 12.2 The Murray Group of submarine canyons.

Source: Hill, P.J., De Deckker, P., von der Borch, C.C. \& Murray-Wallace, C.V. (2009). Ancestral Murray River on the Lacepede Shelf, southern Australia: Late Quaternary migrations of a major river outlet and strandline development. Australian Journal of Earth Sciences, 56, 135-157. 
However, the main processes responsible for canyon development are turbidity currents and slow sediment creep, which enlarge and extend the canyons. ${ }^{42}$ Indirectly, rivers impact on the formation of submarine canyons, in that they deliver sediment into canyon heads on the edge of the continental shelf, exposed during the low sea levels of glacial times. Repeated rhythmic sea level fluctuations over the past $3 \mathrm{Ma}$ at intervals of 100000 to 40000 years caused surges of these sediments down the canyons as turbidity currents, enlarging and modifying them. ${ }^{43}$ The submarine canyons are eroded into a variety of rock types, although many are cut in Cretaceous sediments with floors of basement rocks. ${ }^{44}$ The long profiles of the canyons are concave and initially steep $\left(15^{\circ}\right.$ to $\left.30^{\circ}\right)$, but progressively flatten towards the abyssal plain at slopes of $4^{\circ}$ to $1^{\circ}$. They are usually $\mathrm{V}$-shaped and steep-sided $\left(15^{\circ}\right.$ to $\left.22^{\circ}\right)$ in cross-section, winding in plan and broaden downslope, where the valley floors are commonly flat. ${ }^{45}$

It has been demonstrated that the Murray Canyons Group is still being actively modified, with sediment transport to the oceanic deeps more than $100 \mathrm{~km}$ from the foot slope. ${ }^{46}$ Given the lack of river sediment supply, the marine carbonate 'factories' of the Lacepede Shelf provide the main supply of sediments for turbidity currents. Initially, canyon erosion involved mainly land-sourced sediment, with later cutting predominantly by biogenic carbonates produced on the continental shelf. ${ }^{47}$

\subsubsection{Two coastal enigmas}

Two features of the west coast of Spencer Gulf, discussed in Chapters Eight and Nine, have yet to be adequately explained, namely the shingle ridges between Whyalla and Port Augusta and high-level boulders at Cape Carnot.

Although there is a ready source of shingle from alluvial deposits, the ridges, the upper surfaces of which are 3 to $5 \mathrm{~m}$ APSL and 15 to $75 \mathrm{~m}$ wide, are out of harmony with the prevailing environment, which is sheltered and tide-dominated. There are limited fetches for the build-up of the high-energy waves required to throw shingle up to form the ridges. There are several generations of ridges, some of which are massive and extend sporadically over a distance of $50 \mathrm{~km}$. The ridges incorporate reworked last interglacial shells (Anadara trapezia) and are almost certainly of Holocene age. ${ }^{48}$ Hydro-isostatic uplift and former higher sea levels may help to explain the current elevation of the ridges, but the details of their formation remain a mystery.

There is evidence of spectacular wave activity at the exposed foot of Eyre Peninsula at Cape Carnot, where hundreds of clasts including large boulders, predominantly from the Cape Carnot gneisses, have been thrown inland up to $100 \mathrm{~m}$ and at least $20 \mathrm{~m}$ APSL onto a calcreted surface of last interglacial age. The distribution of boulders, pebbles and other sediments suggests derivation from the south. The boulders have been locally derived and are little weathered, suggesting a relatively young age for the megawave event, which emplaced them. Work is currently underway to date the 
age of the megawave, because there are implications if the wave-deposited boulders were the result of a tsunami. If so, it would have impacted on many other parts of the South Australian coast. Potential megawave deposits also occur on Yorke Peninsula, and a tsunami with waves higher than $20 \mathrm{~m}$ may have impacted on the shingle ridges of the northern Spencer Gulf where the narrowing gulf would have increased wave height considerably.

\subsubsection{Human impacts on the coastline}

Shorelines are typically young features that are ever changing, fragile and in conditions of dynamic equilibrium with the current wind, wave and tidal regimes, which influence the erosion, transport and deposition of available sediments. In the past, people were unaware that shorelines are not fixed in place. Beach sand moves alongshore, offshore and onshore, as well as being blown from the beaches to form backing dunes, which in turn provide reserves of sand for beaches and coastal protection during storms. The stability of the dunes, in turn, depends on a healthy cover of vegetation.

As well as the ongoing dynamic exchanges between beaches, offshore bars and dunes, some barrier shorelines such as the Sir Richard and Younghusband Peninsulas are migrating landward quite naturally, as strong southwesterly winds transport dune sand over back-barrier lagoonal sediments, burying, differentially loading and folding them. The beach migrates landward with the dunes, and occasionally back-barrier sediments are exposed on the beach. Dune drift has sometimes been accelerated by grazing sheep, cattle and rabbits, as well as by the use of destructive Off-Road Recreational Vehicles (ORRV's) in the fragile dunes. ${ }^{49}$ Somewhat perversely, introduced plants such as Pyp grass, Marram grass and Sea wheat-grass have stabilised the dunes, smothered native vegetation and inhibited the 'intermediate disturbance', which the dune ecosystem requires for vibrancy and renewal. ${ }^{50}$

Some coastal areas are relatively stable where the shoreline intersects resistant rocks, which form cliffs. Other cliff lines may be eroding rapidly, such as those of the Nullarbor, where cliff falls are frequent. A rapidly eroding cliff line typically has a crenulated shape in plan, which results from waves actively undermining the cliff line.

There is an inherent human tendency to live as close as possible to the coast, leading in some cases to dwellings being constructed on ephemeral coastal landforms such as sand spits, dunes and low-lying sand ridges. Such locations are very vulnerable, particularly if sea level continues to rise.

In South Australia, there are many examples of unwise land use on coastal systems, and such land use has had serious impacts on the shoreline. For example, landscape change has occurred in the more populated regions of the South Australian coastline since European settlement of the colony in 1836. Human impacts on the coastline have been manifested in different ways and in some contexts in a subtle 
manner. Extensive urban development in coastal regions has covered dunes with built structures, preventing sand from being added to the coastline to nourish beaches. As a result of the predominant northerly transport of sand through longshore drift, many of the southern Adelaide metropolitan beaches have experienced erosion, as have other areas starved of sand by groynes and harbours. In the early settlement period (1836-1910), migrating coastal dunes engulfed residential dwellings such as at Brighton Beach. ${ }^{51}$ Coastal erosion has been accelerated along the Adelaide coast by the loss of sand-stabilising seagrass meadows, through effluent and polluted stormwater discharge. Counterintuitively, impermeable seawalls have actually accelerated erosion by increasing the rate of beach scouring and longshore transport.

Other forms of modification of coastal environments have included deliberate modification to estuaries through residential canal developments; unintended subsidence of some near-coastal environments resulting from groundwater withdrawal, particularly on the northern Adelaide Plains ${ }^{52}$; and artificial beach nourishment through the disposal of mine waste. ${ }^{53}$

The Murray Estuary provides another classic example of human impacts on a dynamically operating system, where impacts on the $>1$ million $\mathrm{km}^{2}$ drainage basin cascade through the river system to make their final deleterious expressions at the lower lakes and Murray Mouth.

\subsection{Conclusions}

The major aim of this book is to help people understand the way the South Australian coast has evolved and to create an awareness of the complexity, variability, dynamism, youthfulness and fragility of our shorelines. Besides the inherent beauty of the coastal landscapes of South Australia, which is self-evident to all with an appreciation of the aesthetics of landscapes, an understanding of the science of coasts enhances our appreciation of the landscapes and renders visits to the coast more intellectually stimulating and enjoyable. Understanding how our coastal landscapes have evolved during repeated changes in sea level superimposed on variable crustal movements helps us to appreciate the dynamism of coastal landscapes and their contrasting sensitivities to environmental change. In a similar manner, a scientific understanding of coastal environments provides insights into inherited features at the coastline as well as the processes responsible for coastal landscape change through time, including the rates of change. This provides important bases from which to model future potential coastal landscape changes that may result from future changes in relative sea level. ${ }^{54}$

The scientific basis for understanding coastal landscapes thus enables us to explain coastal change. Following this, activities can be undertaken and directed at minimising human interference with vulnerable coastal sectors by utilising appropriate management approaches and strategic natural heritage environment protection 
programs. For example, the preservation of a portion of the Hallett Cove coast from residential development to protect internationally significant Permian glacigene sediments and landforms is illustrative of what can be achieved in preserving coastal landscapes. ${ }^{55}$ Given that we now have a good understanding of the ways in which various coastlines work, that they are dynamic systems in states of constant flux, we should be able to manage them far better than we have in the past.

\section{Notes}

1 Twidale, C.R. (2007). Ancient Australian landscapes, Rosenberg Publishing. Sydney, 144 pp.

2 James, N.P. \& Bone, Y. (2011). Neritic carbonate sediments in a temperate realm. Springer, Dordrecht, 254 pp; Murray-Wallace, C.V. (2014). The continental shelves of SE Australia. In: Chiocci, F.L. \& Chivas, A.R. (Eds), Continental Shelves of the World: Their evolution during the last glacio-eustatic cycle. Memoirs 41. Geological Society, London, pp. 273-291.

3 Bourman, R. (2010). The nature of flooding, in Curran, E., Gell, P., Wright, C. \& Ray, D., Chapter 2, The Variable Climate. In: Daniels, C.B. (Ed.), Adelaide: Water of a city, Wakefield Press, Kent Town, SA, pp. 52-53.

4 Hesse, P.P. (2010). The Australian desert dunefields: Formation and evolution in an old, flat, dry continent. In: Bishop, P. \& Pillans, B. (Eds), Australian landscapes. Geological Society, London, Special Publication 346, pp. 141-164.

5 Lewis, S.E., Sloss, C.R., Murray-Wallace, C.V., Woodroffe, C.D. \& Smithers, S.G. (2013). Post-glacial sea-level changes around the Australian margin: A review. Quaternary Science Reviews, 75, 1-24.

6 Veevers, J.J. (2000). Billion-year history of Australia and neighbours in Gondwanaland. Gemoc Press, Sydney, 388 pp.

7 Church, J.A., Clark, P.U., Cazenave, A., Gregory, J.M., Jevrejeva, S., Levermann, A., Merrifield, M.A., Milnes, G.A., Nerem, R.S., Nunn, P.D., Payne, A.J., Pfeffer. W.T., Stammer, D. \& Unnikrishnan, A.S. (2013). Sea level change. In: Stocker, T.F., Qin, D., Plattner, G.-K., Tignor, M., Allen, S.K., Boschung, J., Nauels, A., Xia, Y., Bex, V. \& Midgley, P.M. (Eds), Climate change 2013: The physical basis. Contribution of Working Group I to the Fifth Assessment Report of the Intergovernmental Panel on Climate Change, Cambridge University Press, Cambridge, pp. 1137-1216.

8 Fenner, C. (1930). The major structural and physiographic features of South Australia. Transactions of the Royal Society of South Australia, 54, 1-36; Belperio, A.P. (1995). Quaternary. In: Drexel, J.F. \& Preiss, W.V. (Eds), The geology of South Australia. Vol. 2, The Phanerozoic. South Australian Department of Mines and Energy, Bulletin 54, pp. 219-280.

9 Veevers (2000); Kearey, P., Klepeis, K.A. \& Vine, F.J. (2009). Global tectonics, WileyBlackwell, Oxford, $3^{\text {rd }}$ Edn, 482 pp; Blewett, R.S., Kennett, B.L.N. \& Huston, D.L. (2012). Australia in time and space. In: R.S. Blewett (Ed.), Shaping a nation: A geology of Australia. Geoscience Australia and ANU E Press, Canberra, pp. 47-119.

10 Preiss, W.V. (1987). The Adelaide Geosyncline: Late Proterozoic stratigraphy, sedimentation, 
palaeontology and tectonics. Geological Survey of South Australia, Bulletin 53, D.J. Woolman, Government Printer, South Australia, Adelaide, pp. 249-254.

11 Veevers (2000).

12 Alley, N.F. \& Lindsay, J.M. (1995). Tertiary. In: Drexal, J.F. \& Preiss, W.V. (Eds), The geology of South Australia. Vol. 2, The Phanerozoic. Geological Survey of South Australia, Bulletin 54, pp. 151-217; Murray-Wallace, 2014.

13 Belperio, A.P., Gostin, V.A., Cann, J.H. \& Murray-Wallace, C.V. (1988). Sedimentorganism zonation and the evolution of Holocene tidal sequences in southern Australia. In: de Boer, P.L., van Gelder, A. \& Nio, S.D. (Eds), Tide-influenced sedimentary environments and facies. Reidel, Dordrecht, pp. 475-497; Harvey, N., Barnett, E.J., Bourman, R.P. $\&$ Belperio, A.P. (1999). Holocene sea-level change at Port Pirie, South Australia: A contribution to global sea-level rise estimates from tide gauges. Journal of Coastal Research, 15 (3), 607-615; Gostin, V.A. \& Hill, S.M. (2014). Spencer Gulf: Geological setting and evolution. In: Shepherd, S.A., Madigan, S.M., Gillanders, B.M., Murray-Jones, S. \& Wiltshire, D.J. (Eds), Natural history of Spencer Gulf. Royal Society of South Australia, Adelaide, pp. 21-35.

14 Belperio, Gostin, Cann \& Murray-Wallace (1988).

15 Short, A.D. (2006). Beaches of the South Australian coast and Kangaroo Island: A guide to their nature, characteristics, surf and safety. Sydney University Press, Sydney, 346 pp.

16 Murray-Wallace, C.V. \& Woodroffe, C.D. (2014). Quaternary sea-level changes - A global perspective. Cambridge University Press, Cambridge, 484 pp.

17 Murray-Wallace, C.V. \& Belperio, A.P. (1991). The last interglacial shoreline in Australia - A review. Quaternary Science Reviews, 10, 441-461.

18 Murray-Wallace \& Belperio (1991); Murray-Wallace \& Woodroffe (2014).

19 Bourman, R.P., Belperio, A.P., Murray-Wallace, C.V. \& Cann, J.H. (1999). A last interglacial embayment fill at Normanville, South Australia, and its neotectonic implications. Transactions of the Royal Society of South Australia, 123, 1-15.

20 Cann, J.H. \& Clarke, J.D.A. (1993). The significance of Marginopora vertebralis (Foraminifera) in surficial sediments at Esperance, Western Australia, and in last interglacial sediments in northern Spencer Gulf, South Australia. Marine Geology, 111, 171-187.

21 Murray-Wallace, C.V., Brooke, B.P., Cann, J.H., Belperio, A.P. \& Bourman, R.P. (2001). Whole-rock aminostratigraphy of the Coorong Coastal Plain, South Australia: Towards a 1 million year record of sea-level highstands. Journal of the Geological Society, London, $158,111-124$.

22 Belperio, A.P., Harvey, N. \& Bourman, R.P. (2002). Spatial and temporal variability in the Holocene palaeosea-level record around the South Australian coastline. Sedimentary Geology, 150, 153-169; Lewis, Sloss, Murray-Wallace, Woodroffe \& Smithers (2013).

23 Lambeck, K. \& Nakada, M. (1990). Late Pleistocene and Holocene sea-level change along the Australian coast. Palaeogeography, palaeoclimatology, palaeoecology (Global and planetary change section), 89, 143-176.

24 Belperio, Harvey \& Bourman (2002).

25 Murray-Wallace, C.V. (2002). Pleistocene coastal stratigraphy, sea-level highstands and neotectonism of the southern Australian passive continental margin - A review. Journal 
of Quaternary Science, 17, 469-489; James \& Bone (2011); Playford, P.E., Cockbain, A.E., Berry, P.E., Roberts, A.P., Haines, P.W. \& Brooke, B.P. (2013). The geology of Shark Bay, Geological Survey of Western Australia, Bulletin 146, 281 pp.

26 James, N.P., Bone, Y., von der Borch, C. \& Gostin, V.A. (1992). Modern carbonate and terrigenous clastic sediments on a cool water, high energy, mid-latitude shelf: Lacepede, southern Australia. Sedimentology, 39, 877-903; Murray-Wallace, C.V., Bourman, R.P., Prescott, J.R., Williams, F., Price, D.M. \& Belperio, A.P. (2010). Aminostratigraphy and thermoluminescence dating of coastal aeolianites and the later Quaternary history of a failed delta: The River Murray mouth region, South Australia. Quaternary Geochronology, 5, 28-49.

27 Goode, J.R. \& Harvey, P.D. (2009). Water resources. In: Jennings, J. (Ed.), Natural history of the Riverland and Murraylands. Royal Society of South Australia, Adelaide, pp. 162-177.

28 Sheldrick, J.M. (2013). Nature's line: George Goyder, Surveyor, environmentalist, visionary. Wakefield Press, Adelaide, 457 pp.

29 Goode \& Harvey (2009).

30 Harvey, N. (1996). The significance of coastal processes for management of the River Murray estuary. Australian Geographical Studies, 34, 45-57; Bourman, R.P., Murray-Wallace, C.V., Belperio, A.P. \& Harvey, N. (2000). Rapid coastal geomorphic change in the River Murray Estuary of Australia. Marine Geology, 170, 141-168; James, K.F., Bourman, R.P. \& Harvey, N. (2015). Rapid evolution of a flood tidal deltaic island in the River Murray Estuary, South Australia. A canary in the cage of river management. Journal of Coastal Mangement, 31, 1103-1119.

31 Benbow, M.C. (1990). Tertiary coastal dunes of the Eucla Basin, Australia. Geomorphology, 3, 9-29.

32 Sprigg, R.C. (1952). The geology of the south-east province, South Australia, with special reference to Quaternary coast-line migrations and modern beach developments. Geological Survey of South Australia, Bulletin 29, 120 pp.

33 McLaren, S., Wallace, M.W., Gallagher, S.J., Miranda, J.A., Holdgate, G.R., Gow, L.J., Snowball, I. \& Sandgren, P. (2011). Palaeogeographic, climatic and tectonic change in southeastern Australia: The Late Neogene evolution of the Murray Basin. Quaternary Science Reviews, 30, 1086-1111.

34 Rogers, P.A. (1980). Pinnaroo, South Australia, 1:250 000 Series - Explanatory Notes, Sheet SI54-14. South Australia, Geological Survey.

35 James, N.P., Bone, Y., Carter, R.M. \& Murray-Wallace, C.V. (2006). Origin of the Late Neogene Roe Plains and their calcarenite veneer: Implications for sedimentology and tectonics in the Great Australian Bight. Australian Journal of Earth Sciences, 53, 407-419.

36 Sprigg, R.C. (1979). Stranded and submerged sea-beach systems of Southeast South Australia and the aeolian desert cycles. Sedimentary Geology, 22, 53-96.

37 Tilbury, L.A. \& Fraser, A.R. (1981). Submarine valleys on the Ceduna Terrace off South Australia. BMR Journal of Australian Geology \& Geophysics, 6, 259-264.

38 von der Borch, C.C. (1968). Southern Australian submarine canyons: Their distribution and ages. Marine Geology, 6, 267-279.

39 Sprigg, R.C. (1947). Submarine canyons of the New Guinea and South Australian coasts. Transactions of the Royal Society of South Australia, 71, 296-310; Sprigg (1952); Hill, P.J., 
De Deckker, P., von der Borch, C.C. \& Murray-Wallace, C.V. (2009). Ancestral Murray River on the Lacepede Shelf, southern Australia: Late Quaternary migrations of a major river outlet and strandline development. Australian Journal of Earth Sciences, 56, 135-157. von der Borch (1968); von der Borch, C.C. (1979). Giant submarine canyons. In: Tyler, M.J., Twidale, C.R. \& Ling, J.K. (Eds), Natural history of Kangaroo Island. Royal Society of South Australia, Adelaide, pp. 47-51.

41 Hill, P.J., De Deckker, P. \& Exon, N.F. (2009). Geomorphology and evolution of the gigantic Murray canyons on the Australian southern margin. Australian Journal of Earth Sciences, 52, 117-136.

42 von der Borch (1979).

43 von der Borch (1979).

44 Hill, De Deckker \& Exon, 2009.

45 Hill, De Deckker \& Exon, 2009.

46 Hill, De Deckker \& Exon, 2009.

47 Hill, De Deckker \& Exon, 2009; Schmidt, S., De Deckker, P., Etcheber, H. \& Caradec, S. (2010). Are the Murray Canyons offshore southern Australia still active for sediment transport? Geological Society, London, Special Publications, 346, 43-55.

48 Belperio, A.P., Smith, B.W., Polach, H.A., Nittrouer, C.A., Demaster, D.J., Prescott, J.R., Hails, J.R., Gostin, V.A. (1984). Chronological studies of the Quaternary marine sediments of the Northern Spencer Gulf, South Australia. Marine Geology, 61, 265-296.

49 Gilbertson, D.D. (1981). The impact of past and present land use on a major coastal barrier system. Applied Geography, 1, 97-119.

50 Hilton, M., Harvey, N. \& James, K. (2007). The impact and management of exotic dune grasses near the mouth of the Murray River, South Australia. Australasian Journal of Environmental Management, 14 (4), 220-228.

51 Selby, J. (1984). Geology and the Adelaide environment. Handbook No. 8, Department of Mines and Energy, South Australia; Bourman, R.P. \& Harvey, N. (1986). Landforms. In: Nance, C. \& Speight, D.L. (Eds), A land transformed: Environmental change in South Australia. Longman Cheshire, Melbourne, pp. 78-125.

52 Belperio, A.P. (1993). Land subsidence and sea level rise in the Port Adelaide estuary: Implications for monitoring the greenhouse effect. Australian Journal of Earth Sciences, 40, 359-368.

53 Bourman, R.P. (1990). Artificial beach progradation by quarry waste disposal at Rapid Bay, South Australia. Journal of Coastal Research, Special Issue 6, 69-76.

54 Woodroffe, C.D. \& Murray-Wallace, C.V. (2012). Sea-level rise and coastal change: The past as a guide to the future. Quaternary Science Reviews, 54, 4-11.

55 Douglas, K. (2010). Pictures of time beneath: Science, heritage and uses of the deep past. CSIRO Publishing, Melbourne, 215 pp. 
This book is available as a free fully-searchable ebook from www.adelaide.edu.au/press

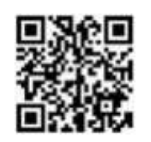

